Historic, Archive Document

Do not assume content reflects current scientific knowledge, policies, or practices. 




$$
\frac{1}{E n 83 B}
$$






\section{U.S. DEPARTMENT OF AGRICULTURE.}

DIVISION OF ENTOMOLOGY.

\section{BIBLIOGRAPHY}

. $\mathrm{OF}$

THE MORE MIPORTANT CONTRIBUTIONS

TO

\section{AMERICAI ECONOMIC ENTOHOLOGY.}

PREPARED. BI ALTHORITY OF THE SECRETARY OH AGRICULTURE,

$\mathrm{BI}$

SAMUEL HENSH AW.

$$
\text { Parts I, II, and III. }
$$

THE MORE IUPUR'ANT WRITINGS

(II

\section{BENJAMIN DANN WALSH}

A.II

CHARLES VALENTINE RILEY.

WASHTNGTON:

QOVERNMENT PRINTING OFFICE.

1890 . 



\section{U.S. DEPARTMENT OF AGRICULTURE.}

DIVISION OF ENTOMOLOGY.

\section{BIBLTOGRAPHY}

OF

THE MORE IMPORTANT CONTRIBUTIONS

TO

\section{AMERICAN ECONOHIC ENTOMOLOGT.}

PREPARED, BY AUTHORITY OF THE SECRETARY OF AGRICULCURE。

$B \Gamma$

SAMUEL HENSHA W.

$$
\text { PART I. }
$$

TIE MORE IMPORTANT WRITINGS

OF

BENJAMIN DANN WALSH.

WASHINGTON:

GOVERNMENT PRINTING OFFICE.

1889 . 


\section{FORTY-SEVENTH CONGRESS, FIRST SESSION.}

Congriss of the United States,

IN THE HOUSE OF REPRESExTATIVES,

June 24, 1882.

Resolved, By the Ilonse of Representatives (the Senate concurring) that there be printed, for the use of the Department of A Arriculture, one thousand copies of a special report, cntitled "Bibliography of Economic Entomology."

Attest:

EwD. McPherson, Clerk.

Passed the Senate Jnly 6, 1882.

F. E. Shomer, Acting Secretary.

A true copy.

EwD. McPunrson,

Clerk. 


\section{LETTER OF TRANSMITTAL.}

\section{U. S. Departinent of Agriculture, Division of ENTOMOLOGY, Tishington, D. C., June 12, 1889.}

SIR: In the absence of Professor Riley, who is now at the Paris Exposition in official capacity, I beg to submit for publication Parts I, II, and III of the Bibliography of American Economic Entomology, which was ordered by Congress in July, 1882. Owing to various unforeseen delays this work has not yet been completed. Its preparation was originally assigned by Professor Riley to Mr. B. Pickman Mann, formerly of this Division, and upon the sererance of his connection with the Department, in the fall of 1885 , it was turned over in. an incomplete and fragmentary condition to Mr. Samuel Henshaw, of Boston, who has added greatly to it and practically rewritten the portions already prepared.

The extent of the work renders it advisable to publish it in several parts, and as there is unquestionably a more urgent need on the part of working economic entomologists for a bibliography of the writings of B. D. Walsh and C. V. Riley than of others, on account of their great number and value, these portions have been finished first. Their immediate publication will probably antecede the publication of the final part only by a few months.

Very respectfully, yours,

Hon. J. M. RusK,

L. O. HowaRD, Acting Entomologist.

Secretary of Agriculture. 



\section{TABLE OF CONTENTS TO PARTS I, II, AND III.}

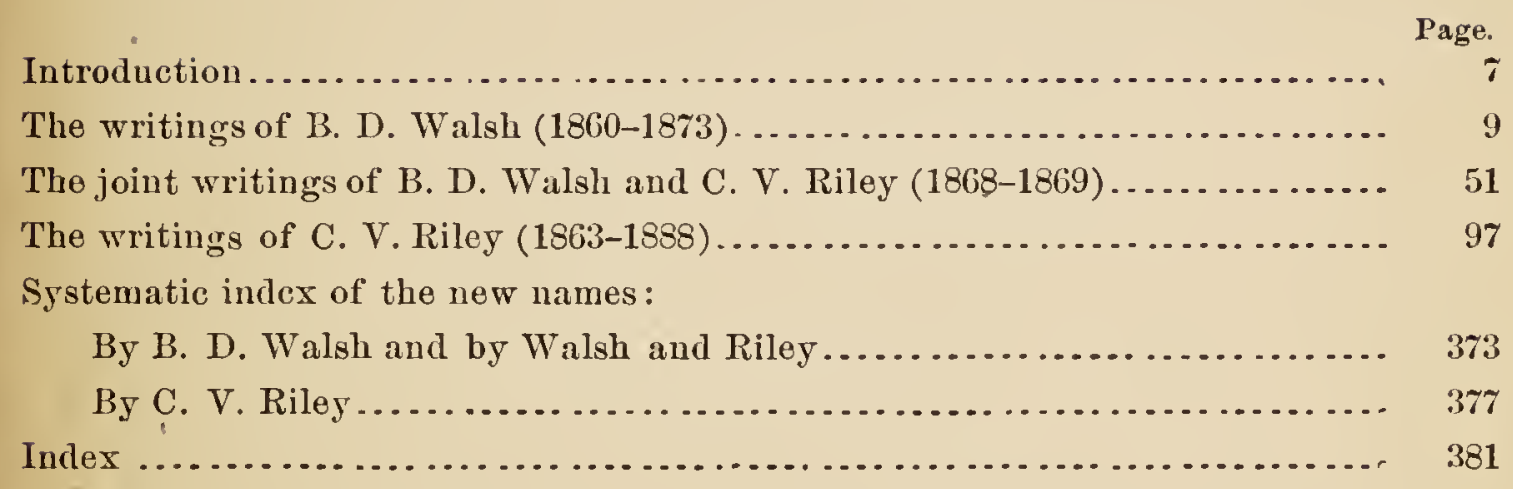



The object of the present lists is to record the principal entomological writings of B. D. Walsh and C. V. Riley. Few will be likely to criticize the association of the names of Walsh and Riley in a list of this kind, so largely devoted to economic entomology, or to question the desirability of collating their writings in advance of others.

As recognized authorities upon entomology, especially from an economic standpoint, their writings have been extensively quoted sometimes with, but frequently without, credit in the agricultural and horticultural journals of the day. These secondary references, though of a certain value.when the original is inaccessible, have, as a rule, been omitted. In citing such as are given I have used my personal judgment. To have given all would have increased the size of the list considerably with but a slight increase in its usefulness.

Occasionally, a publisher to meet some popular demand puts the writings of an author into book form without the knowledge of the latter. Such an occurrence has happened more than once with Dr. Riley's writings. To mention but one: In 1877 Messrs. George Rutledge \& Sons, of London, published "The Colorado beetle, with suggestions for its repression and methods of destruction," with Dr. Riley's name upon the title-page as author. This is a partial reprint of Potato Pests entirely unsanctioned and published withont knowledge of the author. (See London Times, October 17, 1887.) These publishers' reprints are omitted from this list. The "S.-b." after the reference of many of the articles from the agricultural and other journals refers to the series of scrap-books used in divisional work.

A biographical sketch of Dr. Walsh is given in the second volume of the American Entomologist, Vol. II, No. 3, pp. 65-68, January, 1870.

The chief facts in Dr. Riley's life may be found in the "Commonwealth of Missouri" (1875) and the National Farmer, September 20, 1883.

In the preparation of the list I have freely used all data accumulated by the Division, notably the work of Mr. B. P. Mann and a private list of Dr. Riley's.

Many persons, both within and without the Department, have kindly answered my inquiries.-S. H. 



\title{
BIBLIOGRAPHY OF THE MORE IMPORTANT CONTRIBUTIONS TO AMERICAN ECONOMIC ENTOMOLOGY.
}

\author{
THE · WRITINGS OF B. D. WALSH (1860-1873).
}

1. WALSH, B. D. Bark-lice. <Western Rural. S.-b. No. 3, p. 11.

Habits of Lecanium compared with Aspidiotus [= Mytilaspis].

2. WALSH, B. D. Entomological notes. <Prairie Farmer, 17 May, 1860, [v. 21], n. s., v. 5, pp. 308-309, figs. S.-b. No. 1, pp. 42-43.

Notice of Coccus harrisii n. sp. [= Chionaspis furfurus]; figure of its scales; description and figure of Capsus oblineatus [= Lygus pratensis] infesting apple, quince, and pear trees; figuro of larva case and imago and description of Phycita nebulo [ = Acrobasis indiginella]; figures of imago and of injuries of Amphicerus bicandatus; habits of the same and of Scolytus $[=X y l e-$ borus $]$ pyri, Saperda bivittata $[=$ candida $]$ and Chrysobothris femorata; means against the last.

3. WaLsh, B. D. "Cutworms." <Prairie Farmer, 9 August, 1860, [v. 22], n. s., v. 6, pp. 82-83, fig. S.-b. No. 1, pp. 84-85.

Account of the larvo of Lachnosterna quercina [=fusca」 of Elateride of Agrotidce and of Pangus [= Harpalns] caliginosus; figures of larvo and imagos of the same or allied species; also of Heteronychus [=Ligyrus $]$ relictus, Lopha [=Bcmbidium $]$ 4-maculatum and Agonoderus pallipes.

4. WaLSH, B. D. [Ips quadrisignatis, Say.] <Prairie Farmer, 1860, [v. 22], n. s., v. 6, p. - .

Ips 4-signatus [=fasciatus] attacks growing ears of sweet corn.

5. Walsh, B. D.] "Insect Life." < Proc. Agric. Conv.; Ann. meeting Ill. Nat. Hist. Soc.; Comm. Exerc. State Normal Univ. [Bloomington, Ill.], 1860, pp. 11-12.

Report, compiled from Chicago papers of address delivered before the Illinois Natural History Society; comparison between injurious insects and an invading army; necessity of appropriations for carrying on entomological work; economic entomology in Europe; importance of beneficial insects. 
6. W ALsh, B. D. Insects injurious to vegetation in Illinois. < Trans. Ill. State Agric. Soc., September, 1861, v. 4, pp. 335-378, figs. 1-11. Separate: 1861, 43 pp., $1 \mathrm{pl}$. Reprint in part: < Trans. Ill. Nat. Hist. Soc., r. 1. Prairie Farmer, 6 December, 1861, [v. - ], n. s., v. - pp. 370-371.

Ravages of injurious insects; enemies of the same; notes on Cecidomyia destructor, Saperda bivittata $[=$ candida $]$, Chrysobothris femorata, Conotrachelus nenuphar and Blissus lencopterus; natural history, ravages and means against Leucunia unipuncta; figures its larva, pupa and imago; descriptions and figures primary and secondary parasites of the army-worm; figures Hippodamia (= Megilla) maculata, Coccinella munda [= sanguinea $]$ and a larval coccinellid.

7. WALsh, B. D. From Benj. D. Walsh. < Illinois Farmer, October, 1861.

Denies statement attributed by C. Thomas (Illinois Farmer, September, 1861), that he (Walsh) believed in the hibernation of the pupa of Leucania unipuncta.

8. WALsh, B. D. The army-worm question. < Prairie Farmer, 5 December, 1861, [v. 24], n.'s., v. 8, pp. 370-371. S.-b., No. 4, p. 22.

Replies to arguments of C. Thomas (Prairie Farmer, 1861, v. 8, pp. 306-307), on the hibernation of Leucania unipuncta.

9. WALsh, B. D. The army-worm question. Mr. Walsh's reply. $<$ Field Notes, 14 December, 1861.

Controversial answer to the asscrtion of J. H. Klippart (Field Notes, 30 November, 1861), that the larvio of Leucania unipuncta are viviparous.

10. Walsh, B. D. The army-worm and its enemies. <Prairie Farmer, 1861, [v. 24], n. s., v. 8, p. 4. Reprint: <Trans. Ill: Nat. Hist. Soc., v. 1. Prairie Farmer, 6 December, 1861, [v.24], u. s., r. 8, pp. 370-371.

Popular account of some of the parasites of Leucania unipuncta.

11. WALSH, B. D. The army-worm. <Prairie Farmer, 1861, [v. 24], n. s., v. 8, pp. 257-258. Reprint: <Trans. Ill. State Agric. Soc., 1861, v. 4, pp. 373-375.

Hibernation of the egg; spring burning as a means against Lucania snipnncta; description of Hockeria $[=$ Haltichella $]$ perpulchra n. sp.; notes on other parasites.

12. WALSh, B. D. The army-worm and its insect foes. <Prairie Farmer, 1861, [v. 24|, n. s., v. 8, pp. 322-323 ; 337-339; 354355.

Habits and description of larva and imago of Leucania unipuncta; hibernation of the egg; figures of larva, pupa and imago; also of Exorista $[=\mathrm{Ne}-$ morca] lencanice, Pezomachus minimus, Microgaster [=Apantelcs] militaris, Hockeria [= Haltichella] perpulchra and Glyphe viridascens.

13. Walsh, B.D. Bug preying on honey-bee. <Prairie Farmer, 1861. S.-b., No. 4, p. 7.

Unknown heteropteron, said to prey on Apis mellifica. 
14. Walsh, B. D. The pea and its insect foe. <Prairie Farmer, 1861. S.-b., No. 4, p. 12.

Unknown lcaf-mincr and leaf-eater on pea; directions for rearing insects.

15. WaLsh, B. D. The grain weevil. <Journ. 1ll. State Agric. Soc., January, 1862, fig. Reprint: <Trans. Ill. State Agric. Soc. v.

5, pp. 484-485.

Sitophilus $[=$ Calandra $]$ remotepunctata infests wheat.

16. WALSH, B. D. [Ithycerus noveboracensis.] <St. Louis Valley Farmer, March, 1862, v. 14, pp. 82-85, fig.

Ithycerus noveboracensis attacks twigs of fruit trees in nurseries.

17. Walsh; B. D. [Army-worm.] <St. Louis Valley Farmer, 1862, v. 14, p. 161.

Correction of mistake of E. S. Washington (St. Louis Valley Farmer, 1862, v. 14, p. 161), who mistook parasitic larva for young Leucania unipuncta; economy of parasites of army-worm.

18. WALSH, B. D. [Brachytarsus variegatus.] <Journ. Ill. State Agric. Soc., March, 1862, pp. 8-12, fig.

Brachytarsus variegatus parasitic (?) on a large orange-colored cecidomyid (?) larva in stems of wheat.

19. Walsh, B. D. A new insect in wheat, Bruchus. <Journ. Ill. State Agric. Soc., April, 1862. Reprint: <Trans. Ill. State Agric. Soc., $\nabla .5$, pp. 485-490.

20. Walsh, B. D. [Two apple-tree borers.] <Journ. Ill. State Agric. Soc., June, 1862, pp. 21-23.

Treats of Chrysobothris femorata and Saperda bivittata [= candida].

21. WALSH, B. D. [Colorado potato beetle.] <St. Louis Valley Farmer, July, 1862, pp. 209-210. Reprint (?): <Prairie Farmer, 6 June, 1863 , v. —, p. 356 , fig.

Doryphora 10-lineata infests egg plants, potato and tomatn vines, etc., in Kansas and Iowa.

22. WALsh, B. D. Fire-blight. Two new foes of the apple and pear. $<$ Prairie Farmer, 6 September, 1862, [v. 26], n. s., v. 10, pp. 147-149, fig. Separate: pp. 4.

Fire-blight defined; probably caused by attacks of Chloroneura malefica [=Empoasca viridescens $]$ and $C$. maligna $[=E$. obtusa $]$; characters, habits, and ravages of the same: synoptic separation of several genera of Typhlocybini; two (2) new genera and thirtcen (13) new species are described. For a list of the same see the Systematic Index. The figures show C. malefica and $C$. maligna and the venation of allied forms.

(Note.-The descriptive portion with figures is reprinted in Proc. Bost. Soc. Nat. Hist., February, 1864, v. 9, pl. 314-318.)

23. WaLsh, B. D. Plant lice, the corn-root louse, a new enemy to the corn. <Journ. Ill. State Agric. Soc., September, 1862, pp. 8-13, fig. Reprint: <Trans. Ill. State Agric. Soc., r. 5, pp. 491-497, fig.

Aphis maidis (?) infests the roots of young Indian corn as well as the stems of the roasting ears. 
24. WALSH, B. D. List of the Pseudoneuroptera of Illinois contained in the cabinet of the writer, with descriptions of over forty new species, and notes on their structural affinities. <Proc. Acad Nat. Sci. Phil., September, 1862, pp. 361-402.

One hundred and nine (109) species are enumerated; two (2) new genera and forty (40) new species are described. For a list of the same see the Systematic Index.

25. WALSH, B. D. [Erythroneura tricincta Fitch.] < St. Louis Valley Farmer, October, 1862, pp. 305-306, fig.

Erythroneura $[=$ Typhlocyba $]$ tricincta on grape-vines.

26. WALSH, B. D. Grasshoppers and locusts. < Journ. Ill. State Agric. Soc., November, 1862, pp. 1-3. Reprint: < Trans. Ill. State Agric. Soc., v. 5, pp. 497-499.

Injuries of locusts in the Mississippi Valley; differences between locusts and Cicadas.

27. WALSH, B. D. On the genera of Aphidce found in the United States. < Proc. Ent. Soc. Phil., December, 1862, v. 1, pp. 294-311, figs. $1-8$.

Synoptic separation of the genera; list of seventy (70) species found in the United States, with food habitat; Aphis [= Nectarophora $]$ rudbeckice Fitch, $A$. vitis? Scop., A. maidis? Fitch, Lachnus caryo Harris, Thelaxes [= Colopha ulmicola Fitch are described; one (1) new genus and eleren (11) new species are described; see the Systematic Index for a list of the same; the figures show venation and other details. Two (2) new ants, Formica aphidicola and F. [ =Lasius ] latipes, are described.

28. Walsh, B. D. [Observations on Papilio glaucus and $P$. turnus.] < Proc. Ent. Soc. Phil., February, 1863, v. 1, pp. 349-352.

Reasons for considering turnus and glaucus iclentical; the latter a dimorphic ㅇ of the former; distribution of the two forms; citation of similar case among Pierida and of analogous one among Dytiscide ; description of larva from which a black $q$ was raised.

29. Walsh, B. D. [Katydid eggs.] < Prairie Farmer, 28 February, 1863, [v. 27], n. s., v. 11, p. 132, fig.

Oviposition of katydid eggs on apple-twigs.

30. WaLsh, B. D. Fire-blight. < Prairie Farmer, 4 April, 1863, [v. 27], n. s., v. 11, p. 212, fig. S.-b., No. 1, p. 10.

Description and figures of eggs of Chloronenra malefica $[=$ Empoasca viridescens] and the slits in which they are deposited in apple-twigs; cause of fire-blight; suggestion of remedies.

31. WALSH, B. D. Insects injurious to fruit trees. < Prairie Farmer, 2 May, 1863, [v. 27], n. s., v.11, p. 276, fig. S.-b., No. 1, p.9.

Fruit and foliage of pear-trees destroyed by Capsus oblineatus [=Lygus pratensis]; description and figure of imago; habits, food-plants, and remedies.

32. WALSH, B. D. The ten-striped spearman. < Prairie Farmer, 6 June, 1863, [v.27], n. S., v. 11, p. 356, fig. S.-b., No. 1, p. 7.

Mistory, ravages, and means against Doryphora 10-lineata; figure of imago ; mentions other injurious Phytoplaga. 
33. WALSH, B.D. The plum-gouger; a new foe of the plum. < Prairie Farmer, 13 June, 1863, [v. 27], n. s., v. 11, pp. 372-373, figs. 1-3. S.-b., No. 1, p. 6.

Habits, description, and fignres of Anthonomus prunicida n. sp. [=Coccotorus scutellaris], injurious to plums; comparison with Conotrachelus nenuphar; figure of the latter.

34. WaLsh, B. D. The pium-gouger. < Prairie Farmer, $11 \mathrm{July,} \mathrm{1863,}$ $[$ [. 28], n. s., v. 12, p. 21, 2 figs. S.-b., No. 1, p. 10.

Distribution and ravages of Anthonomus prunicida [ECoccotorus scutellaris]; list of insects found on plum-trees; description of Conotrachelus puncticollis n. sp. $[=C$. geminatus $]$; usefulness of Reduvius raptatorius $[=$ Sinca diadema]; figures $A$. prunicida and $R$. vaptatorius.

35. WaLSH, B. D. A new fruit foe. < Prairie Farmer, 18 July, 1863, [v. 2S], 1. s., v. 12, p. 37, fig. S.-b., No. 1., p. 11.

Description and fignre of imago of Epiccerns imbricatus; injnries to fruit trees and gooseberry-bushes; supposed habits of this and allied species; hibernation of the larva of Conotrachelus; description of C. cratagi n. sp.

36. Walsh, B. D. Leaf-hopper. < Prairie Farmer, 25 July, 1S63, [v. 28 , n. s., v. 12, p. 53.

Proconia [ = Oncomctopia $]$ undata injurious to grape-vines in southern Illinois; its eggs laid in twigs.

37. WaLsH, B. D. Locust borers. <Prairie Farmer, 15 August, 1863, [v. 28], n. s., v. 12, p. 101. S.-b., No. 1, p. 12.

Description and habits of Clytus [=Cyllenc] robinice; Ciytus of Carya does not attack Robinia; Cossus robinice mentioned; larva and imagos of Nitidulida found under decaying bark.

38. WALsH, B. D. Insect friends and insect foes. The twice-stabbed lady-bird. <Prairie Farmer, 1863, [v. 28], n. s., v. 12; 22 August, p. 117, figs. 1, 2; 29 August, p. 133, figs. 3, 4. S.-b., No. 1, pp. 11-12.

Description and fignre of imago of Chilocorns bivulnerus ; figure of larva; destruction of injnrious insects by predaceous insects; brief description, of and means against Lytta cinerea [= Macrobasis unicolor], fonnd on potato, English bean, and apple, and $L$. [= Epicauta $]$ vittata, on potato; fignres Lyita atrata [=Epicauta pennsylvanica $]$, found on aster and potato, and larva-cases of Solenobia sp. from under bark of apple-trees; note on allies of Solenobia.

39. WaLsh, B. D. Observations on certain N. A. Neuroptera, by H. Hagen, M. D., of Konigsberg, Prussia'; translated from the original French MS., and published by permission of the author, with notes and descriptions of abont twenty new N. A. species of Pseudoneuroptera. < Proc. Ent. Soc. Phil., October, 1863, v. 2, pp. 167-272, fig.

Dr. Hagen's comments relate to the species described in No. 24; the author's notes supplement these and describe three (3) new genera and twenty-three (23) new species; for a list of these, see the Systematic Index; descriptions of previously deseribed species, with notes on their liabits, distribution, etc., are also given; Batis interlineata $[$ = Siphlurus femoratus $]$ is proposed 
39. W ALSH, B. D.-Continued.

(p. 190) in case $B .[=S$.$] femorata Walsh is distinct from B .[=S$. $]$ femorata Say; in a note (p. 255) Ophiogomphus mainensis $11 . \mathrm{sp}$. is deseribed from Paekard's manuscript; the venation of the Odonata and the terminal abdominal eharaeters of Sialis infu:nata are figured.

40. W ALSH, B. D. On certain remarkable or exceptional larvæ, coleopterous, lepidopterous, and dipterous, with descriptions of several new genera and species, and of sereral species injurious to vegetation, which have been already published in agricultural journals. <Proc. Bost. Soc. Nat. Hist., February, 1864, v. 9, pp. $286-318$.

Fabits of the larva of Cotalpa lanigera, Pelidnota punctata, Cratonychus $[=\mathbb{M e -}$ lanotus] incertus, and Xyloryctcs satyrus; comparative eharacters of the larva and imago of Halisidota antiphola n. sp. [= tessellaris ]; deseription of larva, pupa, and imago of Sphingicampa (n. g.) distigma n. sp. [ =bicolor $]$; characters and affinities of Dryocampa [= Sphingicampa] bicolor?; deseription of imagos of Limacodes scapha and L.? [= Phobetron] hyalinus n. sp., and of larva of the last and J.? [ = Phobetron?] tetradactylus n. sp. ; deseription of the larva, pupa, and imago of Hipparchiscus n. g. venustus n. sp. [= Aplodes mimosaria ]; habits and description of the larva of an undetermined Tabanus, description of the pupa; deseription of the larva, pupa, and imago of Midas fulvipes n. sp., habits of its larva. On pp. 309-318 descriptions of several new species, with brief notes of food-habits, ete., are reprinted from various agrieultural journals.

41. WaLSH, B. D. On dimorphism in the hymenopterous genus Cynips; with an appendix containing hints for a new classification of Cynipida and a list of Cynipida, including descriptions of several new species, inhabiting the oak-galls of Illinois. <Proc: Ent. Soc. Phil., March, 1864, v. 2, pp. 443-500, fig.

Detailed observations proving the frequent oecurrenee of dimorphism in the Cynipida; Cynips [-Amphibolips] aciculata, a dimorphie form of C. $q$. spongifica; eoncludes from analogy "that aciculata $\subsetneq$ generates galls which produce by parthenogenesis of spongifica exelusively, and that $q q$ spongifica coupling in June with these of of oviposit in the same month in the young buds of the oak, the eggs lying dormant till the following spring, when some of the eggs produce $q$ spongifica in June, and sonce $q$ aciculata in the autumn or early in the following spring, which last in their turn, as before mentioned, generate of spongifica to appear in the following June;" interesting details eoncerning the history of the group are given; relations between the true gall-flies (Prenides) and parasitic Cynipida (Inquiline); classification and charaeters of the same; anatomieal structure and homologies of the family; the list includes fifteen (15) speeies inhabiting the various oaks, with descriptions of their galls and of several new speeies; seven (7) species of Inquitince are described; for the new species, see the Systematic Index; the figures illustrate the anatomy of the abdomen and ovipositor.

42. Walsh, B. D. The four-humped Curculio. A new foe of the apple. <Valley Farmer. Reprint: <Prairie Farmer, 27 August, 1864, [v. 30], n. s., v. 14, p. 131, 2 figs. S.-b., No. 1, p. 28.

Description and figures of Anthonomus quadrigibbus, a foe of the apple; comparison with Conotrachelus ncuuphar and Anthonomus pruvicida $[=$ Coccotorus scutellaris]. 
43. Walsh, B. D. On the pupa of the ephemerinous genus Batisca Walsh. <Proc. Ent. Soc. Phil.; August, 1864, v. 3, pp. '200206, fig.

Description and figures of the pupa of Bctisca obesa Say.

44. WALsH, B. D. On certain entomological speculations of the New England school of naturalists. <Proc. Ent. Soc. Phil., August-September, 1864, v. 3, pp. 207-249.

Discussion of statements, chiefly. by Prof. L. Agassiz, upon questions in general entomology. The memoir is divided into sections; in the first, the fistribution of insects in North America is discussed in opposition to the views of Agassiz; in the second section the Darwinian theory of the origin of species is discussed and some remarks on the variation of several species are added; in the third and fourth sections the statements of Prof. Agassiz regarding tho worm-like larva stage of insccts and the resemblances between the pupw of insects and the Crustacea are discussed and criticised; in the fifth section the author argues that the relative rank of the different orders of insects must be determined from a consideration of all the characters of each order and not from the significance of any one character; the sixth section is a review of Dana's classification of insects on the principle of cephalization; and in the seventh section several erroneous statements and generalizations in the same author's paper on classification are pointed out.

45. WALSH, B. D. On phytophagic varieties and phytophagic species. <Proc. Ent. Soc. Phil., November, 1864, v. 3, pp. 403-430.

Many species fced exclusively upon a single food-plant, while other species feed upon many kinds; correlated with this are certain larval or imaginal differences; when these different forms interbrecd they are considered the same species and are termed phytophagic varieties; these when separated with a single kind of food-plant form phytophagic races, and these again by a continuation of their isolation form phytophagic species. Phytophagous forms are most abundant where the imago is wingless. Diapheromera velii, Tingis [=Gargaphia] tilia, and $T .[=G$.$] amorphe are$ described as new; the following are mentioned in the remarks upon spccies and varietics: Haltica [= Disonycha] alternata, Chrysomela scalaris, Clytus $[=$ Cyllene $]$ robinice, C. $[=C$.$\rfloor pictus, Dryocampa [=$ Sphingicampa $]$ bicolor, Sphingicampa distigma [= bicolor $]$, Bombyx [= Sericaria $]$ mori, Halisidota tessellaris, $H$. carya, $H$. antiphola $[=$ tessellaris $]$, Cynips $[=$ Amphibolips $] q$. spongifica, $C .[=$ Andricus $] \dot{q} \cdot$ punctata, $C .[=A] q$. podagrat, and $C .[=A m-$ phibolips] q. inanis.

46. WALSH, B. D. On the insects, coleopterous, hymenopterous, and dipterous, inhabiting the galls of certain species of willow. Part 1st-Diptera. <Proc. Ent. Soc. Phil., December, 1864, v. 3, pp. 543-644.

Structural characters, habits, metamorphoses, etc., of Cecidomyide ; reınarks on the unity of habits in genera; synopsis of cecidomyidlous galls of Salix ; descriptions of new species, their galls and inquilines; for a list of the new species, see the Systematic Index. See No. 197 for Part 2d.

47. WaLsh, B. D. The borer. <Colman's Rural World. Reprint: $<$ Prairie Farmer, 6 May, 1865, v. 15, p. 355.

Notice of soap as a meaus against borers. 
48. WALSH, B. D. The new potato-bug and its natural history. < Pract. Ent., 30 October, 1865, v. 1, pp. 1-4.

Recori of the spread eastwards of Doryphora 10-lineata; description of the egg; food-plants, enenies, and means against the same ; comparative characters of $D$.juncta and D. 10-lineata; snecies of Meloide injurious to the potato.

49. [W ALsh, B. D.] The joint-worm. <Pract. Ent., 27 November, 1865, v. 1, pp. 11, 12 .

Reasons for disbelieving that the joint-worm is the larva of one of the Chalcidide.

50. Walsh, B. D. On phytophagic varieties and phytophagie species, with remarks on the unity of coloration in insects. <Proc. Ent. Soc. Phil., November-December, 1865, v. 5, pp. 194-210, fig. See : <Amer. Journ. Sci., September, 1865, ser. 2, v. 40, pp. 282-284. <Ann. and Mag. Nat. Hist., Norember, 1865, ser. 3, v. 16, pp. 383,384 .

Argues for the origin of races and species by pliytophagic isolation; refers to Datana ministra, D. contracta, Halisidota tessellaris, H. antiphola $[=H$. tessellaris $], H$. harrisii $[=H$. tessellarns $]$, Arhopalus $[=C y l l e n e]$ pictus, $A .[=C$. robinice, A. infaustus [=C. decorus], Callidium anlennatum, C. janthinum, Conotrachelus nenuphar, Doryphora 10-lineata, and D. juncta; unity of coloration explained by assumption of a genetic connection between various spccies; figure showing bullæe on wing of lchneumon.

51. W[Alsh], B. D. [Cicada years.] < Pract. Ent., 25 December, 1865, v. 1, pp. 18-19.

Answer to inquiry of M. S. Hill; Cicada districts of the United States, as given by Fitch in N. Y. Rept. I, p. 39; habits of $C$. [= Tibicen] septendecim.

52. WALsH, B. D. Insects injurious to vegetation in Illinois. <Trans. Ill. State Agric. Soc., 1865, v. 5, pp. 469-483, figs.

Notes on injurious insects in Illinois in 1861; life-history and ravages of Leucania unipuncta.

53. WALsH, B. D. The "Thrips" of the vine-growers. What is it? < Pract. Ent., 25 December, 1865, v. 1, pp. 20-21.

The Thrips of fruit-growers probably not a true Thrips; food-habits of Thrips.

54. WaLsh, B. D. The grub-worm. <Colman's Rural World, December, 1865. S.-b., No. 1, p. 51.

Habits, ravages, and means against Lachnosterna quercina $[=$ fusca $]$; its larva compared with that of Ligyrus relictus; vernacular names of the Lachnosterna and of Allorhina nitida.

55. Walsh, B. D. Borers. <Pract. Ent., 29 January, 1866, v. 1, pp. 25-31, figs. 1-8.

Remarks on the name "borer;" figures, natural history, and means against Saperda bivittata $[=$ candida $]$, Chrysobothris femorata, Bostrichus $[=$ Amphicerus $]$ bicaudatus, LEgcria [= Sannina $]$ exitiosa, A. tipuliformis, Clytus $[=C y l$ lene $]$ robinia, $C .[=C$. $]$ pictus, and Cerasphorus $[=$ Chion $]$ cinctus; need of State aid against injurious insects. 
56. [W 4 LSH, B. D.] [Attagenus? injuring feathers.] <Pract. Ent., 26 February, 1866, v. 1, p. 34.

Anstrer to inquiry of $\mathrm{R}$. Parnell ; ravages of and means against Dermestidce.

57. [WALsh, B. D.] [Codling moth.] <Pract. Ent., 26 February, 1866, v. 1, p. 34 .

Answer to inquiry of Isaac Hicks; natural history and means against $\mathrm{Car}$ pocapsa pomonella.

58. [WaLsh, B. D.] [Aphidida.] <Pract. Ent., 26 February, 1S66, v. 1, p. 34 .

Answer to inquiry of J. H. Foster, jr. ; comparative characters of Eriosoma $[=$ Schizoneura $]$ lanigera and Pemphigus pyri $[=$ Schizoneura lanigera $]$.

59. [WALsh, B. D.] [Mites mistaken for plant-lice.] < Pract. Ent., 26 February, 1866, v. 1, p. 34 .

Answer to inquiry of W. M. Smith; distinctive characters of Insecta and Arachnida; description and habitat of the eggs of Aphis mali.

60. [WALsh, B. D.] [Saddle-back caterpillar.] <Pract. Ent., 26 February, 1866, v. $1,13.34$.

Answer to inquiry of S. P. M. ; description of the larva and imago of Empretia stimulca; urticating properties of the larva.

61. W[ALSH], B. D. [Red-humped prominent.] <Pract. Ent., 26 February, 1866, r. 1, p. 35.

Answer to inquiry of E. D. Wright; life-habits of Notodonta [= Edemasia $]$ concinna.

62. WALSH, B. D. The joint-worm. <Pract. Ent., 26 February, 1S66, v. 1, pp. $37-38$.

Habitats of the larva of Cecidomyia destructor and of Eurytoma sp.; criticism of A. Fitch's report upon the latter.

63. W[ALSH, B. D.]. Entomology all a humbug. <Pract. Ent., 26 February, 1866, v. 1, p. 39.

Ferrness of entomologists and the multiplicity of their duties the reason why so little has' been effected against noxious insects.

64. W[ALsh], B. D. [Cocoons of Ichneumon-flies.] <Pract. Ent., 26 March, 1866, v. 1, p. 46.

Answer to inquiry of M. S. Hill; life-habits of the Microgasters.

65. W[ALSH], B. D. [Mass of eggs.] <Pract. Ent., 26 March, 1866, г. 1, p. 46.

Answer to inquiry of T. R. Payne; characters and life-habits of Orgyia leucostigma.

66. [WALSH, B. D.] [Apple-tree caterpillar; parasites.] <Pract. Ent., 26 March, 1S66, г. 1, p. 46.

Answer to inquiries of G. E. Brackett; food-plants of Clisiocampa americana; characters and habits of Tachinide; habits of secondary parasites.

67. W[ALSH], B. D. Apple-tree borers. <Pract. Ent., 26 March, 1S66, จ. 1, p. 47.

Reprint, with remarks, of "Apple-tree borers" (Jonrn. of Commerce); extract from A. Fitch, of larval habits of Saperda bivitiata [= candida].

2 ENT 
68. WALSH, B. D. The white grub. <Pract. Ent., 30 April, 1866, v. 1, pp. 60-62.

Descriptions and habits of the larval states of Lachnosterna quercina [= fusca] and Ligyrus relictus; ravages and food-habits of the former; the hog as a white-grub destroyer.

69. WALsH, B. D. [Apple-tree scaies.] <Pract. Ent., 30 April, 1866, V. 1, p. 64 .

Answer to inquiry of L. S. Pennington; descriptions and ravages of Mytilaspis pomorum and Chionaspis furfurus; Coccinellide as a means against the former; petroleum as a renedy against bark-lice.

70. WALSH, B. D. [Clothes-moths.] <Pract. Ent., 30 April 1866, v. 1, p. 64 .

Answer to inquiry of S. Canby; habits and means against Tineida.

71. WALSH, B. D. [Poplar borer.] < Pract. Ent., 30 April, 1866, v.1, p. 64 .

Answer to inquiry of P. C. Truman; larva and imago of Saperda calcarata infesting cottonwood.

72. Walsh, B. D. [Worms in flour and rye.] <Pract. Ent., 30 April, 1866, r. 1, p. 64 .

Answer to inquiry of L. D. Hunt; descriptions and habits of Tenebrio molitor and Dermestes lardarius.

73. WALSH, B. D. Popular remedies for noxious insects. < Pract. Ent., 28 Ma5, 1866, v. 1, pp. 71-74.

Criticism of various worthless remedies against injurious insects.

74. WALsh, B. D. [Serica iricolor Say.] <Pract. Ent., 28 May, 1866, v. 1, p. 77.

Answer to inquiry of B. F. Seibert; description, ravages, and habitat of Serica iricolor.

75. WALSH, B. D. [Measuring-worms.] <Pract. Ent., 28 May, 1866, พ. 1, p. 77 .

Answer to inquiry of T. Siveter; habits of Ennomos magnaria [=alniaria]; food-plants, habits, and means against $E .[=$ Eudalimia $]$ subsignaria and Anisopteryx $[=$ Paleacrita $]$ veruata.

76. Walsh, B. D. [Lygus pratensis.] <Pract. Ent., 25 May, 1866, r. 1, pp. $77-78$.

Answer to inquiry of H. B. Howarth; habits and odors of Lygus pratensis; changes insects pass through.

77. WALsh, B. D. [Apple-tree insects.] <Pract. Ent., 28 May, 1866, จ. 1, p. 78.

Answer to inquiry of C. Cooke; an unnamed tineid moth raised from cocoons off twigs of apple-tree; Homiteles sp. and Microgaster sp. bred from cocoons attached to eggs of Clisiocampa americana.

78. WALSH, B. D. [Destructive currant-worm.] < Pract. Ent., $28 \mathrm{May}$, 1866, v. 1, p. 78.

Answer to inquiry of W. M. Smith; cocoon and sexual characters of Nematus ribis $L=$ ribesii]. 
79. WaLsh, B. D. [Egg slits made by Homoptera.] < Pract. Ent., 28 May, 1866, v. 1, p. 78.

Answer to inquiry of C. Dadant; slits in pear-twigs cansed by Chloroneura malefica $[=$ Empoasca viridcscens $] ;$ Proconia $[=$ Oncometopia $]$ undata oviposits in grape-vines.

80. Walsh, B. D. [Plant-lice.] <Pract. Ent., 28 May, 1866, v. 1, p. 78.

Answer to inquiry of J. Flournoy; characters, habits, encmies, and means against Aphidida.

81. WALSH, B. D. [Insects injuring plum-trees.] < Pract. Ent., 28 May, 1866, v. 1, p. 78.

Answer to inquiry of A. C. Hammond; Egeria [=Sannina] exitiosa and an elaterid larva attacking plum-trees; the latter probably attracted by decayed matter, the work of the peach borer.

82. WALSH, B. D. Prof. Dana and his entomological speculations. <Proc. Ent. Soc. Phil., May-June, 1866, v. 6, pp. 116-121.

Rejoinder to J. D. Dana's reply to criticism upon the classification of insects.

83. Walsh, B. D. Clover-worms. <Pract. Ent., 25 June, 1866, v. 1, pp. 82-83.

Summary of published observations concerning Asopia costalis; points which need explanation; probable remedy.

84. WaLsh, B. D. Click-beetles. <Pract. Ent., 25 June, 1866, v. 1, p. 83 .

Note to W.'s "Click-beetles;" snapping of Elateride; Jaeger's Life of N. Am. Insects and Emmons' N. Y. Report unreliable.

85. WALSh, B. D. Cut-worms. <Pract. Ent., 25 June, 1866, v. 1, pp. $85-86$.

Definition, food-habits, and means against cut-worms; climbing habits; cut. worms in California. Sce Nos. 229, 281.

86. WALSH, B.D. The canker-worm. Finding a mare's nest. < Pract. Ent., 25 June, 1866, v. 1, p. 87.

Criticism of communication in Western Rural; improbability of the report that Anisopteryx [= Paleacrita $]$ vernata deposits her eggs on the ground.

87. WALsh, B. D. Driving nails into fruit trees. <Pract. Ent., 25 June, 1866, v. 1, pp. 87-88.

Uselessness of nails as a means against borers; - extracts from various sources, with comments.

88. WALSH, B. D. The new potato-bug. <Pract. Ent., 25 June, 1866, v. 1, pp. 88-89.

Rəcords Doryphora 10-lineata at Bloomington and Athens, Ill.; rate of its eastern progress; need of legislative action against injurious insects.

89. WALSH, B. D. [The painted borer.] <Pract. Ent., 25 June, 1866, v. 1, p. 89.

Answer to inquiry of T. C. Wright; sexual difference in the antenria of Clyan tus $[=$ Cyllene $]$ pictus bred from hickory, 
90. WaLsh, B. D. [Bug allied to the chinch-bug.] < Pract. Ent., 25 June, 1866, v. 1, p. $\$ 9$.

Answer to inquiry of H. B. Howarth; comparative characters of Blissus leucopterus and an unnamed lygæid of similar.habits.

91. WALsh, B. D.' [Canker-worms.] <Pract. Ent., 25 June, 1866, v. 1, p. 89.

Answer to inquiry of C. H. W. Wood ; means against Anisopteryx.

92. WaLSH, B. D. [Apple-tree tineid.] <Pract. Ent., 25 June, 1866, v. 1, p. 89.

Answer to inquiry of C. Cooke; food-plant of Bucculatrix pomifoliella.

93. WALsh, B. D. [Spittle insect.] < Pract. Ent., 25 June, 1866, r. 1, p. 89.

Answer to inquiry of M. V. B. Hathaway; life-habits of species of Aphrophora.

94. WaLsh, B. D. [Insects named.] <Pract. Ent., 25 June, 1866, v. 1, p. 89.

Answer to inquiry of E. Hall ; occurrence of Doryphora 10-lineata at Athens, Ill. ; Hippodamia $[=$ Megilla $]$ maculata devours the eggs of the same; two species of Cassida affect the sweet-potato.

95. Walsh, B. D. [Longicorn borers.] <Pract. Ent., 25 June, 1866, v. 1, p. 90 .

Answer to inquiry of Dr. Trimble; food-habits of Orthosoma cylindricum, [= brunneum $]$, Prionus laticollis, and P. imbricomis.

96. Walsh, B. D. [Canker-worms.] <Pract. Ent., 25 June, 1866, v. 1, p. 90.

Answer to inquiry of F. K. Phœnix ; season of oviposition of Anisopteryx.

97. Walsh, B. D. [White-pine scale.] <Pract. Ent., 25 June, 1866, v. 1, p. 90 .

Answer to inquiry of H. Shimer ; Aspidiotus [= Chionaspis ] pinifolii infesting' Pinus strobus.

98. WALsh, B. D. Doctors differ. <Pract. Ent., 30 July, 1866, v. 1, p. 96.

Criticism of communications in agricultural papers ; tanners' oil injurious to trees; sulphur plugged in trees does not protect the leaves; sheep in an orchard do not keep away Conotrachelns nenuphar.

99. Walsh, B. D. The grain plant-louse. <Pract. Ent., 30 July, 1866, v. 1, pp. $96-97$.

The insect attacking small grains in Georgia is probably a plant-louse.

100. Walsh, B.D. Popular names for insects. < Pract. Ent., 30 July, 1866, v. 1, p. 97.

The use of the same vernacular name for different insects causes uncertainty in identifying and in suggesting means against injurious insects.

101. Walsh, B. D. Scientific names. <Pract. Eut., $30 \mathrm{July}, 1866$, v. 1, pp. 97-99.

Explains the necessity of using Latin for scientitic names. 
102. WaLsh, B. D. [Grape-vine insects.] <Pract. Ent., 30 July, 1866, v. 1, pp. 99-100.

Answer to inquiry of C. S. Jackson; lıabits of an undescribed Fidia; injuries to vines by plant-lonse (Aphis vitis?); enemies of Aphidida.

103. WaLsh, B. D. [Wire-worms.] <Pract. Ent., 30 July, 1866, v. 1, , p. 100.

Answer to inquiry of A. D. Chesebro; summer fallowing as a means against wire-worms.

104. WaLsh, B. D. [Bark.lice.] <Pract. Ent., 30 July, 1866, v. 1, p. 100.

Answer to inquiry of L. E. Harmon; life-history and means against Coccida.

105. WaLsH, B. D. [Tortoise beetles.] <Pract. Ent., 30 July, 1866, v. 1, p. 100.

Answer to inquiry of C. K. Yant: food-plants and larval habits of Cassidida.

106. WALsh, B. D. [Grape bark-louse.] <Pract. Ent., 30 July, 1866, v. 1, p. 100.

Answer to inquiry of J. Bird; description and ravages of Lecanium $[=P u l$ vinaria] ritis.

107. Walsh, B. D. [Plum bark-louse.] <Pract. Ent., 30 July, 1866, v. 1, p. 100.

Answer to inquiry of $\mathrm{O}$. B. Douglas.; description of Lecanium sp.

108. Walsh, B. D. [Saw-fly eggs.] <Pract. Ent., 30 July, 1866, v. 1, p. 100.

Answer to inquiry of L. D. Morse; pósition of saw-1ly eggs on oak-leaf; characters of the larvie of Tenthredinida.

109. Walsh, B. D. [Wheat midge.] <Pract. Ent., 30 July, 1866, v. 1, p. 101.

Answer to inquiry of R. F.; ravages, description, habits, ald means against Cecidomyia $[=$ Diplosis $]$ tritici.

110. Walsh, B. D. [Wheat midge.] <Pract. Ent., 30 July, 1866, v. 1, p. 101.

Answer to inquiry of M. H. Boye; Cecidomyia [=Diplosis $]$ tritici not infrequeutly passes from larval to imaginal state in the same season; means against the sanie.

111. Walsh, B. D. [Grape galls.] <Pract. Ent., 30 July, 1866, v. 1, p. 101.

Answer to inquiry of J. H. Foster, jr.; description of the galls and larva of Cecidomyida.

112. WALsH. B. D. [Apple-tree web-caterpillar.] < Pract. Ent., 30 July, 1866, v. 1, p. 101.

Answer to inquiry of Marion Hobart; description of the eggs of Clisiocampa americana; food-plants of the same and of Hyphantria textor [= cunea]. 
113. WALSH, B. D. [Grape-rine beetles.] <Pract. Ent., 30 July, 1866. v. 1, p. 101.

Answer to inquiry of M. S. Hill; food-habits of the larva and imago of Pelidnota punctata and of Anomala lucicola.

114. WALSH, B. D. [Bot-flies.] <Pract. Ent., 30 July, 1866, v. 1, p. 102.

Answer to inquiry of J. B. Fisher; habits and hosts of several species of Estride; parasite infesting Triplax [= Tritoma $]$ thoracica. See No. 153.

115. WALSH, B. D. [Spruce-tree saw-flies.] <Pract. Ent., 30 July, 1866, v. 1, p. 102.

Answer to inquiry of J. Barratt; description of cocoon and imago of Lophyrus abietis; means against the same. See Pract. Ent., v. 1, p. 114.

116. WALsh, B. D. [Stings of insects.] <Pract. Ent., $30 \mathrm{July}, 1866$, v. 1, p. 102 .

Answer to inquiry of A. O. Brickman; effects of the stings of bees and other inscets.

117. WALSH, B. D. [Blackberry scale.] <Pract. Ent., 30 July, 1866, จ. 1, p. 102.

Answer to inquiry of G. E. Brackett; characters of Lecanium sp. infesting blackberry;

118. WaLsh, B. D. [Eggs in sumach.] <Pract. Ent., 30 July, 1866, v. 1, p. 102.

Answer to inquiry of W. M. Smith; eggs of Orchelimum sp.? or Xiphidium sp.? in pith of sumacb.

119. W[ALSH], B. D. The "new potato-bug" in Maine. <Pract. Ent., 27 August, 1866, v. 1, p. 105.

Extract from Maine Farmer, $26 \mathrm{July}$, 1866, with comments; the larva of Lema trilineata mistaken for that of Doryphora 10-lineata.

120. WAlsh, B. D. [The army-worm.] <Pract. Ent., 27 August, 1866 , v. 1, p. 107.

Extract from Western Rural, 21 July, 1866, with comments; army-worm mistaken for canker-worm; need of precision in using popular names.

121. W[ALSH], B. D. [Fire-cure for potato-beetles.] < Pract. Ent., 27 August, 1866, v. 1, pp. 107-108.

Extract from letter from M. S. Hill, with comments; burning straw effective as a means against Meloide infesting potato-vines; its use against Doryphora 10-lineata; hot water as a nieans against the onion-maggot and peach-borer.

122. Walsh, B. D. A new humbug. <Pract. Ent., 27 Angust, 1866, v. 1, pp. 108-110.

Exposure of proposed remedy against Cecidonyia destructor; life-habits of the same.

123. W[ALSH], B. D. The striped bug. <Pract. Ent., 27 August, 1866, v. 1, p. 110, figs. 1, 2.

Extract from Western Rural, 21 July, 1866, with comments ; characters, habits, means against, and figures of Diabrotica vittata and D. 12-punctata. See No. 148. 
124. WaLsh, B. D. [Grape-vine caterpillars.] <Pract, Ent., 27 August, 1866, v. 1, P. 111.

Answer to inquiry of B. Borden; description of the early stages of Procris $[=$ Acoloithus $]$ falsarius; characters and habits of the species of Procris.

125. Walsh, B. D. [Squash-vine insects.] <Pract. Ent., 27 August, $1 S 66$, v. 1, p. 111.

Answer to inquiry of J. Cope; description and habits of Epilachna borealis; labits of Coccinellide; description and means against the larva of Trochiliun cucurbite $[=$ Melittia ceto $]$.

126. WaLSH, B. D. [Injurious insects.] <Pract. Ent., 27 August, 1866, v. 1, p. 111.

Answer to inquiry of T. Conard; larval liabits and means against Lema trilineata; work of the grain plant-louse (Nectarophora granaria) and of Trochilium cucurbitce $[=$ Melittia ceto $]$; mention of some of the enemies of bees.

127. W $\Delta$ LSH, B. D. [Grape-leaf' galls.] <Pract. Ent., 27 August, 1866, V. 1, pp. 111, 112.

Answer to inquiry of E. Daggy; description of the leaf-gall of Phylloxera vitifolice $[=$ vastatrix $]$; reasons for including it in the Coccide; dipterous enemy of the same. See No. 154.

128. WaLsh, B. D. [Grape-vine insects.] <Pract. Ent., 27 August, 1866, r. 1, p. 112.

Answer to inquiry of W. H. S.; description and means against an undescribed gall on the tendrils and leaf-stalks of a grape-vine; life-habits of parasitic Chalcidide. See No. 160.

129. Walsh, B. D. [Grape-rine beetles.] <Pract. Ent., 27 August, 1866, r. 1, pp. 112, 113.

Auswer to inquiry of W. J. Lawrence ; food-habits of Pelidnota punctata and of Colaspis flavida.

130. WALsh, B. D. [Corydalis cornutus.] <Pract. Ent., 27 August, 1866, v. 1, p. 113.

Answer to inquiry of J. S. Lewis; natural history and habits of Corydalis cornutus.

131. Walsh, B. D. [Tobacco-moth.] <Pract. Ent., 27 August, 1866, v. 1, p. 113.

Answer to inquiry of F. W. Noble; transformations and food-plants of Sphinx $[=$ Protoparce $]$ carolina; food-plants of S. 5-maculata $[=P$. celeus $]$.

132. Walsh, B. D. [Datana ministra.] <Pract. Ent., 27 August, 1866, v. 1, p. 113.

Answer to inquiry of S. S. Lacy ; food-plants and transformations of Datana ministra.

133. WALSH, B. D. [Grape-vine and fuschia beetles.] <Pract. Ent., 27 August, 1866, v. 1, p. 113.

Answer to inquiry of F. K. Phœnix; Colaspis flavida injurious to grapé-vine shoots; Haltica exapta [= carinata $]$ destructive to fuschia ; means against flea-beetles. 
134. WALsh, B. D. [Blister-beetles.] <Pract. Ent., 27 August, 1866, v. 1, p. 113.

Answer to inquiry of J. Barber; food-plants of Lytta marginata $[=$ Epicauta cinerea $], L .[=E$.$] vittata, L. atrata [=E$. pennsylvanica $]$, and $L$. cinerea $[=$ Macrobasis unicolor $]$.

135. WALsh, B. D. [Colaspis flavida; Lema trilineata.] <Pract. Ent., 27 August, 1866, v. 1, p. 114.

Answer to inquiry of J. F. Benner ; Colaspis flavida destructive to grape-vines; distribution and method of breeding Lema trilineata.

136. W ALSH, B. D. [Green worms on gooseberries and currants; Lema trilineata.] <Pract. Ent., 27 August, 1866, v. 1, p. 114.

Answer to incquiry of H. Burt; gooseberrics an 1 currants injured by larva of a saw-fly?; effects of excessive rain, licat, and dronght; food-plants of Lema trilincata.

137. Walsh, B. D. [Galls.] <Pract. Eint., 27 August, 1866, v. 1, p. 114.

Answer to inquiry of $\mathrm{H}$. Shimer; note of galls made by Rhodites radicum, Trypeta solidaginis, and Thelaxes $[=$ Colopha $]$ ulmicola.

138. WALSH, B. D. [Potato and corn insects.| <Pract. Ent., 27 August, 1866, v. 1, p. 114.

Answer to inquiry of T. H. Parsons; seareity of Lema trilineata in Illinois; Doryphora 10-lineata destroyed by turkeys, but not by fowls; Gortyna sp.? injurious to young Indian corn ; rnles for breeding insects.'

139. Walsh, B. D. [Cocoons on apple-trees.] <Pract. Ent., 27 August, 1866, v. 1, p. 114.

Answer to inquiry of M. S. Hill; description of cocoon and imago of Attacus cecropia; the interaction of organisms.

140. WALsH, B. D. Imported insects; the gooseberry saw-fly. <Pract. Ent., 29 September, 1866, v. 1, pp. 117-125, fig.

List of somo injurious Enropean insects imported into America and of American insects importcd into Europe; reasons for the increase and abundance of noxious Enropean insects in America, and why American species do not flonrish in Europe; natural history, description, and means against Nematus ventricosus [= ribesii]; figure of currant-leaf, showing method of deposition of cggs and work of larva; natural history and description of larva and imago of Pristiphora grossularice n. sp.; number of saw-flies infesting the goosebcrry and currant in Europe.

141. Walsh, B. D. [Borers.] <Pract. Ent., 29 September, 1866, v. 1, p. 126.

Answer to inquiry of W. H. R. Lykins; western distribution of Clytus $[=$ Cyllene $]$ robinia.

142. Walsh, B. D. [Wheat midge.] < Pract. Ent., 29 September, 1866, v. 1, p. 126.

Answer to inquiry of C. P. Wickershan; destrnctiveness of Cecidomyia [=Diplosis $]$ tritici; natnre of its cocoon. 
143. W Alsh, B. D. [Crickets.] <Pract. Ent., 29 September, 1866, v. 1, p. 126.

Answer to inquiry of Marion Hobart; eharaeters and food-habits of Acheta [=Gryllus] abbreviatus; katydids not exelusively vegetarians; Ecanthus niveus found feeding on plant-liee.

144. Walsi, B. D. [Walking-stick.] <Pract. Ent., 29 September, 1866, v. 1, p. 126.

Answer to inquiry of L. W. Taylor; eharaeters and habits of Spectrum [= Diaphcromera $]$ femorata.

145. Walsi, B. D. [Apple-tree insects.] <Pract. Ent., 29 September, 1866, v. 1, p. 126.

Answer to inquiry of H. B. Beegle; charaeters and food-plants of Limenitis ursula; deseription and food-plants of the larva of Lagoa opercularis; eharacters of the imago.

146. Walsh, B. D. [Mites on grasshoppers.] <Pract. Ent., 29 September, 1866, v. 1, p. 126.

Answer to inquiry of W. Riddell; Astoma [= Trombidium $]$ locustarum infesting Caloptenns femur-rubrum.

147. W[ALSh], B. D. Grasshoppers and locusts. <Pract. Ent., October, 1866, v. 2 , pp. 1-5, 22.

Description, migration, and ravages of Caloptenus spretus ; limits of its range and means of preventing its increase; eonfusion caused by the use of popular names of insects. On p. 22 a "note," aeeidentally omitted, gives the comparative length" of the wing-eovers and antennæ of Caloptenus spretus and C. femur-rubrum.

148. W[ALSH], B. D. The striped cucumber-bug. <Pract. Ent., October, $1866, \mathrm{v} .2, \mathrm{p} .5$.

Diabrotica vittata attacks German asters. See No. 123.

149. W[ALSH], B. D. Fire-blight. <Pract: Fint., October, 1866, v. 2, p. 7.

Extraet from Horticulturist, with conments; cause of fire-blight unknown; not produced by Scolytus [= Tyleborus $]$ pyri.

150. W[ALSH], B. D. The Hessian fly. <Pract. Ent., October, 1866, v. 2, p. 7 .

Extract from Colman's Rural World, with eomments; late sowing as a means against Cecidonyia destructor.

151. [WALSH, B. D.] [Injurious caterpillars; plant-lice enemies.] $<$ Pract. Ent., October, 1866, v. 2, pp. 7-8.

Answer to inquiry of T. McGraw; habits, deseriptions, and food-plants of larva of Dryocampa senatoria and of Datana ministra; food-habits of larva allied to D. ministra; deseription and habits of larva of Scymnus sp.; S. hamorrhous? bred from gall of Thelaxes [=Colopha] ulmicola.

152. [WaLsh, B. D.] [Tomato-Worm.] <Pract. Ent., October, 1866, r. 2, p. 8.

Answer to inquiry of A. A. Jackson; description of the larva and pupa of Protoparce celens; food-plants and harmlessness of the larva. 
153. [WALsh, B. D.] [Dipterous larva on swallows.] <Pract. Ent., October, 1866, r. 2, p. 8 .

Answer to inquiry of J. B. Fisher; larvæ found on swallows (see No. 114) belong to the Muscidae and not to the CEstrida; extract from letter of Osten Sacken on larval habits of Muscide found with birds.

154. [WALSH,'B. D.] [Bark-louse enemy.] <Pract. Ent., October, 1866, v. 2, p. 8 .

Answer to inquiry of E. Daggy; see No. 127; according to Osten Sacken the bark-louse enemy belongs to Leucopis; systematic position of the genus.

155. [Walsi, B. D.] [Parasitized tomato-worm.] <Pract. Ent., October, 1866, . . 2, pp. 8-9.

Answer to inquiry of T. C. Wright; habits of Microgaster, parasitic on Protoparce celeus; habits of ichneumonized lэrvæ.

156. [WALSH, B. D.] [Beetles on buttercup and azalea.] <Pract. Ent., October, 1866, v. 2, p. 9.

Answer to inquiry of C. H. Peck; identification of Galeruca [=Adimonia] rufosanguinea, found on Ranunculus acris, and of Prasocuris varipes on Azalea. nudiflora; synoptic table, by J. L. Leconte, of the species of Prasocuris.

157. [Walsh, B. D.] [Flying-bug.] < Pract. Ent., October, 1866, v. 2, p. 9.

Answer to inquiry of E. E. Sheldon; Aphodius mistaken for Cecidomyia destructor.

158. [WaLSH, B. D.] [Parasitic cocoon.] <Pract. Ent., October, 1866, v. 2, p. 9 .

Answer to inquiry of $\mathrm{H}$. W. Howarth; description of cocoons made by Microgaster and Pezomachus; habits of Ichneumonide.

159. [WaLsh, B. D.] [Oak-bark louse.] <Pract. Ent., October, 1866, г. 2, p. 9 .

Answer to inquiry of T. Meehan; undetermined Coccus on red-oak.

160. [WALSH, B. D.] [Grape-galls.] <Pract. Ent., October, 1866, v. $2, \mathrm{p} .9$.

Answer to inquiry of W. H. S.; see No. 128; larva of Leucopis sp., an enemy to grape-vine gall-louse; probable identity of the maker of the tendril and leaf-galls; varieties of grape infested by Phylloxera vastatrix.

161. [Walsh, B. D.] ["Saddle-back."] <Pract. Ent., October, 1866. v. 2, p. 9.

Answer to inquiry of 'T. M. Harvey; food-plants, description, and urticating properties of Empretia stimulea.

162. [WALSH, B. D.] [Corn-worm.] <Pract. Ent., October, 1866, v. 2, p. 9 .

Answer to inquiry of J. B. Elīis; method of work of two lepidopterous larvæ.

163. [WALSH, B. D.] [Insects named.] <Pract. Ent., October, 1866, v. 2, p. 10.

Answe to inquiry of W. C. Fish ; comparative characters of Entitia sinuata and $E . r=$ Publilia] concava. 
164. [WALSH, B. D.1 [Grape insects.] <Pract. Ent., October, 1866, v. 2, p. 10.

Answer to inquiry of J. H. Garman; description and habits of larva of Procris $[=$ Harrisina $]$ americana ; Proconia $[=$ Oncometopia $]$ undata and several species of Erythroneura $[=$ Typhlocyba $]$ as grape enemies.

165. [Walsh, B. D.] [Datana ministra.] <Pract. Ent., October, 1866, v. 2, p. 10.

Answer to inquiry of J. B.; increase of injuries cansed by Datana ministra; distinctive characters of the larvie of Geometride.

166. [WALsh, B. D.] [Iulus marginatus.] <Pract. Ent., October, 1866, v. 2, p. 10.

Answer to inquiry of T. Wiggins; characters and food of fulus [= Spirobolus $]$ marginatus.

167. [WALsh, B. D.] [Midge.] <Pract. Ent, October, 1S66, v. 2, p. 10.

Answer to inquiry of W. G. Morris; characters and habits of the larva and imago of Chironomus sp.

168. [Walsh, B. D.] [Rat-tailed larva.] <Pract. Ent., October, 1866, v. 2, p. 10.

Answer to inquiry of J. A. Lapham; characters and habitats of the larvæ of rat-tailed Syrphide.

169. [WALsh, B. D.] [Beetle on thistle.] <Pract. Ent., October, 1866, จ. 2, p. 10.

Answer to inquiry of W. S. Robertson; characters and food-plants of Phyllobrotica $[=$ Diabrotica $]$ longicornis.

170. [WaLsh, B. D.] [Grape.vine Aplis.] <Pract. Ent., October, 1866, v. 2 , p. 10.

Answer to inquiry of H.; grape-vine injured by Aphis vitis.

171. W[ALSH], B. D. The new potato-bug. <Pract. Ent., November, 1866 , v. 2, pp. 13-16, fig.

Eastern progress of Doryphora 10-lineata; rate of travel; hand-picking the only effective remedy; description of a horse machine for their destruction; pecuniary loss inflicted by the species.

172. W[ALSH], B. D. The canker-worm <Pract. Eut., November, 1866, v. 2, p. 16.

Tarring trees effective against Paleacrita vernata.

173. W[ALSH $]$, B. D. The canker-worm again. <Pract. Ent., November, 1866 , v. 2, pp. 16-17.

Critical review of article in New England Farmer; value of tarring as a means against Paleacrita vernata.

174. Walsh, B. D. Notes by Benj. D. Walsh. <Pract. Ent., Norember, 1866, v. 2, pp. 19-20.

Remarks on statement of $\mathrm{H}$. Shimer in his paper, "The grape leaf gall-coccus" (Pract. Ent., pp. 17-19); number of cggs to cach 9 ; tendril and leafgalls probably produced by the same insect; old leaves entirely free from bark-lice by the end of summer; characters of the pupa of Eencopis; systematic position and food-habits of Thysenoptera; critisism of paper by H. Shimer in Prairie Farmer, 3 November, 1861. 
175. W[ $[\Delta \mathrm{LSH}]$, B. D. The striped bug. <Pract. Ent., November, 1866, v. 2, p. 20.

Remarks on note by A.; effects of plaster as a means against Diabrotica vittata.

176. [WALSH, B. D.] [Currant insects; Psocus venosus.] <Pract. Ent., November, 1866, v. 2, p. 20.

Answer to inquiry of I. Hicks; occurrence of Pristiphora grossularice in the Eastern States; Ellopia [=Eufitchia] ribearia injurions to currant; date of introduction of "sulphur-cure" on peach-trees; characters and habits of Psocus venosus.

177. [WALSH, B. D.] [Worm in apple.] < Pract. Ent., November, 1866, v. 2, pp. 20-21.

Answer to inquiry of C. Ward; description and ravages of larva of Trypeta pomonella?

178. [WALsh, B. D.] [Insects attracted to light.| < Pract. Ent., November, 1866, v. 2, p. 21.

Answer to inquiry of Practical Pomologist; conditions favorable for attracting insects to light; kinds most frequently attracted; the proportion of injurious species attracted.

179. [Walsh, B. D.] [Zebra caterpillar.] < Pract. Ent., November, 1866, v. 2, p. 21.

Answer to inquiry of J. H. Parsons; description of the larva of Mamestra picta; times of transformation.

180. [WALsh, B. D.] [Inquiries answered.] <Pract. Ent., November, 1866, v. 2 ; p. 21.

Answer to inquiry of J. Pettit; identification of several beetles; galls on golden-rod made by Euryptychia saligneana and Trypeta solidaginis; characters of short-winged form of Micropus $[=$ Blissus $]$ lencopterus; its occurrence in Canada.

181. [Walsh, B. D.] [Worm in corn.] <Pract. Ent., November, 1866, v. 2, pp. 21-22.

Answer to inquiry of J. B. Ellis; description of larva, habits, transformations, and means against an undetermined noctuid.

182. [Walsh, B. D.] [Bag-worms.] <Pract. Ent., November, 1866, จ. 2, p. 22.

Auswer to inquiry of C. P. Wickersham; characters and synonymy of Thyridopteryx ephemer aformis.

183. [WALSH, B. D.] [Ichneumon cocoons.] <Pract. Ent., November, 1866, v. 2 , p. 22.

Answer to inquiry of S. A. N.; characters of cocoons of Microgaster sp.?

184. Walsh, B. D. Note. <Proc. Ent. Soc. Phil., December, 1866, v. 5 , p. 260.

Withdraws assertion attributed to C. R. Osten Sacken.

185. W[ALSH], B. D. The old-fashioned potato-bugs. <Pract. Ent., December, 1866, v. 2, pp. 25-27, figs.

Natural history and means against Lema trilineata, Lytta [= Epicauta] vittata, $L$. atrata $[=E$. pennsylvanica $], L$. marginata $[=E$. cinerea $]$, and $L$. cinerea [=Macrobasis unicolor]; figures L. trilineata and $E$. vittata. 
186. W[ALSH], B. D. Klippart's wheat plant. <Pract. Ent., December, 1866, v. 2, pp. 27-29.

Adverse criticism of the entomological portion of the above-named book.

1S7. W[ $[\mathrm{LSH}], \mathrm{B} . \mathrm{D}$. Trimble's insect enemies of fruit and fruit trees. <Pract. Ent., December, 1866, v. 2, pp. 29-30.

Favorable review of the above-named book.

188. W[ALSh], B. D. Answer to the above, by B. D. W. < Pract. Ent., December, 1866, v. 2, pp. 31-33, figs.

Answers to questions asked in J. S. Houghton's "Insects in the Orchard" (Pract. Ent., pp. 30-31); food-habits and hibernation of Conotrachelus nenuphar; comparative characters and figures of Aspidiotus conchiformis [= Mytilaspis pomorum] and Coccus harrisii [=Chionaspis furfurus]; natural history of $C$. harrisii; means against and enemies of the two species; figures Chilocorus bivulnerus and Hippodamia [= Megilla] maculata; foodhabits and synonymy of Lytta [=I'omphopœa] sayi; flowing as a means against root-feeding insects; inefficacy of salt, lime, ashes, etc., against the same; insects attacking evergreens not likely to injure fruit trees; cannibal habits of spiders; habits of bees and wasps.

189. [WALSH, B. D.] [Cicada; gooseberry-worm.] <Pract. Ent., December, 1866, v. 2, p. 33.

Answer to inquiry of M. S. Hill; Cicada [= Tibicen] septendecim compared with an undescribed species; ravages of Pristiphora grossularic? on gooseberry bushes.

190. [WaLsh, B. D.] [Vespidae.] <Pract. Ent., December, 1866, v. 2, pp. 33,34 .

Answer to inquiry of M. Hobart; life-habits of Vespida.

191. [WaLsh, B. D.] [Meal-worms: Timber-borers.] <Pract. Ent., December, 1866, v. 2, p. 34 .

Answer to inquiry of M. C. D.; characters, food-habits, and means against Tenebrio molitor and T. obscurus ; characters of Ptinus brunneus infesting pine timber; corrosive sublimate as a means against timber insects.

192. [WaLsh, B. D.] [Corn-Worm.] <Pract. Ent., December, 1S66, r. 2, p. 34 .

Answer to J. B. Ellis; number of broods of Heliothis armigera in the Northern and Southern States.

193. [WALSH, B.D.] [Thousand-legged worms.] <Pract. Ent., December, 1S66, v. 2, pp. 34-35, fig.

Answer to inquiry of G. W. Robinson; description and figure of Iulus multistriatus n. sp. [=Cambala annulata]; habits and means against the same.

194. [W ALsh, B. D.] [Cranberry-galls, etc.] <Pract. Ent., December, 1866 , v. 2 , p. 35.

Answer to inquiry of W. C. Fish; occurrence of galls made by Cecidomyia sp. on leaves of cranberry ; identification of several insects.

195. [WALsh, B. D.] Another humbug. <Pract. Ent., December, 1866 , v. 2 , p. 35.

Extract, with comments, from Cultivator and Conntry Gentleman, 22 November, 1866, exposing worthlessness of P. B. Sheldon's composition for destroying borers, 
196. [Walsh, B. D.] Notices. <Pract. Ent., December, 1866, v. 2, p. 35.

Mention of several agricultural journals.

197. WALSH, B. D. On the insects, coleopterous, hymenopterous, and dipterous, inhabiting the galls of certain species of willow. Part $2 \mathrm{~d}$ and last. <Proc. Ent. Soc. Phil., Décember, 1866January, 1867 , v. 6 , pp. 223-288.

See No. 46 for Part 1st. Supplementary notes on the Cecidomyida (gall-makers and gucst-flies); criticism of statements of Fitch and Harris; discussion of structure and habits of Tenthredinide and insects generally; synopsis of tenthredinidous willow-galls; descriptions of the galls, their makers and inquilines; for the new species described, see the Systematic Index; remarks on species and varieties; figures fore-wings of Tenthredo and Ichneumon.

198. W[ALSH], B. D. Plant-lice-their friends and enemies. <Pract. Ent., January, 1867, v. 2, pp. 37-44, figs.

Method of work and mode of reproduction of Aphidide; their relations to ants; plant-lice enemies; figures Aphis mali and several enemies of plantlice; means against Aphidida.

199. W[ALSH], B. D. Birds versus insects. <Pract. Ent., January, 1867, v. 2, pp. 44-47.

Insectivorous birds not necessarily beneficial; a bird must be shown to eat at least thirty (30) times as many injurious insects as it does beneficial ones before it can be considered useful.

200. [Walsh, B. D.] [Iusects namerl.] <Pract. Ent., January, 1867, v. 2, p. 47.

Answer to inquiry of J. Pettit; identification of many species, mostly beetles; characters and food-habits of Clerus nigripes [=4-guttatus]; habitat of Leptura capitata and Tingis [= Corythuca] ciliata.

201. [Walsh, B. D.] [Aplle-tree insects.] <Pract. Ent., January, 1867, v. 2, p. 47.

Answer to inquiry of M. Hobart ; increasing distribution of Aspidiotus conchiformis [= Mytilaspis pomorum $]$; cnemies of the same; characters of the eggs of Aphis mali.

202. [WaLsh, B. D.] [Work in entomology.] <Pract. Ent., January, 1867, y. 2, p. 47.

Answer to G. Scarborough; advice for the study of entomology by beginners.

203. W[ALSH], B. D. The true Thrips and the bogus Thrips. <Pract. Ent., February, 1867, v. 2, pp. 49-52, figs.

Natural history, characters, habits, and figures of Thrips sp.; characters of the larva and imago of Haltica chalybea ; figure of imago; habits of species of Erythroneura [=Typhlocyba]; description and figures of $E .[=T$.$] vitis.$

204. W[ALSH], B. D. Universal remedies. <Pract. Ent., 1867, v. 2, p. 52.

Exposure of proposed nuiversal remedy against fruit-tree insects.

205. W[ALSH], B. D. Poisoning noxious insects. < Pract. Ent., Feb. ruary, 1867, v. 2, pp. 52-53.

Sugaring with poison as a means against Noctuida. 
206. W[ALSH], B. D. Remarks by B. D. W. <Pract. Ent., February, 1867, v. 2, p. 54 .

Comments on S. S. Rathron's "Bag-worms" (Pract. Ent., pp. 53-54); distribution and food-plants of Thyridopteryx ephemer(eformis.

207. W $[\Lambda \mathrm{LSH}], \mathrm{B}$. D. Habits of the tree cricket (Weanthus niveus). $<$ Pract. Ent., February, 1867, v. 2, p. 54, figs.

Characters of eggrs and method of deposition; characters, food-habits, and figures of the imago.

208. [WaLsh, B. D.] Importing European parasites. <Pract. Ent., February, 1867, v. 2, pp. 54-55.

Imaginary correspondence between Asa Fitch and John Curtis on the importation of parasitic insects.

209. [Walsh, B. D.] [Screw-wormi.] <Pract. Ent., February, 1867, v. 2, p. 55 .

Answer to inqniry of L. D. Morse; nndeternined larva found in osageorange seed; hominivorous habits of Lucilia macellaria.

210. [WaLsh, B. D.] [Attacus cecropia.] <Pract. Ent., February, 1867, v: 2, p. 55.

Answer to inquiry of T. T. Smith; characters of larva and imago of Attacus cecropia; food-plants; method of issnance fronl cocoon; nature of tluid discharged when emerging from cocoon

211. [Walsh, B. D.] [Apple-worm.] <Pract. Ent., February, 1867, v. 2, pp. $55-56$.

Answer to inquiry of W. C. Fish ; characters of the pupa of Sciara mali.

212. [WaLsh, B. D.] [Oak-gall.] <Pract. Ent., February, 1867, v. 2, p. 56.

Answer to inquiry of W. Muir; characters of an nndetermined cynipid gall on oak.

213. [Walsh, B. D.] [Cicada: Grape-vine Procris.] <Pract. Ent., February, 1867, v. 2, p. 56.

Answer to inquiry of M. S. Hill; variations in the imago of Cicada $[=$ Tibicen] septendecim and in the song of the same; characters of the larva of Procris $[=$ Harrisina $]$ americana.

214. [WaLsh, B. D.] [Nitidulidw.] <Pract. Ent., February, 1867, v. 2, p. 56 .

Answer to inquiry of W. H. S.; food-habits of Ips fasciatus and Nitidula bipustulata.

215. [Walsh, B. D.] [Turnip enemy.] < Pract. Ent., February, 1867, v. 2, p. 56.

Answer to inqniry of F. T. Pember; characters and food-habits of Polydesmus complanatus.

216. [Walsh, B. D.] [Wheat midge.] < Pract. Ent., February, 1867, v. 2, p. 57.

Answer to inqniry of C. P. Wickersham; natnre of the membrane enveloping the full-grown larva of Diplosis tritici. 
217. [WaLsh, B. D.] [Queries answered.] <Pract. Ent., February, 1867, v. 2, p. 57.

Answer to inquiry of R. Middleton; toads, frogs, and spiđers beneficial; effects of the stings of various insects.

218. [WALSH, B. D.] [Scales.] <Pract. Ent., February, 1867, r. 2, p. 57 .

Answer to inquiry of M. M. S.; characters and ravages of scales on oleander and orange; means against Coccidce.

219. [WaLsh, B. D.] [Hundred-legged worm.] <Pract. Ent., February, 1867, v. 2, p. 57.

Answer to inquiry of S. P. Monks; identification of Polydesmus virginiensis; distinctive characters of Myriapoda.

220. [WaLsh, B. D.] [Bark-borers.] <Pract. Ent., February, 1867, v. 2, pp. $57-58$.

Answer to inquiry of C. V. Riley; synoptic table and food-babits of several specics of Scolytus; descriptions of $S$. fagi n. sp. and $S$. caryw n. sp. $[=4$-spinosus $]$.

221. [WALSH, B. D.] [Aleurodes.] <Pract. Ent., Fébruary, 1867, v. $2, \mathrm{p} .58$.

Answer to inquiry of D. F. C.; characters and food-plants of an undescribed species of Aleurodes.

222. W[ALSA], B. D. The critic criticized. <Pract. Ent., February, 1867, v. 2, p. 58. Answer [by C. V. Riley]. <Prairie Farmer, 16 March, 1867, [v. 35], n. s., v. 19, p. 169. S.-b., No. 2, p. 58.

Criticism of article by C. V. Riley (Prairie Farmer, 19 January, 1867, [v. 35], I. s., v. 19, p. 37).

223. [WaLsh, B. D.] Obituary. '<Pract. Ent., February, 1867, v. 2, p. 58.

Notice of the late Brackenridge Clemens.

224. W[ALsh], B. D. Wire-worms. <Pract. Ent., March, 1867, v. 2, pp. 61-62, figs.

Characters of Myriapoda and larva of Elaterida, popularly called wire-worms; food-habits of larva of Ludius attenuatus; figure of larva and imago of the same; confusion caused by the use of the term "wire-worms" by correspondeuts of the Country Gentleman.

225. W[ALSH], B. D. Imported insects.-The onion-fly. <Pract. Ent., March, 1867 , v. 2, p. 64 , figs.

Figures of larva and imago of Anthomyia ceparum and of Ortalis [= Tritoxa] flexa; comparative characters of imagos; distribution and means against the two species.

226. W[ALSH], B.D. [Means against cut-worms.] <Pract.Ent., March, 1867, v. 2, p. 66.

Recommends, in reply to J. Townley's inquiry, sugaring with poisoned mon lasses as means against cut-worms. 
227. W[alsh], B. D. Entomology indeed run mad. <Pract. Ent., March, 1867, v. 2, pp. 66, 67.

Reprint of "The bud-worm" (N. C. Rural Journ., September, 1866), with criticism and correction of some of the errors.

228. W[ALSH], B. D. The imported gooseberry saw-fly. < Pract. Ent., March, 1867, v. 2, p. 67.

Reason for re-appearance in June and for the non-appearance of the second brood of Nematus ventricosus [ =ribesii] in Ncw York in 1866.

229. W[ALSI], B. D. Tree eut-worms. <Pract. Ent., March, 1867, v. 2, p. 67.

Cut-worm described (Pract. Lnt., v. 1, pp. 85-86) identified as Hadena chenopodii [= Mamcstra trifoli]. See Nos. 85, 281.

230. W[ALSH], B. D. Doctoring fruit trees again. < Pract. Ent., March, 1867, v. 2, pp. 67, 68.

Extract from Industrial Gazette, 15 December, 1866, with criticism; calomel, sulphur, and substances insoluble in water not absorbed in to the circulation of trees.

231. W[ALsh,] B. D. The grape-vine Colaspis (Colaspis flavida Say). $<$ Pract. Ent., March, 1867, v. 2, pp. 68-69, fig.

Ravages of Colaspis flavida; comparison with allied species; remarks on the law of priority and on certain insects becoming suddenly injurious; figures C. flavida.

232. W[ALSH], B. D. Another universal remedy. <Pract. Ent., March, 1867, v. 2, p. 69.

Extract from reprint (?) in Cultivator and Country Gentleman, 10 January, 1867 , with criticism of proposed remedy against insects injurious to trees.

233. W[ALSH], B. D. Borers. The plug-ugly theory. < Pract. Ent., March, 1867, v. 2, p. 69.

Criticism of theory that a plug driven into a hole in a tree is death to borers.

234. W[ALSH], B.D. A mass of mistakes. <Pract. Ent., March, 1867, จ. 2, p. 70.

Correction of errors in "Remedy for the borer" (Prairie Farmer, 9 February, 1867).

235. W[ALSH], B.D. Hop-growing in the West. < Pract.Ent., March, 1867, v. 2, p. 70.

Extract from Country Gentleman, 31 January, 1867, showing ravages of Phorodon humuli in Vermont; danger of its introduction into the Western States.

236. W[ $\Lambda$ LSH], B. D. Thousand-legged worms. <Pract. Ent., March, 1867, v. 2, p. 70 .

Extract from letter of J. H. Parsons, with comments; injuries to onions by Iulus multistriatus [ = Cambala annulata $] ;$ I. multistriatus undistinguishable from 1. cocruleo-cinctus.

3 ENT 
237. W[alsh], B. D. Fighting the Curculio. <Pract. Ent., March, 1867, v. 2, p. 71.

Extract from Genesee Farmer for 1853, p. 125; ridienle of additions to "jarring" as a means against Conotrachelus nenuphar.

238. W[ALsH], B.D. ["Bushels of butterflies."] <Pract. Ent., March, 1867, v. 2, p. 71.

Extract from Cincinnati Gazette, August, 1866, with comments; occurrence of dead imagos of Attacus cecropia? in large numbers ("10 bushels") in

- Newport, Ohio; food-plants of the larva.

239. [W ALsH, B. D.] [Scab on potato.] <Pract. Ent., March, 1867, v. $\because 2, \mathrm{pp} .71-72$.

Answer to inquiry of 'T. L. J. Baldwin; account of blister-like scabs on potatoes, probably caused by Sciara sp. ; means against the same.

240. [Walsh, B. D.] [Mass of eggs.] <Pract. Ent., March, 1867, v. 2, p. 72.

Answer to inquiry of E. Daggy ; egg-masses of Clisiocampa americana; foodplants of $C$. americana and C. sylvatica [= disstria].

241. [W $\Delta$ LSH, B. D.] [Food of katydids.] <Pract. Ent., March, 1867, V. 2, p. 72.

Answer to inquiry of C. M. ; food of Microcentrum retinervis largely carnivorous.

242. [W ALSH, B. D.] [Caterpillar nest on wild cherry.] <Pract. Ent. March, 1867, v. 2, p. 72.

Answer to inquiry of H. Morey; undetermined larva on wild cherry, foodplants of Hyphantria tcxtor [=cunea].

243. [WaLsh, B. D.] [Insect eggs.] <Pract. Ent., March, 1867, v. 2, p. 72 .

Answer to inquiry of P. Ferris ; undetermined eggs of Lepidoptera and Hemiptera on apple-tree twigs.

244. [WaLsh, B. D.] [Attacus polyphemus, etc.] <Pract. Ent., March, 1867, v. 2, pp. $72-73$.

Answer to inquiry of M. M. S.; variations in Attacus [=Telca] pol!phemus; habits and times of transformations of Arctia [= Pyrrharctia] isabella; references to history of Dryocampa rubicunda.

245. [WaLsh, B. D.] [Cossus robinia, etc.] <Pract. Eut., March, 1867, r. 2, p. 73.

Answer to inquiry of J. Townley; food-habits and injuries of Cossus robinia; result of freezing insects; characters of some wood-borers.

246. [WaLsh, B. D.] [Museum pests.] <Pract. Ent., March, 1867, v. 2, p. 73.

Answer to inquiry of F. L. Van Arsdale; means against Dermcstida.

247. [WaLsh, B. D.] [Katydid eggs.] <Pract. Ent., March, 1867, v. 2, p. 73 .

Answer to C. M. B.; characters of egg's of Microcentrum retinervis. 
248. [WALsh, B. D.] [Squash-vine borer.] <Pract. Ent., March, 1867, v. 2 , p. 73.

Answer to inquiry of E. Nason; ravages and means against Trochilium cucurbita $[=$ Melittia ceto $]$.

249. [WaLsH, B. D.] [Apple-twig borers, etc.] <Pract. Ent., March, 1867, v. 2, pp. 73-74.

Answer to inquiry of A. W. Brumbaugh; work of Bostrichus [=Amphiccrus $]$ bicaudatus; characters and habits of Teniopteryx fasciata ; ravages, habits, and means agannst Macrodactylus subspinosus.

250. [WALSH, B. D.] [Hessian Hy.] < Pract. Ent., March, 1867, v. 2, p. 74.

Answer to inquiry of E. E. Sheldon; hibernation of the larva of Cecidomyia destructor.

251. [WALSH, B. D.] [Tree-cricket.] <Pract. Ent., March, 1867, v. 2, p. 74 .

Answer to inquiry of J. M. Cole; food-habits of Ecanthus nivens; characters of its eggs.

252. [Walsh, B. D.] [Tineids in bee-hives.] <Pract. Ent., March, 1867, v. 2, p. 74 .

Answer to inquiry of J. H. Hunt; characters of case and larva of nndetermined tineid.

253. W[aLSH], B. D. Jumping to conclusions. <Pract. Ent., March, 1867, v. 2, p. 74.

Criticism of article "The potato-bug" (Wisconsin Farmer, 2 March, 1867).

254. W[ALSH], B. D. The common Curculio and its allies. <Pract. Ent., April, 1867, v. 2, pp. 75-81.

Characters of the Rhyncophora ; characters, ravages, life-history, food-habits, number of broods, and means against Conotrachelus nenuphar; ravages, habits, characters, and means against Anthonomus prunicida $[=$ Coccotorus scutellaris $]$ and $A$. 4-gibbus; mention of additional injurious weevils; comparative characters of the three spccics.

255. W[ALSH], B. D. Remarks by B. D. W. <Pract. Ent., April, 1867, v. 2, p. 82.

Comments on C. V. Riley's article, "The imported apple-trce bark-louse" (Prairie Farmer, 23 March, 1867, [v. 35], n. 8., v. 19, p. 184).

256. W[ALSH], B. D. Confessing the corn. <Pract. Ent., April, 1867, v. $2, \mathrm{p} .82$.

Acknowledgment of mistake in quoting from Prairie Farmer.

257. [Walsh, B. D.] [Bibio albipennis.] <Pract. Ent., April, 1867, v. 2, p. 83.

Auswer to inquiry of H. Burt; habits of larva of Bibio atoipennis.

258. [Walsh, B. D.] [Lice on horses.] <Pract. Ent., April, 1867, v. 2, p. 83.

Answer to inquiry of L. West; comparative characters of P'ediculina and Mallophaga. 
259. [WALSH, B. D.] [Cocoon on wild cherry.] <Pract. Ent., April, 1867, v. 2 , p. 83.

Answer to inquiry of A. A. Baker; sexual differences-of Attacus promethea; food-plauts of its larva.

260. [W ALSH, B. D.] [Lepidopterous case-bearer.] < Pract. Ent., April, 1867 , v. 2, p. 83.

Answer to inquiry of J. H. Hunt; larval characters of case-bearing Lepidoptera.

261. [WALSH, B. D.] ["Thousand-legged worms."] <Pract. Eut., April, 1867, v. 2, p. 83.

Answer to iuquiry of J. H. Parsons; Iulus virgatus eating dead seeds; injurious habits of species of Polydesmus.

262. [Walsh, B. D.] [Toads: Glorified squash-bug.] <Pract. Ent., 1867, v. 2, p. 83.

Answer to inquiry of F. C. Hill ; food of toads; poisonousness of Prionotus novenarius $[=$ Prionidus cristatus $]$.

263. [WALSH, B. D.] [Galls on blackberry.] <Pract. Ent., April, 1867, v. 2 , pp. $83-84$.

Answer to inquiry of J. H. Tice; identification of the gall of Diastrophus nebulosus; geuera of Cynipidce confined to single plants.

264. [Walsh, B. D.] [Bark-lice.] <Pract. Ent., April, 1867, v. 2, p. 84.

Answer to inquiry of Dr. Houghton; comparative harmlessuess of Coccus harrisii [ = Chionaspis furfurus]; means agaiust Coccide.

265. [Walsh, B. D.] [Plant-lice.] <Pract. Ent., April, 1867, v. 2, p. 84.

Answer to inquiry of E. Orton; description of eggs of Lachnus strobi; means against Aphidide.

266. [Walsh, B. D.] [Bag-worms.] < Pract. Ent., April, 1867, v. 2, pp. $84-85$.

Answer to inquiry of J. Murphy ; food-habits aud meaus of dispersal of Thyridopteryx cphemeroformis.

267. [W ALSH, B. D.] [Insects injurious to grape.] <Pract. Ent., April, 1867, v. 2, p. 85.

Answer to inquiry of J. Wood; supposed Curculio punctures iu grapes.

268. [WaLsh, B. D.] [Attacus promethea.] <Pract. Ent., April, 1867, จ. 2, p. 85 .

Answer to inquiry of J. B. Lyon; mention of nndetermined parasite of Attacus promethea.

269. [WALsh, B. D.] [Borer in hickory.] <Pract. Ent., April, 1867, v. 2, p. 85.

Answer to inquiry of B. Norris; characters of young and mature larva of Clytus [=Cyllene] pictus.

270. [Walsh, B. D.] [Apple-tree plant-lice.] <Pract. Ent., April, 1867, v. 2, p. 85.

Answer to inquiry of W. W. Linn; Identification of eggs of Aphis mali; enemies of the same. 
271. [W $\mathrm{W}_{\mathrm{ALSH}}, \mathrm{B} . \mathrm{D}$.] [Tulip-tree bark-louse: Basket-worm.] $<$ Pract. Ent., April, 1867, v. 2, p. 85.

Answer to inquiry of I. Hicks; parasites and encmies of undescribed barklouse on tulip-trce; Thyridopteryx ephemeraformis destructive to evergreens.

272. W[ALSh], B. D. The grape-vine Fidia. (Fidia viticida, new species.) <Pract. Ent., May, 1867, v. 2, pp. 87-88, fig.

Ravages, description, and figure of Fidia viticida n. sp.; modification of the clasping organs of insects.

273. W[ALSH $]$, B. D. Enemies of the rice crop. <Pract. Ent., May, 1867, v. 2, p. 89.

Injuries caused by and means adopted against the water-weevil [=Lissorhoptrus simplex] and the rice-grub $=$ [Chalepus trachypygus. $]$

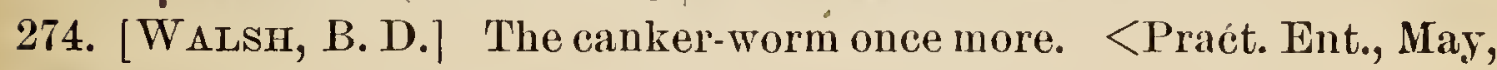
1867, v. 2, p. 89. Abstract : <Cultirator and Country Gentleman, 6 June, 1867, v. 29, p. 370.

Extract from and review of W. G. C.'s " $M_{Y}$ trials with the canker-worms: remedy" (Iowa Homestead, 13 March, 1867); sorghum as a means agannst Anisopteryx.

275. W[ALSH], B. D. None so blind as those who shut their eyes. $<$ Pract. Ent., May, 1867, v. 2, pp. 89-90.

Criticism of error by editors of agricultural papers; rate of eastward progress of Doryphora 10-lineata.

276. W[ALSH], B. D. Self-taught entomologists. < Pract. Ent., May, 1867, v. 2, pp. 91-92.

Criticism of misstatements found in agricultural papers; first occurrence of Doryphora 10-lineata in Illinois in 1864.

277. W[ALSH], B. D. Pear-tree and apple-tree insects. < Pract. Ent., May, 1867 , v. 2, pp. 92-93.

Food-plants of Attacus cecropia, Clisiocampa americana, and Saperda bivittata [= candi.la $]$.

278. W[alsh], B. D. More universal remedies. <Pract. Ent., May, 1867, v. 2, p. 93.

Reprint and eriticism of "Destruction of insects" (Mo. Rept. Bureau Agric., February, 1867, 1. 60).

279. W[aLSH], B. D. Hop-growing in the West. < < Pract. Ent., May, 1867, v. 2, pp. 93-94.

Occurrence in Michigan of Phorodon humuli; its destructiveness; popular ignorauce of eutomology.

280. W[ALSH], B. D. The wheat midge-jumping to a conclusion. $<$ Pract. Ent., May, 1S67, v. 2, p. 94.

Extract, with comment, from Maryland Farmer and Mcchanic, August, 1865; Diplosis tritici not infested with parasites in America; food-habits of Thrips. 
281. W[aLSH], B. D. Tree cut-worms. <Pract. Ent., May, 1867, v. 2, p. 94 .

"Dark-sided cut-worm" an Agrotis and not Hadena chcnopodii [= Mamestra trifolii]. See Nos. 85, 229 .

282. W[alsh], B. D. Quacks and physicians. < Pract. Ent., May, 1867, v. 2, p. 95.

Criticism of proposed universal remedy against insects injurious to the rose (Westeru Rural, 30 March, 1867).

283. W[ALSH], B. 1). The ephemeron or May-fly. <Pract. Ent., May, 1867, r. 2, p. 95.

Length of duration of life of Ephcmerida.

284. W[alsh], B. D. A groundless fear. <Pract. Ent., May, 1867, v. 2, p. 95 .

Extract from Mo. Rept. Bureau Agric., February, 1867, p. 62 ; food-habits of larva and imago of Lytta atrata [= Epicauta pennsylvanica]; places of oviposition.

285. W[ALsH], B. D. Fire-blight. <Pract. Ent., May, 1867, v. 2, p. 96.

Probable cause.

286. [WaLsh, B. D.] [Insect eggs.] <Pract. Ent., May, 1867, v. 2, p. - 96.

Answer to inquiry of W. Willock; identification of eggs of Ecanthus niveus and of one of the Membracide on grape twigs.

287. [WaLsh, B. D.] [Attacus cecropia.] <Pract. Ent., May, 1867, v. 2, p. 96.

Answer to inquiry of J. B. H.; characters of Attacus cecropia.

288. [WaLsh, B. D.] [Twig pruners.] <Pract. Ent., May, 1867, v. 's, p. 96.

Answer to inquiry of M. W. Philips; twigs of pear and other trees amp! tated in the same mamncr as oak twigs by Elaphidion putator [=villosum,

289. [W $\Lambda$ LSH, B. D.] [Biister-beetles.] <Pract. Ent., May, 1867, v, 2 , p. 97 .

Answer to inquiry of J. M. Tracy; food-habits, ravages, and means against Lytta [= Pomphopoa] anea; food-plants of L. [=P.] tarsalis; tabular separation of three species ot Lytta [=Pomphopœa].

290. [WaLsh, B. D.] [Means against Curculio: Gestride: ${ }^{\circ}<$ Pract. Ent., Mas, 1867, r. 2, p. 97.

Answer to inquiry of C. Greene; ineffective means against Conotrachelus nenuphar; CEstridre infesting the ox and rabbit.

291. [WALsH, B. D.] [Insect éggs.] <Pract. Ent., May, 1867, v. 2, p. 97.

Answer to inquiry of P. Ferris; identification of eggs of Clisiocampa sylvatica [=disstria] and Aphis mali. 
292. W[ALSH], B. D. The wheat midge. <Pract. Ent., June, 1S67, r. 2, pp. 99-101.

Extract from letter from S. S. Rathvon, with remarks; natural history of Diplosis tritici.

293. W[ $\mathrm{LLSH}]$, B. D. The new or Colorado potato-bug. <Pract. Ent., June, 1S67, v. 2, pp. 101-102.

Distribution, habits, and extent of injuries of Doryphora 10-lineata.

294. [WaLsh, B. D.] [Gall-flies; saw-flies.] <Pract.Ent., June, 1S67, จ. 2, pp. 102-103.

Answer to inquiry of M. W. Philips; mention of various insects which aro gall-makers; their inodes of life; characters of the larva of Cecidomyide and Tenthredinide.

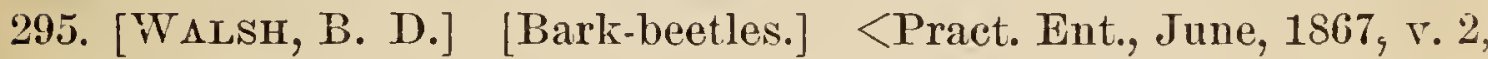
p. 103.

Answer to inquiry of W. C. Fish; identification of spccimens sent; habits of Tomicus pusillus [= Pityophthorns minutissimus] and of $T$. ramulorum [=I. micrographus].

296. [WaLsh, B. D.] [Apple-tree insects.] <Pract. Ent, June, 1867, v. 2, p. 103.

Answer to inquiry of S. Cassi ; characters, food-plants, and ravares of Arctiu [= Spilosoma $]$ virginica; supposed work of Epicarus imbricatus.

297. [Walsh, B. D.] [Attacus cecropia.] <Pract. Ent., June, 1867, v. 2, p. 103.

Answer to inquiry of T. MeGraw; larva of Attacus cecropia usually solitary.

29S. [WaLsh, B. D.] [Grape-vine flea-beetle.] <Pract. Ent., June, 1S67, v. 2, p. 103.

Answer to inquiry of A. Kelley; hibernation of the imago of Haltica chalybea; ravages and means against the same.

299. [WaLsh, B. D.] [Sphyracephala brevicornis.] <Pract. Ent., June; 1867, v. 2, p. 103.

Answer to inquiry of H. B. Howarth; characters and habitat of Sphyraccphala brevicornis.

300. [Walsh, B. D.] [May-bug.] <Pract. Ent., June, 1S67, v. 2, p. 103.

Answer to inquiry of C. H. R.; characters and food-habits of the larva of Lachnosterna qucrcina $[=$ fusca $]$.

301. [WALSH, B. D.] [Blister-beetles: plant-louse enemy.] <Pract. Ent., June, 1867, v. 2, p. 104.

Answer to inquiry of Dr. Houghton; food-habits of Lytta [=-Pomphopoca] anea and $L .[=I$.$] sayi; Chllocorus bivulnerus as a means against Coccide.$

302. [WaLsh, B. D.] [Blackberry borers.] <Pract. Ent., June, 1S67, v. 2, p. 104.

Answer to inquiry of A. S. Fuller; characters of undetermined larva (Age. ria?) and of Oberea perspicillata [= bimaculata] boring in blackberry stems; food-habits of AEgeride. 
303. W $[\mathrm{ALSH}]$, B. D. Scientific nomenclature. < Pract. Ent., July, 1867, v. 2 , pp. $105-106$.

Criticism of the practice of establishing new genera upon slight eharaeters, as illustrated by the Ameriean silk-worms.

304. W[alsh], B. D. Currant plant.lice (Aphis ribis). <Pract. Ent., July, 1867, v. 2, p. 106.

- Method of work of Aphis $[=$ Myzus $]$ ribis.

305. [WALSH, B. D.] [Lucanus elaphus.] <Pract. Ent., July, 1867, v. 2, p. 107.

Answer to inquiry of S. Hayeraft; charaeters and habits of Lucanus elaphus; rarity of the $q$; use of prolonged jaws in of inseets.

306. [WALSH, B. D.] [New York weevil.] <Pract. Ent., July, 1867, v. 2, p. 107.

Answer to inquiry of T. Gregg ; labits and distribution of Ithycerus noveboracensis.

307. [WaLSH, B. D.] [Codling-moth.] <Pract. Ent., July, 1867, v. 2, p. 107.

Answer to inquiry of H. Morey; number of broods, habits, ete., of Carpocap'sa pomonella.

308. [WALSH, B. D.] [Hickory borer, etc.] <Pract. Ent., July, 1867, v. 2, p. 107.

Answer to inquiry of T. Wiggins; times of cmergenee of Clytus [=Cyllene] pictus and $C .[=C$.$] robinice; habits of Corydalus cornutus.$

309. [WaLsh, B. D.] [Wasps.] <Pract. Ent., July, 1867, v. 2, p. 107.

Answer to inquiry of G. W. Smith; food-habits of digger-wasps.

310. [Walsh, B. D.] |Parasitic flies, etc.] <Pract. Ent., July, 1867, v. 2, pp. 107-108.

Answer to inquiry of S. P. Monks; method of transformation of parasitie Hymenoptera; nse of Latin plurals for English words.

311. [WALSH, B. D.] [Workers among Hymenoptera.] <Pract. Ent., July, 1867, v. 2, p. 108.

Answer to inquiry of W. V. Andrews; economy of workers among the soeial Hymenoptera.

312. [Walsh, B. D.] [Cut-worms.] <Pract. Ent., July, 1867, v. 2, p. 108.

Answer to inquiry of V. Abbey; means against Agrotis sp.?

313. [WALSH, B. D.] [Potato-beetle enemies.] <Pract. Ent., July, 1867, v. 2, p. 108 .

Answer to inquiry of W. Smith; scutellerid enemy of larva of Doryphora 10lineata; katydids as an enemy of the same.

314. [WALSH, B. D.] [Black-bug.] <Pract. Ent., July, 1867, v. 2, p. 108.

Answer to inquiry of J. R. Tewksbury; eharaeters and habits of Pirates $[=$ Melanolestes $]$ picipes. 
315. [WaLsh, B. D.] [Burying-beetles.] <Pract. Ent., July, 1867, v. 2, p. 108.

Answer to inquiry of A. D. Strong; characters of Necrophorus marginatus; habits of Silphide; mite parasites of Silphide and other beetles.

316. [WALSH, B. D.] [Insects named.] <Pract. Ent., July, 1867, v. 2, p. 108.

Answer to inquiry of M. S. Hill; identification of specimens sent; food-plants of larva of Chrysomcla [= Gastroidea] cyanea.

317. [WALSH, B. D.] [Spring.tails.] <Pract. Eut., July, 1867, v. 2, pp. 108-109.

Answer to inquiry of E. Daggy; characters, habits, and means against $P_{0}$ duride.

318. [WALSH, B. D.] [Blackberry gall insects.] <Pract. Ent., July, 1867, v. 2, p. 109.

Answer to inquiry of Aculeus; number of abdominal segments of Diastrophus and Aulax; reasons for considering the former the gall-maker and the lattier the guest-fly.

319. [Walsi, B. D.] [Pine and cedar longicorns.] <Pract. Ent., July, 1867, v. 2, p. 109.

Answer to inquiry of $J$. Barratt; sexual characters and food-habits of Callidium antennatum and C. janthinium.

320. [WaLsh, B. D.] [White-pine plant-louse, etc.] <Pract. Ent., July, 1867, v. 2, p. 109.

Answer to inquiry of C. H. Peck; Lachnus strobi on Pinus strobus; undetermined bark-louse, with enormous lateral thoracic plates, found on Rhus glabra.

321. [WALsh, B. D.] [Cut-worms.] <Pract. Ent., July, 1867, v. 2, p. 109.

Answer to inquiry of J. Townley; food-habits of climbing cut-worms.

322. [W ALsh, B. D.] [Currant plant-louse.] <Pract. Ent., July, 1867, v. 2 , pp. $109,110$.

Answer to inquiry of R. L. Walker; Cocinellide as a means against Aphis [= Myzus] ribis.

323. [W alsh, B. D.] [Beetles.] <Pract. Ent., July, 1867, v. 2, p. 110. Answer to inquiry of I. A. Plucīe; characters and food-habits of Tetraopes tornator [= tetraophthalmus] aud of $T$. fcmoratus; comparative characters of Chrysomela bigsbyana and of C.philadelphica; characters of Chrysomelida and Coccinellider.

324. W[ALSH], B. D. Fertilizing plants. <Pract. Ert., July, 1867, v. 2, p. 110.

Part played by insects in fertilizing, plants.

325. W[ALSH], B. D. The peach-worm. <Pract. Ent., July, 1867, v. 2, p. 110.

Larvo of Ephestia zece [= interpunctella] injurious to dried peaches; foodplants and encmies of the same. 
326. W[Alsh], B.D. Valedictory. <Pract. Ent., August-September, 1867, v. 2, p. 111.

Note of thanks for aid received in editing the Practical Entomologist.

327. W[ALSH], B. D. The State entomologist of Illinois. < Pract. Ent., August-September, 1867, v.2, p.111. Reprint: <Can. Farmer, 1 October, 1867, v. 4 . S.-b., No. 2, p. 98.

Bill for appointment of State entomologist of Illinois not carried into cffect.

328. W[ALSH], B. D. The three so-called army-worms. <Pract.Ent., August-September, 1867, v. 2, pp. 111-114.

Confusion caused by the use of the same popular name for dnomis [= Aletia] xylina, Lencania unipuncta, and Clisiocampa sylvatica [= disstria]; habits, etc., of the three species; food-habits of their larvie; characters, parasites, and means against $C$. sylvatica [=disstria].

329. W[ALSH], B. D. The little Turk and its crescent. <Pract. Ent., August-September, 1867, v. 2, pp. 114-115.

Comments on letter from F. C. Hill; oviposition of Conotrachelus nénuphar.

330. [Walsh, B. D.] Apple-worm. (Carpocapsa pomonella.) <Pract. Ent., August-September, 1867, v. 2, p. 115.

Prevalenec of C. pomonella in 1867 ; food-habits of its larva.

331. W.alsh], B. D. Spindle-worms. <Pract. Ent., August-September, 1867, v. 2, pp. 115-116.

Habits, etc., of Aehatodes zeee and of Gortyna nitela.

332. W[ALSH], B. D. A plant growing out of an insect. <Pract. Ent., August-September, 1867, v. 2, p. 116.

Larvæ of. Lachnosterna fusca infested with Cordyceps turned up by the plow in large numbers; larvæ supposed to have caten poisonous seed which has germinated after killing the larvo; sowing the seed as a means against the larvæ.

333. [WALsh, B. D.] The imported gooseberry saw-fly. < Pract. Ent., August-September, 1867, y. 2, p. 116.

Changes in the larva of Nematus ventricosus [ = ribcsii] during the last moult; ravages in Columbia County, N. Y. ; extent of spread from Rochester, N. Y.

334. W[ALSH], B. D. The Colorado potato-bug. <Pract. Ent., August-September, 1867, v. 2, p. 116.

Spread of Doryphora 10-lineata into southern Michigan and western Indiana.

335. W[ALSH], B. D. Apple-tree plant-lice. (Aphis mali.) <Pract. Ent., August-September, 1867, v. 2, pp. 116-117.

Effects of early frosts on Aphis mali.

336. W[ALSH], B. D. The tent-caterpillar of the apple-tree. (Clisiocampa americana.) <Pract. Ent., August-September, 1867, v. $2, \mathrm{p} .117$.

Scarcity of $C$. amerieana in 1867 duc to the abundance of an egg parasite. 
337. [Walsin, B. D.] A new foe of the corn. <Pract. Ent., AugustSeptember, 1867, v. 2, pp. 117-118.

Ravages and description of Sphenophorus zece n. sp. [= sculptilis]; habits of the larva and imago.

338. [WaLsh, B. D.] [Rhyssa atrata.] <Pract. Ent., August-Sep. tember, 1867, v. 2, p. 118.

Answer to inquiry of H. K. Smith; Rhyssa $[=$ Thalessa $]$ atrata ovipositing in hickory.

339. [Walsi, B. D.] [Grape-vine beetles.] <Pract. Ent., AugustSeptember, 1867, v. 2, p. 118.

Answer to inquiry of L. D. Morse; ravages and food-plants of Fidia viticila and of $F$. longipes.

340. [Walsh, B. D.] [Currant insects.] < Pract. Ent., August-September, 1867, v. 2, p. 118.

Answer to inquiry of A. M. Burns; identification of Egcria tipuliformis; mention of species called currant-ivorms; destructiveness of Nematus ventricosus [= ribesii].

341. [Walsh, B. D.] [Rascal leaf-crumpler.] <Pract. Ent., AugustSeptember, 1867, v. 2, p. 118.

Answer to inquiry of J. M. K.; times of transformation and means against Phycita nebulo $[=$ Acrobasis indiginella $]$.

342. [Walsh, B. D.] [Strawberry enemy.] • < Pract. Ent., AugustSeptember, 18ú7, v. 2, p. 118.

Answer to inquiry of C. Faxon; characters, habits, and means against Polydesmus serratus; roots of strawberrs plants injured by the same.

343. [Walsh, B. D.] [Eight-spotted forester.] < Pract. Ent., AugustSeptember, 1867, v. 2, p. 118.

Answer to inquiry of A. Gilbert; characters and food-plants of Alypia octonaculata.

344. [Walsh, B. D.] [Maple bark-louse.] <Pract. Ent., August-September, 1867, v. 2, p. 119.

Answer to inquiry of B. W. McLain; characters of undescribed coccid ou maple.

345. [WaLsh, B. D.] [Apple-tree bark-lice.] < Pract. Ent., AugustSeptember, 1867, v. 2, p. 119.

Answer to inquiry of A. Gilbert; identification of Aspidiotus harrisii $[=C h i-$ onaspis furfurus] and of A. conchiformis [= Mytilaspis pomorum] on appletrees.

346. [Walsh, B. D.] [Habits of larvæ and pupæ.] < Pract. Ent., August-September, 1867, v. 2, p. 119.

Answer to inquiry of M. M. S.; insects which transform under gronnd enter the earth in the larval stage; apparatus used by pupe in foreing their way to the surface of the ground.

347. [W Alsh, B. D.] [Potato-beetles: Cicindela sex-guttata.] <Pract. Ent, August-September, 1867, v. 2, p. 119.

Answer to inquiry of P. B. Sibley ; mention of Lytta cinerea [-Macrobasis unicolor], and of Doryphora 10-lineata as destructive to potato vines; supposed larval habits of Cicindela sex-guttata. 
348. [WaLsh, B. D.] [Wavy-striped flea-beetle.] <Pract., Ent., August-September, 1867, v. 2, p. 119.

Answer to inquiry of E. T. Suelling; food-habits of Haltica striolata $[=$ Phyllotreta rittata $]$.

349. [Walsh, B. D.] [Parasites of eut-worms.] <Pract. Ent., August-September, 1867, v. 2, p. 11.9.

Answer to inquiry of J. Edgerton ; metamorphoses of tachinid parasites of Noctuide.

350. [Walsh, B. D.] [Eggs on sugar-maple.] <Pract. Ent., AugustSeptember, 1867, v. 2, p. 119.

Answer to inquiry of W. Priehard; egg-rings of Clisiocampa americana? on sugar-maple.

351. [Walsh, B. D.] [Click-beetles.] <Pract. Ent., August-September, 1S67, v. 2, p. 119.

Answer to inquiry of J. H. Foster, jr.; food-habits of Melanotus communis and of Monocrepidins vcspertinus.

352. [Walsh, B. D.] [Chrysobothris femorata.] <Pract. Ent., AugustSeptember, 1867, v. 2, p. 119.

Answer to inquiry of J. J. Kelly; food-habits of Chrysobothris femorata.

353. [Walsh, B. D.] [Gall on chestnut.] <Pract. Ent., August-September, 1867, v. 2, p. 119.

Answer to inquiry of W. Kite; mention of an undetermined Phylloxera gall on the flower-catkin of the chestnut.

354. [Walsh, B. D.] [Grape-vine beetle: Bugs.] <Pract. Ent., August-September, 1867, v. 2, p. 119.

Answer to inquiry of B. F. Lazear; habits of Pelidnota punctata; swarming of Corimelcuna pulicaria; defensive odors of Heteroptera.

355. [Walsh, B. D.] [Squash-vine insects.] <Pract. Ent., AugustSeptember, 1867, v. 2, p. 120.

Answer to inquiry of J. H. Parsons; larval habits of Diabrotica vittata; confusion eansed by popular names.

356. [Walsi, B. D.] [Mites.] <Pract. Ent., August-September, 1867, v. 2, p. 120 .

Answer to inquiry of C. Carpenter; eharacters and life-habits of Acarina.

357. [Walsh, B. D.] [Haltica cucumeris.] <Pract. Ent., AugustSeptember, 1867, v. 2, p. 120.

Answer to inquiry of G. S.; food-habits of IIaltica [= Crepidodera] cucumeris.

358. [WaLSI, B، D.] [Insects named.] <Pract. Ent., August-September, 1867, v. 2, p. 120.

Answer to inquiry of M. H. Boye; food-habits of Conotrachelus cratagi, Melanotus communis, Pelidnota mnctata, Desmocerns palliatus, Lucidota atra, Podabrus rugulosus, and $P$. modcstns; variation of Haltica [=Crepidodera] helxines; characters of Dolerus arvensis. 
359. [Walsh, B. D.] [Insects named.] < Pract. Ent., August-September, 1867 , v. 2, p. 120.

Answer to inquirs of $\mathrm{H}$. Burt; identification of several insects; climbing habits of cut-worms.

360. [W ALsh, B. D.] [Hickory-galls.] <Pract. Ent., August-September, 1867 , v. 2, p. 120.

Answer to inquiry of W. C. Fish; characters of galls made by Phylloxera caryaglobuli and $P$. caryecaulis; identification of several beetles.

361. [WaLsi, B. D.] [Yellow swallow-tail; Rose-beetle.] <Pract. Ent., August-September, 1867, v. 2, 1. 120.

Answer to inquiry of J. Barratt; identification of Papilio turnus; transformation and ravages of Macrodactylus subspinosus.

362. [Walsh, B. D.] [Blister-beetles.] <Pract. Ent., August-September, 1867, v. 2, p. 120.

Answer to inquiry of D. W. Kanffman; food-plants and characters of Macrobasis murina $[=$ unicolor $]$ and of Epicauta atrata $[=$ pennsylvanica $]$.

363. [Walsh, B. D.] [Tent-caterpillars.] <Pract. Ent., August-September, 1867, v. '2, p. 121.

Answer to inquiry of S. R. Williams; occurrence of Clisiocampa americana on pear-trees and of $C$. sylvatica $[=$ distria $]$ on black-walnut.

364. [Walsh, B. D.] [Currant-worms.] < Pract. Ent., August-September, 1867, v. 2, 1). 121.

Answer to inquiry of A. M. Mills; characters of the larva of Nematus ventricosus [=-ribesii], of Ellopia [=-Euffitchia $]$ ribcaria, and of Pristiphora grossularie.

365. [WaLsh, B. D.] [Potato-beetle enemies.] <Pract. Ent., AugustSeptember, 1867, v. 2, p. 121.

Answer to inquiry of W. Mans; description and habits of Lebia grandis; hemipterous enemics of Doryphora 10-lineata.

366. W[ALSH], B. D. The Colorado potato-bug. <Pract. Ent., August-September, 1867, v. 2, p. 121.

Extract from Mo. Rept. U. S. Agric. Burean, 1866, p. 344 ; doubts the occurrence of Doryphora 10-lincata in Pennsslvania.

367. [WALSH, B. D.] Entomology. < Prairie Farmer, December, 1867, [v. 36], n. s., v. 20, pp: 358-359.

Address, with discussion by others, at the third annual meeting of the Southern Illinois Fruit Growers and Shippers' Association; ravages and means against Pemphigus pyri $[$ = Schizoncura lanigera $]$, Carpocapsa pomonella, Trypeta pomonella, Scmasia $[=$ Grapholitha $]$ pruinivora, Coliodes $[=$ Craponius] incqualis, Conotrachelus nenuphar.

368. WALsh, B. D. The grasshoppers. < Iowa Homestead, 15 January, 1868 ( v. 13 ?), p. 9. S.-b., No. 2, p. 119.

Range of swarms of Caloptenus spretus in Iowa in 1867.

369. WALSH, B. D. Birds vs. insects. <Prairie Farmer, 1868, [v. 37], n. s., v. 21; 30 Мay, pp. 346-347; 6 June, pp. 362-363; 13 June, pp. $378,379$. 
370. Walsh, B. D. The serenteen-year locust. <Dixie Farmer, 11 June, 186s. S.-b., No. 3, p. 23.

Periodicity and local distribution of the various broods of Cicada [-Tibicen] scptendccim.

371. Walsh, B. D. Entomological. Do locusts sting? <Chicago Republican, 1868. S.-b., No. 3, p. 25.

Sting of Cicada not poisonous; sting of Stizus grandis [== Sphecius speciosus] mistaken for it; habits of the Stizus.

372. WALSH, B. D. The bug-hunter in Egypt. A journal of an entomological tour into south Illinois by the senior editor. <Amer. Ent., 1S68, v. 1; September, pp. 6-14, figs. 1-7; October, pp. 29-36, figs. 23-29.

Habits and fignres of Macroncma zcbratum, Palingenia [= Hexagenia] bilineata, Cicada sp., Stizus grandis [= Sphecius speriosus], Xylocopa carolina $[=$ virginica], and Anthophora sponsa [=abrupta]; sting of Cicada not poisonous, that of the Stizus mistaken for it; habits of Conotrachelus ncnuphar; description of Hull's Curculio-catcher; Conotrachelus anaglypticus and Colaspis sp. injurious to plum-trees ; figures of Rhopalus sp. and Euryomia [= Euphoria] melancholica injurious to pear-trees; figure and habits of Metapodius nasalns [= fcmoratus]; predaceons habits of Arma $[=$ Podisns $]$ spinosns, Evagoras viridis $[=$ Di,lodus Turidus $]$, and Stivetrus fimbriatus [= anchorago]; work of Aspidiotus harvisii [ = Chionaspis furfurus] upon pear, and of Cecidomyia [=Diplosis] tritici in wheat; occurrence of Endrosa [= Lachnosterna $]$ qucrcus, Doryphora juncta, and Trichius delta in Illinois; mite enemy of Aspidiotus conchiformis [= Mytilaspis pomorum]; injury to fruit by Apis mellifica; hot water as a means against Schizoneura lanigera; habits and figures of Chrysopa sp.; figures of Aspidoglossa subangulata, Harpalus pennsylvanicus, and Evarthrus orbatus; figures and descriptions of larva of a carabid and of Chanliognathus pennsylvanicus; Curcnlio-feeding habits of Carabida.

373. WALSH, B. D. First annual report on the noxious insects of the State of Illinois. <Trans. Ill. State Hortic. Soc. for 1867, n. s., v. 1, Appendix. Separate: <Chicago, 1868, 103 pp., tigs. 1-3.

\section{TABLE OF CONTENTS.}

INTRODUCTORY

Chapter 1. The grape Curculio. Coeliodes [=Craponins $]$ incqualis Say.

Its history-Guest inscets, parasites, and cannibals-Remedy ....

Chapter 2. The grape-leaf gall-louse.. Dactylosphara vitifolia, Fitch [= Phylloxcra vastatrix ].

Peculiar to the Clinton and other cultivated varieties of Frost grape-Practical inference therefrom ......................

Chapter 3. The rose-bug. Macrodactylus subspinosns Linn.

Device for destroying it on grape-vines.....................

Chalticr 4. The grape-root borer. Egeria [= Sciapteron $]$ polistiformis Harris.

Its history-Its scientific nomenclature-Remedies.............

Chapter 5. The apple-worm or codling-moth. Carpocapsa pomonella Linn.

Double-brooded-Practical inference therefrom-Remedies.......

Chapten 6. The apple-maggot fly. Trypeta pomonella Walsh.

Occurs at present only in certain Eastern States on the apple, though it was found long ago in Illinois on the crab-Its history. 
373. WALSH, B. D.-Continnerl.

Cinapter 7. The rascal leaf-crumpler. Phycita nebulo Walsh $[=$ Acrobasis indiginclla].

A peculiarly Northwestern species, not found either East or Sonth-

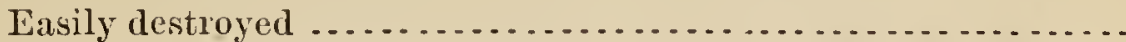

Chapter 8. The oyster-shell bark-louse. Aspidiotus conchiformis Gmel. [ = Mytilaspis pomorum $]$.

Its history-Loses almost all its orgaus when only a few days old, and becomes thencefortl as stationary as a cabbage-How it spreads from tree to tree-Mites and their natural history-Plautfecding inites, parasitic mites, ancl cannibal mites-The barklouse largely preyed on by a minnte cannibal mite-Uscless and

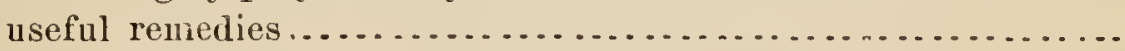

Chapter 9. Harris' bark-louse. Aspidiotus harrisii Walsh $[=$ Chioncuspis furfurus].

How it differs from the preceding-The geographical distribution.

Chapter 10. The apple-root plant-lonse. P'mphigus pyri Fitch [= Schizoneura lanigera $]$.

Often confounded in Illinois with the true "Woolly plaut-louse"The differences-Its history-Causes a form of "rotten-root"Its supposed cannibal foes-Remedies....................

Chapter 11. The plum Curculio. Conotrachelus nenuphar Herbst.

Its history-Its peculiar crescent cut explained-Double-broodedIts supposed enemies, the so-called "Curculio parasite" and the Baltimore oriole-Remedies ...........................

Chapter 12. The plum-gouger. Anthonomus prunicida Walsli $[=$ Coc-. cotorns scutellaris].

Bores a round lole in the plum, instearl of a crescent cut-How and why it does this-Differs in many other respects from the Curculio........................................

Chapter 13. The plum-moth. Semasia $[=$ Grapholitha $]$ prunivora Walsh.

Its history-Probably a guest-moth, aud therefore not injnrious..

Chapter 14. The hateful grasshopper. Caloptenus spretus Walsh.

The Rocky Mountains its natural home-Invades in certain years certain reighboring districts, such as Texas, Missouri, Kansas, Nebraska, and Iowa-Lays there millions of eggs, which develop into barren grasshoppers only-Invasion of 1866-Damage done by the young grasshoppers in the spring of 1867-In Kausas abont one-eighth of the field crops and seven-eighths of the garden crops destrojed by them-Grashopper invasious of A.D. $1820,1856,185 \%, 1864$, and 1867 -Probable results in 1868 of the invasion of 1867 -Has never yct come within 115 miles of Illinois-Can not spread into Illinois as the Colorado potato-bug has done-Reasons why, in all human probability, it cau never reach Illinois at all .................................

374. Walsh, B. D. A friend unmasked. <Amer. Ent, November, 1868 , v. 1, pp. 51-52, fig. 55 .

Description and figures of larva and arlult of Chauliognathus pennsylvanicus; characters and habits of the Tctephoride. 
375. WAI.SH, B. D. Appendix to the article on "Wasps and their habits," in No. 7. <Amer. Ent., April, 1869, v. 1, pp. 162-164.

Habits of Chrysidide; descriptions of Stizus [Megastizus] brevipennis n. sp., Agcria subcorticalis n. sp., .A. architcotus Say, A. cupida Cress., A. bombycina Cress., Ceropales rufiventris n. sp., and Ammophila pictipennis n. sp.; tabular separation of the genera of Sphecida. See No. 543.

376. Walsh, B. D. Mr. Couper's thorn-leaf gall. <Ca. Ent., 15 April, 1869, v. 1, pp. 79-80.

Description of cecidomyidous leaf-gall on Cratcogus; mentions of three additional Cecilomyidous, and an Acaridous gall on the same; Anthonomus cratcogi inquilinous in gall on Cratcogus.

377. WALSH, B. D. The six worst insect enemies of the fruit growers in northern Illinois. <Trans. North. 1ll. Hortic. Soc. for 1867'68, pp. 91-96.

Treats of Carpocapsa pomonella, Aspidiotus con chiformis [= Mytilaspis pomorum], Anisoptcryx [= Paleacrita] vernata, Sapcrda bivittata [= candida], Chrysobothris femorata, Conotrachelus nenuphar, and Anthonomus prunicida $[=C o c-$ cotorus scutellaris].

378. WALsh, B. D. Squash borer. <Cultivator and Conntry Gentleman, 30 September, 1869, v. 34, p. 256. Extract: <Prairie Farmer, 30 October, 1869.

Characters of larva and imago of Ageria cucurbite [= Melittia ceto]; natural - history, means against, and distribution of the same.

379. Walsh, B. D. Apple-tree borers. <Journ. Ill. State Agric. Soc. Reprint: <Trans. Ill. State Agric. Soc., v. 5, pp. 499-501.

Comparative differences between Saperda and Chrysobothris; soap as a means against the same.

380. WALSH, B. D. On a species of Hemiteles (Ichneumonidce), ascertained by the editor to be parasitic in Canada on the imported currant-worm fly (Nematus ventricosus Klug). <Can. Ent., 1 October, 1869, v. 2, pp. 9-12.

Division of Hemiteles into two groups; description of $H$. nemativorus n. sp.; larval and pupal history of the same by C. J. S. Bethune.

381. WALSH, B. D. The imported currant-worm fly (Nematus ventricosus Klug) and its parasite (Hemiteles nemativorus Walsh). <Ca. Ent., 15 November, 1869, v. 2, pp. 31-33.

Correction of errors in No. 380 ; sexual characters of Hemiteles; variation in the time at which the imago state is assumed by hibernating insects; heteropterous enemies of Nematus ventricosus [= ribesii].

382. WALSH, B. D. Larvæ in the human bowels. One of Mr. Walsh's posthumous articles. <Amer. Ent., March, 1870, v. 2, pp. 137141, fig. 93 .

Characters and habits of larval Homalomyia; description of the larva of $H$. wilsoni, $H$. leidyi, and $H$. prunivora n. spp.; mention of recorded cases of diptera in the human bowels; figures larva of $H$. wilsoni. 
383. WALSH, B. D. One day's journal of a State entomologist. <Amer.

Ent. and Bot., May, 1870, v. 2, pp. 197-199.

Sketch of an average day's work of a State entomologist.

3S4. WALSH, B. D. On the group Eurytomides of the hymenopterous family Chalcidides; with remarks on the theory of species and a description of Antigastcr, a new and very anomalous genus of Chalcidida. <Amer. Ent. and Bot., 1870, v. 2, September, pp. 297-301, fig. 1, 2 ; October, pp. 329-335, fig. 3-6 ; December, pp. 367-370, fig. 7-10.

Descriptions, habits, and figures of many Eurytomides; synoptic tables of the species of Eurytoma and Decatoma. For a list of the new species see the Systematic Index.

385. WALSH, B. D. Descriptions of North American Hymenoptera. <Trans. Acad. Sci. St. Louis, 7 May-9 June, 1873, v. 3, pp. 65166 , fig.

Printed posthumously, with notes by E. T. Cresson; description of many previously described Tenthredinidoe and Ichneumonida; fivo (5) new genera and forty-five (45) new species of Ichneumonida are described, for a list of which seo the Systematic Index; figures venation of front wing of Ichneumon.

4 ENT 



\section{U.S. DEPARTMENT OF AGRICULTURE. DIVISION OF ENTOMOLOGY.}

\section{BIBLIOGRAPHY}

OF

TIIE MORE IMPORTANT CONTRIBUTIONS

\section{AMERICAN ECONOHIC ENTOMOLOGY.}

PREPAREI, BY AUTHORITY OF THE SECRETARY OF AGRICULTURE, ISY

SAMUEI, HENSH A W.

$$
\text { PART II. }
$$

'JHE MORE IMPOR'TANT JOINT WRITINGS OF

B. D. WALSH and C. V. RILEY.

\section{WASHINGTON:}

GOVERNMENT PRINTING OFFICE.

1889. 



\section{BIBLIOGRAPHY OF THE MORE INPORTANT' CONTRIBUTIONS TO AMERICAN ECONOMIC ENTOHOLOGY.}

\section{PART II.}

386. [WALSH, B. D., and C. V. RileY.] Salutatory. To the agriculturists and horticulturists of the United States. <Amer. Tnt., September, 1868, v. 1, pp. 1-3.

Inportance and extent of the ravages of insects; practicability of the diminution of these ravages; value of entomological work; aims of the American Entomologist.

387. [WALSH, B. D., and C. V. Riley.] Hogs vs. bugs. <Amer. Ent., September, 1868, v. 1, pp. 3-6.

Effectiveness of swine as a incans against Conotrachclus nemuphar and Carpocapsa pomonella; quotations showing good results from pasturing swine in fruit orchards.

388. [WALsH, B. D., and C. V. Riley.] Insect changes. <Amer. Ent., September, 1868, r. 1, p. 6.

Definition of the different stages of insect transformation.

389. [Walsh, B. D., and C. V. Riley.] A new bark-louse on the osage orange. <Amer. Ent., September, 186s, v. 1, p. 14, fig. S.

Seasons, food-plants, characters, and figures of Lecanium maclurce n. sp.., $[=$ Pulvinaria innumerabilis $]$ and of $L$. acericola n. sp. $[=P$. innumerabilis $]$; characters and economic importance of the genus Aspidiotus.

390. [Whlsh, B. D., and C. V. Riley.] Entomologicai ignorance in the South. <Amer. Ent., September, 1868, r. 1, pp. 14-16.

Reprint and criticism of article, "How to destroy the cotton-worm-a suggestion."

391. [W September, 1868, v. 1, p. 16.

Ravages of Acridida in Illinois, Iowa, and Missouri; mention of the species committing these ravages; means against the same.

392. [WALsH, B. D., and C. V. Riler.] The old and the new philoso. phy. <Amer. Ent., September, 186s, r. 1, 1. 17.

Defense of the practical application of science.

393. [WALsir, B. D., and C. V. RILEY.] The animal kingdom. <Amer. Ent., September, 1868, v. 1, pp. 17-18.

Definition of the "four grand branches of the aninal kiugdom;" mention of their respective classes. 
394. [Walsh, B. D., and C. V. Rilery.] Ad interim committees. $<$ Amer. Ent., September, 1868, v. 1, p. 18.

Duties of ad interim committees of horticultural socicties; the American Entomologist ready to publish any scientific discoveries or obscrvations with regard to rots or diseases of a vegetal nature.

395. [W September, 1868, r. 1, p. 18.

Notice of W. II. Edwards's "The butterflies of North America," pt. 1; of A. S. Packard, jr.'s "Guide to the study of insects," pt. 2 ; and of the "Canadian Entomologist," v. 1, No. 1.

396. [Walsh, B. D., and C. V. Riley.] "Fire.flies." -<Amer. Ent., September, 1868, จ. 1, p. 19, fig. 9.

Answer to inquiry of W. McC.; characters and transformations of Photinus pyrnlis; figures larva, with details of structure, pupa, and imago.

397. [WALsh, B. D., and C. V. Riley.] A new grape root.borer. $<$ Amer. Ent., September, 1868, v. 1, p. 19.

Answer to inquiry of W. D. F. Lummis; characters and ravages of an undetermined longicorn larva; food-habits of Orthosoma cylindricum $[=$ brunnerm].

398. [WALSH, B.D., and O. V. RILEX.] Bugs on grape-vines mistaken for chinch-bugs. <Amer. Eint., September, 1868, v. 1, p. 19.

Answer to inquiry of F. Hecker; characters, ravages, and food-plants of Blissus lencopterus and of Picsma cinerea.

399. [Walsh, B. D., and C. V. Riley.] Leaf-hoppers of the grape $<$ Amer. Ent., September, 1868, v.1, p. 19.

Answer to inquiry of F. Hecker; characters and ravages of Proconia $[=\mathrm{On}$ cometopia ] undata.

400. [Walsh, B. D., and 'C. V. Riley.] Leaf-bugs. <Amer. Ent., September, 1868, v. 1, p. 19.

Auswer to inquiry of C. H. Pcck; food-habits of Tingis [=Gargaphia $]$ tilie aud of $T$. [=Corythnca $]$ ciliata; punctures on leaves caused by Hemiptera.

401. [Walsh, B. D., and C. V. Riler.] Potato bugs. <Amer. Ent., 1868 , v. 1, October, pp. 21-27, fig. 10-19; November, pp. 4149 , fig. 33-48.

Failure of popular authors to distinguish between the different insects infesting the potato plant; brief accounts and figures of one or more stages of the following species: Gortyna nitela, Barillius [= Trichobaris $]$ trinotata, Sphinx 5-maculata $[=$ Protoparce celeus $]$, Lytta $[=$ Epicauta $]$ vittata, L. atrata $[=E$. pennsylvanica $]$, L. marginata $[=E$. cincrea $]$, L. cincrea $[=$ Macrobasis unicolor $]$, L. murina $[=$ M. unicolor $]$, Lema trilineata, and Haltica $[=$ Crepidodera $]$ cucumeris; migrations, habits, enemies, and means against Doryphora 10-lincata; figures of all stages of D. 10-lineata and D. juncta and of numerous enemics of the former.

402. [WALSH, B. D., and C. V. RILEY.] "Grasshoppers." Their devastations in western Fowa and the good that has resulted from them. <Amer. Ent., October, 1868, v. 1, pp. 27-28.

Letter of M. C. Nickerson, with comments; seeds of Vilfa vaginaflora carried by "grasshoppers." 
403. [WALSH, B. D., and C. V. Riler.] An apple growing on a grape. vine. <Amer. Ent., October, 1868, v. 1, p. 28.

Extract from Richmond ( $\mathrm{Va}$.) Whig, with criticism; a gall of Cecidomyia vitispomum mistaken for an apple growing. on a grape-vine. See Nos. 332, 436, 478.

404. [WALsh, B. D., and C. V. Riley.] Ticks and Texas fever. $<$ Amer. Ent., October, 1868, v. 1, p. 28.

Improbability that Ixodes bovis is the cause of the Texas fever of cattJc.

405. [WALSH, B. D., and C. V. RILEY.] Scientific symbols. <Amer. Ent., October, 1868, v. 1, p. 28. Reprint: <Op. cit., Novem. . ber, 1869, Ү. 2, p. 50.

Explanation of the use of the signs designating the sexes.

406. [WALSH, B. D., and C. V. RILEY.] A swarm of butterflies. <Amer. Ent., October, 1868, v. 1, pp. 28-29, 6gs. 20-22.

Record of swarms of Danais archippns; food-plant of larva; figures larva, chrysalis, and imago.

407. [Walsh, B. D., and C. V. Riley.] The sting of the 17.year Cicada. <Amer. Ent., October, 1868, v. 1, pp. 36-37.

Communications from F. W. Collins, R. Richardson, and B. Borden, on the reputed sting of Cicada [= Tibicen] scptendecim and on the habits of Stizus grandis $[=$ Sphecius speciosus $]$.

408. [WALSH, B. D., and C. V. RILEy.] On our table. <Amer. Ent., October, 1868, v. 1, p. 37.

Notice of "The insect world," by L. Figuier.

409. [WALSH, B. D., and C. V. RrLer.] Squash-bug; its change of color. <Amer. Ent., October, 1868, v. 1, p. 37.

Answer to inquiry of J. Periam; changes of color of Corens $[=$ Anasa $]$ tristis during its metamorphoses.

410. [WaLSH, B. D., and C. V. RILeY.] White grub; immunity from it next year in Clinton County, Mo. <Amer. Ent., October, 1868, v. 1, p. 37.

Answer to inquiry of J. P. McCartney; life-liabits of Lachnosterna fnsca.

411. [WALSH, B. D., and C. V. Rrley.] Insect enemies of the Colo. rado potato beetle. <Amer. Ent., October, 1868, v. 1, p. 37.

Answer to inquiry of S. H. Kriedelbangh; identification of three insect encmies of Doryphora 10-lineata.

412. [Walsh, B. D., and C. V. Riley.] "Harvest-bugs" in America, misnamed "jiggers." <Amer. Ent., October, 1868, v. 1, p. 38.

Answer to inquiry of M. McKenzie; habits of parasitic Acarina; distribution of and injurics caused by Sarcopsylla penetrans.

413. [WALSH, B. D., and C. V. RrLey.] Insects named. <Amer. Ent., October, 1868, v. 1, p. 38.

Answer to inquiry of J. T. Smith; food-plants of Aphis mali and of Notodonta $[=$ CEdcmasia $]$ concinna; Campoplex $[=$ Limneria $]$ fugitiva parasitic on larva of Euchetes cglc.

414. [WALSi, B. D., and C. V. RiLeY.] Grapes cut off by the tree cricket. <Amer. Ent., October, 1868, v. 1, p. 38, fig. 30-31.

Answer to inquiry of J. H. Tice; food-habits of QEcanthns nivens; doposition of eggs; figures both sexes. 
415. [Walsh, B. D., and C. V. Riley.] The Buffalo tree-hopper. $<$ Amer. Ent., October, 1868, v. 1, p. 38.

Answer to inquiry of $\mathrm{P}$. Rickert; characters, habits, and means against $C e$ resa bubalus.

416. [WALSH, B. D., and C. V. RILEY.] A scavenger mistaken for a foe. <Amer. Ent., October, 1868, v. 1, p. 38.

Answer to inquiry of Simmons and Tillson; characters and habits of the larva of Copris carolina.

417. [W Alsi, B. D., and C. V. Riley.] Insect foes of the bark-louse: <Amer. Ent., October, 1868, v. 1, p. 39, fig. 32.

Answer to inquiry of J. Weed; habits and figures of larva and imago of Chilocorus bivutnerus; food-habits and figure of Epilachna borealis.

418. [Walst, B. D., and C. V. Riley.] Best works on entomology. $<$ Amer. Fint., October, 1868, v. 1, p. 39.

Answer to inquiry of B. M. Reynolds; mention of several important works on entomology.

419. [WAlsh, B. D., and C. V. Rilex.] Larræ in plum-gum. <Amer. Ent., October, 1868, v. 1, p. 39.

Answer to inquiry of P. Rickert; unknown larva (probably dipterous) found in gum of plum tree; Mycetophila sp., bred from gum of peach-tree.

420. [Walsh, B. D., and C. V. RILEY.] Insect foes of the hop vine. <Amer. Ent., October, 1868, v. 1, p. 39.

Answer to inquiry of H. C. Freeman; characters and habits of larva of $S a$ turnia $[=$ Hyperchiria $]$ io and of Vaness $a[=$ Grapta $]$ interrogationis.

421. [W ALSH, B. D., and C. V. RILEY.] Insect foe of the apple-tree borer. <Amer. Ent., October, 1868, v. 1, p. 39.

Answer to inquiry of J. E. Walker; undetermined carabid larva preying upon larva of Saperda candida.

422. [WAlsh, B. D., and C. V. Riley.] Oak tree caterpillars. <Amer. Ent., October, 1868, v. 1, p. 39.

Answer to inquiry of W. W. Daniells ; characters and habits of larva of Edema albifions.

423. [Whlsh, B. D., and C. V. Riley.] Bark-lice on apple trees. $<$ Amer. Ent., October, 1868, v. 1, p. 40.

Auswer to inquiry of J. G. Fleck; Mytilaspis pomorum destroyed by a minute mite.

424. [WALsh, B. D., and C. V. RILEY.] The "saddle-back" caterpillar. <Amer. Ent., October, 1868, v. 1, p. 40.

Answer to inquiries of E. Baxter and O. A. Kenyon; characters, habits, and urticating propertics of the larva of Empretia stimulea.

425. [WALSH, B. D., and C. V. RILEY.] The regal walnut caterpillar. $<$ Amer. Ent., October, 1868, v. 1, p. 40.

Answer to inquiry of M. Copley; characters and food-plants of larva of Citheronia regalis; times of metamorphosis; characters of the imago.

426. [Walsh, B. D., and C. V. Rhley.] The Hessian fly. <Amer. Ent., October, 1868, v. 1, p. 40.

Answer to inquiry of F. D. Carson; ravages of Cecidomyia destructor; late sowing as a means of avoiding the same. 
427. [Walsh, B. D., and C. V. Riley.] Red cedar caterpillar. < Amer. Ent., October, 1868, v. 1, p. 40.

Answer to inquiry of R. Peter; habits, characters, and mcans against Thyridopteryx ephemeraformis.

428. [Walsh, B. D., and C. V. Riley.] Wheat-midge winter killed. <Amer. Ent., October, 1868, v. 1, p. 40.

Answer to inquiry of J. P. Alexander; cause of the scarcity of Diplosis tritici.

429. [Walsh, B. D., and C. V. Riley.] Grape vine borer. <Amer. Ent., October, 1868, v. 1, p. 40.

Answer to inquiries of A. Barter and J. H. Hogạn ; undetermined cerambycid larva injurious to grape-vines.

430. [Walsh, B. D., and C. V. Riley.] Popular names and scientific names. <Amer. Ent., November, 1868, v. 1, p. 49, figs. 49-51.

Indefiniteness of popular names; figures Julus sp., and the larva and inago of one of the Elaterida.

431. [Walsh, B. D., and C. V. Riley.] Entomological ignorance in the North. <Amer. Ent., November, 1868, v. 1, pp. 50-51, figs. 52-54.

Confusion cxisting in regard to the meaning of the word locust; habits of Acridida and Cicadide; ; figures types of the two families and of twig with eggs of Cicada sp.

432. [Walsh, B. D., and C. V. Riley.] Tit for tat. <Amer. Ent., November, 1868, v. 1, p. 52.

Ridicnle of an absurd entomological item.

433. [Walsh, B. D., and C. V. Riley.] Grasshoppers. <Amer. Ent., November, 1868, v. 1, p. 53.

Abundance and ravages of several species of Acridide and of Acheta $[=$ Gryllns $]$ abbreviatus in the northern central United States, and scarcity of the same in New York in 1868.

434. [W Alsh, B. D., and C. V. Riley.] To keep seed peas from bugs. $<$ Amer. Ent., November, 1868, v. 1, p. 53.

Habits of and means against Bruchus pisi.

435. [Walsh, B. D., and C. V. RILEY.] Mind how you pack insects. <Amer. Ent., November, 3868, v. 1, p. 54.

Care necded to avoid the introdnction of noxions insects.

436. [Walsh, B. D., and C. V. Riley.] The apple growing on a grape vine. <Amer. Ent., November, 1868, v. 1, p. 54.

The "vegetable phenomenon," see Nos. $332,403,478$, proved to be a gall.

437. [Walsh, B. D., and C. V. RILey.] The late exhibition of useful and destructive insects at Paris. <Amer. Ent., November, 1868 , v. 1, p. 55.

Notice of the formation of the Societé d'Insectologie Agricole at Paris, and of the second exhibition of the society.

438. [WALsh, B. D., and C. V. Riley.] Destroying black ants in gardens. <Amer. Ent., November, 1868, v. 1, p. 55.

Answer to inquiry of W. S. Patten; means against Formicide in gardens. 
439. [WALSII, B. D., and C. V. RILEY.] Entomological quackery. $<$ Amer. Eut., November, 1868, v. 1, p. 56.

Reprint of "The Curculio (Iowa Homestead, $22 d$ July, 1868), with eomments; means against Conotrachelus nenuphar.

440. [WALSH, B.D., and C. V.RILEY.] The eruel bug.hunters. <Amer. Ent., November, 1868, v. 1, p. 56.

Inscets are not susceptible of sueh feelings of pain and pleasure as are felt by higher animals.

441. [WALSH, B. D., and C. V. RILEY.] Honey bees eating grapes. $<$ Amer. Ent., November, 1868, v. 1, p. 56.

Reprint of a letter by T.'W., from Ohio Farmer, with comments; Apis mellifica as an enemy of sound fruit.

442. [WALSH, B. D., and C. V. Riley.] Twigs amputated by some unknown animal. <Amer. Ent., November, 1868, v. 1, p. 57.

Answer to inquiry of G. Burnside; method of work of an undetermined fruittree pruner [= Oncideres cingulata?].

443. [WALSH, B. D., and C. V. RILEY.] Twigs girdled by some animal. <Amer. Ent.; November, 1868, v. 1, p. 57.

Answer to incuiries of Judge Brown and P. Earle; method of work of an undetermined fruit-trec pruner [= Oncideres cingulata?]; trees affeeted.

444. [WALsh, B. D., and C. V. Riley.] Hop-vine caterpillar. <A mer. Ent., November, 1868, v. 1, p. 57.

Answer to inquiry of II. J. Dunlap; larva of Grapta interrogationis feeding on hop-vines.

445. [WALSH, B. D., and C. V. RILEY.] "Galls" on leaves of soft maple. $<$ Amer. Ent., November, 1S68, v. 1, p. 57.

Answer to inquiry of A. L. Child; charaeters of undeseribed mite-galls and their architeets; mode of formation of leaf-galls by mites.

446. [WALSH, B. D., and C. V. Riley.] Unsightly galls on the cottouwood. <Amer. Ent., November, 1868, v. 1, p. 57.

Answer to inquiry of A. L. Child; eharaeter of galls made by Pentphigus vagabondus and $P$. populicaulis; their effeets upon the eottonwood and means against them.

447. [WALSH, B. D., and C. V. Riley.] Insects named. <Amer. Ent., November, 1868, v. 1, p. 57.

Answer to incquiry of E. Baxter; Gordins aquaticus a host in Orchelinum gracile; Celonia $[=$ Euphoria $]$ inda destrnetive to the peaeh.

448. [WALsh, B. D., and C. V. Riley.] Thestick-bug. <Amer. Ent., November, 1868, v. 1, p. 58. Reprint : <Can. Farmer, 15 January, 1870.

Description, vernaeular names, and habits of Spectrum [= Diapheromera $]$ femorata.

449. [WALSh, B. D., and C. V. RILEY.] Woolly lice on the beech. <Amer. Ent., Norember, 1868, v. 1, p. 58.

Answer to inquiry of F. H. Guiwits; habits and food-plants of Pempligus imbricator. 
450. [Walsh, B. D., and C..V. Rilex.] The sheep-bot or head-maggot. $<$ Amer. Ent., November, 1868, v. 1, p. 58.

Answer to inquiry of R. W. Seott; CEstrus ovis ordinarily oviparous; sometimes the eggs hateh prematurely inside the hody.

451. [WALsh, B. D., and C. V. Riley.] Leaf-miners of the locnst. $<$ Amer. Ent., November, 1868, v. 1, p. 58.

Answer to inquiry of R. W. Seott; characters, habits, ravages, and means against Hispa scutcllaris $[=$ Odontota dorsalis $]$.

45. [W [WLSH, B. D., and C. V. RiLey.] Leaf-hoppers on celery. $<$ Amer. Ent., November, 1S68, v. 1, p. 58.

Answer to inquiry of R. Parnell; mention of two undeseribed Tettigonide infesting early eclery.

453. [W $\mathrm{WLSH}, \mathrm{B} . \mathrm{D}$., and C. V. RILEY.] Parsuip eaterpillars.-Scorpions. <Amer. Ent., November, 1868, v. 1, p. 59.

Answer to inquiry of F. Brewer; food-plants of larva of Papilio asterias; habits of the imago; habits and sting of Buthus carolinianus; its occurrence in Missouri.

454. [Whlsi, B. D., and C. V. Riley.] Noxious insects named. $<$ Amer. Ent., November, 1S68, v. 1, p. 59.

Answer to inquiry of $\dot{J}$. II. Parsons; larval charaeters and food-plants of Iyphantria textor $[=$ cunea $]$, Notodonta $[=$ dEdemasia $]$ concinua, Arctia [= Spilosoma virginica, Carpocapsa pomonella, and of Trypeta pomonella.

455. [W $\mathrm{WLSH}, \mathrm{B}$. D., and C. V. RILEY.] Cut-worms destroying recently sown wheat. <Amer. Ent., November, 1S68, v. 1, p. 59.

Answer to inquiry of T. R. Allen; eharaeters, habits, and means against nudetermincd Noctuide attaeking wheat.

456. [WALSH, B. D., and C. V. Riley.] The spined soldier bug. $<$ Amer. Ent., November, 1868, v. 1, 1. 59.

Answer to inquiry of I. Hieks; Podisus spinosus as an enemy of Hyphantria textor $[=$ cunca $]$.

457. [WaLsh, B. D., and C. V. Riley.] The preying Mantis, alias Deril's riding horse, etc. <Amer. Ent., November, 1868, v. 1, p. 59.

Auswer to inquiry of A. Pettit; habits of Mantis [ Phasmomantis] carolina; egg-mass of the same.

458. [W Ent., November, 1868, v. 1, p. 59.

Answer to induiry of $\mathrm{F}$. Brewer; eharaeters of Tremex columba; food-habits and parasites of its larva.

459. [WALsh, B. D., and C. Vे. Rilex.] Flesh-worms. <Amer. Ent., Norember, 1868, ₹. 1, p. 59.

Auswer to inquiry of W. J. Stuart; larval habits of an undetermined museid.

460. [W $\mathrm{LLSH}, \mathrm{B}$. D., and C. V. RILEY.] Fall web-worm on hickory. <Amer. Ent., November, 1868, v. 1, 1. 59.

Answer to inquiry of W. W. Daniels; transformation of Hyphantria textor $[=$ cunea $]$; charaeters of its larva and imago. 
461. [WALsh, B. D., and C. V. RILEY.] Butterflies named. <Amer. Ent., November, 1868, v: 1, p. 60.

Answer to inquiry of W. W. Butterfield; characters of Colias philodice, $\mathrm{Va}$ nessa $[=$ Grapta $]$ comma, and Danais archippus.

462. [Walsh, B. D., and C. V. Riley.] Museum pest. <Amer. Ent., November, 1868 , v. 1, p. 60.

Answer to inquiry of T. W. Holt, jr.; means against Dermestide.

463. [WALSH, B. D., and C. V. RILEY.] Insects named: <Amer. Ent., Norember, 1868 , v. 1, p. 60.

Answer to inquiry of $J$. Weed; enemies of plant-lice and bark-lice; foodplant and characters of the larva of Papilio turmus.

464. [WALSH, B. D., and C. V. RILEY.] Grapes spoiled by something. $<$ Amer. Ent., November, 1868, v. 1, p. 60.

Answer to inquiry of J. Wood; grapes injured from some unknown canse; juice from wounded grapes as food for moths.

465. [WALsH, B. D., and C. V. RILEY.] White-pine worms. <Amer. Ent., November, 1868, v. 1, p. 60.

Answer to inquiry of J. T. Little; food-plants of larva of Lophyrus abbotii; transformations of the same.

466. [Walsh, B. D., and C. V. Riley.] The Tarantula of Texas. $<$ Amer. Ent., November, 1868, v. 1, p. 60.

Answer to inquiry of $\mathrm{J}$. Bell; manuer in which $\boldsymbol{P}^{3}$ ompilus $[=$ Pepsis $]$ formosa prepares Mygale hentzii for food for its larva.

467. [WALSI, B. D., and O. V. RiLeY.] Insect foes of the apple-tree. $<$ Amer. Ent., November, 1868, v. 1, p. 60.

Auswer to inquiry of G. C. Brackett; characters of larva of Carpocapsa pomonella; meaus against Datana ministra and Pemphigus pyri $\mathrm{L}=$ Schizoneura lanigéra].

468. [Walsh, B. D., and C. V. Riley.] Grape-leaf folders eaten by spiders. <Amer. Ent., November, 1868, v. 1, p. 60.

Answer to inquiry of A. A. Hilliard; larva of Desmia maculalis destroyed by a spider.

469. [W Alsh, B. D., and C. V. Riley.] Caterpillar of the Troilus butterfly. <Amer. Ent., November, 1868, v. 1, p. 60.

Answer to inquiry of A. S. Fuller; food-habits of larva of Papilio troilus.

470. [Walsh, B. D., and C. V. Riley.] Potato beetles. <Amer. Ent., November, 1868, v. 1, p. 60.

Answer to inquiry of P. H. Foster; identification of Epicauta vittata and Macrobasis unicolor as enemics of the potato.

471. [Walsh, B. D., and C. V. Riley.] Holes round the roots of young ash trees in the nursery. '<Amer. Ent., November, 1868, v. 1, p. 60.

Answer to inquiry of I. Hicks; characters and food-habits of the larva of Xyloryctes satyrus.

472. [WALSH, B. D., and C. V. Riley.] Locust borers. <Amer. Ent., November, 1868 , v. 1, p. 60.

Answer to inquiry of U. Bruner; destructiveness of the larva of Clytus $[=$ Cyllene $]$ robinia. 
473. [WaLSh, B. D., and C. V. RILEY.] The hellgrammite fly. <Amer. Ent., December, 1868, .v. 1, pp. 61-62, figs. 56-57.

Habits of Corydalus cornutus; figures the larva, pupa, and imago; deseription and figure of the eggs of Belostoma americanum mistaken for those of Corydalus.

474. [Walsh, B. D., and C. V. Riley.] The periodical Cicada. <Amer. Ent., December, 1868, v. 1, pp. 63-72, figs. 58-64. .Extract: <Op. cit., June, 1869, v. 1, p. 202.

Characterization of the 13-year brood of Cicada as a new spècies, $C$. [ = Tibicen ] tredecim; dimorphism of the same and of $C .[=T$. $]$ septendecin ; seasons, natural history, transformations, enemies, sting, and injuries of these species; chronological history of their several known broods; figures the several stages of $C .[=T$. $]$ septendecim, the towers made by the pupa and twigs with eggs.

475. [WALSH, B. D., and C. V. RILEY.] The hateful or Colorado grasshopper, Caloptenus spretus, Uhler and Walsh. <Amer. Ent., December, 1868, จ. 1, pp. 73-76, fig. 65.

Comparative characters and figures of Caloptenus spretus and C. femur-rubrum; native habitat, migrations, distribution, and ravages of the former; harmlessness of its second generation in the Mississippi Valley as compared with the first generation; improbability that it will ever become a permanent resident in that region.

476. [WALsh, B. D., and C. V. RILeY.] The twig-girdler, Oncideres cingulatus, Say. <Amer. Ent., December, 1868, v. 1, pp. 7677 , tig. 66.

Oviposition and food habits of Oncideres cingulata; figure of imago and of amputated $t w i g$.

477. [Walsh, B. D., and C. V. RILEY.] An Ichneumon fly mistaken for a wasp. <Amer. Ent., December, 1868, v. 1, p. 77.

Review of paper in Christian Advocate on "The stiletto wasp"; Pimpla [= Thatessa $]$ atrata probably mistaken for a wasp.

478. [Walsh, B. D., and O. V. Riley.] A plant growing out of an insect. <Amer. Ent., December, 1868, v. 1, p. 77.

Sce Nos. 332, 403, 436; extract from Sedalia Press, with comments; larvas of Lachnosterua fusca infested with Cordyceps; larvie supposed to have eaten poisonous secd, which has germinated after killing the larva; sowing the seed as a means against the larva.

479. [Walsh, B. D., and O. V. RileY.] On our table. <Amer. Ent., December, 1868 , v. 1, p. 78 .

Notices of The butterflies of North Amcrica by W. H. Edwards.-The Canadian Entomologist.-Guide to the stndy of insects by A. S. Packard, jr.

480. [WALSH, B. D., and C. V. Riley.] Eggs of the white-marked tussock moth. <Amer. Ent., December, 1868, v. 1, p. 79, fig. 67.

Answer to inquiry of J. M. Hanuah; claracters of egg and larva of Oigyia leucostigma; sexual differences; parasites; figure of the larva.

481. [Walsh, B. D., and C. V. Riley.] Currant borers. <Amer. Ent., December, 1S68, v. 1, p. 79.

Inswer to inquiry of B. N. MeKinstry; means against Trochilium $[=$ Egcria $]$ tipuliformis, $T$. $[=$ Alcatho $]$ caudatum, and Psenocerus supernotatus. 
482. [WALSH, B. D., and C. V. RILEY.] Insect infesting grape seed. <Amer. Ent., December, 1868, v. 1, p. 79, fig. 68.

Answer to inquiry of A. S. Fuller; characters and figure of larva of Isosoma vitis in festing grape seed.

483. [WALSH, B. D., and C. V. RILEY.] Museum pests again. <Amer. Ent., December, 1868, v. 1, p. 79.

Answer to inquiry of J. Huggins; means against Anthreni in collections of natural history.

484. [WALSH, B. D., and C. V. RILEY.] Grape-vine leaf-hoppers. $<$ Amer. Ent., December, 1868, v. 1, p. 79.

Answer to inquiry of P. C. Holmes; means against grape-vine leaf-hoppcrs.

485. [WALsh, B. D., and C. V. Riley.] Apple-tree borer. <Amer. Ent., December, 1868, v. 1, p. 80, fig. 69.

Answer to inquiries of J. T. Zimmerman, C. H. Roberts, and C. R. Babbitt; habits, ravages, and figure of Bostrichus [= Amphicerus] bicaudatus.

486. [Walsh, B. D., and C. V. Riley.] The murky ground beetle. <Amer. Ent., December, 1868, v. 1, p. 80.

Answer to inquiry of E. T. Dale; fcod-habits and bombardier discharges of Harpalus caliginosus.

487. [WAlsh, B. D., and C. V. RILEY.] Curculio and bark-lice. <Amer. Ent., December, 1868, v. 1, p. 80.

Answer to inquiry of D. A. Compton; hibernation of Conotrachelus nenuphar; soft soap as a means against Coccide.

488. [WALSH, B. D., and C. V. RILEY.] Insects to be named. <Amer. Ent., December, 1868, v. 1, p. 80.

Answer to inquiry of E. B. Beach; identification of several lepidopterons larvæ; food-habits of Dryocampa stigma and D. pellucida [= virginieusis].

489. [WALSH, B. D., and C. V. Rrley.] Young pecan trees girdled. Amer. Ent., December, 1868, v. 1, p. 80.

Answer to inquiry of Mann and Redmond; means against Oncideres cingulata.

490. [WALSH, B. D., and C. V. RlLeY.] Insects named. <Amer. Ent., December, 1868, v. 1, p. 80 .

Answer to inquiry of E. T. Dale; identification of several Colcoptera; supposed food-habits of Tragidion fulvipenne; character of cocoons of two species of Microgaster infesting Protoparce celens.

491. [Walsh, B. D., and C. V. Riley.] Eggs of true bugs. <Amer. Ent., December, 1868, v. 1, p. 80.

Answer to inquiry of S. C. Thornton; characters of eggs of Prionidus cristatus. See Amer. Ent., v. 1, pp. 96 and $18 \%$.

492. [WALSH, B. D., and C. V. Rrlex.] Museum pest once more. $<$ Amer. Ent., December, 1868, v. 1, p. 80.

Answer to inquiry of G. M. L. ; larvæ of Anthrenus muscorum injuring whalebone, woolen goods, etc.

493. [Walsh, B. D., and C. V. RrLey.] The Tarantula of Texas again. $<$ Amer. Ent., December, 1868, v. 1, p. 80.

Answer to inquiry of C. Peabody; distribution of Mygale hentzii in Missouri. 
494. [Walsh, B. D., and C. V. RrLex.] The Hessian fly on seed wheat. <Amer. Ent., December, 1868, v. 1, p. 80.

Answer to inquiry of $\mathrm{U}$. Scott; broods and times of transformation of Cecidomyia destructor.

495. [WALSH, B. D., and C. V. Riley.] The apple-root plant-louse. Eriosoma (Pemphigus) pyri, Fitch. <Amer. Ent., January, 1869, v. 1, pp. 81-84, figs. 70-72.

'Habits, ravages, description, enemies; and parasites of, and means against Eriosoma pyri $[=$ Schizoneura lanigera $]$; figures injurcel root, Iarva, and adult with details of structure; figures adult plant-louse found on cottonwood; description and figure of larva, puparium, and imago of Pipiza radicum $\mathrm{n}$. $\mathrm{sp}$.

496. [WALSH, B. D., and C. V. RILEYY.] Ants' nests in gardens. <Amer, Ent., January, 1869, v. 1, p. $\$ 4$.

Means against ants.

497. [WALSH, B. D., and C. V. RILEY.] The parasites of the human animal. <Amer. Ent., January, 1869, v. 1, pp. 84-88, figs. $73-74$.

Brief accounts of Pediculus humanus [= vestimenti], P. cervicalis [= capilis], P. [=Pthirius $]$ pubis, Estrus $[=$ Dermatobia $]$ hominis, Pulex irritans, $P$. [= Sarcopsylla $]$ penetrans, Acanthia lectularia, Conorhinus sanguisnga, and Acarus [= sarcoptes] scabiei; figures and habits of Reduvins [= Opsicetus] personatus and of Pirates [= Rasahus] biguttalus; figure of Conorhinus sanguisuga; classificatory relations of Pediculina and Mallophaga.

498. [Walsh, B. D., and C. V. Riler.] The coffee borer. <Amer. Ent., January, 1869, v. 1, p. 88.

Unnamed coffee borer injurious to coffee trecs in Madras.

499. [W $\triangle$ LSH, B. D., and C. V. RILEY.] Strawberry worms. <Amer. Ent., January, 1869, v. 1, pp. 89-91, figs. 75-76.

Description, natural history, ravages, means against, and figures of larva and imago of Anchylopera [ = Phoxopteris $]$ fragarice, n. sp.; figures all stages of Emphytus [ = Harpiphorus] maculatus; description of its larva and pupa, its natural history, and means against its ravages.

500. [Walsh, B. D., and C. V. Riley.] Fungoid growths. <Amer. Ent.; January, 1869, v. 1, pp. 91-92.

Mention of instances of the growth of fungi on living plants and animals; letter of S. H. Y. Early on the occurrence of fungoid growths on the larvet of Lachosterna fusca.

501. [WALSH, B. D., and C. V. RILEY.] Plums for the million. <Amer. Ent., January, 1869, v. 1, pp. 92-93.

Means against Conotrachelus nenuphar; notes on varieties of plum exempt from the attacks of the samc.

502. [W ALSH, B. D., and C. V. RILEY.] The "Colorado grasshopper." $<$ Amer. Ent., January, 1869, v. 1, pp. 95-96.

Answer to inquiries of W. N. Byers and V. Devinny; specific names indicating particular districts can not be changed because the insect is found in other regions. 
503. [WALSH, B. D., and C. V. RileY.] Universal remedies. <Amer. Ent., January, 1869, v. 1, p. 97.

Criticism of an advertisement of "Best's patent fruit tree and vine invigorator."

504. [Walsh, B. D., and C. V. Riley.] Complimentary. <Ame:", Ent., January, 1869, v. 1, p. 98.

Notices of several notices of the American Entomologist.

505. [Walsh, B. D., and C. V. Riley.] Paper-makers. <Amer.Ent., January, 1869, v. 1, p. 98.

Comparison of the manufacture of paper by man and by the Vespida.

506. [Walsh, B. D., and C. V. RileY.] On our table. <Amer. Ent., January, 1869, v. 1, p. 98.

Notices of L'Insectologie agricole-Cècil's books of natural history.

507. [WALSH, B. D., and C. V. RILEY.] Look out for the eggs of the apple-tree plant-louse. <Amer. Ent., January, 1869, v.1, p. 99.

Abundance of eggs of Aphis mali in winter of 1868-'69, in Missouri and Illinois; means against the same.

508. [WALSH, B. D., and C. V. RILEY.] Greenhouse plants [= pests]. $<$ Amer. Ent., January, 1869, v. 1, p. 99.

Means against Aphidida, Coccides, and Tetranychus telarius.

509. [WALSH, B. D., and C. V. RILEY.] How to hatch pupæ. <Amer. Ent., January, 1869, v. 1, p. 99.

Answer to inquiry of D. P. Smith; methods of raising insects.

510. [WALSH, B. D., and C. V. RILeY.] Drug-store pests. <Amer. Ent., January, 1869, v. 1, p. 99.

Answer to inquiry of J. M. Good; characters of larva of undertermined ptinid ; food-habits of Ptinus brunneus ; food-habits, characters, and means against Calandra oryzoe and C. granaria. (See No. 551.)

511. [WALSH, B. D., and C. V. RILEY.] Apple-tree worms. <Amer. Ent., January, 1869, v. 1, p. 99.

Answer to inquiry of J. J. Thomas; habits, food-plants, and means against Phycita nebulo $[=$ Acrobasis indiginella $]$.

512. [Walsh, B. D., and C. V. Riley.] Crane-fly larvæ. Amer. Ent., January, 1S69, v. 1, p. 100.

Answer to inquiries of R. D. Alexander and - Hickman ; habits of Tipula sp.; food-habits of $T$. trivittata.

513. [Walsh, B. D., and C. V. Riley.] Punctured grape canes. $<$ Amer. Ent., January, 1869, v. 1, p. 100.

Answer to inquiry of B. L. Kingsbury; description of punctures in grape canes probably caused by Orocharis saltator; means against tree-crickets.

514. [WALSH, B. D., and C. V. Riley.] Insects to be named. < < Amer. Ent., January, 1869, v. 1, p. 100.

Answer to inquiry of W. R. Marine; identification of several insects found in apple and peach nurseries.

515. [WALSH, B. D., and C. V. RileY.] Supposed cause of yellows in peach trees. <Amer. Ent., January, 1869, v. 1, p. 100, fig. 77.

Answer to inquiry of C. H. Robcrts; yellows of peach-trees a vegetable disease; figure of healthy and diseased limb; affected trees more subject to the attacks of insects than healthy trees. 
516. [Walsh, B. D., aud C. V. RiLex.] Eggs of katydid. <Amer. Ent., January, 1s69, v. 1, p. 100.

Answer to inquiry of A. A. Hilliard; character of the eggs of Platyphyllum $[=$ Cyrtophyllus $]$ concavus.

517. [Walsh, B. D., and C. V. Riley.] Apple-twig borer. <Amer. Ent., January, 1S69, v. 1, p. 100.

Answer to inquiry of J. T. Zimmerman; ravages of Bostrichus [ = Amphicerus] bicaudatus.

518. [WALSH, B. D., and C. V. Riley.] Galls and their architects. $<$ Amer. Ent., February, 1869, v. 1, pp. 101-110, figs. 78-90.

Definition, classification, and variation of galls; accounts of some galls made by Cynipida, Cecidonyida, and Aphidide and of the gall-makers; natural history, descriptions, and fignres of Cynips [=Amphibolips] q.-spongifica, $C$. $[=A] q$. -inanis, C. [=A.] q.-prnnus I. sp., Cecidomyia s.-strobiloides, C. s.-brassicoides, C. v.-pomum n. sp., C. v.-coryloides n. sp., Pemphigus ragabundus, P. rhois and Colopha ulmicola; description of the imago of Cynips q.-prunus and of Pemphigus ulmifusus n. sp., and of the larvo of the now species of Cecidomyia; dinorphism of gall-makers; presence of inquilines and parasites in galls. (See No. 821.)

519. [Walsh, B. D., and C. V. Riley.] The bogus Colorado potatobug, Doryphora juncta, Germar. <Amer. Ent., February, 1869, v. 1 , p. 110 .

Food-habits of $D$, juncta.

520. [Walsh, B. D., and C. V. Riley.] Ants and aphides. <Amer. Ent., February, 1869, v. 1, p. 110.

Inquiry of W. Batchelor, with answer ; secretion of honey-dew by Aphidide and harvesting of the same by ants.

521. [W alsh, B. D., and C. V. Riley.] The Tarantula of Texas, Mygale hentzii, Girard. <Amer. Ent., February, 1869, v. 1, 1. 11, fig. 91.

Figure of Mygale hentzii: habits of Pompilus [=Pepsis] formosa; quotes from G. Lincecum's "The Tarantula killers of Texas" (Amer. Nat., v. 1, pp. 137-141).

522. [WALsh, B. D., and O.' V. Riley.] The melancholy chafer. <Amer. Ent., February, 1869, v. 1, p. 111.

Ravages and tigure of the iulago of Euphoria melancholicu.

523. [WAlsh, B. D., and C. V. RileY.] Apple worms (Carpocapsa pomonella, Linn.). <Amer. Eut., February, 1869, v. 1, pp.112114, fig. 93.

Natural history, ravages, and means against Carpocapsa pomonella; figures injured apple, larva, pupa, and imago.

524. [WALsh, B. D., and C. V. RILEY.] The asparagus beetle (Crioceris asparagi, Linu.). <Amer. Ent., February, 1869, v. 1, pp. 114-115, fig. 94.

Introduction into the United States; natural history, ravages, parasites of, and means against Crioceris asparagi; figure of egrgs, larvie, aud imago of the same.

5 EN'1 
525. [Walsh, B. D., and C.V. Riler.] A popular delusion. <Amer. Ent., February, 1869, v. 1, p. 116.

No insect passes through all the stages of its growth within one day; life history of Ephemerida.

526. [WALSH, B. D., and C. V. RILEF.] The squirrel bot. <Amer. Ent., February, 1869, v. 1, v. 117.

Comments on paper by S. S. Rathvon; emaseulation of the striped squirrel by Cuterebra buccata.

527. [W ALSH, B.D., and C. V. Riley.] [Periodical Cicada.] <Amer. Ent., February, 1869, v. 1, p. 117.

Comments on letter of R. H. Warder; oviposition of Cicada [= Tibicen] septendeeim in evergreens.

528. [WALSH, B. D., and C. V. RILEy.] Transformations of insects. $<$ Amer. Ent., February, 1869, v. 1, p. 118.

Brief statement of the stages of growth of insects.

529. [WALSH, B. D., and C. V. RrLeY.] Do bees injure raspberries? <Amer. Ent., February, 1869, v. 1, p..118.

Comments on discussion before New York Frnit Growers' Club as to the effects of bees on flowers and fruits.

530. [Walsh, B. D., and C. V. Riley.] Best's fruit-tree invigorator agan. <Amer. Ent., February, 1869, r. 1, p. 119.

Notice of invention of a new "invigorator" by B. Best.

531. [WALSH, B. D., and C. V. RILEY.] The insect extinguisher, by Joseph Treat, N. J. <Amer. Ent., February, 1869, v. 1, p. 119.

Critical review of pamphlet by $J$. Treat.

532. [Walsh, B. D., and C. V. Riley.] More good words. <Amer. Eut., February, 1869, v. 1, p. 119.

Notice of favorable notices of the American Entomologist.

533. [WALSh, B. D., and C. V. Riley.] Lacewing Al. <Amer. Ent., February, 1869, v. 1, p. 119.

Answer to incquiry of J. Huggins; charaeters of Chrysopa sp. ; its hibernation as a pupa and imago.

534. [WALSH, B. D., and C. V. Riley.] Gigantic water-bug. <Amer. Ent., February, 1869, v. 1, p. 119.

Answer to inquiry of S. E. Munford; food-habits of Belosioma grandis [=americanum $]$.

535. [Walsh, B. D., and C. V. RILex.] The white-marked tussock moth again. <Amer. Ent., February, 1869, v. 1, p. 120.

Answer to inquiry of A. S. Fuller; mention of seven parasites attacking Orgyia Tenenstigma.

536. [WaLsh, B. D., and C. V. RiLeY.] Grasshopper eggs-will they hatch? <Amer. Ent., February, 1869, v. 1, p. 120.

Answer to inquiry of C. J. Jones; frosts not likely to prevent the hatching of the eggs of Caloptenus spretus.

537. [WALSH, B. D., and C. V. RILEY.] Injured apple-trees. <Amer. Ent., February, 1869, v. 1, p. 120.

Answer to inquiry of $\mathrm{x}$. C. Broadhead; mexus against Chrysobothris femorata. 
539. [Walsh, B. D., and C. V. Riley.] Bag worms. <Amer. Ent., February, 1869, v. 1, p. 120.

Answer to inquiry of W. W. Butterfield; means against Thyridopteryx ephe. mereformis.

539. [WaLsh, B. D., and C. V. Riley.] Eggs of the apple-tree plantlouse. <Amer. Ent., February, 1869, v. 1, p. 120.

Answer to inquiry of M. W. Seaman ; effect of frosts upon the eggs and larve of Aphis mali.

540. [WALsh, B. D., and C. V. Riley.] Insects named. <Amer Ent., February, 1869, v. 1, p. 120.

Answer to inquiry of J. B. Merwin ; identification of insects sent; characters of Vanessa antiopa and Cynthia $[=$ Pyrameis $]$ atalanta.

541. [WALSH, B. D., and C. V. Riley.] White grubs. <Amer. Eñt, February, 1869, v. 1, p. 120.

Answer to inquiry of W. C. Holmes; undetermined white-grub injuring grass and osage orange.

542. [WALSH, B. D., and C. V. RILEY.] The polyphemus moth, Attacus polyphemus, Linn. <Amer. Ent., March, 1869, v. 1, pp. 121-122, fig. 95.

Attaeus $[=$ Telea $]$ polyphemus, A. cynthia, and Bombyx $[=$ Sericaria $]$ mori as silk-producers; food-plants, description of larva, habits, and seasons of $A$. $[=T$.$] polyphemus; figure of the imago; ravages of A$. secropia; antenna mistaken for wings; mention of Lepidoptera having fissured wings.

543. [WALSH, B. D., and C. V. Riley.] Wasps and their habits. <Amer. Ent., March, 1869, v. 1, pp. 122-143, figs. 96-112.

Structure, classification, and habits of North American predatory Hymenoptera; comparative characters of the digger and trne wasps; figure to show the folding of the wing in true wasps; habits and figures of imagos of Chlorion coruleum, Bembex fasciata, Sphex iehneumonea, Ammophila pictipcnnis, Pepsis formosa, Stizus grandis [= Sphecius speciosus ], S. [=S.] speciosus, Pelopous lunatus $[=$ cementarius $]$, Agenia bombycina, Trypoxylon albitarse, Ceropales rufiventris, Eumenes fraternus, Vespa maculuta, and Polistes rubiginosus; figure of imago of Cryptus $[=$ Linoceras $]$ junceus and of several nests of wasps. (Sec No. 375.)

544. [Walsh, B. D., and C. V. Riley.] Do toads eat worker bees? <Amer. Ent., March, 1869, v. 1, p. 144.

Reprint and review of article by C. Dadant, and of comments of editors of American Bee Journal; usefulncss of toads.

545. [WALSH, B. D., and C. V. RiLeY.] Best's invigorator once again. <Amer. Ent., March, 1869, v. 1, p. 145.

Condemnation of $\mathrm{B}$. Best's patent fruit tree and rine invigorator.

546. [WaLsh, B. D., and C. V. Riley.] Ou our table. <Amer. Ent., March, 1869, v. 1, p. 146.

Notices of Nos. 1 and 2 of Le Naturaliste Canadien.

547. [Walsir, B. D., and C. V. Riley.] Sugar-tree borer. < <ner. Ent., March, 1869, v. 1, p. 146.

Answer to incuniry of E. Simms; characters and means against Athopalus $[=$ Plagionotus $]$ speciosus. 
548. [WALSH, B. D., and C. V. RILEY.] Swellings on apple scions. $<$ Amer. Ent., March, 1869, v. 1, p. 146.

Answer to inquiry of W. Colwell; dipterons galls on apple scions and basswood twigs.

549. [Whlsh, B. D., and C. V. Riley.] Gas-waste vs. Curculio. <Amer. Ent., March, 1869, v. 1, p. 147.

Answer to inçuiry of H.; merits of gas-waste as an insect destroyer.

550. [WALSH, B. D., and C. V. Riley.] Eggs of the apple-tree plantlouse again. <Amer. Ent., March, 1869, v. 1, p. 147.

Answers to incuniries of C. Williams and W. L. French; means against Aphis mali.

551. [Walsin, B. D., and C. V. Riley.] Drug-store pests. <Amer. Ent., March, 1869, v. 1, p. 147.

Answer to incquiry of J. M. Good; food-habits of Lasioderma serricorne. Sec No. 510 .

552. [WALSH, B. D., and O. V. RILEY.] Small galls and minings on apple-twigs. <Amer. Ent., March, 1869, v. 1, p. 1.47.

Answer to inquiry of O. O. A. Gardner; characters of undetermined galls and borings in twigs of apple-trecs.

553. [WALSH, B. D., and C. V. Riley.] Stinking bugs. <Amer. Ent., March, 1869, v. 1, p. 147.

Answer to inquiry of C. L. Janney; habits of an undescribed Brachyrhynchus.

554. [WALSH, B. D., and C. V. RILEY.] Eggs in peach-twigs. <Amer. Ent., March, 1869, v. 1, p. 147.

Answer to inquiry of G. Fisher; character of eggs of Ecanthus niveus.

555. [WALSH, B. D., and C. V. RILEY.] Flat-headed apple-tree borer. $<$ A mer. Ent., March, 1869, v. 1, p. 147.

Answer to inquiry of B. F. Mudge; means against Chrysobothris femorata.

5ว5. [WALsh, B. D., and O. V. RileY.] A bundle of entomological queries. <Amer. Ent., March, 1869, v. 1, p. 148.

Answer to inquiry of W. W. Butterfield; mentions scveral desirable entomotogical books.

557. [Walsh, B. D., and C. V. Riley.] Grape-berry moth. <Amer. Ent, March, 1869, r. i, p. 148.

Answer to inquiry of M. C. Road; meins against Penthina vitivorana $[=E$ Eudemis botrana].

558. [WALSH, B. I), and C. V. RILEY.] Hairy caterpillar. < Amer. Ent., March, 1869, v. 1, p. 148.

Answer to inçuiry of T. S. Gold; characters of the larva and imago of Arctia $[=$ Pyrrharetia $]$ isabella.

559. [WaLSH, B. D;, and C. V. RILEY.] Borer in plum-twigs. <Amer. Ent., March, 1869, v. 1, p. 148.

Answer to inquiry of W. Caldwell; undetermined borer, allied to the oak. pruner, in plum-twigs. See No. 606. 
560. [WALsh, B. D., and C. V. Riley.] Insects named. <Amer. Ent., March, 1869, v. 1, p. 148.

Answer to inquiry of W. W. Butterfield; identifivation of insects sent ; comparative characters of Arhopalus $[=$ Cyllene $]$ pictus and $A .[=C$.$] robinice;$ variation in Clytus [= Neoclytns] capreeu; gencrie eharaeters of Arhopalus and Clytus. (See No. 582.)

561. [Walsh, B. D., and C. V. Riley.] Pear-root borer. <Amer. Eut., March, 1869, v. 1, p. 148.

Answer to inquiry of P. Earle; larva of Prionus laticollis injurions to the pear and grape.

562. [WALSH, B. D., and C. V. RILEY.] Insects named. <Amer. Ent., March, 1869, v. 1, p. 148.

Answer to inquiry of M. II. Boye; Gryllotalpa longipennis: $[=$ columbia $]$ a dimorphic form of $G$. borealis.

563. [WALSH, B. D., and C. V. RrLEY.] The joint-Worm (Isosoma hordei Harris). <Amer. Ent., April, 1869, จ. 1, pp. 149-158, figs. 113118.

Natural history, variation, parasites, ravages, and mcans against Isosoma hordei; unity of habits in insects; generie classifieation of the joint-worm fly; figures male and female imago; figures $\delta$ and $q$ imagros of Semiotellus chalcidiphagus n. sp., Eurytoma sp., aud Decaloma sp., and of 9 imago of Antigaster [=Eupclmus] mirabilis.

564. [WaLsh, B. D., and C. V. RILEY.] The wary-striped flea-bèetle. (Haltica [Phyllotreta] striolata Illiger). <Amer. Ent., April, 1869 , v. 1, pp. 15S-159, fig. 119.

Deseription, habits, and ravages of Phyllotreta striolata [= vitlata]; figures larva, pupa, and imago of the same; quotes from H. Shimer's "The wavy-striped flea-beetle" (Amcr. Nat., December, 1868, v. 2, Pl). 514517 ).

565. [WALSH, B. D., and C. V. Riley.] Concerning certain smart bugs. $<$ Amer. Ent., April, 1869, v. 1, p. 160.

Preferenees of Phylloxera vitifolice [-rastatrix] and Macrodactylus subspinosus for eertain varieties of grape-vines, of Doryphora 10-lineata and Lema trilineata for eertain varieties of potato-vines, and of Mytilaspis pomicorticis [ = pomorum] and Carpocapsa pomonella for eertain varietıes of apple.

566. [Walsh, B. D., and C. V. Riley.] Curculio remedies. <Amer. Ent., A pril, 1869, v. 1, p. 161.

Comments on essay of L. C. Francis on the plum; coal oil not effective against Conotrachelus nenmphar.

567. [WAlsh, B. D., and C. V. Riley.] How great wits jump together. $<$ Amer. Ent., April, 1S69, v. 1, p. 161.

Stopping holes with hard soap ineffective against borers.

568. [Walsh, B. D., and C. V. Riley.] On our table. <Amer. Ent., April, 1869, v. 1, p. 165.

Notiees of Harris's Inseets injurions to Vegctation, L'Insectologie agricole, and several other works not entornological. 
569. [WALSH, B. D., and C. V. RILEY.] Eggs of the oblong-winged katydid. <Amer. Ent., April, 1869, v..1, p. 166, fig. 120.

Answer to inquiries of T. A. Thop, J. L. Rice, B. J. Campbell, H. Cheeney, and A. MeMoore; eggs of Phylloptera $[=$ Amblycorypha $]$ oblongifolia eompared with those of Platyphyllum [= Cyrtophylhus $]$ concavum; figures of the eggs of $A$. oblongifolia.

570. [WaLsh, B. D., and O. V. RiLey.] Mossy rose gall. <Amer. Ent., April, 1869, v. 1, p. 166.

Answer to inquiry of F. W. Collins; eliaracters of Rhodites rosce and its gall.

5i1. [Walsi, B. D., and C. V. RILey.] Caterpillars on lombardy poplars. <Amer. Ent., April, 1869, v. 1, p. 166.

Answer to inquiry of J. F. Gurley; characters of larva, habits, food-plants, and parasites of Acronycta accricola [= americana $]$.

572. [Walsh, B. D., and C. V. Rilet.] Museum pests. <Amer. Ent, April, 1\&69, v. 1, p. 166, fig. 121.

Answer to inquiries of F. W. Hoit, jr., G. M. L., and J. Huggins; figures larva, pupa, and imago of Anthrenus sp.; A. varins eompared with A. museorum.

573. [WALsh, B. D., and C. V. RILey.] Cockroach eggs. <Amer. Ent., April, 1869, v. 1, p. 166.

Answer to inquiry of H. C. Freeman; eharaeter of the egg-cases and adult of Platamodes unicolor; oeeurrence of Ectobia germanica in Illinois; ravages of speeies of Blattide.

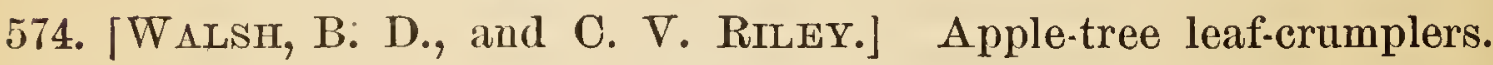
$<$ Amer. Ent., April, 1869, v. 1, p. 166.

Answer to inquiry of J. F. Jones; result of the work of the larvæ of Phycita nebulo $[=$ Acrobasis indiginella $]$ on the growth of apple-trees.

575. [Walsh, B. D., and C. V. Ruley.] A most precious bug. <Amer. Ent., April, 1869, v. 1, p. 167.

Answer to inquiry of E. S. Holmes; eharaeters and variety of Hyleccetus lugubris; destructiveness of Lymexylon navale; use of the maxillary palpi in the $\sigma^{2} \sigma^{2}$ of Lymexylider.

576. [WALsi, B. D., and C. V. RILEY.] Blackberry-cane borers. <Amer. Ent., A pril, 1869, v. 1, p. 167.

Answer to inquiry of C. Parry; eharaeters and habits of larva of unnamed borer $[=$ Bembecia marginata $]$; plants affeeted by speeies of AEgeriada.

577. [Walsh, B. D., and C. V. RILEY.] Rows of eggs in pear-twigs. $<$ Amer. Ent., April, 1869, v. 1, p. 167.

Answer to inquiry of H. C. Freeman; charaeters of unknown eggs found in pear-twigs.

578. [Walsh, B. D., and C. V. RILey.] An orchard giving out. <Amer. Ent., April, 1869, v. 1, p. 168.

Answer to inquiry of W. M. Clemens; habits and means against Saperda bivittata $[=$ candida $]$ and Chrysobothris femorata.

579. [Walsh, B. D., and C. V. Riley.] Plant-louse eggs on apple and mountain ash. <Amer. Ent., April, 1869, v.1, p. 168.

Answer to inquiry of W. Stewart; eggs of Aphis mali on apple-twigs and probably on those of mountain ash; Aspidiotes harrisii $[=$ Chionaspis furfurus] infests both trees. 
580. [W $\Delta$ LSII, B. D., and C. V. RILEY.] Gigantic rhinoceros beetle. $<$ Amer. Ent., April, 1S69, v. 1, p. 168.

Answer to inquiry of F. G. Smith; ehar.ueters of Dynastes tityrus.

581. [Walsh, B. D., and C. V. Riley.] Bee queries. <Amer. Ent., April, 1869, v. 1, p. 168.

Answer to inquiry of W. R. Hoẃard; Galleria cercana always injurious; a new swarm eomposed of both old and new bees.

582. [W ALSH, B. D., and C. V. RILEY.] Insects named. <Amer. Ent., April, 1869, v. 1, p. 168.

Answer to inquiry of W. W. Butterfield; eharaeters of Clytus [ $=$ Neoclytus $]$ caprea. (See No. 560.)

583. [W ALSH, B. D., and C. V. RILEY.] Elm-tree borer. <Amer. Ent., April, 1S69, v. 1, p. 168.

Answer to inquiry of W. M. Gregory; Saperda lateralis and Dryobius sexfasciatus attaek the elm in the larva state. (See No. 696.)

584. [Walsh, B. D., and C. V. RILEY.] The chinch-bug (Micropus leucopterus Say). <Amer. Ent., 1869, v. 1, May, pp. 169-177, fig. 122; June, pp. 194-199, figs. 135-139. Reprint: <2d Ann. Rept. State Ent. Mo., March, 1870, pp. 15-37, figs. 1-10.

See No. 1127 for synopsis of eontents.

585. [Walsi, B. D., and C. V. Riley.] The grape-berry moth (Penthina vitivorana, Packard). <Amer. Ent., May, 1869, v. 1, pl). 177-179, figs. $123-125$.

Natural history, ravages, and means against Penthina vitivorana $[=$ Endemis botrana ] figures, larva, pupa, eocoon, imago, and injured grape.

5S6. [Whlsh, B. D., and C. V. Rileey.] Poisonous flour. <Amer. Ent., May, 1869, v. 1, p. 179.

Application of the term weevil; vesieatory properties of Sitophilus $[=$ Calandra] granaria; poisonons nature of flour made from wheat infested by these inseets.

587. [Walsh, B. D., and C. V. Riley.] Mounding peach-trees. <Amer. Ent., May, 1869, v. 1, pp. 180-181, fig. 126.

Mounding as a means against Sannina exitiosa; figures of and $q$ of the sane.

588. [Walsi, B. D., and C. V. Riley.] Going it blind. <Amer. Eut., May, 1869, v. 1, pp. 182-183.

Remarks on the failure of persons to observe eorreetly.

589. [Walsh, B. D., and C. V. Riley.] Another new Curculio humbug. <Amer. Ent., May, 1869, r. 1, p. 183.

Extract from "agrieultural paper," with eomments on proposed means against Conotrachelus nenuphiar.

590. [WALsh, B. D., and C. V. Riley.] Rear-horses vs. grasshoppers. <Amer. Ent., May, 1S69, r. 1, 1. 1S4, figs. 127-12S.

Vernaenlar names of Mantis [= Phasmomantis] carolina ; its usefnlness; figures of eggs and of and $q$ imago.

591. [Walsh, B. D., and C. V. Rilex.] Appletree plant-lice. (Aphis mali, Linn.) <Amer. Ent., May, 1869, v. 1, 1. 184.

Abundanee of Aphis mali in several localities; its eomparative harmlessness; means against it. 
592. [WALSH, B. D., and C. V. Riley.] Crack.jaw names. <Amer. Ent., May, 1869, v. 1, p. 184.

Combination of vernacular and technical names for the accommodation of different classes of readcrs.

593. [Walsh, B. D., and C. V. Riley.] Send plenty of specimens. <Amer. Ent., May, 1869, v. 1, p. 185.

Reasons why several specimens of insects should be sent for examination.

594. [WaLsh, B. D., and C. V. Rilex.] White-grub fungus. <Amer. Ent., May, 1869, v. 1, p. 186, fig. 129.

Answer to inquiries of J. Smith and of T. J. Freeman; larva of Lachnosterna fusca infested with Cordyceps ravenelii; figure of infested larva.

595. [Walsh, B. D., and C. V. Rilex.] "Buck fly." <Amer. Ent., May, 1Ş69, v. 1, p. 186.

Answer to inquiry of G. W. Copley; characters of larva and imago of Saturnia $[=$ Hemileuca $]$ maia; food-plants of the larva.

596. [WALSH, B. D., and C. V. RILEy.] Swarms of minute flies in rooms. <Amer. Ent., May, 1869, v. 1, p. 186.

Answer to inquiry of S. S. Rathvon; habitat of larva of Sciara sp.

597. [WALSH, B. D., and C. V. RILEY.] Worms in osage orange seed. $<$ Amer. Ent., May, 1869, v. 1, p. 186.

Answer to inquiry of A. Plant; habits of the larva of an undetermined dipteron found among osage orange secd.

593. [WALSH, B. D., and C. V. RileY.] Insects to be named. <Amer. Ent., May, 1869, v. 1, p. 186.

Answer to inquiry of X. Q. Z.; value of names to a collection of insects.

599. [WALSH, B. D., and C. V. RILEY.] The spotted lady-bird. <Amer. Ent., May, 1869, v. 1, p. 186, fig. 130.

Answer to inquiry of R. Seevers; value of Hippodamia [= Megilla $]$ maculata as a destroyer of noxious insects; fignre of the same.

600. [Walsh, B. D., and C. V. RILEy.] Eggs of the white-marked tussock moth. <Amer. Ent., May, 1869, v. 1, p. 186.

Answer to inquiry of S. G. Knight; characters of eggs of Orgyia lencostigma.

601. [Walsh, B. D., and C. V. Riley.] Owl's pellets. <Amer. Ent., May, 1869 , v. 1, p. 187.

Answer to inquiry of C. H. G..; presence of injurious insects in the pellets disgorged by owls $[=$ hawks $]$. See No. 643 .

602. [Walsh, B. D., and O. V. Riley.] Crab-apple borers. <Amer. Ent., May, 1869, v. 1, p. 187.

Auswer to inquiry of J. Huggins; characters of undetcrmined lepidopterous borer infesting crab-apple trces.

603. [WALSH, B. D., and C. V. RILEY.] Mosquitoes. <Amer. Ent., May, 1869, v. 1, p. 187.

Answer to inquiry of A. M. Abbott; life-habits of Culicida; benefits derived from the same.

604. [WALSH, B. D., and C. V. RiLEY.] Large silken cocoon. <Amer. Ent., May, 1869, v. 1, p. 187.

Answer to inquiry of W. W. Butterfield; food-habits of Attacus promethea. 
605. [Walsh, B. D., and C. V. Rilex.] Bugs in alcohol. <Amer. Ent., May, 1869, v. 1, p. 187.

Answor to inquiry of D. P. Smith; alcohol as a means of preserving insects.

606. [Walsh, B. D., and C. V. Riley.] Borer in plum-twig. <Amer. Ent., May, 1869, v. 1, p. 187.

Answer to inquiry of W. Colwell; Elaphidion parallelum $[=$ villosum $]$ bred from plum-twigs; it does not prune the twig. See No. 559.

607. [Walsh, B. D., and C. V. Riley.] Eggs of cut-worm moth. $<$ Amer. Ent., May, 1869, r. 1, p. 188, fig. 131.

Answor to inquiries of G. Pauls, T. A. Thorp, and E. S. Foster; characters and figure of eggs of Agrotis inermis [= sancia]; characters and habits of the larva.

608. [Walsh, B. D., and C. V. Riley.] Snow fleas. <Amer. Ent., May, 1869, v. 1, p. 188.

Answer to inquiry of H. H. G. Bradt; habits and food of Podura $[=$ Achorutes] nivicola.

609. [Walsh, B. D., and C. V. Riley.] Fuzzy galls on blackberrytwigs. <Amer. Ent., May, 1869, v. 1, p. 188.

Answor to inquiry of J. Huggins; characters of Diastrophus cuscutaformis and its gall.

610. [WALSH, B. D., and C. V. RILEy.] Pithy galls on blackberrytwigs. <Amer. Ent., May, 1869, v. 1, p. 188.

Answer to inquiry of T. W. Gordon; characters of the gall made by Diastrophus ncbulosus.

611. [Walsi, B. D., and C. V. Riley.] Moth eggs. <Amer. Ent., May, 1869, จ. 1, p. 188.

Answer to inquiries of A. M. Shute and of J. Huggins; characters f the uggs of an undetermined moth.

612. [WALsh, B. D., and C. V. Riler.] Horse-hair snakes. - <Amer. Ent., May, 1869, v. 1, p. 188.

Answer to inquiry of A. M. Abbott; characters and habitats of Girdiaccea.

613. [WALsh, B. D., and C. V. Riley.] Imitative butterflies. <Amer. Ent., June, 1869, v. 1, pp. 189-193, figs. 132-134.

Immunity of Danaide from and liability of Pieride to the attacks of predatory animals; mimicry of Danaidee by Pieride and of Danais archippus by Limenitis disippus; hibernating habits and description of the larva of the latter, with figures of its larva, chrysalis, imago, and hibernaculum; figure of Danais archippus; theory of the origin of mimicry.

614. [Walsh, B. D., and C. V. Riley.] Cabbage-worms upon gillyflowers. <Amer. Ent., June, 1869, v. 1, p. 199.

Habits and food-plants, seasons, and synonyms of Plutella cruciferarum.

615. [WAlsh, B. D., and C. V. Riley.] "Wasps and their habits." <Amer. Ent., June, 1869, v. 1, p. 200.

Comments on letter of S. S. Ratlivon; species having essentially different habits though externally indistinguishable should be considered specitically distinct.

616. [Walsh, B. D., and C. V. Riley.] The social wasps. <Amer. Ent., June, 1869, v. 1, p. 201.

Comments on paper by D. A. A. Nichols; luabits of Vespa crabro. 
617. [Walsi, B. D., and C. V. Riley.] Mounding peach-trees. <Amer. Ent., June, 1869, v. 1, pp. 201-202.

Comments on letter of R. L. Wells; success of the mounding system against Aegeria $[=$ Sannina $]$ exiliosa.

618. [WALSH, B. D., and C. V. RILEY.] Out of evil there cometh good. <Amer. Ent., June, 1869, v. 1, p. 202.

Probable abundance of the fruit crop in southern Illinois and iu Missouri in 1869 due to the pruning of the trees by Tibicen septendecim in 1868.

619. [WALsh, B. D., and C. V. RILEY.] The periodical Cicada. <Amer. Ent., June, 1869, v. 1, p. 202.

Extract from No. 474; request for iuformation of the appearauce of Cicada [= Tibicen $]$ septendecim in any part of the United States in 1869.

620. [WALSH, B. D., and C. V. RILEY.] The Curculio scarcer than last year. <Amer. Ent., June, 1869, v. 1, p. 202.

Extract from letter of A. M. Brown ; comparative scarcity of Conotrachelus nenuphar in 1869.

621. [WALSH, B. D., and O. V. Riley.] The American Entomological Society. <Amer. Ent., June, 1869, v. 1, p. 203.

Notice of the formation, publications, aims, and nceds of the American Eutomological Society; proposition for the raising of a fund for the support of the society.

622. [WALSH, B. D., and C. V. RiLEY.] Remarkable peculiarity in the insect world. <Amer. Ent., June, 1869, v. 1, p. 204.

Insects contrasted with animals of other groups; as a rule they produce but one brood of offspring iu the course of their lives.

623. [WALSH, B. D., and C. V. Riley.] On our table. <Amer. Ent., June, 1869, v. 1, pp. 204-205.

Notices of: The Harris correspondence; The butterflies of North America, by W. H. Edwards; Guide to the study of insects, by A. S. Packard, jr.

624. [WALSH, B. D., and C. V. RILEY.] Cannibal mites. <Amer. Ent., June, 1869, v. 1, p. 205.

Answer to inquiry of C. S. Davis; Trombidium sp. found preging on grasshopper eggs.

625. [Walsh, B. D., and C. V. Rulex.] Gnats. < Amer. Ent., June, 1869, v. 1, p. 205.

Answer to inquiry of W. O. Hiskey; distinctive characters of Culex and Chironomus; appearance of "clouds" of Chironomus.

626. [Walsh, B. D., and C. V. Riley.] Cut-worms severing cabbage plants. <Amer. Ent., June, 1869, v. 1, p. 205.

Answer to inquiry of N. C. Burch; characters of the larva of Agrotis telifera [=ypsilon $]$.

627. [Walsh, B. D., and C. V. Rilex.] Beetle named. <Amer. Ent., June, 1869, v. 1, p. 205.

Answer to inquiry of J. M. Shaffer; Anisodactylus baltimorensis flying in grcat numbers at Fairfield, Iowa.

628. [Walsh, B. D., and C. V. Rilex.] Tiger beetles. <Amer. Ent., June, 1869, ̀. 1, p. 205.

Answer to inquiry of J. M. Shaffer; habitat of Cicindela vulgaris. 
629. [W.ALsh, B. D., and C. V. Riley.] Cocoons and chrysalids named. <Amer. Ent., June, 1869, v. 1, p. 206.

Answer to inquiry of A. S. Fuller; characters of larva and imago of Ceratocampa [= Citheronia $]$ regalis; food-plants of its larva; characters of the cocoons of Attacus promethea, A. cecropia, A. $[=$ Telea $]$ polyphemus. and of Thy:idopteryx ephemeraformis.

630. [WALSH, B. D., and C. V. Riley.] White-lined morning Sphinx. <Amer. Ent., June, 1869, v. 1, p. 206.

Answer to inquiry of S. Blanchard; characters, transformations, habits, and distribution of Deilephila lineata; food-plants of its larva.

631. [WALsh, B. D., and C. V. Riley.] Insects named. <Amer. Ent., June, 1869, v. 1, p. 206.

Answer to inquiry of W. W. Butterfield; identification of insects sent; differences between the spring and autumn broods of Drasteria erechtea.

632. [Walsh, B. D., and C. V. Riley.] Peach-twig borer. <Amer. Ent., June, 1869, v. 1, p. 206, fig. 140.

Answer to inquiry of W. Muir; characters, habits, and figure of the larva of Gortyna nitela.

633. [Walsh, B. D., and C. V. Riley.] The apple-ťwig borer. <Amer. Ent., June, 1869, v. 1, p. 206, fig. 141.

Answer to inquiry of A. Hinckley; habits, sexual differences, and figure of Bostrichus [= Amphicerus $]$ bicaudatus.

634. [WaL'sh, B. D., and C. V. RILEY.] Apple-tree borers on south side of trees. ' <Amer. Ent., June, 1869, v. 1, p. 206.

Answer to inquiry of J. F. Wielandy; preference shown for the south and southwest sides of trees by the larva of Chrysobothris femorata.

635. [WALSH, B. D., and C. V. Riley.] Cocoons of the Cecropia moth. <Amer. Ent., June, 1869, v. 1, p. 206.

Answer to inquiry of T. W. Gordon; comparison between the cocoons of Telea polyphemus and Attacus cecropia.

636. [WaLsh, B. D., and C. V. Riley.] Flea-beetles. <Amer. Ent., June, 1869, v. 1, p. 206.

Answer to inquiry of F. Hecker; characters of an undescribed Longitarsus infesting wheat fields.

637. [WaLsh, B. D., and C. V. Riley.] Strawberry bugs. <Amer. Ent., June, 1869, v. 1, p. 207.

Answer to inquiry of J. M. Pearson; characters, ravages, and meaus against Corimelcena pulicaria.

638. [WALsh, B. D., and C. V. RILEY.] Eggs on apple-trees. <Amer. Ent., June, 1869, v. 1, p. 207, fig. 142.

Answer to inquiry of $\mathrm{H}$. Compton; characters of eggs of Sinea diadema; figure of the imago; its value as a destroyer of canker-worms.

639. [WALsh, B. D., and C. V. Riley.] Lady-bird larræ. <Amer. Ent., June, 1869, v. 1, p. 207, fig. 143.

Answer to inquiry of E. S. Foster; characters of the larva of Hippodamia convcrgens ; figures its larva, pupa, and imago; nsefulness of Coccinellida. 
640. [W $<$ Amer. Ent., June, 1869, v. 1, p. 207, fig. 144.

Answer to inquiry of W. C. Holmes; figures larva of Lachnosterna fusca attacked by Cordyceps ravenelii.

641. [Walsh, B. D., and C. V. Riley.] Bag-worms. <Amer. Ent., June, 1869, v. 1, p. 207.

Answer to inquiry of C. Parry; means against Thyridopteryx ephemerceformis.

642. [Walsh, B. D., and C. V. RILEY.] Tent-caterpillar. <Amer. Ent., June, 1869, v. 1, p. 208, fig. 145.

Answer to inquiry of S. Blanchard; characters of the imago and figures of the early stagcs of Clisiocampa americana; means against the same.

643. [Walsh, B. D., and C. V. RILEY.] Hawk's pellets. <Amer. Ent., June, 1869, v. 1, p. 208.

Answer to inquiry of C. H. G.; insectivorous habits of Buteo pennsylvanicus. See No. 601.

614. [W ALSH, B.D., and C. V.RILEY.] Plant lice on berberry. < 4 mer. Ent., June, 1869, v. 1, p. 208.

Answer to inquiry of $\mathrm{J}$. R. Preston; means against Aphididce.

615. [Walsh, B. D., and C. V. Riley.] Tent-caterpillar of the forest. $<$ Amer. Ent., June, 1869, v. 1, p. 20s, fig. 146.

Answer to inquiry of G. Whitcomb; characters, habits, parasites, means against, and figure of larva of Clisiocampa sylvatica [= disstria].

616. [WaLsH, B. D., and C. V. RILEY.] Cotton insects. <Amer. Ent., July, 1869, v. 1, pp. 209-214, fig. 147-151.

Descriptions and figures of all stages of Aletia xylina and of Heliothis armigera; habits, seasons, ravages, food-plants of, and means against the same; figures larva of Clisiocampa sylvatica [= disstria].

647. [WALSH, B. D., and C. V. RILEY.] The true Army-worm (Leucania unipuncta Haworth). <Amer. Ent., July, 1869, v. 1, pp. 214217, fig. 152-155.

Descriptions and figures of larva, pupa, and imago of Lencania unipuncta; seasons, ravages, and enemies of the same; figure of Exorista militaris [= Nemorcea leucanice $]$.

643. [WAlsh, B. D., and C. V. RIlEy.] Belated individuals of the periodical Cicada. <Amer. Lnt., July, 1869, v. 1, p. 217.

Occurrence of scattering individuals of Tibiccn septendecim in years before or after their regular period.

649. [WAlsh, B. D., and C. V. Riley.] Is the Curculio scarcer than it was last year? <Amer. Ent., July, 1869, v. 1, pp. 217, 218.

Record of observations to prove the comparative scarcity of Conotrachelus ncmuphar during 1869.

6j0. [W bugs. <Amer. Ent., July, 1S69, v. 1, p. 219.

Reprint of communication of G. Liddle, with comments; Paris green as a means against Doryphora 10-lineata.

651. [Walsh, B.D., and C. V. RrLey.] Dr. Hull's Curculio.catcher. <Amer. Ent., June, 1S69, r. 1, pp. 220-221, fig. 156.

Description and figure of Hull's Curculio-catcher. 
652. [Walsh, B. D., and C. V. Riley.] The New York weevil (Ithy. cerus noveboracensis, Forster). <Amer. Ent., July, 1869, v. 1, pp. 221-222, fig. 157.

Habits, food-plants, distribution, description, and figure of larva and imago of Ithycerus novcboracensis; means against the same.

653. [WALSH, B. D., and C. V. RILEY.] Mounding peach-trees again. $<$ Amer. Ent., July, 1869, v. 1, p. 223.

Letter of A. Dean, with comments; characters and habitat of Mycctophila persice.

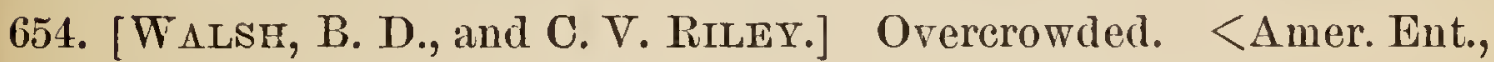
July, 1869, v. 1, p. 223.

Duties of a State entonılogist ; impossibility of answering inquiries reccived during the past month.

655. [Walsh, B. D., and C. V. Riley.] No air-holes needed in sending insects. <Amer. Ent., July, 1869, v. 1, p. 223.

Directions for sending living insects.

656. [Walsh, B: D., and C. V. Rilezy.] Plum-leaf worms. <Amer. Ent., July, 1869, v. 1, p. 223.

Answer to inquiry of W. D. Hiskey; characters of larva of Lyda sp.

657. [WALSH, B. D., and C. V. Riley.] Seed-corn maggot. <Amer. Ent., Juls, 1869, v. 1, p. 224, tigs. 138-139.

Answer to inquiry of G. Pauls; characters, ravagcs, means against, and figure of larva of Anthomyic zeas; characters of the imago; figure of the puparium.

658. [Walsh, B. D., and C. V. Riley.] Cut-worms. <Amer. Ent., July, 1869, v. 1, p. 224.

Answer to inquiry of N. C. Birch; ravages of Agrotis telifera [=ypsilon].

659. [WaLsh, B. D., and C. V. Riley.] New York weeril. <Amer. Ent., Juls, 1869, v. 1, p. 224.

Answer to inquiries of D. H. Kauffmas and of W. D. Turrill ; ravages of Ithycerus noveboracensis.

660. [WALsh, B. D., and C. V. RiLEY.] Insects around peach-trees. <Amer. Ent., Julv, 1869, v. 1, 1. 224.

Answer to inquiry of G. C. Brodhcad; larve of Asilus sp. and of Mycetophila persice found around roots of peach-trees.

661. [WALsh, B. D., and C. V. RiLeY.] Large green worm in a peach. $<$ Amer. Ent., July, 1869, v. 1, p. 224.

Answer to inquiry of G. Wilgus; characters and food-habits of an undetermined larva found in a peach.

662. [WALsh, B. D., and C. V. Riley.] Ichneumon flies. <Amer. Ent., July, 1869, v. 1, p. 224.

Answer to inquiry of $\mathrm{H}$. Klineliaus; characters and figure of cocoons of $\mathbf{M i}$ crogaster sp.

693. [Walsh, B. D., and C. V. Riley.] Raspberry worms. <Amer. Ent., Julv, 1869, v. 1, p. 224.

Answer to inquiry of B. Borden; charactors and ravages of Sclandria $\lceil=\mathbf{M O}$. nophadnus] rubi. 
664. [WALsh, B. D., and C. V. RiLey.] Hairy grape-leaf folders. $<$ A iner. Ent., Tuly, 1869, v. 1, p. 224.

Answer to inquiry of A. C. Davis; characters of larra and imago of Pterophorus [ = Oxyptilus $]$ periscelidactylus.

-665. [WALSH, B. D., and C. V. RILEY.] Row of eggs in maple-twigs, <Amer. Ent., July, 1869, v. 1, p. 224.

Auswer to inquiry of J. Bower; characters of eggs of undetermined katydid.

666. [Walsh, B. D., and C. V. Riler.] Butterfly named. <Amer. Ent., July, 1869, v. 1, p. 224.

Answer to inguirs of A. R. Bodley; characters of Papilio marcellus; foodplants of its larva.

667. [WALsh, B. D., and C. V. Riley.] Grasshopper's eggs. <Amer. Ent., July, 1869, v. 1, p. 224.

Answer to inquiry of E. P. Burlingame; characters of the eggs of an undetermined grasshopper and of the imago of Edipoda [= Dissosteria $]$ carolina.

668. [Walsh, B. D., and C. V. Riley.] Asilus fly larræ. <Amer. Ent., July, 1S69, v. 1, p. 225, figs. 161-162.

Answer to inquiry of G. Pauls; characters, habits, and figure of larva of Asilus sp.; food-habits of larva and imago of $A$. sericeus; figure of the imago of the same; Trupanea [= Promachus $]$ apirorus as a destroger of bees.

669. [WaLSH, B. D., and C. V. Riley.] New insect-foe of the blackberry. <Amer. Ent., July, 1S69, v. 1, p. 225.

Answer to inquiry of C. Parry; comparative characters of Aphididee and Psyllide; habits of Psylla rubi $[=$ Trioza tripunctata $]$.

670. [Walsh, B. D., and C. V. Riley.| Army-worm. <Amer. Ent, July, 1869, v. 1, p. 225.

Answer to inquiry of J. H. Butts; ravages and food-plauts of Leucania unipuncta.

671. [WALsh, 13. D., and C. V. RILEy.] Green grape-vine worm. $<$ Amer. Ent., July, 1869, -v. 1, p. 225, fig. 163.

Answer to inquiry of G. Pauls ; characters, food-plants, and fignre of larva of Pyrophila pyramidoides.

672. [Walsh, B. D., and O. V. Riler.] Rose slug. <Amer. Ent., July, 1869, จ. 1, p. 225.

Answer to inquiries of G. W. Copley and B. S. Morris; characters, ravages, and means against Selandria $[=$ Monostegia $]$ rose.

673. [Walsh, B. D., and C. V. Riler.] Insects named. <Amer. Ent., July, 1869, г. 1, p. 225.

Answer to inquiry of $\mathrm{J}$. Weed ; food-habits of Leptostylus aculiferus and of Podabrus modestus.

674. [W ALSH, B. D., and C. V. Ruley.] Chrysalis of the rirgin tiger motn. <Amer. Ent., July, 1869, v. 1, p. 225.

Answer to inquiry of C. Mallinckrodt; characters of Arctia virgo ; supposed food-plants of its larra.

675. [WALsh, B. D., and C. V. RILEY.] Clover-worms. <Amer. Ent., July, 1869, r. 1, p. 226, fig. 164 .

Answer to inquiry of E. P. Flanders; characters of Asopia costalis; habits of its larva; figures larva, pupa, cocoos, and imago. 
676. [WaLsh, B. D., and C. V. RiLey.] Raspberry brand. <Amel. Ent., July, 1869, v. 1, p. 226.

Answer to inquiry of J. Mr. Beeeher; liarva of small gnat feeding on raspberrybrand.

677. [WALSH, B. D., and C. V. Riley.] Rese-worms. <Amer. Ent, July, 1869, v. 1, p. 226.

Answer to inquiry of G. S. Grover; charaeter, ravages, food-plants, and means against Heliothis margidens $[=$ Pyrrhia exprimens $]$.

678. [WAlsh, B. D., and C. V. Rrley.] Plum-tree plant-lice. <Amer. Ent., July, 1869, v. 1, p. 226, figs. 165-167.

Answer to inquiry of T. W. Gordon; eharaeters of Aphis mmifolice and $A$. $[=M I y z u s]$ cerasi; ravages, enemies, and means against Aphidide; figures larva of coecinellid, syrphid and hemerobi ?.

679. [Walsh, B. D., and C. V. Riley.] Ichneumon-flies. <Amer. Ent., July, 1869, v. 1. p. 226.

Answer to inquiries of S. J. Throp and J. E. Trabue; life-labits of Microgaster sp.?

680. [Walsh, B. D., and C. V. Riley.] A new Curenlio humbug. $<$ Amer. Ent., July, 1S69, r. 1, 1. 226.

Answer to inquiry of E.P. Flanders; uselessness of a patent lamp for destroying Conotrachelus nemuphar.

681. [Walsh, B. D., and C. V. RrLey.] Sweet-potato beetles. <Amer. Ent., July, 1869, v. 1; p. 227.

Answer to inquiries of Subseriber and A. E. Trabne; food-habits and elaracters of larva and imago of Coptocycla aurichalcen and of $C .[=$ Cassida $]$ bivittata.

682. [WALSh, B. D., and C. V. Riley.] Injured strawberry and grapevines. <Amer. Ent., July, 1869, v. 1, 1). 227.

Answer to inquiry of W. P. Pierson; ravages of Capsus oblineatus [= Lygus pratensis].

683. [Walsi, B. D., and C. V. Ruley.] Plum-tree insects. <Amer. Ent., July, 1869, v. 1, p. 227.

Answer to inquiry of J. F. Waters: charaeters of Bibio albipennis; food-habits of its larva.

684. [Walsh, B. D., and U. V. Rilex.] Apple-tree bugs. < mer. Ent., July, 1869, v. 1, p. 227.

Answer to inquiry of W. L. Youse; charaeter of Brochymcna annulute.

685. [Walsh, B. D., and C. V. Riley.] Hickory-stem gall-louse. $<$ Amer. Ent., July, 1869, v. 1, p. 227.

Answer to inquiry of B. F. Long; charaeters of galls of Phylloxera caryetecaulis; food-habits of Thrips.

6S6. [WALSH, B.D., and C. V.RrLey.] Grape-vineleaf-hopper. <Amer. Ent., July, 1869, v. 1, p. 227.

Answer to inquiry of R. M. Copeland; means against Tettigonia $[=$ Typhlocyba] vitis.

687. [WALsh, B. D., and C. V. Rrley.] Twelve-spotted Diabrotica. <Amer. Ent., July, 1869, v. 1, p. 227, fig. 168.

Answer to inquiries of E. S. Foster and IR. D. Parker; charneters and means against Diabrotica 12-punctata; figure of the same. 
688. [WALSH, B. D., and C. V. RILEY.] The caterpillar of the forest. $<$ Amer. Ent., July, 1869, v. 1, p. 227.

Answer to inquiry of M. McKenzie; food-habits and meaus against Clisiocampa sylvatica $[=$ disstria $]$.

6S9. [WALSH, B. D., and C. V. RILEY.] Strawberry destroyer. <Amer. Ent., July, 1869, v. 1, p. 227.

Answer to inquiry of G. W. Copley; habits of unknown strawberry destroyer.

690. [Walsh, B. D., and C. V. Riley.] Eggs of bugs on strawberry. $<$ Amer. Ent., July, 1869, v. 1, p. 227.

Answer to inquiry of A. S. Fuller; characters of eggs of nuknown reduvid attacked by parasites.

691. [WALSH, B. D., and C. V. RILEY.] Frog-spittle insects. <Amer. Ent., July, 1869, v. 1, p. 228. Reprint: <Cultivator and Country Gentleman, 29 July, 1869, г. 34, p. 82.

Answer to inquiry of J. B. Hartwell; habits, characters, and injuries of Aphrophora quadrangularis.

692. [WaLsh, B. D., and C. V. RILEY.] Eggs of ground-beetle. <Amer. Ent., July, 1869, v. 1, p. 228.

Answer to inquiry of E. J. Ayres; characters of eggs of undetermined groundbeetle found under bark of pear-twigs.

693. [Walsh, B. D., and.C. V. RileY.] New insect-foe of the potato. $<$ Amer. Ent., July, 1869, v. 1, p. 228.

Answer to inquiry of I. Hicks; food-habits of Cassida [= Coptocycla $]$ clavata.

694. [WALSH, B. D., and C. V. RileY.] Tomato-stalk borer. <Amer. Ent., July, 1869, v. 1, p. 228.

Answr $\mathrm{r}$ to inquiry of E. J. Ayres; Gortyna nitela injurious to tomato-stalks.

695. [WaLsh, B. D., and C. V. Riley.] Breeding cages. < <Amer. Ent., July, 1869, v. 1, p. 228.

Answer to inquiry of H. S. Redney; description of cage for brceding insects.

696. [WALSH, B. D., and C. V. RiLeY.] Elm-tree borer. <Amer. Ent., July, 1869, v. 1, p. 228.

Answer to inquiry of W. M. Gregory; characters and food-habits of Physocnemum brevilincum. See No. 583 .

697. [Walsh, B. L., and C. V. RIley.] Peach-twig borer. <Amer. Ent., July, 1869, v. 1, p. 228.

Answer to inquiry of G. Fisher; means against undetermined lepidopterous borer in twigs of peach.

698. [Walsh, B. D., and C. V. RileY.] Eggs of periodical Cicada in savin-twig. <Amer. Ent., July 1809, v. 1, p. 228.

Auswer to inquiry of J. A. Greason; Tibicen septendecim ovipositing in twigs of Juniperus sabina.

699. [WALSH, B. D., and C. V. RIley.] Elm.tree saw-fly. <Amer. Ent., July, 1869, v. 1, p. 228.

Answer to inquiry of A. R. Whitney; characters of larva and imago of Cimbex laportei [= americana]; food-plants of its larva.

700. [WALSH, B. D., and C. V. RILEY.] Snout-beetle. <Amer. Ent., July, 1869, v. 1, p. 228.

Answer to inquiry of H. Kleinhaus; supposed food-habits of Bylobius con: fusus. 
701. [Walsh, B. D., and C. V. Riley.] The close of the first volume. $<$ Amer. Lint., August, 1869, v. 1, p. 229.

Prospectus of the second volume of the American Entonologist.

702. [WALSH, B. D., aud U. V. RILEY.] The Royal horned caterpillar. (Ceratocampa (Citheronia) regalis, Fabr.). <Amer. Ent., August, 1869, v. 1, pp. 230-231, pl. 1.

Habits, seasons, sexual characters, food-plants, and vernacular names of Citheronia regalis; descriptions and figures of larva and pupa; figure of larva, pupa, and imago.

703. [WALSH, B. D., and C. V. Riley.] Comparative scarcity of the Curculio again. <Amer. Ent., August, 1869, v. 1, p. 241.

Observations on the comparative abundance of Conotrachelus nemuphar during the early summer of 1869.

704. [Walsh, B. D., and C. V. Riley.] A possible cause of the bee disease. <Amer. Ent., August, 1869, v. 1, pp. 241-242.

Reprint of article by P. H. Philbrook (Amer. Bee Journal, May, 1869), with comments; dipterous enemies of the honey-bce.

705. [W ALSH, B.D., and C.V.RILEY.] Ash and mountain ash. <Amer. Ent., August, 1869, v. 1, pp. 243-244.

Criticisms of paper of H. Shimer (Trans. Ill. State Hortic. Soc., 1868).

706. [WaLSH, B. D., and C. V. RrLey.] How the Gurculio flies by night. <Amer. Ent., August, 1869, v. 1, p. 244.

Extract from lecture by I. P. Trimble, with comment.

707. [WALSh, B. D., and C. V. RILEY.] The periodical Cicada; our first brood established. <Amer. Ent., August, 1869, v. 1, p. 244.

Appearance in Connecticut of a brood of Tibicen septendecim in 1869.

708. [WALSH, B. D., and C. V. RILEY.] 'Be on the guard. <Amer. Ent., August, 1869, v. 1, p. 244.

Necd of care in the trânsportation of living insects; accidental introduction of Doryphora 10-lineata.

709. [Walsh, B. D., and C. V. Riley.] Prophecy fulfilled. <Amer. Ent., August, 1869, v. 1, p. 244.

Spread of Doryphora 10-lineata through Michigan.

710. [WALSH, B. D.; and C. V. RileY.] A poisonous worm. <Amer. Ent., August, 1869, v. 1, p. 245.

Extract from exchange; larva of Protoparce celeus not poisonous.

711. [WALSH, B. D., and C. V. RILEY.] Wheat midge, alias milk weevil, alias red weevil. <Amer. Ent., August, 1869, v. 1, p. 245.

Answer to inquiry of $\mathrm{C}$. Corbit; characters of larva of Cecidomyia $[=D i$ plosis] tritici; change in heads of wheat.

712. [WALsh, B. D., and C. V. RrLEF.] Large fish-fly. <Amer. Ent., August, 1869, v. 1, p. 245.

Answer to inq̨uiry of A. R. McCutchen; eharacters of Chauliodes pectinicornis; habits of the larva of C. rastricornis.

6 ENT 
713. [Walsh, B. D., and C. V. Rrley.] Cottonwood leaf-galls. < Amer. Ent, August, 1869, v. 1, p. 245.

Answer to inquiry of J. B. Taylor; habits of Pemphigus populicaulis; characters of its gall.

714. [W $A L S H, B$. D., and O. V. Riley.] Insects named. , <Amer. Ent., August, 1869, v. 1, p. 245.

Answer to inquiry of J. G. Goodrich; characters of Saperda bivittata $[=$ candida].

715. [Walsh, B. D., and C. V. Riley.] Four-lined leaf-bug on currant. $<$ Amer. Ent., August, 1869, v. 1, p. 246.

Answer to inquiry of M. B. Bateman; characters, habits, and means against Capsus 4-vittatus $[=$ Procilocapsus lineatus $]$.

7i6. [Whlsh, B. D., and C. V. RileY.] Bee moth. <Amer. Ent., August, 1869, v. 1, p. 246, fig. 182.

Answer to inquiry of S. Blanchard; ravages and means against Galleria cercana; figures larva, pupa, cocoon, and imago of the same.

717. [WaLsh, B. D., and C. V. Riley.] Canker-worm parasites. <Amer. Ent., August, 1869, r. 1, p. 246.

Answer to inquiry of J. Petit; mention of Microgaster sp., parasitic on Anisopteryx.

718. [WALSH, B. D., and C. V. RILEX.] Beetles swarming about the lawn. <Amer. Ent., August, 1869, r. 1, p. 246.

Answer to inquiry of S. Thompson; characters of Gyminetis [=Allorhina] nitida; habits of its larva.

719. [WALsh, B. D., and O. V. RILEY.] Tiger-beetle larva. <Amer. . Ent., August, 1869, v. 1, p. 246.

Answer to inquiry of R. J. Dorlge; characters and habits of larva of Cicindel$i d a$.

720. [WALST, B. D., and C. V. RileY.] Large compound gall on grapevine. <Amer. Ent., August, 1869, v. 1, p. 247, fig. 183.

Answer to inquiries of A. S. Fuller and D. W. Kanffman; characters and figure of gall of Lasioptera vitis; habits of its larva; enemy and parasite of the same.

721. [WALSH, B. D., and C. V. Riley.] Insects named. < Amer. Ent., August, 1869, v. 1, p. 247.

Answer to inquiry of M. Treat; habits of larva of Temnochila [= Trogosita $]$ virescens, of Aplodes [= Synchlora] rubivora, and of Calosoma calidum.

722. [WALSH, B. D., and C. V. Riley.] Destructive larvæ. <Amer. Ent., August, 1869, v. 1, p. 247.

Answer to inquiry of B. F. Lee; ravages of an undetermined larva; parasites of Saturnia $[=$ Hemilenca $]$ maia.

723. [WALSH, B. D., and C. V. RILEY.] Eggs of tree-cricket on grapevine. <Amer. Ent., August, 1869, v. 1, p. 247.

Answer to inquiry of B. F. Lec; charactcrs of eggs of Gicanthus niveus; car, nivorous labits of the larva of the same. 
724. [Walsh, B. D., and C. V. RILFi.] Grape-vine leaf-gall. <Amer. Ent, August, 1869, v. 1, p. 248, fig. 184.

Answer to inquiry of A. A. Hilliard; characters and figure of the leaf-galls of Phylloxera vitifolice $[=$ vastatrix $]$; its enemies and means against them; varietics of grape infested; identity of the leaf- and root-galls; criticism of the new genera and families of H. Shimer.

725. [Walsh, B. D., and C. V. RILEx.] Grape-vine insects. <Amer. Ent., August, 1869, v. 1, p. 248.

Answer to inquiry of G. Pauls; characters of Pelidnota punctata; its larval habits; characters, habits, and food-plants of Enchophyllum [=Enchenopa binotata.

726. [Walsh, B. D., and C. V. Riley.] Museum pests. <Amer. Ent., August, 1869, v. 1, p. 248.

Answer to inquiry of C. P. Faulkuer; ravages of Dermestes lardarius.

727. [WALsh, B.D., and C. V.RILeY.] Wheat maggots. <Amer. Ent., August, 1869 , v. 1, p. 248.

Answer to inquiry of S. K. Faulkner; characters of larva of Meromyza americana injurious to heads of wheat.

728. [W ALSH, B. D., and C. V. Riley.] Parasites on "hateful grasshopper." < Amer. Ent., August, 1869, r. 1, p. 249.

Answer to inquiry of S. K. Faulkner; characters and habits of Astoma [= Trombidium $]$ locustarim.

729. [WaLsh, B. D., and U. V.RILEy.] Crippled moths. <Amer. Ent., A ugust, .1869, v. 1, p. 248.

Answer to inquiry of C. P. Faullkner; conditions needed to enable moths to expand their wings; means by which iusects walk on smooth surfaces.

730. [WALSH, B. D., and C. V. RILEÝ.] Insects on the oleander. <Amer. Ent., August, 1869, v. 1, p. 249, fig. 185.

Answer to inquiry of T. W. Gordon; means against undotcrmined Coceid on oleander; habits and tigure of Chilocorus bivulnerus.

731. [WALSH, B. D., and U. V. RILEY.] Insects found on apple-trees. <Amer. Ent, Angust, 1869, v. 1, p. 249.

Answer to inquiry of J. W. Waters; identification of the eggs of Reduvius raptatorius [=Sinea diadema]; habits of Chilocorus bivulnerus.

732. [Walsh, B. D., and C. V. Riley.] Beetles named. <Amer. Ent., August, 1869, v. 1, p. 249.

Answer to inquiry of J. M. Shaffer; Lytta atrata [= Epicauta pennsylvanica $]$ canght on rag-weed.

733. [WALSH, B.'D., and C. V. RILEY.] Gigantic water-bug. <Amer. Ent., August, 1869, v. 1, p. 249, fig. 186.

Answer to inquiry of E. M. Downing ; habits and figure of Belostoma grandis [=americanum $]$.

734. [WALSH, B. D., and C. V. Riley.] Worm eating into green tomatoes. <Amer. Ent., August, 1869, v. 1, p. 249.

Answer to inquiry of D, L, Hall; food-habits of Gortyna nitela. 
735. [W Alsh, B. D., and C. V. Riley.] Miscellaneous. <Amer. Ent., August, 1869, r. 1, p. 249.

Answer to inquiry of G. W. Copley; fond-habits of Chrysochus auratus, Hemilenca maia, and Aphis $[=M y z u s]$ ribis; habits of Lozoteriia [= Caccecia $]$ rosaceana.

736. [WaLsh, B. D., and C. V. Riley.] Insects named. <Amer. Ent., Auguist, 1869, v. 1, 1. 250.

Answer to inquiry of H. A. Munger; food-habits of Cassida pallida $[=$ Coptocycla aurichalcea], Lytta murina [= Macrobasis unicolor $]$, and of the Iarvie of the species of Prionus.

737. [WaLsh, B. D., and C. V. RILey.] Lightning-hoppers. <Amer. Ent., August, 1869, v. 1, p. 250.

Answer to inquiry of T. W. Gordon; characters and habits of Poeiloptera pruinosa; vernacular names of Fulgoridce, Membracidce, and Jassida.

738. [Walsh, B. D., and C. V. RILey.] Bag-worms. <Amer. Ent., August, 1869, v. 1, p. 250 .

Answer to inquiries of T. W. Gordon and S. Thompson; food-habits of Thyridopteryx ephemereformis.

739. [WALsh, B. D., and C. V. Riliey.] Woolly gall on white oak. <Amer. Ent., August, 1869, v. 1, p. 250, fig. 187.

Answer to inquiry of A. S. Fuller; characters and figure of the gall of Cynips $[=$ Andricus $]$ scminator.

740. [Walsh, B. D., and C. V. Filex.] Cabbage pests. <Amer. Ent., Angust, 1869, v. 1, p. 250.

Answer to inquiry of J. A. Williams; characters and habits of an undetermined elaterid larva; means against the larva of Elateride.

741. [WALSH, B. D., and C. V. Rilex.] Bugs gathering on pear shoots. $<$ Amer. Ent., August, 1869, v. 1, p. 250.

Answer to inquiry of E. J. Ayres; characters and habits of Corimelcena pulicaria.

742. [WALSH, B. D., and C. V. RILEY.] Potato-bug. <Amer. Ent., August, 1869, v. 1, p. 250.

Answer to inquiry of J. B. Cartwell ; food-habits of Cassida [= Coptocycla] clavata.

743. [WALsh, B. D., and C. V. Riler.] Insects named. <Amer. Ent., August, 1869, v. 1, p. 251.

Answer to inquiry of H. T. Birch; Trochilium $[=$ Aggeria $]$ acerni bred from maple.

744. [WaLsi, B. D., and C. V. Riley.] Apple-tree worms. <Amer. Ent., August, 1869, v. 1, p. 251.

Answer to inquiry of C. Waters; abundance of undetermined moth (Corycia vestaliata?) ; larva of the same on apple-trees.

745. [WaLSH, B. D., and C. V. Riley.] Oak-fig gall. <Amer. Ent., August, 1869, г. 1, p. 251.

Answer to incquiry of A. Fendler; characters of the gall of Cynips $[=$ Biorhiza] forticornis and of a guest-fly, Ceroptres ficus, inhabiting the same. 
746. [WALsh, B. D., aud C. V. Riler.] Insects named. <Amer. Ent., Angust, 1869, v. 1, 1) 251.

Answer to inquiry of D. L. Phares; irregular appearance of Cicuda tredecim [=Tibicen septendecim $]$; food-hahits of Oncideres cingulata.

747. [WaLsh, B.D., and O. V. Riley.] Small apple-leaf worms. <Amer. Ent., August, 1869, v. 1, p. 251.

Answer to inquiry of $\mathrm{H}$. Compton; means against Spilonota oculana $[=$ Tmetocera ocellana].

748. [WaLsh, B. D., and C. V. RileY.] Rose.bug on apples. <Amer. Ent., August, 1869, v. 1, p. 251 .

Answer to inquiry of A. Dean; food-plants and means against Macrodactylus subspinosus.

749. [WALsh, B. D., and C. V. RILEY.] Unicorn apple-tree caterpillar. $<$ Amer. Ent., Angust, 1869, r. 1, p. 251.

Answer to inquiry of G. C. Brodhead; characters of the larva and imago of Notodonta $[=$ Colodusys $]$ unicornis; food-plants of the larva of the same.

750. [WaLsh, B. D., and C. V. RiLey.] Large water beetle. <Amer. Ent., August, 1869, v. 1, p. 251.

Answer to inquiry of S. E. Mumford; characters of $C_{y}$ bister fimbriolatus. See No. 816.

751. [WaLsh, B. D., and C. V. Rilex.] Beetles around peach.trees. $<$ Amer. Ent., August, 1869, v. 1, p. 252.

Answer to inquiry of E. Hollister, jr.; characters and habits of Helops mullus $[$ = arcus $]$.

752. [WaLsh, B. D., and C. V. Riley.] A quick traveler. <Amer. Ent., August, 1869, จ. 1, p. 252.

Answer to inquiry of G. C. Brodhead; characters and harmlessness of Cermatia forceps.

753. [WhLsh, B. D., and C. V. Rilex.] Unknown moth. <Anier. Ent., August, 1869, v. 1, p. 2.52.

Answer to inquiry of W.(x. Barton; distribution of Junonia lavinia in Illinois.

754. [Walsh, B. D., and C. V. Riley.] Gorn-borer. < Amer. Ent., August, 1869, v. 1, p. 252.

Answer to inquiry of F. M. N.; identification of the larva of Gortyna nitela injurious to corn.

755. [W ALSH, B. D., and C. V. RILEX.] Horns of stag-beetle. <Amer. Eut., August, 1869, v. 1, p. 252.

Answer to inquiry of C. R. Edwards; larral habits of Lucanus elaphus.

756. [WALsh, B. D., and C. V. RILEX.] Imported gooseberry worms. $<$ Amer. Ent., August, 1869, v. 1, p. 252.

Answer to inquiry of C. P. Fianlkner; means against Nematus ribesii.

757. [WALSH, B. D., and C. V. RILEY.] Worm on bark of walnut-tree. $<$ Amer. Ent., August, 1869, v. 1, p. 252.

Answer to inquiry of $\mathrm{F}$. S. Fnller; undetermined notodontoid larva on the bark of walnut. 
758. [WALsh, B. D., and C. V. Riley.] Rotten root. <Amer. Ent., August, 1869, v. 1, p. 252.

Answer to inquiry of J. M. Bcecher; scavenger habits of undetermined larva feeding on dead roots of apple-trees.

759. [Walsh, B. D., and C. V. RileY.] Large dragon-fly. <Amer. Ent., August, 1869, v. 1, p. 252.

Answer to inquiry of G. S. Grover; characters and" usefulness of. Asschna constricta.

760. [Walsh, B. D., anả C. V. Riley.] Stinging larvie. <Amer. Ent., August, 1869, v. 1, p. 252.

Answer to inquiry of E. H. King; characters and urticating properties of Saturnia $[=$ Hemilenca $]$ maia; peach-blow potatoes avoided by Doryphora 10-lineata.

761. [WALSh, B. D., and C. V. RILEX.] Raspberry worms. <Amer. Ent., August, 1869, v. 1, p. 252.

Answer to inquiry of E. H. Beebe; characters of larva of Selandria $[=M o-$ nophadinus] rubi.

762. [WALsh, B. D., and C. V. RileY.] Leafigalls and caterpillars on the sugarberry. <Amer. Ent., August, 1869, v. 1, p. 252.

Answer to inquiry of S. L. Scofield; undetermined gall on leaves of Celtis occidentalis; Orgyia loucostigma feeding on the leaves of the same.

763. [WALsh, B. D., and C. V. RileY.] Dark grape-worm. <Amer. Ent., August, 1869, v. 1, p. 252.

Answer to inquiry of T. W. G.; characters and food-plarts of Thyreus abbotii.

764. [Walsh, B. D., and C. V. Riley.] Too fond of honey. <Amer. Ent., August, 1869, v. 1, p. $25 \%$.

Answer to inquiry of T. W. Gordon; Cernatia forceps found in a jar of honey.

765. [WaLSH, B. D., and C. V. Riley.] Caterpillar of polyphemus moth. <Amer. Ent., August, 1869, v. 1, p. 252.

Answer to inquiry of A. De $\mathrm{W}_{J 1}$; larva of Telea polyphenus feeding on plums.

766. [W ALSH, B. D., and C. V. RILEY.] Why noxious insects increase upon us. <Amer. Ent., September-October, 1869, v. 2, pp.1-2.

Reasons why noxious insects increase; review of articles by E. S. Hull, H. W. Bcecher, and Puritan.

767. [WALSh, B. D., and C. V. RILey.] Tortoise-beetles. <Amer. Ent., September-October, 1869, v. 2, pp. 2-5, figs. 1-3.

Resemblances of insects to other animals or to their surroundings; distribution, food-plants, and figure of Deloyala $[=$ Coptocycla $]$ clavata; description and figure of Physonota quinque-punctata n. sp. [= unipunctata]; figure of the larva of the same; correspondence of structural differences in larvæ with those in inagos of Cassidider, and with differences in food-plants; list of insects injurious to Solanum; figure of pupa and imago of Chelymorpha cribraria $[=a r g u s]$.

768. [WALSH, B. D., and C. V. RILEY.] Scientific nomenclature. $<$ Amer. Ent., September-October, 1869, v. 2, pp. 5-8.

Rules observed in giving specific names to animals and plants; the law of priority; nature and extent of gencric sulbdivisions. 
769. [WALsh, B. D., and C. T. Ruley.] Killing anple-Worms by machinery. <Amer. Ent., September-October, 1869, v. 2, p. 9.

Fxtraet from article of L. P. Haskell, with eomment; use of rags in plaee of hay-bands as traps for Carpocapsa pomonella; destruetion of the insects caught by meaus of a clothes-wringer.

770. [WaLSH, B. D., and C. V. RILEY.] A potter wasp (Odynerns fic. vipes? Fabr.). <Amer. Ent., September-October, 1869, г. 2, p. 10 , fig. 4.

Method employed by Eumenide to provision their nests; eonstruction of the same by species of Odynerus; habits of $O$. flavipes in provisioning a nest with several species of larvas; figure of the imago of the same and of the nest of a speeies of Odynerus; structure of wings and habits of Vespide, Eumenide, and fossorial wasps.

771. [WALSH, B. D., and C. V. RILEY.] Tomato-worms not poisonous. <Amer. Ent., September-Uctober, 1869, v. 2, p. 11.

Prejndiees in regarl to certain animals; presence of the horn on the larvio of almost all Sphingize ; larva of Protoparce celeus not poisonons.

772. [WALSH, B. D., and C. V. RILEY.] Gnoseberry and currant worms. <Amer. Eut, September-October, 1869, v. 2, pp. 12_22, tigs. $5-11$.

Need of precision in nomenclature; relations and distribution of the North Ameriean species of Ribes; inseet cnemies of the same; natural history and description of Ellopia [=Éuftchia] ribearia, Nematus ventricosus [= ribesii], and Pristiphora grossularia; figures larvæ and imagos of the three species and the pupa of the Eufitchia.

773. [WALSH, B. D., and C. V. RILEY.] Striped cucumber beetle. <Amer. Ent., September-October, 1869, v. 2, p. 24, figs. 17-19.

Answer to inquiry of M. M. Gray; deseription of larva, and habits, ravages of and means against the larva and imago of Diabrotica viltata; figures larva, pupa, and imago of the same.

774. [WALSH, B. D., and C. V. RILEX.] Leafy oak.gall. <Amer. Eut., September-October, 1869, r. '2, p. 25, fig. 20.

Auswer to inquiry of B. H. B.; description and figure of the gall of Cynips q.-frondosa.

775. [Walsh, B. D., and C. V. Riley.] Drop of gold. <Amer, Eut., September-October, 1869, v. 2, p. 25.

Answer to inquiry of B. H. B.; egg of Citheronia rcgalis? on shellbark-hickory; characters of eggrs and oviposition of Metapodins nasulns [= femoratus $]$.

776. [Walsh, B. D., and C. V. Rilfy.] The luna moth. <Amer. Ent., September-October, 1869, r. 2, p. 25.

Answer to inquiry of G. W. Finney; characters of Attacus [= Actias] luna; food-plants of the larva of the same.

777. [WaLsh, B. D., and C. V. Rlley.] Hag-moth larra. <Amer. Ent., September-October, 1869, v. 2, p. 25, fig. 21.

Answer to inquiries of C. T. Farrell and M. B. Baldwin; characters of cocoon and imago of Limacoles [=Phobetron] pithecium; number of broods of the moth in the year; figure of the larva; occurrence of Harpactor L = Milyas ] cinctus in Illinois. 
778. [W ALSH, B. D., and C. V. Riler.] Stinging bug. <Amer. Ent., September-October, 1869 , v. 2, p. 25.

Answer to inquiry of J. M. Shaffer; habits and characters of Phymata erosa.

779. [Walsh, B. D., and C. V. Riley.] Pear-tree worms. <Amer. Ent., September-October, 1869, г. 2, p. 25.

Answer to inquiry of B. Hathaway; larva of Notodonta [= Edemasia] concinna found on pear-tree leaves.

780. [Walsh, B. D., and C. V. RILEx.] "Dobson." <Amer. Ent., September-October, 1869, г. 2, p. 25.

Answer to inquiry of Fisherman; ignorance as to what the larva called "Dobson" is.

781. [WALSH, B. D., and C. V. Riley.] White-pine weevil. <Amer. Ent., September-October, 1869, v. 2, p. 26, fig.222.

Answer to inquiry of A. S. Fuller; seasons, ravages, and means against Pissodes strobi; figures larva, pupa, and imago of the same.

782. [WALSH, B. D., and C. V. RILEY.] 'Unnatural secretion of wax. <Amer. Ent., September-October, 1869, v. 2, p. 26.

Answer to inquiry of F. Brewer; description of a case of excessive secretion of wax by Apis mellifica.

783. [Walsh, B. D., and C. V. RILEY.] Raspberry borer. <Amer. Ent., September-October, 1869, v. 2, p. 26.

Answer to inguiry of F. A. Gates; ravages of the larva of Oberea perspicillata [=bimaculata $]$ in blackberry and raspberry bushes; eharacters of the imago of Dryocampa scnatoria; food-plants of the larva of the same.

784. [Walsh, B. D., and C. V. Riley.] Cocoon of horn-bug. <Amer. Ent., September-October, 1869, v. 2, p. 26.

Answer to inquiry of A. R. McClutchen; characters of cocoon of Lucanus dama?

785. [WALSH, B. D., and C. V. RILEy.] Insects named. <Amer. Ent., September-October, 1869, v. 2, p. 26, fig. 23.

Answer to inquiry of J. R. Muhleman; characters and figure of Anphipyra [=Pyrophila $]$ pyramidoides; food-plants and larva of the same and of $A$. pyramidea of Europe; characters of the larva and imago of Agnomonia anilis; supposed food-plants of its larva.

786. [WALSH, B. D., and C. V. RILEY.] Cecropia moth caterpillar. <Amer. Ent., Septèmber-October, 1869, v. 2, p. 26.

Answer to inquiries of H. G. Lewelling and S. H. I. Green; characters and food-plants of the larva of Attacus cecropia.

787. [WaLsH, B. D., and C. V. RILEY.] How cut-worms originate. <Amer. Ent., September-October, 1S69, v. 2, p. 26.

Ayswer to inquiry of T. W. Gordon; cut-worms are larvæ produced from eggs of certain Noctuide.

788. [WALSH, B.D., and C. V. RILIs.] Red-humped caterpillar. <Amer. Ent., September-October, 1869, v. 2, p. 27, figs. 24-26.

Answer to inquiry of D. W. Kanffman; habits, characters, food-plants, and means against larva of Notodonta $[=$ Edemasia $]$ concinna; figures larva, pupa, and imago of the same; poisonousness of the fluids of certain insects. 
7S9. [WaLsi, B. D., and C. V. KILEY.] Insects named. <Amer. Ent., September-October, 1869, r. 2, p. 27.

Answer to inquiry of T. W. G[ordou]; characters and food-plants of Thelia bimaculata and of larva of Procris [= Harrisina] americana and Eudamus tityrus; characters of the imago of the last.

790. [W Ent., September-October, 1869, v. 2, p. 27.

Answer to inquiry of W. H. Martin; characters and food-plants of Chrysochus auratus.

791. [WALsh, B. D., and C. V. Riley.] The trumpet grape-gall. <Amer. Ent., September-October, 1869, v. 2, p. 28, fig. 27.

Answer to iuquiry of D. McClaine; description and figure of galls of Cecidomyia vitislituus $[=$ viticola $]$; occurrence of similar galls on several varieties of grape-vines and on leaves of hickory and hackberry.

792. [WALSh, B. D., and C. V. RiLeY.] Grape-berry moth. <Amer. Ent., September-October, 1869, v. 2, p. 28.

Answer to inquiry of $\mathrm{H}$. C. Barnard; ravages of Penthina vitivorana $[=E u$ demis botrana].

793. [Walsh, B. D., and C. V. Riler.] Oak pruner. <Amer. Ent., September-October, 1869, v. 2, 1. 28.

Answer to inquiry of T. J. Plumb; occurrence of Elaphidion putator $[=$ vitlosum] at Madison, Wis.

794. [Walsh, B. D., and C. V. Riley.] Potato-bugs. <Amer. Lint, September-October, 1869, v. 2, p. 28.

Answer to inquiry of W. R. Shelmire; ravages and food-plants of Lytta [= Epicauta $]$ vittata ; means against potato-eating Meloide; characters of an unknown lepidopterous larva boring in a potato-stalk; directions for packing insects.

795. [WaLsh, B. D., and C. V. Rilery.] Blood-sucking cone-nose. $<$ Amer. Ent., September-October, 18i9, v. 2, p. 28.

Answer to inquiry of G. W. C.; effect of the "bite" of Conorhinus sanguisuga; food-habits of the same.

796. [WALSH, B. D., and C. V. RILEY.] Woolly slug.like worm on apple. <Amer. Ent., September-October, 1869, v. 2, p. 29.

Answer to inquiry of H. A. Green; food-plants and characters of larva of Lagoa opercularis; characters of the imago of the same; improper method of packing living iusects.

797. [Walsh, B. D., and C. V. Riley.] A water-bug. <Amer. Ent., September-October, 1869, v. 2, p. 29.

Answer to inquiry of W. V. Smith; characters of Ranatra fusca; habits and habitat of Nepida.

798. [Walsh, B. D., and C. V. Riley.] Goldenrod galls. <Amer. Ent., September-October, 1869 , v. 2, p. 29.

Answer to inquiry of G. W. C.; characters of galls of Trypeta solidaginis and Cecidomyia solidaginis. 
799. [Walsh, B. D., and C. V. Rilev.] Oak-leaf gall. <Amer. Ent., September-October, 1869, v. 2, p. 29.

Answer to inquiry of B. H. Broadnox; description of galls of Cecidomyia quercus-pilula and C. q.-symmetrica; Cynipida inquilinous in galls of Cecidomyidex; differences between larve of Cynipide and Cccidomyide ; transformations of C. q.-pilulce and of the Cynips sp., inquiiinous in`its gall; distinction between groups of oaks.

800. [Walsh, B. D., and C. V. Rilfiy.] Humble bees. <Amer. Ent., September-October, 1869, v. 2, p. 30.

Answer to inquiry of C. S. Davis; number of species and distribntion of the genus Bombus in North America; habits of and differences between the several forms composing a society of social insects; habits of Bombus pennsylvanicus, Halictus sp., and Andrena sp.

801. [WALSH, B. D., and (U. V. RILEY.] Can land be insured against cut-worms and other insects? <Amer. Ent., September-Oc. tober, 1869 , v. 2, p. 30.

- Answer to inquiry of A. Willis; means against larvie of cut-worms.

802. [WALSH, B. D., and C. V. Rilery.] Beetles named. <Amer. Ent., September-Octoher, 1869 , r. 2, p. 30 .

Answer to inquiry of T. W. Hoyt, jr.; characters of Cassida [= Coptocycla $]$ aurichalcea and Brachinus americanus; effect of the discharge made by Brachinus sp. upon the inside of the human mouth.

803. [Walsh, B. D., and C. V. Riley.] Royal horned-caterpillar. <Amer. Ent., September-October, 1869, v. 2, p. 30.

Answer to inquiries of W. C. Holmes and M. G. Kern; larva of Citheronia regalis found feeding on Syringa.

804. [Walsh, B. D., and C. V. Riley.] Parsnip caterpillar. <Amer. Ent., September-October, 1869, v. 2, p. 30.

Answer to inquiry of T. W. Hoyt, jr. ; characters of larva of Papilio asterias.

805. [WALSH, B. D., and C. V. RILEY.] Insècts named. <Amer. Ent., September-October, 1869, v. 2, p. 31.

Answer to inquiry of C. P. Fanlkner; identification of several beetles; habits of Creophilus villosus, Listotrophus cingulatus, Scarites subterraneus, and Oloma impressa.

306. [Walsh, B. D., and C. V. Riley.] Beetle named. <Amer. Ent., September-October, 1869, v. 2, p. 31.

Answer to inquiry of W. Keycs; llabits and characters of larva of Calopteron terminale; distinctness of $C$. reticulatum from $C$. terminale.

807. [WALSH, B. D., and C. V. Rilex.] Moth named. <Amer. Ent., September-October, 1869, v. 2, p. 31.

Answer to inquiry of W. G. Barton; food-plant of larva and characters of imago of Alaria [= Rhodophora] florida.

808. [WALSH, B. D., and C. V. RiLeY.] Worm boring into cucumber. <Amer. Ent., September-October, 1869, v. 2, p. 31.

Answer to inquiries of G. W. C., O. L. Barler, and E. S. Smith; characters of larva and imago of Phakellura [ = Eudioptis ] nitidalis; food-plants of larva; characters of undetermined larva fousd boring in cucumbers. 
809. [WaLsh, B. D., and C. V. RILEy.] Caterpillar of the io moth. <Amer. Ent., September-October, 1869, v. 2, p. 31.

Answer to inquiry of Mrs. Tildesley; characters of larva and imago of Saturnia $[=$ Hyperchiria $]$ io ; food-plant and urticating propertics of the larva.

810. [Walsh, B. D., and C. V. Riley.] Apple-tree worms. <Amer. Ent., September-October, 1869, v. 2, p. 32.

Answer to inquiry of H. K. Vickroy; habits and characters of larva of Acrobasis $[=$ Pempelia $]$ hammondi; habits of larva of Phycita nebulo $[=$ Acrobasis indiginella ].

811. [WALSH, B. D., and C. V. RileY.] Stinging larvæ. <Amer. Ent., September-October, 1869, v. 2, p. 32.

Answer to inquiry of J. C. Falls; meaning of the vernacular and technical names of Empretic stimulea; urticating properties of lepidopterous larvi.

812. [WALSH, B. D., and C. V. RILEY.] Lappet caterpillar on appletree. <Amer. Ent., September-October, 1869, v. 2, 1. 32.

Answer to inquiry of W. Stark; characters of larva of Gastropacha americana.

813. [Walsh, B. D., and C. V. Riley.] Spined spider. <Amer. Ent., September-October, 1869, v. 2, p. 32.

Answer to inquiries of G. W. Kinney and T. W. Gordon; characters and synonymy of Epeira $[=$ Acrosoma $]$ spinea.

814. [WaLsh, B. D., and C.V. Riley.] Dangerous looking. <Amer Ent., September-October, 1869, v. 2, p. 32.

Answer to inquiry of M. M. Kenzic; characters and sting of Mutilla coccinea $[=$ Spherophthalma. occidentalis $]$.

815. [Walsh, B. D., and C. V. Riley.] Bag-worms again. <Amer. Ent., September-October, 1869, v. 2, p. 32.

Answer to inquiry of T. C. Tipton; ravages of Thyridopteryx ephemerceformis; larmlessuess of larva of Protoparce celeus; habitat of larva of Musca domestica.

816. [WaLsh, B. D., and C. V. Riley.] Large water-beetle. <Amer. Ent., September-October, 1869, v. 2, p. 32.

Answer to inquiry of S. E. Munford; secondary sexual characters in elytra of Cybister fimbriolatus. See No. 750 .

817. [Walsh, B. D., and C. V. Riley.] Beetles under dead fish. $<$ Amer. Ent., September-October, 1869, v. 2, p. 32.

Answer to inquiry of T. Ferrell; food-habits and characters of silpha peltata - $[=$ americana $]$.

818. [WALSh, B. D., and C. V. Riley.] Universal remedies. <Amer. Ent., November, 1869, v. 2, pp. 33-35.

Worthlessness of any one substance as a means against insects.

819. [Walsh, B. D., and C. V. Riley.] Tent-caterpillars and fallweb-worms. <Amer. Ent., November, 1869, v. 2, p. 39.

Critical review of article in Western Rural, Augnst 26, 1869 ; seasons, habits, food-plants, and characters of Clisiocampa americana and Hyphantria textor [=cunea $]$. 
820. [WALSH, B. D., and C. V. RILEY.] The boll-worm or corn-worm. $2 \mathrm{~d}$ article. (Heliothis armigera, Hiibner.) <Amer. Ent., November, 1869, v. 2, pp. 42-44, fig. 29.

Seasous, food-plants, ravages of, and means against Heliothis armigera ; figures of larvæ, pupa, cocoon, and imago of the same; food-plants of Gortyna nitela.

821. [WALsh, B. D., and C. V. Riley.] Galls and their architects. 2d article. <Amer. Ent., 1869-1870, v. 2: Norember, pp. 4550, figs. 30-32; December-January, pp. 70-74, figs. 45-47; February, pp. 103-106, figs. 68-71.

See No. 518; definition and classification of galls; descriptions and figures of galls and larvæ of Nematus salicis-pomum, Euura s.-ovum, and E. s.gemma [=orbitalis]; habits, scasous, and descriptious of the same; habits and seasons of Anthonomus sycophanta, Batrachedra salicipomonella, and Nematus mendicus; differences between gall-makors and guest-flies; occurrence of distinct genera of gall-irsects on plants of distinct genera; descriptions and figures of galls of Cynips [= Andricus] quercus-seminator and C. q.-frondosa; synoptic table of North American genera of Cynipida Psenides; description of Antistrophus n. g. and of A. lygodesmice-pisum n. sp. and its gall; description and figure of the larva and imago of Agrilus ruficollis and its gall; habits, food-plants of, and means against, the same; figure and description of Baridius [= Ampeloglypter] sesostris and its gall; habits, food-plants of, and means against, the same; characters of Madarus ampelopsidos [ = Ampeloglypter ater $]$ and its gall; habits of Buprestidae.

822. [Walsh, B. D., and C. V. Rruer.] Toads in gardens. <Amer. Ent., November, 1869 , v. 2, p. 50.

Value of toads as a means against noxions insects, etc., in gardens.

823. [W ALSH, B. D., and C. V. RILEY.] Notes on the Tarantala-killer. <Amer. Ent., November, 1869, v. 2, p. 52.

Comments on note of C. Peabody; occurrence of Mygale hentzii and Pepsis formosa in Missouri.

824. [Walsh, B. D., and C. V. Rileix.] Swarms of lady-birds. <Amer. Ent., November, 1869, v. 2, p. 55.

Occurrence of countless millions of Coccinellide in England; their origin and movements.

825. [WaLsh, B. D., and C. V. Riley.] The squash-bug does not touch the white bush scollop. <Amer. Ent., November, 1869, v. 2, p. 55.

Coreus $[=$ Anasa $]$ tristis does not attack the white bush scollop variety of the squash-rine; means against the same.

826. [WALSH, B. D., and C. V. Riley.] [Scientific names.] <Amer. Ent., November, 1869, v. 2, p. 57.

Use of English and scientific names of iusects.

827. [WALSH, B. D., and C. V. Rilex.] On our table. <Amer. Ent., November, 1869 , v. 2, pp. 57-58.

Notices of: Record of American entomology for the year 1868.-The Canadian entomologist.-The butterflies of North America, by W. H. Edwards.Guide to the study of insects, by A. S. Packard, jr., etc. 
S2S. [WALSH, B. D., and C. V. Riley.] Locust borer. <Amer. Ent., November, 1869, v. 2, p. 58.

Answer to inquiry of J. Bagly; Arhopalus $[=$ Cyllene $]$ robinice o undistinguishable from $4 .[=C$.$] pictus q$.

S29. [WaLSH, B. D., and C. V. Riley.] Saddle-back larva. <Ámer. Ent., November, 1869, r. 2, p. 59, fig. 36.

Answer to inquiry of G. T. Cost; figure of the larva of Empretia stimulea found on Indian corn.

S30. [WALsh, B. D., and C. V. Rilfy.] Silk spiders. <Amer. Ent., November, 1869, г. 2, p. ร9.

Answer to inquiries of G. Howe and C. W. Spaulding; characters of Epeira $[=$ drgiope $]$ riparia and Neprila plumipes.

831. [WALsi, B. D., and C. V.RHLEx.] Entomological works. <Amer. Ent., November, 1869, v. 2, p. 59 .

Answer to inquiry of S. W. Cowles; mention of works containing descriptions of North Ameriean Colcoptera and Lepidoptera; food-plants of the larva of Endryas unio.

832. [WALSH, B. D., and C. V. RILEY.] Insects named. <Amer. Ent., November, 1869, v. 2, p. 59.

Answer to inquiry of A. H. R. Bryant; characters of the cocoon of Attacus cecropia and the imago of Mutilla coccinea [= Spharophthalma occidentalis].

833. [WALsh, B. D., and C. V. Rilky.] A new bee enemy. <Amer. Ent., November, 1869, r. 2, p. 59.

Answer to inquiry of $\mathrm{F}$. Brewer; characters of an undetermined carabid larva found eating Apis mellifica.

834. [Walsh, B. D., and C. V. RILeY.] Thousand-legged worms. <Amer. Ent., November, 1869, v. 2, p. 59.

Answer to inquiry of J. W. Merchant; characters and poisonousness of Scolopendra castaneiceps; Julus sp. and Polydesmus sp. injurious to strawberries.

835. [Walsh, B. D., and C. V. Ruley.] Cabbage-worms. <Amer. Ent., November, 1869, จ. 2, p. 60, figs. 37-38.

Answer to inquiry of W. C. Holmes; figures larva, pupa, and imago of Pieris protodice; means agaiust cabbage-worms.

836. [WaLsh, B. D., and C. V. Filley.] The rape butterfly. Amer. Ent., November, 1.569, v. 2, p. 60.

Answer to inquiry of J. E. Chase; occurrence of Pieris rape in Bangor, Me.

837. [WALsH, B. D., and C. V. Riley.] Bad packing. <Amer. Ent., Norember, 1869, г. 2, p. 60.

Answer to inquiry of H. C. Beardslee ; characters and food-plants of Empretia stimulea; food-plant of Darapsa $[=$ Ampclophaga $]$ myron ; directions for sending larva by mail.

838. [WALSH, B.D., and C.V.RILEY.] Granddaddy long-legs. <Amer. Ent., Noyember, 1869, v. 2, p. 60.

Answer to inquiry of W. R. Howard; vernacular names and habits of Phalangida.

839. [WaLsh, B. D., and C. V. RILEY.] Borer in apple-twig. <Amer. Ent., Norember, 1869, v. 2, p. 60.

Auswer to inquiry of G. C. Brackett; habits of Rostrichus [= Amphicerus $]$ bicaudatus and Elaphidion parallelum [= villosnm]. 
840. [WALSH, B.D., and C. V. RILEY.] Grape-vine leaf-galls. <Amer. Ent., November, 1869 , v. 2, p. 61.

Answer to inquiry of W. 'T. Heildrup; habits and means against Phylloxera vastatrix; varieties of grape infested by the same.

841. [Walsh, B. D., and C. V. Riley.] Maple-worms. <Amer. Ent., November, 1869, v. 2, p. 61.

Answer to inqniry of H. K. Vickroy; characters and ravages of Dryocampa rubicunda and Acronycta americana; food-plants of Telca polyphemus and Attacus cecropia.

842. [WALSH, B. D., and C. V. RILEY.] Melancholy chafer in apples. $<$ Amer. Ent., November, 1869, v. 2, p. 61, fig. 39.

Answer to inquiry of J. F. Fulton; figure of Euryomia [=Euplooria] melancholica found boring in apples.

843. [WALSH, B. D., and C. V. RILEY.] Worms boring in cucumbers. $<$ Amer. Ent., November, 1869, r. 2, p. 61.

Answer to inquiry of W. B. Ramson ; food-habits of Phacellura [= Eudioptis] nitidalis.

844. [WALSH, B. D., and C. V. RiLey.] Lilac-borer. <Amer. Ent., November, 1869, v. 2, p. 61.

Answer to inquiry of T. J. Freeman; characters, affinities, and means against AEgeria $[=$ Podosesia $]$ syringe.

845. [Walsh, B. D., and O. V. Riley.]. Burying beetles. <Amer. Ent., November, 1869, r. 2, p. 61.

Answer to inquiry of J. H. Osborn; habits of Necrophorus marginatus and of Silphide generally; characters of Hylobius stupidus [= Pachylobius picivorus] found on plum-trees.

846. [WALSH, B. D., and C. V. RILEY.]. Wire-worms in potatoes. $<$ Amer. Ent, Norember, 1869, v. 2, p. 62.

Answer to inquiry of W. R. Shelmire; characters of larva (Melanotus incertus?) boring in potatoes; food-habits and means against larvæ of Elateride.

847. [WALsh, B. D., and C. V. Riler.] Insects named. <Amer. Ent., Norember, 1869, r. 2, p. 63.

Answer to inquiry of J. F. Waters; unknown tortricid and Limacodes sp., found on apple-tree; characters of Chariesterus antennator.

848. [Walish, B. D., and C. V. Riley.] Girdled pear twigs. <Amer. Ent., November, 1869, r. 2, p. 62.

Answer to inquiry of T. A. Thorp; pear twigs girdled by Oncideres cingulata.

849. [Walsh, B. D., and C. V. Rilier.] Insects named. <Amer. Ent., November, 1869, v. 2, p. 62.

Answer to inquiry of E. T. Dale; foorl-habits of Hippodamia glacialis, Straclia [= Murgantia $]$ histrionica and Blepharida rhois; figure of Hippodamia glacialis.

850. [WALSH, B. D., and C. V. Riler.] Tomato-feeding worm. <Amer. Ent., November, 1869, r. 2, p. 62, fig. 41.

Answer to inquiry of A. C. Davis; description, seasons, and food-plants of larta of I'rodenia commeline; figure of dorsal surface of a segment of the same. 
S51. [Walsh, B. D., aud C. V. RiLeY.] Cocoons of Ichneumon flies. $<$ Amer. Ent., November, 1869 , v. 2, p. 62.

Answer to inquiry of C. Mitchell; cocoons of Microgaster sp. found on larva of Protoparce celcus.

852. [WALSh, B. D., and C. V. RILEY.] Gall on spotted tonch-me-not. <Amer. Ent., November, 1S69, v. 2, p. 63, fig. 42.

Answer to inquiry of A. N. Prentiss; description and figures of the gall of Cecidomyia impatientis found on Impaticns fulva.

853. [Walsh, B. D., and C. V. Riler.] Unknown larræ. <Amer. Ent., November, 1S69, v. 2, p. 63.

Answer to inquiry of J.M. Harold; characters of unknown larva allied to Lagoa.

854. [Walsh, B. D., and C. V. RiLEY.] Blood-sucking cone-nose. <Amer. Ent., November, 1869, v. 2, p. 63.

Answer to inquiry of D. B. Watson; occurrence of Conorhinus sanguisugus at Saint Louis, Mo.

855. [WALSH, B. D., and C. V. Riley.] Eggs on a grape-cane. <Amer. Ent., November, 1869, v. 2, p. 63.

Answer to inquiry of J. Cochrane; difficulty of identifying eggs of insects.

856. [Walsh, B. D., and C. V. RILEY.] Gregarious willow-worms. $<$ Amer. Ent., November, 1869, v. 2, p. 63.

Answer to inquiry of G. C. Brackett; characters, habits, and food-plants of the larva of Clostera americana $[=$ Iehthyura inclusa $]$ :

857. [WALsh, B. D., and C. V. RILEy.] Caterpillars named. <Amer. Ent., November, 1869, v. 2, p. 63.

Answer to inquiries of G. W. Copley and W. D. Butler; food-habits of larvæ of Eudamus tityrus and Papilio troilus.

858. [WALsh, B. D., and C. V. Rilet.] Insects named. <Amer. Ent., November, 1869, v. 2, p. 63.

Answer to inquiry of L. G. Saffer; vernacular name of Mutilla coccinca [ = Spharophthalma occidentalis $]$; characters of Stizus $[=$ Sphccius $]$ speciosus.

859. [WALsh, B. D., and C. V. RILey.] Range of the rear-horse. $<$ Amer. Ent., November, 1869, r. 2, p. 63.

Answer to inquiry of V. T. Chanbers; northern range of Mantis $[=$ Phasmomantis] carolina.

S60. [WALSH, B. D., and C: V. RILEY.] Royal horned-caterpillar. <Amer. Ent., November, 1869, r. 2, p. 64.

Answer to inquiry of D. L. Phares; Citheronia regalis more abundant in the Sonth than in the North.

861. [Walsh, B. D., and C. V. Rilex.] Hair-worm or hair-snake. $<$ Amer. Ent., November, 1869, v. 2, p. 64.

Answer to inquiry of E. H. King; Gordius sp. parasitic in the pupa of Orchelimum sp.

862. [WAlsh, B. D., and C. V. RILEY.] Dahlia-stalk borer. <Amer. Ent., November, 1869, v. 2, p. 64.

Answer to inquiry of G. C. Broadhead; larva of Gortyna nitele boring in stalk of dallia.

863. [Walsh, B. D., and C. V. Riley.] Parsnip worm. <Amer. Ent., November, 1869, v. 2, p. 64.

Answer to inquiry of J. Adams; larva of Papitio asterias feeds on parsnip. 



\section{U.S. DEPARTMENT OF AGRICULTURE. DIVISION OF ENTOMOLOGY.}

\section{BIBLIOGRAPHY}

oF

THE MORE IMPORTANT CONTRIBUTIONS

To

\section{AMERICAN ECONONIC ENTOMOLOGY.}

PREPARED, BY AUTHORITY OF THE SECRETARY OF AGRICUI,TURE,

$13 Y$

SAMUEI HENSHA W.

\section{PART III.}

THE MORE IMPORTANT WRITINGS

OF

CHARLES VALENTINE RILEY.

WASHINGTON:

GOVERNMENT PRINTING OFFICE. 



\section{BIBLIOGRAPHY OF THE MORE IMPORTANT CONTRIBUTIONS TO AMERICAN ECONOMIC ENTOMOLOGY.}

\section{PART III.}

864. R[ILEY], C. [Y.] The house-Hy. <Prairie Farmer, 2 May, 1863, [r. 27], 1. s., r. 11, pl. 276-277. S.-b. No. 1, p. 9.

Stomoxys caleitrans distinguished from Musca domestica; habits of each; transformations of the latter; habit of larva of collecting underneath boards.

S65. R[ILEY], C. [V.] The May-beetle. <Prairie Farmer, 6 June, 1S63, [v. 27], n. s., v. 11, p. 356. S.-b. No. 1, p. 7.

Ravages of Phyllophaga quercina [=Lachnosterna fusca]; description and haloits of larva and imagos; remedies.

Stib. R[LLEY], C. V. Larva of the ten-striped spearman. <Prairie Farmer, 8 August, 1863, [v. 25], n. s., v. 12, pp. 85-86, fig. S.-b. No. 1, p. 11.

Description of eggs; figure and first description of larva of Doryphora 10 lineata; habits of larva; seasons; remedies; enemies of larva.

S67. R[uleY], C. V. The squash-bug. <Prairie Farmer, S August, 1863, [v. 28], n. s., v. 12, p. S6. S.-b. No. 1, 1. 11.

Description of junagos and larve of Coreus $[=$ Anasa $]$ tristis; habits, seasons, remedies.

865. Rlley, C. V. The cut-worm. <Prairie Farmer, 12 March, 1864, [v. 29], n. s., v. 13, p. 169.

Answer to communication of G. R. Huffuan; habits and transformations of Agrotidide; means against them.

S69. [Ruley, C. V.] Entomological. <Prairie Farmer, 21 May, 1864, [v. 29], u. s., v. 13, 1. 361 .

Answer to communication of J. S. Lawver; ravages of unknown caterpillars, probably cut-worms, and of Ithycerus noveboracensis on young appletrees; means against these insects.

S70. [RuleY, C. V.] Apple-borers. <Prairie Farmer, 14January, 1865, [v. 31], n. s., v. 15, p. 21, 5 figs. S.-b. No. 1, p. 30.

Description and figure of larva and inago of Buprestis [= Chrysobothris] femoratu; injury done by the larva; remedies. Fignre of imago of Saperda bivittata $[=$ candida $]$. 
871. [Riley, C. V.1 Peach-tree borers. <Prairie Farmer, 25 February, 1865, [v. 31], n. s., v. 15, pp. 122-123, 6 figs. S.-b. No. 1, pp. 30-31.

Descriptions and fignres of larva, pupa, cocoon, and $\delta$ and $q$ imagos of Egeria [=Sannina $]$ exitiosa; description of egg; seasons and habits of larva and imago; remedics. Figure of inago of Dicerca divarieata.

872. [Riley, C. V.] Entomology. <Prairie Farmer, 22 April, 1865, [v. 31], n. s., v. 15, p. 306 . S.-b. No. 1, pp. 32-33.

Coming forth of insects in spring; desirability of observing noxious inseets and of recording observations; abundance of eggs of Orgyia this season; methods of destroying them.

873. [Rilex, C. V.] Flea-beetles and Curculio. <Prairie Farmer, 27 May, 1865, [v. 31], n. s., v. 15, p. 418, fig. S.-b. No. 1, p. 33.

Prevalence of and means against Halticide; habits of and means against Conotrachelus nemuphar; figure of pupa.

874. [RILEY, C. V.] Applé-tree caterpillars. <Prairie Farıer, 3 June, 1865, [v. 31], n. s., v. 15, pp. 437-438. S.-b. No. 1, p. 34 .

Answer to communication from J. C. Brown; descriptions of larva, pupa, and imago, of Chcetochilus pometellus; habits of the same; other caterpillars injurious to the leaves of apple trees and mcans against them.

875. [RILEY, C. V.] Curculio catcher. <Prairie Farmer, 10 June, 1865 [v. 31] , 1. s., v. 15, p. 457 , fig.

Figure of E. S. Hull's Curculio eatcher, with explanatory text.

876. [RILEy, C. V.] The army-worm. <Prairie Farmer, 8 July, 1865, [v. 32], n. s., v. 16, pp. 3-4, 3 figs. S.-b. No. 1, pp. 36-37.

Answer to communication from W. R.; descriptions and figures of larva, pupa, and imago of Lencania unipuncta; number of broods unknown; remedies.

877. [RILEx, C.V.] The currant-worm. <Prairie Farmer, $15 \mathrm{July}$, 1865, [v. 32], n. s., v. 16, p. 27, 4 figs. S.-b. No. 1, p. 36.

Description of eggs; descriptions and figures of larva, pupa, and imago of Euftchia ribearia; habits, seasons, remcdies.

878. [RILey, C. V.] Swallows. <Prairie Farmer, 15 July, 1865, [v. 32], n. s., v. 16, p. 27 . S.-b. No. 1, p. 36.

Usefulness of swallows in the destrnetion of noxions insects.

879. [RILey, C. V.] Another insect friend. <Prairie Farmer, 22 July, 1865, [v. 32], n. s., v. 16, p. 50. S.-b. No. 1, p. 35.

Rogas n. sp. parasitic on larva of Sesia pelasgus? [ = Hemaris thysbe]; economie benefits of parasitism.

880. [Rilex, C. V.] Singular caterpillar. <Prairie Farmer, 22 July, 1865, [v. 32], n. s., r. 16, p. 50. S.-b. No. 1, p. 35.

Descriptions of larva, pupa, and imago of Notodonta $[=$ Coclodasys $]$ unicornis; habits; food-plants.

881. [Rllex, C. V.] Collecting and preserving insects. <Prairie Farmer, 5 August, 1865, [r. 32], n. s., v. 16, pp. 101-102, fig.

Interest and importance of entomology ; directions for the eonstruction of nets and cabinets, and for the eapture, killing, preparaicion, and preservation of insects. 
822. Riley, C. V. The grass-bug and its habits: Currant worms. $<$ Cultivator and Convtry Gentleman, 10 August, 1865, v. 26, p. 98. Reprint: <Boston Cultivator, 19 August, 1865, v. 37, p. 259 . S.-b. No. 1, p. 60 .

Habits of Cercopidide; nature of the imago of eurrant-worms.

883. [RIlex, C. V.] Apple plant-louse. <Prairie Farmer, 19 August, 1865, [ن. 32], n. s., v. 16, p. 127 . S.-b. No. 1, p. 40.

Answer to inquiry of J. Doron; habits and fecundity of Aphis mali; means against it.

881. R[ILEY], C. [V.] Seventeen-year locust. <Prairie Farmer, 19 Au. gust, 1S65, [v. 32.], 11. s., v. 16, p. 127. S.-b. No. 1, pp. 40-41.

Agrees with S. P. G. in doubting that Cicada $[=$ Tibicen $]$ septendecim lives seventeen years immature, and gives reasons for his doubt.

885. [Rilex, C. V.] Tobacco-worm. <Prairie Farmer, 2 September, 1S65, [v. 32], n. s., v. 16, p. 165 . S.b. No. 1, p. 41.

Answer to inquiry of A. B. Knowlton; habits of Macrosila quinquenaculata [ = Protoparce celeus $]$.

886. [RIley, C. V.] The chinch-bug. <Prairie Farmer, 9 September, 1865, [ซ. 32], n..s., v. 16, p. 190 . S.-b. No. 1, pp. 50-51.

Critieism of communication by D. H. Sherman; Blissus lencopterus does not always deposit its eggs on grain of wheat, if it ever does șo; proposed remedy therefore ineffieient.

887. Rilex, C. V. The sheep gad-fly. <Prairie Farmer, 14 October, 1865, [г. 32], n. s., v. 16, pp. 28S-289, figs. 1-6. S.-b. No. 1, pp. $48-49$.

Answer to inquiries of a subscriber; figures and deseriptions of larva, pupaease, and imago of Cephalemyia [=Estrus] ovis; habits of and means against it; imago viviparous.

888. [RILEY, C. V.] Chinch-bug not in seed grain. <Prairie Farmer, 21 October, 1S65, [v. 32], n. s., v. 16, p. 308. S.-b. No. 1, p. 4. Supposed evidenee that the eggs of Blissus leucopterus are not deposited and do not winter in seed wheat.

889. [RILEY, C. V.] Lice on calves. ' < Prairie Farmer, 13 January, 1S65, [จ. 33], n. s., v. 17, p. 24.

Directions, on the authority of Robert Jennings, for freeing ealves of liee.

890. [RILey, C. V.] The chinch-bug once more. A reply to D. H. Sherman. <Waukegan [Ill.] Gazette, 20 January, 1866, v. 16, No. 18, p. 4.

Critieal review of artiele of D. H. Sherman.

891. Rilex, C. V. The chinch-bug. <Prairie Farmer, 3 March, 1866, [v. 33], n. s., r. 17, p. 133. S.-b. No. 1, p. 71.

Answer to inquiry of W. R. Everett; means against Blissus leucopterus; habits, hibernation, and oviposition.

882. [Rrley, C. V.] Wire-worms. <Prairie Farmer, 3 March, 1866, [v. 33], n. s., v. 17, p. 133, figs. 4-5. S.-b. No. 1, p. 71.

Answer to inquiry of - - Creswell; moans against larvio of Elateride. 
893. R[ILEY], C. V. Entomoiogical. <Ṕrairie Farmer, 24 March, 1866, [v. 33], n. s., v. 17, p. 192, figs. 5-6. S.-b. No. 1, p. 68.

Answers to inquiries of E. T. Nelson, J. Doron, and H. W. Shore; habits and figures of Amplicerns bicaudatus; remedies. Apple-twigs picrced by one of the Uroceridce.

894. Riley, C. V.' The chinch-bug. <Pract. Ent., 26 March, 1866, v. $1, \mathrm{pp} .47-48$.

Criticism of D. H. Sherman's communication on this insect; Blissus 7eucopterus does not, oviposit in the fuzzy end of wheat-grain; brief life-history.

895: Riley, C. V. The chinch-bug once more. <Waukegan [Ill.] Gazette, 31 March, 1866, v. 16, No. 28, p. 4. S.-b. No. 1, p. 70.

Reply to D. H. Sherman's sccond communication; Blissus leucopterus does not deposit its eggs in the grain of wheat; means against it.

896. [linley, C. V.] Bark-lice remedy. <Prairie Farmer, 7 April, 1866, [₹.33], n. s., v. 17, p. 229. S.-b. No. 1, p. 79.

Answers to inquiries of a subseriber and of S. J. B.; means against Mytilaspis ponicorticis [= ponorum $]$.

897. [Rulex, C. V.] "Bug" on melon, etc. <Prairie Farmer, 7 April, 1866, [v. 33], n. s., v. 17, p. 229 . S.-b. No. 1, p. 79.

Answer to inquiry of M. E. W.; means against Liabrotica vittata.

898. [RIlex, C. V.] Warbles. <Prairie Farmer, 21 April, 1866, [v. 33 ], n. s., v. 17, p. 276.

The occurrence of lumps on the back of cattle caused by larvæ of Bypoderma bovis is not unusual or alarming.

899. Riley, C. V. The ailanthus silk-worm. <Prairie Farmer, 28 April, 1866, [r. 33], n. s., v. 17, p. 289, fig. S.-b. No. 1, p. 93. Partial reprint: <New York Tribune, 29 May, 1866, v. 26, No. 7844, p. 7. S.-b. No. 1, p. 92.

Describes attempts to introdnce Bombyx arrindia and Samia [=Atlacus $]$ cynthia into Enrope for commercial purposes. Describes and figures egg, larva, and inago, and figures pupa of Samia [= Attacus $]$ cynthia ; habits, seasons, and hardiuess, and disadvantages for purposes of silik culture of this species; supcriority of native species.

900. [Rlley, C. V.] Lice on pigs. <Prairie Farmer, 28 April, 1866, [v. 337, n. s., v. 17, p. 292.

Means against.

901. Riley, C. V. Novel facts about cut-worms. <Prairie Farmer, 2 June, $1866,[$ [ . 33], n. s., v. 17, pp. 371, 372, figs. 3-8. S.-b. No. 1, p. 89.

Climbing habits of the larre of Agrotidida; figures and descriptions of the larvæ of Agrotis cochranii $[=A$. messoria $]$, A. clandestina, and ? Hadena subjuncta; enemies of cut-worms.

902. [RIley, C. V.] The canker-worm. <Prairie Farmer, 16 June, $1866,[$ v. 33], n. s., v. 17, p. 412 . S. b. No. 1, p. 96.

Answer to inquiry of a subscriber; means against Anisopteryx.

903. R[ILEY], C. V. Large fish-fly. <Prairie Farmer, 16 June, 1866, [r. 33], n. s., r. 17, p. 412 . S.-b. No. 1, p. 96.

Answer to inquiry of A. B. Knowlton; habits and distribution of Perla dorsata. 
904. Riley, C.V. The bee-moth. <Cultivator and Country Gentieman, 21 June, 1866, v. 27, p. 399. S.-b. No. 1, p. 97.

Answer to inquiry of E. S. Fowler; habits of Galleria cercana.

905. Rilex, C. V. The potato-bug. <Prairie Farmer, 23 June, 1866, [r. 33], n. s., r. 17, p. 432. S.-b. No. 1, p. 97.

Alswer to inquiry of J. D. Eilington; eastward spreading of and meins against Doryphora decemlineata.

906. [Riley, C. V.] Army-worm. <Prairie Farmer, 23 June, 1866, [r. 33], n. s., v. 17, p. 432 . S.-b. No. 1, p. 97.

Oceurrenee of Lencania mipuncta in various parts of Illinois.

907. Riley, C. V. White willow insects. <Prairie Farmer, 30 June, 1866; [r. 33], n. s., r. 17, p. 452 . S.b. No. 1, p. 101.

Answer to inquiry of L. G. H.; deseriptions of larva, pupa, and imago of Vanessa antiopa; deseription of larva of Nematus ventralis; habits of and means against these.

908. Riler, C. V. Still they come. < Prairie Farmer, 30 Jnne, 1866, [r. 33], n. s., r. 17, p. 452. S.-b. No. 1, p. 101.

Answer to incquiry of S. D.; means against Doryphora decomlineata.

909. Riley, C. V. The worm question. <Ohio Farmer, $7 \mathrm{July,} \mathrm{1866,}$ v. 15, p. 209 . S.-b. No. 2 , p. 17.

Comments on a eontroversy between J. K. and J. Broeket eoneerning Pyrrharctia isabella; molting, pupation, and eoeoon-making of this and other eaterpillars.

910. Riley, C. V. Army-worm and canker-worm wisdom. < Prairie Farmer, 21 July, 1866, [r. 34], n. s., v. 18, p. 38. S.-b. No. 1, p. 101 ; No. 2, p. 40.

Comments on entomologieal ignoranee amongst members of the Frut Grower's Society of Western New York; effieney of meuns against Anisopteryx.

911. R[ILEY], C. V. [Attacus cecropia.] < Prairie Farmer, 21 July, 1866, [v.34], n. s., v. 18, p.40. S.-b. No.1, p.104; No. 2, p. 40.

Answer to inquiry of F. T.; habits of Attacus cccropia; its nsefulness for silk.

912. R[ILEY], C. V. [Cantharis cinerer.] < Prairie Farmer, 21 July, 1866, [r. 34], n. s., v. 18, p. 40. S.-b. No. 1, p. 104; No. 2 , p. 40. Answer to inquiry of W. D. Hoord; critieizes the fignre of Lyfta fabricii [=Macrobasis micolor $]$ in Harris' Insects; usefulness of the Meloide as vesieants; habits of and means against $\mathbb{M}$. unicolor.

913. Riley, C. V. [Edema albifrons.] <Prairie Farmer, 1 August 1866, [v. 34], n. s., v. 1S, p. 73. S.-b. No. 1, p. 110.

Answer to inquiry of $\mathrm{H}$. Kennedy; probability of unknown notodontoid proving Edema albifrons.

914. Riley, C. V. Practical entomology in reality. <Maine Farmer, 2 August, 1866. S.-b. No. 2, p. 21.

Critieal review of Braekett's Praetieal Entomology No. 9; some eut-worms do elimb trees; Gestrus oris is viviparous.

915. Riley, C. V. [Clytus speciosus.] <Prairie Farmer, 4 August, 1866, [r. 34], n. s., v. 18, p. 73. S.-b. No. 1, p. 110.

Answer to inquiry of C. L. Edwards; habits of and means against Clyfus [=Plugionotus $]$ speciosus injuring maple-trees; deseription of larva of Anisota $[=$ Dryocampa $]$ rnbicunda whieh feeds npon maple leaves. 
916. Rulex, C. V. Grape-leaf louse. < Prairie Farmer, 4 August, 1866, [v. 34], 1. s., r. 18, p. 73. S.-b. No. 1, p. 110.

Answer to inquiries of "Subscriber"; description, habits and development of Pemphigus vitifolice [ = Phylloxera vastatrix ].

917. Riley, C. V. White willow worm. <Prairie Farmer, 4 August, 1866, [v. 34], n. s., v. 18, p. 73. S.-b. No. 1, p. 110.

Descriptions of larva and imago of Nematus ventralis; food-plants; ravages and number of broods.

918. Ruler, C. V. Insects in timber. <Prairie Farmer, 4 August, 1866, [v. 34], n. s., v. 18, p. 73. S.-b. No. 1, p. 110.

Unknown species of Tortricide injurious to forests in Brown and Schuyler Counties, Illinois, in 1865.

919. Riley, C. V. Dernene Kartoffel-Käfer. <Deutsche Prairie Farmer, August, 1866, 2 figs. S.-b. No. 2, p. 14.

Descriptions and figures of larva and imago of Doryphora decemlineata; its eastern migrations; habits; means against it.

920. Riley, C.'V. Cicadias and walking-sticks. <Prairie Farmer, 1 September, 1866, [r. 31], u. s., v. 18, p. 136. S.-b. No. 2, p. 41.

Answer to inquiry of J. D. Swain; condensed acconnt of Cicada canicularis [=tibicen]; comparison with C. [= Tibicen] septendecim; mentions Spectrum [= Diapheromera $]$ femoratum.

921. [Riley, C. V.] Locust-borer. <Prairie Farmer, 1 September, 1866, [v. 34], n. s., v. 18, p. 140.

Answer to inquiry of O. H. S.; nearly all of the locust groves in the West have been destroyed by Clytus $[=$ Cyllene $]$ robinice; no remedy known.

922. RrLey, C. V. Apple-tree caterpillars. <Prairie Farmer, 8 September, 1866, [v. 34], n. s., v. 18, p. 152. S.-b. No. 2, p. 41.

Answer to inquiries of $\dot{S}$. Caverno and H. M. Lyman; habits, descriptions of larvæ, and imagos of Datana ministra and Notodonta [=Edemasia $]$ concinna; means against them; description of pupa of Datana ministra.

923. Rilex, C. V. Joint-worm. <Prairie Farmer, 8 September, 1866, [v. 34], n. s., v. 18, p. 152. S.-b. No. 2, p. 4 l.

Answer to inquiry of G. W. Conklin; habits of and means against Trosoma hordei.

924. Rulfy, C. V. [NTematus ventralis.] <Prairie Farmer, 8 September, 1866, [v. 34], n. s., v. 18, p. 152.

Answer to inquiry of G. E. W. ; ravages of Nematus ventralis in Kalmar, Minu.

925. [RILeY, O. V.] Ten-lined potato-beetle. <Prairie Farmer, 8 September, 1866, [v. 34], 1. s., v. 18, p. 152. S.-b. No. 2, p. 42.

Larva of Lema trilineata on potato plants in Maine mistaken for that of Doryphora decemlineata.

926. [Riley, C. V.] Locusts. <Prairie Farmer, 3 November, 1S66, [v. $34]$, n. s., v. 18, p. 290.

Occurrence and ravages of Calopterins spretus in portions of Kansas and western United States in 1866.

927. Rutex, C. V. Caterpillars on the pine. <Prairie Farmer, 10 No-

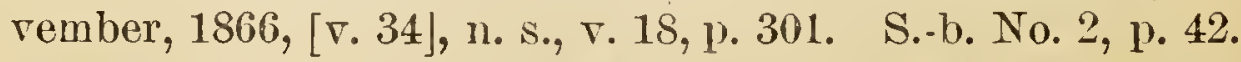

Auswer to inquiry of N. R. Strong and A. L. Jones; detailed description of larva of Lophyrus abbotii; habits of larva; means against the insect. 
928. Riley, C. V. Elm-and pear-tree borer. <Prairie Farmer, 10 November, 1866, [v. 34]; n. s., v. 18, p. 301. S.-b. No. 2, p. 42.

Answer to inquiry of James Matteson; description and habits of Tremex columba.

929. Riley, C. V. Grasshoppers and locusts. <Prairie Farmer, 24 November, 1866, [r. 34], n. s., v. 18, p. 333. S.-b. No.2, pp. 4344.

Answer to inquiry of J. N.; distinguishes grasshoppers from locusts; characterizes Achetade $[=$ Gryllide $]$, Gryllide $[=$ Locustide $]$, and Locustidee [= Acridide $]$; oviposition, transformations, ravages, and migrations of Acridide; recognition of Caloptenus spretus.

930. Riley, C. V. Black-knot once more. <Gardeners' Mo. and Hortic., Noręmber, 1866, v. 8, pp. 331-332. S.-b. No. 2, p. 31. Fungoid origin of black-knot [Spheria morbosa]; larves of Conotrachelus nenuphar present in the swellings.

931. R[ILEY], C. V. Brimstone for borers. <Prairie Farmer, 8 December, 1866, [v. 34], n. s., v. 18, p. 365. S.-b. No. 2, p. 44.

Criticism of a communication by W.; sulphur inserted in trunks of trees ineffectual as a means against insects.

932. Riley, C. V. 'The wire-worm. <Cultivator and Country Gentleman, 27 December, 1866, v. 28, p. 414. S.-b. No. 2, p. 34.

Critical review of $J$.D. Gros' "The wire-worm;" myriapods and the larva of Elaterida are called wire-worms; separable by the number of their legs; means against them.

933. [RILEY, C. V.] Tilden tomato and the tobacco-worm. <Prairie Farmer, 5 January, 1867, [v. 35], n. s., v. 19, p. 5.

Remarks on conumunication of T. B. ; tomato plants eaten by tobacco-worms [Protoparce carolina] in preference to tobacco plants; possibly the worms observed were tomato-worms $[P$. celeus $]$.

934. [RILey, C. V.] Remarks on Saperda, Chrysobothris, Carpocapsa, and Conotrachelus. <Prairie Farmer, 12 January, 1867, [v. 35], n. s., v. 19, p. 23.

Report of remarks made at the annual meeting of Southern Illinois Fruit Growers' Association.

935. [RIley, C. V.] Bark-lice. <Prairie Farmer, 12 January, 1867, [v. 35], n. s., v. 19, p. 24.

Washing apple-trees with lye effective against bark-lice.

936. Riler, C. V. Insects in the flower garden. A troublous time. <Prairie Farmer, 19 January, 1867, [v. 35], n. s., r. 19, p. 37. S.-b. No. 2, p. 45.

Answer to communication by Kate Sherman; describes larva of [Heliothis phlogophagus] injuring Phlox.

937. [RILEX, C. V.] Salt and vinegar for insects. <Prairie Farmer, 19 January, 1867, [v. 35], n. s., v. 19, p. 37. S.-b. No. 2, p. 45.

Review of 'T. Glover's Report of the U. S. Entomologist for 1865, T. Glover's Entomological exhibition in Paris, and W. C. Lodge's Fruits and fruit trees of the Middle States; use of salt and vinegar as means against insects; criticism of errors. See Nos. 222, 939, 94\%. 
938. Riler, O. V. Hickory bark borer, Scolytus carya, n. sp. <Prairie Farmer, 2 Februars, 1867, [v. 35], n. s., v. 19, pp. 68, 69, 6 figs. S.-b. No. 2, p. 50.

Descriptions and figures of larva and imago of Scolytus caryes n. sp. [=4-spinosus] and of its borings in bark and wood of Carya; habits and ravages; figure of the pupa of s. desiructor of Europe.

939. [Riley, Q. V.] Correction. <Prairie Farmer, 2 February, 1867, [r. 35], n. s., v. 19 , p. 69. S. b. No. 2, p. 50.

Correction of statement made in No. 937; T. Glover not responsible for calling Saperda bivittata [= candida] a butterfly. See Nos. 222, 937, 942.

940. Riley, C. V. Dahlia and aster stalk-borer, Gortyna nitela Guenée. <Prairie Farmer, 23 February, 1867, [v. 35], n. S., v. 19, p. 116, 2 figs. S.-b. No. 2, p. 58.

Description of larra, pupa, and inago of Gortyna nitela; habits of and means against this insect.

941. R[ILEY], C. V. Borers and canker-worms. <Prairie Farmer, 9 Marcb, 1867, [v. 35], n. s., v. 19, p. 151. S. b. No. 2, p. 61.

Critical review of E. H. C.'s "Remedy for the borer" and of J. Huggins' "Canker-worm ;" indefiniteness of the word borer; borers confined to particular trees according to species; relations between Clytus $[=$ Cyllene $]$ pictus and $C .\left[=C_{\text {. }}\right]$ robinia ; habits of and means against canker-worms. See No. 954 .

942. [RILex, C. V.] The critic criticised. < Prairie Farmer, 16 March, 1867, [v. 35], n. s., v. 19, p. 169. S.-b. No. 2, p. 58.

Reply to B. D. Walsh's "The critic criticised;" insists upon the correctness of one criticism made; acknowledges incorrectness of another. See Nos. $222,937,939$.

943. Riley, C. V. [Solenobia.] <Prairie Farmer, 16 March, 1867, [v. 35], n. s., v. 19, p. 169. S.-b. No. 2, p. 58.

Answer to inquiry of J. C. Plumb; brief description of the larva of ? Solenobia; habits of the genus.

944. Riley, C. V. Bark-lice. Their history, together with sundry remedies. <Prairie Farmer, 23 March, 1867, [v. 35], n. s., v. 19, p. 184. S.-b. No. 2, pp. 61-62. Extract: <Cultivator and Country Gentleman, 23 May, 1867, v. 29, p. 334. <Pract. Ent., April, 1867, v. 2, pp. 81-82.

Criticises several patent remedies for ravages of bark-licc, Coccide; ignorance of entomology amongst intelligent writers; natural history of Mytilaspis pomicorticis $[=$ pomorum $]$.

945. Riley, C. V. The phlox-worm. <Prairie Farmer, 6 April, 1867, [v. 35], n. s., v. 19, p. 219, 2 figs. S.-b. No. 2, pp. $63,64$.

Describes and figures larva and imago of Heliothis phloxiphaga; describes pupa; seasons and habits.

946. RILey, C. V. The potato-beetle. <Prairie Farmer, 6 April, 1867, [v. 35], n. s., v. 19, p. 219 . S.-b. No. 2, p. 64.

Answer to inquiries of $\mathrm{H}$. Tilden; Doryphora decemlincata remains permanently in regions invaded by it; hibernates as an imago under ground. 
947. Riley, C. V. Meadow-worms. <Prairie Farmer, 6 April, 1867, [r. 35], n. s., v. 19, p. 219 . S.-b. No. 2, p. 64.

Answer to inquiry of B. S.; habits of Tipula in all stages.

948. Riley, C. V. Clover-worms. <Prairie Farmer, 1867, [v. 35], n. s., v. 19, 20 A pril, pp. 260-261, 10 figs.; 27 April, p. 279. S.-b. No. 2, pp. 67, 68 .

Habits and ravages of Pyralis olinalis [ = dsopic costalis $]$; figures and detailed descriptions of larva, pupa, cocoon, and imago.

949. Riley, C. V. The apple-leaf crumpler. <Prairie Farmer, 27 April, 1867, [r. 35], n. s., v. 19, p. 279, 4 figs. S.-b. No. 2, p. 68. Answer to inquiry of A. H.; description of pupa, tigure of larva-case and imago of Phycita nebulo $[=$ Acrobasis indiginella $]$; habits and means against the same.

950. Riley, C. V. Cocoons on the flowering ash. <Prairie Farmer, 27 April, 1867, |v. 35|, n. s., v. 19, p. 279 . S.-b. No. 2, p. 68.

Answer to inquiry of A. B. Pierce; descriptions of larva, cocoon, and imago of Attacus promethea; food-plants of larva; method of emergence from cocoon.

951. Rrley, C. V. Scarred apple-trees. Prairie Farmer, 27 April, 1867, [v.35], n. s., v. 19, p. 279. S.-b. No. 2, p. 68.

Answer to inquiry of P. M. Williamson; descriptions of the injuries to appletrees caused by Tettigonia sp., Coccus harrisii [=Chionaspis furfurus], and Mytilaspis pomicorticis [= pomornm $]$.

952. Riley, C. V. Aphides. <Prairie Farmer, 18 May, 1867, [r. 35,], n. s., v. 19, p. 332 . S.-b. No. 2, p. 73.

Answer to inquiry of J. Taylor; color and propagation of Aphis mali; means against the same.

953. Riley, C. V. Tree-cricket. Prairie Farmer, 18 May, 1867,|v. 35], n. s., v. 19, p. 332 . S.-b. No. 2, p. 73.

Answer to inquiry of A. N. Prentiss; liabits of Ecanthus niveus.

954. Rlley, C. V. Note. <Prairie Farmer, 1S May, 1867, [v. 35], n. s., v. 19, p. 332. S.-b. No. 2, p. 73.

Correction of No. 941 ; critieism unfounded.

955. Riley, C. V. The strawberry-worm, Emphytus maculatus Nortou. < Prairie Farmer, 25 May, 1867, [r. 35], n. s., v. 19, p. 348, 9 figs. S.-b. No. 2, p. 72.

Descriptions and figures of all stages, geographical distribution, seasons, habits, and oviposition of and means against Emphytus [=Harpiphorus] maculatus.

956. RILey, C. V. White-pine worm: Lophyrus abbotii. < Prairie Farmer, 25 May, 1867, [v. 35], n. s., v. 19, p. 348, 7 figs. S.-b. No. 2. p. 72.

Deseription of imago of Lophyrus abbotii; figures larva, pupa, cocoon, $q$ imago and $\delta$ and $q$ antenne; habits and scasons of larvæ.

957. [Rrley, C. V.] Stag-beetle. < Prairie Farmer, 25 May, 1867, [r. 35], 11. s., v. 19, p. 348. S.-b. No. 2, p. 72.

Answer to inquiry of S. Barrier; habits of Lucamus elaphus. 
958. [Riney, C. V.] The Curculio. <Prairie Farmer, 1 June, 1867, [v. 35], n. s., r. 19, p. 368. S.-b. No. 2, p. 73.

Successful rcsults from the use of machines for destroying Conotrachelus nenuphar; this insect hibernates in the imago state.

959. Rlley, C. V. Fifteen-spotted lady-bird. <Prairie Farmer, s June, 1867, [v. 35], n. s., v. 19, p. 381.

Answer to inquiry of A. B. Knowlton; food, variable coloration of imago, and usefulness of Mysia [Anatis] 15-pructata.

960. Rilex, C. V. Cherry Aphis. <Prairie Farmer, S June, 1867, [v. $35]$, n. s., v. 19, p. 381.

Answer to inquiry of G. Lee; habits, ravages of and means against Myzus cerasi.

961. Riley, C. V. 'Tree-cricket. <Prairie Farmer, 8 June, 1867, [v. $35]$, n. s., r. 19, p. 381.

Eggs of Ecanthus nivens deposited in raspberry canes canse the death of the wood above them.

962. Riley, C. V. Apple-tree borer. <Prairie Farmer, 8 June, 1867, [v. 35], n. s., v. 19, p. 381.

Answer to inquiry of A. B. Campbell; commends D. B. Wier's remedy against the applc-tree borer; Saperda bivittata $[=$ candida $]$ goes through its transformations in two years, though commonly believed to require three years.

963. Riley, C. V. Insects affecting apple-tree roots. <Prairie Farmer, 15 June, 1867, [v. 35], n. s., v. 19, p. 397. S.-b. No. 2, p. 100.

Letter from O. B. Galusha, with answer; descriptions of young and mature wingless individuals of the root-inhabiting form, Pemphigus pyri, of Schizoneura lanigera; habits, seasons, and reproduction of this form; its gallmaking and means against it; description of larva of Cccidomyia species found with the lice; and of larva and imago of Mycetophila persica [n. sp. ?]; seasons of the latter'; larva of Saperda calcarata bores in roots of apple; larva of Helops micans feeds on dccaying apples; Julus [Spirobolus] marginatus infested with Gamasus juloides.

964. Riley, C. V. A chapter on cut-worms. <Prairie Farmer, 22 June, 1867 , [v. 35], n. s., v. 19, pp. 413-414, 7 figs. S.b. No. 2 , pp. $79-80$.

Extract from J. Townley's "Do cut-worms destroy tree buds?". Buds of fruit trees destroyed by the larve of Agrotidida; other ravages and means against the same; descriptions of the larre of Agrotis subgothica $[=A$. herilis and A.tricosa], A. telifera [=A. ypsilon], and Celcena [= Hadena] renigera; description of $A$. cochranis n. sp. [=A. mcssoria $]$; figures larva and imago of $A$. cochranis, $A$. telifera, and Celcena renigera; and imago of $A$. subgothica; habits, seasons, and vernacular names of Agrotidida.

965. [Riley, C. V.] Strawberry-worm. <Prairie Farmer, 22 June, $1867,[$ ․ 35], n. s., v. 19, p. 414 . S.-b. No. 2, p. 80.

Answer to inquiry of A. R. Whitney; geographical distribution of $\mathrm{Em}$ phytus $[=$ Harpiphorns $]$ maculatus.

966. Riley, C. V. Insects stripping the bur-oak. < Prairie Farmer, 13 July, 1867, [r. 36], n. s., v. 20, p. 21. S.-b. No. 2, p. 81. Answer to inquiry of A. B. Price; habits of Lachnosterna pilosicollis [= tristis. $]$ 
967. Rilex, C. V. Borers. <Prairie Farmer, 13 July, 1867, [г. 36], 1. s., v. 20, p. 21 . S.-b. No. 2, p. 81.

Answer to inquiry of $\mathrm{J}$. Wentworth ; means against Clytus [=-Cyllene] robinice and Xylcutes $[=$ Cossns $]$ robinice.

968. Rilex, C. V. Potato-beetle. <Prairie Farmer, 13 July: 1867, [v. 36], n. s., v. 20, p. 21. S.-b. No. 2, p]. \$1-\$2.

Answer to inquiries of J. L. W. and G. L. Merriwether; Doryphora 10-lineata thrce-brooded; its occurrence at Shipman, Ill.

969. [Riley, C. Y.] Smith's patent Curculio trap. <Prairie Farmer, 13 July, 1867, [r. 36], 11. s., v. 20, p. 21. S.-b. No. 2, p. S2.

Communication from N. C. Coffinan, with reply; coudemus J. Smith's Curcalio trap.

970. Rilex, C. V. [Aphis ribis.] <Prairie Farmer, 3 August, 1867, [r. 36], n. s., v. 20, p. 69 . S.-b. No. 2, p. 81 .

Auswer to inquiry of C. J. Eckhart; means against Myzus ribis.

971. Rilex, C. V. Mantis carolina. < Prairie Farmer, 3 August, 1S67, [v. 36], n. s., v. 20, p. 69. S.-b. No. 2, p. S1.

Auswer to communication of J. H. Graves; cggs of Mantis [ $=$ I'hasmomantis $]$ carolina found in Ogle County, Ill.

972. RILEX, C. V. Lappet caterpillars on the apple. <Prairie Farmer, 3 August, 1867, [v. 36], u. s., v. 20, p. 69 . S.-b. No. 2, p. 81.

Answer to communication of Perkins and Congdon; description of the larva, pupa, cocoon, and imago of Gastropacha $[=$ Tolype $]$ velleda.

973. Rrlex, C. V. Apple-bark lice on pears. <Prairie Farmer, 3 August, 1867, [v. 36], n. s., v. 20, p. 69. S.-b. No. 2, p. 81 .

Mytilaspis pomicorticis $[=$ pomorum $]$ on the fruit of pcar-trees; said to occur on currauts, pluu, and black oak.

974. Rrley, O. V. Currant.bush borer. <Prairie Farmer, 3 August, $1867,[$ v. 36$]$, n. s., v. 20, p. 69 . S.-b. No. 2, p. $\$ 1$.

Answer to inquiry of $\mathrm{H}$. B. Kinue; habits, description, and means against Ager'a tipuliformis.

975. Rrley, C. V. Apple-leaf erumpler. <Prairie Farmer, 3 August, $1867,[$ v. 36], n. s., v. 20 , p. 69 . S.b. No. 2, p. $\$ 1$.

Answer to inquiry of H. C. Clock; habits and means against Plycita nebulo [= Acrobasis indiginella $]$.

976. Riley, C. V. Tomato-stalk borer. <Prairie Farmer, 3 August, 1867, [v. 36], n. s., v. 20, p. 69. S.-b. No. 2, p. 81 .

Answer to inquiry of O. G. Nevins; food-plints of Gortyna nitela.

977. Riley, C. V. A few errors corrected. <Wisc. Farmer, 17 August, 1867. S.-b. No. 2, p. 83.

Habits of Doryphora 10-lineata and of Carpocapsa pomonclla.

978. Rrley, C. V. Curculio. <Prairie Farmer, 7 September, 1867, [v. $36]$, n. s., v. 20, p. 148 . S.-b. No. 2, p. $\$ 2$.

Answer to inquiry of J. Shearer; means against Conotrachelus nenuphar.

979. Riler, C. V. Hop-vine caterpillars. <Prairie liarmer, 7 Septem: ber, 1867 , [v. 36], и. s., v. 20 , p. 148 . S.-b. No. 2, p. 82.

Communication from J. H. Graves, with answer; Mantis [= Phasmonantis $]$ carolina brecels as far north as Ogle Coụnty, Ill. Description of larva and imago of Hypena humnli $[=$ scabru $]$; means against it. 
980. RILey, O. V. Wheat-worms. < Prairie Farmer, 7 September, 1867, [v. 36], n. s., r. 20 , p. 148 . S.-b. No. 2 , p. 82.

Communication from C. Camplell, with answer; description of larva and imago and habits of Pyralis $[=$ Asopia $]$ farinalis; ravages of Tenebrio molitor; means against both species.

981. Riler, C. V. [Root-borer.] <Prairie Farmer, 7 September, 1867, [v. 36], n. s., v. 20, p. 148 . S.-b. No. 2, p. 82.

Communication from S. T. Kelsey, with answer; ravages of an unknown cerambycid larva which destroys the roots of various plants.

982. Riley, C. V. Bark-lice on the pear. <Prairie Farmer, 7 September, 1867 , [v. 36], n. s., v. 20 , p. 148 . S.-b. No. 2 , p. 82.

Letter from T. D. Plumb, with answer; Mytilaspis pomicorticis [= pomorum] lives on fruit of pear and crab-apple; the scale a secretion; extent of injuries caused by this insect.

983. Riley, C. V. A nuisance made useful. <Prairie Farmer, 7 September, 1867, [v. 36], n. s., v. 20, p. 148. S.-b. No. 2, p. 82.

Means against Doryphore 10-lineata discredited.

984. Riley, C. V. Strawberry leaf-roller. <Prairie Farmer, 5 October, 1867, [v. 36], n. s., v. 20, p. 212. S.-b. No. 2, p. 100.

Answer to inguiry of N. R. Strong; Anchylopera [= Phoxopteris $]$ fragarice injures strawberry leaves; larvæ of Selandria $[=$ Monostegia $]$ rasce also eat leaves of the strawberry.

985. Riley, O. V. False caterpillars on the pine. < Prairie Farmer, 5 October, 1S67, [v. 36], n. s., v. 20, p. 212. S.-b. No. 2, p. 101.

Auswer to inquiry of A. S. Fuller; habits and description of Lophy/rus lecontei.

986. Riley, C. V. An unknown worm. <Prairie Farmer, 5 October, 1867, [v. 36], n. s., v. 20, p. 212. S.-b. No. 2, p. 101.

Extraet from Beaver Dam Citizen, with comments; habits and rescription of Eristalis sp.

987. [RIley, C. V.] Bark-louse. <Prairie Farmer, 19 October, 1867, [v. 36], n. s., v. 20, p. - . S.-b. No. 2, p. 75.

Benzine and soap as a means against bark-lice.

988. [RILeY, C. V.] Editorial excursion to the Rocky Mountains. $<$ Prairie Farmer, 7 December, 1867, [r. 36], n. s., v. 20, pp. 353354. S.-b. No. 2, pp. 112-113.

List of plants, insects, and mammals observed.

989. Riley, C. V. Bark-lice. <Prairie Farmer, 21 December, 1867, [v. 36], n. s., v. 20, p. 389 . S.-b. No. 2, p. $11 \%$.

Answer to inqquiries of G. Backster and J. C. Cobbey; means against Mytilas. pis pomicorticis [= pomorum].

990. Rilex, C. V. Root Aphis. <Prairie Farmer, 21 December, 1867, [v. 36], n. s., v. 20, p. 389 . S.-b. No. 2 , p. 112.

Answer to inquiry of J. M. Jordan; means against the root and stem forms of Schizoneura lanigera.

991. [RILEY, O. V.] The Colorado potato-beetle. <Prairie Farmer, 21 December, 1867, [r. 36], 11. s., r. 20, p. 389. S.-b. No. 2, p. 112. Communications from C. W. Murtfeldt asserting the possession of poisonous qualities by the larvie of Doryphora 10-lineata. 
992. Riley, C. V. Cut-worm. Fall and spring plowing. <Moore's Rural New Yorker, ——, 1867. S.b. No. 2, p. 94.

Criticism of article by Agricola.

993. Riley, O. V. Entomology. <Prairie Farmer Annual [No. 1 for 1S68], 1867, pp. 53-59, 6 tigs. S.-b. No. 2, pp. 125-126; No.14, pp. 216-219.

Descriptions and figmes of larva, pupa, and imago of Coptocycla $[=$ Cassida $]$ bivittata; habits, seasons, and neans agaiust it ; list of Cassidide injurious to swcet-potato. Descriptions of larva, nidus, and imagro of Desmia maculalis, fignres pupa; habits and seasons of and means agrainst it. Figures Colaspis flarida; deseribes its smpposed habits. Food-plants of Heliothis armigera. Figures larva and imago of Gorlywa nitcle; its food-plants, scasons, and hibernation. Figures larva and imago of Heliothis phlogophagus; synonymy, geographical distribution, and weans agrainst it; rewarks on the balance of nature. Higures larva, pupa, cocoon, and imago of Asopia costalis; its synonymy and ravages.

994. Rrley, C. V. Bark-lice. < Prairie Farmer, 15 February, 1868, [v. 37], n. s., v. 21, p. 100. S.-b. No. 2, p. 118.

Answer to inquiry of J. Hawkins; natural limitation and parasites of Myti. laspis pomicorticis [=pomorum]; it attacks healthy and unhealthy trees; means against it; experience with.washes.

995. Rrley, C. V. Potato beetle. < Prairie Farmer, 22 February, 1868, [v. 37], n. s., v. 21, p. 117. S.-b. No. 2, p. 119 ; No. 3, p. 58.

Answer to inquiry of F. T. Moore; invention of a machine for killing Doryphora 10-lincata; hand-picking and heavy mulching the most available reusedies.

996. Rilex, C. V. Apple-tree plant-lice. <Prairie Farmer, 22 February, 1868, [v. 37], 11. s., v. 21, p. 117. S.-b. No.2, p. 119 ; No. 3, p. 58 .

Letter from L. M., with answer; habits of and means against Aphis mali.

997. Riley, C. V. Apple-root blight. <Prairie Farmer, 22 February, 1868, [r. 37], n. s., v. 21, p.117. S.-b. No. 2, p. 119; No.3, p. 58 .

Answer to inquiry of C. S. J.; Schizonemra lanigera not the cause of "rotten root."

998. Riley, C. V. Apple leaf.crumpler. <Prairie Farmer, 22 February, 1868, [v. 37], n. s., v. 21, p.117. S.-p. No.2, p. 119 ; No. 3, p. 58.

Answer to inquiry of J. M. Pearson; means against Phycita nebulo $[=A c r o-$ basis indiginella].

999. RILey, C. V. Tree-cricket. <Prairie Farmer, 14 March, 1868, [ن. 37], n. s., v. 21, p. 164. S.-b. No. 2, p. 120 ; No. 3, p. 58.

Letter from J. J. Hngrins, with answer; place of oviposition of Geanthus niveus; list of plants in which this spccies oviposits.

1000. Riley, C. V. Egg-masses and cocoous on apple-trees. <Prairie Farmer, 14 March, 1868, [v. 37], 11. s., v. 21, p. 164. S.-b. No.2, p. $120 ;$ No. 3, p. 58 .

Answer to inquiry of a correspondent; description of egg-masses and of larva of Orgyia lcucostigma; bencficial influcnce and means of encouraging parasites. 
1001. Riley, C. V. Hop insects; Hop Aphis. < Prairie Farmer, 21 March, 1868, [r.37], n. s., v. 21, p. 184. S.-b. No. 3, p. 58.

Brief account of and means against Hypena humuli $[=$ scabra $]$ and Phorodon humuli.

1002. Riley, C. V. Supposed eggs of the preýing Mantis. <Prairie Farmer, 28 March, 1868, [v. 37], n. s., จ. 21, p. 201. S.-b. No. 2, p. $121 ;$ No. 3, p. 59.

Answer to inquiry of J. H. Graves; cocoons of Rhogas sp. attached in a mass to twigs of an apple-tree.

1003. Riley, C. V. Oak tree borer. <Prairie Farmer, 28 March, 1868, [v. 37], n. s., v. 21, p. 201 . S.-b. No. 2, p. 121; No. 3, p. 59 .

Answer to inquiries of E. G. Mygatt; habits and food-plants of Xylentes $[=$ Cossus $]$ robinia ; means against it.

1004. Riley, C. V. Maple-bark lice. < Prairie Farmer, $2 S$ March, 1868, [v. 37], n. s., v. 21, p. 201 . S.b. No. 2, p. 121 ; No. 3, p. 59.

Lecanium sp. found on twigs of sugar-maple.

1005. Riley, C. V. Eggs of the katydid. < Prairie Farmer, 28 March, 1868, [v. 37], n. s., v. 21, p. 201 . S.-b. No. 2, p. 121; No. 3, p. 59 .

Answer to inquiry of W. Colwell; habits and food-plants of Platyphyllum $[=$ Cyrtophyllus $]$ concavus.

1006. Riley, C. V. Eggs of tree-cricket in raspberry canes. <Prairie Farmer, 28 March, 1868, [v. 37], n. s., v. 21, p. 201. S.-b. No.2, p. $121 ;$ No. 3, p. 59 .

Letter from E. T. Nelson, with answer; oviposition of Ecanthus niveus in raspberry canes; means against this insect.

1007. Riley, C. V. Bark-lice. <Prairie Farmer, 28 March, 1868, [v. 37], n. s., v. 21, p. 201 . S.-b. No. 2, p. 121; No.3, p. 59.

Answer to inquiry of C. D. Robinson; means against Mytilaspis pomicorticis [=pomorum $]$.

1008. RLLey, C. V. Bark-lice again; the native species. <Prairie Farmer, 28 March, 1868, [r. 37], n.'s., v. 21, p. 201. S.-b. No.2, p. $121 ;$ No. 3, p. 59.

Letter from N. Coloman, with answer; comparative characters of Mytilaspis pomicorticis [= pomorum $]^{\prime}$ and Diaspis harrisii [=Chionaspis furfurus $]$; food-plants of the latter.

1009. Riley, C. V. Dahlia-stalk borer. <Prairie Farmer, 28 March, 1868, [v. 37], n. s., v. 21, p. 201 . S.-b. No. 2, p. 121; No. 3, p. 59. Answer to inquiry of S. M. Wierman; means against Gortyna nitela.

1010. Rilex, C. V. Apple.worm. <Prairie Farmer, 28 March, 1868, [v. 37], n. s., v. 21, p. 201. S.-b. No. 2, p. 121; No. 3, p. 59.

Answer to communication of S. J. C.; Carpocapsa pomonella hibernates as a larva within the cocoon. 
1011. Riley, C. V. False caterpillars on the Scotch and Austrian pines. <Prairie Farmer, 2 May, 1868, [v. 37], n. s., 21, p. 285, fig.

Description and figures of larva, cocoou and imago, and of male antenna of Lophyrus lecontei; food-plants and habits of larva; value of technical science.

1012. Riley, C. V. Prevention of bark-lice. <Prairie Farmer, 9 May, 1868, [v. 37], n. s., v. 21, p. 301 . S.-b. No. 3, p. 60.

Means against Mytilaspis pomicorticis $[=$ pomorum $]$ and Phycita nebulo $[=$ Acrobasis indiginella]; figure of the latter.

1013. Riley, O. V. Beetles in stomach of meadow-lark. <Prairie Farmer, 9 May, 1868, [v. 37], n. s., v. 21, p. 301. S.b. No. 3, p. 60 .

Fragments of Nottiglossa [= Oncometopia] undala and of Platynus excavatus or $P$. aruginosus found in the stomach of Slurnella magna.

1014. Riley, C. V. Beetle on sugar-maple. <Prairie Farmer, 9 May, 1868, [v. 37], n. s., v. 21, p. 301 . S.-b. No. 3, p. 60.

Eburia quadrigeminata found under bark of a felled sugar-maple, also on honey-locust.

1015. Rilex, C. V. White worms in wells. <Prairie Farmer, 9 May, 1868, [v. 37], n. s., v. 21, p. 301. S.b. No. 3, p. 60.

Fish or frogs placed in wells will free them from worms.

1016. Riley, C. V. Tanzy for borers. <Prairie Farmer, 9 May, 1868, [v. 37], n. s., v. 21, p. 301. S.-b. No. 3, p. 60.

Means against borers in apple- and poach-trees.

1017. Riley, C. V. Peach-borer. < Prairie Farmer, 9 May, 1868, [v. 37 , n. s., v. 21, p. 301. S..b. No. 3, p. 60.

Refers to articles ou means against Egeria $[=$ Samnina $]$ exitiosa.

1018. RILEx, C. V. Black grape-vine caterpillars. < Prairie Farmer, 9 May, 1868, [v. 37], n. s., v. 21, p. 301 . S.·b. No. 3, p. 60.

Descriptions of larva and imago of Thyreus abbotii; the abundance of parasites prevents serious injury by the larva.

1019. Riley, C. V. The potato-beetle. <Cultivator and Country Gentleman, 21 May, 1868, v. 31, p. 378.

Criticism of article ou the "Colorado potato-bug" (Cultivator and Country Gentleman, $₹ 3$ April, 1868, p. 309); use of hellebore against Doryphora 10lineata.

1020. Riley, C. V. The May-beetle; white grub. <Journ. of Agric., 1868, 4 figs. S.-b. No. 3, p. 10.

Habits, food-plants, enemies, and means against Lachnosterna quercina [=fusca]; figures the larva, pupa, and imago of the same.

1021. Riley, C. V. Canker-worm. <Colman's Rural World, 1868. S.-b. No. 3, p. 16.

Habits of and means against Anisopteryx $[=$ Paleacrita $]$ vornata.

1022. Riley, C. V. The apple.worm or codling-moth. <Colman's Kural World, 186s, fig. S.b. No. 3, p. 16.

Seasous of and meaus against Carpocapsa pomonella; figures all stages except egg.

8 ENT 
1023. RILey, C. V. Remedy for the apple-borer. <Colman's Rural World, 1868. S.-b. No. 3, p. 16.

Means against Saperda bivittata $[=$ candida $]$.

1024. Riley, C. V. Grape-vine hoppers. <Colman's Rural World, 1868. S. b. No. 3, p. 16.

Tettigonia coagulata injurious to leaves of grape-vines.

1025. Riley, C. V. Thousand-legged worm. <Colman's Rural World, 1868. S.:-b. No. 3, p. 16.

Habits of Julus [ = Spirobolus] marginatus.

1026. RILEx, C. V. Honey-locust seed-weevil. <Prairie Farmer, 20 June, 1868, [v. 37], n. s., v. 21, p. 397. S.-b. No. 3, p. 59.

Habits, description of, and means against Spermophagus robinice.

1027. Ruley, C. V. Potato-beetle. <Prairie Farmer, 20 June, 1868, [v. 37], n. s., v. 21, p. 397. S.-b. No. 3, p. 59.

Natural history of and means against Doryphora 10-lineata.

1028. Rrley, C. V. Large moth on apple.tree. <Prairie Farmer, 27 June, 1868, [v. 37], n. s., v. 21, p. 410 . S.-b. No. 3, p. 60.

The larva of Attacus cecropia spins its eoeoon on apple and other trees.

1029. Riley, C. V. Will unimpregnated eggs hatch? <Prairie Farmer, 27 June, 1868, [v. 37], n. s., v. 21, p. 410. S.-b. No. 3, p. 60 .

Remarks upon the statement by H. D., of Champaign, Ill, eoneerning the batehing of unimpregnated eggs of Attacus cecropia; mentions the families and genera of insects in which parthenogenesis occurs.

1030. [RILEY, U. V.] Wire-worms: Experiments in killing. , <Prairie Farmer, 27 June, 1868, [v. 37], n. s., v. 21, p.410. S.-b. No. 3, p. 60.

Effect of several liquid preparations upon the larve of Elateridce immersed in them; eorn soaked in turpentine grew unmolested by wire-worms.

1031. [RILex, C. V.] [Pear-slug and currant-worm.] <Prairie Farmer, 27 June, 1868, [v. 37], n. s., v. 21, p. 410 . S.-b., No. 3, p. 60.

Means against Selandria [ Eriocampa] ccrasi and Nematus ventricosus [=ribesii].

1032. RILEx, C. V. What becomes of bumble-bees? <Cultivator and Country Gentleman, 2 July, 1868, v. 32, p. 18.

Answer to Anna's "Bumble-bees;" only the queens of Bombus survive the winter; new colonies formed by hibernated queens.

1033. Riley, C. V. Large gray straight-horned snout-bectle. <Prairie Farmer, 4 July, 1868, [v. 38], n. s., v. 22, p. 2-3, figs. S.b. No. 3, pp. 31, 56 .

Descriptions and figures of larva and imago of Ithycerus noveboracensis; method of oviposition; injuries to apple, oak, and other trees.

1034. Riley, C. V. The seventeen-year Cicada. <Prairie Farmer, 4 July, 1868, [v. 38], n. s., v. 22, p. 2. S.-b. No. 3, pp. 31, 56.

Dates and localities of occurrences of Cicada [ = Tibicen $]$ septendecim; oceurrence of $C .[=T$.$] tredccim in Missouri.$ 
1035. Riley, (C. V. Raspberry eanes dying. <Prairie Farmer, 11 July, 1868 , [v. 38], n. s., r. 22, p. 10, 1 fig. S.-b. No. 3, pp. 31, 56.

Answer to inquiry of J. A. Jackson; death of raspberry canes discussed; in this case not the result of injury by insects.

1036. Riley, C. V. Bag-worms. <Prairie Farmer, $11 \mathrm{July,} \mathrm{1868,}$ [v. 38], n. s., v. 22 , p. 10 . S.-b. No. 3, pp. $31,56$.

Lutter from B. B. Warfield, with answer; habits, food-plants, and means against Thyridopteryx ephenercformis; description of the female.

1037. Riley, C. V. Oak and rose galls. <Prairie Farmer, 11 July, 1868, [v. 38], n. s., v. 22, p. 10 . S.·b. No. 3, pp. 31, 32, 56.

Answer to inquiry of F.H. G.; ciescriptions of galls and imagos of Cynips [= Phodites] bicolor on rose and of Cynips [= Andricus] seminator on white oak; occurrence of Cicada [= Tibiccn] septendecim in Michigan.

1038. Riley, C. V. Apple-borer and root A phis. <Prairie Farmer, 11 July, 1868, [v. 38], n, s., v. 22, p. 10 . S.-b. No. 3, pp. 32, 56.

Answer to inquiry of W. (olwcll; ravages of Saperda bivittata [=candida] and of Schizoneura lanigera.

1039. Riley, C. V. Evergreen plant-lice. <Prairie Farmer, 11 July, 1868 , [v. 38], n. s., v. 22, p. 10 . S.-b. No. 3, pp. 32, 56.

Answer to inquiry of J. Cochrane; balsam-fir injurea by Lachnus strobi?; means against it.

1040. Rlley, C. V. Bark-lice again. < Prairie Farmer, 18 July, 1868, [r. 38], n. s., v. 22 , p. 18, 2 figs. S.-b. No. 3, pp. 34, 54.

Answer to inquiries of J. Holgeson, S. D., J. Sutherland, and J. H. G. ; descriptions and figures of the scales of Mytilaspis pomicorticis [= pomorum] and Diaspis harrisii [ = Chionaspis furfurus ].

1041. Rrley, C. V. Larvæ of grape-vine flea-beetle. <Prairie Farmer, 18 July, 1868, [v. 38], n. s., v. 22, p. 18 . S.-b. No. 3, pp. 34,54 . Answer to inquiry of J. A. Pettingil; leaves of grape-vine eaten by larva of Haltica chalybea; description of larva; habits and means against it.

1042. [Riley, C. V.] A corn Curculio <Prairie Farmer, 25 July, 1868, [v. 3S], n. s., v. 22, p. 26 . S.-b. No. 3, p. 33.

Communication from L. V. Smith, with answer; seasons and ravages of Sphenophorus sculptilis.

1043. Rilex, C. V. Ephemera flies; a hard story. < Prairie Farmer, 15 August, 1868, [v. 38], u. s., v. 22, p. 50. S.-b. No. 3, pp. $36,57$.

Extract from Peoria (Ill.) Transcript, with letter of J. Cochrane, of Havana, Ill. ; notes on the above; appcarance of swarms of Palingenia $[=$ Hexagcnia] bilineata in Illinois and of other may-tlies in Europe; life-history of Ephemeride.

1044. Rilex, C. V. Driving potato-beetles. <Prairie Farmer, 15 August, 1868, [v. 38], n. s., v. 22, p. 50. S.-b. No.3, pp. 36.

Doryphora 10-lineata can not be driven; Macrobasis unicolor can ; care should be taken in sending the fornier through the mail, so as 11 t to increase its distribution.

1045. Riley, C. V. Gregarious walnut caterpillar. < Prairie Farmer, 15 August, 1868, [v. 38], n. s., v. 22, p. 50. S.-b. No. 3, pp. 36, 57. Answer to inquiry of "a subscriber;" leaves of walnut destroyed by larvæ of Datana ministra; habits and means against the same. 
1046. Riley, C. V. Bugs on grape-vines. <Prairie Farmer, 15 August, 1868 , [v. 38], n. s., v. 22, p. 50. S.-b. No. 3, p. 36.

Letter from J. H. Bingham, with answer; new growth of stems and leaves of grape-vines injured by Corimelena pulicaria ; means against it.

1047. Riley, C. V. Corn-worms. <Prairie Farmer, 15 August, 1868, [r. 38], u. s., r. 22, p. 50. S.-b. No. 3, p. 36.

Letter from E. Daggy, with answer; injury to maize by an undeseribed species of Hadena?.

1048. Riley, C. V. Large worm on apple-tree. <Prairie Farmer, 15 August, 1868, [v. 38], n. s., v. 22, p. 50. S.-b. No. 3, p. 36.

Answer to inquiry of J. M. Devore; description of Papilio turnus, $\&$, form glaucus, whieh pupated on trunk of apple-tree.

1049. Riley, C. V. White-pine trees killed by borers. <Prairie Farmer, 26 September, 1S68. [v. 38], n. s., v. 22, p. 98.

1050. Riley, C. V. Swarms of butterflies. <Prairie Farmer, 26 September, 1868, [v. 38], n. s., v. 22, p. 98.

1051. Riley, C. V. Worms feeding on the hawthorn. <Prairie Farmer, 26 September, 1868, [v. 38], n. s., v. 22, p. 98.

1052. Riley, C. V. Twig borers, sack-bearers, etc. < Prairie Farmer. 19 December, 1868, [r. 38], n. s., v. 22, p. 194.

1053. Riley, C. V. Oil beetles. <Prairie Farmer, 19 December, 1868, [r. 38], n. s., v. 22, p. 194.

1054. Riley, C. V. Apple-tree caterpillars. <Prairie Farmer, 19 December, 1868, [v. 38], n. s., v. 22, p. 194.

1055. Riley, C. V. Twigs punctured by periodical Cicada. <Prairie Farmer, 19 December, 1868, [r. 38], n. s., v. 22, p. 194.

1056. Riley, O. V. Report of committee on entomology. <Trans. Ill. Hortic. Soc. for 1867, 1868, n. s., v. 1, pp. 105-107, figs. 1-8.

Critieism of previous reports; effeet of cold on Aphis mali; distribution, food-plants, and means against Doryphora 10-lineata; distiuctions between D. 10-7incata and D. juncta; ravages of Lytta [=Epicauta $]$ vittata, $L$. $[=E$. $]$ cinerea, and $L$. atrata $[=E$. pennsylvanica $]$ on potato, and $L .[==P o m-$ phopoa] cenca on fruit-trees; means against them; ravages of Haltica [=Crepidodor $]$ cucumeris on potato; habits, ravages, and speeific characters of Cassidida found on sweet potato; Saperda bivillata [= candidu $]$ bieunial; history and development of Mytilaspis pemicorticis [=pomorum]; its food-plants, supposed hermaphroditism [parthenogenesis] and mode of produetion of scale of this speeies; difficulty of explaining the production of galls; habits, characters, food-plants, and ravages of Conotrachelus nenuphar, Carpocapsa pomonclla, Heliothis armigera, Gortyna nitela; Manestra picta, Procris $[=$ Harrisina $]$ amcricana, Selandria vitis $[=$ Blennocampa pygmaa], Darapsa [= Ampelophaga myron, and Desmia maculalis; notes on other insects injurions to grape, apple, and wheat, and on Mycetophila persica, Emphytus [=Harpiphorus] maculatus, Agrotis [= Hadena] devastatrix, and Hadena juncta; note on reeent writings by the author. 
1057. Riley, C. V. Entomology. <Prairie Farmer Annual [No. 2 for 1869 ], 1868, pp. 30-41, 6 figs. S.-b. No. 14, pp. 220-226.

Directions for collecting and preserving insects; descriptions of apparatus and cabincts; means against cabinet pests; descriptious and figures of all stages, except egg, of Lophyrus abbotii and L. Tecontei; habits and foodplauts of and means against both specics; figures of eggs, pupæ, and imago of Cicada [=Tibicen] septendecin aud of twig punctured by imago; dates and localities of occurrence of this species and of $C .[=T$.$] tredecim; C$. $[=T$. $]$ cassinii a form of this insect; figures larva, puparium, aud imago of Cephalemyia $[=$ Estrus $]$ onis; habits and ravages of and means against it; imago viviparous in the nostrils of sheep.

1058. Riley, C. V. The American Meromyza, Meromyza americana, Fitch. Attacking wheat just before it ripens. <Moore's Rural New Yorker, 30 Januarv, 1869, v. 20, p. 71, fig. S.-b. No. 3, p. 83.

Habits and ravages of Meromyza americana; figures larva, pupa, and injured stalk of wheat; related Europeau species have similar habits; remedies and natural enemies.

1059. RILEY, C. V. First annual report on the noxious, beneficial, and other insects of the State of Missouri, made to the State Board of Agriculture, pursuant to an appropriation for this purpose from the legislature of the State. <4th Ann. Rept. State Board of Agric. for 1868, March, 1869, pp. 182-187, 98 figs. Separate: <Jefferson City, Mo., March, 1869, pp. $182-$ 187, 2 pl., 98 figs. Notice: <Amer. Ent., April, 1869, v. 1, p. 165.

CONTENTS.

Page.

INTRODUCTORY

\section{NOXIOUS INSECTS.}

THE BARK-LICE OF THF APPLE-TREE

Two species kuown to occur in the United States, 7-Harris's barklouse not numerous cnough to do material damage, 7 .

The oyster-shell bark-louse, Mytilaspis pomorum................

Difference in the scales of the two species, 7-Introduction of the oyster-shell bark-louse from Europe and its spread iu the United States, 8-Precautionary mcasures to prevent its iutroduction into Missouri, 8-Its habits studied by different observers in 1867,9 -Seasonal uotes on the development of the insect, 10Only one annual brood in Missouri, 12-Formation and nature of the scale, 12-Rare occurrence of males, 14-Difference of opinion amoug observers as to the mode of growth of the scale, 14-Diffculty of explaining the spread of the insect from one tree to another, 15-Its occurrence upon other kinds of trees, 15-Natural enemies, 16-Artificial remedies, 16-Examination of young trees before planting, 16-Washing with alkalics, etc., 17-Scrubbiug the branches with a stiff brush, 17-Fumigating, 17-Application of sheep-manure, 17-Washes in general ineffective, 17The insect can most successfully be fought during three or four daýs of the year only, 18. 
1059. Riley, O. V.-Continued.

The Periodical Cicada, Tibiccn septendecim ....................

Its singular life history, 18-Seventeen and thirteen year races, 19-The two races not distinct species, 19-Two distinct forms occurring in both broods, 20-Season of their appearance and disappearance, 22-Natural history and transformations, 22Elevated chambers of the pupa, 22-The larvæ frequently occurring at great depth in the ground, 24-The operation of emerging from the pupa, 24-Only the males are capable of singing, 24Trees in which the females deposit their eggs, 24-Mode of oviposition, 24-The newly hatched larva, 25-The $W$ on the wings of the Cicada, 25-Enemics, 26-Fungus infesting the imago, 26-The sting of the Cicada, 26-Wide-spread fear of the insect on account of its supposed stinging powers, 26-Explanations of the sting, 27-Injury caused by the insect, 29-by the larva, 29by the imago, 29-Fruitless attempts to stop the injury, 30-Chronological table of all well-ascertained broods in the United States, $30-$ The insect will appear during the ncxt 17 years somewhere in the United States every year except in 1873, 41-Number of broods that will appear in the next 17 years in the different States, 42 .

APPLE-TREE BORERS . . . . . . . . . . . . . . . . . . . . . . . . . . . . . .

The round-headed apple-tree borer, Saperda candida.............

It is more numerous in trees on high land than on low ground, -42-Extent of its injury, 43-Its larva, 43-Appearance of the imago, 43-The hole nıade by the young larva, 44-It remains nearly three jears in the larva statc, 44-Its pupa state, 44Remedies, 45-Alkaline washes, 45-Killing the larva by hot water, 45-Cutting out the larva, 46.

The flat-headed apple-tree borer, Chrysobothris femorata............

Differences between it and the foregoing species, $46-$ Habits of the bcetle, $4 \overline{7}$-Amount of injury caused by it, 47-Parasite attacking it, 47-Remedies, 47.

The PEach Borer, Sannina exitiosa ...........................

Its nature, 47-Differences in the sexes, 48-Remedies, 48-The mounding system the best remedy, 48-Testimony as to the value of the mounding system, 48-Other remedies, 49 .

The Plum Curculio, Conotrachelus nenuphar ....................

Difference of opinion among authors on some points in its natural history $y$, 50-Reasons for this difference of opinion, 51-Facts in its natural history, 52-It causes the spread of the peach-rot, 52Fruit trees attacked and those not attacked by it, 53-It may hibernate as larva or pupa, but does generally as imago, 53Mode of egg-laying, 54-It has one annual brood, 55-Walsh's experiments to show that it is two-brooded, 55-Natural remedies, 56-No parasites known to infest it, 56-Enemics, 57; The Pennsylvania soldier-beetle and its larva, 57; Lacewing-larva, 57; The subangular ground-beetle, 58; Ground-beetle larva, probably of the Pennsylvania ground-beetle, 59-Hogs as Curculio destroyers, 59-Artificial remedies, 60-Jarring the trees the most effectual method, 50-Dr. Hull's Curculio catcher, 60Lessons for the fruit-grower from the account of the Curculio, 62. 


\section{Riley, C. V.-Continued.}

THE CODLING MOTH OR APPLE WORM, Carpocapsa pomonella..........

It is common whererer apples are grown, 62-Description of the insect in its different states, 63-Its life-history, 63-Other fruits attacked by it, 64-Remedies, 65-Picking up the fallen fruit. 65-Entrapping the worms the best remedy, 66-Trimble's hay band system and how to apply it, 66-Attracting the moth by fires, 67.

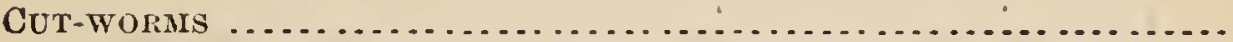

The natural history of twelve distinct species, 67-Defnition of the term "cut-worm," 67-Habits of cut-worms, 67-Their natural history briefly given, 68-Difficulty of breeding them in captivity, 69-Climbing cut-worms, 69-Injury done by them to orchards, 69-Fruit trees and shrubs they attack, 70-They attack large trecs, 71.

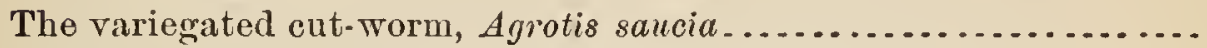

The full-grown larva, 72-The eggs, 72-Habits of the larva, 72Cut-worm moths deposit their eggs on the leaves and not on the ground, 73-The inago, 73-Description of the insect as larva, pupa, and imago, 74 .

The dark-sided cut-rorm, Agrotis messoria.....................

General characters of the larva, 74-Habits of, and injury done by it, 75-Description of imago, 75; of the larva and chrysalis, 76.

The climbing cut-worm, Agrotis scandens ......................

Injury done by the larva, 77-General charasters of the larva, 77, of the moth, 78-Description of the larva, 78; of the imago, 78.

The w-marked cut-wornı, Agrotis clandestina ...................

Gencral characters of the larva, 79-Plants it attacks, 79-Characters of the moth, 79-Description of the larva and chrysalis, 79.

The greasy eut-worm, Agrotis ypsilon .......................

The larva very variable in coloration, 80-Its injury to tomato and tobacco plants, 80-Gencral characters of the moth, 80-Description of larva, chrysalis, and imago, 81.

The western striped cut-worm, dgrotis herilis ...................

Resemblance of its larva to that of the corn rustic, 81-General characters of the worm and moth, 82-Description of the larva, $8 \%$.

The dingy cut-worm, Agrotis subgothica .......................

Difference between it and the foregroing species, 82-General characters of pupa and imago, 82-At least three species of onr cutworms are difficult to distinguish, 83-Description of larva, chrysalis, and imago, 83.

The glassy cut-worm, Hadena devastatrix ......................

Habits and general characteristics of the larva, 83-Characteristics of the moth, 84-Description of larva and chrysalis, 84 .

The speckled cut-worm, Hadena subjuneta ......................

Characteristics and habits of the insect, 84-Description of larva, chrysalis, and imago, 85.

The small white bristly cut-worm, Hadena renigera................

Habits of the worm, 86-Characteristics of the moth, 86-Description of larva, chrysalis, and imago, 86 .

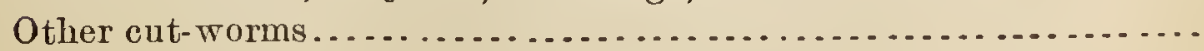

Fitch's account of the corn cut-worm and the yellow-headed cutworm, 87.

The wheat cut-worm ...................................

Injury caused by it, 87-Description of the larva, 88 . 


\section{RILEY, C. V.-Continued.}

Cut-worms-Continued.

Remedies against cut- worms

Natural enemies, 89; Microgaster militaris, 89; Paniscus geminatus, 89; The spined soldier-bug, 89 ; 'The cut-worm lion, 89-Other euemies, 90-Artificial remedies for climbing cut-worms, 90 ; for common field cut-worms, 91.

INSECTS INFESTING THE POTATO .............................

General remarks, 91-Number of species affecting the potato, 92.

The stalk-borer, Gortyna nitela ............................

Habits of the larva aud imago, 92-Remedy, 93.

The potato stalk-weevil, Trichobaris trinotata .................

Its geographical distribution, 93-Its habits, 93-Remedy, 95.

The potato- or tomato-worm, Protoparce celeus.................

It can not stiug with its horn, 95-Its chrysalis, 95-How the imago differs from the tobacco-worm moth, 95-Remedies and parasites, 96 .

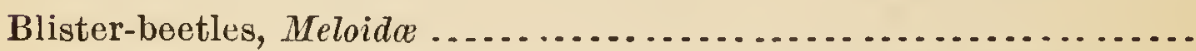

The striped blister-beetle, 96-The ash-gray blister-bectle, 97The black-rat blister-beetle, 98-The black blister-beetle, 98The margiued blister-beetle, 98-Synonymical remarks, 98Remedies for blister-beetles, 99.

The three-lined leaf-beetle, Lema trilineata....................

Merdigerous liabit of the larva, 99-It has two annual broods, 100-Other notes on the habits of the insect, 100 .

The cucumber flea-beetle, Crepidodera cucumeris ..................

The Colorado potato-beetle, Doryphora 10-lineata................

Its past history and future progress, 101-Its native home, 101-Its gradual spread eastward, 102-Its confusiou with the bogus Colorado potato-beetle, 103-How the two species differ in habits, 104 ; in their larval states, 104 ; in the egg state, 105-1)escription of the larva of Doryphora juncta, 106-Differences in the imagos of the two species, 106-Habits of the Colorado potatobeetle, 107-When it appears aud disappears, 107-Number of eggs laid by each female, -107-Food-plants, 107-Singular fact that $D$. juncta has not acquired the habit of attacking the potato, 108-Natural remedies, 109-Complicated economy of nature, 109-Decrease in the number of potato-beetles ou account of increase in the number of parasites, 109-The Colorado potato-beetle parasite, 111-Its general character and habits, 111-Description of Lydella doryphora, 111-Lady-birds and their larvæ, 112-The spined soldier-bug, 113-The common squash-bug, erroneously considered an enemy of the potato-beetle, 113-The bordered soldier-bug, 114-The many banded robber, 114-The rapacious soldier-bug, 114-The Virginia tiger-beetle, 115-The fiery grouna-beetle, 115-Blister-beetles, 115-The larvæ not touched by fowl, 115-Artificial remedies, 116-Ineffectiveness of mixtures tried, 116-Killing the beetle early in spring, 116Pincers for crushiug the iusect, 116-Benson's machine, 116Proper choice of varieties of potatoes, 117-The pest will overrun the Eastern States, 117-Carelessness in transmitting specimens of the beetle, 117 . 
1059. Riley, C. V.-Continued.

ThE APPLE-ROOT PLANT-LoUse, Schizoneura lanigera ...............

Three distinct kinds of rots affecting the roots of apple-trees, 118-The root-louse the cause of one of these rots, 118-The canse of the other rots still hidden, 119-The root-louse especially injurious in southerly latitudes, 119-It occurs also on other parts of the tree besides the root, 120-Description of the winged lonsc, 120-Fitch's description of the winged form refers to another species, 120 - The root-louse belongs to the genns Eriosoma, 121-Natural enemies, 121 ; Chalcis-fly, 121 ; the root-louse Syrphus-fly, 121; Scymuns cervicalis, 122-Artificial remedies, 123.

THE WOOLLY ELMr.TREe Louse, Schizoneura rileyi .................

Its general appearauce and habits, 123-Description of the winged form, 124 .

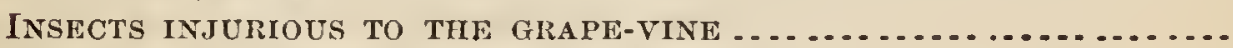

'The new grape-root borer, Prionus laticollis ......................

Reports on the damage cansed by it, 124-Description of the larva, 126-It belongs probably to the cylindrical Orthosoma, 126Former accounts of the natural history of this beetle, 127-Its injury known for several years, 127-Remedies, 128.

The grape curculio, Craponius incqualis .....................

Nature of the damage done by it, 128-Its larva, 12ß-The perfect bcetle, 129-No injury done by it in 1868, 129.

The grape-seed Curculio, Isosoma vitis.........................

General appearance of the maggot, 1:9-Mr. Saunders' acconnt of the damage done by it, 130 .

The grape-cane gall Curculio, Ampeloglypter sesostris..............

The gall caused by it, 131-The larva, 131-Its transformation, 131-Description of the beetle, 132-Differences between it and a closely allied species, 132 - The gall cansed by the punctures of the female beetle, 132-Remedy, 132.

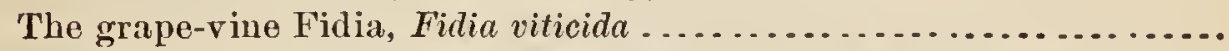

It is very injurious in Missouri, 132-Habits of the bcetle, 132Remedies, 1333.

The grape fruit-worm, Eudenis botrana .......................

Amount and extcnt of the injury caused by it, 133-Characteristics of the larva, 134-Transformations, 134-Description of larva, chrysalis, and imago, 135-Remedies, 135.

The eight.spotted forester, Alypia 8-maculata ..................

Characteristics of the larva, 136-It is not numerous enough to cause serious injury, 136-Other caterpillars resembling it, 136.

The grape-vine plume, Oxyptilus periscelidactylus ................

Work of the larva, 13\%-Its habits and characteristics, 137-The moth, 137-Remedy, 138.

The snowy tree-cricket, Ecanthus niveus ........................

Characteristics of the insects, 138-It is injurious, 138-Nature of the injury caused by it, 138-Remedy, 139.

The RASPBERRY GEOMETER, Synchlora rubivoraria.................

Habits of the larva, 139-Parasite attacking it, 139-Characteristics of the moth, 139-Description of the larva, 139; of the imago, 140.

THE GOOSEbERrY FRUIT-WORM, Dakvuma convolutella ..............

Accounts of the injury cansed by it, 140-Habits of the worm, 140The moth, 141-Remedies, 141-Description of larva, chrysalis, and imago, 141. 


\section{Riley, C. V.-Continued.}

THE STRAWBERT LEAF-ROLLER, Phoxopteris fragaria ...........

Extent and nature of the damage caused by it, $142-$ Habits of the insect, 142-Áccounts of its injury in Indiana and Illinois, 142Remedy, 143-Description of the imago and larva, 143.

ThE White-MARKED TUssock-Hoth, Orgyia leucostigma ............

The cgg-mass, 144-The larva and larval changes, 144-The fullgrown larva, 145-Habits of the larva, 145-Mode of casting off the larval skin, 145-The cocoon, 146-The imago, 146-Two anunal broods, 146-Food-plants, 146-Remedies, 147.

THE BAG-WORM, alias BASKET-WORM, alias DROP-WORM, Thyridopteryx ephemariformis .....................................

Its geographical distribution, 148-Injury caused by it, 148-The egg, 148- The larva and its growtb, 148-Habits of the larva, 149-The chrysalis, 149-The sex distinguishable in the chrysalis state, 149-The imago, 149-Food-plants, 150-Parasites, 150; Cryptus inquisitor, 150; Hemitcles thyridopterygis, n. sp., 150Remelies, 151.

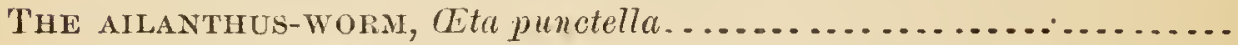

Injury done to the Ailanthus tree, 151-Habits of the larva, 151The chrysalis, 151-The imago, 15:-Geographical distribution, 152-Remedy, 152-Description of larva and chrysalis, 152; of the imago, 153.

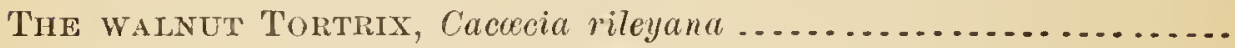

Habits of the larva, 153-General appearance of the moth, 153Phytophagic form of the insect on snowberry, 153-Description of larva, chrysalis, and imago, 154; of the varioty symphoricarpi, 154.

THE SEED-CORN MAGGOT, Anthomyia zens .....................

Accounts of damage caused by it, 154-The maggot, 155-Transformation, 155-Description of the imago, 155-Remedy, 15jHabits of Anthomyia larve, 156.

The WHITE GRUB, Lachnosterna fusca .......................

Account of the damage caused by it, 156-Injury done by the perfect insect, 157-Résumé of its life-histnry, 107-Remedies, 157Regularity in the appearance of the beetle, 158 - Accounts of the fungus infesting tho white grub, 158.

The AMERICAN MERomyzA, Meromyza americana..................

Nature of the damage caused by it, 159-Characteristics of larva, chrysalis, and imago, 160-European Diptera with similar habits, 160-Remedics, 161.

THE SHEEP BOT-FLY or HEAD-MAGGOT, CEstrus ovis...............

The insect in its different states, 161-Its larva, 162-Pupa, 162Characteristics of the imago, $162-$ Fatal results of the presence of the maggot in the hear of the sheep, 163-Rabbits attacked by gad-fly, 164-Testimony regarding the viviparous lrabits of the bot-fly, 164-Remedics, 165.

INSECT ENEHIES OF THE HONEY-BEE......................

The bec-moth or wax-worm, Galleria cereana .................

General appearance of the moth, 166-There arc no moth-proof bce-hives, 166-Habits of the worm, 167-How its presence in the hive may be recognizck, 167-Prevention and remedy, $16 \%$.

* Reprint: <Cultivator and Country Gentlemau, 14 May, 187», v. 39, pp. 310-311, 
1059. Riley, C. V.-Dontinued.

INSECT ENEMIES OF THE HONEY-BFE-Continued.

The bee-killer, Promachus apivorus......................... 168

It is an Asilid fly, 168-Mr. Thompson's account of the fly, 168-

How it captures and kills bees, 168-No remedy known, 168.

BENEFICIAL INSECTS.

THE REAR-HORSE, alias CAMEL-CRICKET, alias DEVIL'S RIDING-HORSE, Phasmomantis carolina..................................

Its food, 169- How it grasps its prey, 169-Difference in the sexes, 170-The larva, 170-The egg-mass, 170-The mode of egg-laying, 170-Voracious disposition of the Mantis, 171-Its beneficial influence, 171-Trachina parasite of the Mantis, 171.

\section{INXOXIOUS INSECTS.}

The Solidago gall-Moth, Gelechia gallresolidaginis ................

Gall caused by Trypeta solidaginis, 173-Gall produced by the Solidago gall-moth, 173-- Its natural history, 173-Provision of the larva for its protection within the gall, 174-Previous account of the gall, 174-Gall cansed by Cochylis hilarana on Artemisia campestris, 175-Description of the Solidago gall-moth as larva, chrysalis, and imago, 175-Parasites attacking it, 175; the inflating chalcis, 176; Eurytoma bolteri, 11. sp., 176; Hemitcles (?) cressonii, 1. sp., 177; Microgaster gelechice, 11. sp., 177; other parasites, 178-Oberea larvio intruding in the gall, 178.

THE CHICKWEed [= KNoTWEed] Geometer, Hrematopis grataria....

Its uatural history, 179-Description of larva and chrysalis, 179.

The thistle Plune, Platyptilns cardnidactylns ..................

Work of its larva on thistle-heads. 180-Description of the larva, chrysalis, and imago, 180.

1060. RuLEx, C. V. Eggs of the Mantis or rear-horse <Moore's Rural New Yorker, 10 April, 1869, v. 20, p. 234, 2 figs. S.-b. No. 3, p. 52.

Answer to inquiry of T. C. Bartle; description of Mantis [= Phasmomantis] carolina; its food, habits, oviposition, and parasites; figures its egg-masses and those of Phylloptera [Amblycorypha] oblongifolia.

1061. Riley, C. V. Native bark-lice ou apple-trees. <Prairie Farmer, 17 April, 1869, [v. 39], n. s., v. 23, p. 122, 1 fig. S.-b. No. 3, p. 57.

Answer to inquiry of T. B. Garduer ; life history of and means against Diaspis harrisii $[=$ Chionuspis furfurus $]$; figure of the same.

1062. Rilex, C. V. Curculio. <Prairie Farmer, 17 April, 1867, [v. 39], u. s., v. 23, p. 122 . S.-b. No. 3, 1. 57.

Answer to inquiry of James Weed; habits of and means against Conotrachelus nenuphar.

1063. Riley, C. V. Cherry-tree borers. <Prairie Farmer, 17 April, 1869, [v. 39], u. s., v. 23, 1. 122 . S.-b. No. 3, p. 57.

Answer to inquiry of Onargo Horticultural Society; larve of Buprestis [=Dircera $]$ divaricata and of Trochilium sp., injurious to cherry-trees; softmaple attackel by $T$. 「= Egeria $]$ acerni; means against these insects. 
1064. Riley, C. V. White-grub fungus. <Prairie Farmer, 15 May, 1869, [v. 39], n. s., v. 23, p. 154 . S.-b. No. 3, p. 76.

Letter froin $\mathrm{D}$. W. Tindall, with answer; ravages of Lachnosterna quercina $[=$ fusca $]$ in Clinton Connty, Mo., in 1868; Torrubia growing on the larvæ in 1869 .

1065. Riley, C. V. The canker-worm, Anisopteryx vernata Peck. <Moore's Rural New Yorker, 29 May, 1869, v. 20, p. 345, figs. S.-b. No. 3, p. 73.

Description, figures, and natural history of canker-worms; the two species are confounded.

1066. Riley, C. V. The seed.corn maggot, Anthomyia zeas, Riley. Destroying the seed after it is planted. <Moore's Rural New Yorker, Jurte, 1869, fig. S.-b. No.3, p. 81. Advance print, with changes: <1st Ann. Rept. State Ent. Mo., March, 1869, pp. 154-156, figs. 86-87.

See No. 1059 for synopsis of contents.

1067. Rilex, C. V. Cherry-tree plant-lice. <Moore's Rural New Yorker, 10 July, 1S69, v. 20, p. 443 . S.-b. No. 3, p. 83.

Answer to inquiry of G. J. Magee; means against Aphis [= Myzus $]$ cerasi.

1068. Riley, C. V. Gooseberry span-worms. <Moore's Rural New Yorker, $10 \mathrm{July}, 1869$, v. 20, p. 443 . 's.-b. No. 3, p. 83.

Letter from A. Yancey, with answer; occurrence of Euftchia ribearia in Iowa; habits and means against it; habits of and influence of weather on Blissus leucopterus; scarcity of Doryphora 10-lineata in Iowa.

1069. Riley, C. V. Apple-leaf crumpler mistaken for Curculio. <Prairie Farmer, $10 \mathrm{July,} \mathrm{1869,} \mathrm{[r.} \mathrm{40],} \mathrm{n.} \mathrm{s.,} \mathrm{v.} \mathrm{24,} \mathrm{p.} \mathrm{218,} \mathrm{fig.}$ S.-b. No. 3, p. 80.

Letter from B. T. 'Taylor; improper use of the word Curculio ; figures larvacase and imago of Phycita nebulo $[=$ Acrobasis intiginella $]$; means against it; outline figure of Conotrachelus nenuphar.

1070. Riley, C. V. Peach-tree borer. <Prairie Farmer, 10 July, 18ỏ9, [v. 40], n. s., v. 24, p. 218 . S.-b. No. 3, p. 80.

Answer to iuquiry of C. Allen; habits of and means against Ageria $[=$ San. vina] exitiosa.

1071. Riley, C. V. To protect plums from Curculio. Prairie Farmer, 10 July, 1869, [v. 40], n. s., v. 24, p. 218. S.-b. No. 3, p. 80.

Answer to inquiry of H. H. S.; recommends the collection of the imago of Conotrachelus nenuphar by jarring.

1072. RILEY, C. V. White-grub; information wanted. <Prairie Farmer, 28 August, 1869, [v. 40], n. s., v. 24, p. 274, 4 figs. S.-b. No. 3, p. 95 .

Letter from A.T.V., with answer; habits of and means against Lachnosterna quercina $[=f u s c a]$; figures of larva and imago.

1073. Riley, O. V. Unknown corn pest. <Prairie Farmer, 28 August, 1869 , [v. 40 ], n. s., v. 21, p. 274 . S.-b. No. 3, p. 95 .

Letter from E. B. Hickey, with answer; ravages of cut-worms and of an unknown pest on majze; brief description and habits of the latter. 
1074. Riley, O. V. Lairra of the grape-vine flea-beetle. <Moore's Rural New Yorker, 28 August, 1869, v. 20, p. 555. S.-b. No. 3 , pp. 100, 103.

Answer to inquiry of D. D. Vosburgh; habits, ravages, and means against Graptodera $[=$ Haltica $]$ chalybea.

1075. Riley, C. V. Rose bug. <Moore's Rural New Yorker, 28 August, 1869 , v. 20, p. 555. S.-b. No. 3, pp. 100, 103.

Answer to inquiry of a sulscriber; description of imago, transformations of, and means against Macrodactylus subspinosus.

1076. RILEY, C. V. Large green caterpillar on the apple. <Moore's Rural 'New Yorker, 28 August, 1869, v. 20, p. 555. S.-b. No. 3, p. 100 .

Answer to inquiry of S.E.A. Palmer; descriptions of larva and inago of Attacus cecropir; its habits and seasons.

1077. Riley, C. V. Conical galls on leaves of wild grape-vine. <Moore's Rural New Yorker, 28 August, 1869, v. 20, p. 555. S.-b. No. 3, p. 100.

Answer to inquiry of D. McClaine; description of galls of Cecidomyia vitisviticola; characters of the larvie of Cecidomyia.

1078. Riley, C. V. A strange bug. <Moore's Rural New Yorker, 28 August, 1869, v. 20, p. 555. S. b. No. 3, p. 100 ; No. 4, p. 3.

The insects described in North Carolina's "A strange bug," were probably Psocus venosus; habits of the genus P'rocus.

1079. Riley, C. V. Currant-worms and black-currants. <Moore's Rural New Yorker, 28 August, 1869, v. 20, p. 555. S.-b. No.3, p. 100 ; No. 4 , p. 3 .

Critical review of Addi on currant-worms; in North America three species of larva feed on the leaves of currants, and two species of borers live within the stem.

1080. Riley, C. V. Curculio. <Moore's Rural New Yorker, 28 August, 1869 , v. 20 , p. 555 . S.-b. No. 3 , p. 100 ; No. 4 , p. 3.

Commendation of an editorial criticism of Northwest's article on the Curculio.

1081. [RILEY, C. V.] Insects injurious, to the grape-vine. [No. 1.] <Amer. Ent., August, 1869, v. 1, pp. 231-234, figs. 169-173. Reprint, with slight changes: <2d Ann. Rept. State Ent. Mo., March, 1870, pp. 87-91, figs. 60-63.

Treats of Prionus laticollis and P. imbricornis. See No. 1127 for synopsis of contents.

1082. [RILEY, O. V.] Insects infesting the sweet-potato. <Amer. Ent., August, 1869, v. 1, pp. 234-238, figs. 174-181. Reprint, with slight changes: <2d Ann. Rept. State Ent. Mo., March, 1870, pp. 56-64, figs. $26-38$.

Treats of tortoise-beetles, Cassidida. See No. 1127 for synopsis of contents.

1083. Riley, C. V. The borers. <Western Rural, September, 1869.

S.-b. No. 4, p. 2.

Means against Ligeria cucurbita $[=$ Melittia ceto $]$. 
1084. Riley, .C. V. Supposed bark-lice eggs in Missouri. <Prairie Farmer, 4 September, 1869, [v. 40], n. s., v. 24, p. 282 . S.-b. No. 3, p. 95 .

Letter from J. Reed, with answer; eggs of a moth mistaken for those of Mytilaspis pomicorticis $[=$ pomorum $]$; the latter unknown in Missouri.

1085. Riley, C. V: New York weevil on apple-trees. <Prairie Farmer, 4 September, 1869, [v. 40], n. s., v. 24, p. 282, 3 figs. S..b. No.3, p. 95 .

Letter from R. M. Guy, with answer; figures of larva and imago, description of imago, geographical distribution, methods of oviposition, foor-plants, and means against Ithycerus noveboracensis.

1086. [RILfy, C.V.] Insects injurious to the grape-vine. No. 2. <Amer. Ent., September-October, 1869, v. 2, pp. 22-24, figs. 12-16. Reprint, with slight changes. <2d Ann. Rept. State Ent. Mo., March, 1870, pp. 71-73, figs. 44-48.

Treats of Charocampa pampinatrix [=Ampelophaga myron]; see No. 1127 for syuopsis of contents.

1087. Riley, C. V. Larva of the imperial moth. <Prairie Farmer, 9 October, 1869, [v. 40], n. s., v. 24, p. 322. S.-b. No. 3, p. 92.

Letter of C. H. Thayér, with answer; description of larva, pupa, and imago of Ceratocampa [=Eacles] imperialis; food-plauts of the same and of $C$. [=Citheronia] regalis.

1088. Riley, C. V. Apple snout-beetle or four-humped Curculio. <Prairie Farmer, 9 October, 1869, [v. 40], n. s., v. 24, p. 322. S.-b. No. 3, p. 92 .

-Letter from R. W. Gandy, with answer; habits and description of Anthonomus quadrigibbus; recommends jarring.

1089. Rilex, O. V. That venomous potato-worm! <Moore's Rural New Yorker, 20 November, 1869, v. 20, p. - . S.-b. No. 3, pp. $107 ; 112$.

Critical review of several recent articles upon tomato-worms; structure and harmlessness of larvæ of Sphingide; geographical distribution of Sphinx [ = Protoparce $]$ carolina and $S$. quinquemaculata $[=P$. celeus $]$.

1090. [RIley, C. V.] The bag-worm, alias basket-worm, alias dropworm, Thyridopteryx ephemerceformis, Haw. <Amer. Ent., November, 1869, v. 2, pp. 35-38, fig. 24.

Geographical distribntion, food-plants, seasons, transformations, parasites, copulation, and oviposition of and means against Thyridopteryx ephemeraformis; figures and descriptious of larva, larva-cases, pupa, and imago; description of eggs; abodes constructed by insects.

1091. [RILey, C.V.] Insects injurious to the grape-vine. No. 3. <Amer. Ent., November, 1869, v. 2, pp. 54-55, figs. 33-35. Reprint, with slight changes. <2d Ann. Rept. State Ent. Mo., March, 1870, pp. 74-76, figs. 49-51.

Treats of Philampelus achemon; see No. 1127 for synopsis of contents.

1092. Riley, C. V. The saddle-back caterpillar. <Moore's Rural New Yorker, 4 December, 1869,v. 20, p. -, fig. S.-b. No.3, p. 103.

Letters from A. W. Baker and G. T. Cost, with answer ; figures and characterization of the larva of Empretia stimulea; food-plants, urticating properties, and transformations; description of the imago. 
1093. Riley, C. V. The serenteen-year Cicada. <Prairie Farmer, 1869. S.-b. No. 3, p. 55.

Answer to communication of W.J.B., concerning Cicada [ = Tibicen] septendecim.

1094. Riley, C. V. Death of a hen. < Rural New Yorker, 1869 fig. S.-b. No. 3, p. 75 .

Occurrence of Goniocotes hologaster in great numbers on a hen ; means against the same; figure of it.

1095. Riley, C. V. Cut-worm eggs. <Prairịe Farmer, - 1869. S.-b. No. 3, p. 81 .

Habits and place of oviposition of Agrotis inermis [= saucia]; description of its eggs and larve.

1096. Riley, C. V. Potato bugs. <Prairie Farmer, - 1869. S.-b. No. 3, p. 81.

Means against Doryphora 10-lineata.

1097. Rilex, C.V. That glow-worm. <Cultivator andi Country Gentleman, 6 January, 1870, r. 35, p. 5, fig. S.-b. No. 4, p. 23. Reprint: <Amer. Ent., October, 18s0, v. 3, n. s., v. 1, p. 254, fig.

Figures larva and imago of Photuris pennsylvanica ; Photinus pyralis also luminous in larval and adult stages; comparison with Lampyris noctiluca.

1098. [Rilex, C. V.] In memoriam. <Amer. Ent., December, 1S69January, 1870, v. 2, pp. 65-68.

Biographical and obituary notice of B. D. Walsh.

1099. [RILEY, C. V.] The harlequin cabbage-bug, Strachia histrionica, Hahn. <Amer. Ent., December, 1869-January, 1870, r. 2, pp. 79-80, fig. 56.

Enumeration of the enemies of the cabbage in the United States; methods of their iujury; importation aud spread of some species; figures of the imago; description of eggs, habits, treographical distribution, seasons, and odors of Strachia [= Murgantia] histrionica; cxtract from G. Lincecum's "Texan cabbarc-bug."

1100. [RILeY, C. V.] An entomologist caught napping. <Amer. Ent., December, 1869-Jannary, 1870, r. 2, p. 84 .

Criticism of the view that trees, grasses, or any other particular forms of vegetation are the natural coveringrs of the carth; this criticism applied especially to John Curtis.

1101. [RILey, C.V.] Poisonous qualities of the Colorado potato-bug. <Amer. Ent., December, 1869-January, 1870, v. 2, pp. 85-86.

Extract from " Vinona Republicau," with remarks upon the poisonous nature of the blood of Doryphora 10-lineata.

1102. [RILEY, C. V.] Insects injurious to the grape-vine. No. 4. <Amer. Ent, December, 1869-January, 1870, v. 2, pp. 89-90, figs. 5S-59. Reprint, with slight, changes: <2d Ann. Rept. State Ent. Mo., March, 1870, pp. 76-78, figs. 52-53.

Treats of Philampelus satellitia $L=$ pandorus $]$; see No. 1127 for synopsis of contents. 
1103. [RILex, C. V.] Toads vs. bugs. <Amer. Ent., December, 1869January, 1870, v. 2, p. 91.

Translation of extracts from Fogt's "Noxions and beneticial auimals;" existence of a commerce in toads between France and England; usefulness, tameness, and gratitude of toads.

1104. [RILEx, C. V.] The tomato-worm again. <Amer. Ent., December, 1869-January, 1870, v. 2, pp. 91-92.

Reprint, with comments, of article entitled "The tomato-worm," from Syracuse Standard; absurd nature of newspaper accounts of insects.

1105. [RIlex, C. V.] Mr. Walsh's successor. <Amer. Ent., December, 1869-January, 1870, v. 2, pp. 92-93.

Condition in which B. D. Walsh left the office of State Entomologist of Illinois at his death; plans of his intended second report; provisions for the preparation of the same and the filling of the office.

1106. [Rrley, C. V.] To our subscribers. <Amer. Ent., December, 1860-January, 1870, v. 2, p. 93.

Proposed change in the character of the American Entomologist.

1107. [RILex, C. V.] The Walsh entomological collection. <Amer. Ent., December, 1869-January, 1870, v. 2, pp. 93-94.

Statement of the conditions uuder which the Walsh collection of insects is to be sold; cxpression of preferences in regard to its disposition; extent and method of preservation of the collection.

1108. [RILEy, C. V.] A State entomologist for Minnesota. <Amer. Ent., December, 1869-January, 1870, r. 2, p. 94.

Commendation of resolutions passed by the Minuesota State Horticultural Society recommending the appointment of a state entomologist; promotion of entomological studies by appropriations from the several States.

1109. Riley, C. V. [Field for the entomologist in the South.] < Amer. Ent., v. 2, December, 1869-January, 1870, p. 94; February, 1870, p. 121.

Extent and novelty of entomological work in the sonthern United States; J. P. Stelle at work in this tield.

1110. [Riley, C. V.] On our table. <Amer. Ent., December, 1869January, 1870, v. 2, pp. 95, 96.

Notices of J. T. C. Ratzcburg's works on "Forest trees" and "Weeds of Germany and Switzerland."

1111. [RILEY, O. V.] Information wanted. <Amer. Ent., December, 1869-Januars, 1870, v. 2, p. 96.

Answer to inquiry of M. A. Kcndall; habits of Xylocopa carolina [= virginica $]$, Rhyssa $[=$ Thalessa $]$ lunator, and Spectrum $[=$ Diapheromera $]$ feniorata.

1112. [Rlley, O. V.] The Cecropia inoth, Attacus cecropia, Linn. <Amer. Ent., February, 1870, v. 2, pp. 97-102, fig. 59 [bis]-67.

Descriptions and figures of larva, cocoon and imago of Attacus cecropia; figure of pupa; descriptions of egg and of young larva at its several stages; nomenclature, food-plants, and parasites; its value as a silk-worin; figures and descriptious of Ophion macrurum, Exorista cecropice n. sp., and Chalcis [ = Spilochalcis $]$ maries n. sp.; figure of larva of Ophion macrurum and of cocoons of Cryptus numcius; habits of these parasites; Exorista cecropice considercd a variety of $E$. militaris [= Nemorcea leucanie $]$. 
1113. RILEy, C. V. Report of the committee on entomology. Read . . . before the Missouri State Horticultural Society. < Amer. Ent., February, 1870, г. 2, pp. 106-109. Reprint: <2d Ann. Rept. State Ent. Mo., March, 1870, pp. 5-8, 13-15.

See No. 1127 for synopsis of contents.

1114. [RIley, C. V.] Silk-worm eggs. <Amer. Ent., February, 1870, v. 2, p. 109.

Seventy-eight packages of silk-worm eggs, valued at $\$ 800$ per package and weighing two tons, shipped from Yokohama to France via California and the Pacific Railroad.

1115. Riley, C. V. Imported insects and native American insects. <Amer. Ent., February, 1870, v. 2, pp. 110-112, fig. 72-75. Reprint: <2d Aun. Rept. State Ent. Mo., March, 1870, pp. 8-12.

See No. 1127 for sruopsis of contents.

1116. [RILEX, C. V.] The trumpet grape-gall, Vitis viticola O. S. <Amer. Ent., February, 1870, v. 2, pp. 113-114, fig. 76.

Figure of the gall of Cecidonyia vitis-viticola. C. v.-lituns a synonym; occurrence of similar gall in England on Tilia probably cansed by mites.

1117. [RILEx, C. V.] The goat-weed butterfly, Paphia glycerium Doubleday. <Amer. Ent., February. 1870, v. 2, pp. 121-123, figs. 81-83. Reprint, with slight changes. <2d Ann. Rept. State Ent. Mo., March, 1870, pp. 124-128, figs. 94-96.

See No. 1127 for synopsis of contents.

1118. [Rlley, C. V.] Insects injurious to the grape-vine. No. 5. <Amer. Ent., February, 1870, v. 2, pp. 123-124, fig. 84. Reprint, with slight changes. <2d Aun. Rept. State Ent. Mo., March, 1870, pp. 78-79, fig. 54 .

Treats of Thyreus abbotii; see No.' 1127 for synopsis of contents.

1119. [Rllex, C. V.] Scorpion in Kansas. <Amer. Ent., February, 1870 , v. 2 , p. 126.

Answer to inquiry of $\mathrm{K}$. Kelsey; occurrence of Buthus carolinianus in Texas, Missouri, and Kansas.

1120. [limex, C. V.] The grain Bruchus of Europe just imported. <Amer. Ent., February, 1870, v. 2, pp. 126-127, fig. 85.

Answer to inquiry of A. S. Fuller; notice of the recent importation into New York of the Enropean Bruchus granarius; danger of and remedy for such importation; habits and ravages of and means against the beetle in Europe as deseribed in J. Curtis's, "Farm Insects ;" figure of the imago and of infested beans; figures of larva, pupa, and imago of B. pisi and of infested pea.

1121. [RILey, C. V.] Locust borer. <Amer. Ent., February, 1870, v. 2, pp. 127-128, figs. 86-89.

Answer to inquiry of J. M. Shaffer; habits, food-plants, seasons, and ravages of and means against Xyleutes $[=$ Cossus $]$ robinice; figures larva, pupa, and male and femále imagos.

9 ENT 
1122. [Riley, C. $\dot{V}$.$] Eggs of snowy tree-cricket on raspberry canes.$ <Amer. Eut., February, 1870, v. 2, p. 128.

Answer to inquiry of J. B. Root; oviposition of and means against Geanthus niveus.

1123. [RILEY, C. V.] Spotted rove-beetle. <Amer. Ent., February, 1870 , v. 2, p. 128.

Answer to inquiry of J. Huggins; habits of Staphylinus maculosus and of rovebeetles in general.

1124. [Riley, C. V.] Raspberry gouty gall. <Amer. Ent., February, 1870 , v. 2, p. 128, fig. 90.

Answer to inquiry of C. Carpenter; ravages of and means against Agrilus ruficollis; description and fignre of larva.

1125. [RILex, C. V.] Parasitic cocoons. <Amer. Ent., February, 1870 , v. 2, p. 128, fig. 91.

Answer to incjuiry of G. C. Brackett; figures cocoons and conjectnres as tn the habits of [Hicroplitis ceratomice var. actuosus].

1126. [Ruley, C. V.] The pigeon Tremex in apple. <Amer. Ent., February, 1870, v. 2, p. 128.

Answer to inquiry of J. Huggins; babits and food-plants of Tremex columba; description of imago; Rhyssa [= Thalessa] lunator destroys the larva.

1127. RILEx, C. V. Second annual report on the noxious, beneficial, and other insects of the State of Missouri, made to the State Board of Agriculture, pursuant to an appropriation for this purpose from the legislature of the State. <5th Ann. Rept. State Board of Agric. for 1869, March, 1870, pp. 136 + 6, 99 figs. Separate: <Jefferson Cit5, Mo., March, 1870, pp. 136+6,99 figs.

CONTENTS.

Preface

\section{NOXIOUS INSECTS.}

Report of the Committee on extomology of the State Horti-

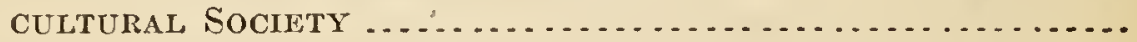

Noxions insects less injurious in Missouri in 1869 than nsual, 5The army-worm and the grain plant-louse considerahly injurious in Missouri in 1869, 5 -The chinch-bug and the codliug-moth less injurious, 6-A species of Thrips destroying great numbers of the Curculio, 6-Eggs of the apple-tree plant-louse destroyed by insect foes and birds, 6-According to Dr. Hull the "scab" in apples is caused by the apple-tree plant-louse, 7-The pickle-worm doing great damage during 1869,7 -rmportance of preventing the introduction of injurions insects, 7-Cultivation causes insects to multiply undnly, 8-More attention paid in Europe to injurious insects than in this country, 8.

Imported insects and native American insects..................

The imported currant-worm much more injurious than the native, 8-Other instances showing the greater destructiveness of imported insect enemies than of their native representatives, 9-Almost all our worst insect pests and pernicious weeds have been introdnced from Europc, 10-Few American insects and plants have become naturalized in Europe, 11--The American fauna and 


\section{7. lilley, C. V.-Continued.}

flora not so highly improved and developed as in Europe, 12Australian fauna still more "old-fashioned" than America, 12The parasites of injurious insects are not imported with the insects themselves, 13-Government aid should bo solicited to exterminate recently imported injnrious insects, 13-Bnt little attention given so far by our Government to assist the study of economic entomology, 14-Danger of introdncing the oyster-shell bark-louse into Missouri, 15-Immunity of the Pacifie States from many of our frnit insects, 15.

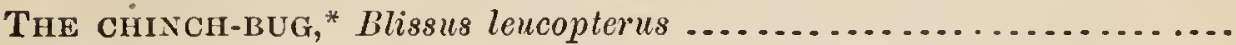

It is the most injurious of all insects infesting grain, 16-Its past history, 17; it was known in South Carolina in Revolutionary times, 17; it was injurious in Missouri as early as 1854, 17; noticed in Illinois in 1840, 17; it was very injurious in Missouri in 1868,17 ; bnt hardly noticed in 1869,17 -Probable reason why it was not noticed in Missouri in former times, 18-Why it is not injnrious in Massachnsetts and New York, 18-Its natural history, 18-The pupa state in the different insect orders, 18-Time required for different insects to complete the cycle of development, 19-The chinch-bug is two-brooded in Missouri, 19-Its winter quarters, 20-Its rapid multiplication, 20-Dr. Shimer's account of its nuptial flights, $21-\mathrm{It}$, deposits the eggs underground on the roots of the plant, 21-The egg, 22-Dimorphous forms of the ehinch-bug, 22-Its destructive powers, 22-Account of its appearance in immense numbers, 23-Heading off the marching bugs by a barrier of pine boards, 2:3-Heavy rains destruetive to the chinch-bug, 24-Moisture injurious to the egg, 24-The chinch-bug is always worse in a dry season than in a wet one, 24-Dr. Shimer's theory on epidemic disease affecting the chinch-bug, 25-Cannibal foes of the chinch-bug, 25; several species of ladybirds, 25; the weeping lacewing, 26 ; how the lacewing larva seizes its prey, 26; the insidious flower-bug, 27; the common quail, 28-Amount of damage done by the chinchbug, 28-Remedics, 28-Burning in winter the old corn-stalks and otber dead stuff on and near the fields, 29-Mixing winter rye among spring wheat, 29 -Intercepting the marching bugs by fence-boards, 29-Sowing gas-lime, 30-Other remedies, 30Bogus chineh-bugs, 31-Several species of Heteroptera confonnded with the trne chinch-bug, 31-The smell emitted by the half-winged bugs, 32-The insidions flower-bng; 32-The ashgray leaf-bug and its injury to grape-vines, 33-The flea-like negro-bug, 3:3; injury caused by it to raspberry, strawberry, and garden flowers, 34-Two other speeies of negro-bug, 35-Recapitulation of the natural history of the chinch-bug, 36 .

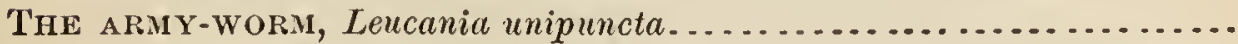

Four distinct caterpillars designated as army-worms in this countr. 37.

The tent-caterpillar of the forest, Clisiocampa disstria.............

It can not properly be called an aruiy-worm, 37 .

The cotton-worm, Aletia xylina ...........................

Historical cata on the injury caused by it, 38-The egg, 38-The worm and its habits, 39-Mr. Lyman's incorrect account of its development, 39-The moth and its habits, 40-Its hibernation, 40 -Remclies, 41. 


\section{Rilex, C. V.-Continued.}

The Southern grass-worm, Laphygma frugiperda.................

It resembles in habits the veritable army-worm, 41.

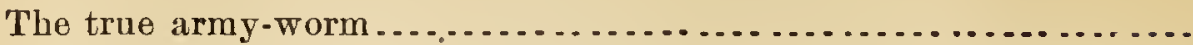

Its past history, 41-Rev. Powers's account of its invasion in the New

England States in 1770, 42-Accounts of later invasions previous to $1861,43-$ Years of its appearance in Illinois, 43 - The invasion of the year 1861, 44-Its appearance in Missouri in 1869, 44-Its sudden appearance and disappearance, 45-Reason for the apparently sudden appearance, 45-Army-worm years are wet with the preceding year dry, 46-Reason for the increase and decreasc of the number of worms, 46-Its natural history, 47-Previous accounts of its natural history, 47-When the eggs are laid, 47Where they are laid, 48-Misdirected instinct in insects and birds, 48-Exceptions to the normal habit of the worm, 48-Color of the worm, 49-The chrysalis and imago, 49-Parasites, 50; the red-tailed Tachina-fly, 50; its beneficial work, 50 ; it infests also other insects, 50 ; Walsh's description of the fly, 51 ; it has been redescribed as Exorista osten sackenii, 51; the yellowtailed 'I'achina-fly, 51 ; description of the fly, 51 ; the glassy Mesochorus, 52; the diminished Pezomachus, 52; the military Microgaster, 5\%; the purged Ophion, 53; the army-worm Ichneumon-fly, 53-Habits of the army-worm and suggestions for its destruction, 53-Burning grass meadows in winter or early spring, 54-Plowing late in the fall, 54-The marching of the worms, 54-Plants they prefer, 54-They become beneficial by devouring the chess in the fields, 55-Ditching, 55-Description of the insect as larva and imago, 56 .

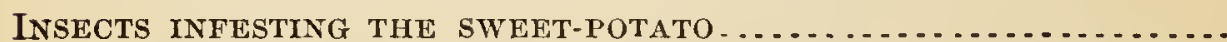

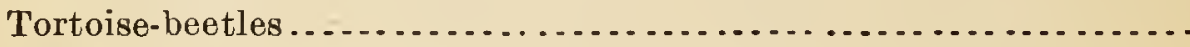

The clubbed tortoise-beetle affects the Irish potato, 56-Its general appearance, 57-Characteristics of tortoise-beetles, 57Merdigerous habits of tortoise-beetles and others of the same family, 58-General appearance of the larva, 58-Their dung parasol, 59-Larval molts, 59-Egg of tortoise-beetles, 60-The chrysalis, $60-\mathrm{Ha}$ !its of and injury done by the beetles, $60-$ Remedies, 61.

The two-striped sweet-potato beetle, Cassida bivitiata...............

It seems to be confiued to that plaut, 61-The larva and the use of its fork, 61-Its pupa and iınago, 61.

The golden tortoise-beetle, Coptocycla aurichalcea.................

Food-plants and characteristics of the larva, 62 -Brilliant color of the beetle, 62 .

The pale-thighed tortoise-beetle, Coptocycla aurichalcea.............

It is hardly distinguished from the foregoing species, 62.

The mottled tortoise-beetle, Coptocycla guttata ..................

Characteristics of the beetle, 63; of the larva, 63.

The black-legged tortoise-beetle, Cassida nigripes................

Characteristics of the imago and larva, 63.

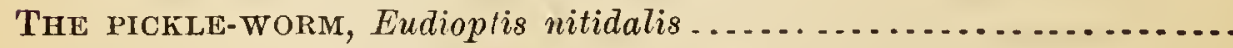

Other insects infesting cucurbitaceous vines ....................

The squash-borer, 64-It seems to be confined to the Eastern States, 64-The striped cucumber-beetle, 64-Injury done by the beetle, 64 ; by the larva, 65 -The larva and pupa, $65-$ Number of annual generations, 65-Remedies, 66-Extent of the injury caused by it, 66-The 12-spotted Diabrotica, 66 , 


\section{Riley, C. V.-Continued.}

The pickle- worm

Characteristics and description of the worm, 67-Its habits, 67 Characteristics of the moth, 68-Accounts of injury done by the worm in Missouri and Illinois, $69 ;$ in other portions of the country, 70-It was not known before as injurious, 70-Remeds, 70.

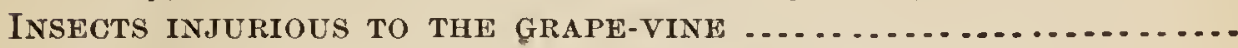

The hog-caterpillar of the vine, Ampelophaga myron ...............

The egg, 71-Characteristics of the larva, 71-Its habits when about to transform, 72-The chrysalis and imago, 72 -It is onebrooded North and two-brooded farther South, 72-It is very injurious, 73-The Microgaster parasite and its development, 73Habits of caterpillar infested with the parasite, 73.

The achemon Sphinx, Philampelus achemon ....................

Appearance and habits of the larva, 74-The chrysalis, 75-The insect is single-brooded, 75-The moth and its issuing from the pupa-shell, 75-No parasites known, 76.

The satellite Sphinx, Philampelus pandorus....................

How to distinguish its larva from that of the foregoing species, 76 - Development of the larva, 76-Variations in color of the larva, 77-Its position when at rest, 77-The moth, 78.

The Abbot Sphinx, Thyreus abbotii .........................

Its distribution, 78-The larva varies much in color, 78-The chrysalis and imago, 79 .

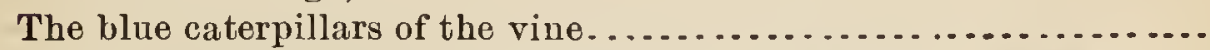

The eight-spotted forester, Alypia octomaculata, 80-Larva previously mistaken for it, 80 -Habits and characteristics of the larva, 80-Harris's description of the larva, 81-The moth, 81Mr. Andrew's account of its ravages, 81 -Remedies, 82.

The beautiful wood nymph, Eudryas grata, 83-Characteristics of the moth, 83-Close resemblance between the larva of this and the foregoing species, 83-The differences pointed out, 83-Development of the insect, 83 .

The pearl wood nymph, Eudryas unio, 83-It greatly resembles the beautiful wood nymph, 83-Its probable larva, 84-Practical importance of distinguishing these closely allied species, 84 .

The American Procris, Harrisina americana ......................

Work of its larva, 85-Description of full-grown larva, 86-The moth, 86-It is not very destructive, 86-Two annual broods of the insects, 86-Parasite of the American Procris, 87.

The new grape-root borer, Prionus laticollis .....................

Correction of opinion formerly expressed, 87.

The broad-necked Prionus, 87-Duration of the larva state, 87Its transformation, 88-It bores also in apple roots, 88-Great damage done by the borer, 88-No good remedy known, 88.

The tile-horned Prionus, Prionus imbricornis, 89-How it differs from the foregoing, 89-Its occurrence on prairie land, 90-Small dimorphous male form, 90-The larva subsists also upon the roots of herbaceous plants, 90-Practical considerations, 91.

The grape-seed nuaggot, Isosoma vitis .......................

The grape-seed Curculio larva of the first report is that of a hymenopterous insect, 92-The perfect insect is closely allied to the joint-worm fly, 92-Mr. Saunders' account and description of the imago, 93. 


\section{Riley, C. V.-Continued.}

The CANKer-Worm, Paleacrita vernata : Anisopteryx pomctaria.......

The eggs, 94-The larva and larval changes, 95-Importance for the orchardists to recognize the true canker-worm, 95-The imported elm leaf-beetle mistaken for it, 95-Description of the larva, 96-Its food-plants, 96-The chrysalis, 96-Only one annual brood in the latitude of St. Louis, 37-The moth and its varieties, $97-$ It is less injurious in Missouri than in the Eastern States, 97-Remedies, 98-Classification of remedies proposed, 98-The trough and bandage systcms, 99-Muriate of lime as remcdy, 100-Jarring the tree, 101-Late fall plowing, 101Summer plowing, 102-Efficiency of hogs, 102-Enemies, 102; birds, mites, and parasites, 102 ; ground-beetles, 103 ; the fraternal potter-Ivasp, 103.

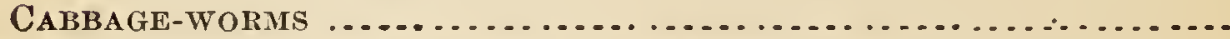

The Southern cabbage butterfly, Pieris protodice.................

Its geographical range, 104-Injury caused by it in Missouri, 104 -Description of the larva, 105-The chrysalis and imago, 105Habits and other food-plants, 105.

The potherb butterfly, Pieris olearacca, 105-It is a Northern species, 105-It will very likely never occur in Missouri, 106-Geographical range of insects principally influenced by temperature, 106-Isentomic lines, 106-Southern insects found near St. Louis, 106.

The imported cabbage butterfly, Pieris rapa, 106-Amount of damage caused by it in Canada, 107-Its spread westward, 107-It will undoubtedly spread to St. Louis, 107-The insect in Europe, 107-History of its introduction, 107-The insect in its different stages, 108-Its food, 108-Remedies, 109-Parasites, 109.

The cabbage Plusia, Plusia brassicre.........................

Characteristics and habits of the larva, 110-Its transformations, 111-Remedics, 111-Description of larva, chrysalis, and imago, 111-A similar worm occurring on thistles, 112.

The zebra caterpillar, Mamestra picta .......................

Habits and characteristics of the larva, 112-'The chrysalis and the moth, 113-Two annual broods, 113-Food-plants, 113.

The TARNished Plant-Bug, Lygus pratensis ....................

Injury caused by it to various trees and plants, 114-It is a very variable species, 114-Its development, 114-No effective remedy known, 115-Preventive measures, 115.

The philenor swallow-taIl, Papilio philenor ...................

Its food-plant, 116-Damage done by it, 116-Characteristics and development of the larva, 116-Description of the larva, 117The pupa, 117-The imago, 117-Prevention, 118.

THE CotTonwood DAGGER, Acronycta lepusculina .................

General appearance of the larva, 119-Two annual broods, 119Chrysalis and moth, 119-Larva of other species belonging to the genus Acronycta, 119-Parasites, 120-Description of larva and imago, 120-Characters and habits of other species of the same genus, 121.

The Missouri bee-killer, Proctacanthus milbertii................

The truc scientific name of the Nebraska bee-killer, 121-Wing-veins of the genera Asilus, Promachus, and Erax, 122-Description of the Missouri bee-killer, 122-How to destroy the flies, 123-Habits and life-histury of Asilus-flies, 123-Description of larva and pupa of Erax bastardi (?), 124-Synonymical notes on the imago, 124. 
1127. Rilex, C. V.-Continued.

INNOXIOUS INSECTS.

The gont-weed butterfur, Paphia glycerium .................

Its geographical distribution and position iu classitication, 125-Its food-plant, 125-Habits of the larva, 126-Larval changes, 126Conformity in the color of the larra with that of the leaves, 127-Description of the full-growu larva, 127-Transformation of the larva to chrysalis, 127 - The two sexes of the imago, 1:27Hibernation, 128.

THE BLACK BREEZE-FLY, Tabanus atratus ......................

Breeze-flies beneficial in the larva state, 128-Tormenting power of breeze-flies, 128-Their mode of flight, 129-Ou knowledge of their larval character and habits, 129-General characters of the larva of the black breeze-fly, 129-It is semi-aquatic, 129Walsh's description of the larra, 130-Habits and food of the larva, 130-Its transformations, 131-Description of the pupa, 131-Probable habits of breeze-fly larvo on the Western prairies, $13 \%$.

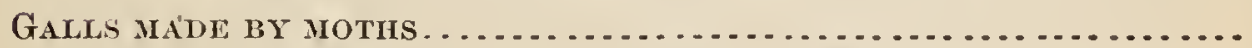

THE FALSE INDIGO Gaxt-MOTH, walshia amorphella..............

The gall and its structure, 132-General appearance of the larva and the moth, 133-Descriptiou of larva and imago, 133.

THE MISNAMED GALL-MOTH, Euryptyehia saligneana..............

Is it a true gall-maker or an inquiline?, 134-Walsh's description of the larvit, 134-Descriptiou of the imago, 134-Generic characters, 134-Reasons why the insect is an intruder aud not a gallmaker, 134-Euumcration of the known gall-making moths, 135How the gall is formed, 135 .

1128. [RILะY, C. V.] Mr. Walsh's portrait. <Amer. Ent., March, 1870, v. 2, p. 129.

Remarks accompanying the portrait of $B$. D. Walsh; resolutions passed on the death of Walsh by the London branch of the Eutomological Society of Ontario; by the American Entomological Society, the Illinois State Horticultural Society, and by the Kiusas State Horticultural Society.

1129. Rilex, C. V. The plum Curculio, Conotrachelus nenuphar Herbst. <Amer. Ent., March, 1870, r. 2, pp. 130-137, fig. 92.

Paper read before the Illinois State Horticultural Socicty at its 14th annual meeting; summary of established facts and discussiou of mooted points in the life-history of Conotrachelus nenuphar; seasons, habits, transformations, food-plauts, cnemies of and means against the same; descriptions and figus es of larva and imago; figure of pupa; hibernation aud the effects of climate on the prolongation of the life of iusects.

1130. Riley, C. V. Insects injurious to the grape-vine. No. 6. <Amer. Ent., March, 1870, v. 2, pp. 150-153, figs. 100-102. Reprint, with slight changes : $<2 d$ Ann. Rept. State Ent. Mo., March, 1870, pp. 80-82, fig. 55 .

Treats of Alypia octomaculata; see No. 1127 for synopsis of contents. 
1131. [Rilex, C. V.] Pithy blackberry gall. <Amer. Eut., March, 1870, v. 2, pp. 159-160, fig. 103.

Answer to inqniry of C. W. ["S. C."] Spaniding; descriptions and figures of larva and gall of Diastrophus nebulosus; fignre of pupa; seasons, foodplant, guest-fly [Periclislus sylvestris], and parasite [Eurytoma diastrophi] and means against this species; the gcnus Diastrophus confined to Rosacece, Cynips to Cupuliferce and Antistrophus to Composite.

1132. [Riley, C. V.] Clover-worms. <Amer. Ent., March, 1870, v. 2, p. 160.

Answer to inquiry of G. Pauls; geographical distribution, food-habits, vernacnlar names and synonymy of and means against Asopia costalis.

1133. [RILeY, U. V.] Seed ticks under bark of apple-trees. <Amer. Ent., March, 1870, v. 2, p. 160.

Answer to inquiry of $\mathrm{O}$. B. Galusha; character of insects as regards the nnmber of legs; occurrence of fxodes unipunctata under outer bark of apple-trees at Morris, Ill.

1134. [Riley, C. V.] Parásitic cocoons. <Amer. Ent., March, 1870, v. 2, p. 160.

Answer to inquiry of S. W. Beckworth; occnrrence of a mass of cocoons of [Microplitis ceratomice var. actuosus] under red-oak at South Pass, Ill."

1135. [Rlley, C. V.] Is any knowledge useless? <Amer. Ent. and Bot., April, 1870, v. 2, pp. 164-166.

Keprint of article from Manufacturer and Builder, November, 1869 ; minute investigations iu science may be of great practical importance; cases in which a knowledge of life-history of Galeruca calmariensis [=xanthomelcena ], Conotracketus nenuphar, and Lymexylon.navale was or might have been of great value.

1136. [RIley, C. V.] Tomato fruit-worm. <Amer. Ent. and Bot., April, 1870, v. 2, p. 172.

Notice of statement by J. J. Wcir that Beliothis armigera was bred from larvæ which fed on the fruit of tomato in England; food-plants of this insect.

1137. Rilex, C. V. Insects injurious to the grape-vine. No. 7. <Amer. Ent. and Bot., April, 1870, v. 2, pp. 173-174, figs. 107-108. Reprinted, with slight changes, from $<2 d$ Ann. Rept. State Ent. Mo., March, 1870, pp. 85-87, figs. 58-59.

Treats of Procris [= Harrisina] americana; see No. 1127 for synopsis of contents.

1138. [RILEy, C. V.] The death web of young trout. <Amer. Ent. and Bot., April, 1870, v. 2, p. 174.

Reprint, with review, of Seth Green's "An enemy to young trout;" young trout and young white-fish killed by the web of an unknown aquatic larva, probably one of the caddis-llies; habits of the larvæ of Phryganeida. See No. 1160.

1139. [RILEY, C. V.] "Scab" in apple v. apple-tree plant-lice. <Amer. Ent. and Bot., April, 1870, v. 2, p. 178.

Notes the freedom of apple-trees in 1870 from the eggs of Aphis mali, and the opportunity to test the question of the connection of these insects with the "scab." 
1140. [Riley, C. V.] Insects named. <Amer. Ent. and Bot., April, 1870, v. 2, 1. 179.

Answer to inquiry of M. Holvart; identification of several insects; foodplants of Grapta comma, Geometra [=Zerene] catenaria, Serica vespertina, and Tetraopes 5-maculatus; geographical distribution of Grapta comma; description of larva of Ecpantheria scribonia.

1141. [RILey, C. V.] Supposed trout enemy. <Amer. Ent. and Bot., April, 1870, v. 2, pp. 179-180.

Answer to inquiry of F. Mather; identification of several insects; habits and occurrence of Capnia minima; occurrence of Piophita casci and Ptinus brunneus at Honeoye Falls, N. Y.

1142. [RILex, C. V.] Food for trout. <Amer. Ent. and Bot., April, 1870, v. 2, p. 180.

Answer to inquiry of Seth Green and Collins; with knowledge of the character of the worms which forms a desirable food for young trout, it may be possible to suggest some method of propagating the worms artificially.

1143. [Rlley, C. V.] Hair-snakes. <Amer. Ent. and Bot., April, 1870, v. 2, p. 180.

Answer to inquiry of E. W. M.; parasitic habits, abodes and prolificaey, and classificatory relations of Gordius varius and G. aquaticus.

1144. [RILEY, C. V.] Egg-sack of some unknown spider. <Amer. Ent. and Bot., April, 1870, v. 2, p. 1 șo.

Answer to inquiry of A. Engelinann; figure of eggr-sack of Epeira sp.?

1145. [RILEY, C. V.] Do worker bees sting the droues to death? <Amer. Ent. and Bot., April, 1870, v. 2, p. 180.

Answer to inquiry of M. W. V.; there is no good rcason to donbt that worker bees sting the drones to death when the mission of the latter is ended.

1146. [RILey, C. V.] Red spider. <Amer. Ent. and Bot., April, 1870, v. 2, p. 180 .

Answer to inquiry of R. H. Warder; Trombidium [=Tetranychus $]$ telarius imported from Enrope; sizc, color, and abodes of and means against the same.

1147. [RILey, C. V.] Insect named. <Amer. Ent. and Bot., April, 1870, v. 2, p. 180.

Answer to inquiry of M. Barrett; food-habits of Psocus venosus and other Psocide.

1148. [Rlley, C. V.] To destroy plant-lice. <Amer. Ent. and Bot., April, 1870, v. 2, p. 180.

Answer to inquiry of B. F. Lazear; means against Aphididce on house plants.

1149. [RILEY, C. V.] Raspberry rootgall. <Amer. Ent. and Bot., April, 1870, v. 2, p. 181, fig. 110.

Answer to inquiry of K. Parsons; description and fignre of gall of Rhodites radicum occurring on roots of Rosacce ; genera of parasites raised from it; interest of the question of the manner and extent of parasitization of this gall.

1150. [RILEy, C. V.] Spined slug.worm. <Amer. Ent. and Bot., April, 1870, v. 2, p. 181.

Answer to inquiry of L. G. Saffer and A. R. Bodley; brief description of the larva of Limacodes sp. 
1151. [RIley, C. V.] Apple-tree insects. <Amer. Ent. and Bot., April, 1870, v. 2, p. 181.

Answer to inquiry of L. Camfield; identification of specimens and directions for the destruction of Orgyia leucostigma and Phycita nebulo $[=$ Acrobasis indiginella ].

1152. [RutEY, C. V.] Native apple-tree bark-lice. <Amer. Ent. and Bot., April, 1870, v. 2, p. 181, fig. 111.

Answer to inquiry of A. C. Hammond; food-plants of and means against Diaspis harrisii [=Chionaspis furfurus]; figure of infested twig of apple; the presence of cnemies and parasites prevent this species becoming a formidable pest.

1153. [RlLEY, U. V.] The hedge-hog caterpillar. <Amer. Ent. and Bot., April, 1870, v. 2, p. 182, fig. 112.

Answer to inquiry of H. Burt; deseriptions and figures of larva and imago of Arctia [= P'yrrharctia] isabella; figure of pupa and cocoon; habits and hibernation; its larva and that of Ecpantheria scribonia called "foverworm," and igworantly supposed to cause malarial fevers; food-habits of Horinus [ = Merinus] levis.

1154. [Rrley, C. V.] Chick-weed Geometer. <Amer. Ent. and Bot., April, 1870, v. 2, p. 182.

Answer to inquiry of J. Huggins; identification of specimens; reference to account of Hamalopis grataria; Cermatia forceps common in houses in the latitude of St. Louis, Mo.; the sulphur remedy for canker-worms absurd.

1155. [Ruley, C. V.] Bean-weevil. <Amer. Ent. and Bot., April, 1870, จ. 2, p. 182 .

Answer to inquiry of G. W. Copley; specimens identified; occurrence and ravages of Bruchus obsoletus in Illinois.

1156. [Rímy, O. V.] Bag-worm at South Pass, Ill. '<Amer. Ent. and Bot., April, 1870, v. 2, p. 182.

Answer to inquiry of G. H. Baker; occurrence of Thyridopteryx ephemerceformis at South Pass, Ill.; importance of its destruction.

1157. [Riler, C. V.] Eggs of oblong-winged katy-did. <Amer. Ent. and Bot., April, 1870, v. 2, p. 182.

Answer to inquiry of E. D. Ladd; differences between the eggs of Phylloptera $[=$ Amblycorypha $]$ oblongifolia and those of Platyphyllum $[=$ Cyrtophyl. lus] concavus; the former occur on currant and various trees.

1158. [RILEY, U. V.] Insects injurious to the grape-vine. No. 8. <Amer. Ent. and Bot., Mas, 1870, v. 2, pp. 208-209, tig. 127. Reprint, with slight changes: <3d Anu. Rept. State Ent. Mo., A pril, 1871, pp. 61-63, fig. 24.

Treats of Desmia maculalis; see No. 1301 for synopsis of contents.

1159. [RILey, C. V.] The periodical Cicada alias the 17-year and 13 vear locust. <Amer. Ent.' and Bot., May, 1870, p. 211.

Quotes, from the 1st Ann. Rept. State Ent. Mo., the localities in which Cicada $[=$ Tibicen $]$ septendecim and $C .[=T$. $]$ tredecim will appear in $18 \% 0$, with re. quest for reports of the occurrence of these insects.

1160. [RILEY, C. V.] The death-web of young trout. <Amer. Ent. and Bot., May, 1870, v. 2, p. 211.

Supplementary to No. 1138; the larve mentioned belong to the genus Simulium. 
1161. [RILey, C. V.] Worms under mulch has. < Amer. Ent. and Bot., May, 1870, v. 2, p. 212.

Answer to inquiry of J. F. Flugg; description, season, habits, and ravages of and means against the larva of Tipula sp.

1162. [Riley, C. V.] A new pear-tree insect. < Amer. Ent. and Bot., May, 1870, v. 2, p. 212, fig. 129.

Answer to iuquiry of E. J. Ayres; food-habits and ravages of and means against Platycerus quercus; figure of imago.

1163. [Riley, C. V.] Apple-twig borer. <Amer. Ent. and Bot., May, 1870, v. 2, p. 212.

Answer to inquiry of J. B. Myers; Bostrichus [=Amphicerus $]$ bicandatus bores into the axil of limbs of pear-trees.

1164. [RILEy, C. V.] Cocoons of polyphemus moth. <Amer. Ent. and Bot., Mas, 1870, v. 2, 212.

Answer to inquiry of H. J. Junlap; cocoon of Attacus [= Telea $]$ polyphemus found on Morello cherry-tree.

1165. [RILEY, C. V.] Galls on supposed dock. <Amer. Ent. and Bot., May, 1870, v. 2, p. 212.

Answer to inquiry of S. V. Summers; Gelechia galle-solidaginis forms galls on stems of Solidago; Gastrophysa [=Gastroidca] cyanea breeds ou Rumex.

1166. [Riley, C. V.] Mossy rose-gall. <Amer. Ent. and Bot., May, 1870 , v. 2, p. 213, fig. 130.

Answer to inquiry of W. M. Locke; description of gall, larva, and imago of Rhodites rose; figure of the gall; description of a parasitic larva.

1167. [Riley, C. V.] Punctures on the rose-twig. <Amer. Ent. and Bot., May, 1870, v. 2, p. 213, tig. 131.

Answer to inquiry of G. W. Copley; punctures in rose-stem; eggs, probably of a cricket, imbedded in pith of the same; description of the egg and figure of injured stem.

1168. [RILey, C. V.] Snout-beetle., <Amer. Ent. and Bot., May, 1870, v. 2, p. 213.

Answer to inquiry of Mary Treat; Hylobius confusus a timber borer and nsually in pinc.

1169. [RILEx, C. V.] The oyster-shell bark-louse in Missouri. <Amer. Ent. and Bot., May, 1870, v. 2, pp. 213-214, fig. 132.

Answer to inquiry of $\mathrm{B}$. P. Hanan; occurrence of Aspidiolus conchiformis [= Mytilaspis pomorum $]$ in Missouri; importance of the thorough extirpation of the insect; figure of a piece of bark infested by the same.

1170. [Rilex, C. V.] The pod-like willow-gall. <Amer. Ent. and Bot., May, 1870, v. 2, p. 214, fig. 133.

Answer to inquiry of J. R. Mruhleman; description and figure of the gall of Cecidomyia salicis-siliqua; figure of larva; food-plants, synonymy, and description of the pupa of the same.

1171. [Rilex, C. V.] Bee-nest. <Amer. Ent. and Bot., 1870, r. 2; May, p. 214, fig. 134; September, p. 307.

Answer to inquiry of $J$. R. Muhleman; description and figure of larva of Prosopis affinis in hot, low currant-stem; probability that Ceratina dupla brecls twice a year. 
1172. [RILey, C. V.] Beetles named. <Amer. Ent. and Bot., May, 1870, r. 2, p. 214.

Answer to inquiry of S. V. Summers; specimens identified; difference between Canthon levis and C. chalcites.

1173. [RILeY, C. V.] Great discovery : Curculio extermination possible! <Amer. Ent. and Bot., June, 1870, r. 2, pp. 225-227. Notice : <Cultivator and Country Gentleman, 9 June, 1870, v. 35, 1. 361 .

Reprint of articles by J. E. Chamberlain and Mrs. H. Wier on the destruction of the Curculio; letter from W. B. Ransom; criticism of the same; means against Conotrachelus nenuphar; distinctions between $C$. nenuphar and $A \dot{n}-$ thonomus quadrigibbus.

1174. [RILEx, C. V.] The death-web of joung tront. <Amer. Ent. and Bot., June, 1870, r. 2, pp. 227-228, figs. 143-144.

Value and progress of fish-culture; habits of Simulium piscicidium, with the observations of Seth Green aud Sara J. McBride; figures larva and pupa of S. piscicidium and the imago of S. molestum.

1175. [RILfy, C.V.] Insects injurious to the grape-vine. No.9. <Amer. Ent. and Bot., June, 1870, v. 2, pp. 234-235, fig. 148. Reprint, with slight changes: $<3$ d Ann. Rept. State Ent. Mo., April, 1871 , pp. 65-68, fig. 27.

Treats of Pterophorus [= Oxyptilus $]$ periscelidactylus; see No. 1301 for synopsis of contents.

1176. [RILey, C. V.] The apple Curculio. < Amer. Ent. and Bot., June, 1870, v. 2, p. 243, fig. 152.

Figures of the imago of Anthonomus quadrigibbus.

1177. [Rilex, C. V.] The new Curculio remedy. <Amer. Ent. and Bot., June, 1870, v. 2, p. 243.

Results of experiments in the use of Ransom chip-trap for Conotrachelus nenuphar.

1178. [Riley, C. V.] Tarantula of Texas. <Amer. Ent. and Bot., June, 1870, v. 2, p. 244.

Answer to inquiry of L. J. Stroop; the figure of Mygale hentzii given in volume one is somewhat incorrect.

1179. [RILEx, C. V.] Ailanthus silk-worm naturalized. <Amer. Ent. and Bot., June, 1870, v. 2, p. 244.

Answer to inquiry of A. S. Fuller; introduction and naturalization of Attacus cynthia.

1180. [RIlex, C. V.] Cypress-gall. <Amer. Ent. and Bot., June, 1870 , v. 2, p. 244, fig. 153.

Answer to inquiry of J. P. Stelle; description and figures of gall and description of gall and imago of Cecidomyia cupressi-ananassa n. sp. on cypress; figures breast-bone of the larva.

1181. [RILEY, C. V.] Tent-caterpillar of the forest. <Amer. Ent. and Bot., June, 1870, v. 2, p. 245.

Answer to the inquiries of A. M. Brown and J. H. Evans; habits, food-plants, and ravages of Clisiocampa sylvatica [=disstria] and C. americana. 
1182. [RILEY, C. V.] Worm-boring into peach. <Amer. Ent. and Bot., June, 1870 , v. 2, p. 245.

Answer to inquiries of W. C. Flagg, A. C. Hamquond, and M. M. Hooton; food-plants and description of larva of Dylina cinerea $[=$ Lithophane antennata].

1183. [RILey, C. V.] Insects named. <Amer. Ent. and Bot., June, 1870, v. 2, p. 245.

Answer to inquiry of A. Engelman; descriptions of Smilia auriculata and Membracis ampelopsidis; both species common on grape-vines.

1184. [RILEy, C. V.] Lice on "snow-balls. <Amer. Ent. and Bot., June, 1870, v. 2, p. 245.

Answer to inquiry of Mrs. C. L. Seymour; means against Aphidide.

1185. [RILeY, C. V.] Twig-borer. <Amer. Ent. and Bot., June, 1870, v. 2 p. 245 , fig. 154 .

Answer to, inquiries of S. H. Kriedelbaugh and G. F. Merriam; figures of male and female Bostrichus $[=$ =Amphicerus $]$ bicaudatus, which bore into the axils of grape-buds.

1186. [Riley, C. V.] Bee enemy. <Amer. Ent. and Bot., June, 1870, Г. 2, p. 245.

Answer to inquiry of F. Brewer ; Staphylinus maculosus, found eating a bee, is rather a scavenger than an insect of prey.

1187. [RILEY, C. V.] Knots on apple-tree roots caused by root-lice. $<$ Amer. Ent. and Bot., June, 1870, v. 2, p. 246.

Answer to inquiry of B. N. McKinstry; ravages of and means against Schizoneura lanigera on roots of joung apple-trees.

1188. [Riley, C. V.] Beetles named. <Amer. Ent. and Bot., June, 1870, v. 2, p. 246.

Answer to inquiry of W. W. Daniells; Ithycerus noveboracensis injures appleleaves.

1189. [RIley, C. V.] Bag-worm. <Amer. Ent. and Bot., June, 1870, v. 2, p. 246.

Answer to inquiry of M. M. Hooten ; occurrence of soung larva of Thyridopteryx ephemeraformis on peach-trees; manner in which they carry their cases.

1190. [RILEY, C. V.] The larder-beetle. <Amer. Ent. and Bot., June, 1870, v. 2, p. 246.

Answer to inquiry of S. H. Kriedelbaugh; food-habits and description of the larva and imago of Dermestes lardarins.

1191. [Riley, U. V.] Water-bug.' <Amer. Ent. and Bot., June, 1870, จ. $2,1,246$.

Answer to inquiry of W. H. Harrington; habits and description of Ranatra fusca.

1192. [RILEY, C. V.] Gregarious worms on horse-chestnut. <Amer. Ent. and Bot., June, 1870, v. 2, p. 246.

Answer to inquiry of W. R. Howard; oviposition, food-plant, and parasite of Tortrix [= Cacoecia] rileyana.

1193. [RILey, C. V.] Pupa of the disippus butterfly. <Amer. Ent. and Bot., June, 1870, v. 2, p. 246, fig. 155.

Answer to inquiry of T. Montgomery; figure and colors of pupa of Limenitis disippus; food-plants and hibernations of larva. 
1194. [RILEY, C. V.] Prickly-rose gall. <Amer. Ent. and Bot., June, 1870, v. 2, p. 216.

Answer to inquiry of J. Cochrane and J. P. Stelle; brief description of the gall of Rhodites bicolor on wild rose.

1195. [RILEY, C. V.] Insects feeding on sap of black-walnut. < Amer. Ent. and Bot., June, 1870, v. 2, p. 246.

Answer to inquiry of M. Barrett; food-habits of Psocus venosus.

1196. [Riley, C. V.] Locust-borer. <Amer. Ent. and Bot., June, 1870, v. 2, p. 246.

Answer to inquiry of "Arbor;" means against Arhopalus [ = Cyllene $]$ robinice.

1197. [RILey, O. V.] To exterminate cockroaches. <Amer. Ent. and Bot., June, 1870, v. 2, p. 246.

Answer to inquiry of R. F. Weitbree; means against cockroaches.

1198. [RILey, O. V.] The white-lined morning Sphinx. (Deilephila lineata, Fabr.) <Amer. Ent. and Bot., July-August, 1870, v. 2, pp. 257-258, figs. 162-164. Reprint, with additions and slight changes : <3d Ann. Rept. State Ent. Mo., April, 1871, pp. 140-142, figs. 60-62.

Treats of Deilephila lineata; see No. 1301 for synopsis of contents.

1199. [RILEy, C. V.] Descriptive entomology. <Amer. Ent. and Bot., July-August, 1870, v. 2, pp. 258-261. Abstract: <Cultivator and Country Gentleman, 6 April, 1871, v. 36, p. 218.

Critical review of a remark by $J$ A. Lintner; calculation of the cost, labor, and extent of a work containing the description and figure of every existing species of insect.

1200. [RILEY, O. V.] The tent-caterpillar of the forest. (Clisiocampa sylvatica, Harr.) <Amer. Ent. and Bot., July-August, 1870, v. 2, pp. 261-266, figs. 165-168. Reprint, with additions and slight changes: <3d Ann. Rept. State Ent. Mo., April, 1871, pp. 121-129, figs. 52-54.

Treats of Clisiocampo sylvatica $[=$ disstria $]$; see No. 1301 for synopsis of contents.

1201. [Riley, C. V.] The Ransom Curculio remedy. <Amer. Ent. and Bot., July-August, 1870, v. 2, pp. 268-271.

Discussion of the efficacy of the Ransom chip-trap against Conotrachelus nenuphar; extracts from and criticism of articles by E. S. Hull, W. B. Ransom, and others on this subject,

1202. [Riley, C. V.] Insects injurious to the grape-vine. No. 10. $<$ A mer. Ent. and Bot., July-A ugust, 1870, v. 2, pp. 272-273, fig. 170. Reprint, with additions and slight ehanges. <3d Ann. Rept. State Ent. Mo., A pril, 1871, pp. 68-69, fig. 28.

Treats of Spilosoma virginica; see No. 1301 for synopsis of contents.

1203. [RILey, C. V.] The Walsh entomological cabinet. <Amer. Ent. and Bot., July-August, 1870, v. 2, p. 275.

Remarks on the purchase and disposal of the entomological collection of $B$. D. Walsh. 
1204. [RILEY, C.V.] The currant-worm! <Amer. Ent. and Bot., JulyAugust, 1870, v. 2, p. 275.

Comments upon the confusing way in which some horticultural publications treat of the currant-worm, without discrimination of species.

1205. [Rrley, C. V.] Water larva. <Amer. Ent. and Bot., July-August, 1870, v. 2, p. 275.

Answer to inquiry of F. Mather; habits of the larvie of Ephemerida.

1206. [Riley, C. V.] Large biack potato-beetles. <Amer. Ent. and Bot., July-August, 1870, v. 2, p. 275.

Answer to inqniry of R. S. Elliott ; Epieauta corvina? injuring potato-vines in Kansas.

1207. [RILEy, C. V.] Destroying cherry plant-lice. <Amer. Ent. and Bot., July-Angust, 1870, v. 2, p. 275.

Answer to inquiry of G. C. Brackett; neans against Myzus cerasi.

1208. [Riley, C. V.] Caterpillars on grape-rines. <Amer. Ent. and Bot., July-A ugust, 1870, v. 2, p. 275.

Answer to inquiry of G. A. Watson; larve of Alypia octomaculata and Acromycta oblinita fonnd on grape-vines; food-plants of the latter species.

1209. [RILEy, C. V.] Ash-gray blister-beetle. <Amer. Ent. and Bot., July-August, 1870, v. 2, p. 275.

Answer to inquiry of P. II. Foster; Lyttu cinerea [= Macrobasis unicolor $]$ feeding on the three-thorned Acacia.

1210. [Riley, C. V.] Specimens lost. <Amer. Ent. and Bot., JulyAugust, 1870; v. 2, p. 276.

Answer to iuquiry of C. H. Roberts; food-habits and description of larva of Gortyna nitela and of an undeternined moth on peach-trees.

1211. [RILEY, C. $\dot{V}$.] White willow worm. <Amer. Ent. and Bot., JulyAugust, 1870, v. 2, p. 276.

Answer to inquiry of S. H. K.; food-plints and description of larva of and means agaiust Nematus ventralis.

1212. [RILEy, C. V.] Bark-lice on grape-vine and raspberry saw-fly. $<$ Amer. Fint. and Bot., July-August, 1870, v. 2, p. 276.

Answer to inquiry of $\mathrm{S}$. Thompson; Lecanium $[=$ P'ulvinaria $]$ vitis common on grape-vines in Europe and North America; its oviposition and oceurrence iil Illinois; description and means against the larva of Selandria $[=$ Monophaduus ] rubi.

1213. [RILEY, C. V.] Apple-tree borer; variations in the two-striped Saperda: <Amer. Ent. and Bot., July-Angust, 1870, v. 2, p. 276.

Answer to inquiry of D. B. Wier; colorational variations in Saperda bivittata $[=$ candida $]$; abundance and ravages of Capsus oblineatus $[=$ Lygus pratensis].

1214. [RILEx, C. V.] The plum Curculio breeds in apple. <Amer. Ent. and Bot., July-August, 1870, v. 2, 1. 276.

Answer inquiry of E. Leming; Conotrachelus nemuphar breeds in the fruit of apple. 
1215. [RIley, C. V.] Cecropia worm. <Amer. Ent. and Bot., JulyAugust, 1870, v. 2, p. 276.

Answer to inquiry of J. F. Thompson; occurrence and ravages of the larva of Attacus cecropia on apple-trces.

1.216. [RILey, C. V.] Gigantic rhinoceros beetle. <Amer. Ent. and Bot., July-August, 1870, v. 2, p. 276.

Answer to inquiry of L. G. Saffer; variations in coloration of Dynastes tityus.

1217. [Rlley, C. V.] Roman-nosed pupa. <Amer. Ent. and Bot., July-August, 1870, v. 2, p. 276.

Answer to inçuiry of E. D. Van Winkle; food-habits of Limenitis ursula and L. disippus; the pupæ of the two species are alike.

1218. [Rrley, C. V.] The onward march of the Colorado potato-beetle. A word to our Canadian neighbors. <Amer. Ent. and -Bot., September, 1870, v. 2, pp. 289-291, fig. 181.

Remarks on the spread of Doryphora decemlineata into Ontario, and means of checking it; efficacy and proper use of Paris grecn; other remedies; Lebia grandis at natural enemy of the larvæ.

1219. [Rrley, C. V.] The tarnished plant-bug. (Capsus oblineatus, Say). $<$ Amer. Ent. and Bot., September, 1870, v. 2, pp. 291-293, fig. 182. Reprinted, with additions and slight changes, from $<2 d$ Ann. Rept. State Ent. Mo., March, 1870, pp. 113-115, fig. 83.

Treats of Capsus oblineatus [= Lygus pratcnsis]; seo No. 1127 for synopsis of contents.

1220. [RILEY, C. V.] Osage orange for the mulberry silk-worm. <Amer. Ent. and Bot., September, 1870, v. 2, p. 293.

Reprint and critical review of S. Cormaby's article on the above; important articles should not be published anonymously.

1221. [Ruley, C. V.] Insects injurious to the grape-vine. No. 11. <Amer. Ent. and Bot., September, 1870, v. 2, p. 295, fig. 185. Reprint with slight changes. <3d Ann. Rept. State Ent. Mo., April, 1871, pp. 77-79, fig. 34.

Treats of Pelidnota punetata; sce No. 1301 for synopsis of contents.

1222. [RIley, C. V.] The slug on pear and cherry trees. <Amer. Ent. and Bot., September, 1870, v. 2, p. 296.

Reprint and critical review of "Addi" on the above; ravages of and means against Selandria $[=$ Eriocampa $]$ cerasi.

1223. [RILEY, C. V.] Appendix to joint-worm article published in vol. 1, No. 8 <Amer. Ent. and Bot., September, 1870, v. 2, pp. 296297.

Introduction to and explanation of the preparation and publication of Walsh's Eurytomides. See No. 384.

1224. [RILEY, C. V.] Entomology indeed run mad! <Amer. Ent. and Bot., September, 1870, v. 2, p. 305.

Critical review of Mark Miller's article on the currant-worm; Nematus ventrieosus [= ribesii] confomnded with Eufitchia vibcaria.

1225. [RILEY, O. V.] Red spider. <Amer. Ent. and Bot., September, 1870, v. 2, p. 305 .

Ravages and transformations of Tetranychus telarius. 
1226. [Riley, C. V.] Insects named. <Amer. Ent. and Bot., September, 1870, v. 2 , p. 306.

Answer to inquiry of J. K. Kidd; food-habits of Silpha peltata [= americana $]$ and allied forms, of Calosoma scrutator and of Laphria [=Dasyllis $]$ thoracica; mimicry between Laphria and Bombus and its use.

1227. [RILEY, C. V.] Caterpillar of white-marked tussock moth. <Amer. Ent. and Bot., September, 1870, v. 2, p. 306, tig. 186.

Answer to inquiry of G. C. Brackett; figure of larva and description of imago of Orgyia lencostigma; posture of male in repose; habits of female; Saperda bivittata $[=$ candida $]$ usualls perishes if it has not changed to a pupa before the death of the tree; Chrysobothris femorata lives for weeks on dead wood.

1228. [RILEY, C. V.] Does the apple Curculio go underground to transform? <Amer. Ent. and Bot., September, 1870, v. 2, p. 306.

Answer to inquiry of W. Muir; Anthonomus quadrigibbus transforms within the fruit; it docs not attack stone fruit.

1229. [RILey, C. V.] Walnut caterpillars. <Amer. Ent. and Bot, September, 1870, v. 2, p. 306.

Answer to inquiry of G. M. Levette; seasons, habits, and food-plant of and means against Dataina ministra; description of larva.

1230. [RILEy, C. V.] Striped blister-beetle. <Amer. Ent. and Bot., September, 1870, v. 2, p. 306, fig. 187.

Answer to inquiry of A. Galt; means against Epicauta vittata and other Meloide ou potato vines; figure of Epicanta vittata.

1231. [RILex, C. V.] Grape-vine Fidia. <Amer. Ent. and Bot., September, 1870, v. 2, p. 307, fig. 188.

Answer to inquiry of J. Hetzel; habits, ravages, and food-plants of and means against Fidia viticida; figure of this species.

1232. [RILEY, C. V.] Some interesting insects. <Amer. Ent. and Bot., September, 1870, v. 2, p. 307.

Answer to inquiry of A. S. Fuller; ravagos of Bruchus obsoletus in Lima beans; of Butalis cerealella in flint corn in stems and of Lobesia $L=$ Endemis $]$ botrana in blossoms of blackberry; description of the larva case of Phycita nebulo $[=$ Acrobasis indiginella $]$ and of galls of Cccidomyia tubicola on Carya.

1233. [Rilex, C. V.] The green hag-moth. <Amer. Ent. and Bot., September, 1870 , v. 2, p. 307.

Answer to inquiry of S. B. Shaw ; food-plants, and synonymy of Callochlore viridis $[=$ Parasa chloris $]$; description of larva aud imago; the larva doscribed by Reakirt does not belong to this species.

1234. [RILey, C. V.] The antiopa butterfly. <Amer. Ent. and Bot., September, 1870, v. 2, p. 307.

Answer to inquiry of A. S. Moss; desscription of larva and imago of $\mathrm{Va}$ nessa antiopa ; the larva feeds on willow; vernacular name and comparative abundance.

1235. [RILEY, C. V.] Rose-gall and pupa of archippus butterfly. <Amer. Ent. and Bot., September, 1S70, r. 2, p.307, fig. 189.

Answer to inquiry of L. B. Custar; fignre of pupa of Danais archippus; descriptions of three undetermined galls on rose-leaf formed by Rhodites sp.?

10 ENT 
1236. [RILEY, C. V.] White grubs in strawberry beds. <Amer. Ent. and Bot., September, 1870, v. 2, p. 307.

Answer to inquiry of J. B. Miller ; food-liabits of larva and description of imago of Cyclocephala immaculata.

1237. [Riley, C. V.] Larra of the thoas swallow-tail. <Amer. Ent. and Bot., September, 1870, v. 2, p. 308.

Answer to inquiry of E. H. Spragne; food-plant and description of larva of Papilio thoas [=eresphontes]; the larva rare in Missouri.

1238. [Riley, C. V.] Larva of clubbed tortoise-beetle. <Amer. Ent. and Bot., September, 1870, v. 2, p. 308.

Answer to inquiry of A. R. Bodley; Cassida, Coptocycla and Deloyala feed on Convolvulacee with the exception of Deloyala $[=$ Coptocycla $]$ clarata which feeds on Solunacee.

1239. [RILex, C. V.] The banded Ips in calyx of pear. <Amer. Ent. and Bot., September, 1870, v. 2, p. 30 S.

Answer to inquiry of G. C. Brackett; food-habits and description of Ips fasciatus.

1240. [Rilex, C. V.] The larder-beetle. <Amer. Ent. and Bot., September, 1870, v. 2, p. 308, fig. 191.

Answer to incquiry of F. S. Sleejer; fignres of larra and imago and of magnnified hair of larva of Dermestes lardarius; ravages in collections of preserved animals.

1241. [Riley, C. V.] Moth named. <Amer. Ent. and Bot., September, 1870, v. 2, p. 308.

Answer to inquiry of E. M. Hale; description of Ctenucha latreillana [=irrginica J; its abundance in 1870 in the vicinity of St. Lonis, Mo.

1242. [RIley, C. V.] The little Cicada. <Amer. Ent. and Bot., Sep. tember, 1870, v. 2, p. 308 .

Answer to inquiry of G. O. Hardeman ; occurrence of Cicada [= Meiampsalta $]$ partula in Missouri.

1243. [Ruter, O. V.] The brown mantispian. <Amer. Ent. and Bot., September, 1870, v. 2, p. 308.

Answer to inquiry of G. C. Bracket; Mantispa brunnea common, predaceous, and bencficial.

1244. [RILey, O. V.] Small reddish snont-beetle on apple. <Amer. Ent. and Bot., September, 1870, v. 2, p. 30.

Answer to inquiry of $\mathrm{J}$. Weed ; food-habits and description of Anthonomus cratagi.

1245. [Rlley, C. V.] Prickly rose-gall. <Amer. Ent. and Bot., September, 1870, v. 2, p. 309, fig. 192.

Answer to inquiry of "Subseriber;" description and figure of galls and description of Rhodites bicolor.

1246. [RILEY, C. V.] Questions answered. <Amer. Ent. and Bot., September, 1870, v. 2, p. 309.

Answer to inquiries of K. Parsons; formation and use of portable cases by Tincina; habits and character of the young of Mytilaspis pomicorticis [=pomorum $]$; food-habits of ants. 
1247. [RILEY, C. V.] Hog-caterpillar of the vine infested with parasites. $<$ Amer. Ent. and Bot., September, 1870, v. 2, p. 309.

Answer to inqquiry of J. M. Wilson; occurrence of larva of Darcusa $[=1 \mathrm{~m}$ pelophaga] myron parasitized by Apanteles conyregatus.

1248. [Riley, C. V.] Larva of Abbot Sphinx. <Amer. Ent. and Bot., September, 1870, v. 2, p. 309.

Answer to inquiry of S. E. Todd; occurrence of larva of Thyreus abbotii on grape-vine; meaus against the same.

1249. [Riley, C. V.] Cecropia worm. <Amer. Ent. and Bot., September, 1870, v. 2, p. 309.

Answer to incuiry of E. G. Hofman ; occurrence of Attacus cceropia on plum.

1250. [RILEy, C. V.] Flat-headed borer in soft maples. <Amer. Ent. and Bot., September, 1870, v. 2, p. 309.

Answer to inquiry of L. R. Elliott; ravages of and means against Chrysobothris femorata on soft náple; ravages of Arhopalus [ $=$ Cyllene] robinia on black-locust.

1251. [Riley, U. V.] Cherry plant-lice and their foes. <Amer. Ent. and Bot., September, 1870, r. 2, p. 309, fig. 193.

Answer to inquiry of C. H. Rolerts; occurrence on cherry-trees of Aplis $[=$ Myzus $]$ cerasi, and of its enelwies, the larva of Hippodamia convergens and Syrphus sp.; fignre of the larval, pupa, and imago of the former; positions in which both speeics transform.

1252. [Riley, C. V.) Grape-vine flea-beetle. <Amer. Ent. and Bot., September, 1870, v. 2, p. 309.

Answer to incuiry of C. II. Roberts; ravages of Halticn chalybea; means against this species and Selandria vitis $[=$ Blennocampa pygmea $]$ on grapevincs.

1253. [RrLey, C. V.] Blood-sucker and pear-slug. <Amer. Ent. and Bot., September, 1S70, v. 2, p. 309.

Answer to inquiry of G. A. Watson; food-lhabits of Pirates [= Melanolestes $]$ picipes and of Hemiptera in general; means against Selaudria $[=$ Eriocampa $\}$ cerasi.

1254. [Riley, C. V.] The codling-moth. (Carpocapsa pomonella, Linnaeus.) <Amer. Ent. and Bot., October, 1870, г. 2, pp. 321-322. Reprint: <3d Ann. Rept. State Ent. Mo., April, 1871, pp. 101-104.

Treats of Carpocapsa pomonella; see No 1301 for synopsis of contents.

1255. [RILeY, C. V.] Insects injurious to the grape-vine. No. 12. <Amer. Ent. and Bot., October, is70, v. 2, pl. 327-328, figs. 204-205. Reprint, with slight changes: <3d An11. Rept. State Ent. Mo., April, 1871, pp. 79-81, figs. 35, 36 ; Cultivator and Country Gentleman, 1 June, 1871, v. 36, j). 343.

Treats of Graptodera [= Haltica] chalybca; see No. 1301 for synopsis of contents.

1256. [Riley, C. V.] The fall army.worm. <Amer. Ent. and Bot., October, 1870, v. 2, pp. 328-329, figs. 206-207.

Seasons, food-plants, and ravages of Laphygma frugiperda; fignres larve of Leucania unipuncta and Laphygma frugiperda ; comparison between the latter and Heliothis armigera. 
1257. [RILEY, C. V.] The rape butterfly; our new cabbage pest. $<$ Amer. Ent. and Bot., October, 1870, v. 2, p. 338.

Spread of and means against Pieris rape.

125S. [Rlley, C. V.] Paris.green for the Curculio. <Amer. Ent. and Bot., October, 1s70, v. 2, p. 338.

Inefficacy of the use of Paris-green against Conotrachelus nenuphar.

1259. [RILEY, C. V.] Beetles working in wheat, oats, and rye; the grain Silvanus. <Amer. Ent. and Bot., October, 1870, v. 2, p. 339, fig. 208.

Answer to inquiry of M. H. Boye; figure, description, and ravagcs of Silvanus surinamensis; means against the same.and against Calandra granaria in grain; habitat and probable origin of the Silvanus.

1260. [Riley, C, V.] Beetles in dried English currants. <Amer. Ent. and Bot., October, 1870, v. 2, p. 339.

Answer to inquiry of T. V. Mfunson; Silvanus surinamonsis brecding abun: dautly in dried English currants.

1261. [RILEy, C. V.] The same in flouring-mills. <Amer. Ent. and Bot., October, 1870, v. 2, p. 339.

Answer to inquiry of S. Blanchard; abundance of Silvanus surinamensis in flouring-mills.

1262. [RIley, C. V.] Carolina Sphinx. <Amer. Ent. and Bot., October, 1870, v. 2, 1. 339.

Answer to inquiry of W. R. Howard; the larva of Macrosila [= Protoparce $]$ carolina feeds on tobacco.

1263. [RIley, O. V.] Insects clustered on apple-trees. <Amer. Ent. and Bot., October, 1870, v. 2, p. 339.

Answer to inquiry of R. L. Ham; habits and food of Psocus venosus.

1264. [RIley, U. V.] Larræ named. <Amer. Ent. and Bot., October, 1870, v. 2, p. 339 .

Answer to inquiry of T. W. Gordon; stinging powers of the larve of Empretia stimulea and Hyperchivia varia $[=i 0]$; Microgaster sp. parasitic upon Hacrosila quinquemaculata [ = Protoparce coleus].

1265. [RILey, C.V.] Mite-gall on sugar-maple. <Amer. Ent. and Bot., October, 1870 , v. 2, p. 339.

Answer to inçniry of A. Furnas; description of gall of Acarus aceris-crumcna n. sp. on" leaves of sugar-maple; similar mite-galls occur on plum and cherry.

1266. [Rilet, C. V.] Cheese-fly and blow-fly. <Amer. Ent. and Bot., October, 1870, v. 2, p. 339.

Answer to inquiry of B.; skippers in cheese are larvæ of Piophila casei; those found in bacon of Calliphora vomitoria.

1267. [RILEY, O. V.] Fall army-worm. <Amer. Ent. and Bot., October, 1870, v. 2, p. 340.

Answer to inçniries of K. Kelsey and G. Panls; seasons, ravages, and foodplants of Laphygma frugiporda; sensons and food-plants of Leucania unipuncta. 
1268. [RILeY; C. V.] Larva of imperial moth; Thoas swallow-tail. <Amer. Eut. and Bot., October, 1870, v. 2, p. 340.

Answer to inquiry of G. M. Dodge; larva of Ceratocampa [= Eacles] imperialis feeds on maple.

1269. [RILex, C. V.] Large Asilus fly. <Amer. Ent. and Bot., October, 1870, v. 2, p. 340.

Answer to inquiry of L. G. Saffer; food-habits of Iromachus rertebratus, $P$. $[=$ Erax $]$ bastardii, and Asilus missouriensis $[=$ P'roctuonuthens milbertii $]$; oceurrence of undetermined galls under white-oak trees.

1270. [Riley, C. V.] Mole cricket. <Amer. Ent. and Bot., October, 1870, v. 2, p. 340 .

Anstrer to inquiry of V. K. Deyo; habits of Gryllotalna borealis.

1271. [RIley, C. V.] A rare capture in Illinois. <Amer. Eut. and Bot., October, 1870, r. 2, p. 340.

Auswer to inquiry of H. S. Boutell; geographieal distribution of Callidryas philea; oceurrenee of Thysania zcnobia in Iowa.

1272. [Rlley, C. V.] Hag-moth larra. <Amer. Ent. and Bot., October, 1870 , v. 2, p. 340, fig. 209.

Answer to inquiries of D. M. Hunter and G. Panls; figure of larva and deseription of imago of Limacodes $[=$ Plobetrum $]$ pithecium; larva found on apple-tree; formation of its eveoon.

1273. [Riley, C. V.] Insects named. <Amer. Ent. and Bot., October, 1870, v. 2, p. 340 .

Answer to inquily of Mrs. E. U. B.; larva of Papitio astcrias feeds on parsnip; that of Alaria $[=$ Rhodophora $]$ florida on evening primrose; habits of the imingo of the latter.

1274. [RILey, C. V.] Some friends and foes. <Amer. Ent. and Bot., October, 1870, จ. 2, p. 340 .

Answer to inqniry of C. W. Spanlding; fond-habits of Harpactor [= Mrilyas $]$ cinctns, Mysia [=Anatis] 15-punctata, and Calosoma calidmm; Prionns imbricornis bred from grape-vine roots.

1275. [RILEy, O. V.] The royal-horned caterpillar. <Amer. Ent. and Bot., October, 1870, v. 2, p. 340 .

Answer to inquiry of J. T. Hodgen; larva of Ceratocampa [=Citheronia] regalis fonnd on persimmou.

12:6. [RILey, C. V.] Caterpillars named. <Amer. Ent. and Bot., October, 1870, v. 2, p. 341, fig. 210.

Answer to inquiry of E. H. King; fond-plants and descriptions of larve of Papilio asterias and of Acronycta oblinita; funetion of the osmaterium of the former; vernaenlar name aud figure of larva, eoeoon, and imago of the latter.

19i7. [RILex, C. V.] The Abbot Sphinx; parasites on its larva. $<$ Amer. Ent. and Bot., October, 1s70, v. 2, p. 341.

Answer to inquiry of T. W. Gordon; deseription of Thyreus abbotii; life-history of Mierogaster sp. parasitic on larvie of Sylhingide.

1278. [Rrler, C. V.] Crane-flies; rose-bugs; ants. <Amer. Ent. and Bot., October, 1870, v. 2, p. 341.

Answer to inquiry of J. W. Potts; fook-halits of Tipula sp. and of Macrodactylus subspinosus; strueture and habits of the several sexes of Formicide. 
1279. [Riley, C. V.] Cabbage-worms. <Amer. Ent. and Bot., Oetober, 1870, v. 2, p. 341.

Answer to inquiry of B. H. Foster; ravages of and means against Pieris rapa.

1280. [Rrley, U. V.] The unicorn prominent. <Amer. Ent. and Bot., October, 1870, v. 2, p. 341.

Answer to inquiry of E. Payno; description of larva and imago of Notodonta $[=$ Colodasys $]$ unicornis; food-plants and mimicry of the larva.

1281. [Rrlex, O. V.] Insects injurious to the grape-vine. No. 13. <Amer. Ent. and Bot., December, 1870, v. 2, pp. 353-359, figs. 218-219. Reprint with changes: <3d Ann. Rept. State Ent. Mo., April, 1871, pp. 84-96, figs. 37-40. See: <Bull. de la Soc. Cent. d'Agric., 1870.

Treats of Phylloxcra vastatrix; see No. 1301 for synopsis of contents.

1282. [Rilex, C. V.] The fall army-trorm. <Amer. Ent. and Bot., December, 1870, v. 2, pp. 363-365, figs. 221-223.

Descriptions of egg, larva, pupa, and imago of Prodenia autumnalis n. sp. $[=$ Laphygma frugiperda $]$; variation of the inagos; seasons, habits, and ravages of and means against the same; figures of larva and imago of Prodenia commeline and of imago of Leucania unipuncta.

1283. [RrLex, C. V.] The so-called web-worm of young trout. <A mer. Ent. and Bot., December, 1870, v. 2, pp. 366-367.

Editorial remarks appended to S. J. McBride's communication; description of Simulium piscicidium n. sp.

1284. [Rrley, C. V.] Hybria between a grape-vine and a hickory. <Amer. Ent. and Bot., December, 1870, v. 2, p. 373.

Correction of error in mistaking a gall of Cccidomyia vitis-pomum for a hybrid fruit.

1285. [RILey, C. V.] Death of noted entomologists. <Amer. Ent. and Bot., December, 1870, v. 2, p. 373.

Notice of death of Julius Letlerer and J. T. Lacordaire.

1286. [RIley, C. V.] Osage orange for the mulberry silk-worm. <Amer. Ent. and Bot., December, 1870, v. 2, p. 373.

Explanation of diff rences in cxperience in feeding silk-worms on osage orange.

1287. [Rilex, C. V.] Insects named. <Amer. Ent. and Bot., Decenber, 1870, v. 2, p. 373.

Answer to inquiry of Mrs. M. Chappellsmith; Astoma [= Trombilium $]$ locustarum parasitic on grasshoppers; similar mites on other insects; food-habits of Nemobius vittatus and Orocharis saltator.

1288. [Ruley, C. V.] Locust-borer. <Amer. Eut. and Bot., December, 1870 , v. 2, p. 373.

Answer to inquiry of W. R. Howard; seasons and method of oviposition of Arhopalus $[=$ Cyllena $]$ robinice in black-locust; description of eggs and imago of the same.

1289. [RIlex, C. V.] The northern lady-bird; its larva. <Amer. Ent. and Bot., Jecember, 1870, v. 2, p. 373.

Answer to inquiry of C. E. Billings; food-habits and description of larva of Epilachna borealis. 
1290. [Riley, C. V.] Not eggs, but parasitic cocoons. < Amer. Eut. and Bot., December, 1870, r. 2, p. 373.

Answer to inquiry of R. Conch; occurrence and true nature of cocoous of Mierogaster sp. on larva of Darapsa $[=$ Ampelophaga $]$ myron.

1291. [Riley, C. V.] The cabbage Plutella. <Amer. Ent. and Bot., December, 1870, v. 2, p. 374.

Answer to inquiry of C. E. Bessey; ravages of Plutella cruciferarum on cabbages.

1292. [Riley, C. V.] Gigantic rhinoceros beetle. <Amer. Ent. and Bot., December, 1870, v. 2, p. 374, fig. 224.

Answer to inquiry of "Subscriber;" figure of male and description of the male aud female of Dynastes tityus; distribution; food-habits of larva.

1293. [Rilex, C. V.] Bee-bread devoured by worms. <Amer. Ent. and Bot., December, 1870, v. 2, 1. 374.

Answer to inquiry of L. C. Francis ; food-habits of Ephestia zece [= interpunctella] and Galleria cereana; ravages of the former in old beehives.

1294. [RIley, O. V.] Rape butterfly. <Amer. Ent. and Bot., December, 1870 , v. 2, p. 374.

Answer to inquiry of J. E. Cowden; ravages of Pieris rape on cabbages.

1295. [Rrley, C. V.] Grape-leaf' gall. <Amer. Ent. and Bot., December, 1870, v. 2 , p. 574.

Answer to inquiry of H. C. Bcardsleo; occurrence of Phylloxera vastatrix at Painesville, Ohio.

1296. [RIley, C. V.] Bean weevil. <Amer. Ent. and Bot., December, 1870, v. 2, p. 374.

Answer to inquiry of $\mathrm{H}$. Kleinhans; ravages and distribution of Bruchus obsoletus.

1397. [RILEY, C. V.] Cabbage insects. <Amer. Ent. and Bot., December, 1870, v. 2, p. 374.

Answer to inquiry of W. R. Howard; ravages, distribution, and synongms of Plutella cruciferarum; first occurrence of Strachia $[=$ Murgantia $]$ histrionica in Missouri.

1298. [RIley, C. V.] Two-striped walking știck. <Amer. Ent. and Bot., December, 1870, v. 2, p. 374.

Answer to inquiry of C. R. Edwards; occurrence of Spectrun bivittatum in Kentucky.

1299. [Riley, C. V.] Ladder spider. <Amer. Ent. and Bot., December, 1870, v. 2 , p. 374 .

Answer to inquiry of L. G. Saffer; explanation of the vernacular name of Epeira $[=$ Argiope $]$ riparia.

1300. [RILey, C. V.] Sugaring for moths; preserving larvæ. <Amer. Ent. and Bot., December, 1870, v. 2, 1\%.374.

Answer to inquiry of H. S. Boutwell; occurrence of Papilio thoas $[=$ cresphontes $]$ in Illinois; directious for the preparation of a tluid for preserving caterpillars. 
1301. Riley, C. V. Third annual report on the noxious, beneficial, and other iusects of the State of Missouri, made to the State Board of Agriculture, pursuant to an appropriation for this purpose from the legislatare of the State. <6tb Ann. Rept. State Board of Agric. for 1870, April, 1871, pp. 176+7, 73 figs. Separate: Jefferson City, Mo., April, 1871, pp. 176+7, 73 figs.

CONTENTS.

PREFACE ...............................................

NOXIOUS INSECTS.

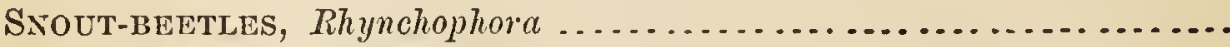

The whole vegetable kingdom and every part of each plant serve as food for insects, 5-Enumcration of insects affecting the different parts of the apple-tree, 5-Other food-habits of insects, 7Vast extent of the science of entomology, 8-Beauty and simplicity of classification in entomology, 8- Each family distinguished by its general appearance, 8--Unity of habits in each family, 9-Distinguishing characters of snout-beetles, 9-Their larvie, 10-They are among the most injurious beetles, 10-Injurious snont-beetles in Europe, 11.

The common plum Curculio, Conotrachelus nenuphar...............

It is single-brooded, 11-Experiments to prove this fact, 12-It hibernates as beetle, 13-Form of the egg, 13-Feeding liabits of the beetle, 13-Creaking noisc produced by it, 14-Stridulation in other insects, 14-It is nocturnal rather than diurnal, 14Habits of the beetle at night, 14-Remedies, 15-The Ransom chip-trap process, 15; cxplanation of the process, 15 ; it is not so successful as anticipated, 15 ; it is not a ncw discovery, 16 ; number of Curculios caught by it, 16 ; its success dependent on the character of the soil, 17; directions for using the process, 17; more experiments nceded, 17 -Offering premiums for collecting specimens, 17-Absurdity of the application of Paris greell for the Curculio, 18-Jarring by machincry, 18-The Hull Curcnliocatcher defective in several respects, 18-The Ward Curculiocatcher, 20 ; how it could be improved, 20 ; rules for using the machine, 21-Curculio-catcher invented by Claxton \& Stevens, 22-Hooten's Curculio-catcher, 22; its advantages and mode of operation, 24-Two true parasites of the Plum Curculio, 24-The Sigalpluus Curculio parasite, 24; Fitch's account of it, 25; Walsh's doubt abont its being parasitic on the Curculio, 25 ; experiments and observations proving that it is a parasite of the Curculio, 25 ; its development and frequent occurrence around St. Louis, 25 ; it attacks also other soft-bodied larva, 26 ; points in its natural history, 26 ; its position in the system, 27 ; description of the imago, larva, pupa, cocoon, and of the var. rufus, 27--The Porizon Curcilio parasite, 28; how it differs from the foregoing, 28; description of the imago, 28-Importance of the work of these parasites of the Curculio, 29-Artificial propagation and distribution of parasites, 29.

The apple Curculio, Anthonomus quadrigibbus....................

How it differs from the plum Curculio, 30-Its natural history, 30Food-plants, 30-The punctures it drills into the fruit, 31-The egg, 31-The larva aud its habits, 31-The larva transforms within the fruit, 32-Amount of damage it does, 33-How its 
1301. Riley, C. V.-Continued.

work in the fruit can be distinguished from that of other insects, 33-It is very injurious in Sonthern Illinois and parts of Missouri, 33-It is less injurions to apples than the plum Cureulio, 33-Injury done by it to pears, 33-The rot in apples prineipally produced by it and by the plum Cureulio, 34-Season of its appearance, 34-Remedies and preventive measures, 34-Deseription of larva and pupa, 35 .

The quince Cureulio, Conotrachelus cratagi .....................

Its food-plants, 35-It is very injurious to the quince in the East, 36-Dr. Trimble's aeeount of the damage done by it, 36- How the beetle differs from the two preeeding Curenlios, 36-Its transformations and habits, 37-Its puneture on the fruit, 37-It hibernates in the larva state, 37-Its larva mistaken by Dr. Fiteh for that of the plum Cureulio, 38-The imago state lasts only two months, 38-It does not attack the apple, 38-Remedies, 38-Description of the larva and pupa, 39 .

The plum-gouger, Coccotorus scutellaris .......................

How it differs from the preeeding speeies, 39-Injury eaused by it, 39-Food-plants, 40-It is often mistaken for the plum Cureulio, 40-Season of its appearanee, 40-Holes bored by it in the fruit, 41-The larva lives within the kernel of the fruit, 41-Remcdies, 41

The strawberry erown-borer, Tyloderma fragaria .................

Distribution of the insect, 42-Injury done by it, 42-Habits and charaeters of the larva, 43-Habits of the beetle, 43-Remedies, 43-Parasite, 44-How the larva differs from that of the grapevire Colaspis, 44-Deseription of the imago and larva, 44.

The pea-weevil, Bruchus pisi ..............................

Inseet enemies of the garden-pea, 44-Charaeters of the Bruchida, 45-Habits of other species of Bruchide, 45-Frequent oceurrence of its larva in green peas, 45-Charaeteristics of the beetle, 46It is in all probability an indigenous North American inseet, 46The beetle does not sting the peas, $46-$ The eggs are fastened by the female beetle on the outside of the pod, 47-The larva and its habits, 47-Its transformations, 47-Remedies and preventives, 48-Examination of peas intencled for secd, 48-Coneerted action neecssary to exterminate the insect, 48-Mr. Saunders's aeeount of the oecurrence of the pea-weevil in Canada, 49-Other preventive measnres, 49-Birds destroying the inseet, 50 .

The grain Bruchus, Bruchus granarius .........................

Its introduetion from Europe, 50-How it differs from the peaweevil, 50-Curtis's aecount of its habits in Europe, 51.

The American bean-weevil, Bruchus faba .......................

Food-plants, 52-Its geographical distribution, 52-Accounts of damage done by it in New York and Penusylvania, 52-It has only lately beeome injurious, 53-Habits of the larva and bectle, $54-$ The proper nomenclature of the spceies, 54-Deseription of the imago, 55-Its differences from allicd specics, 55-Note on deseriptions based upon individual variations, 56 .

The New York weevil, Ithycerus novcboracensis..................

Damage caused by it to fruit trees, 57-Former descriptions of the inseet, 57-Its breeding habits, 57-The pear blight not eaused by the beetle, 58 .

The imbrieated snont-beetle, Epicarus imbricatus ................

Injury done by it to vegetation, 58-Its natural history still unknown, 58-General appearanee of the beetle, 58. 
1301. Rilex, C. V.-Continued.

The corn Sphenophorus, Sphenophorus sculptilis..................

Damage caused by it to corn plants, 59-Characteristics of the beetle, 59-Its larval history still unknown, 59-Probable habits of the larva, 59-Walsh's description of the imago, 59.

The cocklebur Sphenophorus, Rhodobanus 13-punctatus ............

It is not injurious, 60 -Coloration of the beetle and its probable identity with S. 13-punctatus, 60-The larva, 60-Enumeration of other injurious swont-beetles, 60.

INSECTS INJURIOUS TO TUE GRARE-VINE

The grape leaf-folder, Desmia maculalis ........................

Its geographical distribution, 61-Generic chararters, 61-Charac. ters of the moth, 61-Sexual differences, 62-Habits of the larva, 62-Renedy and prevention, 62-Natural enemies, 62-Description of the larva, 62 .

The grape-vine epimenis, Psychomorpha epimenis................

Its larva formerly mistaken for that of the pearl wood nymph, 63Characters of the moth and sexual differences, $63-$ Habits of the larva when about to transform, 64-Its grape-vine feeding habits formerly unknown, 64-Description of the larva, 64 ; of the chrysalis, 65.

The grape-vine plume, Oxyptilus periscelidactylus ..................

Work of its larva and of that of the grape-vine Epimenis, 65-Both larvie rather beneficial when not too numerous, 65-Characters of the larva, 66-Peculiar form of the pupa, 66-Protective mimicry of the pupa, 67-Habits and appcarance of the moth, 67-Is it single or double-brooded, $6 \%$.

The common yellow bear, Spilosoma virginica....................

How the young larva differ from the mature larva of the grapevine plume, 68-Food-plants, 68-Color variations in the larvæ, 69-The chrysalis, 69-The inago, 69 -Parasite, 69-Remedy, 69.

The smeared dagger, Acronycta oblinita ......................

The larva is polyphagous, 70-Characters of the larva, pupa, and imago, 70-Remedy, 70-Parasites, 71-Description of imago and larva, 71 ; of the pupa, 72.

The pyramidal grape-vine worm, Pyrophila pyramidoides............

Distinguishing characters of the worm, 72-Its food-plants, 72Its transformations, 72-It is single or double-brooded according to latitude, 73-Its closely allied congener in Europe, 73-Remedies, 73-Description of the larva, 73; of the pupa and imago, 74-How it differs from Amphipyra pyramidea, 74-Description of the larva and imago of the spattered copper under-wing, 75.

The grape-root borer, Sciapteron polistiformis ...................

Its distribution, 75-Distinguishing characters of the larva, 76Its transformation, 76-Characters of the moth, 76-Description of the imago and its sexual differences, 76-Work of the larva on grape-roots, 77-Remedies, 77.

The spotted Pelidnota, Pelidnota punctata......................

It is usually not injurious, 77-The larva and its habits, 78-The beetle, 78-Description of the larva, 78.

The grape-vine flea-beetle, Haltica chalybea....................

It is well known to the grape-grower in Missouri, 79-Its distribution and food-plants, 80-Hibernation, 80-Damage done by the beetle in spring, 80-The eggs, 80-Damage caused by the larva, 80; their transformation, 80-Remedies, 80-Description of the larva and pupa, 81 . 
1301. Riley, C. V.-Continued.

The grape-vine Colaspis, Colaspis flavida ......................

Fitch's aeconnt of the inseet, 82-Varieties of the beetle, 82-The larva in all probability attacks sometimes that of the leaf-folder, 82-It lives on the roots of the strawberry, 82-Larva of the Enropean Colaspis barbara, 8:-Differenee in habits of larvis of allied species, 83-Singular charaeters of the larva of the grapc-vine Colaspis, 83-Work of the larva on strawberry roots, 83-Remedy, 84-Description of the larva, 84 .

The grape-leaf gall-louse, Phylloxera vastatrix....................

Its life-history not yet fully studied, 84-Previous aeconnts of the insect by Fitch,. Shimer, and Walsh, 85-The root disease in France, 85-The Phylloxera vastatrix reeognized as the cause of this disease, 85-Identity of the gall-louse with the root-iuhabiting insect, 86-The Auneriean and Europeau inseets are identieal, 86-Remedies tried in Francc, 86-The disease direetly eaused by the Phylloxera, 87-Injury done by the Phylloxera in Missouri, 87-Formiug of the gall, 87-Propagation of the lice and multiplieation of the galls, 88-The gall-liee deseend in the latter part of the season to the roots, 88-Change of the inseet after passing from the leaves to the root, 88-Questions still to be settled in the life-history of the Phylloxera, 88-Rare ocenrrence of the winged form, 89-The inseet can be transported from one place to another on roots, 89-It hibernates on the roots, 89-Grape-vines that should be planted, $89-$ Number of indigenous speeies of the grape-vine, 90-Grape-vines which are most seriously infested with the grape-leaf louse, 90-Danger in planting the Clinton among other grapes, 91-Insects aequiriug different food-habits as illustrated in the apple-maggot and the pine-leaf seale, 92The different forms of the grape-leaf louse, 93-Diseussion on the proper place of the insect in the classifieation, 93-On Dr. Shimer's proposed new families Dactylospharide and Lepidosaphida, 93-Objeetions to Fitch's specifie name vitifolik, 95-Identity of the European with the Ameriean inseet, 95-The apple-root louse is identieal with the woolly Aphis, 95-The gall-inhabiting form of the Phylloxera identical with the root-inhabiting type, 96Characters of the genus Phylloxera and its plaee in the system, 96.

The Colorado potato-Beetle aGain, Doryphora 10-lineata........

Its onward mareh, 97-It invades the Dominion of Canada, 97How it erossed Lake Miehigau, 97-It will probably spread through Ontario unless preventive measures are taken, 98-Exeellent chance to prevent its spread in Canada, 98-The Paris green remedy, 99-It is effieient if judieionsly applied, 99-It does not affeet the tuber, 99-Natural cheeks to the increase of the potato-bcetle, 100-The great Lebia destroying the larvie, 100-Bogus cxperiments, 100-The true remedy, 101-How to prevent the inseet from becoming too numerons, 101-Planting early varieties of potatoes, 101 .

The Codling-Moth AGAIN, Carpocapsa pomonella .................

Hay-bands around the trunk of the trce more cffectual than rags placed in the fork, 102-The codling-moth is single-brouded in the more northern countries, but donble-brooded in the latitude of St. Lonis, 102-Sexual differenees of the motl, 103-Scxual charaeters in the gencra Argynnis and Grapta, 103-The codlingmoth also infests peaches, 103. 


\section{Rlley, C. V.-Continued.}

'I'HE CORN-WORM alias BoLL-worM, Heliothis armigera.............

Its geographical range, 104-Injury done by it to corn, 104-It attacks tomatocs and other plants, 105-Food-plants of the stalkborer, 105-The egg of the corn-worm, 105-Mr. Glover's acconnt of the habits of the boll-worm, 106-The larva is very variable in color, 107-Its transformations, 107-Number of annual broods, 107-Amount of damage done by it, 107-Remedies, 108-Attracting the moth by sweets, 103-Hcard's moth-trap, 109.

THE FALL ARMY-WORM, Laphygma frugiperda ...................

Reports of its appearance in 1870, and how it was generally mistakcn for the true army-worm, 109-It was also mistaken for the boll-worm, 111-Injury caused by it, 111-How it differs from the true army-worm, 112-It is a very variable species in the imago state, 113-The spiderwort ow let-moth, and how it differs from the fall arny-worm moth, 113-Number of annnal broods and time of appearance of the fall army-worm, 114-'The eggs and how they are deposited, 114-Preventive measures, 115-It is never injurious during two consecntive jears, 115-Parasitic checks, 116-Description of the imago, 116; of the varieties and the earlier states, 117 .

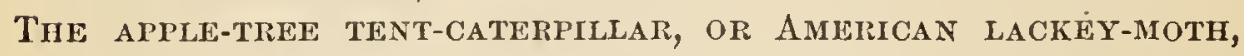
Clisiocampa americana...............................

The web-nests of the caterpillar and importance of their destruction, 118-The egg-mass, 118-The caterpillar and its liabits, 119Transfornations of the insect, 119-The imago very variable in color, 119-Food-plants of the catcrpillar, 120-Remedies, 120Parasites and enemies, 120.

The tent-Caterpillar of the forest, Clisiocampa disstria ........

The egg-mass and how the eggs are deposited by the fcmale moth, 121-Developmen t of the larva, 122-Fitch's description of the fnllgrown larva, 123-Confusion arising from want of uniform rule in describing larvæ, 123-The cocoon, 124-The chrysalis and the moth, 124-The web spun by the caterpillar, 124-Mr. Ferris's observations on differences in habits, appearance, and food-plants of the caterpillar, 125-Phytophagic varieties or species, 127Food-plants of the caterpillar, 127-Its destructive powers, 127Remedies, 128-Natural enemies and parasites, 128-Snmmary, 129.

THE FALL WeB-Worm, Hyphantria cunea ......................

It is often mistaken for the tent-caterpillars, 130-It feeds upon almost every kind of tree and shrub, 130-The wcb spun by the worm, 130-General appearance of the worm, 130-The chrysalis and imago, 131-Nnmber of aunual broods, 131-Plants it prefers, $131-$ How it differs from the tent-catcrpillar, 132-Remedies, 132-Description of the larva, 132.

The Blui-SPaNgled PEACH-Worm, Callimorpha lecontei ............

Winter retreat of the larva, 132-General appearance of the larva, 133-Chrysalis and imago, 133-Callimorpha vestalis Packard synonymous with C. fulvicosta, 133-Food-plants, 134-Description of the larva, 134 .

The AsII GRAY PINION, Lithophane cinerea .....................

Food-plants of the larva, 135-Transformations of the insect, 135Characters of the moth, 13\%-Dcscription of larva and imago, 135-Remarks on allied species, 136. 
1301. Riley, C. V.-Continued.

\author{
BENEFICIAL INSECTS.
}

THE GLASSY-WINGED SOLDIER-BUG, Campyloneura vitripennis .........

It preys upon different species of leaf-hoppers, 137-Its larva and pupa, 138-How it seizes its prey, 133-Coloration of the insect, 138-It was never observed before to attack the leaf-hoppers of the grapc-vine, 139-Habits of the Phytocoride, 139.

\title{
INNOXIOUS INSECTS.
}

The White-lined Morning Spinnx, Deilephila lincata.

Resemblance of the moth to a humming bird, 140--Interest attached to the study of lepidopterous larva, 140-Larval variations in the same specics, 141-Food-plants of the larva, 141The light and dark colored forms of the larva, 142-Its geographical range, 142-Parasite, 142.

TwO OF OUR COMMON BUTTERFLIES .........................

Tho archippus butterfly, Danais archippus .....................

Synonymy of its specific name, 143-Its geographical distribution, 143-Characters of the Danaide, 143-Sexual differences, 143Food-plants, 144-Hibernation, 144-Two annnal broods, 144Description of the egg, 144-The larva and its larval changes, 145-How the horns of the larva become longer at each molt, 145-The full-grown larva, 146-Interest attached to the metamorphoses of insects, 146-How the larva becomes a chrysalis, 147-The hardened chrysalis, 147-Duration of the chrysalis state, 147-The issuing of the butterfly, 148-Protective colors of insects, 148-Nauscons odor of the archippus butterfly in all its stages, 149-The Tachina-parasite of the archippus larva, 149Action of the parasitized larva, 149-How the Tachina larva and other inscets prepare the lid of their puparia, 149-Characters of this Tachina-fly, 150-Difficulties of the study of the Tachinarie, 150-Two forms occurring in Tachina archippivora, 150The butterfly often congregating in inmense swarms, 151-Probable reasons of this assembling in swarms, 152.

The disippus butteifly, Limenitis disippus....................

Distinguishing eharacters of the Nymphalide, 153-Food-plants and geographical range, 153-The egg, 153-Deseription of the ogg, 154-Development of the larva, 154-Description of the inature and young larva, 154-The insect hibernates as young larva, 155-Case prepared by the larva for its winter quarters, 155Modifications of the case, 156 -Peculiar habit of the autunual larvæ, 156-Parasites, 15\%-Tachina-fly, 15\%-The Disippus eggparasite, 157-The disippus Microgaster, 158.

Mimicry as illustrated by these two butterflies, with some remarks on the theory of natural selection .........................

Conformity of color between animals and their surroundings, $159-$ Detinition of the term "mimicry," 160-Pungent odor possessed by the Danaide, 160-Their mode of flight, 160-Protection they derive from their peculiar odor, 161-Pieride and Danaide in the valley of the Amazon, 161-Mimetic forms of Pieride, 161-Explanation of the origin of mimetic forms, 162-Mimicry between the archippus and disippus butterflies, 163-The ursula butterfly, 163-Its caterpillar and chrysalis undistinguishable from those of the Disippus, 163-Its imago has no protectivo color, 164-Mr. Bennett's objections to the theory of natural selection producing mimetic forms, 165-Mr. Seudder's objections, 166Discussion of Mr. Sendder's arguments, 167-Mr. Murray's ob- 
1301. Riley, C. V.-Continued.

jections to the connection between mimetic resemblances and natural selection, 170-Natural selection not the only power prodncing mimicry, 171-Reasons for discussing in this report the theory of natural selection, 172-Natural selection involves belief in the doctrine of evolntion, 173-Darwinism is neither irreligious nor atheistic, 174 .

1302. RILey, C. V. Snout-beetles injurious to fruits. <Trans. Ill. Hortic. Soc. for 1870, 1871, n. s., v. 4, pp. 89-124, figs.1-11. Reprint, with additions and omissions : <3d Ann. Rept. State Ent. Mo., April, 1871, pp. 5-44, figs. 1, 3, 4, 7-14.

See No. 1301 for synopsis of contents.

1303. Rilex, C. V. Bark-lice on rose bushes. <Moore's Rural New Yorker, 24 June, 1871, r. 23, p. 393. S.-b. No. 4, p. 3.

Answer to inquiry of W. A. French; occurrence of and means against Lccanium rose $[=$ olece $]$ and Diaspis rose on rose bushes.

1304. Riley, C. V. Canker-worms; not army-worms. <Moore's Rural New Yorker, 24 June, 1871, v. 23, p. 393.

1305. Riley, C. V. How to distinguish between Limenitis disippus Godt., and $L$. ursula Fabr., in their preparatory states. $<$ Ca. Ent., July, 1871, v. 3, pp. 52-53, fig. 24.

Description and figures of structural cliaracters distinguishing the larva and pupa of Limenitis disippus from those of L. ursula; see No. 1306.

1306. Riley, C. V. Friendly notess. <Ca. Ent., September, 1871, v. 3, pp. 117-119.

Distinctive structural charaeters of pupæ of Limenitis disippus and L. ursula; criticism of W. Couper's articles; description, food, and babits of Gelechia [=Holcocera $]$ glandulella n. sp.; reviow of statements concerning the dimorphism of Grapta interrogationis.

1307. Rilex, C. V. Friendly criticism. <Gardener's Mo. and Hortic., November, 1871, v. 13, p. 341.

Inefficacy of the roller remedy for potato-beetles and grasshoppers; identifies "Mclolontha philophaga" as Lachnosterna quercina [=fusca].

1308, Riley, C. V. Parasites on fowls. The chicken mite. <Moore's Rural New Yorker, 16 December, 1871. S.-b. No. 5, p. 31.

Answer to inquiry of H. Hales; injuries to fowls cansed by Dermanyssus galline? [= avium].

1309. RILEY, C. V. The American Entomologist. <Cultivator and Country Gentl., 21 December, 1871, v. 36, p. 809. Reprint: <Gardener's Mo. and Hortic., January, 1872, v. 14, p. 23. <Ca. Ent., Januar5, 1872, v. 4, p. 19.

Announcement of the continned suspension of publication of the American Eutomologist.

1309a. [RILEx, C. V.] (Lxodes bovis.) <Rept. Comm. of Agric. on the diseases of cattle. Washington, 1871, p. 118, fig.

Description and figure of Lxodes bovis n. sp.

1310. Rluer, C. V. The acorn moth. Holcocera glandulella, n. sp. <Ca. Eut., January, 1872, v. 4, pp. 18, 19.

Description of larva and imago of Holcocera glandulella n. sp.; habits of larva; food-plant and description of larva of Balaninus rectus. 
1311. Riley, C. V. Fourth annual report on the noxious, beneficial, and other insects of the State of Missouri, made to the State Board of Agriculture, pursuant to an appropriation for this purpose from the legislature of the State. <7th Ann. Rept. State Board of A gric. for 1871, April, 187ะ, pp. 146+6, 66 figs. Separate: <Jefferson City, Mo., April, 1872, pp. 146+6, 66 figs. Notice: < Horticulturist, Angust, 1872, v. 27, 1). 251. <Ent. Mo. Mag., July, 1872, v. 9, 1. 47.

\section{CON'TEN'TS.}

Preface

NOXIOUS INSECTS.

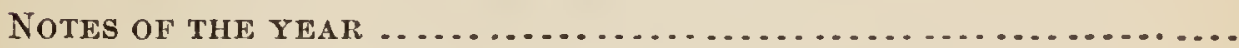

The Colorado potato-beetle, ${ }^{*}$ Doryphora 10 -lineata ...............

Its injuries in 1871,5-Its appearanee in great numbers in early spring, 5-Exorbitant price of Paris green, 6-Natural enemies of the beetle very abundant, 6-Diminution in numbers of the beetle later in the season, 7-Causes of sueh diminution, 7-Damage eaused by the potato-beetle in Missouri, 7-It invaded Canada in 1870, 8-The three-lined potato-beetle mistaken for it in New York and Massaehusetts, 8-Its further spread eastward irresistible, 8-Slow spread of the inseet in the South, 9-Its presont extent northward, 9-It spreads but does not leave the distriets al ready invaded, 9-It is not injurions to potatoes in Colorado at a eertain altitude, $10-$ New food-plants, $10-$ It feeds upon eabbage, 10-Its hibernation, 11-Objections raised against the nse of Paris green, 11-Paris green is an effieient remedy and now in general use, 12-Box for dusting Paris green, 12-Mixing the poison with diluents, $12-$ No serious eases of poisoning have eome to knowledge, 13-Anticlote for Paris green; 13-Other applieations, 13-Messrs. Saunder's and Reed's experiments with various substanees, $14-$ Experiments with deeoctions of various plants, 15-Air-slaeked lime as a remedy, 15-Mechanieal means, 15-Squire's brushing machiue, 15-Creighton's improved patent inseet destroyer, 15-Disadvantage of all meehanical means, 16A simple and effeetive way of brushing off and killing the bugs, 16-Natural enemies inereasing, 16-Chiekens aequiring a taste for eggs and larve of the beetle, 16-Spiders are among its enemies, 17-The 15-spotted lady-bird and its larva, 18-The iey lady-bird, 18-The ring-banded soldier-bug; 19-The dotted-legged plant-bug, 19-The spined soldier-bug in its earlier states, 20The Nebraska bee-killer, 21-The Kansas bombardier-beetle, 21Rove-beetles of the genera Philonthus and Quedius, 21.

The eodling-moth again, Carpocapsa pomonella................

Time of year that the first moths appear, 22-Time required for development, 22-Proper time to apply the bandages around the tree, 22-It attaeks peaehes, 22-Best kind of bandages, 23Wier's apple-worm trap, 23-Advantages and disadvantages of the trap, 24-Overestimating the value of Wier's trap, 25-Jarring, 25-Mr. Chapin's method of knoeking down the wormy apples, 26-When this operation should begin, 26-Fires, lights, and bottles of liquid not to be recommended as a remedy, 27-Worthlessness of Todd's book, "The apple eulturist," 20 -Natural ene- 


\section{Riley, C. V.-Continued.}

mies, 28-The Penusylvania soldier-beetle and its larva, 28-The two-lined soldier-beetle and its larva, 29-Description of the larva of Telephorus bilineatus, 30-Summary, 30.

The periodical Cicada, Tibicen septendecin .......................

Reproduction, with corrections and additions, of the chronological table of Broods I to VI from Report I, 31 .

The grape-vine Colaspis again, Colaspis flavida .................

Redescription of the larva from woll-preserved specimens, 34.

The haRlequin CabBage-BUg, Murgantia histrionica ...............

It was not known in Missouri prior to 1870, 35-Its geographical range and color variations, 35-Insect enemies of the cabbageplant, 35-Dr. Lyncecum's account of its habits and injury caused by it in Texas, 36-Its appearance in Missouri in 1870, 36-The egg, 37-The larva and pupa, 37-Several annual broods, 37-The mature bug, 37-Injury caused by it, 37-Its congener in Europe, 38.

The rascal Leaf-CrUMpler, Acrobasis indignella ..................

Its proper scientific name, 38-It is hardly noticed in summer time, 38-Injury caused by it, 39-It hibernates as larva, 39-Habits of the larva, 39-The larval case, 39-Characteristics of the moth, 39-Food-plants, 39-Remedies, 40-Natural enemies, 40-Le Baron's description of Tachina phycite, 40-Limneria fugitiva, 41Desicription of imago, larva, and chrysalis of the rascal leafcrumpler, 41-Description of the variety nebulella, 42.

The walnut Case-Bearer, Acrobasis juglandis ..................

Other casc-bearers enumerated, 42 -The case of the walnut casebearer, 42-Differences between the moth and that of the rascal leaf-crumpler, 43-Natural enemies, 43-Description of Perilitus indigator, 43.

The aPPle-leaf Skeletonizer, Pempelia hammondi ...............

Its work on the leaves of apple-trees, $44-$ The worm and the chrysalis, 44-Appearance of the moth, 45-Mr. Hammoud's account of the injury caused by the worm, 45-The European Acrobasis consociella, 45-Remedies and parasites, 45-Description of the imago, larva, and pupa, 46.

THE GREEN APPLE LEAF-TYER, Teras cinderella .................

It occurs almost always in company with the foregoing, 46Characters and habits of the worm, 46-The chrysalis, 47-Deseription of imago, larva, and chrysalis, $4 \%$.

THE LESSER APPLE LEAF-FOLDER, Teras malivorana ................

Its larva and pupa closely resemble those of the foregoing species, 47-Mr. Wier's account of its habits, 48-Remedy, 49.

The apple-leaf BuCCUlatrix, Bucculatrix pomifoliella ............

It is not very injurious in Missouri, 49-Account of damage caused by it in New York, 50-The worm and its habits, 50-Its transformations, 50-Season of the appearance of the moth, 50-Remedies, 50-Habits of Bucculatrix thuiella, 51-Description of larva and pupa of the apple-leaf Bucculatrix, 51 .

The APPLE-TWIG BORER, Amphicerus bicaudatus..................

Its frequent occurrence in Missouri, 51-Character's of the beetle, 52-The holes made by it in the twigs, 52-The holes are made only for food and protect:on, 52-The insect breeds probably in the sap-wood of forest trces, 52-The larva of Sinoxylon basilare mistaken for that of the apple-twig borcr, 52-Remedy, 53. 


\section{Riley, O. V.-Continued.}

INSECTS INJURIOUS TO THE GRAPE-VINE ....................

The red-shouldered Sinoxylon, Sinoxylon basilare ................

Characteristics of the insect as imago, larva, and pupa, 54-Damage done by it to grape-rines, fruit trees, and hickory, 54-Description of the larva and pupa, 54.

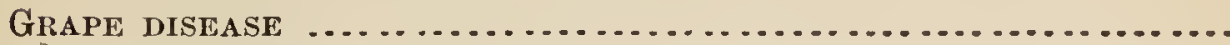

The grape-leaf gall-louse, Phylloxera vastatrix...................

Its scientific name, 55-The law of priority, 55-European grapevines valueless in the eastern United States, 55-Deterioration of some of our native vines, 56-Climatic reasons for the failure of Enropean vines, 56-The principal cause of this failnre is the Phylloxera, 56-Further proof of the identity of the American with the European insect, 57-Reasons for the identity of the gall-louse with the root-louse, 57-Further facts respecting the habits of the root-lonse, 58-Underground forms, 58-The young lice and their habits, 59-Hibernation, 59-The pupa, 59The winged female, 59-Susceptibility of different vines to the attacks of the louse, 60-Classification of the North American grape-vines according to their practical inportance, 60-Synopsis of the true grape-vines of the United States, by Dr. George Engelmann, 60-Difficulty of separating the cultivated varieties of grape-vine, 61-Importance of a proper classification of cultivated grape-vines, 62-Importation into Europe of resisting American vines, 62-Enumeration of the cultivated varieties and their susceptibility to the disease, $63-$ No variety is entirely exempt from the attacks of the root-louse, 64-American vines which resisted the root-louse in Europe, 64-Means of contagion from one vine to another, 64-The spread of the root-lice from one vine to auother, 64-Transportation of the louse npon the roots of seedlings and cuttings, 64-Spread of the disease in France, 64-The winged female of the root-lonse and her function, 65-The vernal leaf-gall, 65-Preference of the winged Phylloxera for the Clinton grape and its allies, 65-Power of flight of Phylloxera caryafolia, 66-Deposition of the eggs upon the leaf, 66-Probable rcasons why the injuries of the Phylloxera are greater in Europe than in America, 66-Ontward and more visible effects of the root-disease, 67-Practical suggestions, 67No need to destroy the Clinton vines, 67-Influence of soil on the intensity of the disease, 67-Remcdies, 68-Destruction of the gall-lice, 68-Destruction of the root-lice, 68-Results of experiments in France with rarious substances, 68-Irrigation and submersion, 69-Resume of the insect's history, 69-No need of unnecessary alarn, 70 .

BENEFICIAL INSECTS.

\section{SILKWORMS}

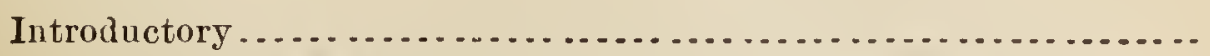

The Morus multicaulis fever and its reaction, 72-Increasing attention lately given to silk-culture in America, 72-North America well adapted to the raising of silk, 73-General ontlines of the natural history of the eight species of silkworms treated of in this report, 74 . 
1311. Riley, C. V.-Continued.

The mulberry silkworm, Sericaria mori.........................

Its past history, 75-Earlest silk-culturc in China and India.75Its introduction into Europe, 76-Vaiue of silk produced in France, 76-The "Silk Supply Association" in England, and its objects, 76-Countries exporting raw silk, 77-The name given to silk by different nations, 77-History of the mulberry silkworm in America, 77-Its introduction and fallure of earlicr efforts, 77-Renewal of silk-culture within the past decade, 77Silk manufacture in the United States, 78-Favorable prospects for raising silk in this country, 78-Silk-growing in California, 79-Mr. Prevost's "California Silk-grower's Manual," 79-False statements and exaggerations in Prevost's book, 79-Sale of Californian silkworm eggs, 80-Disastrous effect of the FrancoPrussian war on the egg trade, 81 -Success of silk-culture in California dependent on the ability to reel the silk, 81-Silk-enltnre in Kansas, 82-Mons. Boissière's silk establishment and its ehances of success, 82-Silk-growing in Missouri, 83-The fall season in Missonri eminently propitious for rearing silkworms, 84-Natural history of the silkworm, 84-Races of the silkworm produced by domestication, 84-Effects produced on the insect by domestication, 85-The egg, 86-Larva and larval ehanges, 86-Cocoon, chrysalis, and moth, 87-No insect parasite of the silkworm in Europe, 87-The "Uji" disease in China and Japan, 87-Diseases of the silkworm, 88; the Muscardine, its effeet and cause, 88; the Pébrine disease, its symptoms and eanse, 89; nature and origin of these diseases, 90-Other diseases of the silkworm, 91-Best varieties or races, 90-Different forms of eoeoons produced by different races, $92-$ How best to rear silkworms, 92-Rearing a very simple process, 92-Character of elimate of the Japanese sills districts, 93-Koeping the eggs dnring the winter, 93-Hatching of the eggs, 93-Room and building for the rearing of the worms, 93-The feeding net or fillet, 94Importance of carrying all the worms simultaneously through thcir molts, 94-Regularity of feeding, 95-Regulating the temperature, 95-Cocoonery, 96-Choking the elirysalis, 96-Egglaying, 97-Sclecting and fastening the cocoons for breeding purposes, 97-Treatment of the femalc moths after copulation, 97Preservation of the eggs, 97-Reeling, 98-Great skill required to accomplish the work properly, 98-Classification of raw silk, 98-Preparing the cocoons for reeling, 98-Olijects of and manipulations in recling, 99-Best food for the worms, 100-Varieties of the mulberry, 100-Cultivation of the mulberry, 100-Osage orange as silkworm food, 100-Introduction of the osage orange into France, 100-Experiments in America with feeding silkworms on osage orange, 101-Advantages and disadvantages of the osage orange, 102.

The cecropia silkworm, Attacus cecropia.......................

Changes made in its scientific generic name, 103-General appearance of the moth, 103-Fitch's explanation of the specific name, 104-Food-plants, 104-The cccoon, 104-Value of the cocoon as compared with that of the polyphcmus moth, 105-How the moth issues from the coconn, 105-The moth inmediately after hatching, 106-Tho egre, 106-Description of the lirral changes, 
1311. Ruley, C. V.-Continued.

106-Strange habit of birds of using the empty cocoon as a storohouse, 107-The cecropia worm can not be classed as an injurious insect, 107-Samia columbia ought to be considered a variety of cecropia, 107-Parasites, 107-The long-tailed Ophion, 107; its mode of oviposition, 108; habits of its larva, 108-The eccropia Tachina-fly, 108; low it affects its victim, 108; its larva and imago, 109-The Mary Chalcis-fly, 109; how it escapes from the cocoon of the moth, 109 ; description of the inago, 110-The cecropia Cryptus, 110 ; its habits, 110 ; description of the two sexes, 111; how it differs from the allied species, 111.

'The Ailanthus silkworm, Attacus cynthia......................

Difference between the silkworms of the castor-bean and Ailasthus, 112-Introduction of the Ailanthus silkworm into Enrope, 113Ailanthiculture in Europe, 113-Its introduction into America, 114-Disarlvantages of the Ailanthus silkworm, 115-Its acclimatization in A merica and Australia, 115-Valne of the cocoon, 115Mr. Forgemol's device for unwinding the cocoon, 116-Natural history of the Ailanthus silkworm, 117-The egg and node of egg-laying, 117-Larval changes, 117-Pupation, 118-The imago and its variations, 118-Food-plants, 118-Directions for raising the worms, 119-A good word for the Ailanthus tree, 120.

The promethea silkworm, Attacus promethea ...................

Value of the cocoon, 121-Mode of egg-laying, 121-Larval changes, 121-How the cocoon is fastened to the twig, 129-Striking sexual difference in the moth, 122-Callosamia angulifera onght not to be considered as a different species, 12:-Food-plants of the worm, 123-Natural enemics, 123.

The 1una silkworm, Actias luna ............................

The beautiful appearance of the moth, 123-The cocoon, 124-Foodplants, 124-Larval changes, 124-Season when the imago issues, 125-No parasites of the worm known, 125-Actias selene probably identical with luna, 125.

The polyphemus silkworm, Telea polyphemus .................

Mode of egg-laying, 125-The egg, 126-Food-plants, 126-Larval ehanges, 126-The cocoon, 126-Mr. Trouvelot's acennit of tho issuing of the moth, 127-Wonderful vitality of the chrysalis, 127-Characters of the moth and its variations, 123-The broad antennse of the male moth mistaken for a third pair of wings, 128-Difficulty of reeling the cocoon, 129-Number of annual broods, 1:29-Parasites, 129 .

The yama-maï silkworm, Anthcrea yama-mai ...................

Its native home and food-plant, 130-Its introduction into Europe and Australia, 130-Attempts at raising it in Anerica, 130--The egg and how it should be kept over winter, 131-Climate most favorable for the worm, 131-The worm and its resemblance to the leaf, 132-Food-plants, 132-Larval changes, 132-The cocoon and the value of its silk, 133-The moth and its habits, 133-Difficulties of rearing the worm, 133-Mr. Adams's account of rearing the yama-maï worm in Japan, 134-The Uji parasite, 136.

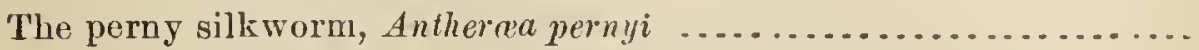

Its native home, 1:37-How it differs from the preceding, 137-Larval changes, 13\%-The cocoon and its silk, 137-The noth, 1:3Its culture in China, 138-The tusseh silkworm, 138. 
1311. RILEY, C. V.-Continued.

. Summary .............................................

Successful silk culture possiblo in this country, 138-Comparative value of the different species of silkworms, 138.

INNOXIOUS INSECTS.

The horned Passalus, Passalus cornutus........................

Its frequent occurrence in old logs, 139-The noise produced by the betle, 139-It occurs only in decaying wood, 140-1'Te larva and its cxceptional character, 140-Description of tho larva, 140-Previous description of Passalus larva, 141-Description of the pupa, 141.

The GREAT LeOPARD Moth, Ecpantheria scribonia .................

Characters of the larva, 141-Food-plants, 142-Hiberuation and transformations, 142-The imago, 142-The larva able to resist extreme cold, 143-Description of tho larva, 143.

The ISABella tiger noth, Pyrrharctia isabella..................

Characters of the larva, 143-Foodl-piants, 143-Cocoon and chrysalis, 143-The moth, 144-The popnlar name "fever-worm" in the South, 144-No parasite known of this and the preceding species, 144.

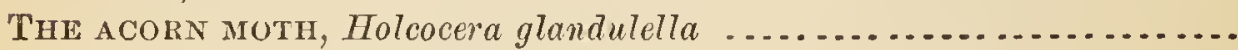

The egg laid in acorns that have been ruined by Balaninus rectus, 144-Habits of the larva, 144-Characters of larva and moth, 145-Description of imago, larva, and pupa, 145.

1312. Riley, C. V. Thomas Wier's apple-worm trap. <Amer. Agric., April, 1872, v. 31, pp. 142-143, 1 fig.

Description and figure of Wier's apple-worm trap.

1313. [RrLer, C. V.] Remarkable parasitic fungus. <Sci. Amer., 25 May, 1872 [v. 40], n. s., v. 26, p. 347.

Description and figure of unidentified fungus infesting the larva of the white grub, Lachnosterna fusca.

1314. Rrlex, C. V. Cut-worm lion. <Colman's Rural World, 15 June, 1872, fig. S.-b. No. 5, p. 47.

History of tho larva and inago of Calosoma calidum, an enemy to cut-worms.

1315. Riley, C. V. Uut-worms. < Cultivator and Country Gentleman, 20 June, 1872, v. 37, p. 392.

Dandelions and other weeds furnish food for young cnt-worms which hatch in the fall; land should bo kept clear of wecds at that season.

1316. Rntey, C. V. Flat-headed apple tree-borer in horse chestunt. <Colman's Rural World, 22 June, 1872, fig. S.-b. No. 5, p. 47. Answer to inquiry of S. S. R。 ; natural history of larva and imago of Chrysobothris femorata.

1317. Rulwy, C. V. A new insect. <Western Planter, 29 June, 1872. S.-b. No. 5, p. 49.

Answer to inquiry of F. Halsinger; Nysius 11. sp., very destrnctivo to potatoes.

1318. RrLer, C. V. Codling-moth; jarring down infested fruit. $<$ Cultivator and Country Gentleman, 4 July, 1872, v. 37, p. 422.

Excrement ontside of the fruit indicates the exit of the worm, with some varieties; with others the worm may be often found after the excrements are visible. 
1319. Riley, C. V. Food for silkworms. <Colman's Rural World, 13 July, 1872. S.-b. No. 5, p. 40.

Osage orange superior to red-mulberry.

1320. Riley, C. V. The apple maggot-fly, Trypeta pomonella Walsh. <Amer. Agric., July, 1872, v. 31, pp. 263-264, 2 figs.

Answer to letter of J. H. Spatter; eomparative deseriptions and figures of larvæ, pupæ, and imagos of Trypeta pomonella and Carpoeapsa pomonella ; figures slowing injuries of both speeies; distribution and means against Trypeta pomonella.

1321. Riley, C. V. Worms on Dutchman's pipe. <Colman's Rural World, 3 August, 1872, fig: S.-b. No. 5, p. 136.

Answer to inquiry of J. T. C.; life-history of Papilio philenor.

1322. Riley, C. V. Apple-leaf worn. The apple-leaf skeletonizer. $<$ Colman's Rural World, 10 August, 1872, fig. S.-b. No. 5, p. 138.

Answer to inquiry of L. R. Bryant; habits and times of appearanee of Pempelia hammondi.

1323. Riler, C. V. Eggs in grape-canes and apple-twigs. <Amer. Agric., August, 1872, v. 31, p. 302, figs. 1-7.

Figures of eggs and of twigs punctured by Orocharis saltator, Eeanthus niveus, and Ceresabubalus; figures imagos of the same; habits, deseriptions of eggs, and imagos of the three species.

1324. Riley, C. V. Borers in evergreens. <Gardener's Mo. and Hortic., December, 1872, v. 14, p. 373.

Larvæ of Monohammus litillator the worst enemy of the white-pine; another species of Cerambycide injurious to red-cedars; a host of bark-borers affect all kinds of evergreens.

1325. Riley, C. V. Einige unserer schädlicherer Insekten. <St. Louis, Mo., 1872, p. 35, il. S.-b. No. 19, pp. 174-190.

Causes of the deealence of vitieulture in the United States; habits, ravages, speeific identity, and figures of several stages of the leaf-inhabiting and root-inhabiting forms of Phylloxera vastatrix; identity of the European and American grapo Phylloxera; susceptibility of the different speeies of grape to the attacks of the same; priucipal manifestations of attack; preventive and renedial measures; description and figures of Conotrachelus nenuphar; habits, ravages, parasites, enemies, and means against it; description of Ransom's trap, Hull's, Ward's, and Hooten's machines for capturing the imagos; figures of the machines. Natural history, food-plants, distribution, enemies, parasites, and means against Doryphora decemlineata; figures of all stages of the same; use of Paris green and other powders; mechanical devices for eollecting the insects.

1326. Riley, C. V. Harvest mites. '<Amer. Nat., January, 1S73, r. 7, pp. 16-19, fig. 5. Extract : <Colman's Rural World, 21 June, 1876, 2 figs. S.-b. No. 10, pp. 170, 171.

List of inseet parasites on man; description, figures, habits of and means against Leptus $[=$ Tetranychus $]$ americanus $\mathrm{n} . \mathrm{sp}$. and $L .[=T$. $]$ irritans $\mathrm{n}$. sp.

1327. Riley, C. V. Vanessa antiopa. <Ent. Mo. Mag., January, 1873, v. 9, p. 195.

Habits and food-plants of Vanessa antiopa. 
1328. Riley, C. V. Entomological correction. <Cultivator and Country Gentleman, 6 March, 1873, v. 38, p. 149.

Lema trilineata does not occur in sonthwestern Missouri, as stated by W. R. Howard.

1329. RILEY, C. V. Fifth annual report on the noxious, beneficial, and other insects of the State of Missouri, made to the State Board of Agriculture, pursuant to an appropriation for this purpose from the legislature of the State. <8th Ann. Rept. State Board of Agric. for 1872, 18 A pril, 1873, pp. $160+8,75$ figs. Separate: <Jefferson City, Mo., 18 A.pril, 1873, pp. $160+8,75$ figs. Review by A. S. Packard, jr.: <Amer. Nat., August, 1873, v. 7, pp. 471-477, figs. 115-130. Reply to Packard and rejoinder by Packard : <Amer. Nat., March, 1874, v. 8. pp. 181-188.

CONTENTS.

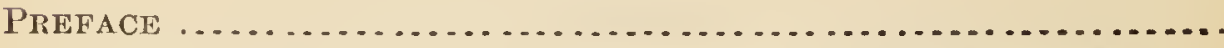

.Entomology, its relations to agriculture and its advancement* ....

Definition of cntomolog 5 , 5-The tcrm "insect," 5-The four subkingdoms of the animal kingdom, 6-Characteristics of insects, 7-Classification of insects, 8-Hymenoptera, 9-Coleoptera, 10-Lepidoptera, 11-Hemiptera, 12-Diptera, 13-Orthoptera, 14-Nenroptera, 14-Osculant and aberrant groups, 15-Importance of entomology as a study, 17-Economic importance of entomology, 18-Relation of insects to agriculture, 18-Damage inflicted by insects to agriculture and horticulture, 19-Progress of ecollomic entomỏlogy, 19-Economic entomology in Europe, 19-Insects in America much more injurious than in Europe, 21State entomologists and entomologists in public positions in the United States, 21-How to counterwork noxions insects, 23Prevention, 24-Checking the sprcad of injurious insects, 24Curc, 25-Modification of Dr. Hull's Curculio-catcher, 25-Encouragement of the natural enemics of injurious insects, 26Duties of a State entomologist, 27-Annual report, 27-Correspondence and other duties, 28 - How to collcet, preserve, and study insects, 29-Appliances for collecting, 29-Use of the umbrella, 29-The knapsack, 30-The hand-net, 30-The frame of the net, 30-The bag of the net, 31-Use of the sieve, 31-Sugaring, 32-Attracting moths by light, 32-How to kill insects, 32The cyanide bottle, 32-Use of chloroform, 33-Entomotaxy, 34--Insect-pins, 34-How to pin inscets, 34-How to mount small insects, 34--Spreading-board, 35-Drying-box, 36-Insect boxes and cabinet, 3\%-Mr. Lintner's boxes for Lepidoptera, 38-Substances for lining insect.boxes, 40-Preserving inscets in the collection, 41-Relaxing specimens, 41-Breeding insects, 41Breeding-cage, 42-Notc-book of the collector, $43-\mathrm{How}$ to transmit insects, 44-Text-books, 44.

NOXIOUS INSECTS.

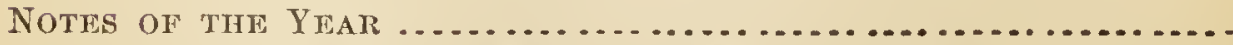

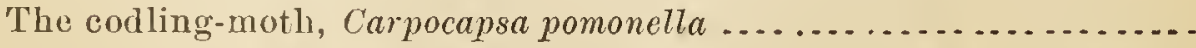

Experiments with Wicr's apple-worm trap, 46-Value of different matcrials for bandages, 47-Jarring, 48-Occurrence of the apple-

* Pages 17-27 were reprinted under titlo Entomology in <Rept. State Board Agric. Kiansas for 1873, 1874, pp. 266-274. 
1329. Riley, C: V.-Continued.

worm in California, 49-Enemies and parasites, 49-The ringlegged Pinpla, 49-The delicate long-sting, 50-Other enemies, 51-Efficiency of the spined soldier-bug, 51-False doctrines for exterminating the codling-moth, 51.

The Colorado potato-beetle, Doryphora 10-lineata................

Its comparative harmlessuess in 18\%2, 52-New food-plants, 5\%-

Its progress eastward up to 1872,52 -Experimonts with Paris grecn, 53-New enemies, 53-The rust-red social wasp, 54-The rose-breasted grosbeck, 54 .

The apple-twig borer, Amphicerus bicaudatus ..................

It attacks also pear twigs, 54-It has been brea from grape canes by Dr. Shimer, 54.

Egg of the horned Passalus, Passalus cornutus..................

The egg, 55-The newly latched larva, 55-Rapid developmeut of the insect, 55 .

Egg of the common May beetle, Lachnosterna fusca................

Description of the eggs and how they are deposited, 55.

Egrg of the broad-necked Prionus, Prionus laticollis ................

Characteristics of the eggs and where they are deposited, 56 .

Eggs of American tent-caterpillar, Clisiocampa americana..........

Correction of the figure given in Report III of the egrg-belt, 56.

Counterworking the tobacco-worm, Protoparce cclcus..............

Mr. White's method of planting the Jamestown weed among tho potatoes and poisoning the blossoms thereof, 56 .

The grape Piylloxera, Phylloxera vastatrix .....................

Its popular nane, 57-Accounts of the unusual mortality among grape-vines in the spring of $18 \% 2,57$ - Causes of this mortality given in the accounts, 59-Excessive drought and overbearing, 60-The Phylloxera is the true cause, b0-Actual proof of the Phylloxera having caused the mortality among grape-vines, $61-$ Influences that favored the increase of the lice in 1872, 61-Importance of a full understanding and managerncnt of the Phylloxcra, 62-Its range in North America, 62-Its spread in Europe, 63-Inconstancy in the habits of the gall-lice, 63-The leaves of the Clinton vine no longer affected by the gall-lico sinco 1871, 63-Method of formation of the leaf-gall, 64-Relative immunity of American vines in Europe, 64-Propagating American varieties from cuttings, 65--Appreciation of American vines in Lurope, 66-Careless statcment published as to the immunity of Labrusca vine, 66-Grafting the grape-vine, 67-New theories, 67-The Phylloxera is the true canse and not the effect of the disease, 67-Mr. Laliman's theory that the insect has always existed in Europe, 68-Oidium tuckeri of Europe and America idcutical, 69-Mr. Saunders's account of the yresence of Oidium tuckeri in America, 70-Means of contagion of the diseasc from one vine to another, 69-Flying capacity of the winged Phylloxera, 70-The male louse, 71 -Remedies, 71-Efficacy of carbolic acir and soot, 71-Value of submersion or irrigation, 72-Sprinkling.with quicklime, ashes, etc., 72-Mr. Lichtenstein's experiments to allure the lice, 72-Experinents with carbolic acid, 73.

The OYSTER-SHel, BARK-LOUSE OF THE APPLE, Mfylilaspis pomorum..

Its occurrence in Missouri, 74-Its appearance in Luray County, Missouri, 74-Mr. Hanan's account of its spread, 75-Its oceurrence in Southern Missouri, 76-Its occurrence in Mississippi and Georgia, 78-Its appearance in Kansas, 79-It is double-brooded 


\section{Riley, C. V.-Continued.}

in the South, 79-The waxy secretion of Homoptera, 80-The newly hatched louse, 80-'The larval scalc, 81-Devclopment of the female scale, $81-$ Growth of the male scale, 82-The male louse, 83-Rare occurrence of the winged male, 84-Agamic multiplication, 85-Mode of spreading, 85-Food-plants, 86-Varioties of the applc-tree preferred by it, $86-$ Enomies and parasites, 87; mites, 87; Aphelinus mytilaspidis and Dr. Le Baron's account of its habits, 88-Easy transportation and introduction of the Aphelinus, 90-Remedies, 90-Application of oily substances, 90-Bibliographical and descriptive, 91-The generic name, 91Signoret's classification of the Coccide, 92-Spccific name, 92Characteristics and habits of three allied species, 93-A new name necessary for our applc-tree specics, 94-Description of the eggs and the winged male, 95 ; of the male and female scale and of the female louse, 96.

THE PINE-LEAF SCALE-INSECT, Chionaspis pinifolii ...................

Nature of the malady cansed by it, 97-Natural history of the insect, 98-The male, 99-There are two aunual broods, 99-It is confined to the pines proper, 100-Natural encmies, 100 ; the twice-stabbed lady-bird, 100 ; the painted lady-bird and rlescription of its larva, 101-Remedies, 101-Stripping the old leaves, 102-Application of powdered and liquid substances, 102.

THE HICKORY BARK-BORER, Scolytns 4-spinosus ...................

Accounts of the damage caused by it in Missouri, 103-Habits of the Eliropcan Scolytus destructor, 104-Varions kinds of hickory attacked by the hickory bark-borer, 105-Its natural history, 105-Natural enemies, 106-Description of the three-banded Spathius, 106-Mr. Cresson's description of Bracon scolytivorus, 106-Remedies, 107-Description of the imago, 107-Is it different from Scolytus 4-spinosus? 107.

The rosie CHAFer, Macrodactylus subspinosus....................

Great damage caused by the bcetle in 1872, 108-Remedy, 109Harris's account of its natural history, 109.

Tine FaLSE CHINCH-BUg, Nysius angustatus .....................

It was not known as injurious before 1872,111 -Accounts of injury done by it, 111-How it differs from the true chinc'i-bug, 112Its probable natural history, 112-Description of imago, larra, and pupa, 113-Variation in the imago, 113-Its great abundance in the fall of 1872,114 .

Insects injurious to the Grape-vine $\ldots \ldots \ldots \ldots \ldots \ldots \ldots \ldots \ldots$

The grape-vine apple-gall, Cecidomyia vitis-pomum ...............

The breast bone of gall-gnat larvæ, 114-The gall mistaken for an apple, 114-Form of the gall, 115-Habits of the larra, 116.

The grape-viue filbert-gall, Cecidomyia vitis-coryloides..............

Appearance of the gall, 116-Larva of the gall-maker, 117.

The grape-vine tomato-gall, Lasioptera vitis.....................

Its curious resemblance to a tomato, 117-Various shapes assumed by it, 118-The larva, 118-Enemies of the larva, 118.

The grape-leaf trumpet-gall, Cecidomyia riticola ..................

Characteristics and occurrence of the gall, 118.

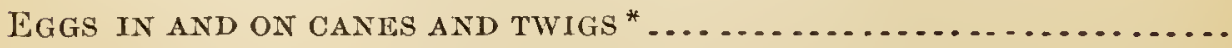

* Pages 119-125 were reprinted under title Insect punctures, in <Rept. State Board Agric. Kansas for 1873, 1874, pp. 274-279, figs. 47-59. 
1329. Riley, C. V.-Continued.

Probable eggs of the jumping tree-cricket, Orocharis saltator; 119-

The egg-punctures on grape-cane, 119-Characters of the egg, 119-General appearance of the cricket, 120.

Eggs of the snowy trec-cricket, AEcanthus niveus, 120-Trees and shrubs attacked by this ericket, 120-The egg, 1:0-Habits and natural history, 120-Injury done by it, 121-The eggs nistaken by Fitch for those of the Buffalo tree-hopper, 121.

Egg-punctures of the Buffalo tree-hopper, Cercsa bubalus, 121-De. velopment of the larva, 121-Characters and habits of the perfect insect, 122-Egg-punctures of some unknown tree-hopper, 122.

Egg-punctures of the frosted lightening-hopper, Paciloptera pruinosa, 122-Development and habits of the insect, 122.

Egg.punctures probably of Orchelimum glaberimum, 123-The egg, 123-Characters and habits of the imago, 123.

Eggs of the oblong-winged katydid, Amblycorypha oblongifolia, 123-They have been mistaken by Harris for those of the broadwinged catydid, 123-Ovipositors and modes of egm-laying in the three katydids occurring in Missouri, 124-Increase in thickness of katydid eggs before hatehing, 124.

STINGING LARVA

The potato-worm falsely considered as a stinging caterpillar, 125General harmlessuess to man of insect larve, 125-Stinging caterpillars in Europe and North Anterica, 126-List of such larvæ in United States, 126-Description of larva and chrysalis of Acronycta xylinoides, 126.

The buek moth or maia moth, Hemilenca maia ...................

Flight and characteristics of the moth, 127-The egg and mode of egg-laying, 128-Appearance of the full-grown larva, 129Larval changes, 129-Color variations of the larva, 130-Habits of the young larva, 130-The sting of the larva, 131-The pupa, 131-Issuing of the moth, 132-Irregularity and retardation in development, 132; the species benefits thereby, 132-Food-plants, 132-Natural enemies, 132.

The io moth, Hyperchiria io ...............................

The male and female moth, 133-The egg, 134-The larva and its urticating power, 134-Larval changes, 135-Pupation, 135Food-plants, 136-Parasites, 136.

The GREEN-STRIPED MAPLE-WORM, Dryocampa rubicind $a . . . . . . . . .$.

Account of its occurrence in great numbers in Kansas, 137-Injury lone by it to soft maples, 138-The egg, 138-Larval changes, 1:38-The chrysalis, 139-The imago, 139-Natural onemies, 139Description of Belvoisia bifasciata, 140-Remedies, 141.

\section{INNOXIOUS INSECTS.}

The hellgrammite Fly, Corydalus cornutus.....................

The eggs, 143-Respiratory apparatus of the larva, 143-Habits of the larva when about to transform, 143-The pupa, 144-Sexual difference in the imago, 145.

The Goat-weed Butterfly, Paphia glycerium....................

The egg, 146-Habits of the larva, 146-Larval changes, 146Transformation, 147-New food.plant, 147-Simulation of the color of the food-plant by the larva, 147-Two annual broods, 148-Hibernation of the imago, 148-Natpral enemies, 149. 
1329. Riley, C. V.-Continued.

ON A NEW GENUS IN THE LEPIDOPTEROUS FAMILY TINEIDE WITH REMarks on tile fertilization of YuCCA, Pronuba yuccasella........

Generic characters of Pronuba, 150-Description of Pronuba yuc150 casella, 151-Plants requiring the aid of insects for fertilization, 152-Fcrtilization of orchids, 152-Fructification of Yucca, 153Yuccas inust rely on insects for fertilization, 153-Insects frequenting Yuccas, 154-Diurnal and nocturnal habits of Pronuba, 154-How the female moth fertilizes the plant, 154-Oviposition, 155-The larva within the young fruit, 155-Description of the larva, 155-Only a small percentage of fruit not infested by the larva, 156-The larva leaves the capsule and enters the ground for hibernation, 156-Mutual adaptation of plant and insect, 156-The moth doubtless occurs wherever Yuccas grow wild, 157--Easy transportation of the cocoon, 158-Further facts regarding the fructification of Yucca filamentosa and gloriosa, 158Yuccas seeding in Europe, 159-Range of the insect, 159-Mr. Stainton's opinion on the characters on the Yucca moth, 160.

Note.-Pages 1-44 were also printed as a separate, with title-page cover. $<$ Jefferson City, Mo., 1873. S.-b. No.19, pp. 150-173.

1330. Riley, C. V. New York without a State entomologist. <Moore's Rural New Yorker, 5 May, 1873. S.-b. No. 8, p. 103.

Needs of a State entomologist for Now York; Salix humilis infested with larva of Plectrodera scalator.

1331. Riley, C. V. Tent-caterpillar of the forest. $<$ N. Y. Tribune, 23 May, 1873. S.-b. No. 8, pp. 64-65.

Answer to inquiry of S. 'T. Gilbert; means against cggs of Clisiocampa sylvatica $[=$ disstria $]$.

1332. Riley, C. V. Apple-tree borer. <N. Y. Tribune, 23 May, 1873, S. b. No. 8, p. 64 .

Answer to inquiry of J. Durbin; means against Saperda bivittata [= candida].

1333. Riley, C. V. Punctured grape-canes. <N. Y. Tribune, 23 May, 1873. S.b. No. 8, p. 64 .

Answer to inquiry of E. Snyder; food-habits and means against Ecanthus niveus.

1334. Riley, C. V. The codling.moth. Weir's trap. <Amer. Agric., May, 1873, v. 32, p. 184, figs.

Unsatisfactory results of experiments with the Weir trap; relative value of materials used; criticism of J.S.Parker's theory for the extermination of Carpocapsa pomonella; this species breeds in apples, wild crabs, pears, peaches, and plums; figures fomales and the abdomen of the males of Pimpla annulipes and Macrocentrus delicatus parasitic upon the apple-worm.

1335. Riley, C. V. Influence of extreme cold on the Curculio. <Gar. dener's Mo. and Hortic., May, 1873, v. 15, pp. 137-139.

Critical review of T. T. Southwick's article of same title; extract from $3 d$ Ann. Rept. State Ent. Mo. 
1336. Riley, C. V. On a nerr genus in the lepidopterous family Tineidce, with remarks on the fertilization of Yucca. <Trans. Acad. Sci. St. Louis, June, 1873, г. 3, pp. 50̃-64, 2 figs. Re. printed, witl omissions and slight changes, from $<5$ th Ann. Rept. State Ent. Mo., 18 April, 1873, pp. 150-160, figs. 74-75. Reriew by P. C. Zeller: <Verl. k.-k. zool.-bot. Ges. Wien, 1876, Jahrg. 1875, Bd. 25, pp. 340-342. Reply to Zeller: $<$ Trans. Acad. Sci. St. Louis, Jauuary-March, 1876, v..3, pp. $325-326$.

Description and figures of Pronuba n. g. and of larva and imago of $P$. yuccasella n. sp. Sce No. 1329 for synopsis of contents.

1337. Riley, C. V. Supplementary notes on Pronuba yuccasella. <Trans. Acad. Sci. St. Louis, June, 1873, v. 3, pp. 178-180, fig. 3. Extract: <6th Ann. Rept. State Ent. Mo., April, 1874, pp. 131-135, fig. 3 .

Descriptions and figures of male and female pupa of Pronuba yuccasella; hibernation, imagination, seasons, and distribution of the same; species of Yucca pollinated by it.

133S. Riley, C. V. [To destroy the cotton-worm.] <Ill. Jour. of Agric., June, 1873. Reprint: <Colman's Rural World, 1873; < Rural Alabamian, July, 1873, v. 2, pp. 289-293; <Mobile Register, 1873 ; <Farmer's Advocate, 1873. Extract: <6th Ann. Rept. State Ent. Mo., 1874, pp. 17-18.

Ravages of Aletia argillacea $[=x y l i n a]$ in the cotton fields of Southern United States; inefficiency of measures hitherto employed against them; recommends the nse of Paris green; directions for its use ; natural history, description of egg, larva, and inago of the Aletia; hibcrnation of the imago.

1339. Riley, O. V. [Imported plants and insects.] <Trans. Acad. Sei. St. Louis, July, 1873, v. 3, pp. 42-43 Proc.

Verbal communication; inequality of the exchange of plants and insccts between Europe and North America; cxtent and causes of the same.

1340. Riley C. V. [Mimicry and protective resemblances.] <Trans. Acad. Sci. St. Louis, July, 1S73, v. 3, pp. 44-45 Proc.

Verbal communication; mimicry of Danais archippus by Limenitis disippus and consequent greater abundance of the latter than of $L . u r s u l a$.

1341. Riley, C. V. [Silk-worms fed with osage orange.] <Trans. Acad. Sci. St. Louis, July, 1873, г. 3, p. 47 Proc..

Verbal communication; successful rearing of silk-worms on Maclura aurantiaca; exhibition of cocoons made by these worms.

1342. RILEY, C. V. [On the cause of deterioration in some of our native grape-vines.] <Trans. Acad. Sci. St. Louís, July, 1873, v. 3, pp. 51-52 Proc.

Verbal communication; abstract from 4 th Ann. Rept. State Ent. Mo.; failure of grape-vines attributed largely to the ravages of Phylloxcra vastatrix.

1343. Riley, C. V. [Insects affecting the ailanthus.] <Trans. Acad. Sci. St. Louis, July, 1873, v. 3, pp. 53-54 Proc.

Mentions Eta compta $[=$ punctclla $]$ and Attacus cynthia. 
1344. Kiley, C. V. [Posthumous papers by B. D. Walsh.] < Trans. A cad. Sci. St. Louis, July, 1S73, v. 3, p. 77 Proc.

Verbal communication; disposition of sundry entomological manuscripts left by B. D. Walsh.

1345. Rlley, C. V. [Remarks on Simulium piscicidium.] <Trans. Acad. Sci. St. Louis, July, 1873, v. 3, p. 69 Proc.

Verbal communication; nature and supposed ravages of Simulium piscicidium.

1316. Riley, C. V. [On Antherca yama-mai as a silk-producer.] <Trans. Acad. Sci. St. Louis, July, 1873, v. 3, p. 84 Proc.

Verbal communication; superiority of Antherca yama-mai to other silkworms tried as substitutes for Sericaria mori.

1347. Riley, C. V. [On galls growing on wild sage.] <'Trans. Acad. Sci. St. Louis, July, 1873, v. 3, p. 84 Proc.

Verbal communication; occurrence of threc distinct undescribed galls on Artemisia tridentata in Utah.

1:348. Riley, C. V. [On a larva of Scenopinus sp. from the human lungs.] <Trans. Acad. Sci. St. Louis, July, 1873, v. 3, p. 90 Proc.

Verbal communication; a larva of Scenopinus sp. found in human expectoration; nsual food-habits of the larva of this genns.

1349. Riley, C. V. Agricultural editorial excursion. < Prairie Farmer, 1873, v. 44: 2 August, p. 241; 9 August, p. 248; 16 August, p. 256 ; 23 August, p. 265; 30 August, p. $273 ; 6$ September, p. 281. Reprint: <Colman's Rural World, 1873, 2, 9, 16, 23, and 30 A ugust, 6 and 13 September. See: <Colorado Mountaineer, 1 August, 1877. S.-b. No. 14, p. 102.

Bricf notes on locusts.

1350. Rilex, C. V. Enemies of the elm. $<\mathrm{N}$. Y. Tribune, 7 August, 1873. S.-b. No.«8, pp. 56-57. Reprint: <Gardener's Mo. and Hortic., Angust, 1876, г. 18, p. 246.

Answer to inquiry of T. S. Watson; natural history of and means against Galeruca calmaricnsis $[$ = xanthomelcena $]$.

13.51. Riley, O. V. Entomological information. $<\mathrm{N}$. Y. Tribune, 16 August, 1873. S.-b. No. 8, p. 58.

Answer to inquiry of J. W.; deseription of a number of traps for alluring and destroying insects.

135\%. Riley, C. V. "Controlling sex in butterflies." <Amer. Nat, September, 1875, v. 7, pp. 513-521. Separate: <Salem, Mass., August, 1873, pp. 9.

Critical review of Mary Treat's article of sane title; femalcs require more nourishment than malcs; sex determined in the egg; oviposition of Papilio and Anisota [=Dryocampa]; larvæ can not be forced to eat more than is natural to them; expcriments on Thyridopteryx ephemeroformis, Orgyia leucostigma, Clisiocampa americana, Hyperchiria io, Hemileuca maia, and dnisota [= Dryocampa rubicunda to detcrmine the effect of the stinting of food upon the determination of sex; effect of this npon the number of molts and the longevity of Orgyia lencostigma and Megatoma serra; note on alternation of gencrations in Cynips $[=$ Andricus $]$ quercus-operator and $C .[=A$. quercus-operatola; nature of parthenogenesis. 
1353. Riley, C. V. Cotton caterpillar.-Boll-worm. < Rural Alabamian, October, 1873. S.b. No. 16, p. 121.

Criticism of recent articles on Anomis $[=$ Aletia $]$ xylina,' Heliothis armigera, and Phylloxera vastatrix.

1354. Riley, C. V. On the oviposition of the Yucea moth. <Amer. Nat., October, 1873, v. 7, pp. 619-623. Abstract: <Trans. Acad. Sci. St. Louis, 10 December, 1873-25 A pril, 1874, v. 3, pp. 208-210. Reprint, with slight changes and omissions. <6th Ann. Rept. State Ent. Mo., April, 1874, pp. 131-135, fig. 38.

See No. 1363 for synopsis of contents.

1355. Riley, C. V. Phylloxera: correction. <Gardener's Mo. and Hortic., November, 1873, v. 15, p. 342.

Critical review of report of remarks before Academy of Natural Sciences of Philadelphia.

'1356. RILEy, C. V. Hackberry butterflies. Descriptions of the early stages of Apatura lycaon, Fabr., and Apatura herse, Fabr.; with remarks on their synonymy. <Trans. Acad. Sci. St. Louis, 10 December, 1873, v. 3, pp. 193-20s, figs. 3-6. Reprint, with slight changes. <6th Ann. Rept. State Ent. Mo., April, 1874, pp. 136-148, figs. 39-42.

Treats of A. lycaon [=celtis] and A.herse [= clyton]. See No. 1363 for synopsis of contents.

1357. Rrley, V. C. Economic entomology. <Trans. Kansas State Board A gric. for 1872, 1873, pp. 292-325, 18 figs.

Extract: <Sci. Amer.

Characterization of entomology ; importance of and means against noxious insects; list of imported noxious insects and plants; chapters on Anisota [ = Dryocanipa rubicunda ], Eriosoma pyri [ = Schizoneura lanigera ], Paleacrita vernata, Galleria cereana, Estrus ovis, Bruchus pisi, Macrodactylus subspinosus, Conotrachelus nenuphar, aud Nysius destructor [= angustatus]. In general, descriptions and figures of the several stages and accounts of the habits and food-plants of and means against these insects, with some accounts and figures of their enemies and parasites, are given. Describes especially larva of Anisota $[=D$.$] rubicunda and of Paleacrita vernata and of all active$ stages of Nysius destructor [=angustatus]. Figures larva, puparium, and imago of Pipiza radicum, inagos of Nothrus ovivorns, Microgaster [ = Apanteles] militaris, Calosoma scrutator, C. calidum, and Blissus leucopterus and imago and nests of Eumenes frateruns.

Some of the chapters are bascd upon and some are reprinted from the 1st, 2d, and $3 d$ Ann. Repts. State Ent. Mo.

135S. Riley, C. V. Curculios on pears. <Ill. Journ. Agric., 1873. S.-b. No. 16, pp. 109-110, figs. 1-2.

Habits, history, and means against Conotrachelus nenuphar, C. cratogi, and Anthonomus quadrigibbus; figures the two last-named species.

1359. Rrley, C. V. Length of thread of the silk-worm. < Popular Sci. Monthly, February, 1874, v. 4, p. 508.

Correction of statements in A de Quatrefaye's "Silk-worms and sericulture" as to tie length and weight of the fiber in a single cocoon of Sericuria mori. 
1360. Riley, C. V. A new (?) ægerian maple-borer. <Amer. Nat, February, 1874, v. 8, pp. 123-124.

Critical review of P. Gennadius's "A new agerian maple-borer." Trochilium acericolum is the well-known Egeria acerni, injurious to maple-trces.

1361. Riley, C. V. Entomology in Missouri. < Amer. Nat., March, 1874, v. 8, pp. 1S1-188.

Reply to criticisms of A. S. Packard; discussion on the number of segments in the head of an insect, on classification, and on Mytilaspis pomicorticis [= ponorum $]$.

1362. Riley, C. V. Economic entomology. <Amer. Nat., March, 1874, v. 8, pp. 189-190.

Demand for more attention to and better representation of the agricultural interests of the country. Inadequacy of measures propounded for the wholesalo destruction of noxious insects.

1363. Rrley, C. V. Sixth annual report on the noxious, beneficial, and other insects of the State of Missouri, made to the State Board of Agriculture, pursuant to an appropriation for this purpose from the legislature of the State. <9th Ann. Rept. State Board of Agric. for 1873, March, 1874, pp. 169+12, 55 figs. Separate: $<$ Jefterson City, Mo., March, 1874, p1. 169+12, 5っ tigs.

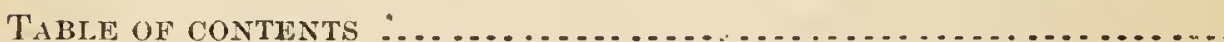

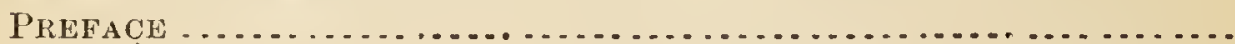
3

NOXIOUS INSECTS.

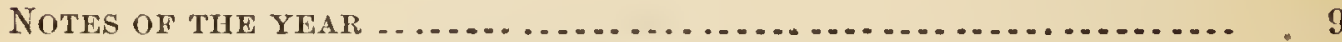

The codling-moth, Carpocapsa pomonella .......................

Failure of the apple crop in 1873, 9-Dr. Le Baron's observations on the habits of the worm, 9-Proportion of worms leaving the fruit before it falls, 10-How it affects pears, 10-Time and method of using bandages, 10-Westward spread of the insèct, 10 .

The Colorado potato-beetle, Doryphora $10-$ lineata ................

How it has affected the price of potatoes, 11-New food.plants, 11-Its progress eastward during 1873, 12-Improved methods of using Paris green, 13-Device for jarriug off the bugs, 14-European publications on the insect, 15-Danger of its introduction into Europe, 15-Precantionary meastures to bo taken in Europe, 16.

The cotton-worm, Aletia xylina

Paris green suggested as remely, 17-Address before the National Agricultural Congress, 17-Mr. Glover's summary on experience with Paris green, 19-Experiments with the poison, 19-Johnson's sprinkling machine, 20-Patents on Paris grcen, 20-The Royal mixture, 21-Hibernation of the insect, 22-Natural enemies, 23-Geographical range, 23-Position of the moth when alighting, 24.

The canker-worm, Paleacrita vernata; Anisopteryx pometaria ........

Dr. Le Baron's summary of remedies, 24-Mr. Milliken's experience with the rope and tin trap, 25-The Paris green remedy, 26-A new trough, 26-Birds which destroy the worm, 27-Mr. Mann's observations on the insect, 23-'Two species have bitherto been confounded, 28-The English sparrow and the increase of the white-morked tussock-moth, 29. 
1363. Riley, C. V.-Continued.

INSECTS INJURIOUS TO THE GRAPE-VINE .....................

The grape Phylloxera, Phylloxera vastatrix....................

The term "Phylloxera," 30-Bibliographical history, 30-Charac-

ters of the genus and its position in the system, 33-Biological history, 33-Different forms which tho insect assumes, 33-The gall-inbabiting form, 34-The root-inhabiting form, 38-Balbiani's discovery of the true sexual individuals and the winter egg of Phylloxera quercus, 41-The winter egg not essential to the winter life of the grape Phylloxera, 42-Polymorphism in Phylloxera, 43-Conclusive proof of the identity of the root-and galllice, 44-Practical considerations, 44-The more manifest and $\mathrm{cx}$ ternal effects of the disease, 44-Mode of spreading, 45-Swarming of winged specimens of Phylloxera crryafolic, 45-Power of flight in the grape Phylloxera, 45-Spread of the discase through the winged females, 46-Susceptibility of different vines to the disease, 46-Practical importance of knowing the more resisting and more susceptible vines, 46-List of the cultivated species and varieties of vines indicating their relative susceptibility to Phylloxera, 47-Prophylactic means of coping with the disease, 48 -Grafting the more susceptible on to the roots of resisting vines, 48-Other preventive neasures, 50-Natural encmies, 50Insect enenies of the gall-louse, 50-Enenies of the root-louse, 52-The Pliylloxera mite, 52-Differcnt fornis assumed by mites in their development, 52-Hoplophora arctata, 53-Pcculiaritics of the Oribatida, 54-Direct remedies, 55-Submersion a perfect remedy, 55-Application of pure insecticides without satis'actory results, 56-Range of the insect in America, 57-Injury caused by it in Amcrica, 58-Reasons why the insect is more injurious in Europe, 59-False theories, 60-The Phylloxera is the causc and not the effect of the diseasc, 60 -It is a native American insect aud has been imported iuto Europe, 62 -It is peculiar to the grape-vine, 63-The American oak Phylloxera and its natural history, 64-Conclusion, 65.

Appendix and notes to the article on grape Phylloxera............

Diaguosis of Phylloxera vastatrix, 66-Influence of the insect's puncture, 67-The supposed male of the gall-louse, 67-The noncultivation of the Clinton grape, 67-7ransient nature of the leaf-galls, 68-Constancy of the differcnces betwcen the forms assumed by the insect, 68-Supposed sexual individuals, 68 Number of generations anuually produced, $69-\mathrm{Numbcr}$ of molts, 69 -Transplanting root-lice on to the leaves, 69-Naturo of the swelling on the roots produced by Phylloxera, 70-The tiue grape-viues of tho Unitod States, by Dr. G. Engelmann, 70Exceptional instances where the European vine has succeeded in America, 76-Grafting the more susceptible on to the roots of the resistiug varietios, 78-Descriptions of Tyroglyphus phylloxer a aud Hoplophora arctata, 81-Efficacy of inundating the vineyards, 82-Facts showing that the disease of grape-vines in America is principally caused by Phylloxcra, 82-Description of Phylloxera rileyi, 86 -The true sexual individuals and the winter egg, 86.

The blue caterpillars of the vine ...........................

1. The grape-vine Epimenis, Psychomorpha epimenis, 87 - Habits and characters of the larva, 87-Deseription of larva and chrysalis, 88.

2. 'Tho beantiful wond nymph, Eudryas grata, 88-Characters aud food-plauts of tho larva, 85-The moth and the egg, 89-Descrip. tiou of the egre aud larva, 80 - of the chrysalis, 90. 
1363. Riley, C. V.-Continued.

InsECTS INJURIOUS TO THE GRAPE-VINE-Continued.

. 3. The pearl wood nymph, Eudryas unio, 90-Its larva almost undistinguishable rom that of the foregoing species, 90-Foodplant, 91-Distinguishing characters of the moth, 91-Mr. Lintner's description of the larva, 92-Mr. Lintner on the difference between the larva of Eudryas grata and E. unio, 93.

4. The eight-spotted forester, Alypia octomaculata, 94-Description of the larva, 94 ; chrysalis and imago, 95.

Summary, 95-Comparison of the larvæ of these four species, 95Remedies 96.

The Red-Legged HAM-Beetle, Necrobia rufipes ..................

Its popular namc, 96-It has been the cause of an interesting lawsuit, 96 ; entomological information necessary to a just verdict, 98-Another case before a jury requiring botanical knowledge, 98-Injury caused by the beetle in St. Louis, 99-'The eggs, and how they are deposited, 99-The larva and its habits, 99-The pupa, 99-Prevention, 100-Other species associated with it, 100Habits of other species of Clerida, 101-How Necrobia ruficollis saved the life of Latreille, 101-Description of the larva of $\mathrm{Ne}$ crobia rufipes, 101-Description of the pupa, 102.

ThE ClOVER-HAY WORM, Asopia costalis........................

Its geographical distribution, 102-It has probably been imported from Europe, 101-Its past history and accounts of damage caused by it, 102-Its natural history, 105-Remedies, 105-Doscription of larva and chrysalis, 106; of the imago, 107-Its allied congener, Asopia olinalis, 107.

The Legged Maple-Borer, AEgeria acerni ........................

The burrows of the larva, 108-Appearance of the moth, 108-Remarks on the nomenclature of the species, 108-Injury caused by it to maples, 109-It attacks only trees already injured by some cause or another, 109-Remedies, 110-Description of imago, larva, and pupa, 110.

The Rasplerry root-Borer, Bembecia marginata .................

Work of Oberea perspicillata in canes of raspberry and blackberry, 111-Injury caused by the root-horer, 111-General appearance and habits of the worm, 112-Description of imago and larva, 113.

The Northern BRenthian, Eupsalis minuta....................

Its occurrence and distribution, 113-Characteristics of the beetle, 114-Fighting habits of the males, 114-How the male assists the female in ovipositing, 115-How much time is required for the transformations of the insect, 115-Habits of the larva, 115-Description of the larva, 115; of the pupa, 116-Real position of the brenthians in the system, 116-The specific and generic names, 116-How another larva has been mistaken for that of the Northern brenthian, 117-Description of this larva, which evidently belongs to the Tenebrionida, 118.

THE JUMPING SUMACH-BEetle, Blepharida rhois .................

Sumach industry in Europe and America, 118-Species of sumach possessing economic value, 119-Appearance and habits of the beetle, 119-The egg-masses, 120-Development and habits of the larra, 120-Transformation, 120-The two anuual broods, 120-Injury caused by it to the sumachs, 121-Geographical range, 121-Remerlies, 121-Description of larva and pupa, 121Variations of the beetle, 122 . 
1363. Riley, C. V.-Continued.

\section{BENEFICIAL INSECTS.}

The UNADORNed Tiphia or white grul Parasite, Tiphia inornata .. Other enemies of the white-grub, 123-Cocoon and lava of Tiphia, 123-It is undoubtedly a parasite of the white-grub, 124-Characters of the grenus Tiphia, 124-Habits of Tiphia femorata, 124Habits of the Tiphia larva, 124-Characters of the Unadorned Tiphia, 125-Bectle parasitic upon it, 125-Description of larva and imago, 126-The species has becil described under three different 11ames, 126.

\section{INNOXIOUS INSECTS.}

The dominican CASE-BeARER, Coscinoptera dominicana.............

Character's of the bectle, 127-Mode of oviposition, 128-Oviposition of Chlamys plicata, 128-The joung larva and its foodhabits, 129-The case of the larva, 129-Characters of the larva, 130-Time required for its development, 130.

The YUCCa мотн, Promuba yuccasella ... . . . . . . . . . . . . . . . . . .

Its natural history completed, 131-Description of the ehrysalis, 131-Hatching of the ehrysalis, 132-Method of oviposition, 133Oviposition is followed by pollination, 134-The egg in the soung fruit and the embryo larva, 134-It is the only iusect that can well fertilize the Yuccas, 135.

Hackberry butterflies. . . . . . . . . . . . . . . . . . . . . . . . .

The European purple Emperor, 136-Insufficient former account of their earlier states, 136-Species of Celtis in Missouri, 137.

The eyed Emperor, Apatura celtis . . . . . . . . . . . . . . . . . . . .

The full-gromn larva, 137-Habits of tho larva, 138-Pupation, 138-The imago, 139-The egr and the young larva, 139-Two annual broods, 139-Hibernation of the young larva, 140.

The tawny Empcror, Apatura clyton ... . . . . . . . . . . . . . . . . . . .

How it differs from the eyed emperor, 140-The egg, 141-Larval changes and habits, 141-Egg parasitc, 142.

Bibliographical ..... . . . . . . . . . . . . . . . . . . . . . . . . . .

The generie name, 142-The specific names of the two specics, 143-Fabricius's original description of lycaon and herse, 144Other species of the genus in the United States, 145-On the validity of alicia, 145-Descriptions of the earlier states of both species, 146-Their popular names, 148-The scientific specific names, 149.

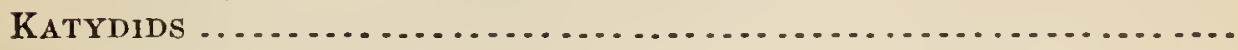

General considerations, 150-Spring in Europe and America, 151Stridulating noise produced by crickets and grasshoppers, 152Sounds inaudible to man, 152-Grasshoppers, katydids, locusts, 153-Habits and general appearanee of our katydids, 154-They oviposit above ground, 154-Their ovipositors not rudimental, 155.

The angular-winged katydid, Microcentrum retinerve ..............

It is the most common species in Missouri, 155-Gencral character of the insect, 155-The eggs, 155-Erroneous statement eoncerning the cgg, 156-How the fenalc deposits the eggs, 156-Number of eggs laid by the female, 155 -Hatching of the larva, 158Food of the larva, 158-Changing from the pupa to the perfect 
1363. Riley, C. V.-Continued.

state, 159-Its song, 159-It is capable of domestication to a certain degree, 160-Description of the immature states, 161-Natural enemies, 162-The back-rolling Wonder, an egg-parasite, 162-Curious habit of the female Antigaster, 162-Description of Antigastcr mirabilis, 163-Striking sexual differences, 163.

The narrow-winged Katydid, Scudderia curvicauda .................

Distinguishing characters, 164-Method of oviposition, 165-The egg, 165-Its song, 166--Description of larva and pupa, 166.

The broad-winged Katydid, Cyrtophyllus concavus ..................

It is the true katjdid, 167-Distinguishing characters, 167-Mode of oviposition as observed in confinement, 167-Mr. Jaeger's erroneous statcment regarding the oviposition, 168-Its song, 168.

The oblong-winged katydid, Amblycorypha oblongifolia

It has not yet been found in Misscuri, 169-Distinguishing characters, 169-The eggs not yet known, 169-Abnormal female specimen, 169.

1364. RILEY, C. V. The Colorado potato-beetle abroad. <N. Y. Tribune, 1 April, 1S74. S.-b. No. 10, 上. 37.

Criticism of some articles on Doryphora decemlincata published in Europe; danger of the importation of the inseet into Europe, and suggestion of means to prevent such introduction.

1365. Riley, C. V. Cabbage-lice. <N. Y. Tribune, 8 April, 1874. S.-b. No. 10, pp. 33-34.

Answer to letter from Mrs. M. Walker; meáns against Aphis brassicce.

1366. Rrley, C. V. Peach-borers. <N. Y. Tribune, S April, 1874. S.-b. No. 10, p. 34 .

Answer to letter from W. J. Clary; a peach-tree whose base was surrounded by ice in winter was free from borers; this observation of slight signifcance.

1367. Riley, C. V. Apply soap. <N. Y. Tribune, 8 April, 1874. S.-b. No. 10, p. 34 .

Answer to letter from T. H. Wakeley; means against Saperda bivitlata $[=c a n-$ dida] and Chrysobothris femorata.

1368. Riley, C. V. Meadow enemy. <N. Y. Tribune, 8 April, 1874. S.-b. No. 10, p. 34.

Answer to letter from D. Freeman ; ravages of a species of Tipula in grass lands in California ; characters of the genus; llabits of and means against the same.

1369. Riley, C. V. A remedy for the cotton-worm. <N. Y. Tribune, 22 April, 1874. S.-b. No.10, pp. 25-26. Reprint: <Vicksburg Herald, 1 May, 1874.

Experiments with Paris green; advocacy of its use against Aletia argillacea [=xylina $]$; directions for and successful results of this use.

1370. Riley, C. V. Descriptions of two new subterranean mites. <Trans. Acad. Sci. St. Louis, 25 A pril, 1874, v. 3, pp. 215-216, figs. 8-9.

Description and figures of Tyroglyphus phylloxerce n. sp. [p. 215] and of Hoplophora arctata $\mathrm{n.}$ sp. [p.216]; food-habits of the same. 
1371. Rilex, C. $\nabla$. The habits of Polistes and Pelopceus. < Amer. Nat., April, 1874, v. 8, pp. 229-231.

Critical review of P. R. Uhler's article "On a remarkable wasp's nest found in a stump in Maryland;" probably the nests and specimens of Pelopøus lunatus $[=$ cementarius $]$ were mistaken for those of Polistes fuscatus $[=m e$ tricus], in which case the observations criticised present no remarkable features.

1372. Riley, C. V. The plum Curculio; natural history and how to catch him. <N. Y. Semi-weekly Tribune, 1 May, 1874. S.-b. No. 10, pp. 18-19; 38-40. Extract: <Cultivator and Country Gentleman, 14 May, 1874, v. 39, p. 310. < New England Farmer, 18 July, 1874, [v. 53, n. s., v. 29, p. 1. See : <Indust. Record, 5 February, 1875. S.-b. No. 16, pp. 46-48.

Natural history of and means against Conotrachchus nenuphar; figures of the sereral stages of the insect and of machines for catching the same.

1373. Riley, C. V. The apple-trorm; natural history; remedies. $<\mathrm{N}$. Y. Tribune, 20 May, 1874. S.-b. No. 10, pp. 8-9; 37-38.

Description and figures of the several stages of Carpocapsa pomronella; habits of and means against the same.

1374. Riley, C. V. The grape Phylloxera. <Popular Sci. Monthly, May, 1874, v. 5, pp. 1-16, 7 figs. Reprinted, with slight changes, from <6th Anu. Rept. State Ent. Mo., April, 1874, pp. $30-46$.

See No. 1363 for synopsis of contents.

1375. Riley, C. V. Rose chafers on grape-vines. <Colman's Rural World, 20 June, 1874, fig. S.-b. No. 17, pp. 103, 104.

Natural history and means against Macrodactylus subspinosus; figure of the same.

1376. Riley, C. V. More about the grape-vine pest. <Popular Sci. Monthly, June, 1874, v. 5, pp. 158-170, 10 figs. Reprinted, with changes and omissions, from <6th Ann. Rept. State Ent. Mo., April, 1874, pp. 47-60, 64-65.

See No. 1363 for synopsis of contents.

1377. Riley, O. V. Scale insects on magnolia. <N. Y. Tribune, 15 July, 1874. S.-b. No. 10, p. 24.

Answer to inquiry of R. H. Day ; occurrence of an undescribed Lecanium sp.? on the leaves of Magnolia fuscata.

1378. Riley, C. V. Uonfounding friend with foe. <N. Y. Tribune, 15 July, 1874, 2 figs. S.-b. No. 10, p. 24.

Answer to inquiry of E. J. Day; usefulncss of Arma [= Podisus $]$ spinosus figure of the same. Injury to plums by Anthonomus prunicida $[=$ Coccotorus scutellaris]; figure of and means against the same.

1379. Riley, O. V. The Colorado potato-beetle in New York. <N. Y. Tribune, 15 July, 1874. S.-b. No. 10, p. 24.

Answer to letter from J. H. P.; eastern limit of the range of Doryphora des cemlineata in 1873 and 1874. 
1380. Riley, C. V. Large willow-worm. <N. Y. Tribune, 15 July, 1874. S.-b. No. 10, p. 24.

Answer to letter of J. H. P. ; food-plants, habits, and means against Cimbex laportei $[=$ americana $]$.

1281. Riley, C. V. Black blister-beetles on potatoes. <N.Y.Tribune, 22 July, 1874. S.·b. No. 10, p. 17.

Answer to inquiry of A. Barr; ravages of and means against Epicauta puncticollis.

1382. Riley, C. V. Pear-tree slug. <N. Y. Tribune, 22 July, 1874. S.-b. No. 10, p. 17.

Answer to letter of C. S. B.; means against Selandria [= Eriocampa] cerasi.

1383. Riley, C. V. The plug-ugl. theory. <N. Y. Tribune, 22 July, 1874. S.-b. No. 10, p. 17.

Answer to letter of O. J. B. ; insertion of sulphur, calomel, and similar powders in the trunks of trees has no effect upon the sap or upon the insects which injure the trecs.

1384. Riley, C. V. Cockscomb elm-gall. <N. Y. Tribune, 22 July, 1874. S.-b. No. 10, p. 17.

Answer to inquiry of J. S. Ruby; Thelaxes $[=$ Colopha $]$ ulmicola forms excrescences on the American elm.

1385. Riley, C. V. Pitcher-plant insects. <Hartford [Conn.] Daily Courant, 15 August, 1874, v. 38, No. 195, p. 1. See: <N. Y. Tribune Extra : Lecture and Letter series No. 21, August, 1874, pp. 56-58, fig. Reprint : <Nature, 8 October, 18i4, v. 10, pp. 463-465, figs. 1-2. A bstract : <Sci. Amer., 12 September, 1874 [v. 45], n. s., v. 31, p. 168. <Amer. Nat., November, 1874, v. 8, pp. 684-687. Reprint of abstract: <Hardwicke's Science Gossip, December, 1874, v. 10, pp. 272-275, figs. 179-182. Extract: <Ca. Ent., November, 1874, v. 6, pp. 207-214, figs. 25-26. Reprint of extract: <Proc. Amer. Assoc. Adv. Sci. for 1874, June, 1875, v. 23, pp. 18-25, 2 figs. Separate of reprint: <Salem, Mass., December, 1874, pp. 18-25, figs.

Insect-catching habits of Sarracenia variolaris; list of its victims; habits and figures of all stages of Xanthoptera $[=$ Exyra $]$ semicrocea and Sarcophaga sarracenice: capture of insects by other plants.

1386. Riley, C. V. On the habits and transformations of Canthon hudsonias, Forst.; the common " tumbledung." < Hartford [Conn.] Daily Courant, 18 August, 1874, No. 11162, v. 38, No. 197, p. 2. Reprint: <N. Y. Tribune Extra: Lecture and Letter series, No. 21, August, 1874, pp. 75-76.

Breeding habits and oviposition of Canthon hudsonias [=lavis].

1387. RILEY, C. V. On the larral habits of the cantharid genera Epi. cauta and Henous. <Hartford [Conn.] Daily Courant, $18 \mathrm{Au}$. gust, 1874, No. 11162, v. 38, No. 197, p. 2. See: $<$ N. Y. Tribune Extra: Lecture and Letter series, No. 21, August, 1874, p. 76 .

Hahits and hypermetamorphosis of Meloe angusticollis; probably parasitic fool-habits of young larras of Epicauta and Henous; the imagos phyte. phagous, 
1388. Rrley, C. V. Humming-bird moths caught by the tongue. <Moore's Rural New Yorker, 29 August, 1874, v. 30, p. 140.

Method of eapture of insects, particularly moths by the fluwers of Physianthus albens; capture of insects by other flowers.

1389. Rilex, C.V. The io moth (Saturnia io). <Illust. Journ. Agric., August, 1874, figs.

Answer to inquiry of G. Barter; natural history of Saturnia [= Hyperchiria $]$ io ; figures larva and $\delta$ and $\$$ imagos.

1390. Riley, C. V. Descriptions and natural history of two insects which brare the dangers of Sarracenia variolaris. <Trans. Acad. Sci. St. Louis, 1 September, 1874, v. 3, pp. 235-240, figs. $10-11$.

Description of leaf of Sarracenia variolaris and its function of entrapping and digesting insects; description aud figures of eggs, larva, chrysalis, and imago of Xanthoptera [=Exyra] semi-crocea and larva, puparium and imago of Sarcophaga sarracenice n. sp.; liabits of the two species; comparison of S. sarraceniu with S. carnaria and of the genera Musca, Calliphora, and Sarcophaga; notice of A. S. Packard's "Transformation of the common housefly."

1391. [RILEy, C. V.] [Discussion on entomology.] <Trans. Ill. State Hortic. Soc. for 1873, 1874, n. s., v. 7, pp. 100-104.

Description, habits, and means against Anisopteryx; effect of late plowing; enemies of Doryphora 10-lineata; habits of Gastrophitus equi.

1392. [Rrley, C. V.] Note on leaf-hopper. <Trans. Ill. State Hortic. Soc. for 1873,1874, n. s., v. 7, p. 138.

Means against Erythroneura $[=$ Typhlocyba $]$ vitis.

1393. [RILEY, C. V.] [Notes on the strawberry crown borer.] <Trans. Ill. State Hortic. Soc. for 1S73, 1874, n. s., v. 7, p. 147.

Description, habits, and means against Tyloderma fragarice.

1394. RrLey, C. V. Lecture on entomology. <Trans. Ill. Hortic. Soc. for 1873,1874 , n. s., v. 7, pp. 172-178, figs. 1-3. Reprint: <3d Ann. Rept. Sec. State Pomol. Soc. Mich. for 1873, 1874, pp. 443448. Abstract: <Rept. U. S. Commis. Agric. for 1873, 1874, [30 March, 1875], pp. 389-390.

Habits of and means against Carpocapsa pomonella; habits, transformations, prolificacy of and means against Phylloxera vastatrix; description and figures of leaf-galls; figures of root-and gall-forms; histors and meaning of the word "Phylloxera;" statement by D. B. Wier concerning the invention and use of Wier's apple-worm trap.

1395. RrLex, C. V. "Walking-sticks or specters" becoming injurious. $<$ N. Y. Weekly Tribune, 11 November, 1874 , fig. S.-b. No. 23, p. 103.

Ravages in Yates County, N. Y., vernacular names, habits of, and meaus against Diapheromera femorata; description of its eggs; figure of imago.

1396. RrLey, C.V. Entomological notes. <Sci. Amer., 5 December, 1874 [v. 45], u. s., v. 31, p. 356.

Pemphigus imbricator found on beech; vesicatory potato-bectles, Meloida; cow manure and cow urine one of the earliest supposed remedies for Phylloxera. 
1397. Riley, C. V. The bark-louse. <Beach, A. E. The Science Record for 1874, N. Y., 1874, p. 356.

Discovery of the male of Mytilaspis conchiformis [ = pomorum $]$.

1398. Riley, C. V. Codling-moth heresies. <N. Y. Tribune, 2 January, 1875. S. D. No. 13, p. 163.

Criticism of paper of S. B. Peck; Carpocapsa pomonella confines its attacks to one apple and does not enter the ground.

1399. Riley, C. V. Shall we scrape our trees? $<$ N. Y. Tribune, 6 February, 1875. S.-b. No. 10, p. 10.

Careful scraping of trees carly in spriug is beneficial as a safeguard against the attacks of many injurious insects.

1400. Riley, C. V. What are army-worms? <N. Y. semi-weekly Tribune, 6 February, 1875.

Differences between Laphygme frugiperda and Leucania unipuncta.

1401. Riler, C. V. The hickory bark-borer, Scolytus caryce. <Colman's Rural World, 6 February, 1875. S.-b. No.17, p. 105.

Natural history of Scolytus caryce $[=4-$ spinosus $]$.

1402. Rilex, C. V. Genuine vs. bogus chinch-bugs. <N. Y. Tribune, 10 February, 1875, figs. S.-b. No. 10, p. 10.

Auswer to inquiry of C. H. Cushing; food-habits and figures of Nysius destructor $[=$ angustatus $]$ and Blissus lencopterus; larva of Deilephila lineata feeds on purslaue.

1403. Riler, C. V. Remedies for Phylloxera. <N. Y. Tribune, 10 February, 1875. S. b. No. 10, p. 22.

At present no insecticide is effective agaiust Phylloxera vastatrix; grafting of more susceptible varieties ou the roots of the least susceptible advised.

1404. Rulex, C. V. Newest facts of grape Phylloxera. <N. Y. Tribune, 10 February, 1875. S.-b. No. 10, pp. 21-22.

Succession of different forms of individuals in the cycle of development of phylloxcra described; seasons at which the different forms appear; places in which eggs are laid by the winged females.

1405. Riley, C. V. Is the Colorado beetle poisonous? <N. Y. Weekly Tribune, 17 February, 1875. S.-b. No. 10, p. 9.

Insists upon the poisonous nature of the fumes from scalded or burning masses of Doryphora decemlineata, in opposition to statements by Prof. T. J. Burrill.

1406. Riley, C. . . Notes of Phylloxera. <N. Y. Tribune, 4 March, 1875. S.-b. No. 10, pp. 20-21.

Critical review of A. S. Fuller's "Distribution of the grape-louse;" maintains the specific identity of the so-called gall-inhabiting and root-inhabiting forms of Phylloxera, and the North American Origiu of this insect.

1407. [RILEx, C. V.] The Colorado potato-beetle abroad. <N. Y. Weekly Tribune, 17 March, 1875. S.-b. No. 10, pp. 14-15.

Statement and criticism of measures adopted by sereral European Governments to prevent the introduction of Doryphora decemlineata into their countries. 
1408. Riley, C. V. Bud-eating insects. <Culticator and Country Gentleman, 25 March, 1875, r. 40, p. 183.

Habits, food-plants, and means against Agrotis scandens; means against field cut-worms.

1409. Riley, C. V. Description of a new species of Agrotis. <Proc. Bost. Soc. Nat. Hist., Mareh, 1875, v. 17, pp. 286-28s.

Description of Agrotis morrisoniana n. sp. [p. 286].

1410. Riley, C. V. On the summer dormaney of the larva of Phyciodes nycteis, Doubleday, with remarks on the natural history of the species. <Proc. Amer. Assoc. Adv. Sci. for 1874, 4 June, 1875, v. 23, pp. 108-112. Separate: <Salem, Mass., March, 1875, pp. 108-112. Abstract: <Hartford [Coun.] Daily Courant, 18 August, 1874, No. 11162, г. 38, No. 197, p. 2. See: $<\mathrm{N}$. Y. Tribune Extra: Lecture and Letter series, No. 21, August, 1874, p. 75 .

Observations on Phyciodcs mycteis and Argynuis bellona; significance of the same; detailed description of the larva and pupa of $P$. nycteis.

1411. Riley, C. V. Descriptions of two new moths. <Trans. Acad. Sci. St. Louis, 1 February [Mareh], 1S75, v. 3, pp. 240-242, figs. $12-13$.

Descriptions and figurcs of Tanthoptera [=Exyra] ridingsii n. sp. and Cerura multiscripta n. sp.

1412. Riley, C. V. The climate for Doryphora. <N. Y. Tribune, 2 April, 1575. S.-b. No. 10, p. 16.

Comments on letter from D. L. Garver; Doryphora decemlineata would be likely to thrive as well in the clinutes of Enrope as in North America; its transportation across the ocean is not improbable.

1413. Riley, C. V. [On an Acridium eaten out by ants.]. <Trans. Acad. Sci. St. Lonis, 6 April, 1875, v. 3, p. 102 Proc.

Verbal communication; inner soft parts of an Acridium amcricannm eaten ont by Myrmica minuta.

1414. Riley, C. V. [On the chrysalis of Pronuba yuccasella.] <Trans. Acad. Sci. St. Lonis, 6 April, 1875, v. 3, 1. 106 Proc.

Verbal communication; adaptation of pupa of Pronuba ynccasella to its needs of prying its ways through the soil.

1415. Ruley, C. V. [On regulatiug sex in insects.] <Trans. Acad. Sci. St. Louis, 6 April, 1S75, v. 3, p. 108 Proc.

Verbal communication; critical revicw of Mrs. Treat's "Controlling sex in buttcrflies"; female insects need more nourishment than the maies, bnt sex is determined in all animals at conception.

1416. Riley, C.V. [On the peculiarities of Nephila plumipes.] <Trans. Acad. Sci. St. Lonis, 6 April, 1875, v. 3, p. 109 Proc.

Verbal communication; comparison of the structure of male and female $\mathrm{Ne}$ phila plumipes; habits and silk-production of the femalc.

1417. Riley, C. V. [On the peculiarities of the Mexican honey-ant.] <Trans. Acad. Sci. St. Louis, 6 A pril, 1S75, v. 3, 1) 109 Proc.

Verbal comunication; structural and functional division of the neuters of Myrmecocystus mexicanus in to two distinct kinds. 
1418. Riley, C. V. [On the peculiarities of Physianthus albens.] <Trans. Acad. Sci. St. Louis, 6 April, 1875, v. 3, p. 109 Proc.

Verbal communication; the flowers of Physianthus albens so constructed as to hold large Sphingidee fast by the tonguc.

1419. Riley, C. V. [On the capture of moths by Physianthus albens.] $<$ Trans. Acad. Sci. St. Louis, 6 April, 1875, v. 3, p. 115 Proc. Reprinted, with changes, from <Moore's Rural New Yorker, 29 August, 1874, . 30 , p. 140.

Verbal communication; method of captnre of insects, particularly moths, by the flowers of Physianthus albens; records the captnre of a nnmber of Noctuidee and of Sphingidee, especially Deilephila lineata; Nerium oleander and Enothera grandiftora are said to capture Syphinx-moths in Europe.

1420. Riley, C. V. [On the Yucca borer.] <Trans. Acad. Sci. St. Louis, 6 April, 1875, v. 3, p. 139 Proc.

Verbal commnnication; entomological intcrest attaching to the Yncca; abode and synonymy of Megathymus yucce.

1421. Riley, C. V. [New biological facts regarding the grape Phylloxera.] <Trans. Acad. Sci. St. Louis, 6 A pril, 1875, v. 3, pp. 147148 Proc.

Sequence of development of ccrtain forms of Phylloxera; sexnal forms of thrce species of Phylloxera obtaincl ; alleged discovery by J. Lichtenstein of the winged form of $P$. vastatrix on Quercus coccifera in Europe, discredited, and this form considered by E. G. Balbiani as a new species, named P. Tichtensteinii.

1422. RILEY, C. V. [On the connection of locust invasions with the occurrence of drought.] <Trans. Acad. Sci. St. Louis, 6 April, 1875, v. 3, p. 163 Proc.

Verbal communication; no connection between the occurrence of dronght and of locust invasions.

1423. RrLey, O. V. Seventh annual report on the noxious, beneficial, and other insects of the State of Missouri, made to the State Board of Agriculture pursuant to an appropriation for this pur. pose from the legislature of the State. <10th Ann. Rept. State Board of Agric. for 1874, April, 1875, pp. $7+196+4,40$ figs. Separate: <Jefferson City, Mo., April, 1875, pp. $7+196+4$, 40 figs.

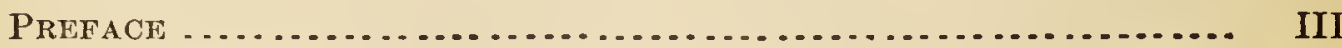

TAble of Contents .................................... VII

NOXIOUS INSECTS.

The Colorado Potato-Beetle, Doryphora 10-lineata ..............

Its gradual spread eastwar 1, 1-It reached the A tlantic during the year 1874, 1-Injurics done dnring the sear 1874, 2-Alarn about it in Europe, 3-Prohibiting the importation of Amerlcan potatoes by European governments, 3-The insect probably introduced into Europe in the pcrfect form, 3-It wunld donbtless thrive in Enrupe if imported, 4-Its ravages exaggerated and underraterl, 5-On the safcty and advisability of the use of Paris green, 8-Past experience with the poison, 10-I Iflnence of Pari s green on the plant and on the soil, 11-Influence of the green on 


\section{Riley, C. V.-Continued.}

\section{The Colorado pótato-Bertle-Continued.}

man indirectly through the soil or through the plant, 13-The beetle eats as well as the larva, 14-It passes the wiuter as imago, 14-New food-plants, $14-\mathrm{New}$ means of destruction, 15-The Gray sprinkler, 15-'The proper scientific name of the beetle, 16Mr. Carrière's ridiculous statements, 17.

The CHINCH-BUG, Blissus leucopterus..........................

Its disastrous work in 1874, 19-Circular distributed among farmers, 19-A ppearance and transformations of the chinch-bug, 20The short-winged form, 20-Description of the chinch-bug and its earlier states, 21-Its past history in America 22-Its past history in Missouri, 22-D structive powers of : l le chinch-bug, 24-Its injuries in 1874, 24-Its injuries in Missouri in 1874, 25Food-platts, 26-Time required for the comviete development of various insects, 27 -Nunber of annual broods, 27 -Its rapid incrcase, 28-Where the eggs are laid, 28-Flight of the chinchbug, 29-Its migrations on foot, 30-Heavy rains destructive to it, 30-Direct remedies, 31-Irrigation, 31-Preventive measurcs, 32-Burning, 32-Rolling, 33--Mannring and early sowing, 34Mixing seed, 34-Preventing the migrati $\mathrm{n}$ of the bug: from one fie'd to another, 35-Importance of winter work and combined action, 36-Other possible remedies, 37-Abstaining from the cultivation of grains. 38-Vatural enemies, 33; lady-birds, 39; lace-wing fly and habits of its larva, 40 ; the insidious flower-bug and the many-banded robber, $41-$ Birds destructive to the ehinchbug, 41-Discussion of other proposed remedics and preventive measures, 41-The chinch-bug injurious to stock, 43-Prognosticating, 44-Unnecessary lears, 44-Bogus chinch-bugs, 45-The false chinch-bug, 46-The insidious flower-bug and the ash-gray leaf-bug, 47-The flea-like negro-bug, 48-Recapitulation, 49.

Appendix to the article on the chinch-bug .....................

List of correspondents who replied to the circular, 51-Questions answered by correspondents, 52-Answers given by correspondents, 53.

THE Flat-HEADED APPLE-TREe BoRER, Chrysobothris femorata ......

Extent of its ravages in fruit and shade trees, 71 -Its natural history, 72-Natural cnemies, 73-Chalcid larva, 74-The cherished Bracon, 75-The useful Labena, 75-Ants, 76-Remedies, 76Keeping young trees vigorous and healthy, 77 -Coating the trunks and larger branches with soap and other greasy substances, 77Scraping, 78-Wrapping wire ganze around the trunk, 79-Cutting out the newly-hatched larva, 79.

Canker-worms, Paleacrita vernata ; Anisopteryx pometaria...........

Confusion regarding the two species of canker-worms, 80-Distinguishing characters of the spring canker-worm, 80-Description of egg, larva, and chrysalis of Anisopteryx vernata, 82-How the fall canker-worm differs from the preceding, 83-Description of egg, larva, and chrysalis of Anisopteryx pometaria, 84-Practical importance of distinguishing the two species, 85-Comparative description of the spring and fall canker-worms, 86-Conclusion, 88-Extracts from the original essay on the canker-worm by W. D. Peck, 89.

The grape Phylloxera, Phylloxera vastatrix ...................

Completion of its natural history, 90-The true sexual individuals discovered, 91-Epitome of the life-history of the grape Phyllox- 


\section{Riley, C. V.-Continued.}

The Grape Piylloxera-Continued. era, 91-Different forms presented by the species, 93-Its power to change its habit, 93-Specific identity of the gall-and rootlouse, 94-Untrustworthy experiments made by the Department of Agriculture, 95-Proof of the identity of the two forms, 95The gall-lonse is but a transient form, 96-Where do the winged females lay their eggs? 96-The winged female lays the egg wherever she is carricd by the wind, 97-Particular part of the vine chosen by the winged fomale for laying her eggs, 98-The trne sexual individuals, 98-Injury done by Phylloxera in A merica during the year 1874, 99-Range of the insect in America, 101Does it occur in Sonth Carolina and Georgia? 102-The Phylloxera in California, 103-Injury done during the year 1874 in France, 103-Its spread in Europe, 104-Direct remedies, 105-Natnral enemies, 106-Susceptibility of different varicties of grape-vine, 106-Grafting as a means of counteracting the work of Phylloxera, 108-Underground grafting, 109-Mcthods of grafting above ground, 112-Roots to irse as stock, 115-Varieties to graft, 116American grape-vines abroad, 116.

Appendix to the article on grape Phylloxera .................... Symopsis of the American species of the genus Plyylloxera, 117The American oak Phylloxera, 118-Its ratural history, 119-Description of Phylloxera rileyi and the differcnt forms presented by it, 119-Further points in its life history, 120.

The Rocky Mountain locust, Caloptenus spretus................

Its natural history, 121-Method of egg-laying, 121-The egg, 122The vewly-hatched locust and its development, 122-Where the eggs are laid by preference, $123-$ The invaling swarms are formed by a single species, 124-Difference between the Rocky Mountain and the red-legged locusts, 125-MIr. 'Thomas's description of the red-legged locust, 126-Variations, 126-Measurements of Caloptenus femur-rubrum, 127-Description of Caloptenus spretus and of its larva and pupa, 12y-Measurements of Caloptenus spretus, 130Sumbing up tho differcnce between the two specics, 132-Chronological history, 132-Locust invasions in the Old World, 132-Accounts of earlier loenst invasions in Ancrica, 133-Chronological history of the Rocky Mountain locnst, 134-Earlier invasions, 135-Data regarling the invasion of 1867,137 -The invasion of 1373,141 -The invasion of 1874,143 -The invasion of 1874 in Missonri, 144-Questions addressed to correspondents in each county in Missouri regarding the locust, 144-Summary of the answers given by correspondents, 145 - The invasion of 1874 in Kansas, 148-In Nebraska, 151-In Iowa and Minnesota, 153In Colorarlo, 154-In Daksta and Manitoba, 155-Flight and ravages of a locust swarm, 156-Food-plants, 158-Time of appearance of invading swarms, 160 -Eastern limits of locust invasions, 161-Native home of the species, 162-Explanation of the nuigratory instinct, 164-This locust can not thrive in the Mississippi Valle $5,164-\mathrm{I}$ t is an subalpine insect, $165-$ What injury may be expected in Missonri in 1875, 166-Ravages of migratory locusts in the Atlantic States, 167-Description of the Atlantic migratory locust, 169-Differences between Caloptenus spretus, differentialis, and atlanis, 170-Injnry from other, non-migratory, locusts, 171-The differential and two-striped locusts, 173-Encmics and parasites, 174-Birds destroying locusts or their eggs, 174-The 


\section{Riley, C. V.-Continned.}

The Rocky Mountain Locust-Continued.

silky mite, 175-The locust mite and Dr. Le Baron's description thereof, 176-The anongmous Tachina-fly, 178-The common flesh-fly, 180-Remedies, 181-Classification of protective measures, 181-Natural agencies, 181-Destruction of the eggs, 181Destruction of the joung wingless locusts, 182-Driving off the winged locusts, 184-Further suggestious, 185-Locusts as food for man, 186-The popular and scientific names of the insect, 187-Prairie fires vs. the Rocky Mountain locust, 189.

Appendix to the article on the Rocky Mountain locust.............

I etters of three correspondents from Texas and Kansas regarding locust invasions, 191.

1424. Riley, C. V. The ways of bag-worms. <N. Y. Semi-weekly Tribune, 14 April, 1875, 3 figs. S.-b. No. 10, pp. 11, 36.

Figure of the larva-case of an undetermined species of Psychide and of the scveral stages of Thyridopteryx ephcmeraformis; habits of and means against the latter.

1425. [RILEY, C. V.] [Poisonous qualities of the Colorado potatobeetle.] <N. Y.Tribune, 14 A pril, 1875. S.-b. No. 10, p. 17, 34. Mentions instances of poisoning from the fumes given out by scalded or crushed masses of Doryphora decemlineata.

1426. [RILEx, C. V.] Cure for canker-worm. <N. Y. Tribune, 21 April, 1875. S.-b. No. 10, p. 25.

Paris green recommended for destruction of canker-worms when other remedies are lacking. Paris green not to be nsch against all insects.

1427. [Rilex, O. V.] Paris green: Its effects on plants and soils, and through them on man. <N. Y. Tribune, 12 May, 1875. S.b. No. 10, pp. 15-16; 34-35.

Paris green is not iujurious to plants or the soil, nor dangerous to man when properly applied.

1428. [RILEY, C. V.] Swellings on roots of Ampelopsis. <Colman's Rural World, 5 June, $1875 . \quad$ S.-b. No. 10, p. 1.

Answer to letter of $\mathrm{H}$. Hillier; swellings on roots of Ampelopsis possibly occasioned by root-lice, but not by Phylloxera.

1429. Riley, C. V. Apple-tree plant-lice. <Colman's Rural World, 5 June, 1875.

Answer to lettcr of A. Moyer; occurrence of and mcans against Aphis mali.

1430. Riley, C. V. [Torrubic elongata, the white-grub fungus.] <Colman's Rural World, 12 June, 1875, v-, p-.

Torrubia elongata proposed as the name for the white-grub fungus; figures of the same.

1431. Riley, C. V. The Colorado potato-beetle, Doryphora decemlineata. <Garden [London], 24 July, 1875, v. 8, pp. 71-72, 5 figs. S.'-b. No. $\cong 3$, p. -

Description and figures of all stages of Doryphora decemlineata and D. juncta; migrations, habits, prolificacy, enemies, and parasites of $D$. decemlineata; means against it; the use of Paris green; probability and probable method of its introduction into Europe and means of preventing such introduction; figures Lydella [= Exorista $]$ doryphore, Harpactor [= Milyas $]$ cinctus, Arma $r=$ Podisus $]$ spinosus, and Hippodamia convergens. 
1432. Riley, C. V. Locusts vs. chinch-bugs. <N. Y. Tribune, 4 August, 1875. S. b. No. 10, p. 40.

Looust ravages are likcly to prevent scrions injury by Blissus leucopterus; the latter more noticeable than usual; excessive rains in 1875 , also unfavorable to the development of Blissus leucopterus.

1433. Riley, C. V. No locust injury in Kansas and Missouri this fall. $<$ N. Y. Tribune, 1 September, 1875. S.-b. No. 10, p. 166.

Predicts imnunity from attacks of Caloptenus spretus in the fall of 1875 in Kansas and Missouri.

1434. Riley, C. V. Prof. Riley and the locusts. <St. Louis Daily Globe-Democrat, 4 September, 1875 , v. 1, No. 108, p. 3 . S.-b. No. 10, pp. 158-159.

Reply to C. A. Davis's "Prof. Riley and the locusts;" food-plants, habits, parasites, and period of development of Caloptenus spretus; need of more extended investigation of this insect in its native haunts and breeding places.

1435. Rilex, C. V. The grape-leaf gall. <Cultivator and Country Gentleman, 9 September, 1875, v. 40, p. 567.

Identity of the root and leaf-forms of Plylloxera rastatrix.

1436. Riley, O. V. White-grub fungus. <N. Y. Tribune, 6 October, 1875. S.-b. No. 10. p. 26.

Answer-to inquiry of A. C. G.; brief history of Torrubia elongata, a parasite of Lachnosterna fusca.

1437. Rilex, C. V. Flying locusts in Illinois. <Cultivator and Country Géntlewan, 2s October, 1875, v. 40, p. 679.

Caloptenus spretus confonnded with C. femur-rubrum by B. F. J.; C. spretus does not occur in Illinois.

143S. Rilex, C. V. Remarks on canker-worms and description of a new genus of Phalcenidce. <Trans. Acad. Sci. St. Louis, 5 November, 1875, v. 3, pp. 273-280, figs. 14-21. Separate : <St. Louis, Mo., 1875, pp. S, figs. Reprint: <Sth Ann. Rept. State Ent. Mo., May, 1876, pp. 12-18, figs. 3-10. Notice: <Ca. Eut., November, 1875, v. 7, p. 219. <Proc. Bost. Soc. Nat. Hist., February, 1876, v. 18, p. 201.

Treats of Paleacrita [n. g.] vernata and Anisopteryx pometaria; see No. 1482 for synopsis of contents.

1439. RILEY, C. V. Notes on the natural history of the grape Phylloxera, Phylloxera vastatrix, Planchon. <Trans. Acad. Sci. St. Louis, 5 November, 1875, г. 3, pp. 281-287, fig. 22. Extract: <Amer. Nat., June, 1881, r. 15, pp. 483-484.

Discovery of the nidus in which eggs are deposited by the winged female of Phylloxera vastatrix; development, habits, description, and figures of the same; description of the male and of the impregnated egg; figure of the male of $P$. caryacaulis; summary of the natural history of $P$. vastatrix.

1440. [RrLey, C. V.] Grubs and guess-work. <N. Y. Semi-weekly Tribune, 12 November, 18i5. S.-b. No. 10, pp. 17-18.

Characterizes some subdivisions of the Lamellicornia by their habits; contrasts the lårve, inagos, and habits of Lachnosterna quercina [=fusca] and Lygyrus relictus; means against the former. 
1441. R[ILEY], O. V. Entomological. Apple-tree borers; timber encourag es them; new bag-worm. <Colman's Rural World, 13 November, 1875. S.-b. No. 10, p. 188.

Timber-trees near apple orchards increase the likelihood of the attacks of Saperda bivittata $[=$ candida $]$ upon the apple-trees; habits and food-plants of Psyche confederata.

1442. Riley, C. V. The army-worm; an important point yet to ascertain in its history. How it comes and goes; its natural ene. mies; preventive measures. $<\mathrm{N}$. Y. Tribune, 16 November, 1875, 8 figs. S.-b. Yo. 10, pp. 29-31; 31-33.

Various applications of the name "army-worm;" seasons, habits, and natural enemies of and means against Leucania unipuncta; supposed method of oviposition; figures of it in its several stages, of Exorista flavicauda, Microgaster [= Apanteles] militaris, Ophion purgatum, and Pezomachus mininus, and of cocoons of the last; habits of these parasites.

1443. Riley, C. V. The flying locusts in Illinois. < Cultivator and Country Gentleman, 25 November, 1S75, v. 40, p. 744.

Extent of swarms flying south over Kansas and Nebraska on September (4th?).

1444. R[ILEy], C. V. Scabby potatoes. <N. Y. Tribune, 15 December, 1875. S.-b. No. 10, pp. $20,29$.

The scab in potatoes is caused by imperfectly studied Acarina.

1445. [RIley, C. V.] Not the Hessian-fly. <N. Y. Tribune, 15 December, 1875. S.-b. No. 10, pp. 20, 29.

Answer to inquiry of J. H. K. ; significance of the name and habits of Aphodius inquinatus.

1446. R[ILEY], C. V. How to destroy locusts. <Colman's Rural World, 23 Dewer, 1875. S.-b. No. 10, p. 185.

Answer to letter of C. Herschel; means against Acridide; recommends flooding and ditching.

1447. Riley, C. V. Paris green as an insect destroyer. $<$ N. Y. Tribuue, 28 December, 1875. S.-b. No. 10, pp. 13-14; 28-29.

Paris green as a means against Doryphora decemlincata; R. C. Kedzie's investigations show that Paris green is not deleterious to the soil or the crops.

1448. Riley, C. V. Oak apple. <Amer. Cyclopædia, 1875, v. 12, pp. 558-559, 3 figs. S.-b. No. 14, pp. 47-48.

Description of galls of Cynips terminalis, C. [=Amphibolips] quercus-spongifica, and $C .[=A$.$] q.-inanis; manner of their formation; figures the latter$ two galls and a parent $f y$; nature of galls and problems involved in their study.

1449. [Riley, C. V.] Phylloxera. <Amer. Cyclopædia, 1875, v. 13, pp. 477-480, figs. 1-8. S.-b. No. 10, pp. 84-87.

Habits, food-plants, and characters of the genus Phylloxera; natural history of $P$. vastatrix; figures its several forms and the galls formed by it; history of the ravages in the vineyards of France. 
1450. [Rilex, C. V.] Potato-bug. <Amer. Cyclopædia, 1875, v. 13, pp. 768-771, fig. 1-7. S.b. No. 10, pp. 89-92.

Food-plants, original home, geographical distribution, natural history, enemies of, and means against Doryphora decentincata; figures of it and of Lydella $[=$ Exorista $]$ doryphore, Arma $[=$ I'odisus $]$ spinosus, Harpactor [= Milyas $]$ cinches, Mrysia $[=$ Anatis $]$ 15-punctata, and Doryphora juncta.

1451. Riley, C.V. Rocky Mountain locust. < Ainer. Cyclopredia, 1875, v. 14, pp. 371-374, figs. 1-10.

Ravages, description, natural history, migrations, and enemies of and means against Caloptenus spretus; figures of it with details of its structure and habits; figures C. femur-rubrum, Astoma gryllarium [= Trombidium locustarume ], Trombidiun scriceum, and Sarcophaga cornaria.

1452. Riley, C. V. The hateful or Rocky Mountain locust, Caloptenus spretus. $<\mathrm{N}$. Y.Tribnne, 1875. Reprint: <Trans. Kans. State Hortic. Soc. for 1874, 1875, v. 4, pp. 172-176.

Answer to inquiry of Z. F. Hopkins; probable limit of the ravages and range of Caloptenus sprctus in Kansas, Missouri, and neighboring States in 1875; means against and veruacular name of this species; vernacular names of Acridide and Locustide in general.

1453. Riley, C. V. Prairie fires and hateful locusts: is there any connection between them" $<\mathrm{N}$. Y. Tribune, .1875. Reprint: <Trans. Kans. State Hortic. Soc. for 1874-75, v. 4, pp. 176-180.

Criticism of the effects of the dronght, hot winds, locusts, and short crops in Kansas caused by the burning of the prairie grasses as stated in Kansas Farmer, 23 September, 18 8 ; benefits resulting from prairie fires by the destruction of hibernating Elissus loucopterus, Nysius destructor [= angustatus], etc.; relations of prairie fires to the origin and maintenance of prairies.

1454. Riley, C. V. [Address ou entomology.] <Trans. Ill. State Hortic. Soc. for 1874, 1875, n. s., v. 8, pp. 103-111. Partial reprint: <Trans. Kans. State Hortic. Soc. for 1874, 1875, v. 4, pp. 103-104.

AEgeria rubi $[=$ Bembecia marginata $]$ injurious to blackberry and raspberry; the cause and cure of scab in apples; ravages, food-plants, seasons, habits, and means against Chrysobothris femorata; evidence for the identity of the leaf-and root-forms of Phylloxera vastatrix; means against the same.

1455. Riley, C. V. Discussion of the honey-bee. <Trans. Ill. State Hortic. Soc. for 1874, 1875, n. s., v. 8, pp. 131-132.

Apis mellifica as an enemy to horticulture; importance of insects in the fertiiization of flowers.

1456. Rilex, C. V. Notes on locusts. <Trans. Ill. State Hortic. Soc. for 1874,1875 , 1. s., v. 8, pp. 136-137.

Native habitat of Caloptemus spretus.

1457. Riley, C. V. Nonsense abont the Phylloxera. <Colman's Rural World, 12 January, 1876. S.-b. No. 10, p. 3. See: $<$ N. Y. Tribune, 1876. S.-b. No. 10, p. 27.

There is no such species as the American corn-grape, which is reported capable of resisting the attacks of Phylloxera vastatrix. 
1458. Rrley, C. V. Small borer in apple-twig. <Colman's Rural World, 26 January, 1876. S.-b. No. 10, p. 1.

Answer to letter of F. Holsinger; description and habits of Psenocerus supernotatus.

1459. Riley, C. V. Worms on cottonwood. <Colman's Rural World, 26 January, 1876. S.-b. No. 10, p 1.

Answer to letter of J. H. Davidson; occurrenco of larvie of Drasteria erechthea on Populus monilifera and on Trifolium; description of the imago.

1460. Riley, C.V. Ailanthus silk-worm in Missouri. <Colman's Rural World, 27 January, 1876. S.-b. No. 10, p. 2.

Answer to letter of "Subscriber ;" extent aud unprofitableness of the culture of Samia [= Atlacus] cynthia; naturalization of the worm in the United States.

1461. R[ILEY], C. V. Oause of smut in wheat. <Colman's Rural World, 26 Jiuuary, 1876. S.-b. No. 10, p. 2.

Critical review of a report by Pulaski Graugo, Teun., on the cause of smut in wheat; absurdity of tho report; occurrence of Brachytarsus variegatus in the smut, and of larve of Cecidomyia, Meromyza, and Chlorops in the lower joints of wheat; smut caused by Ustilago segetum.

1462. Riley, C. V. Colorado potato-beetle's native home. <N. Y. Tribune, 9 February. 1576 . S.-b. No. 10, pp. 12-13.

Geographical distribution of Doryphora decemlineata prior to 1859.

1463. Riley, C. V. An entomological question. <Prairie Farmer, 26 February, 1876, v. 47 , p. 68 . S.-b. No. 10, pp. 4,5 ; No. 42 , pp. 76, 77. See: <Prairie Farmer, 4 March, 1876, v. 47, p. 76. S.-b. No. 10, p. 4.

Reply to Proximo's "An entomological question;" commendation of legislative efforts to effect the appointment of a uational ontomological commission; text of the two bills introduced into Congress; criticism of the same.

1464. Riley, C. V. Insect ravages. An interesting letter from Prof. O. V. Riley. How to protect our agricultural interests; legislation, wise and otherwise; the duty of Congress. <St. Louis Daily Globe-Democrat, 4 March, 1876, v. 1, p. 3. S.-b. No. 10, pp. 5-8.

Importance and extent of injuries inflicted by insects in North Amorica; notice of existing legislation upon means against injurious insects; statement of legislation needed for protection against locusts; criticism of bills introduced into Congress for the appointıent of a national entomological conmission.

1465. Riley, C. V. Notes on the Yucca borer, Megathymus yucce, Walk. <Trans. Acad. Sci. St. Lonis, 10 January-23 March, 1876, v. 3, pp. 323-344, figs. 25-31. Separate : <St. Lonis, Mo., January, 1876, pp. 23, figs. 25-31. Reprint: <sth Ann. Rept. State Ent. Mo., May, 1876, pp. 169-182, figs. 40-55.

See No. 1482 for syuopsis of contents; see No, 1602. 
1466. RILEY, C. V. Entomology. An interesting lecture on the insect world. The subject considered both practically and scientifically. <St. Louis Daily Globe-Democrat, 25 March, 1876, v. 1, p. 3. S.-b. No. 10, pp. 161-164. Reprint, with omissions: <Ware's Valley Monthly, Angust, 1876, v. -, pp. 281-289. S.-b. No. 14, pp. 163-167.

Definition of entomology; claims of the science as a liberalizing study; its economic importance; metamorphoses, abundance, and almost omnipresence of insects.

1467. [Riley, C. V.] The insect world. Lecture by Professor Riley at Washington University. A practical subject for fruit-growers. <St. Louis Republicau, 26 March, 1876. S.-b. No. 10, pp. 178, 179.

Advantages and interest of the study of insects as compared with that of other animals; econounic importance of the study; ravages of Glossina morsitans.

1468. Riley, C. V. Legislation in regard to insects injurious to agriculture. <Nation, 30 March, 1876, v. 22, p. 208.

Amount of insect injuries in the United States; demand for an independent commission; duties and limits of such a commission.

1469. Rilex, C. V. Entomology. Another lecture by Professor Riley. How to counteract the ravages of insects; direct remedies; practical hints to farmers, etc. Some of the duties of the State entomologist. <St. Louis Daily Globe-Democrat, 1 April, 1876, v. 1, p. 3. S. b. No. 10, pp..135-138; 179-184. Reprint, with omissions: <Ware's Valley Monthly, Septem. ber, 1876 , v. -, pp. 369-380. S.-b. No. 14, pp. 168-173.

Classification of means against insects; canse of the destructive occurrence of insects; importation of foreign pests; history of the introduction and spread of Pieris rape, Phylloxera vastatrix, and Doryphora decemlineata; natural history of these insects; spread of insects by small degrees; advantageous means against certain insects; cncouragement of enemies of and parasites on noxious insects; need of distinguishing friends from foes; need of co-operation and of legislation for the destruction of insects; duties of a State entomologist.

1470. [RILey, C. V.] Scarlet mite. <Colman's Rural World,12 April, 1876, fig. S.-b. No. 10, p. 160.

Answer to letter of G. W. Barnes; occurrence, habits, and figure of Trombidium sericeum; habits of $T$. holosericeum; use of $T$. tinctorium as a dye.

1471. Riley, C. V. Hibernation of Amphipyra [=Pyrophila] pyramidoides. <Psyche, March [13 April], 1876, v. 1, p. 152.

Extract from 3d Ann. Rept. State Ent. Mo., pp. 72-73, with additional note; this species sometimes hibernates as a pupa, and doubtless frequently as a moth.

1472. Riley, C. V. Bag-worms and borers. How to protect our shadetrees and insure their growth. How to render shade-trees healthy. Letter from the State entomologist. KSt, Louis Re- 
1472. Riley, C. V.-Continued.

publican, 14 April, 1876, No. 16843, p. 3,3 figs. S.-b. No. 10, pp. $173-175 ; 175-178$.

Causes of the death of shade-trees in the city of St. Louis; description, figures, and natural history of and means against Thyridopteryx ephemerceformis and Chrysobothris femorata.

1473. RILey, C. V. The locust plague; how to arert it. <Proc. Amer. Assoc. Adv. Sci. for 1875, 1876, v. 24, pp. 215-222. Separate: <Salem, April, 1S76, 1p. 215-222.

Extent of the ravages of Caloptcuns spretus in 1873, 1874, and 1875; classification of and special remarks on the several means to be cuployed against the same; need of more extensive investigation of the insect in its native haunts and breeding places.

1474. R[ILEY], O. V. Honey locust weevil. <Colman's Rural World, 26 April, 1876.

Answer to inquiry of E. H. B.; larva of Spermophagns robinice has legs and spins a cocoon.

1475. Riley, C. V. Apple and peach borers. <Colman's Rural World, 9 May, 1876. S.-b. No. 16, p. 11.

Ansiver to inquiry of F. H. ; habits, natural history, and means against Chrysobothris femorata and AEgeria [= Sannina] exitiosa.

1476. Riley, C. V. Notes on the codling-moth. <Colman's Rural World, 17 May, 1876. S.-b. No. 13, 1. 153.

Natural history of Carpocapsa pomonella.

1477. Riley, C. V. Plums and cotton. <N. Y. Weekly Tribune, 17 May, 1S76. S.-b. No. 10, p. 167.

Answer to letter of J. C.; a belt of cotton-batting around the trunk of the tree is no protection against the injury to plums by Conotrachelus nemuphar.

1478. Riley, C. V. Rose-bug remedy. <N. Y. Weekly Tribune, 17 May, 1876, fig. S.-b. No. 10, p. 167.

Answer to letter of Mrs. S. P. Smith; description, figure, habits, and preferred food-plants of and means against Macrodactylus subspinosus.

1479. Riley, C. V. Smut in wheat. <N. Y. Weekly Tribune, 17 May, - 1876. S.-b. No. 10, pp. 167-168. Reprint: <Colman's Rural World, 14 June, 1876. S.-b. No. 10, p. 169.

Critical review of two quoted communications by A. S. and by L. Heskett, on the cause of smut in wheat; sinut caused by the growth of Ustilago segetum;

Brachytarsns variegatus breeds in various smuts; description of the beetle.

1480. [Ŕrlex, C. V.] Potato-beetle; progress. <N. Y. Weekly Tribune, 17 May, 1876. S.b. Ne. 10, p. 168.

Arrival of Doryphora decemlineata at the Atlantic coast; its ravages there and means against them.

1481. Riley, C. V. Locusts as food for man. <Proc. Amer. Assoc. Arlv. Sci. for 1875,1576 , v. 24, pp. 20S-214. Separate: <Salem, May, 1876, pp. 20s-214.

Reference to previous writings on the use of locusts as food for man; historical eridence of the extensive use of locusts as food; methods of preparing locusts for food; species used hitherto ; use of Caloptenus spretus ; peculiarities of individual taste or national custom.

13 ENT 
1482. Riley, C. $\nabla$. Eighth annual report on the noxions, beneficial. and other insects of the State of Missouri, made to the Stato Board of Agriculture, pursuant to an appropriation for this purpose from the legislature of the State. <11th Ann. Rept. State Board of Agric. for 1875, May, 1876, pp. 185+4, 55 figs. Separate: <Jefferson City, Mo., May, 1876, pp. 185+4, 55 figs.

PREFACE ............................................... III

TABLE of Contents ..................................... V

\section{NOXIOUS INSECTS.}

The Colorado potato-Beetle, Doryphora 10-lineata..............

Damage during the year, 1-Abundant in Atlantic States, 1Swarming on Coney Island, 2-Injuring egg-plant, 2-Its scientific name, 2-Additional enemies, 3-Eaten by the crow, 3-Remedies, 3-Cost of applying Paris green, 3-Preparing the poison, 3-Use of straw as a protection, 4-Machine for sprinkling, 4Machine for brishing off the insects, 4-Expericnce with Paris green, 5-Experiments of Profs. R. C. Kedzie and Wm. McMurtrie show that it may be used with safety, 6-Trial of other remedies, 6-The insect's native home, 8-The theory that it came from the Rocky Mountain region essentially correct, 10-Poisonous qualities of the insect diseussed, 10 .

Canker-worms, Palcacrita vernata; Anisopteryx pometaria...........

Two specics long confounded, 12-They differ generically; new genus (Paleacrita) proposed for one, 13-The 'two compared in all stages, 13, 17-Characters of the genus Paleacrita, 17-Distinguished as spring aud fall canker-worms, 17-Practical consiclcrations from their differences of habit, 18-Stunting the larvio does not produce male motlis, 19-Traps recommended, 20, 21.

THE Arмy worm, Lencania unipuncta........................

Its generic name, 22-The term "army-worm" applied to various insects, 23-Past history of the army-worm, 24-Known since 1854 in Missouri, 27-It lollowed the 1871 conflagration aromnd Peshtigo, Wis., 28-Its history in 1875; very general all over the country, 28, 29-Its history in Missouri in 1875, 30-Sexual differences, 30-Sexual orgaus illustrated, 30, 32-Natural history of the species, 32-lllustrated in all states, 32, 33-It occurs in Europe, Asia, New Zealand, and Australia, 34-Description of the egg, 34-Where the eggs are laid, 34-Conclusions drawn from structure, 36, 37-When the cgus are laid, 40 -In what state does the insect hibernate?, 43-Habits of the worm, 45-Why it escapes detection when young, 45-Why it travels in armies, 46-Time of its appearance, 46-Are there one or two broods?, 47-The fall army-worm, 48-How distinguished from the real army-worm, 48-Plants preferred by the army-worm, 49-Its sudden appearance and disappearance, 50-It swarins duriug wet preceded by very dry seasons, 51-Its natural enemies, illustrated, 52-Remedies, 54-Philosophy of winter burning, 54, 55-Prevention, 55-Sinmmary of the leading facts concerning it, 56 .

The Rocky Mountain locust, Caloptenus suretus..................

Previous experience in spriug of 186\%, 57-Predictions verified, 58General outlook in spring of $1875,60-$ Extent of country ravaged, 60-The outiook in Missouri, 61-Country ravaged often as bare as in midwinter, 61-Account by counties, 62-Atchison County, 


\section{RILEY, O. V.-Continued.}

The Rocky Mountarn Locust-Continued.

62-Andrew County, 62-Benton County, 63-Barton County, 63-Bates County, 63-Buchanan County, 64-Caldwell Connt5, 64-Cass County, 64-Clas Connty, 67-Cliuton Connty, 68-Dade County, 68-De Kalb Connty, 69-Gentry County, 69-Hickory County, 69-Holt County, 69-Heury County, 69-Jackson County, 69-Johnson Connty, 72-Lafayette Connty, 73-Nodaway County, 73-Newton Count5, 73-Pettis County, 73-Platte County, 73-Ray Counts, 74-St. Clair County, 75-Vernon County, 76-Condition of things in other States, 76-Kansas, $76-$ Nebraska, 79-Iuwa, 81-Mininesota, 81-Colorado, 84-Dakota, 85-Montana, 87-Wyoming, 88-Texas, 88-Indiau Territory, 88-Manitoba, 89-Damage done in Missouri, 89-Destitution in Missouri, 91-Address of relief committee from Saint Louis Merchants' Exchange, 93-Cases of starvation, 94-The Governor's proclamation, 95-The locusts 110 a divine visitation, 97-Natural history; mode of molting illustrated, 98-Habits of the nufledged young, 100-Directions iu which the young travel, 101Rate at which they travel, 10\%-They reached but a few miles east of where they hatched, 102--Not led by "kings" or "queens," 103-The species taken. for such, illustrated, 103, 104-The exodus in $1875,104-$ Time of leaving of the winged insects, 104-Direction taken by the winged insects, $105-D e s t i u a t i o n$ of the departing swarms, 106-Native home of the specics, 109-Views previonsly expressed confirmed, 110-Conditions of migration, 112-Conditions which prevent the permanent settlement of the species in Missonri, 113-Modification of the species by climatie conditions, 114, 155-Definition of the species, 114-How distingnished in all stages from species nost nearly allied, 117-Experience in spring of 1875,118 -Contrast in summer and fall, 119No evil without some compensating good, 120 -Injury to fruit and fruit trees, 121-Food-plauts, 121-Only one kind of plant not touched under all circumstances, 121-Changes that followed the locusts, 121-The widespread appearance of a new grass, ordinarily unnoticed, 122 -Appearance of large worms, 123 -The locusts did not return in the fall, 124-Natural enemies, 124-Remedies against the unfledged insects, 125-Artificial means of destroying the eggs, 125-Various means of destroying the unfledged young, 126-Thcy are within man's control, 126-The proper ditch to make, 128-Machines used in Colorado, 129-Best means of protecting fruit trees, 130-How to avert locust injuries, 131-Prevention, 131-Legislation, both national and local, 132-Bills before the Forty-fourth Congress, 133-Neel of a national entomological commission, 133-The bounties offercd in Minnesota, 138-'The requisites of a good bounty law, 138, 139-How a bounty law would work, 140-Suggestions, 140-Lessons of year, 142Locnsts as food for man, 143-They have becn used from time immemorial, and are used extensively at the present day, 145The Rocky Mountain species quite palatablc, 146-Mode of preparation, 147-False opinions and predictions, 148-Unnecessary alarm caused by other species, 148-Injuries of native species in 1875, 150-Locust flights in Illinois in 1875, 151-They were composed of local species, 15?, 153-Explanation of these flights, 154Locust prospects in 1876, 155-No danger from them in Missouri, 156 , 


\section{Riley, C. V.-Continued.}

The grape Phylloxera, Phylloxera vastatrix....................

The injuries not great in Missouri in 1875, 157-Completion of its natural history, 157-Where the winged female lays her eggs, 157, 161-The sexed individuals illustrated, 158-Description of the true female, 159-Description of the impregnated egg, 159, 162-Practical considerations growing out of these latest discoveries, 163-Decortication of the bark to destroy the impregnated egg, 163-The insect may be imported from one country to another on cuttings as well as rooted plants, $163-$ Best time to attack the root-lice, 163-Phylloxera ravages in California, 163-Great destruction around Sonoma, 164-Need of action by the State authorities, 164-Occurrence of Phylloxera in the Southern Statcs, 164-Report of committee appointed by the Americau Pomological Society, 165-Its occurrence in Georgia, 166, 167-American grape-vines in Europe, 167-Large demand for our vines, 167The American vines flourishing in Southern France where the European varieties perish, 167-The orders for some varieties exceeded the supply, 168-Probable future demand, 168.

\section{INNOXIOUS INSECTS.}

The Yucca borer, Megathymus yucce .........................

The only North American buttertly whose larva has the boring habit, 169-The arbitrary nature of classificatory divisions, 170But.terflies and moths not easily separated, 170-Biological history of the species, 171-Illustrations of all states, 171, 172Habits of the larva, 171, 172,181- Mode of pupation, 172,180Flight of the imago, 173; 181-Position of wings when the imago rests or walks, 173-Bibliographical notes, 173-Detailed descriptions of the different states, 174, 175, 181-Structural characters illustrated, 175-Affinities of the species, 176-It is a true butterfly, belonging to the hesperians, 178-Characters of the castnians contrasted with those of hesperians, 176, 177, 178-In classinication it is better to widen than restrict in the higher groups, 179-Enemies of the Yucca borer, 179-Concluding remarks, 179-Unsafe to describe species from mere drawings, 179.

NOXIOUS INSECTS-Continued.

SUPPLEMENTARY .NOTES ON THE ARMY-WORM, Leucania unipuncta ....

Completion of its natural history, 18:-Oviposition of the moth described, 183-Eggs described, 183-Conclusions previously arrived at verified, 184-Description of the different larval stages, 184.

1483. Riley, C.V. Is the Colorado potato-beetle poisonous? <Colman's Rural World, 7 June, 1876. S.-b. No. 10, pp. 164-165.

Extract from the 8th Ann. Rept. State Ent. Mo., pp. 10-12 ; abstract and critical review of Grote and Kayser's "Are potato-bugs poisonous?"; considers the experiments inconclusive.

1484. [RILEY, C. V.] The eggs of the army-worm. <Colman's Rural World, 7 June, 1876. S.-b. No. 10, p. 170. Reprint: <Trans. Acad. Sci. St. Louis, June, 1876, v. 3, p. 211 Proc. <Amer. Nat., August, 1876, v. 10, pp. 508-509.

Reasous why eggs of Lencania unipuncta have not been observed heretofore; verification of author's conclusions as to the probable method of oviposition of this species; description of eggs and young larva. 
1485. R[ILEY], C. V. Persian insect powder. $<\mathrm{N}$. Y. Tribune, 7 June, 1876. S.-b. No. 10, p. 168.

Answer to letter of G. W. Holmes; impossibility of prescribing means against unknown iusects; Paris green ursuitable for protection of beariug fruit trees; pyrethrum recommended.

1486. R[ILEY], C. V. Cocoons of silkworms. $<\mathrm{N}$. Y. Tribune, 7 June, 1876. S.-b. No. 10, p. 168.

Answer to letter of A. R. Sprout; description of larva and cocoou of Callosamia $[=$ Attacus $]$ promethea ; colors of imagos; food-plants of larvæ; deposition of eggs; silk of little value.

1487. [Riley, C. V.] Is Paris green absorbed? <N. Y. Tribune, 7 . June, 1876. S.-b. No. 10, pp. 168-169.

Answer to latter of M. F. ; plants colored by certain tinctures placed at their roots; Paris green not absorbed into the tissues of plauts in perceptible quantities, but neutralized in the soil.

1488. RILEX, C. V. Ditching for young locusts. <Colman's Rural World, 14 June, 1876. S.-b. No. 10, pp. 171-172 ; 203-204; 204205.

- Critical review of J. Stayman's article on same subject; proper width and depth of ditches to check the march of uufledged Caloptenus spretus and other locusts.

1489. Riley, C. V. Periodical Cicada, "17-year locust." <N. Y. Semi-weekly Tribune, 23 June, 1876, 3 figs: S.-b. No. 10, pp. 166-167.

Occurrence of Cicada [= Tibicen ] septendecim at Lexington, Va., in 1876; list of localities at which these insects will appear this year; chronological history of a brood ; figures of larva, pupæ, and imago.

1490. Riley, C. V. Specific for Colorado potato-beetle. <Colman's Rural World, 28 June, 1876. S.-b. No. 10, p. 160. Reprint, with omissions: $<$ N. Y. Tribune. S.-b. No. 14, p. 7.

Answer to lettel. of R. Barbonl'; directions for the nse of Paristgreen as a means against Doryphora decemlineata.

1491. Riley, C. V. [Inquiries concerning the Colorado potato-beetle, and Mayor Brown's answer thereto.] <Trans. Acad. Sei. St. Louis, June, 1876, v. 3, pp. 170-172 Proc.

Verbal communication; critical review of answer of Mayor Brown to inquiries of $A$. C. Hardy de Boislieu as to the means of preventing the introduction of Doryphora decemlineata into Belgium; quotes the 6th Ann. Rept. State Ent. Mo., p. 16, showing that the fear of such iutroduction is not unfounded; inaccuracy of Mayor Brown's opinions; manuer in which Doryphora decemlineata will probably reach Europe if at all.

1492. RiLEX, C. V. [On the ravages of young locusts in western Missouri.] <Trans. Acad. Sci. St. Louis, June, 1876, v. 3, pp. 179 180 Proc.

Verbal communication; alarmiug nature of the ravages of uufledged Calop. tenus spretus in western counties of Missouri at the present time; probable future departure of the wiuged locusts : means to be adopted against the locusts now. 
1493. Riley, C. V. [Lecture on the Rocky Mountain locust.] <Trans. Acad. Sci. St. Louis, June, 1876, v. 3, p. 180 Proc.

Brief abstract of lecture; prediction of the speedily approaching end of the ravages of Caloptenus spretus in Missouri for 18.5 ; plentiful crops to be expected subsequently.

1494. Riley, C. V. [Predictions verified.] <Trans. Acad. Sci. St. Louis, June, 1876, v. 3, p. 185 Proc.

Verbal communication; accuracy of author's conclusions as to the probable doings of Caloptenus spretus in Missouri later in the season.

1495. Riley, C. $\nabla$. [On changes in vegetation caused by locusts.] $<$ Trans. Acad. Sci. St. Louis, June, 1876, v. 3, pp. 188-189 Proc. See : <Amer. Nat., February, 1876, v. 10, p. 125.

Verbal comuunication; remarks on the extraordinary development of Vilfa vaginceftora for a season after the ravages of Caloptenus spretus have occurred an illustration of "the struggle for existence;" the interesting character of such instances of abnormal multiplication of a species ; criticism and defense of the expressions "struggle for existence" and "natural selection."

1496. Rilfey, C. V. Jumping seeds and galls. <Trans. Acad. Sci. St. Louis, June, 1876, v. 3, pp. 190-192 Proc. Reprint: <Gardener's Mo. and Hortic., July, 1878, v. 20, pp. 213-214. See: <Amer. Nat., February, 1876, v. 10, p. 125. Pacific Rural Press, 6 April, 1878.

Description of the sceds (of an unknown plant) which are inhabited by the larvæ of Carpocapsa saltitans; ; manner in which these larvæ canse the seeds to roll and jump; habits of larva within the seed ; description of the plant bearing the seeds; the secd of Tamariscus moved by the larva of Nanodes tamarisci, which feeds within it; description of the gall of Cynips [=Nenroterus] quercus-saltatorius and of the jumping of these galls.

1497. Riley, C. V. [On the use of Paris green as an insecticide.] <Trans. Acad. Sci. St. Louis, June, 1876, v. 3, p. 193. See: $<$ Amer. Nat., Februars, 1S76, v. 10, p. 126.

Verbal communication; contirmation, by experiments of R. C. Kedzie, of author's conclusions in regarl to the safety of Paris green as an insecticide; this substance metamorphosed into a less soluble form in the ground and held in the ground if not used to excess; when applied in small but sufficient quantities not injurious to plants; objections to the use of the "Potato-pest poison" made at the Lodi [N. J.] Chemical Works.

1498. Riley, C. V. New use for the American Agave. <Trans. Acad. Sci. St. Louis, June, 1876, v. 3, pp. 195-196 Proc. See: <Amer. Nat., February, 1876, v. 10, p. 126.

Verbal communication; use of the dried flower-stalk of Agave americanus for lining insect-boxes.

1499. Riley, C. V. [Food of insectivorous plants.] <Trans. Acad. Sci. St. Louis, June, 1876, v. 3, pp. 201-202 Proc.

Drosera, Dioncea and other plants digest, absorb, and appropriate nitrogenous matters; glands for the appropriation of animal food not yet found in the Sarracenias.

1500. Riley, C. V. Parasites on bees. <Trans. Acad. Sci. St. Louis, June, 1876, v. 3, p. 212 Proc.

Bees in California infested with triungulins of a Meloë sp. which sometimes kill the bees; usual habits of such trinugulins. 
1501. Riley, C. V. The locust pest. <Sci. Amer., 1 July, 1876 [ v.49], n.. s., v. 35, p. 9 .

Effects of water and cold on the eggs of Caloptenns spretus.

1502. Riler, C. V. Swallows; bed bugs, <Colman's Rural World, 5 July, 1876. S.b. No. 10, p. 166.

Answer to letter of R. R. Pierce; nests of Hirundo fulva generally infested by Acanthia lectularia; those of Hirrndo americana rarely so; while this habit might cause annoyance about a dwelling, it is of little consequence when the bird nests under the eaves of a churcli.

1503. [Rlley, C. V.] Berry and cherry twigs. '<N. Y. Tribune, 5 July, 1876. S. b. No. 10, p. 169.

Answer to letter of W. Keyser; eggs of Ecanthus niveus laid in twigs of Rubus and Prunus; description, habits of, and means against Oberea tripunctata.

1504. R[iLEY], C. V. Three worms and their work. <N. Y. Weekly Tribune, 12 July, 1876, 2 figs. S.-b. No. 14, p. 132.

Answer to letter of "Snbscriber;" means against larvæ of Agrotidida, of Elateride, and earth worms, Lumbricus.sp.; eggs of Agrotis ypsilon laid in the spring; breeding-habits and economic importance of Lumbricus; figures of an clatrid larva and imago.

1505. [RILEY, C. V.] Mite parasites of the Colorado potato-beetle. <Mirror and Farmer, 15 July, 1876, v. 2S, No. 29, p. 2. S.b. No. 14, p. 221. Reprint: <Gardener's Mo. and Hortic., September, 1876, v. 1S, 1. $279 . \quad<$ Trans. Acad. Sci. St. Louis, December, 1877, v. 3, p. 219 Proc. Note: <Amer. Nat., October, 1876, v. 10, p. 636 .

Ectoparasitism of a gamasid mitc [ Uropoda americana] on Doryphora decemlineata; list of vertibrate cnemies of $D$. decemlineata.

The reprints note the occurrence of $D$. decemlineata in New Hampshire and its ravages along the Atlantic coast. See No. 1610.

1506. [RILEY, C. V.] [Wheat insects.] <Blair [Nebr.] Times, 20 July, 1876. S.-b. No. 10, pp. $200-201$.

Quotes from 1st Ann. Rept. State Ent. Mo., pp. 159-161; wheat injured in Nebraska in 1876 by Cecidomyia destructor and Meromyza aneericana; ravages of larva, description of imago and means against the latter; occurrence of Disonycha favircntris in Nebraska.

1507. Riley, C. V. A new enemy of wheat. <N. Y. Tribune, 21 July, 1876. S.·b. No. 14, pp. 129-130; 130-131.

Answer to letter of W. Robson; occurrence, habits, and ravages of Leucania albilinca in Maryland, Peunsylvania, and Kansas; history and description of larva, pupa, and imago of the insect; evolution of new habits and forms among insects.

1508. [RILEY, C. V.] Chinch-bug; bee-moth. <Colman's Rural World, 26 July, 1876 . S.-b. No. 10, pp. 201-205.

Answer to letter of G. R. Christian; means against Blissus lcucopterus and Galleria cercana; food, seasons, habits, and description of the latter.

1509. Riley, C. V. The grape-root borer, Aggeria polistiformis. <Colman's Rural World, 26 July, 1876, 2 figs. S.-b. No. 10, pp. 205-206.

Answer to letter of F. J. Kron; cxperiments on means agrainst AEgeria [= Sciapteron $]$ polistiformis; habits of larva ; figures of imago ; grographcal distributiou. 
1510. Riley, C. V. Sweet-potato beetles; "beautiful bugs." <N. Y. Weekly Tribune, 26 July, 1876, 3 figs. S.-b. No. 10, p. 213.

Answer to letter of W. Snowden; characters and habits of Cassidida; description and figures of larva and imagos of Coptocycla [ = Cassida $]$ bivittata and C. $[=C$.$] nigripes; descriptions of C$. aurichalcea and C. guttata; these species feed on leaves of Ipomoa batatas and $C$. aurichalcea, also on lcaves of Convolvulus and of Solannm dulcamara; means against them.

1511. [Rlley, C. V.] Those centennial insects. <N. Y. Weekly Tribune, 26 July, 1876. S.-b. No. 10, p. 219.

Criticism ô communication of I.. . M. ; list of principal insects preying upon storer corn.

1512. R[ILEY], C. V. Wheatmidge; "rue-worms." <N. Y. Tribune, 2 August, 1876. S.-b. No. 10, p. 202.

Larvæ of Papilio asterias feeding on Ruta graveolens; description, habits, seasons, ravages of, and means against Cecidomyia $[=$ Diplosis $]$ tritici.

1513. Riley, C. V. Apple and peach borers. <Colman's Rural World, 9 August, 1876. S.-b. No. 14, pp. 3-4; 55-56. Extract: <Cultivator and Country Gentleman, 7 September, 1876, v. 41, p. 566. Answer to inquiries of F.-H.; Chrysobothris femorata distinguished from $S a$ perda bivittata $[=$ candida $]$ and Egeria $[=$ Sannina $]$ exitiosa; habits and description of the first; habits of the last and means against both.

1514. Riley, C. V. Large saw-fly. <Colman's Rural World, 9 August, 1876. S.-b. No. 14, p. 4.

Answer to inquiry of J. B. J.; description of larva and imago of Cimbex laportei [=americana]; its food-plants and transformations.

1515. Riley, C. V. Cottony scale-insect on maples. <Colman's Rural World, 9 August, 1876. S.-b. No. 14, pp. 4-5.

Answer to inqury of C. F. Mills; Lecanium acericola $[=$ Pulvinaria innumerabilis ] injurious to Acer ¿asycarpum at Springfield, Ill.; habits, description of the scale, and manner of ovipositiou; no great injury ever done by insects of this genus.

1516. Riley, C. V. Hickory vs. locust borer. <Colman's Rural World, 9 August, 1876. S.-b. No. 14, p. 5.

Answer to inquiry of F. M. D. ; description of larva and imago and natural history of Arhopalus [= Cyllene] pictus; characters distinguishing this from A. $[=C$.$] robinik; food-plants and soasons of the latter.$

1517. Riley, C. V. Stag.beetle. <Colman's Rural World, 9 August, 1876. S.-b. No. 14, p. 5.

Answer to inquiry of S. Lee; occurrence and characters of Lucanus elaphus ; food of larva.

1518. Riley, C. V. Eggs of the angular-winged katydid. '<Colman's Rural World, 9 August, 1876. S.-b. No. 14, p. 5.

Answer to inquiry of $\mathrm{V}$. Kl'iegel; descriptions of eggs, imagos, and song of Microcentrum retinerve; habits and ravages and means against the same.

1519. RILex, C. V. Experience with the Colorado potato-beetle. <Colman's Rural World, 9 August, 1876. S.-b. No. 14, p. 6.

Letter from N. Coleman; larva of Doryphora decemlineata in confinement pupated on the surface of the ground; imagos cat the tubers underground. 
1520. [RILey, C. V.] An elm enemy. <N. Y. Semi-reekly Tribune, 11 August, 1876. S.-b. No. 14, pp. 54-55.

Habits and ravages of and means against Galcruca calmariensis [=xanthomelona $a$.

1521. Rilę, C. V. The locust in $1876 .<\mathrm{N}$. Y. Weekly Tribune, 16 August, 1876. S.-b. No.14, p. 73.

The occurrence aud ravages of Caloptenus spretus in Minuesota and Colorado in 1876; their absence from other portions of the conntry occasionally inhabited by them; their destruetion by Astoma gryllaria [= Trombidium locustarum ] and inability to maintain themselves in parts of the region they infest.

1522. [RILEY, C. V.] The war on "corn-worms." <N. Y. Semi-weekly Tribune, 18 August, 1876. S.-b. No. 14, p. 73.

Review of article by A. Brewster ; ravages of and means against larvæ of Elatcride, Agrotidide and Lachuosterna quercina $[=f u s c a]$ and the "grubworm," injurious to growing naize.

1523. Riley, C. V. Spined soldier-bug. <Ohio Farmer, 19 August, 1876, v. 50, p. 118.

1524. Riley, C. V. "Potato-pest poison." <Sci. Amer., 19 August, $1 S 76$ [r. 49], n. s., r. 35, p. 116.

Condemning some of the patent poisons for Doryphora decemlineata.

1525. Riley, C. F. Cottonwood borers. <N. Y. Weekly Tribune, 23 August, 1876. S.-b. No. 14, p. 55.

Answer to inquiry of J. R.; food-plants and ravages of and means against Plectrodera scalator.

1526. Riley, C. V. Harmless insects. <N. Y. Weekly Tribune, 23 August, 1876. S.-b. No. 14, p. 55.

Answer to letter of a "Subscriber;" occurrence of Psocus venosus on appletrees; habits and molting.

1527. Riley, C. V. Locust prospects. <N. Y. Tribune, 6 September, 1876. S.-b. No. 10, pp. 213-215; No. 14, pp. 74-75. Reprint: $<$ Prairie Farmer, 16 September, 1876, v. 47, p. 298. S.-b. No. 10, pp. 207-209.

Answer to letter of G. H. H. ; movcments and ravages of Caloptenus spretus in Aug., 18i6, in Dakota, Minnesota, Iowa, Nebraska, and Colorado.

1528. Riley, C. V. Some notes on potato-beetles. < Sci. Amer., 9 September, 1876 [r. 49], n. s., v. 35, p. 164. Reprint: <Ohio Farmer, 16 September, 1876, v. 50, p. 179 . S.-b. No. 14, pp. 6,7 .

Critical review of S. R. M.'s "Facts about potato-beetles;" Doryphora decemlineata flies in the day-tine, but not at night; feeds upon several species of plants; hibernates as an imago, whieh should be destroyed in early spring.

1529. Riley, C. V. Entomological works wanted. <Colman's Rural World, 20 September, 1876. S.-b. No. 14, p. 2.

Answer to letter of J. W. Newman; notice of some works on entomology for the use of students. 
1530. [RILex, C. V.] Grape-leaf' Philloxera enem. < Colman's Rural World, 20 September, 1876. S.-b. No. 14, p. 3.

Answer to letter of A. Engleman ; Leucopis sp.? parasitic in galls of Phylloxera vastatrix and P. rileyi.

1531. [RILEY, C. V.] Grape-leaf gall. < Golman's Rural World, 20 September, 1876. S.-b. No. 14, p. 3.

Answer to letter of A. A. Briggs; Phylloxera vastatrix does comparatively little damage on the leaves of grape-vines; Clinton and Taylor vines peculiarly subject to the attacks of the leaf-inhabiting form; Concord vines seldom attacked by it and not serionsly injured by the root-inhabiting form; means against the leaf-inhabiting form.

1532. RIley, C. V. New locust theory wanted. <Colman's Rural World, 27 September, 1876. S.-b. No. 14, p. 62.

Answer to letter of W. T. D.; facts not theories wanted in regard to the flights of Caloptenus spretus.

1533. Rlley, C. V. Cecropia wórm on elder. <Colman's Rural World, 27 September, 1876, 1 fig. S.-b. No. 14, 1) 63.

Answer to letter of A. S. Van Winkle; description of larva, cocoon, and imago of Samia [= Attacus] cecropia; figure of larva; habits and seasons; availability of the cocoon for silk.

1534. RILEY, C. V. The harlequin cabbage-bug. <Colman's Rural World, 4 October, 1876. S. b. No. 14, p. 56.

Answer to letter of R. J. Waters; habits, ravages, distribution, and means against Strachia [ = Murgantia] histrionica; colors of early stages and of imagos.

1535. [R̈mey, C. V.] Butterfly chrysalis. <N. Y. Tribune, 13 October, 1876. S.-b. No. 19, p. 224. Reprint: $<$ N. Y. Tribune, 21 October, 1876. S.-b. No. 10, p. 223.

Answer to inquiry of E. B. S.; occurrence of Danais archippus in swarms in central United States in autumn of 1876 ; colors of larva and pupa; larva feeds on Asclepias.

1536. [RILey, C. V.] Domesticated katydid. <N. Y. Tribune, 18 October, 1876. S.-b. No. 19, p. 214. Reprint: $<\mathrm{N}$. Y. Tribune, 21 October, 1876. S.-b. No. 10, p. 219.

Answer to letter of C.A.P.; longevity and food of Mrorocontrum retinerve.

1537. [RILEY, C. V.] Unjust accusation? <N. Y. Tribune, 21 October, 1876 . S.b. No. 10, p. 209 ; No. 19, p. 242.

Answer to inquiry of a "Correspondent;" Harpalus erraticus accused of destroying shrubbery; predaceous habits of Carabide.

153S. RILEY, C. V. The Rocky. Mountain locust. <Colman's Rural World, 1876, v. - 30 October, 6 November, 13 November. S.-b. No. 10, pp. 185-188. See: < Kansas Farmer, November, 1876. S.-b. No. 10, pp. 225-235. <N. Y. Tribune, October, 1876. S.-b. No. 10, 1. 215.

Verification of predictions in regard to the limitation of the ravages of Caloptcnus spretus in western Missouri in 1876; gathering eggs, ditching, rolling, and burning recommended as means against them ; recommends the employment of soldiers, of hogs, and of poultry, late planting, and the destruction of the locusts in their native country; Blissus leucopterus more 
1538. Riley, C. V.-Continued.

injurious in Western Missouri in 1876 than Caloptenus spretus; prospect of frcedom from injury by the former for the next two sears; Vilfa vaginaflora introduced into the castern prairies by the locusts ; limit to the eastern range of the locusts; they are not led by kings or quecns; occurrence of larvæ of Deilephila lineata after the disappearance of the locusts; locust flights in Illiwois.

1539. [RILey, C. V.] Canker-worms at the West. <N. Y. Tribune, 31 October, 1876. S.-b. No. 17, p. 59.

Occurrence of Paleacrita veruata in Michigan in 1872 and in Ohio in 1874, 1875, and 1876 ; brief account of $P$. vernata and Anisopteryx pometaria; their habits, ravages, and means against them.

1540. Riley, C. V. [The venation of Anisopteryx and variation in imagos.] <Ca. Ent., September [October], 1876, v. 8, pp. 178179.

Variation in the venation of the wings of Anisopteryx pometaria and in the imagos of so-called species.

1541. Kiley, C. V. A new enemy of the grasshopper. <Lawrence [Kans.] Journal. Reprint: <Industrialist [Manhattan, Kans.], 2 November, 1876 , v. 2 , No. 30, p. 2. S. b. No. 10, pp. 209-210.

Letter of F. H. Snow with comments; eggs of Caloptenus spretus destroyed by larvie of Anthomyia.calopteni [=augustifrons]; characters of the larva; eggs destroyed by larvie of some Iclmcumou? [= Systachus oreas]; need of destroying eggs by artificial means.

1542. Riler, C. V. Silk culture in Kansas. <Nationalist, 10 November, 1876. S.-b. No. 14, p. 1.

Importance of silk culture; practicability of the culture and prospects of its increase in the United States; measures for its promotion in Kansas; successful raising of silkworms on osage orange [.Ifaclura anrantiaca].

1543. Riley, C. V. Bee killers: Asilus flies. <N. Y. Weekly Sun, 15 November, 1876. S.-b. No. 10, p. 201.

Habits of Asilide, especially of Trupanea [= Promachus] apirora and Asilus missouriensis [ = Proctacanthus milberti]; description of $T .[=P$.$] apivora;$ larva of Asilus sericeus feeds on roots of Rheun rhaponticum.

1544. Riley, C. V. How to use Paris green for the cotton-worm. $<$ Colman's Rural World, 15 Norember, 1876. S.-b. No. 10, pp. 210-211. See : $<$ N. Y. Tribune, 15 December, 1876. S.-b. No. 14, p. 7.

Auswer to letter of C. W. Niver; directions for the use of Paris green by the dry and wet method; description of sprinkling machiues.

1545. [Rilfy, C. V.] Notodonta concinna. <Colman's Rural World, 15 November, $1876 . \quad$ S.-b. No. 10, p. 219.

Answer to letter of $\dot{J}$. Barritt; description of larva of Notodonta $[=$ Edemasia] eoneinna; habits, food-plants, and mcans against the same.

1546. [RILEY, O.V.] The dog-day harvest fly. <Colman's Rural World, 15 November, 1876. S.-b. No. 10, p. 220.

Answer to inquiry of C. A. U.; description of Cicada pruinosa [= tibicen]; method of sonifaction; habits; wotice of some manuals of entomology. 
1547. [Riley, C. V.] Snake-worms. <Colman's Rural World, 15 No. vember, 1876. S.-b. No. p. 10, p. 220.

Answer to letter of J. Armstrong; description of larve of Sciara sp.; thcir habit of moving in congregations; their abode and enemies.

1548. Riley, C. V. Locnst eggs. <Colman's Rural World, 15 Norember, 1876. S.-b. No. 10, p. 223.

Answer to letter of C. T.; female Acridide lay more than oue litter of eggs; the occurrence of egg-like parasites in males has led to the supposition that the males bore eggs.

1549. Riley, C. V. Locust flights east of the Mississippi. <Colman's Rural World, 22 November, 1876. S.-b. No. 10, pp. 211-212; 221-222; 223-225. Reprint: <Sci. Amer., 16 December, 1876 [₹. 49], n. s., . 35, p. 392, 2 figs. S.-b. No. 10, pp. $216,217$. $<$ Trans. Kans. Acad. Sci., 1877, v. 5, pp. 62-64.

Limitation of plants and animals to certain geographical regions; regions in which alonc Caloptenus spretus survives; species confonnded with C. spretus; occurrence of swarms of Acridium amcricanum in Ohio; description, geographical distribution, and ravages of the same; swarms of Caloptenus differentialis, C. atlanis, and C. femur-rubrum in Illinois; ravages of the same. The reprint in the Sci. Amer. contains figures of Caloptenus spretus and Acridium americanum.

1550. Riley, C. V. Locusts again. <N. Y. Tribune, 22 November, 1876. S.-b. No. 10, p. 222.

Effects of winter on the vitality of the cggs of Acrididce.

1551. Riley, C. V. The army-worm; its natural history complete. <Sci. Amer., 9 December, 1876 [v. 49], n. s., v. 35, p. 372, 4 tigs. S.-b. No. 10, pp. 217-219. Reprint, with slight changes: <Proc. Amer. Assoc. Adv. Sci. for 1876, 1877, r. 25, pp. 279283,2 figs.

Geographical distribution of Leucania unipuncta; figures of all'stages and of ovipositor of femalc; place and manner of oviposition; description of eggs and young larvie; number of annual broods; summary of the natural history of this species.

1552. RILEy, C. V. The apple-bark louse. <Ca. Farmer, 15 December, 1876 . S. b. No. 14, p. 50 .

Seasons, habits, and ravages of Mytilaspis pomicorticis [= pomorum]; description of young larve; of males and femalcs and formation of scales.

1553. Rilex, C. V. The apple maggot; a formidable enemy. $<\mathrm{N}$. Y. Semi-reekly Tribune, 15 December, 1876. S.-b. No. 14, pp. 7-8.

Answer to lettcr of P. M. Augur; description of larva and imago of Trypeta pomonella; ravages, fook-plants, habits, and means against the same; literature of the subject.

1554. Riley, C. V. Entomological notes; confounding friend with foe. $<$ Colman's Rural World, 20 December, 1876. S.-b. No. 14, p. 4.

Description of scales and eggs of Diaspis harrisii [ = Chionaspis furfurus] and of colors of larva, pupa, and imago of Chilocorus bivulnerus; ravages of the Diaspis; habits and usefulness of the Chilocorus. 
1555. RILEy, C. V. Locust injury next spring. The territory in Missouri that will probably suffer therefrom. <Colman's Rural World, 20 December, 1876. S.-b. No. 14, pp. 5-6. Reprint: <Industrialist [Manhattan, Kans.], 17 February, 1877, v. 2, No. 44, p. 4. S.-b: No. 14, p. 49.

Predietion of ravages of Caloptcmespretus to oceur in spring of 1877 in Missouri.

1556. [RILey, C. V.] Anputating insects. <N. Y. Semi-weekly Tri'bune, 29 December, 1876, 2 figs. S.-b. No. 14, pp. 8-9.

Deseription of the work of Elaphidion putator [ = villosum] and Oncideres cingulata; habits of both; figures of larva, pupa, and imago of the latter; similarity in habits of Oncideres amputator and $E$. putator to those of $O$. cingulata.

1557. [Riley, C. V., et al.] The Rocky Mountain locust or grasshopper, being the report of proceedings of a conference of the Governors of several Western States and Territories, together with several other "gentlemen, held at Omaha, Nebr., on the 25th and 26th days of October, 1876, to consider the locust problem; also a summary of the best means now known for counteracting the evil. <St. Louis, $1876,8 \circ, \mathrm{pp} .3+58,8$ figs. See: <N. Y. Tribune, 1876. S.-b. No. 10, p. 223.

Preface, proceedings, pp.1-36. Practieal considerations and suggestions for the suppression of Caloptenus spretus; description, oviposition, transformations, and habits of the same; its enemies and parasites; means against it; deseription of Anthomyia calopteni n. sp. [= angustifrons]. Figures. Prepared by J. S. Pillsbury, P. Pusey, and C. V. Riley.

1558. Riley, C. V. Potato pests. Being an illustrated account of the Colorado potato-beetle and the other insect foes of the potato in North America, with suggestions for their repression and methods for their destruction. <New York: Orange Judd Company [1876], pp. 108, 49 figs., map. Review : <Cultivator and Country Gentl., 11 January, 1877, r. 42, p. 25. Reply to review: <1bid., 1 February, 1877, v. 42, p. 78. S.-b. No. 14, pp. 56-57.

TABLE OF CONTENTS.

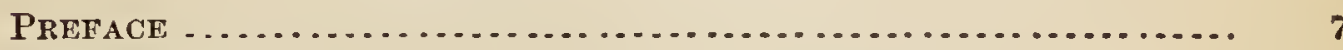

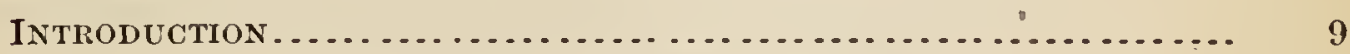

The Colorado potato-beetle, Doryphora 10-lineata .............. 11

Its past history ........................................ 11

Predietion that it would reach the Atlantic, 12-Its mareh aeross the eountry, 13-It reaehes the Atlantie, 14-Its swarming in large cities, 16-Its occurrenee out at sea, 17.

The insect's native home ................................

When it first attaeked the potato, 18.

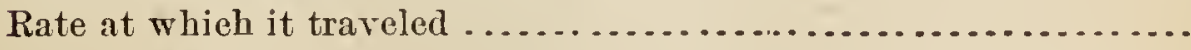

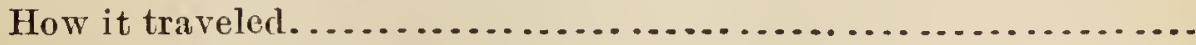

Mostly in the beetle state, 21-Assisted by man, 21-Tendency to migrate in swarms, 23.

It spreads, but does not travel in the sense of leaving onc distriet for another. 


\section{Riley, C. V.-Continued.}

The Colorado potato-Bentli-Continued.

Area invaded by it . . . . . . . . . . . . . . . . . . . . . . . . . . . .

Causes which limit its spread . . . . . . . . . . . . . . . . . . . . . . .

Intense heat in the South, 25-Excessive dryness in the mountains, $26^{\circ}$.

How it affected the price of potatoes.........................

The modification it has undergone........................

Its natural history . . . . . . . . . . . . . . . . . . . . . . . . . . . .

First made known in 1863, 28-The female capable of laying 1,000 eggs, 29-Three broods a year, 28.

Its poisonous qualities. . . . . . . . . . . . . . . . . . . . . . . . . . .

Exhalations from the crushed bodies injurious: 29.

Its food-plants . . . . . . . . . . . . . . . . . . . . . . . . . . . .

The number inereases with each year, 32 -Varieties of potatoes preferred, 33.

The beetle eats as well as the larva .........................

Its natural enemies . . . . . . . . . . . . . . . . . . . . . . . . . . .

Birds which feed upon it, 35-36-Domestic fowls, 36-Reptiles, 36Spiders and ites, 36-38-True inseets, 39-Rust-red soeial wasp, 40-Lady-birds, 40-43-Ground-beetles; 44-45-Rove-beetles, 46Blister-beetlés, 46-Soldier-bugs, 47-51-Tachina-fly, 52-Asilusflies, 53.

Remedies .............................................

Encouragement of natural enemies, 54-Preventive measures, 54Mechanical means of destruction, 55-Pincers for, 56-Sun-scalding, 56-Horse-machine, 57-Machines for colleeting, 58, 59-Poisonous applications to the plant, 60-Paris green, 61-Different modes of using Paris green, 62-65-Other poisonous applications tested, 66-Patent poisons, 68.

The use of Paris green ..................................

Its influenee on the plant, 70-Its inflnenee on the soil, 71-Its inflnenee on man ind irectly through the soilor through the plant, 74 .

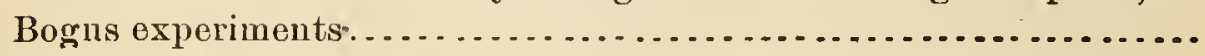

Alarm about the insect abroad ..........................

Unneessary prohibition of traffic in American potatoes, 77-How the insect will most likely get to Europe, 78 -The ehanees of its getting there, $79-82$-Conld it beeome aeclimated there?, 82.

Nomenclature .................................... The bogus Colorado potato-beetle, Doryphora juncta ..............

It has always existed east of the Mississippi, 85-It never attacks the cultivated potato, 85-Easily confounded with its potatofeeding congener, 86-How the two differ, 86-88.

OTHER INSECT FOLS OF THE POTATO.

The stalK-Borer, Gortyna nitela..........................

Habits, 90-Remedy, 91.

The POTATo stalK-WEevil, Trichobaris trinotata ................. Habits, 9:-Remedy, 93.

The potato or tomato worir, Protoparce celeus................. Habits, 94-Remedies, 95-Parasites, 96.

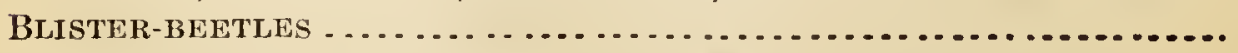

The striped blister-betle, Epicauta vittata $\ldots . . . \ldots \ldots \ldots \ldots \ldots \ldots$.

The ash-gray blister-betle, Macrobasis unicolor ..................

The black-rat blister-beetle, Macrobasis unicolor. 
1558. Rilex, C. V.-Continued.

Blister-beETLES-Continued.

The blaek blister-beetle, Epicauta pennsylvanica................

The margined blister-beetle, Epicunta cinerea...................

Reınedies, 100.

THE THREE-LINED POTATO-BEETLE, Lema trilineata .............. 100

Habits, 101, 10:-Remedies, 10:2.

The cucumber Flea-beetle, Crepidodera cucumeris ................

Habits, 103-Remedies, 103.

The Clumbed tortoise-Bentle, Coptocycla clarata ...............

Habits, 103-Remedies, 104.

1559. Riley, C. V. Gall-insects. <Johnson's New Universal Cyclopædia, 1876, v. 2, pp. 412-4i6, 16 figs. S.-b. No. 10, pp. 76-80.

Definition of the term "gall-insects"; classification and habits of the same; mention by name and figures of typieal species and galls made by them; dimorphism and metagenesis of cynips.

1560. Rilex, C. V. Gall-nuts. <Johnson's New Universal Cyclopædia, 1876, v. 2, p. 417,1 tig." S.-b. No. 10 , p. 81 .

Definition of "gall-nuts" formed by Cynips galle-tinctorice on twigs of Quercus infectoria; local origin, ehemical eomposition, use in the arts.

1561. Riley, C. V. Galls. <Johnson's New Universal Cyclopædia, 1876, v. 2 , pp. 418-419, 2 tigs. S.-b. No. 10, pp. 82-83.

Definition of "galls;" their variety of form, texture, and loeation; their nature and source.

1562. Rilex, C. V. Locust prospects. <Colmau's Rural World, 3 January, 1877: S.-b. No. 14, pp. 57-58; 58-59.

Explains means of prognosticating the advent of Caloptenus spretus in the spring of 1877 ; recommends measures of precaution and the procurement of information eoncerning means against these insects, and gives assurance that the invasion of the loeusts will be but temporary.

1563. Rulex, C. V. Bots. <Sei. Amer., 6 January, 1877 [v. 50], u. s., v. 36, pp. 9-10. Reprint: -S.-b. No. 14, pp. 235-236. <Lancaster Farmer, 15 September, 1877, v. 9, p. 142. S.-b. No. 14, p. 129. <Colman's Rural World. S.-b. No. 14, p. 100.

Habits, ravages, and means ugainst Gastrophilus equi, Cephalomyia $[=$ Estrus $]$ ovis, and Hypoderna bovis.

1564. [RILEx, C. V.] Academy of Science. Brilliant and profound address of Prof. O. V. Riley. The splendid record of the Academy for the past year. Reports of officers and committees and election of managers for the ensuing year. <St. Louis Times, 16 January, 1877, r. - . S:-b. 14, pp. 91-96. Reprint: <Trans. Acad. Sei. St. Louis, December, 1877, v. 3, pp. 238254 Proc. Separate : <St. Lonis, 1877, 16 pp. Translation: $<$ Anzeiger des Westerns, 16 January, 1877, v. 43, p. 3. S.-b. No. 14, pp. 50-54.

Review of progress made in science in North America, and especially by the Acarleny of Seicnce of St. Louis in 1876 ; remarks on entomologieal observations and publications, and especially on Doryphora decemlineata, Phylloxera vastatrix, and Caloptenus spretus. 
1565. Riley, C. V. Is this a grasshopper year? Prof. Riley's opinion concerning the prospect for bugs. It all depends on the kind of weather we have during February. <St. Louis Daily Globe Democrat, 7 February, 1877, v. 2, No. 263, p. 3. S.-b. No. 14, pp. 69-70. Reprint: <Industrialist [Manhattan, Kans.] 17 February, 1877, v. 2, pp. 1, 4. S.-b. No. 14, p. 49. See: <Colman's Rural World, 1877. S.-b. No. 1, pp. 59-i30.

Replies to questions as to the likelihood of the hatehing of eggs of Caloptenus spretus in the spring of 1877; the degree of development attained before winter; possibility of the resumption of development after it has once been arrested.

1566. [Rrley, C. V.] Are the locusts hatching? Mistaken identity. $<$ Colman's Rural World, 14 February, 1877, 2 figs. S.-b. No. 14, p. 62.

Modified extract.from 8th Ann. Rept. State Ent. Mo., May, 1876, pp. 149-150, Tragocephala [=Chortophaga] viridifasciata and Tettix granulatus mistaken for Caloptenus spretus; geographical distribution of the first; hibernation and colors of the two former; figures of both.

1567. Riley, C. V. Condition of locust eggs: Inquiries answered. $<$ Colman's Rural World, 21 February, 1877. S.-b. No. 14, pp. $67-68 ; 68$.

Replies to inquiries as to the degrees of development attained by eggs of Caloptenus spretus submitted for examination.

1568. Riley, C. V. Tarred paper for fruit trees. <Colman's Rural World, 7 March, 1877. S.-h. No. 14, p. 61.

Critical review of article by E. Gaylord; the inclosure of trunks of fruit trees in tarred paper serviceable as a protection from the sun, rabbits, mice, and borers.

1569. Rulex, O. V. Insect on the grape. <Gardener's Mo. and Hortic., March, 1877, v. 19, p. 90.

Varieties of grape attacked by Desmia maculalis; means against the same.

1570. Rrley, C. V. Ninth annual report on the noxious, beneficial, and other insects of the State of Missouri, made to the State Board of Agriculture, pursuant to an appropriation for this purpose from the legislature of the State. <12th Ann. Rept. State Board of Agric. for 1876, March, 1877, pp. 7+129+3, 33 figs. Separate: <Jefferson City, -Mo., March, 1877, pp. $7+129+3,33$ figs.

Preface ..................

TABle of Contents....................

III

V

CURRaNt AND GoOSEberRy worms

There are several species, having different habits, 1-Three which may be destroyed by similar methods, 1-Botanical details as to the currant and goosebcrry, 2.

THE GOOSEBERRY SPAN-WORM, Eufitchia ribearia ..................

Its natural history, 3-Most destructive gooseberry insect in Missouri, 3-Generic nomenclature, 3-Characters of the moth, 4Description of the egg, 4-Where the eggs are laid, 4-The in- 
1570. Riley, C. V.-Continued.

The GOOSEBERRY SPAN-WORM-Continned.

sect single-brooded, 5-How it spreads, 5-A native species, 5Its past history, 5-It prefers the gooseberry to the currant, 6The moth is closely imitated by one which greatly differs structurally, 6-Parasites, 6-Remedies, 7-Other currant spanworms, 7 .

The mported CURrant-worm, Nematus ribesii ....................

Belongs to the "false-caterpillars," 7-The different specific names it has received, 7-An imported species, 8-Its introduction and spread, 8-Independently imported at several eastern points, 9Its natural history, 9- How the eggs are laid, 10-Nature and habits of the worm, 11-Characters of the parent flies, 12-Preventive measures, 13-Rcmedies, 13-White hellebore the best, 13-How best used, 14-15-The worm is not poisonous, 16-Natural enemies, 17-It furnishes a forcible example of arrenotoky, or the power of producing male offspring without impregnation, 18-Results of parthenogenesis in different insects, 18-It also furnishes an interesting instance of defunctionation of special parts, 19-The saw of the female imperfect compared with others, 20-Evolutionary bearings of this fact, 21-Descriptive, 21Variation in the antennæ and wing veins, 22.

The native CUrRant-worm, Pristiphora grossularice ............... Wherein it differs from the imported species, 23-Its habits, 24Where the eggs are laid, 25-How the winter is passed, 25-Its occurrence in Missouri, 26-Rentedies, 26-Descriptive, 26.

The straWrerRY-WORM, Harpiphorus maculatus ...................

Also a false-caterpillar, 27 -It has a wide range, 27-How the eggs are deposited, 28-Character'and habits of the worm, 28-Remedies, 28-Descriptive, 28.

ABвot's White PINE-Worm, Lophyrus abbotii....................

Destructive power of the insects of its genus in Germany, 29Evergreens which it prefers, 30-Habits and characters of the worm, 30-Variation in the antenna, 30-Characters of the perfect flies, 30-31-How the eggs are laid, 31-Natural enemies, 31-Remedies, 32-Descriptive, 32.

LE Conte's pine-worm, Lophyrus lecontei......................

A more general feeder than Abbot's species, 32-The close resemblance of the worms, 33-How they differ, 33-Descriptive, 33Other species of the genus, 34 .

The Colorado potato-Beetle, Doryphora 10-lineata ..............

Injury in the West in $18 \% 6,34$-Spread of the insect during the Jear, 34-35-Its great abundance on the Atlantic coast, 35-Rate at which it traveled since 1859,37 -An average of 88 miles a year, 37-How it traveled, 37; principally in the beetle state, and greatly assisted by nıan, 37-Its migrating habit, 38Area invaded by it ncarly 1,500,000 square miles, 38-Causes which limit its spread, 38-Will it reach the Pacific slope?, 39How it affected the price of potatoes, 39-The modification it has undergone, 40-A mite parasite added to its natural enemies, 41-Its introduction to Europe, 42-A living specimen found last summer in the Bremen dock-yards, 42-Could it live and multiply in Europe?, 43-Action taken by European goveruments to prevent its introduction, 44-Consideration of the Kearney "potato-pest poison," 45.

13 ENT-Z14 
1570. RILey, C. V.-Continued.

THE ARMY-WORM, Leucania unipuncta ............................

Further notes and experiments thereon, 47-Two generations produced annually at St. Louis, and a probable third generation, exceptionally, 48-Summary of its natural history, 49.

THE WHEAT-HEAD ARMY-WORM, Leucania albilinea ..................

A new enemy to wheat, 50-First complaint of it in the East, 51First appearance in Kansas, 51-Habits and natural history, 52The egg differs from that of the army-worm, 53-Wherein the worm is distinguished from its destructive congener, 54-Two broods each year, 54-Natural enemies, 54-Remedies, 55-Descriptive, 55.

The Rocky Mountain Locust, Caloptenus spretus..................

It continues to interest the people of the West, 57-Previous opinions justified, 57-The invasion of 1876, 59-Few in British America, 59-Condition of things in Montana, 59-In Wyoming, 59in Dakota, 59-In Minnesota, 60; locusts and alkali soil, 61; good done by Governor Pillsbury, of Minnesota, 61-In Colorado, 62-In Iowa, 63-In Nebraska, 64-In Kansas, 65-In Missouri, 66-Flights in opposite directions at the same time, 66-Counties in Missouri that were overrun, 67-Red-legged locust troublesome in east Missouri, 68-Detailed reports from counties in Missouri, 68-Andrew County, 68-Atchison County, 68-Barry County, 68-Barton County, 69-Bates County, 69-Benton County, 69-Buchanan County, 69-Cass County, 69-Cedar County, 70-Caldwell County, 70-Clay County, 70-Dade County, 70-De Kalb County, 70-Gentry County, 70-Greene County, 71-Harrison County, 71-Henry County, 71-Hickory County, 71-Holt County, 71-Jasper County, 72-Jackson County, 73-Johnson County, 73-Lafayette County, 73-Lawrence County, 73-McDonald County, 74-Newton County, 74Nodaway County, 74-Pettis County, 74-Platte County, 74Polk County, 75-Ray County, 75-Saint Clair County, 75-Vernon County, 75-In Indian Territory, 76-In Texas, 76-In Arkansas, 76-Destination of the departing swarms of 1875, 77-They reached into British America, 78-Source of the swarms of 1876, 79-Eastern line reached, 80 - Rate at which the insects spread, 80-Direction of flight, 81--Influence of wind in determining the course of locust swarms, 81 -Locust flights east of the Mississippi, 81-Geographical range of species, 82-Causes which limit the spread of the Rocky Mountain locust, 83-Flights of Acridium americanum, 84-Does the female of the Rocky Mountain locust lay more than one egg-mass?, 85-How the eggs are laid, 86-Philosophy of the egg-mass, 87-How the young locust escapes from the egg, 88-How it escapes from the ground, 90Additional natural enemies, 91-Animals which destroy the eggs, 91-The Anthomyia egg-parasite, 92-The common flesh-fly, 95Other undetermined enemies of the eggs, 96-Insects which destroy. the active locusts, 98-Experiments with the eggs and conclusions therefrom, 99-Experiments to test the effects of alternately freezing and thawing, 99-Experiments to test the influence of moisture upon the eggs, 104-Experiments to test the effects of burying at different depthis and of pressing the soil, 104-Experiments to test the effects of exposure to the free air, 104- The Omaha conference, 106-Remedies and suggestions, 108-Des ruction of the young or unfledged locusts, 108-Protec- 
1570. Riley, C. R.-Continued.

The Rocky Mountain Locust-Continued.

tion of fruit-trees, 110-Legislation, 111-Act passed by the Missouri legislature, 111-Acts passed by the Kansas legislature, 112 -Act providing for the destruction of locusts in Minnesota, 114-Area in which eggs were laid, 116-Condition of eggs, 117Temperature of the winter of 1876-'7\%, 120-Prospects for 1877, 121.

INNOXIOUS INSECTS.

The Hellgrammite, Corydalus cornutus......................

Its curious egg-mass described, 126-Resembling bird-dung at a distance, 126-Where laid, 127-The egg-burster, 127-Characters and habits of the newly-hatched larva, 127-Difficulty of rearing it in still water, 128-The eggs that have been hitherto mistaken for those of Corydalus, 128-They are probably those of Belostoma grandis, 128.

THE YUCCA BORER, Megathymus yиcce .......................

It is single-brooded, 129-Will thrive in the latitude of St. Louis, 129-The larva molts quite often, 129.

1571. RILEY, C. V. Important observations on the Rocky Mountain locust or grasshopper pest of the West. <Sci. Amer., 28 April, 1877 [ ₹.50], n. s., v. 36, pp. 260-261, 5 figs.

Observations on the egg-laying habits of Caloptenus spretus; figures egg, eggmasses, method of oviposition, and female anal characters.

1572. RILEY, C. V. Experiments with locust eggs and conclusions therefrom. <Sci. Amer., 5 May, 1877 [v. 50], n. s., v. 36, pp. 276-277. S.-b. No. 1t, p. 101.

Experiments upon the vitality of eggs of Caloptenus spretus; effects of alternately freezing and thawing, of exposure to great moisture or to the free air, and of burying them at different depths.

1573. Riley, C. V. Prof. Riley's report to the Governor of Kansas: The grasshopper question: Interesting information. <Commonwealth [Topeka, Kans.], 12 May, 1877, No. 2500, p. 2. S.-b. No. 14, pp.63-67. Reprint: <St. Louis Daily Globe-Democrat, 14 May, 1877 , v. 2, No. 359 , p. 3. S.-b. No. 14, pp. 70-72. Notice: <Ibid., p. 4. S.-b. No. 14, p. 70. See: <Kansas Farmer, 16 May, 1877. S.-b. No. 14, p. 59.

Reply to letter of Governor G. T. Anthony ; area within Kansas in which eggs of Caloptenus spretus were laid in 1876; the degree to which the young from these eggs had perished or were likcly to commit ravages in the summer of 1877 ; causes of the destruction of a great proportion of the young locusts; means of completing this destruction.

1574. Riley, C. V. The strawberry leaf-roller, Anchylopera fragarice. <Gardener's Mo, and Hortic., May, 1877, v. 19, pp. 143-144, fig. S.-b. No. 14, p. 45.

Reprint, with additional introduction and note, from 1st Ann. Rept. State Ent. Mo., March, 1869, pp. 142-143, fig. 80 . See No. 1059 for synopsis of contents. 
1575. [RILex, C. V., et al.] U.S. Entomological Commission. Circular No. 1. [Riley, Packard, Thomas.] <Washington: 1877, 80, $4 \mathrm{pp}$.

Queries regarding the migrations, appearances, habits, and ravages of Caloptenus spretus; directions for making replies.

1576. Riley, C. V. U. S. Entomological Commission. Circular No. 2. $<$ Washington: $1877,8^{\circ}, 4$ pp.

Plans of work; request for information regarding the natural history, insect enemies, and parasites of Caloptenus spretus and other locusts; means against the same.

1577. [RILEY, O. V., et al.] Bulletin of the United States Entomological Commission. Destruction of the young or unfledged lo. custs. No. 1. [Riley, Packard, Thomas.] <Washington: 1877, 80, 12 pp. See : <Sci. Amer., 2 June, 1877 [v. 50], n. s., v. 26, p. 344 .

Enumeration of means of destroying young or unfledged locusts; quotations of laws passed by States of Missouri, Kansas, and Minnesota to provide for the destruction of locusts and their eggs.

Supplement to Bulletin No. 1, 2 pp. Summary of means for the destruction of young locnsts.

1578. [RILEY, C. V., et al.] Bulletin of the United States Entomological Commission. On the natural history of the Rocky Mountain locust, and on the habits of the young or unfledged in. sects as they occur in the more fertile country in which they will hatch the present year. No. 2. [Riley, Packard, Thomas.] $<$ Washington: May, 1877, 80, 15 pp., figs. 1-11, map.

Description, oviposition, hatching, transformations, and habits of Caloptenus spretus; map of the country that will suffer most severely, showing the eastern limit of injury the present year.

1579. Riley, C. V. The grape leaf-folder. <Journ. and Farmer, 14 June, 1877. S.-b. No. 14, p. 133.

Description of larva, imago, habits, ravages, distribution, seasons, and foodplants of Desmia maculalis.

1580. Rilsy, C. V. The rascal leaf-crumpler. <Journ. and Farmer, 14 June, 1877. S. b. No. 14, pp. 133-134.

Description of larva, larva-case, imago, habits, ravages of, distribution, seasons, food-plants, and means against Phycita nebulo [ = Acrobasis indiginella ].

1581. Riley, C. V. The Hessian-fly. <Journ. and Farmer, 14 June, 1877. S.-b. No. 14, p. 135.

Description of eggs, larva, puparium, and imago of Cecidomyia destructor; civil histury, seasons, habits, ravages of and means against it; habits of Semiotellus [= Merisus $]$ destructor.

1582. Riley, C. V. Locust prospects. <Sci. Amer., 16 June, 1877, [v. 50], n. s., v. 36, p. 369.

Causes of the destruction of a great proportion of the young of Caloptenus spretus; a general and disastrous invasion improbable for some vears.

1583. [Riley, C. V.] Insect enemies. <N. Y. Tribune, 16 June, 1877. S.-b. No. 14, pp. 234-235.

1. Apple-borers; answer to letter of V. B. P.; young apple-trees killed by Xyleborus obesus. 
1583. Riley, C. V.-Continued.

2. Rose-chafer; answer to letter of I. M. H.; means against Macrodactylus subspinosus.

3. Bark-louse; answer to letter of J. L. K. ; seasons and ravages of and means against Mytilaspis pomicorticis [= pomorum].

4. Flea-beetle; answer to letter of J. E. R.; habits, ravages, and means against Graptodera [= Haltica] chalybea.

1584. Riley, C. V. The Hellgrammite. <Sci. Amer., 23 June, 1873 [v. 50], n. s., v. 36, pp. 392-393, 3 figs.

Structure and habits of Corydalus cornutus, description and figures of eggmasses, eggs, larva, pupa, and imagos; adaptations of sexual structure to conditions; figure and description of eggs of Belostoma grande $L=$ americanum].

1585. Riley, C. V. The 'hopper in Iowa. Report by Professor Riley, Chief of the U. S. Entomological Commission. <Chicago Daily Tribune, 4 July, 1877, v. 32, p. 3. S.-b. No. 14, pp. 112114. Extract: <N. Y. Tribune, 4 July, 1877. S.-b. No. 14, p. 128.

Report to the governor of Iowa as to the observed and anticipated ravages of Caloptenus spretus in sonthwestern Iowa in 1877 ; the young locusts inostly destroyed by the weather; their natural enemies and the efforts of man; localities infested; recommends diversification of crops ; summary of means against the young locusts; claims for the first recommendation of proper ditching; description of apparatus for catching and killing locusts.

1586. Riley, U. V. Strawberry worm and remedy. <N. Y. Tribune, 18 July, 1877. S.-b. No. 14, p. 231.

Description of egg, larva, and imago, habits of and means against Emphytus [= Harpiphorus $]$ naculatus.

1587. Riley, C. V. Fighting the Hessian-fly. <N. Y. Tribune, 18 July, 1877. S.-b. No. 14, pp. 232-233. Reprint: <Colman's Rural World, 5 December, 1877. S.-b. No. 14, pp. 268-269.

Habits, seasons, parasites, introduction, spread, and ravages of and means against Cecidomyia destructor; description of eggs and larva.

1588. Riley, C: V. The grasshopper. Considered practically and scientifically with a retrospective and prospective glance at his history. <Daily Rocky Mountain News [Denver, Colo.], 1 August, 1877, v. 18, p. 4. S.-b. No. 14, pp. 81-84; 110-112. Reprint: <Colorado Farmer, 2 August, 1877, v. 9, No. 31, p. 4. $<$ Chicago [Ill.] Daily Tribune, 7 August, 1877, v. 32, p. 7. S.-b. No. 14, pp. 84-86.

Observations on the past aud present conditions of Caloptenus spretus in 1877 in the regions invaded by it; work of its enemies and parasites; complication of the locust problem in Colorado owing to the climate of the State; prospects of future injury ; means against the locusts in Colorado; work of the U. S. Entomological Commission.

1589. Riley; C. V. In reference to wheat-worms. <Prairie Farmer, 11 Angust, 1877. S.-b. No. 14, p. 127 ; No. 20, p. 86.

Critical review of C. Thomas' "A wheat insect" (Prairie Farmer, 21 July, 1877), with correction of some obscurities in regard to Meromyza americana and Gortyna nitela. 
1590. Riley, C. V. Locust flights. An appeal from Prof. C. V. Riley. $<$ Manitoba Daily Free Press, 8 September, 1877. S.-b. No. 14, p. 91.

Reprint of questions of Circular No. 1 of U. S. Entomological Commission, with request for answers and other information from observers in Manitoba.

1591. Riley, C. V. The locusts in Kansas. <Sci. Amer., 8 September, 1877 [ . 51 ] , n. s., v. 37, p. 164.

No danger of locust invasion in Kansas and adjacent States in the fall of 1877; diseased conditions of late swarms; seasons of drought and locust swarms generally followed by rainy seasons and a scarcity of locusts.

1592. Riley, C. V. A satisfactory grasshopper-machine. <Sci. Amer., 8 September, 1877 [ v. 51], n. s., v. 37, p. 169.

Description and figure of a machine for the killing of locusts.

1593. [RILey, C. V.] Mistaken identity. <N. Y. Tribune, 12 Septem. ber, 1877. S.-b. No. 14, p. 233.

Answer to letter of Subscriber; Lema trilineata mistaken for Doryphora 10 lineata; first occurrence of the latter in Vermont in 1876.

1594. Rlley, C. V. Injured orchard. $<$ N. Y. Tribune, 12 September, 1877. S.-b. No. 14, p. 233.

Answer to letter of G. W. T.; occurrence of numerous nests of Formicida about the roots of orchard trees; probability that the ants are harmless; means against ants.

1595. [RILEY, C. V.] The stalk-borer. - <N. Y. Tribune, 12 September, 1877. S.-b. No. 14, p. 233.

Allswer to letter of Wisc.; food-plants of Gortyna nitela; description of larva.

1596. Riley, C. V. Locust prospects in southwest Missouri this fall. <Journ. and Farmer, 27 September, 1877. S.-b. No. 14, pp. $236-237$.

Ravages of Caloptenus spretus in Missouri in 1876 and prospects of same in 1877 ; history of locust flights in 1877.

1597. Riley, C. V. The Colorado potato-beetle in Europe. German thoroughness. <Sci. Amer., 29 September, 1877 [v. 51], n. s., v. 37, p. 198. S.-b. No. 14, pp. 123-124.

Occurrence of Doryphora 10-lineata at Bremen and at Mülheim, in Germany; thorough measures taken to eradicate the pests; economic value of the measures.

1598. [RILex, C. V.] TThe cussed red-leg. <Chicago [Ill.] Times, 29 September, 1877. S.-b. No. 14, pp. 119-123. Reprint: <Mo. Rept. Kansas State Board of Agric., 1877, pp. 32-41. S.-b. No. 14, pp. 146-161. Abstract: <Amer. Nat., November, 1877, v. 11, pp. 663-673. <Ca. Nat. and Quart. Jour. Sci., December, 1877, v. 8, pp. $363-374$.

Distinction between the terms locust and grasshopper; nature of varieties and species; distribution of Caloptenus spretus ; laws governing its migrations and distribution; exemplification of these laws by records of flights during 1877 ; means against locusts; distinctions between Caloptenus spretus and $C$. femur-rubrum; habits and transformations of Astoma gryllaria (=the young of Trombidium sericenm [= locnstarum ]); habits of the latter. 
1599. Rlley, C. V. [White-grub-fungus.] <N. Y. Weekly Tribune, 4 October, 1877. Notice: <Amer. Ent., June, 1880, [v.3], n. s., v. 1, p. 140.

1600. Riley, C. V. On the larval characters and habits of the blister. beetles belonging to the genera Macrobasis Lec. and Epicauta Fabr.; with remarks on other species of the family Meloidce. <Trans. Acad. Sci. St. Louis, 5-16 November, 1877, v. 3, pp. 544-562, figs. 35-39; figs. $1-12$ of pl. 5 with 1 p. expl. of pl. Separate: < [St. Louis, Mo., 1877], pp. 1-19, figs. 35-39; figs. 112 of pl. 5 with 1 p. expl. of pl. Abstract: <Sci. Amer., 1877 [r. 51], II. s., v. 37; 1 December, p. 346; 15 December, p. 373; 404 il. S.-b. No. 14, pp. 272-275. <Ent. Mo. Mag., January, 1878, v. 14,pp.169-175. Reprint, with ehanges and omissions: <Amer. Nat., 1878, v. 12 ; April [19 March], pp. 213-219, figs. 1-2; May [22 April], pp. 232-290, figs. 3-5, pl. 1 with 1 p. expl. of pl. Separate: <Boston: 1878, pp. 213-219; 282-290; pl. 1 with 1 p. expl. of pl.

Views of earlier authors as to the habits of meloid larva; nature of the newly hatched larva (triungulin); natural history of Meloe and Sitaris, with reference to the literature, descriptions of the triungulins, especially of $M$. barbarus?; figures of the several stages; nature of hypermetamorphosis; food-habits and breeding habits of Macrobasis and Epicauta, especially of E. vittata; summary of what is known of the larval habits of other genera of Mcloida; descriptions and figures of all the earlier stages of $E$. vittata ; descriptions of eggs and triungulins of E. cinerea, E. pcunsylvaniea, aud Henous confertus.

1601. Riley, C. V. On a remarkable new genus in Meloida infesting mason-bee cells in the United States. <Trans. Acad. Sci. St. Louis, 16 November, 1877, v. 3, pp. 563-565, fig. 40; fig. 13 of pl. 5, with 1 p. expl. of pl. Separate: < [St. Louis, Mo., 1877], pp. 20-22, fig. 40 ; fig. 13 of pl. 5 , with 1 p. expl. of pl. Ab. stract: <Amer. Nat., April [19 March], 1878, v. 12, pp. 218219.

Description of imagos, nltimate stage of second larva, and coarctate larva of Hornia minutipennis, n. g. et n. sp., parasitic in cells of Anthophora sponsa [= abrupta $]$; figures $\delta$ imago and coarctate larva of the same; illustrates the stages of degradation in tarsal claws of several genera of Meloida; synoptic table of the North American genera of Meloini.

1602. Riley, C. V. Additional notes on Megathymus yucca. <Trans. Acad. Sei. St. Louis, 16 November, 1877, v. 3, pp. 566-568. Separate : < [St. Louis, Mo., 1877], pp. 23-25.

Supplementary to No. 1465; habits, seasons, and number of molts of the larva; description of larva in second and third stage and of variations in the imago; description of coloradensis n. var.; Aigiale cofaqui a variety of Megathymus yucce; Erynnis alcece bores in stems of Malva sylvestris in Europe; Elaphidion tectum and Scyphophorus yucce in stems of Fucca.

1603. Ruler, C. V. ' Further remarks on Pronuba yuccasella and on the pollination of Yucca. <Trans. Acad. Sci. St. Louis, 16 No- 
1603. RLEY, O. V.-Continued.

vember, 1877, v. 3, pp. 568-573. Separate: < [St. Louis, Mo., 1877], pp. 25-30. Translation : <Stett. Ent. Zeit., 1878, Jahrg. 39, pp. 377-382.

Critical review of remarks on Pronuba by Chambers, Zeller, and Boll; Hyponomenta quinquepunctella mistaken for Pronuba yuccasella; variations in the former; uniformity in the latter; behavior of Pronuba in flowers of Yucca; question of the method of fertilization of $\overline{Y u c c a}$.

1604. RILEx, C. V. On the differences between Anisopteryx pometaria, Harr. and Anisopteryx cescularia W.-V., with remarks on the genus Paleacrita. <Trans. Acad. Sci. St. Louis, 16 November20 December, 1877, v. 3, pp. 573-577. Separate : < [St. Louis, Mo., 1877], pp. 30-34.

Characters of Anisopteryx ascularia show that it is congeneric with $A$. pometaria; criticism of Packard's Monograph of Geometridce; structural characters separating Anisopteryx and Paleacrita.

1605. Rilex, C. V. Wheat rust and Hessian fly. <N. Y. Tribune, 19 December, 1877. S.-b. No. 14, p. 235.

Means against Puccinia graninis; $P$. graminis and Ecidium berberidis are alternate generations of one species.

1606. Riley, C. V. A new oak-gall on acorn cups. <Trans. Acad. Sci. St. Louis, 20 December, 1877, v. 3, pp. 577-578.

Description of gall of Cynips quercus-glandulus u. sp. [p. 578] on cupules of all species of prinus group of Quercus; remarks on the allied structure of the galls of C.fecundatrix in Europe, and of C.quercus-frondosa; occurrence of galls of $C$. [= Amphibolips] quercus-prunus on cupules of acorns.

1607. [Rilex, C. V.] [Maggots in sance.] <N. Y.Tribune, 26 December, 1877. S.-b. No. 14, p. 234.

Larva of Drosophila sp. in canned sauce; D. nigricornis common in similar substances.

1608. [RILEx, C. V.] [Round-headed apple-tree borer.] <N. Y. Tribune, 26 December, 1877. S.-b. No. 14, p. 234.

Ravages of and moans against Saperda bivittata [= candida].

1609. Riley, C. V. Entomological notes. <Trans. Acad. 'Sci. St. Louis, December, 1877, v. 3, pp. 217-218 Proc. See: <Amer. Nat., October, 1876, จ. 10, p. 635.

Generic resemblance of Carpocapsa saltitans to $C$. pomonella; correction of vernacular name of Cicada $[=$ Tibicen $]$ scptendecim; occurrence of the same in Virginia in 1876; yearly development of $C .[=T$.$] tredecim; Sericaria mori$ reared for five years on Maclura aurantiaca with increased vigor and healthfulness; Salix nigra stripped by larvæ of Vanessa antiopa; habits of the same.

1610. Riley, C. V. Entomological notes. <Trans. Acad. Sci. St. Louis, December, 1877, v. 3, p. 219 Proc. See: <Colman's Rural World, 1876. S.-b. No. 10, p. 165. <N. Y. Tribune, 1876. S.-b. No. 9, p. 215. <Amer. Nat., October, 1876, v. 10, p. 635 .

Occurrence and ravages of Leucania albilinea in Kansas; ectoparasitism of Uropoda americana on Joryphora decemlineata; list of vertebrate enemies of 
1610. Pullex, C, V.-Continued.

$D$. deeemlineata; occurrence of $D$. decemlineata in New Hampshire; its ravages along the Atlantic coast; see No. 1505.

1611. Rileri, C. V. Centennial insects. <Trans. Acad. Sci. St. Louis, December, 1877, . 3 , pp. 220-221 Proc.

List and characterization of insects observed injuring exhibits in the Centenuial Exposition.

1612. Riley, C. V. Parasites on eggs of Caloptenus spretus. <Trans. Acad. Sci. St. Lonis, December, 1877, v. 3, p. 226 Proc.

A large proportion of locust eggrs throughout the country are being destroyed by paíasites, predaceous insects, and other causes; precautions against threatened injury; discovery of four new enemies of locust eggs.

1613. Riley, C. V. Locust flights east of the Mississippi. <Trans. Acad. Sci. St. Louis, December, 1877, v. 3, pp. 226-228 Proc.

Locust swarms in Ohio, Illinois, Georgra, and South Carolinia not composed of Caloptenus spretus; causes which limit the eastward flight of C. spretus.

1614. Rilex, C. V. Geographical range of species. <Trans. Acad. Sci. St. Lonis, Decemuer, 1877, v. 3, pp. 230-233 Proc.

Range of species in our time affected only by the interposition of human influence; the limits of this range definitely established by classified knowledge, and impassable, cxcept by man's assistance; Caloptenns spretus can not change its habits; the difference in the susceptibility of different species to change inexplicable.

1615. Riley, C. V. [Auticipated locust injury next summer.] <Trans. Acad. Sci. St. Louis, December, 1877, v. 3, p. 236 Proc.

Abundance and advanced state of development of eggs of Caloptenus spretus in the States invaded in 1876; probable abundance and ravages in 1877 .

1616. Riley, C. V. [Japanese mode of packing silk-worm eggs.] <Trans. Acad. Sci. St. Louis, December, 1877, v. 3, p. 236 Proc.

Mode in which the eggs of Sericaria mori are packed in Japan for transportation.

1617. Riley, C. V. Locust experience. <Trans. Acad. Sci. St. Louis, December, 1877, v. 3, p. 267 Proc. See: <Colman's Rural World, 1877. S.-b. No. 14, p. 265.

Northern limit of the permanent breeding-grounds of Caloptenus spretus; confirmation of views regarding laws governing locust iuvasions; discovery of a new law.

1618. Riley, U. V. Mite transformations. <Trans. Acad. Sci. St. Lotiis, December, 1877, v. 3, pp. 267-268 Proc. See: <Colman's Rural World, 1877. S.-b. No. 14, p. 265.

Habits and transformatious of Trombidium sericeum $[=T$. Iocustarum $]$; Astoma gryllaria an immature form of the same.

161.9. Riley, C. V. [Mygale hentzii and Pepsis formosa.] <Trans. Acad. Sci. St. Louis, December, 1877, v. 3, 1). 269 Proc.

The bite of Mygale hentzii not so deadly as is gencrally supposed; habits of Pepsis formosa in preying on the spider. 
1620. Riley, C. V. [Ravages of Termes flavipes.] <Trans. Acad. Sci. St. Louis, December, 1877, v. 3, p. 269 Proc.

Note to communication of R.D. Grant on some ravages of Termes flavipes.

1621. Riley, C. V. On the oviposition of Saperda bivittata Say. <Trans. Acad. Sci. St. Louis, December, 1877, v. 3, pp. 269-270 Proc. See: <Colman's Rural World, 28 November, 1877. S.-b. No. 20, p. 6.

Description of egg and manner of oviposition of Saperda bivittata [= candida].

1622. Rilex, C. V. On migratory butterflies. <Trans. Acad. Sci. St. Louis, December, 1877, v. 3, pp. 273-274 Proc. See: <Valley Naturalist, January, 1878, v. 1, p. 2.

Phenomena and causes of the migrations of butterflies, especialls of Danais archippus.

1623. Riley, C. V. [Phylloxera and grape-rot.] <Trans. Acad. Sci. St. Louis, December, 1877, v. 3, p. 275 Proc. See: <Colman's Rural World, 28 November, 1877. S.-b. No. 14, p. 268.

Disagreement with views of A. J. Cook as to there being any connection between the work of Phylloxera vastatrix and the ordinary grape-rot.

1624. Riley, C. V. The periodical Cicada. <Western Farmer's Al. manac for 1878, 1877, p. 48. S.-b. No. 14, p. 138. Reprint: <Colman's Rural World, 28 November, 1877. S.-b. No. 14, pp. $265-266$.

Regular pcrioaicity of the appearance of Cicada [= Tibicen] septendecim and C. $[=T$.$] tredecim; popular description and natural history of the same;$ chronology of twenty-two different broods, geographically classified.

1625. Riley, C. V. The locust plague in the United States: being more particularly a treatise on the Rocky Mountain locust, or so-called grasshopper, as it occurs east of the Rocky Mountains, with practical recommendations for its destruction. <Chicago : Rand, McNally \& Co., 1877, 236 pp., 3 pl., 42 figs. Extract: <Manitoba Standard, 1877. S.-b. No.14, pp. 97-98. Notice: <Cultivator aud Country Gentl., 30 August, 1877, v. 42, p. 557. <Gardener's Mo. and Hortic., October, 1877, v. 19, p. 317. <Ent. Mo. Mag., October, 1877, v. 14, p. 118.

TABLE OF CON'TEN'TS.

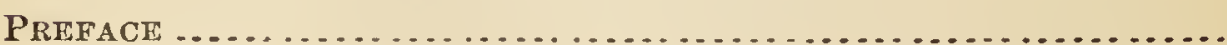

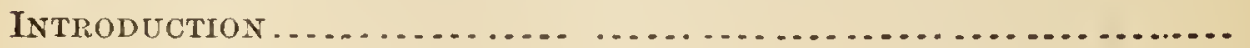

Chapter I :

Characters of the species................................

Classificatory position of the Rocky Mountain locust, 13-How it differs from other specics, 14--Easily confounded with the common red-legged locust, 14-Detailed descriptions of both, 15Its still closer rescmblance to the Atlantic migratory locust, 22Characters of this last, $22-$ Species $v 8$. variety and race, $23-$ Comparisons of these thrce closely-allied species in their early stages, 26-A green variety of the Rocky Mountain locust not infrequent, 27-Purely an American insect, 28. 
1625. Riley, C. V.-Continued.

CiIApter II:

Chronological history ................................

The locust plague in the "Old World," 29-Extent of its injuries, 30-Migratory species in Europe, Asia, and Africa, 30-The ravages of the locnst in Amcrica, 31-Its earlicst visitations, 31-Injuries on the Pacific coast, 32-Injuries east of the Rocky Mountains, 33-Invasions of 1818-'19, 33-Of 1845-'49, 34-Of 1855, 34Of 1856,35 - Of $1857-67,35,36$-Of 1866,36 -Damage the following year, 37 -The invasion of 1873,38 -That of 1874,39 - Why so disastrous, 41-General ontlook in the spring of 1875, 42-Sevcrity of the injurics from the young insects that year, 43-Destitition that prevailed, 44-Amount of loss sustained, 45-Destination of departing swarms of 1875,47 -The invasion of 1876,49 -Eastern limit reached, 53-Omaha conference, 53 .

\section{Chapter III :}

Native home and geographical range of the species east of the

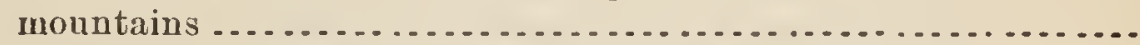

Source of the devastating swarms that reach into the Mississippi Valley, 55-Their origin in the extreme Northwest country lying east of the mountains, 56-Cause of their emigration, 57-Difference betwcen summer and fall swarms, 58-The species not at home in the Mississippi Valley, 62-Not permanent or able to perpetuate itself there, 62-Conditions which prevent such permanence, 63-Not likely to do serious harm east of the ninety-fourth moridian, 65-Reasons why, 65 .

Chapter IV :

Natural history and transformations $\ldots . . . . . . . . . . . . . . .$.

How the eggs are laid, 69-Philosophy of the egg-mass, 71-The female capable of linying more than one egg-mass, 72-The escape of the young locust from the $\mathrm{egg}$, 73-Its emergence from the ground, 78-Growth and transformations, 78-Acquisition of wings, 80 -Number of molts, 82 -Flight at night, 83 .

\section{Chapter V :}

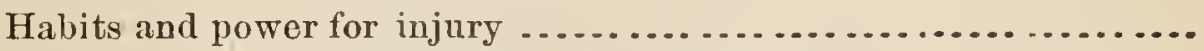

Flight and ravages, 85-Migratory instinct and great destructive power confined to a single species west of the Mississippi, 88Food-plants, 89-Injury to fruit trees, 93-Time of appearance of invadin - swarms, 94-Rate at which they spread, 95-Direction of their flight, 96-Where the eggs are preferably laid, 96-Time of hatching, 97-Habits of the young or unfledged locusts, 98Directions in which the joung travel, 100-Rate at which they travel, 100-Linit of their east ward spread, 100-Not led by kings or quecns, 101-Direction taken by the departing swarms, 103Their destination, 104.

\section{Chapter VI:}

Efrects of the young inscets in the conntry where they hatch, but where they are not indigenons .........................

Experience with the young locusts in spring, 107-Contrast in summer and fall, 108-No evil withont some compensating good, 108-Changes that follow the locusts, 109-The prevalence of large green worms, 110-The sudden appearance of a peculiar grass, 110 . 
1625. Riley, C. V.-Contiuued.

Chapter VII : "

Natural enemies of the Rocky Mountain locust ..................

Birds and other vertebrate animals, 113 -The good offices of birds. 113-Invertebrate animals, 114-Animals that attack the eggs, 115-The silky mite, 115-The Anthonyia egg-parasite, 118-The common flesh-fly, 123-Undetermincd larva, 123-Ichneumonflies, ground-beetles, click-beetles, and myriapods, 126-Insects that destroy the active locust, 126-The locust-mite, 128--The anonymous Tachina-fly, 131-Yellow-tailed Tachina-fly, 134Flesh-fly, 135.

\section{Chapter VIII :}

Practical considerations

How best to prevent locust injuries, 139-Encouragement of natural enemies, 139-Destruction of the egg 8 , 139-Experiments with the eggs and conclusions drawn therefrom, 140-Effects of alternately freezing and thawing, 141-Influence of moisture, 143-Exposure to the free air, 148-Burying at different depths, and pressure of the soll, 149-Table of temperatures, 152-Harrowing in the fall, 153-Collecting the eggs, 153-Plowing, how most effectual, 153-Irrigation, tramping, 154-Destruçtion of the young or unfledged locusts, 155-Burning, 155-Crushing, 157-'1'rapping, 157-Ditching and trenching, 161-Catching, 161-Different contrivances for this pnrpose, 162-Use of destructive agents, 162-Coal-oil pans, 163-The use of coal-tar, 164-The protection of plants by special applications, 165-The best means of protecting fruit and shade trees, 166-Sulphur fumes and smudges, 167-Destruction of the winged locusts, 167-Preventive measures, 169-Suggestions that may prove of service, 170-Use of hogs and poultry, 171-The Signal Service, 172-Military aid, 173-Diversified agriculture, 174-Organized effort, 176-State legislation, 176-Missouri locust law, 177-Kansas locust laws, 178, 179-Minnesota locust law, 180-Nebraska locust law, 184-How to avert locust invasions, 186.

\section{Chapter IX :}

Ravages of locusts east of the Mississippi......................

Migratory locusts in the eastern States, 187-The Atlantic locnst, 187-Injury from other non-migratory species, 190-Often a serious matter during hot, dry seasons, 193-Locust flights in Illinois in $1875,195-$-The species of which the swarms were composed, 197-Locust flights east of the Mississippi not composed of the Rocky Mountain species, 201-Necessity of discriminating betwcen specics, 201.

Chapter X :

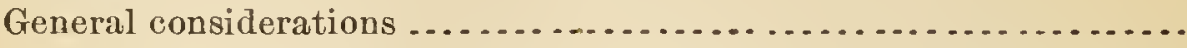

Nomenclature, 207-Locust vs. grasshopper, 207-Prairic fires vs. locust ravages, 209-Fasting and prayer, 213-Not a divine visitation, 216-Influence of the wind in determining the course of locust Hights, 216-Locists as food for man, 217.-Unnecessary alarm caused by comparatively harmless species, 227.

1626. Riley, C. V. On an extensile penetrating organ in a gamasid mite. <Proc. Amer. Assoc. Adv. Sci. for 1876, 1877, v. 25, pp. 273-275, 1 fig. See: '<Ca. Ent., September [October], 1876, r. 8, p. 180 . 
1626. Riley, C. V.-Contimued.

Habits and description of Oropoda vegetans and $U$. americana n. sp.; nature of the adhesive filament of these mites; structure of the supposed maxillary penetrating organ in Uropoda.

1627. Riley, C. V. On the curious egg-mass of Corydalus cornutus, Linn., and on the eggs that have hitherto been referred to that species. <Proc. Amer. Assoc. Adv. Sei. for 1876, 1877, v. 25, pp. 275-279, 1 fig. Reprint: <9th Ann. Rept. State Ent. Mo., March, 1877, pp. 125-129, figs. 30-33. See : <Ca. Ent., October [November], 1S76, v. 8, pp. 181-182.

See No. $15 \% 0$ for synopsis of contents.

1628. Riley, C. V. Phylloxera and grape-rot. <N. Y. Tribune, January, 1878. S.-b. No. 19, pp. 193; 224. Reprint: <Colman's Rural World, 1878. S.-b. No. 14, pp. 266-267. Extract: <Gardener's Mo. and Hortic., July, 1S79, v. 21, pp. 213-214. S.-b. No. 23, pp. 118; 143-145. <Anı. Rept. [U. S.] Commissioner Agric. for 1878, 22 Norember, 1879, pp. 237-238. See: $<$ Gardener's Chronicle, 9 August, 1879. S.-b. No. 26, p. 15.

See No. 1\%21 for synopsis of contents.

1629. Riley, C. V. Address by Prof. C. V. Riley, retiring, before the St. Louis Academy of Science. <St. Louis Republican, $8 \mathrm{Jan}$ uars, 1878. -S.-b. No. 14, p. 269. Reprint: <Trans. Acad. Sci. St. Louis, 1880, v. 4, pp. 1-6 Proc.

Review of progress male in science in 1876 ; success of the investigation into the Rocky Mountain locust scourge.

1630. Riley, C. V. New facts about the round-head apple-tree borer. $<$ N. Y. Weekly Tribume, 20 February, 187s. S. b. No. 19, pp. 193-194. Reprint: <Colman's Rural World, 20 March, 1878. S.-b. No. 14, pp. 267-268. Reprint, with slight omission: $<$ Ilid., 12 March, 1879. S.-b. No. 23, pp. 101-102. See: <Mirror and Farmer, 6 April, 1878. S.-b. No. 20, p. 3.

Description of egg and manner of oviposition of Saperda bivittata $[=$ candida]; seasons of oviposition; meaus against the same.

1631. [RIley, C. V.] Buggy beans. <N. I. Tribune, 20 February, 187S. S.-b. No. 14, p. 234.

Habits and distribution of and means against Bruchus faba ; edibility of the same.

1632. Rilex, G. V. On the transformations of the red mites. <Amer. Nat., March [23 February], 187s, v. 12, pp. 139-146, figs. 1-6.

Habits, description, and tigures of Trombidium locustavum [p. 142], T. giganteum [p. 143], T. muscarum [p. 144], and Hydrachna belostome [p. 146], n. sp.; figures and description of most of the stages of the same; definition of Trombidium. [Advance extract from No. 1643.]

1633. Riley, C. V.] Clothes moths. <Sci. Amer., 23 March, 1S7S [v. 52], n. s., v.38, p.177. 5.-b. No. 19, p. 238. Reprint: <Kansas Farmer, 17 April, 1878. S.-b. No. 19, p. 225. <Colman's Rural World, 3 April, 1878. S.-b. No. 19: pp. 198-19y. 
1633. Rilex, C. V.-Continued.

Indiscriminate use of names and habits of several species of Tinea injurious to woolen goods, fur, hair, and similar substances; means against the moths.

1634. Riley, C. V. Pieris vernalis and P. protodice. <Ca. Ent., February [March], 1878, v. 10, p. 39.

Conformation of T. E. Bcan's conclusion that P. vernatis is the spring form of $P$. protodice.

1635. Rnley, C. V. Migratory butterflies. <Sci. Amer., 6 April, 1878 [จ. 52], n. s., จ. 38, p. 215, fig. S.-b. No. 19, p. 250 . Extract: <Amer. Ent., April, 1880 [v. 3], n. s., v. 1, p. 102, fig. 34.

Occurrenee of migratory swarms of Danais archippus in central southern United States in the autumn of $187 \%$, and of return migrations in spring; explanation of these migrations; mentions other migratory Rhopalocera; distribution of Danais archippus and Cynthia [= Pyrameis] cardui; figure of Danais archippus.

1636. Riley, C. V. The horn-bug. <Sci. Amër., 20 April, 1878 [จ. 52], n. s., v. 38, p. 249,1 fig. S.-b. No. 19, p. 241.

Natural history, deseription of egg, larva and pupa, and figures of larva, pupa, and imago of Passalus cornutus.

1637. Riley, C. V. Egg-feeding mites. <Ca. Eut., March [April], 1878, v. 10, pp. 58-59.

Citation of reeords of Acari feeding on eggs.

1638. [RILEY, C. V.] Bad work of the grain Aphis <N. Y. Tribune, 26 June, 1878. S.-b. No. 19, p. 224.

Habits and ravages of and means against Aphis avence $[=$ Nectarophora granaria ].

1639. [RIley, C. V.] Of Doryphora. <N. Y. Tribune, 26 June, 1878. S.-b. No. 19, p. 243.

Natural history, enemies, and spread of Doryphora decemlineata; description of larva and imago; methods of using Paris green.

1640. Riley, C. V. The apple-tree borer. <N. Y. Tribune, 24 July, 1878. S.b. No. 19, p. 195.

Means against Chrysobothris femorata.

1641. [Ruley, C. V.] The raspberry saw-fly. <N. Y. Tribune, 24 July, 1878. S.-b. No. 19, pp. 197; 226.

Habits of and means against Selandria [= Monophadnus $]$ rubi.

1642. [RщEY, C. V.] Inquiring friends. <N. Y. Tribune, 24 July, 1878. S.-b. No. 19, p. 198. .

Means against Ageria tipuliformis.

1643. [Rrlex, C. V., et al.] First annual report of the United States Entomological Commission for the year 1877, relating to the Rocky Mountain locust and the best methods of preventing its injuries and of guarding against its invasions, in pursuance of all appropriation made by Congress for this purpose. With map and illustrations. <Washington, 29 July, 1878, p1. 16+ 
1643. Riley, C. V.-Continued.

$477+295,111$ figs., 5 pls., 2 maps. See : <Sci. Amer., 5 July, 1879 [r. 55], n. s., v. 41, p. 8. S. b. No. 23, p. 121.

\section{TABLE OF CONTENTS.}

LETTER OF TRANSHITTAL ................................ $\quad$ II

LETTER OF SUBMITTAL................................. xIII

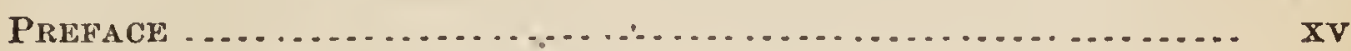

Introduction: By C. V. Riley.

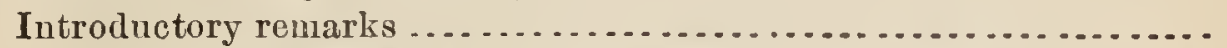

Creation and organization of the Commission, 1-Division of labor, 1-Circulars sent out, 2-6-Area over which eggs were laid in 1876, 6-Ontlook in spring in more southern States, 7-Letter to Governor Anthony, of Kansas, on the condition of things in May, $8-10-$ State of things in Minnesota in spring, 11-Ontlook in Ne. braska in June, 13-Second mecting of the Commission, 14Outlook in Iowa in June, 15-Visit to Colorado, Utah, and Montana in June, 17-Visit to Colorado in July, 17-20-Third mecting of the Commission, 21-Trip to the Pacific coast, 21-Trip to British America, 22-List of chapters, 23-Charauter and synopsis of chapters, 24-29-Prospects for 1877, 29.

Chapter I: By C. Thomas.

Classification and nomenclature; characters of the species ........ Families of the Orthoptera, 32-Locnst vs. grasshopper, 33-Generic nomenclature, 37-Generic diagnosis, 40-Species of the genus Caloptenus, 42-Full definition of Caloptenus spretus and of its nearest congeners, 43-52.

Chapter II : By C. Thomas.

Chronological history of locust injuries......................

Compared with locust ravages in the Eastern Hemisphere, 53-Injury in the Northwest early in the present century, 54-Brief reviens from 1820 to $1877,54-56$-Locust history in Texas, 57-62; in Indian Territory, 63; in Arkansas, 64; in Missouri, 64-68; in Kansas, 68-74; in Nebraska, 74-77; in Iowa, 77-80; in Minnesota, 80-87; in Daliota, 88-92; in Montana, 92-96; in Idaho. 96; in Wyoming, 97; in Colorado, 99-102; in Utah, 102-104; in New Mexico and Arizona, 105; in Nevada, 105; in Oregon and Washington 'Territory, 106; in British North America, 108-112-Tabular view of locust years, 113.

Chapter III : By C. Tliomas.

Statistics of losses.

Difficulty of obtainïng reliable data, 114-Estimates in Kansas, 115; in Minnesota, 116; in Missonri, 117-Loss in Kansas, Nebraska, Iowa, and Missouri in 1874, 118-Loss to different crops, 120-Loss to Missouri in 1875, 121-Total loss during the years 1874-'77, \$200,000,000, 122.

Chapter IV : By C. Thomas.

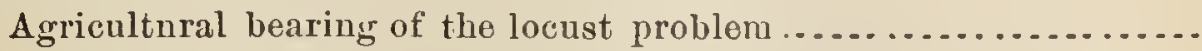

Drawback to the scttling of the West, 124-What is likely to be the effect in the future, 125-Modification and settlenent of the Western plains, 129-Crops which suffer most, and those which suffer least, 130-Small grains not affected by invading swarms, 128-Need of judgment in planting, 129. 


\section{Riley, C. V.-Continued.}

Chapter V: By A. S. Pachard, jr.

Permanent breeding-grounds of the Rocky Mountain locust........

Permanent breeding-grounds, 131-Definition of the permanent region, 133-Its character and extent, 134-The Rocky Mountain locust a sub-borcal insect, 135-The sub-pcrmanent region, 136The temporary region, 136.

Chapter VI: By C. Thomas and A. S. Pachard, jr.

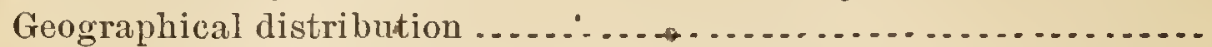

Eastern limits of spread, 137-Northern limits, 139-Western limits, 140-Southern limits, 141-Sub-permanent region, 142.

Chapter VII: By A. S. Pachard, jr., and C. Thomas.

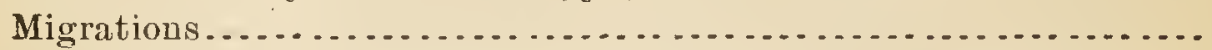

Classification of flights, 143-Invading swarms, 143-Returning swarms, 143-Local flights, 143-Height at which swarms move, 144-Effect of change of wind and weather on flights, 145Flight at night, 147-Migrations previous to 1877 east of the Rocky Mountain Plateau, 148-Direction of invading swarms prior to 1877, 149-Direction of flight in 1876, 151-Migrations within the permanent region, 153-158; in Montana, 153; in Wyoning, 156; in Colorado, 157; in Eastern Idaho and Utah, 158; in the lower snake Valley, 158-Return migrations from the temporary region previous to $1877,159-162$-Return nigratious in 1877, 162-165-Local flights in 1877, 165-Record of flights for July 3 and July 20, 1877, 165-169-Summary of flights by States, 170-174-Southward flights in 1877, 175-Movements in different directions at one time, 176-Destination of return swarms, 177 .

Chapter VIII: By C. V. Riley.

Habits and natural history ...............................

Destructive powers of locusts, 212-215-Stoppage of railroad trains, 215-Rate at which locust swarms move, 215-Velocity of flight, 216-Direction of invading swarms, 217-Time of appearance of invading swarms, 217-Flight at night, 218-Height of flight, 219-General habits at night, 219-Where tho eggs aro laid, 222Manner in which the eggs aro laid, 223-Philosophy of the eggmass, 225-The female lays moro than one egg-mass, 226-Interval between different egg-layings, 227-Number of oggs laid, 228-The hatching process, 23-231- Where and under what conditions of soil the young hatch most freely, 231-Time of hatching, 231-Habits of the young or unfledged locusts in the temporary region, 232-Dircetions in which the young travel, 234Rate at which the young travel, 235-They reach but a few miles east of where they hatch, 235-Not led by kings and queens, 236Time of year when wings are acquired, 237-Direction taken by swarms dcparting from the temporary region, 238-Destination of departing swarms, 238-Do the return swarms breed? 239-Do return swarms from the temporary region retrace their course? 240-The species essentially singlc-brooded, 240-243-Reasons why it cannot produce two generations annually, 243-The species can not permanently $d w e l l$ in the temporary region, $244-$ The insects which hatch there do not remain, 246-Extensive and thick egg-laying seldom occurs twice consecutively in the same locality, 247-Reasons why it does not, 248-Causes of migration, 249 -Food-plants, 251-Crops and plants most liked and those feast liked, 252-254-Unnecessary alarm caused by comparatively harmless species, 255. 
1643. Riley, C. V.-Continued.

Chapter IX: By A. S. Pachard, jr.

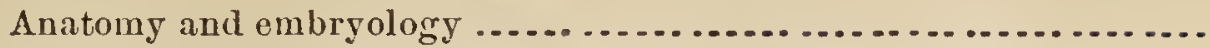

External anatomy, 257-Divisions of the body, 258-Sexual differences, 259-Internal anatomy, 261-The digestive system, 262264. - The nervous system, 264-The heart, 266-The tracher and dilated air-sacs, 26\%-Mode of breathing, 269-The locust an aëronaut, 270 -The male reproductive system, 270 - The female reproductive system, 271 -Organs of special sense, 272-The tine anatomy of the locust, 273-Embryology of the Rocky Mountain locust, 277-Different egr-layers, 278-How the embryo lies within the erg, 278-How it bursts the egg, 279.

Chapter X: By C. V. Riley.

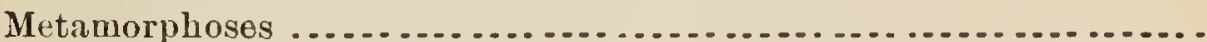

The six stages of growth, 279-Variability in the lepth of coloring, 281-The process of molting, 281-Tiwe required for it, 283-Differences in the immature stages between the Rocky Mountain, the lesser, and the red-legged locusts, 283.

Chapter XI : By C. V. Riley.

Invertebrate cnemies ........................................

Value of the locust's minute cnemies, 284-Animals that destroy the eggs, 285-The Anthomyia egg-parasite, 285-The common flesh-fly, 289-Ground-beetles and their larvie, 289-Harpalus larvæ, 289-The egg-fceding Amara, 291-Blister-beetle larvæ, 292-Their character and locust egg-fecding habits, 293-History of the oil-beetle, 294-History of Sitaris, 295-History of Hornia, 296-History of Epicauta, 297-MLacrobasis and Henous, 301Other mcloid genera, 302-Soldier-beetle larvio, 302-Asilid larva, 303-Click-beetle larvæ, 304-Miscellaneous species, 305Chalcid-fly, 306-Animals that prey on the locust after it is born, 306-The locust-mite, 306-The cfficacy of its work, 308-Its transformations, 309-Other mites, 312, 313-Ground-beetles, 313-Tiger-beetles，314-Asilus-flies，317-Digger-wasps，317Tachina-flies, 319-Their efficacy in destroying locusts, 321Flesh-flies, 323-Ichneumoll-flirs, 324-Hair-worms, 326-Their curious life-history, 337-332-Insects attacked by hair-worms, 327-How hair-worms get into locusts, 332-Miscellaneous locust enemies, 334.

Chapter XII : By C. Thomas.

Vertebrate enemics

Good offices of birds probably underrated, 334-Experience of correspondents, 336-Some of the most useful birds, 338-Paper by Professor Aughey on the beneficial work of birds, 338-Enormous number of birds destroyed for market, 346-Damage done to insectivorous birds by birds of prey, 348-The English sparrow, 349-What public sentiment necds, 349.

Chapter XIII : By C. V. Riles.

Remedies and devices for destruction .........................

Encouragement of natural ageucies, 351-Destruction of the eggs, 351-Harrowing in the autumn, 353-Experiments to test the effect of alternately freezing and thawing, 353-Expériments to test the effects of exposure to air, 354-Expcrience with harrowing, 355-Plowing, 356-Experiments to test the cffects of burying at different deptlis, 356-Expcricnce in plowing, 358-Irrigation, 359-lixperiments to test the effects of moisture on the

13 ENT- -15 


\section{3. 'Rrley, C. V.-Continued.}

\section{Chapter XIII-Continued.}

eggs, 359-Tramping, 361-Collecting, 361-Destruction of the young or unfledged locusts, 362-Burning, 363-The burning of prairies, 363-The Hetzel burning machine, 363-The Horner burning contrivance, 363-Hand burners, 364-The Atwood machinc, 364-Use of wire and kerosene, 364-Crushing, 364-The Drum locust-erusher, 365-The Simpson locust-crusher, 366The Hoos locust-crusher, 367-The Hansberry locust-crusher, 368-The Kenworthy locust machine, 370-J. C. Melcher's machine, 3\% I-The Peteler machine, 371-The King suction-machine, 374-The Flory locust-nıchine, 376-Tlapping locusts, 37\%-Nets and soines, 377-Ditching and trenching, 378-Protection by barricrs, 381-Coal-oil, 381-Coal-oil pans, 383-The Canfield pan, 384-The Adams pan, 385-The Anderson coal-oil contrivance, 386-Mr. Long's contrivance, 386-Mr. Watrous's contrivance, 387-Mr. Swearingen's contrivance, 387-Use of coaltar, 387-The Robbins pan, 388, 390-Use of coal-tar previous to $1877,380^{\circ}-$ Other machines for the use of coal-tar, 391-Catching and bagging, 391-Principles and facts to be borne in mind in catching locusts, 391-The Riley machine, 392-Mr. Thompson's net, 392-The Elliot catcher, 394-The Wilson-Rhode catcher, 395-Contrivance for catching tlie pupæ, 394-The Godard catcher, 395-The Benson catcher, 396-The Hutchins catcher, 396-The Sylvester catcher, 397-The Hcro 'hoppcr-catcher, 398The Belt device, 398-Hand-nets, 399-Use of destructive agents, 399-Buhach or Persian insect-powder, 400-Veith's insect-fluid, 400-Sulpho-carbonate of potassium, 401-Naphthaline, 401Paris green, 401-The protection of fruit trees, 403-Destruction of the winged insects, 404-Fumigation, 405-The effect of concussion, 405-Diversified agriculture, 406-Legislation, 407Bounty laws, 409-Missouri locust act, 409-Kansas locnst acts, 410-Minnesota locust acts, 412-Nebraska locust act, 413-Suggestions that may be of servicc, 414-More attention necded to the growth of root-crops, 415 -The benefits of irrigation, $415-$ Hogs and poultry, 415-Non-planting, 415-Use of soldiers, 416Preventive measures against tho winged insects, 417-Further investigation needed, 417-Means that have been suggested against the winged insects, 418-Systematic burning of young, 418-Co-operation with Dominion Government, 419-Protection by smoke, 419-Farmers should receive the locust probabilities, 420 .

Chapter XIV : By C. V. Riley.

Influence of prairie fires on locust incrcase ....................

Reasons given why prairie fires do not influence locust increase, 421-Possible indirect connection in the past, 422.

Chapter XV: By C. V. Riley.

Influence of weather on the species.........................

Meteorological conditions affecting the life of the locust, 423Effects of weather on the young locusts, 424-Effects of weather on the eggs, 424-Possibility of predicting consequences upon meteorological grounds, 424-The temperature of the soil, 425Thermal constant for the hatching of locust $\mathrm{cggs}, 426-\mathrm{Number}$ of hours which eggs must be exposed to hatch at a temperature of $60^{\circ} \mathrm{F} ., 431$-Number of hours required in 1875 . 
1643. RIley, C. V.-Continued.

Chapter XVI: By C. V. Rilej.

Effects that generally follow severe locust injury .................

Contrast between summer and antumn, 432-No evil without some compensating good, 433-Changes that follow the locusts, 433Sudden appearance of plants and insects not ordinarily noticed, 434-The white-lined morning Sphinx, 435-Tame grasses permanently injured, wild grasses not, 435-Permanent effects on different plants, 436-Injury to fruit trees, 436.

Chapter XVII: By A. S. Pachard, jr.

Uses to which locists may be put............................

Locusts as food for man, 438-441-As fish-bait, 441-Analysis of locust-juices, 442-They furnish a large quantity of formic acid and a new oil, 442-443-Locusts as manure and as poultry food, 443.

Chapter, XVIII: By C. V. Rilej.

Ravages of other locusts in the United States ...................

Ravages of locusts that are occasionally migratory in the Atlantic States, 443-Great destruction in past years in New England, 444-'The most common species concerned in this work, 446Locust flights in Illinois, 446-The species composing thern, 447The phenomenon exceptional, 447-Locusts ordinarily non-migratory, occasionally become so under favoring conditions, 448Looust flights in Ohio, 449-Importance of discriminating between spccies, 450-Geographical limits of species, 450-The migratory locusts of the Pacific, 451-Chronological account of their ravages, 451-Species concerned, 452-Late injuries in southern California, 454-Tabular view of locust years, 456-Injury from other non-migratory locusts, 456-The species concerned, 459.

Chapter XIX: By A. S. Pachard, jr.

Ravages of locusts in other conntries.........................

Locust injuries in Central America, 460-Great destruction in Honduras and Guatemala, 462-The locusts in South America, 465-The locusts in the Old World, 467-Injuries in Germany, 468-Habits of the European species, 469-Injuries in Russia, 470-Different species affecting the Old World, 471-Geographical distribution of the European migratory locust, 472-476-Notes on Algerian locusts, 476-Injury in China, 477-In southern Australia, 477.

\section{APPENDICES.}

APPENDIX I:

Mr. Allen Whitman's report from Millnesota ....................

State of things in spring, [4]-Exertions of farmers, [4]-Different rieans employed to destroy the eggs, [4]-Effects of temperature and rain-fall on the eggrs, [5]-Dates of hatching, [6]-Late hatching, [7]-Progress during spring, $[\mho]$-First winged, [10]Statistics of damage, [11].

APPENDIX II:

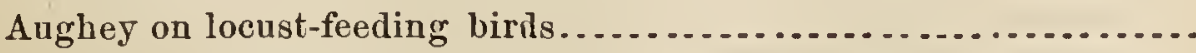

Letter of transmittal, [13]-Examinations of the contents of the stomachs of birds of Nebraska, giving the number of locusts, number of other insects, and number of sceds of the different birds considered in their proper classificatory position, [14]-[62]. 
1643. RILEy, C. V.-Continued.

APPENDIX III:

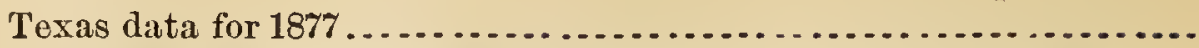

Report of Jacob Boll, special assistant, [62]-Reports from correspondents and other miscellaneous reports, chronologically arranged, [64] $-[82]$.

APPENDIX IV :

Missouri data for 1877

Reports from corresponderts, and other data, chronologically arranged, [83].

\section{APPENDIX V:}

Kansas data for 1877

Report by George F. Gaumer, special assistant, [85]-Report by $\mathbf{A}$. N. Godfrey, special assistant, [88]-Reports from correspondents and miscellaneous matter, chronologically arrauged, [90]-[103].

APpendix VI:

Iowa data for 1877

Detailed data from correspondents, and from other sources, chronologically arranged, [104]-[110].

APPENDIX VII :

Colorado data for 1877

Report from William Holly, special assistant, [111]-Data from correspondents and from other sources, [113]-[116].

APPENDix VIII :

Nebraska data for $187 \%$

Journal kept by Prof. Samuel Aughey, special assistant, [117] [128]-Miscellaneous data from correspondents, chronologically arranged, [128]-[132]-Record kept by Hon. J. Sterling Morton, [132].

Appendix IX:

Narrative of the first journey made in the summer of 1877, by Mr. Packard

Diary notes through Kansas, Colorado, and Utah, [135]-Observations in Montana, [137]-Results of the journey, [138].

APPENDIX $\mathrm{X}$ :

Narrative of a second journey in the summer of 187\%,"by Mr. Packard . [139]

From Chicago to Utah, [139]-Observations in Oregon and Washington Territory, [140]--From Vancouver Island to California, [141]-Variations in Caloptenus spretus, atlanis, and femur-rubrum, [143].

\section{APPENDIX XI :}

British-American data

Characteristics and prevailing winds of Manitoba, [145]-Data from the Cypress Hills region, [146]-The locust breeds permanently in the third prairie steppe, [146]-No damage ever done in the Peace River country, [146]-Ravages in the Northwest in the early part of the century, [147]-Records by the Hon. Donald Gunn, [148].

APPENDIX XII:

Autumn flights in 1877

Southward movements in Minnesota and Iowa, [150]-In Nebraska and Missouri, [151]-In Arkansas and Kansas, [152]-In Colorado and Texas, [155]. 


\section{Riley, C. V.-Continued.}

Appendix XIII :

Flights and migrations in 1877

Locust movements in the more southern portion of the temporary region, [156]-[164]-Flights in the more northern parts of the locust country, $[164]-[197]$.

\section{APPENDIX XIV :}

Answers to the question: Did any locusts remain in the temporary region after the departure of the return swarms $9 . . . . . . . .$. Answers from Arkansas, Colorado, and Iowa, [198]-Answers from Kansas, [199]-Answers from Missouri, [200]-Answers from Minnesota, Nebraska, and Texas, [201].

\section{APPENDIX XV :}

Prevailing direction in which the young insects travel ............

Movements of young in Iowa and Nebraska, [202]-Movements in Dakota, Minnesota, and elsewhere, [203].

\section{APPENDIX XVI:}

Time of year when the bulk of the insects become winged .........

Data from various States and Territories, [205]-[206].

APPENDIX XVII:

Habits of the insects at night

Nocturnal habits of locusts in Iowa, Dakota, and Nebraska, [207]In Minnesota and elsewhere, [208]-[210].

\section{APPENDIX XVIII :}

Facts relating to the eggs .

Data as to time of hatching of eggs, proportion destroyed, causes of destruction, etc., in Colorade and Dakota, [211]-In Iowa and. Kansas, [212] -In Minnesota, [213]-In Missouri and Nebraska, [216]-In Texas and Utah, [21\%].

\section{APPENDIX XIX :}

Means of destruction.

Means employed in Dakota and Nebraska, [218] - In Iowa, [219]In Minuesota, [220]-Elsewhere, [221].

\section{APPENDIX XX:}

Injury: crops affected

Injury in the different States and Territories, [22:2]-[225].

APPENDIX XXI :

Previous visitations-Aid of animals.

Data from Nebraska and Iowa, [226]-From Minnesota, [227]From Dakota, [229].

\section{APPENDIX XXII:}

Minnesota data

Early injury in Minnesota, [230]-Data for 1877, [231]-[235].

\section{APPENDIX XXIII :}

Are the eggs ever laid thickly for two consecutive years in the same

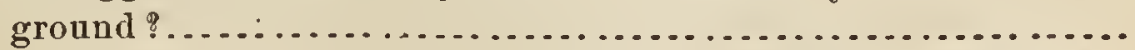

Answers to the above question from Arkansas, Colorado, and Iowa, [236]-From Kansas, [237]-From Missouri, [238]-From Minnesota, Nebraska, and Texas, [239].

APPENDIX XXIV :

Miscellaneous data...................................

From Minnesota and Nebraska, [240]-From Iowa, [241]-From Dakota, [242]. 
1643. Riley, C. V.-Continued.

APPENDIX XXV:

Data from Dakota, Montana, Utah, and New Mexico............ [243]

From Dakota, [243]-[247]-From Montana, 248-From Utah, [253]-From New Mexico, [259].

APPENDIX XXVI:

List of corfespondents

In Arkansas, British America, and California, [261]-In Colorado and Dakota, [262]-In Idaho and Iowa, [263]-In Kansas, [264]In Minnesota, [265]-In Missouri, [267]--In Montana, [269]In Nebraska, Nevada, and New Mexico, [270]-In Texas, Utah, and Washington Territory, [271]-In Wyoming, [272]. .

APPENDIX XXVII :

Bibliography on the locusts of America. By B. P. Mann .......... [273]

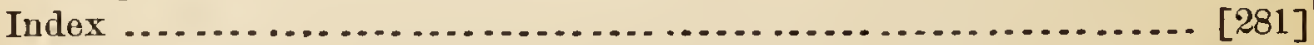

Errata. . . . . . . . . . . . . . . . . . . . . . . . . . . . . . . . . . . [295]

1644. Riley, C. V. Attractive but untrue. <N. Y. Tribune, 31 July, 1878. S.-b. No. 19, p. 198.

Absurdity of statement that " a parasite of the strawberry plant has been found to wage a war of extermination against the Phylloxera."

1645. Riley, C. V. Locusts eat the castor bean. <N. Y. Tribune, 14 August, 1878. S.-b. No. 19, pp. 198, 227-228.

Acridida relish Fagopyrum and Linum but eat Ricinus communis with relnctance, though with impunity.

1646. [RILEY, C. V.] The stalk-borer. <N. Y. Weekly Tribune, 21 August, 1878, v. 37. S.-b. No. 19, pp. 227; 242-243; 244.

Description, food-plants, and habits of larva and description of imago of Gortyna nitcla; G. nebris a variety of G. nitela.

1647. Riley, C. V. That hundred and fifty million dollars. <Sci. Amer., 24 August, 1878 [v. 53], n. s., v. 39, p. 117. S.-b. No. 19, p. 245.

Critical review of sensational reports in current agricultural papers; an appropriation of $\$ 5,000$ made to the U. S. Department of Agriculture for cotton insect investigation.

1648. Riley, C. V. Silk-worm breeding. <Sci. Amer., 24 August, 1878 [v. 53], n. s., v. 39, p. 119 . S.-b. No. 19, p. 244.

Number of annual generations of Sericaria mori; inferiority of races breeding more than once annually.

1649. Riley, C. V. Cotton-worm. <Daily Constitution [Atlanta, Ga.], 8 September, 1878, v. 11, No. 73, p. 1.

Aletia argillacea $[=x y l i n a]$ feeds from the extra-floral nectar-glands of the cotton-plant.

1650. RILEY, C. V. That "fatherless and motherless race." The basket-worm, alias drop-worm, alias bag-worm, Thyridopteryx ephemerceformis. <Sci. Amer. Suppl., 28 September, 1878, fig. S.-b. No. 19, pp. 245-246.

Critical review of W. H. Gibson's article extracts fronl author's "The bagworm," with additions; degradation and breeding habits of female Psychide; method of imagination, fecundation, and oviposition of Thyridop- 
1650. Riler, C. V.-Continued.

teryx ephemercformis; description of eggs and figures of all other stages; down in which the eggs are enveloped is extruded from the abdomen with the eggs; food-plants, parasites, and means against the species; its follicles arailable for silk production ; this species proterogynous but most insects proterandrous.

1651. Riley, C. V. Notes on the life-history of the blister-beetles, and on the structure and development of Hornia. <Kansas City Review of Science and Industry, September, 1878, vol. 2, No. 6, p. 353. S.-b. No. 19, p. 209. Reprint: <Proc. Amer. Assoc. Adv. Sei. for 1878 [14 July], 1879, v. 27, pp. 284-285. See: $<$ Ca..Ent. September [October], 1878, v. 10, pp. 177-178.

Occurrence in Epicauta and Macrobasis of the hypermctamorphoses characteristic of Meloide; specification of the stages of the same; summary of the life-history of Hornia minutipennis parasitic on Anthophora abrupta.

1652. Riley, C. V. On the larval characteristies of Corydalus and Chauliodes, and on the development of Corydalus cornutus. $<$ Kansas City Reriew of Science and Industry, September, 1878, v. 2, No. 6, p. 354. S.-b. No. 19, pp. 210-211. Reprint: <Ca. Ent., May, 1879, v. 11, pp. 96-98. < Proc. Amer. Assoc. Adv. Sci. for 1878, [14 July], 1879, v. 27, pp. 285-287. See: $<$ Ca. Ent., September [October], 1878, v. 10, p. 178.

Characters and economic value of larva of Corydalus cornutus; characters in brief of the imago; characters of larva of Chauliodes; description of egge of both genera; situation of egg-masses of Corydaius and physical character of their covering; description of respiratory apparatus and method of respiration of larvæ of Corydalus.

1653. Riley, C. V. Biological notes on the gall-making Pémphigince. $<$ Kansas City Review of Science and Industry, September, 1878 , г. 2 , No. 6 , p. 380 . S.-b. No. 19, pp. 211-212: 212 . Reprint: < Proc. Amer. Assoc. Adv. Sei. for 1878, [14 July], 1879, v. 27, pp. 288-289. Abstract: <Nature, 28 November, 1878, v. 19, p. 75. Extract: <Sei. Amer., 26 October, 1878 [₹. 53], n. s., r. 39, p. 266. S.-b. No. 19, p. 244.

Method of hibernation of gall-making Pemphigina on. Ulmus.

Note.-Nos. 1651-1653 and 1668-1669 were reprinted from Proc. Amer. Assoc. Adv. Sci., v. 27, under a separate cover. Salem, February, 1879.

1654. [RILeY, C. V.] The cottonwood killer. <N. Y. Weekly Tribune, 9 October, 1878. S.-b. No. 19, p. $242 . \quad$ Extract: <Amer. Ent., July, 1880 [v. 3], n. s., v. 1, pp. 159-160.

Habits, ravages, and food-plants of Lina scripta; description of and means against the same; Trypela pomonella an example of the acquisition of new habits in insects.

1655. [RILEy, C. V.] A new insect foe to green corn. <N. Y. Tribune, 9 October, 1878. S.-b. No. 19, pp. 234; 244.

Ravages of Cetonia [ = Euphoria] inda.

1656. [Rllex, C. V.] Inquiring friends. <N. Y. Tribune, 9 October, 1878. S.-b. No. 19 , p. 245.

Ravages and food-plants of Hylesinus opaculus; impracticability of means against bark-borers in large trees. 
1657. Riley, C. V. Notes from the South. Facts abont the cottonworm. <Sci. Amer., 16 November, 1878 [v. 53], n. s., v. 39, pp. 312-313. S.-b. No. 19, pp. 213-214; 239-241. See: <Amer. Rural Home, 27 September, 1878. S.-b. No. 23, p. 128.

Note of a trip in the southern United States in 1878; commission to investigate insects injurious to the cotton-plant; food-plants and habits of the larva and imago of Aletin argillacea $[=x y l i n a]$; use of poisonous baits and of Paris green; Anomis exacta injurious in certain regions.

1658. RILEY, C. V. Some further facts regarding that "fatherless race." <Sci. Amer. Suppl., 30 November, 1878. S.-b. No. 19, pp. 238-239.

Description and figures of male copulatory organs of Thyridopteryx ephemerceformis; description of method of copulation; figures larva, pupa, imagos, and follicles of the same; "parthenogenesis, though not improbable, seldom takes place in this species;" nature of the down intermingled with the eggs; previous error concerning this down.

1659. [RILEY, C. V.] "The carpet bug." <N. Y. Tribune, 1 December, 1878. S.-b. No. 19, p. 236.

Ravages of and means against Anthrenus scrophulariax; figures larva, pupa and imago.

1660. [Rrley, C. V.] A bug that eats bees. $<\mathrm{N}$. Y. Tribune, 4 December, 1878. S.-b. No. 19, p. 237. Reprint: <Prairie Farmer, 4 January, 1879, r. 50, p. 3. S.-b. No. 23, p. 110.

Description and habits of Phymata erosa.

1661. [RILEY, C. V.] Tomato worm. <N. Y. Tribune, 4 December, 1878. S.-b. No. 19, p. 237.

Excessive abundance of larva of Sphinx quinquemaculata [= Protoparce celeus] near Port Hope, Ontario, in 1878.

1662. [RILer, C. V.] Worm snake. <N. Y. Tribune, 4 December, 1878. S.-b. No. 19, p. 237.

Habits and aborle of larvæo of Sciara sp. at Orange, Conn.

1663. [Riley, C. V.] Carpet pests. <N. Y. Tribune, 4 December, 1878. S.-b. No. 19, p. 237.

Food habits, spread of, and means against Anthrenus scrophularice.

1664. Riley, C. V. Corn worm. <N. Y. Tribune, 4. December, 1878. S.-b. No. 19, pp. $235 ; 237$.

Food-plants and means against Heliothis armigera.

1665. [RILey, C. V.] Hessian-fly. <N. Y. Tribune, 4 December, 1878. S.-b. No. 19 , pp. $235 ; 237$.

Indications of the ravages of and food-plants of Cecidomyia destructor.

1666. [RILEY, C. V.] Apple-worm. <N.Y.Tribune, 4 December, 1878. S.-b. No. 19 , pp. $235 ; 237$.

Baldwin apples more exempt than other varieties from the attacks of the second brood of Carpocapsa pomonella.

1667. Rilex, C.V. Anent the English sparrow. <Evening Star [Washington, D. C.], 28 December, 1878, r. 52, No. 8030, p. 1. S.-b. No. 19, pp. 214-215; No. 23, p. 151.

Value of Passer domesticus as a destroyer of insects and in other respects; objections to the special protection of the same. 
1668. RILEY, C. V. Silk-culture; a new source of wealth to the United States. <Kansas City Review of Science and Industry, 1878, v. 2, pp. 419-423. S.-b. No. 19, pp. 216-218. Reprint: <Proc. Amer. Assoc. Adv. Sci. for 1S78, [14 July], 1879, v. 27, pp. $277-$ 283. Extract: <Kansas Farmer, 1879: 26 February, 12 Norember. S.-b. No. 23, pp. 105-106; No. 39, pp. 91-92. See: <Ca. Ent., September [October], 1878, v. 10, p. 178. <St. Louis Globe-Democrat, 28 August, 1878. S.-b. No. 19, p. 203.

Practicability and desirability of the extensive establishment of silk-culture in the United States; skctch of cfforts made towards such establishment; requisites to its success.

1669. Riley, C. V. The philosophy of the movements of the Rocky Mountain locust. <Kansas City Review of Science and Industry, 1878, v. 2, pp.424-427. S.-b. No.19, pp. 218-220. Reprint: <Proc. Amer. Assoc. Adv. Sei. for 1878, 14 July, 1879, v. 27, pp. 271-277. See: <St. Louis Daily Globe-Democrat, $24 \mathrm{Au}$ gust, 1878, v. 4 , No. 95 .

Limits of brceding-grounds of and region invaded by Caloptenus spretus; causes, periods, and directions of flights of the same; causes of the limitation of the flights; ravages; generalizations regarding locust invasions; work of the U. S. Entomological Commission.

1670. Riley, C. V. A complete life-history of the army-worm, Leucania unipuncta, and its parasites. <25th Ann. Rept. Secr. Mass. Board A gric. for 1877, 1878, pp. 243-253, figs.

Early history, synonymy, distribution, seasons, enemies, and parasites of Leucania unipuncta; labits of larva and of female imagos; descriptions of all stages; figures of all stages except the egg; figures of two unnamed parasitic Ichneumons. Parasitie habits of Exorista $[=$ Nemorac $]$ leucanice, E. flavicauda, Microgaster $[=$ Apanteles $]$ militaris, Pezomachus mininus, and Ophion purgatus-; descriptions of Miorogaster $[\div$ A.] militaris, Mesochorus vitreus, and Ophion purgatum. Ichneumon leucarice also a parasite.

1671. Rilex, C. V. Phylloxera. <Johnson's New Unirersal Cyclopædia, 187S, v. 3, pp. 1241-1243, 8 figs. S.-b. No. 10, pp.192-194.

Definition of the genus Phylloxera; list of the sixteen (16) described United States species; descriptions of their galls; distribution, history, description, and figures of various stages and ravages of and means against Phyl. loxera vastatrix.

1672. Rilex, C. $\nabla$. Potato-bug. <Johnson's New Universal Cyclopædia, 1878, v. 3, pp. 1361-1364, 9 figs. S.-b. No. 10, pp. 195-198.

List of principal enemies of potato-plant; spread, natural history, food-plants, enemies of, and means against Doryphora decemlineata; figures of the same in its different stages, and of Lydella [ = Exorista $]$ doryphorce, Calosoma calidun, Hippodania convergens, Mysia $[=$ Anatis $]$ 15-punctata, Arma $[=$ Podisus] spinosus, Harpactor $[=$ Milyas $]$ cinctns, Perillus circumcinctus, and Doryphora juncta.

1673. Rrley, C. V. Weevil. <Johnson's New Universal Cyclopædia, 1878 , v. 4, p. 1338, fig. S.-b. No. 14, p. 46.

Definition of "weevil;" mention of numerous species, with statement of their food-plants and manner of obtaining food; habits and means against Sitophilus $[=$ Calandra $]$ granaria and $S .[=C$.$] oryzee.$ 
1674. Riley, C. V. The locust swarms that derastate the trans-Mississippi country; their source, movements, and eastern limit. $<$ Western Farmer's Almauac for 1879, 1878, pp.48-50. S.-b. No. 19, pp. 247-248.

Limits of the breeding-grounds of and of regions invaded by Caloptenus spretus; causes, periods, and directions of their flights; causes of the limitations of the "same physical and principally atmospheric; amount of ravages.

1675. [RILey, C. V.] Prof. Riley in favor of the birds. <Evening Star [Washington, D. C.], 9 January, 1879, v. 53, No. 8039, p. 3. S.-b. No. 19 , pp. 223-224; No. 23, p. 94.

From St. Louis [Mo.] Globe-Democrat. List of some birds which are beneficial to horticuiture and some which are noxious.

1676. Riley, C. V. Letter from Prof. C. V. Riley. <Colman's Rural World, 15 January, 1879. S.-b. No. 23, pp. 107-108.

Letter to N. J. Colman transmitting report as former treasurer of the Missouri State Horticultural Society; transmission of documents for distribution; proposal for a revised and condensed edition of author's reports as State entomologist of Missouri.

1677. [RILEY, C. V.] Michigan apples and codling-moth. <N. Y. Tribune, 15 January, 1879. S. b. No. 23, p. 109.

Freedom of apples from Carpocapsa pomonella in 1878 in Michigan due to the smallness of the apple crop in $187 \%$ and to the efforts made by the orchardists to exterminate the insects.

1678. Riley, C. V. Notes on the Aphididae of the United States, with descriptions of species occurring west of the Mississippi. $<$ Bull. U. S. Geol. and Geog. Surr. Terr., 28 February, 1879, v. 5, pp. 1-32, pl. 1-2, with 2 pp. expl. of pl. Separate: <Washington, 22 January, 1879, $32 \mathrm{pp}$., 2 pl., with 2 pp. expl. of pl. Abstract: <Sci. News, 15 April, 1879, v. 1, pp. 184-186.

Part 1, pp. 1-17, by C. V. Riley, entitled "Biological notes on the Pemphigince, with descriptions of new species;" history and description of Schizoneura americana n. sp. [p. 4], Colopha ulmicola, Pemphigus populi-monilis n. sp. [p. 13], P. populi-transversus n. sp. [p. 15], P. p.-ramulorum n. sp. [p. 16], $P$. acerifolii n. sp. [p. 16], P. fraxinifolii n. sp. [p. 17], and Hormaphis spinosus.

Part 2, pp. 18-32, by J. Monell, entitled "Notes on Aphidina, with descriptions of new species." Describes nine (9) new species of Siphonophora, five (5) of Aphis, two (2) of Rhopalosiphum, nine (9) of Callipterus, three (3) of Chaitophorus; description of other specics of these genera and of Drepanosiphum and the genera above named; synoptic tables of some of the species.

1679. [RILEY, C. V.] . [Plant-lice on potatoes.] <N. Y. Tribune, 12 February, 1879. S.-b. No. 23, p. 109.

Aphididce reputed injurious to potato plants, probatly Aphis solani.

1680. Rilfiy, C. V. Missouri entomological reports. <Colman's Rural World, 19 February, 1879. S.-b. No. 23, p. 102.

Proposal for republication of the reports of the State entomologist of Missouri; reasons for the non-publication of a tenth report; sketch of what that report would have contained. 
1681. Rilex, C. V. Entomological notes. The chinch-bug. <Farmer's Review. February, 1879, 2 figs. S.-b. No. 23, pp. 111-112.

Figures of all stages, ravages, natural history, and means against Blissus lencopterus; its method of hibernation, and the effect of weather upon it.

1682. Riley, C. V. Notes on the apple-worm. <Colman's Rural World, 5 March, 1879. S.-b. No. 23, p. 102. Reprint with slight changes: <Amer. Nat., August [July], 1879, v. 13, pp. 523524. <Ann. Rept. [U. S.] Commissioner Agric. for 1878, 22 November, 1879, pp. 238-239.

Sce No. 1721 for synopsis of contents.

1683. Riley, C. V. The rice-ireevil. Serious injury to stored and to cribbed corn. <Farmer's Review, March, 1879, fig. S.-b. No. 23, p. $99 ; 112$.

Figures larva, pupa, and imago of Calandra oryze and imago of C. granaria ; habits, ravages, and means against the same; description of egg and method of oviposition of C. oryza; use of carbon bisnlphide against these insects; poisonous effects of eating the comminuted beetles.

1684. Riley, C. V. [Letter to W. G. Le Duc.] <Boston Daily Herald, 4 April, 1879. <Psyche Advertiser, 11 April, 1879, v. 2, p. 9. <Ent. Nach., 1 July, 1S79, jahrg. 5, p. 177.

The reason for which the author resigned as entomologist of the U. S. Department of Agriculture was not ill-health.

1685. Riley, C. V. Preventing rot in plums. <N. Y. Tribune, 9 April, 1579. S.-b. No. 23, p. $110 ; 129$.

Trapping and jarring recommended as a means against Conotrachelus nenuphar.

1686. [RILEx, C. V.] A new insect pest. <Colorado Farmer, 10 A pril, 1879 , v. 12 , No. 15, p. 6. S.-b. No. 23 , p. 108 。

Injnry to orchards and ornamental trees in California by Dorthesia [characias?], introduced from Australia; ravages of $D$. characias in southern Africa; prospective ravages in California; means against it.

1687. Riley, C. V. The nerrous system and salivary glands of Phylloxera. <Psyche, 11 April, 1879, v. 2, pp. 225-226.

Correctness of E. L. Mark's conclusion that the author had mistaken nerve cords for trachex; 'dissent from M. Cornu's view that the root swellings cansed by Phylloxera are due to mechanical action of the puncture and the subsequent a bsorption of liquids; swelling considered to be caused by the introduction of a salivary secretion.

1688. RILEY, C. V. Mr. Henderson's experiments. <Gardener's Mo. and Hortic., A pril, 1879, v. 21, pp. 120-121. S.-b. No. 23, p. 107.

Review of P. Henderson's "Carnivorous plants;" believes that Dionca and Drosera are nourished by the insects digested by thcir leaves.

1689. Riley, C. V. The migrations and hibernation of Aletia argillacea. <Washington [D. C.] World, 10 May, 1879. < Seience News, 1 June, 1879, v. 1, pp. 230-232. S.-b. No. 23, pp.119120. <Sci. Amer., 14 June, 1879 .[v. 54], n. s., v. 40, p. 375. <Galveston [Tex.] Daily News, 24 October, 1879, v. 38, p. 2. 
1689. Riley, C. V.-Continued.

S.-b. No. 23, pp. 166-167, No. 42, pp. 38-39. Abstract: < Amer. Nat., November [25 October], 1879, v. 13, p. $726 .<$ Farmer's Review, September, 1879. 'S.-b. No. 23, p. 108.

Ravages of inseets, particularly of Aletia argillacen $[=x y l i n a]$ in the United States; hibernation theories; anthor's belief in the probable hibernation of the motb in the southern parts of the entton belt; speeics mistaken ior Aletia; description and food-plants of Aspila virescens.

1690. Riler, C. V. Insects affecting clover. <N. Y. Tribune, 14 May, 1879. S.-b. No. 23, p. 90;97; 129.

Habits, ravages of and means against Hylesinus trifolii and Cecidomyia leguminicola; prior observations upon the same; characters distinguishing C. leguminicola from $C .[=$ Diplosis $]$ tritici and $C$. destructor.

1691. Rilex, C. V. [Eeanthus niveus.] <N. Y. Tribune, 14 May, 1879. S.-b. No. 23, p. $95 ; 98$.

Oeeurrenee of eggs of $E$ Eanthis niveus in twigs of apple, raspberry, grape, and other plants; slight injuries to be expected from the same; means against them.

1692. [RILey, C. V.] Insect powders and their use. <N. Y. Tribune, 14 May, 1879. S.-b. No. 23, p. 95; 96; 130-131.

Abstraet of W. Saunders" "Inseet powder," with additions; differences between Persian and Dalmatian inseet powder; methods of using them against insects.

1693. [Rilex, C. V.] The grasshopper prospect. <N. Y. Tribune, 14 May, 1879. S.-b. No. 23, p. 98.

Prospect of injuries by Caloptenus spretus in 1879; a new species injurious in the Sierra Valley of California.

1694. RILEY, C. V. The westward progress of the imported cabbageworm. <Amer. Nat., June [20 May], 1879, v. 13, p. 393. See: <Colorado Farmer, 10 April, 1879. S.-b. No. 23, p. 108. $<$ Farmer's Review, April, 1879. S.-b. No. 22, p. 64 . <Colman's Rural World, 1879. S.-b. No. 23, p. 108. <Ann. Rept. [U. S.] Commissioner A gric. for 1878, 22 November, 1879, p. 239. Spread of Pieris rape into Illineis and Missouri; means against the same.

1695. [RILEY, C. V.] Lures for moths. <N. Y. Tribune, 28 May, 1879. S.-b. No. 23, p. 95 .

Trapping Carpocapsa pomonella in shallow dishes of sweetened liquid more harmful than benefieial, as many useful inseets are destroyed; the method serviceable against Heliothis armigera.

1696. [RILEy, C. V.] The currant-worm. <N. Y. Tribune, 11 June, 1879. S.-b. No. 23, p. 106.

Deseription, habits, distribution, and spread of and means against Nematus ventricasus $[=$ ribesii $]$; methods of usiug hellebore.

1697. [RILEY, C. V.] Sweet potato beetle. <N. Y. Tribune, 11 June, 1879. S.b. No. 23, pp. 106-107; 131.

Description of all stages, habits, food plants, and means against Coptooycla $[=$ Cassida $]$ nigripes. 
1698. Rilex, C. V. [The serenteen year Cicada.] <N. X. Tribune, 1879. Reprint: <Colınan's Rural World, 25 June, 1879. S.-b. No. 23, p. 152.

Bonndaries of the arcas in which Cicada $[=$ Tibicen $]$ septendecim is expected to occur in 1879; request for information of its appcarance.

1699. Riley, C. V. The imported carpet-beetle, Anthrenus scrophularia, L. <Farmer's Reriew, 1879, fig. S.-b. No. 23, pp. 9698. Extract: <Amer. Ent., March, 1880 [v. 3], n. s., v. 1, p. 54.

Letter of J. H. Parsons, with answer; description of iarva and inlago of Anthrenus scrophularice; its history, habits, ravages, and means against them; figures larva, pupa, and imago.

1700. [RILEY, C. V.] The cheese-skipper. <N. Y. Tribune, 2 July, 1879. S.-b. No. 23, p. 93. Notice: < Farmer's Reriew, 7 September, 1879. S.-b. No. 23, p. 103.

Description of larva, pupa, and imago, habits and means against Piophila casei.

1701. Rilex, O. V. The thick-thighed walking-stick. <Sci. Amer., 5 July, 1879 [v. 55], n. s., v. 41, pp. 7-8, fig. S.-b. No. 23, p. 121. Reprint, with slight ehanges: <Ann. Rept. [U. S.] Commissioner Agric. for 1878, 22 November, 1879, pp. 241-245, pl. 3.

Treats of Diapheromera femorata. See No. 1721 for synopsis of contents.

1702. Riley, C. V. The cotton-worm. <Mobile Register, 9 July, 1879. S.-b. No. 68, p. 204. See: <Colorado Citizen, 17 July, 1879. S.-b. No. 23, p. 91. <Galveston Nerrs, 19 July, 1879. S.-b. No. 23, p. 93.

Remarks at the Cotton Exchange about prospective injuries from Aletia argillacea $[=x y l i n a]$; sudden appearance and means against the same; more injurious in wet than dry weather.

1703. RileY, C. V. Other insects affecting cheese. $<$ N. Y. Tribune, 9 July, 1879. S.-b. No. 23, p.92. Reprint: <Amer. Dairyman. $<$ Western Rural, 9 August, 1879, v. 17, No. 32, p. 250. S.-b. - No. 23, p. 92.

Habits and transformations of Tyroglyphus siro, Corynetes $[=$ Necrobia $]$ rufipes, and Dermestes lardarius; tenacity of life of the Tyroglyphens and assumption of Hypopus form by the same; anecdote of Latreille; injury done in chcese by Musca corvina.

1704. Rilfi, C. V. Pupation of the Nymphalide. Abstract: <Pscehe, 11 July, 1879, v. 2, pp. 249-251.

Notice of prevalent explanations of the manner in which suspended pupa of Lepidoptera support themselves while shedding the larval skin; explanation of the process in Vanessa antiopa and Paphia glycerium.

1705. Riley, O. V. Fire-flies. <Sei. Amer., 26 July, 1879 [v. 55], n. s., v. 41, p. 49. S.-b. No. 23, p. 104.

Definition of "Fire-flies;" description of larva, pupa, and imago of Photinus pyralis; Photuris ponnsylvanicus, the conmonest species in the more northern statcs; absence or imperfect development of wings in certnin female Lampyrida. 
1706. Riley, C. V. Grape-scale insect, new species. <Pacific Rural Press, 16 August, 1879. S. b. No. 32, p. 66.

Answer to inquiry of editor of Press; a new coceid, allied to Pulvinaria vitis.

1707. Riley, C. V. Dragon-flies. <Sci.Amer., 23 August, 1879 [v. 55], n. s., v. 41, p. 113. S.-b. No. 23 , p. 100.

Description and natural history of Libellulidce.

1708. Riley, C. V. Failure of tea roses. Habits of Fuller's rose beetle, Aramigus fulleri Horn. <Sci. Amer., 30 August, 1879 [จ.55], n. s., v. 41, p. 129, fig. S.-b. No. 23, pp. 114-116. Reprint: <Gardener's Mo. and Hortic., October, 1879, v. 21, pp.310-31.1, fig. S.-b. No. 23, pp. 126-127. Reprint, with additions: <Ann. Rept. [U. S.] Commissioner Agric. for 1878, 22 Novem. ber, 1879, pp. $255-257$, pl. 17 , f. 2.

See No. 1721 for syuopsis of contents.

1709. Riley, C. V. The "Devil's darning needle." <Sci. Amer., 6 September, 1879 [v. 55], n. s., v. 41, p. 148. S.-b. No. 23, p. 104. Review : <Sci. Amer., 27 September, 1879 [v. 55], n. s., v. 41 , p. 194. S.-b. No. 23 , p. $103 \frac{1}{2}$.

Diapheromera femorata winters in the egg-state; W. J. McGee confounds the above with a species of Ranatra; the term "Devil's darning needle" mostly associated in the popular mind with the dragon-flies (Libellulidw).

1710. [RIley, C. V.] The red-spider on roses. <Sci. Amer., 13 September, 1879 [v. 55], n. s., v. 41, p. 161. S.-b. No. 23, pp. 116117.

Nature, ravages, and means against Tetranychus telarius; habits and transformations of Acarina.

1711. Riley, C. V. Philosophy of the pupation of butterflies. <Sci. Amer. Suppl. No. 193, 13 September, 1879, p. 3069, 3 figs. S.-b. No.23, p.125. Reprint: < Science News, 15 September, 1879, v.1, pp. 346-350. Reprint with changes : < Nature, 16 October, 1879, จ. 20, pp. 594-595. <Kosmos, Jannary, 1880, br. 6, pp. 313318. <Proc. Amer, Assoc. Adv. Sei. for 1879, 1880, v. 28, pp. 455-463, figs. <Separate: Salem, Mass., July, 1880, 9 pp., 6 figs. <Amer. Ent., July, 1880 [v. 3], n. s., v. 1, pp. 162-167, figs. 65-70. Abstract: <The Field Nat. and Sci. Student, January, 1883, pp. 179-180. S.-b. No. 42, p. 1. <Bull. Philos. Soc. Wash., 1879, v. 3, pp. 41-43.

Illustrates the prevalent explanation of the manner in which suspended chrysalids become attached to their supports; deseribes and illustrates the more correct process; structure of the terminal joint of the chrysalis especially in Vanessa antiopa, Terias sp., Danais archippus, and Paphia glycerium.

1712. Riley, C. V: Parasites of the cotton-worm. <Ca. Ent., September, 1879 , v. 11, pp. 161-162.

List of parasites of Aletia argillacea $[=x y l i n a]$; descriptions of Trichogramma pretiosa n. sp. [p. 161], Cirrospilus [= Tetrastichus] esurus n. sp. [p. 162], and Tachina aletire n. sp. [n. 16:2]. 
1713. Riley, C. V. [Insect injurious to junipers.] <Ca. Ent., Septem. ber, 1879 , v. 11, p. 177.

Jnnipers on Long Island injured by Dapsilia rutilana.

1714. Riley, C. V. The imported cabbage-worm in the South. <Farmer's Review, September, 1879. S.-b. No. 23, p. 106.

Spread of Pieris rapae westward and sonthward; its present distribution; southern limit of distribution of Doryphora 10-lineata.

1715. Riley, C. V. The shedding of the trachere and double cocoons. <Amer. Nat., October, 1879, v. 13, p. 652.

Review of two notes by E. Potts.

1716. Riley, C. V. Leaf-galls on the grape-vine. $<\mathrm{N}$. Y. Tribune, 1 October, 1879. S.-b. No. 23, pp. 117; 173. See: <Kansas Farmer, 26 November, 1579. S.b. No. 26, p.9. <West. Rural, 10 December, 1879.

Habits, ravagres, reproduction, and distribution of Phylloxera vastatrix.

1717. Riley, C. V. The Croton bug as a library pest. <Library Journal, September-October, 1879, v. 4, p. 376.

Letter to Weston Flint; ravages of and means against Blatta $[=$ Ectobia $]$ germanica.

1718. RILEY, C. V. The Ailanthus silk-worm, Attacus (Samia) cynthia. <Science News, 15 October, 1579, v. 1, pp. 377-383. Extract: <Amer. Ent., March, 1880 [v. 3], n. s., v. 1, pp. 56-58, fig. 16. <Farmer's Review, S January, 1880, v. 4. S.-b. No. 23, pp. $167-168$.

Description of eggs, larvie, and imagos of Samia [=Attacus] cynthia; history, food-plants, acclimation, and artificial rearing of the same, and of Samia [=Attacus] ricini; differences between the eggs, larvie, and cocoons of the two species; availability of these and other species for silk-cnlture; snperiority of Sevicaria mori for this purpose; occurrence of parthenogenesis and of retardation of development in Bombycida.

1719. Riley, C. V. The cotton-worm. Letter from Prof. O. V. Riley on some recent cotton-worm articles in the News. <Galveston [Tex.] Daily News, 24 October, 1879, v. 35, No. 185, p. 2. S.-b. No. 23, pp.164-165. Reply : <Ibid., 31 Uctober, 1879, No. 191, p. 4.

Critical review of W. J. Jones's "The cotton caterpillar," and of Investigator's "The cotton-worm;" denies"that Aletia argillacca [=xylina $]$ hibernates in the pupa state; author not interested in entomological discoveries for mercenary ends.

1720. Riley, C. V. [Spread of Pieris rapw into Alabama.] <Ca. Ent., October, 1S79, v. 11, p. 196.

Pieris rape now quite common in Alabama; it has reached Selma but not Mobile.

1721. Riley, C. V. Report of the entomologist. <Ann. Rept. [U. S.] Commissioner A gric. for 1878, 22 November, 1879, pp. 207-257, +1 p. expl. of pl., pls. 1-7. Separate: <Washington, Octo- 
1721. RILEY, C. V.-Continued.

ber, 1879 , pp. $52+1$ p. expl. of pl., 7 pl. Notice: <Gardener's Mo. and Hortic., November, 1879, v. 21, pp. 349-350. S.-b. No. 23, p. 29 .

LETTER OF SUBMITTAL................................ 207

INSECTS AFFECTING THE COTTON PLANT $\ldots . . . \ldots \ldots \ldots . . . . . . .$.

Report of special investigations carried on in 1878, 210-Organization and personnel of the commission of inquiry, 210-Circnlar letter of inquiries, 210-Report of A. R. Grote, 213-Seasons, hibernation, and migrations of Aletia argillacea $[=x y l i n a], 213-$ Discovery of parasites, 214-Food-plants of the imago, 214.

THE SILK-WORM: A BRIEF MANUAL OF INSTruCtions FOR THE PRo-

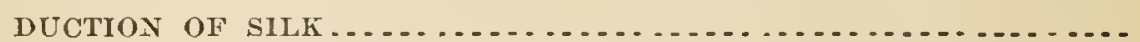

[A reprint of spccial report No. 11.] Culture of Sericaria mori in the United States, 215-Profits of producing cocoons, 217-Profits of reeling, 217-Profits in raising eggs, 218-Nature of the silkworm, 218-The egg, 219-The larva, 219-The cocoon, 220-The chrysalis, 221-The moth, 221-Enemies and discases, 221-Muscardine, 221-Pébrine, 22:-Other diseases, 223-Varieties or races, 223-Wintering and hatching the eggs, 224-Feeding and rearing the worms, 225-Prcparation for spinning, 228-Gathering the cocoons, 229-Choking the chrysals, 229-Eyg-laying; reproduction, 230-Reeling, 232-Food-plants, 235-Glossary of terms nsed, 236.

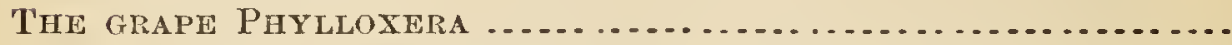

Importance of American grape-culture, 237-Grafting of vines, 237-Distribution of Phylloxera, 23ð-Hoplessness of means against, 238.

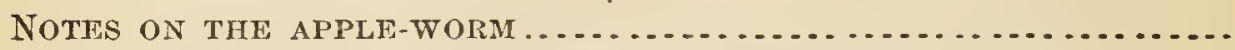

Canses of the scarcity of Carpocapsa pomonella in Michigan, 238Means against the same, 239.

The WRSTWARI) PROGRESS OF THE IMPORTED CABBAGE-WORM ...... Spread of Pieris rape, 239-Means against the same, 239.

Chapin's A PPle-Leaf Sewer, Phoxopteris nubcculana Clem ...........

Habits and natural history, 239-Its injury to apple-trees, 239Means against it, 239-Description of larva and chrysalis, 239Synonymy, 239.

The thick-thighed waLking-stick, Diapheromera femorata Say ....

Vcrnacular names, 241-Nomenclature, 241-Characters, 241-Destructive powers, 241-Habits and natural history, 243-Its appearance cvery alternate ycar, 244-Natural enemies, 244Remedies, 245-Descripition of egg, 245-The larva, 245.

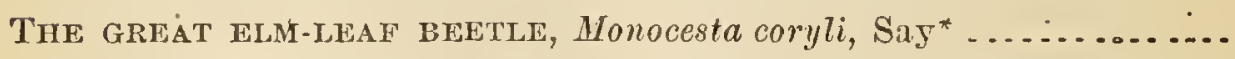

Past history, 245-Ravages, 246-Habits, 246-The eggs, 246-The larvæ, 246-Habits of larvæ, 246-The pupa, 246-Rernedies, 247.

'The Juniper web-worm, Dapsilia rutilana, Hiibn ................

Importation, 247-Distribution in Europe, 247-Habits, 247-Remedies, 248-Description of larva, 248; of pupa, 248; of imago, 248.

*Translation: <Acker- und Gartenbau-Zeitung, 1 June, 1880, v. 11, p. 87, fig. S.-b. No. 23, p. -. 
1721. Riley, C. V.-Continued.

THE Clover-Root borer, Hylesinus trifolii, Muiller *..............

Occurrence in New York, 248-Habits in Europe, 249-Food-plants, 249-Natural history, 249-Remedies, 250-Differential characters of $H$. opaculus and $H$. trifolii, 250-Enemies, 250-Description of larva, 250 ; of pupa, 250.

The Clover-SEED MIDGE, Cecidomyia leguminicola, Lintner ...........

Ravages in Now York, 250-Habits, 251-Remedies, 251-Description of imago, 251-Larva, 252-Cocoon, 25\%-Pupal excuvium, 252-Comparative characters of $C$. tritici, $C$. destructor, and $C$. leguminicola, 252.

THE APPLE COLEOPHORA, Coleophora malivorella, n. sp. $\nmid \ldots . . . . . . . .$.

History, 253-Habits, 253-Injuries, 253-Larval habits, 254-Enemies and remedies, 254-Description of larva and imago, 254.

Fuller's Rose-beetle, Aramigus fulleri Horn .....................

History, 255-Distribution, 255-Ravages, 255-Habits and characters of imago, 256-Remedies, 257-Description of egg, larva, and pupa, $25 \%$.

1722. Rruer, C. V. [Parasites bred from the cotton-worm.] <Ca. Ent., November, 1879, v. 11, p. 205.

Nine species of parasites have been bred from Aletia argillacea [=xylina].

1723. RileY, C. V. The bee-moth. <N. Y. Tribune, 1879. Reprint: <Farmer's Review, 3 Jauuary, 1880. S.-b. No. 23, p. 158.

Description of larva and imago, habits, ravages, and means against Galleria cereana.

1724. RILEY, C. V. The silk-worm; being a brief manual of instructions for the production of silk. <Special Report No.11 [U. S.J, Dept. Agric., Washington, 1879, pp. 31, 8 figs. Second edition: <Washington, 1882, 37 pp., 8 figs. Third edition: $<$ Washington, 1883, 37 pp., 8 figs. Fourth edition: Fifth edition: Sixth edition: $<$ Bull. No. 9 Div. Ent. U. S. Dept.

- Agric., 11 July, 1886, 65 pp., 29 figs., 2 pl. Seventh edition: $<$ Ibid., April, 1888.

Treats of Sericaria mori. Seo No. 1721 for synopsis of contents.

1725. RrLex, C. V. London purple as an insecticide. <Farmer's Review, 29 January, 1880, v. 4, No. 5, p. - .

1726. [Rrley, C. V.] [The food-habits of thrushes.] <Amer. Ent., January, 1880 [v. 3], 11. s., v. 1, pp. 2-3.

Notice of S. A. Forbes' "The food-habits of thrushes;" incompleteness of our knowledge of the food-habits of hirds and of Carabide; author's opinion favorable to the birds.

1727. [KILwY, C.V.] The grape Phylloxera in California. <Amer. Ent., January, 1880 [v.3], n. s., v. 1, p. 3.

Phylloxera vastatrix as destructive to Vitis vinifera in California as in Europe; tho winged female supposed not to have appeared yet in California ; speculations upon this modification of habit, if true.

* Translation: <Acker- und Gartcnbau-Zeitung, 1 Angust, 1880, v. 11, p. 119, 2 figs. S.-b. No. 23, p. - Extract: <Prairic Farmer, 22 November, 1879, v. 50, p. 370. S.-b. No. 23, pp. 168-169. <Amer. Rural Farmer, 18 December, 1879. S.-b. No. 45, pp. 23-24.

†Translation: <Acker- und Gartenbau-Zeitung, 1 September, 1880, v. 11, p. 135, fig. S.-b. No. 23, p. 182. 
1728. [RILey, C. V.] On the hibernation of the cotton-worm, Aletia argillacea Hiibn. <Amer. Ent., Jannary, 1880 [v. 3], n. s., v.1, pp. 6-11, figs. $3-5$; p. 15.

Advance print from Bull. No. 3 U. S. Ent. Commission, pp. 24-31. See No. 1736 for synopsis of contents.

1729. [RILEY, C. V.] [Inquilines in galleries of the common white-ant.] $<$ A mer. Ent., Jannary, 18so, [r. 3], n. s., v. 1, p. 15.

Trichopscnins depressus and three undescribed Aleocharini found inquilinons in galleries of Termes flavipcs in Texas by E. A. Schwarz; the Trichopscnius previously known by a single specimen from Georgia.

1730. [Riler, O. V.] Large white scale on acacias, etc. <Amer. Ent. January, 1880 [v. 3], n. s., v. 1, p. 20.

Occurrence and ravages of Dorthesia characias? in California and southern Africa; characters of the insect.

1731. [Riley, C. V.] [Ravages of moths in cushions.] <Amer. Ent., Januars, 1880 [v. 3], 1. s., v. 1, p. 20.

Conclusions of disenssion by Gernan Society of Rail way Companies as to the best method of preventing the ravages of moths in the cushions of railway carriages.

1732. [RILey, C.V.] [Grape Phylloxera in Geelong, Victoria.] <Amer. Ent., January, 1880 [v. 3], n.s., v. 1, p. 20.

Occurrence of Phylloxera vastatrix in Geclong, Victoria.

1733. Rilex, C. V. Borers in black-ash : Fall web-worm: Apple-tree insects. . <Amer. Ent., January, 1880 [v. 3], n. s., v. 1, pp. '2ב23.

Black-ash trees in New York killed by the borings of Parandra brunnea; ash trees bored also by Trochilium [ Fatua] denudata; the leaves of the same and other trees destroyed by Hyphantria textor [= cunea]; apples injured by the "gimlet-worm"; habits, ravages of, and means against Bucculatrix pomifoliella; figure of cocoons and imago of this moth.

1734. [RILey, C. V.] Skxippers injuring smoked hams. <Amer. Ent., January, 1880, [v. 3], n. s., v. 1, pp. 23-24.

Answer to communication from E. A. Smith; hams injured by larvæ of Piophila casei; means against tuese and other insects injuring hams.

1735. [RILEy, C. V.] Tipula eggs in the stomach of the cat-bird. $<$ Amer. Ent., January, 1880 [v. 3], n. s., v. 1, p. 24.

Answer to communication from S. A. Forbes; description of eggs and method of oviposition of Tipula trivittata?

1736. Riley, C. V. The cotton-worm. Summary of its natural history, with an account of its enemies and the best means of controlling it; being a report of progress of the work of the com. mission. <Bull. No. 3, U. S. Ent. Commission, 28 January, 1880, 144 pp., 1 pl., 84 figs. Extract: <Amer. Ent., Mareh, 1880 [v. 3], n. s., v. 1, pp. 67-68, figs. 19-20. <Farmer's Review, January, 1880, 2 figs. S. b. No. 23, pp. 163-164. 
1736. Rilex, C. V.-Continued.

INTRODUCTORY

Text of circular sent out by the commission, 1-History of the investigation, $1-$ Nced thereof, 2-Early work of Townend Glover, Thomas Affleck, and D. L. Phares, 2-Special report ordered by Congress, 3-Character of the Bulletin, 3-Division of the cotton-belt in the southern or hibernating and the northern or non-hibernating portions, 4-Practieal aim of the commission, 4-Persons who have assisted, 4.

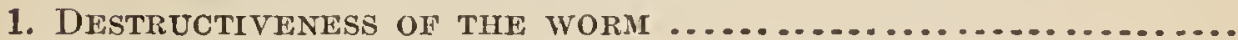

Losses occasioned by it .................................

Increase of injury westward, 7-Least injuryin northern portion of belt, 7-Tabular statement of loss for past 15 years, 8 .

2. Popular and SCientific NaMes for the insect ..............

Most desirable popular name, 8-Different technical names by which the inseet has been known, 8-Earliest description of it, 8 .

3. Cilaracters and stages of tine insect $\ldots \ldots \ldots \ldots \ldots \ldots \ldots \ldots$

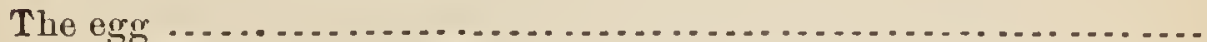

The worm always hatched from an $\mathrm{cgg}, 9-$ Where the egg is laid, 9-Number of eggs to a leaf, 10-All eggs perish during winter, 10-Other eggs mistaken for those of dletia, 10.

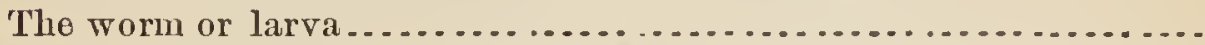

Charaeter of newly-hatched worm, 10-Number of molts, 11Variation in color, 11-Peculiar habits, 11-Flourishes on the cotton-plant only, 12.

The chrysalis .............................................

Duration of chrysalis state, 13-It never transforms below ground, 13-How it mày be distinguished from other species, 13.

The moth or imago .......................................

Distinguishing characters of the moths, 14-Sexual differences, 14-Different habits at night and at day, 14-Fecundity, 15It finds its natural food on the cotton-plant, 15-Fond of fruits, 15-Character of its tongue, 15.

4. TIME ElaPSING From ONE GENERATION to ANOTHIRR .............

It varies greatly, but averages about one month, 16 .

5. TIME OF YeAR WHEN THE FIRST WORMS APPEAR ...............

Prevailing opinions erroneous, 16-The worms hatch in April, 16-First worms always in small numbers, 17 -The third generation usually ealled the first, 17 .

6. Condition of SOIL and Plant CONNECTED witi the appearancle OF THE FIRST WORMS

The worms appear first on low, moist, and rich lands, 18-Few exceptions to the rule, 18-The plant must be well advanced and luxuriant, 18-Some shelter generally near, 19-Reoccurrence year after year in the samespots, 19 -Theory explaining first appearance under the circunstances olserved, 19.

7. WET WEATHER FAVORS THE DEVELOPMENT OF THE WORMS.......

Humid and hot atmosphere most favorable, 20-Heavy storms destroy, 20-Effect of dryness, 21-Indirect influences of wet weather, 21-It prevents the working of the worm's natural enemies, 21. 


\section{Riley, C. V.-Continued.}

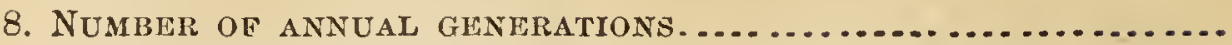

Prevailing general belief erroneous, 21-Early generations often overlooked, 22-Also often exterminated by natural enemies, 22 -At least seven annual generations in southern portion of belt, and probably more, 22 .

9. Migrations and power of flight of the moth .............

The moth has great power of wing, 23-It flies many hundreds of miles north of eotton belt, 23-Appearanec of the worm on eotton first planted great distances from any other cotton thus aeeounted for, 23-Migrating habit developed only in later monthis when they beeome numerous, 24.

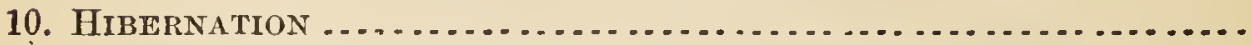

Different opinions and beliefs, 24-Difficulty surrounding the question, 24-Erroneous conelusions easily drawn, 25-Fallacy of the belief that the ehrysalis winters underground, 25-26Ability of the moth to survive the winter, 26-Other moths easily mistaken for it, 27 -Theory of annual introduction of the speeies from some exotie eountry, 28-Arguments for and against the theory, 29, 30-Hibernation of the moth in the southern portion of the belt'substantiated, 30 - But a very small proportion of those whieh abound in the fall live to perpetuate their kind the next spring, 31-Loealities where the moth hibernates, 31 .

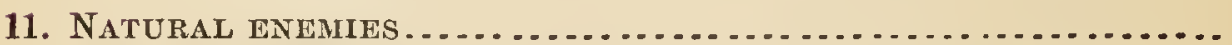

Vertebrates.........................................

Quadrupeds, birds, and reptiles that feed upon the worm, 32Introduction of English sparrow, 33.

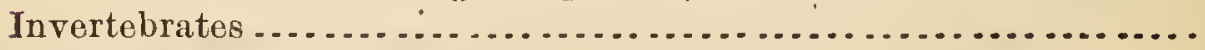

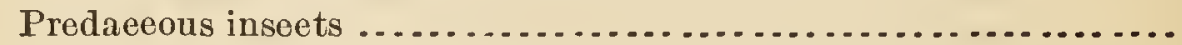

Wasps, ants, and other Hymenoptera, 34-The good work of ants, 34-How they are drawn to a cotton-field by the aphides, 34-Beetles which prey upon the worm and others which presumably do so, 35-Enemies among the half-winged bugs or Heteroptera, 36-Among two-winged flics or Diptera, 36Among nerve-winged inseets or Neuroptera, 37.

Parasites ..............................................

Previous belief that none preyed on Aletia, 38-Infesting the egg, 38-Infesting and issuing from the worm, 39-Flesh flies and Tachina flies, differences between them, 40-42-Issuing from the ehrysalis, 42-A parasite known but not named in 1852-Ten distinet parasites infesting Aletia, and two other undetermined speeies, 47.

12. Remedies: Means of COPING With the INSECT ..............

Favorable showing as to what has been aceomplished in the South sinee the war, 48 .

Prevention.............................................

Modes of eultivation, 48-Topping, 48-Use of carly varieties, 48-Isolating fields, 48-Diversified agriculture, 49-Rotation of erops, 49-Proteetion of natural enemies, 49-Early vs. late planting, 49-Interspersing corn with cotton, 49-Jute, 49.

Mechanical means of killing the worms ......................

Simple methods of brushing and dragging, 50 .

Machines for brushing off the worms ..................... 
1736. Riley, C. V.-Continued.

12. Remedies: Means of Coping With the Insect-Continued.

The Ewing brushing machine, 50 - The Helm brusining machine, 51-The Wood-Smith brushing machine, 52-The Iske brushing machine, 53-Use of kerosene and coal oil with shallow pans or cloth franles, 54.

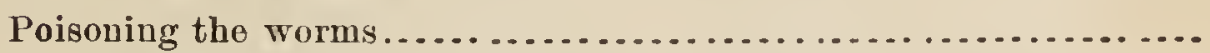

Inpetus given to invention by the nse of nineral poisons, 54Valne of concerted action, 54-General principles to be observed in poisoning, 55-Dry vs. wot applications, 55-Advantage in being prepared, 55.

Arsenical componnds...................................

Their valuc, 55-Safe and harmless where carefully nsed, 55Cantion vecessary, 56-Antidote to arsenic poison, 56-Paris green, 56-When first recommended against the cotton-worm, 56-Its value, advantages, and disadvantages, 56-Modes of using it, 57-Patents issued for Paris green mixtures, 57-They shonld be disregarded, 58-Arsenic, 58-It causes the squares to fall, 58-Patent granted for its use in 18r1, 59-Jolnson's dead-shot, 59-Arseniate of soda, 59-Texas cotton-worm de. stroyer, 60-Lodi pest poison, 60 .

London purple .......................................

Its nature, and how produced, 60-Its efficacy as an insceticide, 60-Analysis of, 60-It proves a valuable poison for the worms, 61-Cheaper than Paris green, 62-Its pcrsistency, 62.

Pyrethrum powder .................................

Its origin and nature, 62 -Its remarkable insccticide qualities, 62-Most effectual on the cotton-worm, 63-Perfectly harmless to man, 63-The extract of the plant has the same virtne, 63Growth of the plant in Califoruia, 63-Experiments conducted, 64-The alcoholic extract very potent, 64-Probable cost of using it, whether as powder or extract, 65-Highly oncouraging prospects from its use, 65 .

Keroscne oil ........................................

It canses instant death to the worm, but is difficult to apply without injuring the plant, 66-Vaporized by means of steam, 66-Used as a soap, 66.

Cotton-seed oil .........................................

Acts mnch as kerosene, 66-Made into soap with ashes from hull of seed, 66-Might be profitably nsed around oil factories, 66 .

Carbolic acid ............................................

As a means of keeping off the woth, $67-$ Will not kill the worm without injuring the plant, $6 \%$.

Sulphnr ..........................................

Extracts or decoctions from varions plants ..................

Yeast ferment; fungns infection ...........................

Proposition by Dr. Hagen, 68-Dr. Bail's experiments, 68-Not in accord with the leading mycologists, 68-Expcriments with beer-mash, 69-With beer-mash and yeast ferment, 70.

Machines and coutrivances for powdering..................

Simple contrivance for mixing, 74-Ordinary method of applying dry poison, 75-Patented machines, 75-Hand duster, 75The Willie duster, 75-The Hurd blower, 76-Combined duster 
1736. Rilex, C. V.-Continued.

12, Remedies: Mleans of Coping With the Insect-Continued. and sprinkler, 78-The Davis duster, 78-The Levy duster, 79-The Taylor duster, 80-The Allen duster, 81-The Young duster, 81-The Goodheart duster, 81.

Machines and contrivances for sprinkling and spraying..........

Gray's hand sprinkler, 81-The Ruggles sprinkler, 82-The Ramsey sprinkler, 82-The Taylor sprinkling apparatus, 83-The Townsend sprinkler, 83-The Willie spriukler, 84-The Shanck sprinkler, 84-Peck's spray machine, 84-Fountain pump, 85Machines for spraying on a large scale, 85-The Goodin sprinkler, 85-The Yeager sprinkler, 86-The Ruhmann spriukler, 87-The Johnson spray machine, 88-The Warner-saddle sprinkler, 90-The Binkley atomizer, 90-The Schier atomizer, 91-Ruhmann's improved atomizer, 93-The Daughtry atomizer, 94 .

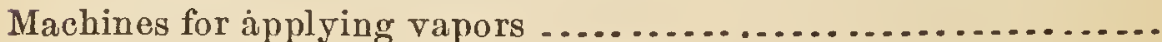

The Steinmann vaporizer, 97-The Pearl vapor generator, 99.

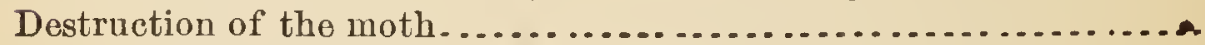

Results so far not eucouraging, 100-Action must be taken early in the season, 100 .

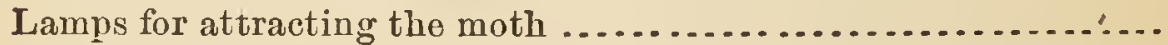

Usually resorted to when too late to do practical good, 100Fires, 100-Troukle of keeping them up throughout the night, 101-Beneficial insects killed by lamps and fires, 101-Advantage of lamps, 101-The Garrett lamp, 101-The Binkley lamp, 102-The MeQueen lamp, 103-The Rigel lamp, 103The Walker laup, 103-Simple form of lamp, 104-The Pugl lamp, 104-Lamps in motion, 105-Le Blanc's cotton-moth destroyer, 105-The Fordtran cotton-moth destroyer, 105.

Poisoned sweets and fluids as means of destroying the moth......

Sweets attractive, 106-Ripe fruits and melons often suffer, 106Baits that allure and kill, 106-Experiments with them, 107Moths less attracted during summer than in autumn, 107-Little inducement to use baits in autumn, 108-They are most beneficial in spring, 108-White rags, 108-Theory of Dr. J.L. Lupton, 108.

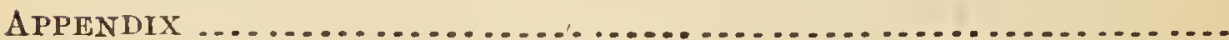

Answers to circular from West Feliciana Parish, Louisiana, 109From Evergreen, Ala., 111- From Henderson, Tex., 113-From Hempstead, Tex., 115-Different views as to hibernation and mode of perpetuatiou of the insect, 116-Auswers to cireular from Livingston, Ala., 117-From Parish of Concordia, La., 119-From Natchitoches, La., 122-From Jackson, Miss., 126From Larissa, Tex., 127-From Perry Couuty, Ala., 128From Walterborough, S. C., 128-Erom Jamestown, Fla., 130From San Antonio, Tex., 131-From Kirkwood, Miss., 133From Woodville, Miss., 135.

1737. [RIley, C. V.] The 17-year Cicada in Iowa. <Amer. Ent., February, 1880 [v. 3], n. s., v. 1, pp. 25-26.

Review of C. E. Bcssey on the 17-year Cicada in Iowa; limits of the broods of 1854-1871, 1861-1878, and 1862-1879 of Cicada [= Tibicen] septendecem in Iowa; occurrence of the last brood in Missouri; comparisou of the distribation of these broods with the distribution of timber trees. 
1738. [RILEY, C. V.] .Vegetal-feeding ground-beetles. < Amer. Ent., February, 1880 [v. 3], n. s., v. 1, p. 26.

Notes from various sourees upon the phytophagous habits of Carabida.

1739. [RILEY, C. V.] The pear-leaf blister. <Amer. Ent., February, 1880 [r.3], n.s., v. 1, p.26. Notice: <Ibid., March, 1880 [v.3], n. s., v. 1, p. 74 .

Review of T. J. Burrill's "The pear-leaf blister"; ravages of Typhlodromus pyri on leaves of pear-tree; eharaeters of this mitc; noxions habits of Acarina, espeeially of Phytoptus.

1740. [RILex, C. V.] Fuller's rose-beetle in California. <Amer. Ent., February, 1880 [v. 3], n. s., v. 1, 1. 26.

Oecnrrenee and ravages of Aramigus fulleri in California.

1741. [RIley, O. V.] Lepidium vs. bed-bugs. <Amer. Ent., February, 1880 [v. 3], n. s., v. 1, p. 26.

Notice of S. M.'s "Lepidium, the bed-bug destroser ;" Acanthia Tectularia said to be attraeted to and killed by Lepidium sp.

1742. [RILEY, O. V.] Aniseed and grain weevils. <Amer. Ent., February, 1880 [v. 3], n. s., v. 1, p. 26.

Notice of reports that Calandra granaria were attraeted from grain to anisced and killed by it.

1743. Riley, C. V. Two valuable insecticides. <A ner. Ent., Febru$\operatorname{ar.y}, 1880$ [ . 3$]$, n. s., v. 1, pp. 41-45.

From Bull. No. 3, U. S. Ent. Commission, 1p. 60-65. Seo No. 1736, for synopsis of contents.

1744. [RILEY, C. V.] Use of buckwheat to destroy insects. <Amer. Ent., February, 1880 [v. 3], n. s., v. 1, p. 48.

Extraet from "The Farmer" with remarks on the planting and plowing in of buek wheat as a means against injurious inseets.

1745. [RILEY, C. V.] Tipula eggs in stomach of cat-bird. <Amer. Ent., February, 1880 [v. 3], u. s., r. 1, p. 50.

Answer to eommunication from S. A. Forbes; two kinds of eggrs found in stomaeh of eat-bird; these birds eat gravid females of Tipula.

1716. [RILEx, C. V.] Beetles supposed to be feeding on wheat. <Amer. Ent., February, 1880 [v. 3], u. s., v. 1, p. 50.

Answer to letter from P. H. M.; larva of Cryptorhopalum sp. supposed to have injured grains of wheat, was probably feolling on the remains of true grain insects; food-habits of larvie of Dermestide.

1747. Rilex, C. V. The apple-twig borer. <Amer. Ent., February, 1880 [v. 3], n. s., v. 1, pp. 50-51, figs. 11-12.

Answer to letter from H. G. Woleott; habits, food-plants, and means against Amphicerus bicaudatus; figure of made and female imago and of bored apple-twigs; habits and food-plants of Sinoxylon basillare and of Bostrichus.

1748. [RILEx, C. V.] Stinging caterpillars. <Amer. Ent., February, $1880[$ v. 3], n. s., v. 1, p. 51.

Answer to letters from T. Pollard and G.W. S.; food-plants, general appearanee, vernacular name, urticating properties and deseription of imago of Lagoa opercularis. 
1749. Rilfey, C. V. A new genus of Proctrotmupidce. <Amer. Ent., February, 1880 [v. 3], n. s., v. 1, p. 52, figs. 13-14. Review: <Ibid., December, 1880 [ซ. 3], n. s., v. 1, p. 293.

Description and figures of Didictyum $[=$ Hexaplasta $]$ zigzag n. g. et n. sp. reared from chrysalis of Aletia argillacea $[=x y l i n a]$.

1750. Riley, C. V. Agricultural advancement in the United States. <Farmer's Review, 1880, v. 4: 4 March, p. 153; 11 March, p. 174. S.-b. No. 23; pp. 153-15s. Notice: <Ibid., 4 March, 1850, p.-. S.-b. No. 23, p. 150. Reprint: <Journ. Amer. Agric. Assoc., April, 1881, v. 1, pp. 47-54. Separate of reprint: <August, 1881, pp. 47-54.

Suggestions for the organization of an agricultural association; comparison of the relations of government to the advancement of agriculture in England, Germany, France, and the United States; necessary changes in the United States Department of Agriculture.

1751. Riley, O. V. Parasites of the plum Curculio. <Farmer's Review, 4 March, 1880, v. 4, p. -, 2 figs. S.-b. No. 23, pp. 169170.

Figures of larva, pupa, cocoon, and imagos of Sigalphus curculionis; habits, variations, usefulness, and dissemination of the same; habits, colors, and sẻasons of Porizon [ $=$ Thersilochus] conotracheli.

1752. [RILEY, O. V.] Trapping the carpet-beetle. <Amer. Ent., March, 1880 [v. 3], n. s., r.1, pp. 53-55, fig. 15.

Figures larva, pupa, and imago of Anthrenus scrophularia; food-plants and habits of imago and ravages of larva; importation, distribution, vernacular names of and means against the same.

1753. [Rlley, C. V.] Silk-worm eggs: Silk culture. <Amer. Ent., March, 1880 [v. 3], n. s., v. 1, p. 55.

Methor of obtaining eggs of Sericaria mori and information on silk culture.

- 1754. [Riley, C. V.] [Hickory Scolytus.] <Amer. Ent., March, 1880 $[$ ₹. 3], n. s., จ. 1, p. 58 .

Occurrence of Scolytus quadrispinosus in Washington Territory.

175.j. [Riler, C. V.] [Tenacity of life.] <Amer. Ent., March, 1880 [v. 3], n. s., v. 1, p. 68.

Resistance of Cleonus sp. to the influence of various insecticides.

1756. [RILeY, O. V.] [Danais archippus.] <Amer. Ent., March, 1880 [v. 3], n. s., v. 1, p. 73.

Occurrence of a colorational variety on the island of Antigua.

1757. [RILEY, C. V.] Reports of the U. S. Entomological Commission. <Amer. Ent., March, 1880 [v. 3], n. s., v. 1, p. 73.

Method of obtaining the first report of the U. S. Entomological Commission.

1758. [RILEY, C. V.] [Habits of the cotton-moth.] <Amer. Ent., March, $1880[$ v. 3], n. s., v. 1, p. 74.

Request for information on the habits of the imago and the food-plants of the larva of Aletia argillacea $[=x y l i n a]$ during March and April.

1759. [Riley, C. V.] Typhlodromus pyri. <Amer. Ent., March, 1880 [v. 3], n. s., v. 1, ]. 74 .

Reference to early account of the pear-leaf blister-mite. 
1760. [RILEY, C. V.] Food-habits of ground-beetles. <Amer. Ent., March, 1880 [v. 3], n. s., v. 1, p. 75.

Note on request of S. A. Forbes for Carabidce found in situations suggesting herbivorous habits.

1761. [RILEY, C. V.] Moths and butterflies caught by the tongue. <Amer. Ent., March, $1880^{\circ}[$ r. 3], n. s., v. 1, p. 75.

Notice of several articles on the capture of Noctuide and Sphingide by the flowers of Physianthus albens; capture of Sphingidee by the flowers of Nerium oleander and EEnothera grandiftora, and of Syrphus sp. by the flowers of Bidens chrysanthemoides.

1762. [RILey, C. V.] [Queen bees in the mails.] Amer. Ent., March, 1880 [v. 3], n. s., จ. 1, p. 75.

Circumstances under which queen bees may be sent by mail; exclusion of pinned insects from the same.

1763. [Riley, C. V.] Common tiger-beetle. <Amer. Ent., March, 1880 [v.3], n. s., v. 1, pp. 77-7S.

Answer to inquiry of J. L. Seney; habitat, distribution, and food-habits of Cicindela repanda.

1764. [RILey, C. V.] Gall on Pelargonium. <Amer. Ent., March, 1880 [v. 3], n. s., v. 1, p. 78.

Answer to letter from Mary Treat; gall at base of Pelargonium probably made by a mite; the Podura found in it were undonbterlly fceding on diseased gall-tissue.

1765. [Rrler, C. V.] Catalogues and monographs of insects. <Amer. Ent., March, 1880 [ . 3], n. s., v. 1, p. 78.

Answer to letter of P. S. B.; mention of monographic works and catalogues of North American insects.

1766. [RILEY, C. V.] Leaf-hoppers injuring wheat fields. <Amer. Ent., March, 1880 [v.3], n. s., v. 1, p. 78.

Answer to letter of R. L. B.; habits and ravages of Cicadula exitiosa, Diedrocephala flaviceps, and Jassus sp. in the southerm United States, and of Jassus sexnotatus in Europé; means against the same.

1767. Riley, C. $\nabla$. A new leaf-hopper injurious to small grain. <Amer. Ent., March, 1880 [v. 3], n. s., v. 1, p. 78.

Description of Diedrocephala flaviceps n. sp. injurious to wheat and oats in Texas in 1876.

1768. Riley, C. V. The bird question dispassionately considered. $<$ Farmer's Review, 1 April, 1880, v. 4, p. 211. S.-b..No. 23, pp. $147-148$.

Extract from E. Perris's "Birds vs. Insects," with introductory ; conclusions as to the value of birds in agriculture as destroyers of noxions insects.

1769. Riley, C. V. The cotton-worm in the United States. <Amer. Ent., April, 1880 [v.3], n. s., v.1,pp.93-95. Reprint, with slight changes: <Proc. Amer. Assoc. Adv. Sci. for 1879, 23 February, 1881, v. 28, pp. 464-466. Separate of reprint: <Salem, Mass., August, 1880, 3 pp.

Date and manner of first appearance of larvæ of Aletia argillacea $[=x y l i n a]$; number of annual generations and the existence of parasites upon it; his- 
1769. Ritex, C. V.-Continued.

tory and refutation of the aunual immigration theory; division of the cotton belt into regions wherein, respectively, A. argillacea $[=x y l i n a]$ is permanent and temporary ; food-habits and enemios of the same.

1770. [RILEX, U. V.] The migrations of butterflies. <Amer. Ent., April, 1880 [v. 3], n. s., v. 1, pp. 100-102, figs. 34-35.

Migratory fliglats of Lepidoptera supposed to be due to excessive nultiplication of individuals and to a true migratory instinct; direct ous, times, and extent of migrations of Danais archippus; explanation of the migratory instinct; distribution of $D$. archippus and Pyrameis cardui; figures the former and its mauner of clustering.

1771. [RrLeY, C. V.] Gouty gall on blackberry and raspberry canes. <Amer. Ent., April, 1880 [v, 3], n. s., v. 1, p. 107.

Answer to letters of P.S., T. A. C., and J.W.; seasons, ravages of and means against Agrilus ruficollis.

1772. [RILEx, C. V.] Sowing cotton seeds in hot-beds and transplanting as a means of preventing injury from the cotton-worm. < Amer. Ent., April, 1883 [v. 3], n. s., v. 1, p. 107.

Impracticability of W. J. W.'s suggestion as indicated in title.

1773. [RILEY, O. V.] Not the cotton-moth. <Amer. Ent., April, 1880 [v.3], 11. s., v. 1, p. 107.

Answer to inquiry of D. B. Woodbury; food-plants of Tolype velleda.

1774. [RrLex, C. V.] Moths caught in Alabama: Muscle-shaped barklouse on apple-trees South <Amer. Ent., April, 1880 [r. 3], n. s., v. 1, pp. 107-108.

Mentions several insects received from J. F. Bailey, of Marion, Ala.; larva of Papilio philenor feeds on Aristolochia; Bombus virginicus $\$$ robs hives of Apis mellifica; Mytilaspis pomicorticis $[=$ pomorum $]$ not before received from so far south; means arainst the same.

1775. [Riley, C. V.] Chrysalides supposed to be those of Aletia. $<$ Amer. Ent., April, 1880 [v. 3], n. s., v. 1, p. 108.

Answer to letter of W. J. Jones; pupæ of Agrotis inermis [ = saucia] and Prodenia lineatella from cotton field.

1736. [Riler, C. V.] Apple-twig borer. <Amer. Ent., April, 1880 [v. 3], n. s., v. 1, p. 108.

Answer to inquiry of. T. V. M.; occurrence and habits of Amphicerus bicaudatus.

1767. [RrleiY, C. V.] Clover-weevil. <Amer. Ent., April, 1880 [v. 3], n. s., v. 1, p. 108.

Answer to inquiry of W. W. F.; several "weevils" infest clover-seeds; Hylesimus trifolii infests the roots and lower part of the stem.

1778. [RILEx, C. V.] Effects of cold applied to the chrysalides of butterflies. <Amer. Ent., May, 1880 [v. 3], n. s., v. 1, pp. 110-111.

Notice of the experiments of W. H. Edwards; effects of hibernation in the chrysalis and imago states.

1779. [Rrley, O. V.] Moth issuing from a larva. < Amer. Ent., May, 1880 [v. 3], n. s., v. 1, p. 114.

Notice of J. J. Weir on the issuance of Orgyia sp. from the larva without passing through the pupal stage. 
1780. [Riley, O. V.] The rose-slug. <Amer. Ent., May, 1880 [v. 3], 11. s., г. 1, pp. 115-116, figs. 42-43.

Description of eggs, larvæ, and inago, history and means against Selandria [= Monostegia $]$ rosa ; figures, egg, larvæ, imago, with details of structure, aud injured leaf.

1781. [Riley, C. V.] Dr. Asa Fitch. <Amer. Ent., May, 1880 [v. 3], I. s , v. 1, pp. 121-123.

Biographical sketch of Asa Fitch, with notice of his collection of insects and his writings.

1782. [RILEy, C. V.] Flea-beetle on young tobacco plants. <Amer. Ent., May, 1880 [v. 3], n. s., v. 1, p. 123.

Leaves of Nicotiana tabacum eaten by Epitrix hirtipennis [=Crepidodera par$v u l a]$ and probably by $E .[=C$. $]$ cucumeris; leaves of Solanum eaten by the first named and by $E .[=C$.$] brevis; distribution of these and other species$ of Epitrix [= Crepidodera $]$.

1783. [Ritex, O. V.] The proboscis of the common house-fly. <Amer. Ent., May, 1880 [v. 3], n. s., v. 1, p. 125.

Review of paper by G. Macloskie.

178t. [Riley, C. V.] Notes on South American Lepidoptera. <Amer. Ent., May, 1880 [v. 3], n. s., v. 1, pp. 125-126.

Report of meeting of the Entomological Society of London; length of proboscis of and presence of seent organ in Sphingide; perception' of colors in Rhopalocera; secondary sexual character in Callidryas and other genera; according to R. Meldola the proboscis of Macrosila cluentius is $23.5^{\mathrm{cm}}(97$ inches) long.

17S5. [Riley, C. V.] Floating apiaries. <Amer. Ent., May, 1880 [v. 3 \}, n. s., v. 1, pp. 126-127.

Notice of an unsuccessful attempt to increase the product of an apiary by floating it southward late in the season and back to the north in the spring, on the Mississippi Rirer.

1786. [Riley, C. V.] American Staphylinida wanted. <Amer. Ent., May, 1880 [v. 3], n. s., v. 1, p. 127.

Notice of A. Fauvel's works on Staphylinide and his request for additional material.

1787. [Rlley, C. V.] Probable parthenogenesis in the Hessian fly. <Amer. Ent., May, 1880 [v. 3], n. s., v. 1, p. 127.

Review of paper by II. A. Hagen; Cecidomyia destructor less injurious than formerly in the older wheat-growing regions, its area of abundance having moved westward with the westward extension of wheat culture.

1788. [RILEy, O. V.] Raspberries destroyed by weevils. <Amer. Ent., May, 1850 [v. 3], n. s., v. 1, p. 127.

Ravages of Otiorhynchus picipes in England; warning against its introduction into the United States.

1788a. [Rilex, C. V.] Cotton culture and the insects affecting the plant at Bahia, Brazil. <Amer. Ent., May, 1880 [v. 3], 1. s., v. 1, pp. $12 \checkmark-129$.

Letter of R. A. Eles, with remarks on specimens sent. 
1789. [Rilex, C. V.] Hemispherical larra at bottom of ant hill. <Amer. Ent., May, $1880 \mid$ v. 3], n. s., v. 1, p. 129.

Answer to inquiry of D. S. Sheldon; habitat of larra of Microdon globosus.

1790. [Rlley, C. V.] Chrysalides dug up in cotton field, mistaken for those of the cotton-worm. <Amer. Ent., May, 1880 [v. 3], n. s., v. 1, p. 129.

Answer to letter of R. Worrel.

1791. [Riley, C. V.] Aleurodes on Oxalis. <Amer. Ent., May, 1880 [v. 3], n. s., v. 1, pp. 129-130.

Answer to letter of S. A. Courad; description of all stages of Aleurodes sp. from leaves of Oxalis sp.

179. [RILEY, O. V.] Larvæ in stomach of black-bass. <Amer. Ent., May, 1880 [v. 3], n. s., v. 1, p. 130.

Answer to inquiry of S. A. Forbcs; two coleopterous larve from the stomach of Micropterus salmoides; one a dytiscid, the other perhaps a dascyllid.

1793. [Rıley, C. V.] Insects from stomach of rock-bass. <Amer. Ent., May, 1880 [v. 3], n. s., v. 1, p. 130.

Answer to letter of S. A. Forbes; coleopterous larva from the stomach of cormmon sun-fish (Lepiopomus pallidus) and rock-bass (Roccus lineatus).

1794. [RIley, C. V.] New enemy to sugar-cane. <Amer. Ent., May, 1830 [v. 3], n, s., v. 1, p. 130, fig. 48.

Auswer to letter of $\mathrm{D}$. Th.; ravages of Ligyrus rugiceps upon sugar-cane, maize, and grasses; recommends use of lamp and kerosene pan, and figures one form of such apparatus.

1795. [Rilex, C. V.] Parasites of the plum Curculio. <Amer. Ent., May, 1880 [v. 3], 11. s., v. 1, pp. 131-132, figs. 49-50.

Answer to letter of W. S. Barnard; quotes from 3d Ann. Rept. State Ent. Mo., pp. 24-26; habits of Sigalphus curculionis; habits, varieties, and figures of all stages of the same; food-habits of Semasia $[=$ Grapholitha $]$ prunivora on which the Sigalphus is parasitic.

1796. [Riley, C. V.] Blister-beetles from New Mexico. <Amer. Ent., May, 1880 [v. 3], n. s., v. 1, p. 132.

Answer to inquiry of J. M.; Macrobasis albida common in the Sonthwest and valuable as a vesicant; Diplotaxis not known to be a vesicant.

1797. [Rilex, C. V.] Abnormal cocoon. <Amer. Ent., May, 1880 [v. 3], n. s., จ. 1, p. 132.

Answer to letter of W. S. Barnard; occurrence of Callosamia [=Attacus $]$ promethea and Orgyia antiqua at Ithaca, N. Y.; description of abnormal cocoon of the latter found on sugar-maple.

1798. [RILEx, C. V.] Insects found about orange-trees. <Amer. Ent., May, 1880 [v. 3], n. s., v. 1, p. 132.

Answer to inquiry of J. S. Barnwell; list of insects from Darien, Ga.; most of them have $n$ o relation to orange trecs; notes on Aphis sp., Chilocorus bivulnerus, Syrphus sp., Neoclytus erythrocephalus, Drasterius amabilis, Platy-

- nus punctiformis, Forficula sp., Gryllotalpa borealis, and Psocus venosus. 
1799. [RILey, C. V.] Luperus brunneus, Crotch. <Amer. Ent., May, 1880, [v. 3], n. s., v. 1, p. 132.

Lupcrus noxius Riley MSS., is a pale form of $L$. brunneus; description of the typical and other forms of the same; distinctive characters of $L$. bruncus and $L$. morulus from other North American species and from each other; eharacters of the genus Calomicrus.

1800. [Riley, C. V.] Professor Riley on army-worms. <N. Y. Weekly Sun, 20 June, 1880. S.-b. No. 26, p. 89.

Interview with reporter; summary of present knowledge of Leucania unipuncta.

1801. Riley, C. V. Cotton-caterpillars. <Selma [Ala.] Times, 25 Juue, 1880 .

1802. Riley, C. V. Notes on our commoner insects. <Amer. Ent., June, 1880 [v. 3], n. s., r. 1, pp. 133, 134, figs. 51-52.

Description and figures of larva, pnpa, cocoon, and imago of Arclia $[=$ Pyrrharctia] isabclla; habits, seasons, food-plants, parasites, vernacular names and variations of the same; figure of Ophion macrurum; descriptions of Ichneumon carulcus, I. signatipes, and Trogus obsidianator; description of larva of Ecpantheria scribonia.

1803. Riley, C, $\nabla$. The white-grub fungus. <Amer. Ent., June, 1880 [v. 3], n. s., v. 1, pp.137-140, figs. 53-55.

Description and figures of Torrubia ravenelii and of its frnctification ; forms in which it occurs on larve of Lachnosterna quercina $[=$ fusca $]$; list of some articles upon it; its synonymy and distribution; listiof related species and their distribntion; occurrence of related species on other inscets.

1804. Riley, C. V. The true and the bogus Yucea moth, with remarks on the pollination of Yucca. <Amer. Ent., June, 1880 [v.3], 1. s., v. 1, pp. 141-145.

History of observations on Prodoxus decipichs; habits, parasite, and foodplants of the same; evolution of Prodoxus and Promuba; criticism of errors resulting from mistaking Prodoxus dccipiens for Promuba yuccasclla; failure of Fucca angustifolia to become fertilized in the absence of Pronuba yuccasclla; Hyponomenta quinquepunctella Chambers is the same as Prodoxus decipicns.

1805. [Riley, C. V.] [utermittance of phosphorescence in fire-flies. <Amer. Ent., June, 1880 [r. 3], n. s., v. 1, p. 146.

Criticism of a discussion kefore the London En tomological Society ; the winged imagos of Lampyride can intermit their light; the larva and wingless inagos can suppress their light.

1806. [RILey, C. V.] Grain Aphis vs.rust. <Amer. Ent., June, 1850 [v. 3], n. s., v. 1, p. 147.

Ravages of Aphis avena [Nectarophora granaria] and of rust on wheat and oats in Georgia; the work of anlides promotes the growth of some kinds of rust.

1807. [Riley, C. V.] Mold and Phylloxera. <Amer. Ent.; June, 1850 $[$ v. 3], n. s., r. 1, 1). 147.

Criticism of statements by Rommier; development of mycelinm on phylloxerized roots does not result in the destruction of the Phylloxera. 
1808. [RILEY, C.V.] Infecting Phylloxera with fungus disease. <Amer. Ent., June, 1880 [v. 3], n. s., v. 1, p. 148.

Abstract of discussion at mceting of Académie des Sciences de Paris on the infection of Phylloxera vastatrix by parasitic fungi ; particular fungi infect only particular insects; method of experimentation to determine which fungi to use and how to apply them; improbability of success in these exporiments.

1809. [Rrley, C. V.] Fungus in Cicada. <Amer. Ent., June, 1880 [v. 3], n. s., v. 1, p. 148.

Notice of C. H. Pock's description and J. Leidy's note on Massospora cicadina; Cicada $[=$ Tibicen $]$ septendecim and $C .[=T$.$] tredecim subject to the attacks$ of the same.

1810. [RILEY, C. V.] On the nature of the phosphorescence of the glowworm. <Amer. Ent., June, 1880 [v. 3], n. s., v. 1, p. 148.

Conclusions drawn by Jousset de Bellesme; probability that tho phosphorescent substance is a gascous product; nature of phosphorescence.

1811. [Riley, C. V.] Death of mules caused by insects. <Amer. Ent., June, 1880 [v. 3], n. s., v. 1, p. 148.

About 6,000 mules rcported killed in the Ouachita Valley, Louisiana, by the attacks of Simulium sp.

1812. [RILEY, O. V.] [May beetles swarming in Alabama.] <Amer. Ent., June, 1880 [ จ. 3], n. s., v. 1, p. 148.

Abundance and ravages of Lachnosterna quercina [=fusca] on oak-trees around Mobile, Ala., in May, 1880.

1813. [RILEY, C. V.] Fungus diseases of beneficial insects. <Amer. Eut., June, 1880 [v. 3], n. s., v. 1, p. 149.

Abstract of communication by C. Bronguiart and Max Cornu on an epizootic among Syrphus mellinus caused by a spccies of Entomophthora; almost a!l insecticides liable to the objection that they kill useful as well as noxious insects.

1814. [RILEY, C. V.] Early appearance of cotton-worm. <Amer. Ent, June, 1880 [v. 3], n. s., v. 1, p. 149.

Extracts from letter of J. M. Bell and from the Goliad [Tex.] Guard and from G. Witting on the date of appearance of Aletia argillacea [= xylina] in Texas.

1815. [RILEY, C. V.] The butterfly tongue. <Amer. Ent., June, 1880 [v. 3], n. s., v. 1, p. 149.

Notice of and extract from paper by E. Burgess; conclusions as to the manner in which butterflies imbibe their liquid food.

1316. [Rmex, C. V.] Cottony maple scale. <Amer. Ent., June, 1880 [v. 3], n. s., v. 1, p. 149.

Notico of J. D. Pntnam on Pulvinaria innumerabilis.

1817. [Riley, C. V.] Necrological. <Amer. Ent., June, 1880 [v.3], n. s., v. 1, p. 150 .

Obituary noticos of E. A. H. v. Kiesenwettor, S. C. Snellen van Vollenhoven, and F. L. do Laporto.

1818. [Riley, C. V.] . Effects of severe cold on insects. < Amer. Ent., June, 1880 [v. 3], n. s., v. 1, p. 150.

A steady even if severe winter not prejudicial to insect life. 
1819. [RILeY, C. V.] Revision of the Lampyrida. <Amer. Ent., June, 1880 [v. 3], n. s., v. 1, p. 150.

Notice of H. S. Gorham's work on the Lampyride and his request for additional material.

1820. [RIley, C. V.] Apple-twig borer. <Amer. Ent., June, 1880 [r. 3], n. s., v. 1, p. 151.

Answer to inquiry of A. S. H. ; occurrence of dmphicerus bicaudatus on appletrees in Virginia.

1821. [Rrlex, C. V.] Grape-vine flea-beetle. Cimer. Eut., June, 1880 [r. 3], n. s., v. 1, pp. 15\%-153.

Answer to letter of J. Nilis; ravages of Graptodera $[=$ Haltica $]$ chalyber on grape-vines in Pennsylvania.

1S22. [RIley, C. V.] Cynipid gall on oak trigs. <Amer. Ent., June, 1880 [v. 3], n. s., v. 1, p. 153, tig. 56.

Answer to letter of J. A. Warder; fignre of gall of Cynips (u. sp.?) from twitg of Querous prinus var. acuminata; comparison of this gall with that of $C$. [=Andricus $]$ q.-punctata; the flies bred from these galls issue in sp.ring and are all femalcs, but probably have a bisexual form producing a different gall.

1823. [Rrley, C. V.] White-grub fungus. <Amer. Ent., June, 1880 [v. 3], n. s., v. 1, p. 153.

Answer to letter of H. S.; occurrence of Torrubia ravenelii at Iola, Kans.

1824. [RIley, C. V.] Galerita janus. <Amer. Ent., June, 1880 [v. 3], n. s., v. 1, p. 153 , fig. 57.

Answer to inquiry of H. D. M. Fair ; distribution, habitat, transformations, and seasons of Galerita janus; figure of larva of G. lecontei.

1825. [Rrlex, O. V.] Not Fuller's rose-beetle. <Amer. Ent., June, 1880 [v. 3], n. s., v. 1, pp. 153-154, fig. 58.

Answer to inquiry of J. Stewart; habits and synonymy of Agonoderus commea $[=$ pallipes $]$; figure of the same.

1826. [RIley, O. V.] Not Aletia chrysalides. <Amer. Ent., June, 1880 [v. 3], n. s., v. 1, p. 154.

Answer to letter of G. P. White; pupa of Agrotis sancia from colton fields; food-habits of larva; ravages of Aletia argillacea $[=x y l i n a]$ at Brown Station, Ala., in August, 1879.

1827. [Riler, C. V.] Mud-wasp and parasite. <Amer. Ent., June, 1880 [r. 3], n. s., v. 1, p. 154, figs. 59-60.

Answer to inquiries of Mary Treat; nidification of several species of Odynerus ; food-habits of O. birenimaculatus; figure of $O$. flavipes and of a nest of $O d y$ nerus sp.; figure of Cryptus junceus.

1828. [Rllex, C. V.] Monographs again. <Amer. Ent., June, 1SS0, [r. 3], n. s., v. 1, pp. 154-155.

Answer to letter of C. D. Marsh; references to works. Elateride, Curculionide and Coceide.

1829. [Riley, C. V.] Rearing wood-borers. <Amer. Ent., June, 1880 [r. 3], n. s., v. 1, p. 155.

Answer to letter of W. H. Harriugton; directions for rearing larva which bore in wood or under bark, 
1830. Riley, C. V. On a new tineid genus allied to Pronuba, Riley. <Amer. Ent., June, 1880, [v. 3], n. s., v. 1; pp. 155-156.

Description of Prodoxus n. g. [p. 155] of Tineina and of larva, pupa, and imagos of $P$. decipiens n. sp. [p. 155].

1831. Riley, C. V. A parasite on Prodoxus decipiens. <Amer. Ent., June, 1880, [v. 3], n. s., v. 1, p. 156.

Description of larva and imago of Exothecus prodoxi n. sp.; habits of larva.

1832. Riley, C. V. How to manage the cotton-worm: Suggestions to cotton planters. <Farmer's Review, 8 July, 1880. S.-b. No. 24, p. 68.

Means against Aletia xylina.

1833. [Rmex, C. V.] The cotton.worm investigation. <Selma [Ala.] Morning Times, 21 July, 1880, v. 55, No. 190, p. 3. Reprint: <Amer. Ent., August, 1880 [v. 3], n. s., v. 1, p. 197.

List of persons engaged in the cotton-worm investigation; statement of work to be done by each.

1834. [Riley, C. V.] A foe to cottonwood. <Amer. Ent., July, 1880 [v. 3], n. s., v. 1, pp. 159-161, figs. 61-64. Extract: <Supul. to Amer. Ent., July, 1880, p. 1.

Description of egg, larva, and imago and figures of all stages of Melasoma [=Lina $]$ scripta; description and figures of variations of the imago; habits, ravages, seasons, food-plants, and means against the same; figure of $M$. $[=L$.$] lapponica and of larva of M .[=L$.$] populi; description of these$ larvæ and of that of $M .[=L$.$] tremule; food-plants and distribution of$ these spccies; acquisition of now habits by insects.

1835. [RILEY, C. V.] The northern army-worm. <Amer. Ent., July, 1880 [v. 3], n. s., v. 1, pp. 170-171, figs. 72-75.

Ravages of Leucania unipuncta in 1880 ; natural history, means against, doscription, and figures of all stages of the same.

1836. [RIley, C. V.] The periodical Cicada. <Amer. Ent.. July, 1880 [v. 3], 11. s., จ. 1, pp. 172-173, fig. 76.

Broods of Cicada [= Tibicen] septendecim and $C .[=T$.$] trodecim which appear$ in 1880 .

1837. [RILEY, C. V.] Use of guano for grape Phylloxera. <Amer. Ent:, July, 1880 [v. 3], n. s., v. 1, p. 173. Reprint: <Suppl. to Amer. Ent., July, 1880, p. 2.

Application of sulphide of carbon with infusorial earth or guano.

1838. [RILEx, C. V.] Fertilizers of alpine flowers. < Amer. Ent., July, 1880 [v. 3], n. s., v. 1, p. 175. Reprint: <Suppl. to Amer. Ent., Juls, 1880, p. 2.

Relative frequency, according to $\mathrm{H}$. Müller, of the visits of insects to flowers in high alpine regions as compared with such visits at lower levels.

1839. [RILey, C. V.] ('arnivorous habits of caddis-worms. <Amer. Ent., July, 1880 [ .. 3], n. s., v. 1, p. 176.

Notice of paper by G. C. Goody. 
1840. [RILey, O. V.] Development of the eyes and Inminosity in the fire-flies. <Amer. Ent., July, 1880 [v. 3], n. s., v. 1, p. 176.

Abstract of H. S. Gorhan's observations.

1841. [Rller, C. V.] Grape Phylloxera not at the Cape. <Amer. Ent., July, 1880 [v. 3], n. s., v. 1, p. 176. Reprint: <Suppl. to Amer. Ent., July, 1S80, p. 1.

Examination of roots of unhealthy vines by R. McLachlan and R. Trimen show that the disease of the vines is not caused by Phylloxera vastatrix.

1942. [RILEx, C. V.] · [Bill providing for the extermination of insects.] <Amer. Ent., July, 1880 [v. 3], n. s., v.1, pp. 176-177.

Text of and comments ou a bill introduced in to the California Assembly, providing for the extermination of insects.

1843. [RILEY, C. V.] [Appropriation for the U. S. Entomological Commission.] <Amer. Ent., July, 1880 [v. 3], n. s., v. 1, p. 177.

Notice of the appropriation by Congress of $\$ 25,000$ for completing the work of the U. S. Entomological Commission.

1844. [Riley, C. V.] Pronuba vs. Prodoxus. <Amer. Ent., July, 1880 [v. 3], n. s., v. 1, pp. 177-17S.

Comments on letter of $\mathrm{V}$. T. Chambers.

1845. [RILey, C. V.] Interesting cotton-worm notes from Vera Cruz, Mexico. <Amer. Ent., July, 1880 [v. 3], n. s., v. 1, p. 179. Reprint with slight omission : <Suppl. to Amer. Ent., July, 1880, p. 3.

Letters from S. T. Trowbridge and R. de Zayas Enriquez, with notes on the irregular occurrence of Aletia argillacea $[=x y l i n a]$ in Vera Cruz.

1846. [RuleY, C. V.] Clover root borer. <Amer. Ent., July, 1880 [v. 3], n. s., v. 1, pp. 179-180, fig. 81. Reprint: <Suppl. to Amer. Ent., July, 1880, p. 4. See: <Prairie Farmer, 31 July, 1880. S.-b. No. 45, p. 15.

Answer to letter of W. A. Henry; description and figures of larva, pupa, and imago of Hylesinus trifolii; ravages, habits, aud means against the same.

1847. [RILey, (.. V.] Mud-wasp and spider egg-nest. <Amer. Ent., July, 1880 [ ซ. 3], n. s., v. 1, p. 180, figs. 82-84.

Answer to letter of Mary Treat; figures of cells and of imago of Eumenes fraternat, which stores its cells with larvw of Paleacrita vernata; figure and descriptions of egg-nests of Epeira sp.

1848. [RueY, C. V.] Worm in joints of wheat. <Amer. Ent., July, 1880 [จ. 3], n. s., v. 1, pp. 180-181, fig. 85. Reprint: <Suppl. to Amer. Ent., July, 1880, p. 4.

Answer to letter of J. K. P. Wallace; ravages of an unknown, apparently hymenopterous, larva in wheat stalks; figure of larva and pupa of Meromyza americana and of stalks injured by the same.

1849. [Rlley, C. V.] Linden and ash destroyers. <Amer. Ent., July, 1880 [v. 3], n.s., v.1, p.181. Peprint: <Suppl. to Amer. Ent., July, 1880, p. 4.

$17 \mathrm{ENT}$ 
1849. Riley, C. V.-Continued.

Answer to letter of Shelby Reed; season of appearance of Odontota rubra on Tilia; larvæ of Hyphantria textor [= cunea] feeding on the same; Sapcrda calcarata boring in poplar, and an unknown larva (Neoclytus capraa?) boring in black-ash.

1850. [RILEY, C. V.] Larva boring along the axis of apple-twigs. <Amer. Ent., July, 1880 [r. 3], n. s., v. 1, p. 181.

Answer to letter of T. V. Munson; twigs of apple-trees bored by larv $\infty$ of Oberea sp. ?

1S51. [RIley, C. V.] Aquatic larvæ. <Amer. Ent., July, 1880 [v. 3], n. s., v. 1, p. 181.

Answer to letter of S. A. Forbes; larva of Anax junius and Palingenia [= Hexagenia] bilineata named; the latter common in the stomach of fishes.

1852. [RILEY, C. V.] First appearance of cotton-worm in prairie belt. Amer. Ent., July, 1880 [v. 3], n. s., v. 1, p. 181. Reprint: $<$ Suppl. to Amer. Ent., Julv, 1880, pp. 3-4.

Answer to letter of J. F. Bailey; larræ of Aletia argillacea [=xylina] appear first on lands where the cotton is luxuriant.

1853. [RILEY, C. V.] Gyrinus larva; terrestrial insects in stomach of shad. <Amer. Ent., July, 1880 [v. 3], n. s., v. 1, p. 182.

Answer to letter of S. A. Forbes; character of larva of Gyrinus; a mass of terrestrial insects including Typhlocyba vitis? a muscid, a Eurytomid, Jassus sp., Triphleps insidiosus, and other species from the stomach of Ohio shad.

1854. Riley, C. V. Further remarks on the differences between Pro. nuba and Prodoxus. <Amer. Ent., July, 1880 [v.3], n. s., v:1, p. 182.

Differences between Pronuba yuccasella and Prodoxus decipiens in the form, sculpture, and color of the terminal joint, and of the ovipositor.

1855. [RILEY, C. V.] The grape-vine flea-beetle, Graptodera chalybea Illig. <Amer. Ent., August, 1880 [v. 3], n. s., v. 1, pp. 183184, fig. 86 .

Habits, seasons, ravages of, and means against Graptodera [= Haltica $]$ chalybea; figures, injured leaf, and larvæ, cocoon, and imago of the same.

1856. Riley, C. V. Further notes and observations on the armyworm. <Amer. Ent., 1880 [v. 3], n. s., v. 1: August, pp. 184, 185 ; September, pp. 214, 215. Reprint, with changes: <Sci. Amer., 4 September [v. 57], n. s., v. 43, p. 152. S.-b. No. 23, p1). 161-162.

Progress of knowledge npon the number of annual generations of Levicania unipuncta; stages of growth at which it hibernates; the destructive generation probably not the first of the season; explanation of the partial efficacy of the burning of fields in winter as a means against this insect; counection of wet and dry seasons with its increase; its natural habits; errors of A. Fitch.

1857. [RILey, C. V.] Sprinklers and atomizers. <Amer. Ent., 1880 [จ. 3], n. s., v. 1: August, pp. 185̃-189, figs. 87-98; September, pp. 211-214, figs. 111-117.

Extracts from pp. 56-57 and reprint of pp. 85-94 of Bull. Na.3, U.S. Ento: mological Commission, See No.1736 for synopsis of contents. 
1858. Rrley, O. V. The use of pyrethrum. <Amer. Ent., August, 1880 [v. 3], n. s., v. 1, pp. 193-195.

Record of experiments by W. A. Henry upon the effect of Pyrethrum powder on Halticide, Meloida, Pieris rapa, Coreus [= Anasa $]$ tristis, and Blattida; and of the fumes of burning pyrethrum on various insects.

1859. [Rrley, C. V.] [Colorado potato-beetle in New Hampshire.] $<$ Amer. Ent., August, 1880 [v. 3], 1. s., v. 1, p. 195.

Ravages of Doryphora 10-lineata in Coos County, N. H., in 1879.

1860. [RILey, C.V.] Retarded development in a blister-beetle. <Amer. Ent., August, 1880 [v. 3], n. s., v. 1, p. 196.

Einal transformations of individuals from a single batch of eggs of Epicauta vittata occurring at the first, second, and third year after hatching.

1861. -[RILEY, C. V.] . Ox.eye daisy as an insecticide. <Amer. Ent, August, 1880 [v. 3], n. s., v. 1, p. 196.

Experiments by W. S. Barnard upon the effect of alcoholic extracts of the flowers and stems of the ox-eje daisy on insects; "no evidence that they will prove of any practical value."

1862. [RrLEy, O.V.] Directions for raising pyrethrum. <Amer. Ent, August, 1880 [v. 3], n. s., v. 1, p. 197.

Directions for sowing the seeds and cultivating the plants of pyrethrum.

1E63. [Rllex, C. V.] State Entomologist for New York. <Amer. Ent., August, 1880 [r. 3], n. s., v. 1, pp. 197, 198.

Notice of the appointment of J. A. Lintner as State Entomologist of New York.

1S64. '[Rrley, O. V.] Economic investigations in the South and West. $<$ Amer. Ent., Angust, 1880 [マ. 3], n. s., v. 1, p. 198.

Mceting of the U. S. Entomological Commission; plau of work to be done in 1880-1881; partial list of persons engaged in the work.

1865. [RILEY, C. V.] [Number of entomologists in Europe.j <Amer. Ent., August, 1880 [v. 3], n. s., v. 1, p. 198.

Tabulation of the number of entomologists of the several countries of Europe.

1866. [RILEY, C. V.] [Catalogus coleopterorum by Gemminger and Harold.] <Amer. Ent., August, 1880 [v. 3], n. s., v. 1, p. 199.

Commendation of the above work and of the supplementary list of Elateridw by E. Candeze; need of co-operation for the completion of the whole cata. logue.

1867. [RILEY, C.V.] Carnivorous propensity of plant-feeders. <Amer. Ent., August, 1880 [v. 37, n. s., v. 1, p. 200.

Larvie of Plusia brassice devour those of Pieris rapa and Pionea rimosalis in default of more natural food.

1868. [RrLey, C. V.] Beetles injuring cabbages and fuchsias. <Amer. Ent., August, 1880 [v. 3], n. s., v. 1, p. 200, fig. 106.

Answer to letter of G. T.; ravages, distribution, and figures of Epiccrus imbricatus; description of eggs, ravages, food-plants, and nleans against Graptodera [ $=$ Haltica $]$ carinata.

1869. [Rrlex, O. V.] Spiler and nest. <Amer. Ent., August, 1880, $[$ v. 3], n. s., v. 1, 1). 200.

Answer to letter of Mrs. J. B. Harrison; distribution and distinctive charac. ters of Acresoma stellatum. 
1870. [Riley, C. V.] Damage to wheat: Worm boring in the stalk. <Amer. Ent., August, 1880 [v. 3], n. s., v. 1, p. 201.

Answer to letter of A. R. Frost; food-plants and ravages of larva and figure of larva and imago of Gortyna nitela.

1871. [RILey, C.V.] Larva from stomach of blue-bird. <Amer. Ent., August, 1880 [v. 3], n. s., v. 1, p. 201.

Answer to letter of S. A. Forbes; larva of Meracantha contracta and of Callimorpha sp. from stomach of blue-bird; habits aud characters of the same.

1872. [RILEY, C. V.] Butterfly larva injurious to cotton squares. <Amer. Ent., August, 1880 [v. 3], n. s., v. 1, p. 201.

Answer to letter of B. F. Cooke; larva of Thecla (poeas?) feeding on leaves and bolls of cotton-plant; a species of Microgaster parasitic in the larva.

1873. [RILEY, C. V.] Cut-worms from stomach of robin. <Amer. Ent., August, 1880 [r. 3], n. s., v. 1, p. 201.

Answer to lctter of S. A. Forbcs; larvæ of Agrotis (messoria?) from stomach of robin; Agrotis cochrani $=$ A. messoria.

1874. [Riley, C. V.] Large phosphorescent larva. <Amer. Ent., August, 1880 [r. 3], n. s., v. 1, pp. 201-202, fig. 108.

Answer to lctter of S. F. Clarke; occurrence in Maryland and Missouri of a luminous larva(MFlanactes sp.?) [= Phengodes sp. ]; fignies of the larva, of its head and leg cnlarged and of its probable parent; occurrence in the more northern States of a similar larva, probably that of Asaphes memnonius.

1875. Riley, C. V. Worms injuring wheat. <Amer. Ent., August, 1880 [v. 3], n. s., v. 1, p. 202.

Answer to letter of J. Monaghan; ravages of larva of Meromyza americana.

1876. Riley, C.V. A sh-rootborer: Supposed eggs of Odontota. <Amer. Ent., August, 1880 [v. 3], II. s., v. 1, pp. 202-203.

Answer to letter of Shelby Reed ; habits and ravages of Parandra brunnea; Pimpla sp. parasitic upon its larva; probable manner in which the eggs of Odontota rubra are laid.

1877. [Riliey, C. V.] Army-worm notes and inquiries: Its work on clover. <Amer. Ent., August, $18 \$ 0$ [v. 3], n. s., v. 1, 1). 203.

Answer to letter of L. T. Deronsse; Lencania unipuncta frequently leaves clover-plants untouched while eating the grasses growing with the clover, but under some cireumstances destroys young clover-plants.

1878. [RILEY, C. V.] Ichneumon from stomach of bluebird. < 4 mer. Ent., August, 1880 [r. 3], n. s., v. 1. p. 203.

Answer to letter of S. A. Forbes; Lampronota sp. eaten in quantity by bluebirds.

1879. [Riley, O. V.] Leaf-miner on white oak. <Amer. Ent., August, 1880 [v. 3], n. s., v. 1, p. 203.

Answer to lettcr of E. W. Claypole; description, habits, and ravages of Lithocollctis cincinnatiella.

1880. [Riley, C. V.] Screw-worm: Its parentage in doubt. <Amer. Eut., August, 1880 [v. 3], n. s., v. 1, p. 203.

Answer to letter of A. R. 'Kilpatricl; Lucilia macellaria supposed to be the parent of the "screw-worm"; food-habits of certain Muscide. 
1881. [RIley, C. V.] Silk culture: How to dispose of cocoons. <Amer. Ent., August, 1880 |v. 3], n. s., v. 1, pp. 203-204.

Answer to letter of C. F. Durksen; need of silk-filatures in the United States; present means of selling cocoons.

1882. [Riley, C. V.] Best cottou-worm destrojer. <Amer. Ent., August, 1880 [v. 3], n. s., v. 1, p. 204.

Answer to letter of J. G. Danterive; reference to the most reliable poison and the best machines and methods for applying poison to kill Aletia argillacea $[=$ xylina $]$.

1883. [RILey, C. V.] Twice-stabbed lady-bird. <Amer. Ent., A tugust, 1880 [v. 3], n. s., v. 1, p. 204, fig. 109.

Answer to letter of H. N. Patterson; Coccinellide beneficial by feeding on Aphidide and Coceide; figure of Chilocorns bivulnerus; significance of the presence of this beetle in large numbers on trees.

1884. [Riler, C. V.] Pseudo-scorpion. <Amer. Ent., August, 1880 [v. 3], n. s., v. 1, p. 204.

Auswer to inquiry of C. H. S. Davis; habitats and food-habits of Chelifer cancroides and other Chernetide.

1885. [RILEY, C. V.] Bluebirds feeding on parasitic and predaceous insects. <Amer. Ent., August, 1880 [v. 3], n. s., v. 1, pp. 204205.

Answer to letter of S. A. Forbes; bluebirds more destructive to parasitic and predaceous insects than the thrushes; percentage of such food found in the stomachs of the bluebird; larve of Leucania unipuncta, Telephorus bilineatus, and Nephelodes violans eaten by the same; probable hibernation of the first named; habits, hibernation, distribution, and popular name of the Nephelodes.

1856. RILEY, C. V. The cotton destroyers. <New Orleans Democrat, 21 September, 1880, v. 5, No. 276, 1. 8. S.-b. No. 23, pp. 1'70-173. Reprint: <Selma [Ala.] Times, 29 September, 1880. < Sonthern Enterprise [Atlanta, Ga.], December, 1880, v. 5, pp. 77-82. S.-b. No. 23, pp. 184-189; No. 61, pp. 3-5; No. 63, pp. 57-59; 60-62. Keprint, with slight changes: <Proc. Amer. Assoc. Adv. Sci. for 1880, 14 October, 1881, v. 29, pp. 642-649. Separate: <Salem, July, 1881, pp. 26-33. Extract: <Sci. Amer., 16 October, 1880 [ .57 ], n. s., v. 43, p. 241 . S.-b. No. 23, pp. 159160. <Amer. Ent., October, 1880 [v.3], n. s., v. 1, pp. 245-247. $<$ Prairie Farmer, 30 October, 1880, v. 51, No. 44, p. 2. S.-b. No. 23, p. 153. Abstract: <Farmer's Review, 7 October, 1880. S.-b. No. 23, pp. 162-163. <Journ. Appl. Sci., November, 1880, v. 11, pp. 170-171.

Facts and principles established by the U. S. Entomological Commission, applicable to the whole cotton belt, regarding the times and manner of first appearance of Aletia argillacea [ = xylina] and Heliothis armigera upon the cotton-plant; habits of the larva and imagos and the best means of dostroying the same; relative efficacy of several insecticides; methods of preparing and applying the same; importance of early poisoning; main object of the cotton-worm inquiry accomplished. 
1887. [RILEY, C. V.] The use of poisons to destroy insects. <Farmer's Review, 23 September, 1880, v. 5, p. 200. S.-b. No. 23, pp. 148-149; 165-166. Reprint: <Amer. Ent., October, 1880 [v. $3]$, n. s., v. 1 , p. 244

Advocacy of the use of Paris green and London purple as means against certain insects; danger of the use of the same against many insects; criticism of A. J. Cook's, recommendation for their use against Paria aterrima and Carpocapsa pomonella; limitations within which they may be used.

1 88 . [RILEY, C. V.] Supplementary instructions to agents of the United States Entomological Commission. <Amer. Ent., September, 1880 [v.3], n. s., v. 1, p. 218.

Call for experiments to ascertain the minimum quantity of poisons which can be uscd effectually against Aletia argillacea $[=x y l i n a]$; effect of poisons on the screral stages of this insect; food-plants, parasites, and enemies of the same; , effect of yeast ferment upon it.

1889. Rrley, C. V. Dimorphism in locusts (Acrididce). <Amer. Ent., September, 1880 [v. 3], n. s., v. 1, pp. 219-220.

Review of paper by S. H. Scudder; certain forms described as species of Pezotettix are dimorphic forms of Caloptenus; extract from 8th Ann. Rept. State Ent. Mo., 18\%6, p. 115.

1890. [RILEY, C. V.] A seale insect on maple hitherto unobserved by American entomologists. <Amer. Ent., September, 1880 [v. 3], n. s., v. 1, pp. 220-221.

Notice of paper by Miss E. A. Smith, with emended reprint of a portion of the samc; habits, colors, and behavior of young larvæ and transformations of the male of Pseudococcus aceris.

1591. [RILEY, C. V.] How flight in insects is directed. <Amer. Ent., September, 1880 [v. 3], n. s., v. 1, p. 221.

Abstract of paper by Jousset de Bellesme; direction of flight not determined by the motion of the wings, but principally by the displacement of the center of gravity, resulting from the changes of pasition of other parts of the body.

1392. [RILEx, C. V.] Entomological work at the Department of Agriculture. <A mer. Ent., September, 1880 [v. 3], n. s., v. 1, p. 222.

Notice of the continuation of the appropriations by Congress for field-work and experiments in the entomological division of the U. S. Department of Agriculture.

1593. [RILEY, C. V.] Entomological papers read before the A. A. A. S. <Amer. Ent., September, 1880 [v. 3], n. s., v. 1, p. 223.

Titles of twenty-eight [28] papers read at the Boston meeting.

1594. [Rrtey, C. V.] Entomologists at Boston. <Amer. Ent., September, 1880 [v. 3], n. s., v. 1, p. 223.

Notice of the 29th meeting of the A. A. A. S. at Boston, August-September, 1880.

1595. Riley, C. V. Winged Phylloxera in California." <Amer. Ent., September, 1880 [v. 3], n. s., v. 1, pp. 224-225.

Letter from J. S. Hyde, with remarks; cxtracts from papers by E. W. Hilgard; winged fertile females of Phylloxera vastatrix found in California; local cvidcnce of the spread of this insect; means of eradicating the same. 
1896. [Rilex, C. V.] Worm infesting meal sacks. <Amer. Ent., September, $18 s 0$ [v. 3], n. s.; v. 1, p. 229.

Answer to letter of J. Greenwood, jr.; description of larva and imago of Ephestia zere [=interpunctella $]$; food-habits of the larva.

1897. [Rrlex, C. V.] Hesperid larva feeding on Canna. < Amer. Ent., September; 1880 [v. 3], n. s., v. 1, p. 229.

Answer to letter of N. S. Reed; occurrence of Pamphila ethlius in Illinois and South Carolina; its larva injurious to Canna flaccida.

1398. [RIlex, C.V.] Grape-vine apple-gall. < Amer. Ent., September, 1880 [v. 3], n. s., v. 1, p. 229, fig. 119.

Answer to letter of A. R. McCutchen; occurrence of Cecidomyia? vilis-pomum and of Calosoma scrutator in Georgia; figures gall of the first named; foodhabits of the Calosoma.

1899. [RIley, C. V.] Apple-tree plant-lice in Oregon." < Amer. Ent., September, 1880 [v. 3], n. s., v. 1, pp. 229-230.

Answer to letter of H. B. May; occurrence and ravages of Aphis mali? in Oregon; means against the same.

1900. [RILEY, C. V.] Phylloxera work. Wood-lice on grape-vine roots. <Amer. Ent., September, 1850 [v. 3], n. s., v. 1, p. 230.

Answer to letter of H. B. Trimble; occurrence of Phylloxera vastatrix at West Chester, Pa.; roots of grape-vines destrojed from unknown cause, perhaps by young of Phyloscia or Porcellio.

1901. Rrley, C. V. New hickory galls made by Phylloxera. <Amer. Ent., September, 18:0 [v. 3], n. s., v. 1, p. 230.

Description of Phylloxera caryce-scissa $\mathrm{n}$. sp. and $P$. carycte-avellana n. sp. from Florida; larva of Diplosis found in the galls.

1902. Rrley, O. V. Food-habits of the longicorn beetles or wood-borers. -<Amer. Ent., 1880 [v.3], n. s., v. 1; October, pp. 237-239; November, pp. $270-271$.

Food-plants and food-habits of the Prionida and Cerambycidee of the United States.

1903. [RILey, C. V.] Additional experiments with Pyrethrum. <Amer. Ent., October, 1880_[v. 3], n. s., v. 1, p. 242.

Details of experiments made by $\mathrm{H}$. G. Hubbard on the effect of very minute quantities of Pyrethrum powder on very young larvæ of Aletıa aryillacea $[=$ xylina $]$.

1904. [RILEy, C. V.] A new enemy to the strawberry. < Amer. Ent., October, 1880 [ . 3], n. s., v. 1, pp. 242-243, fig. 121.

Review of paper by A. J. Cook; extracts from the same; description and habits of larva and imago of Paria aterrima; means against the imago; habits of larva of Colaspis flavida; figure of the same; number of segments and spiracles in larve of Coleoptera.

1905. [RILEY, C.V.] A new enemy to corn: The long-horned Diabrotica. $<$ Amer. Ent., October, 1880 [v. 3], n. s., v. 1, p. 247.

Notice of recent articles on the ravages of the larva of Diabrotica longicomis; food-habits and means against the same; food-habits of Drastcrins amabilis.

1906. [Riley, C. V.] Phylloxera congress in Spain. <Amer. Ent., October, 1880 [v. 3], n. s., v. 1, p. 247.

Notice of a congress to be held in Spain to consider all topics connceted with the ravages of Phylloxera vastatrix. 
1907. [RILEx, C. V.] The grape Phylloxera not permanently destructive. <Amer. Eut., October, 1880 [v. 3], n. s., v. 1, p. 248.

Recovery of grape-vines formerly injured by Phylloxera vastatrix in California and Missouri; belief that in Europe grape-vines will be grown again on the lands of late jears ravaged.

1908. [Riley, C. V.] Sale of silk-worm eggs. <Amer. Ent., October, $1 S 80$ [r.3], n. s., v. 1, p. 24 S.

$\$ 6,000,000$ worth of silk-worm eggs sent from Japan to France via San Francisco in each of the four years 1874-1877.

1909. [RILEY, C. V.] [Death of S. S. Haldeman.] <Amer. Ent., October, 1880 [v. 3], n. s., v. 1, p. 248.

Obituary notice.

1910. [Riley, C. V.] [Retirement of Mr. Fuller.] <Amer. Ent., Oc- tober, 1880 [ ₹. 3], n. s., v. 1, p. 248.

Announcement of the retirement of A. S. Fuller as assistant editor of the American Entomologist.

1911. [RILEY, C. V.] Insect enemies of growing rice. <Amer. Ent., October, 1880 [ . 3], n. s., v. 1, p. 253.

Answer to letters of J. L. Leconte and J. Screven; ravages of and means against the "grub" $[=$ Chalepus trachypygus $]$ and the "maggot" $[=$ Lissorhoptrus simplex] in rice fields in Georgia.

1912. [RIley, C. V.] Blind-eyed Smerinthus. <Amer. Ent., October 1880 [v. 3], n. s., v. 1, p. 254.

Answer to inquiry of Mrs. J. B. Harrison; occurrence at lamp-light in N. H. of Smerinthus excecatus; food-plant of the larva of the same.

1913. [RILEY, C. V.] White waxy secretion on stems of bitter-sweet. <Amer. Ent., October, 1880 [v. 3], n. s., v. 1, p. 254.

Answer to inquiry of J. A. Lintncr; method of oviposition and gharacters of egg-mass of Enchophyllum [=Enchenopa $]$ binotata; seasons, habits, and food-plants and description of the eggs of the same.

1914. [RILey, C. V.] Prickly-ash larva: Tachinid eggs. <Amer. Ent., October, 1880 [ . 3], n. s., v. 1, p. 254.

Answer to inquiry of $\mathrm{R}$. W. Jones; larva of Papilio cresphontes on prickly ash; eggs of Tachina sp. on larva of Aletia argillacea [=xylina].

1915. [Riley, C. V.] Worms on cabbage: Boll-worm feeding on leaf. <Amer. Ent., October, 1880 [v. 3], n. s., v. 1, p. 254.

Answer to inquiry of R. W. Jones; food-habits of larvio of Heliothis armigera and of Pionea rimosalis.

1916. [RIley, C. V.] Buggy peas. <Amer. Ent., October, 18.80 [v. 3], n. S., v. 1, p. 254 .

Answer to letter of A. Berger; abundance of Bruchus pisi in Wisconsin; means against it.

1917. Riley, C. V. Glow-worm. <Amer. Ent., October, 1880 [v. 3], n. s., $\nabla .1$, p. 254 , fig. 123.

Answer to letter of J. J. Dean ; occurrence of larva of Photuris pennsylvanica at Chatham, N. J.; figures larva and imago of the same: larva and imago of Photinus pyratis, also lnminous; males and females of these species winged; female of Lampyris noctiluca wingless and more luminous than the male. 
1918. [RILEY, C. V.] The use of fungus growths to destroy insects. <Amer. Ent., Norember, 1880 [ . 3], n. s., v. 1, pp. 269-270.

Abstract of paper by A. N. Prentiss; the constant presence of spores of fungi in the air vitiates the valuc of most experiments on the application of the fungi to insects; insects rarely affected by the spores which are in the air while the plants are more so affected; yeast more injurious mechanieally than infectiously.

1919. [RILey, C. V.] New species of scale insects. <Amer. Ent., November, $1880[$ [. 3], n. s., v. 1, pp. 275 -.276.

Review of paper by W. H. Ashmead on the red scale.

1920. [Riley, C. V.] Remedy for cabbage.worms. <Amer. Ent., November, 1880 [ [. 3], n. s., v. 1, p. 276.

Pyrcthrum powder the most satisfactory means against all larvie affecting the leaves of cabbage.

1921. [Riley, C. V.] Pyrethrum for the screw-worm. <Amer. Ent., November, 1880 [v. 3], n. 's., v. 1, p. 276.

Notice of paper by A. R. Kirkpatrick; directions for the use of pyrethrum powder against the "screw-worm" $[=$ Lucilia macellaria $]$; objections to the use of other remedies.

1922. [RILeY, C. V.] Oviposition in the Tortricidce <Amer. Ent. November, 1880 [v. 3], n. s., v. 1, p. 276.

Notice of and extract from paper by C. H. Fernald.

1923. [RILey, C. V.] About Phora being merely a scavenger and not a true parasite. <Amer. Ent., November, 1880 [v. 3], n. s', v. 1, p. 277.

Letter from C. R. Osten Sacken, with remarks; Phora aletice not a parasite; oviposition and habits of larva of the sane.

1924. [Riley, C. V.] Gall on Solidago leaves. <Amer. Ent., November, 1880 [v. 3], n. s.; v. 1, p. 278.

Answer to letter of H. Barnes; occurrence of galls of Cecidomyia carbonifera on leaves of Solidago nemoralis? at Mulberry Corners, Ohio.

1925. [Riley, C.V.] Oak gall: Cynips q.-decidua Bass. <Amer. Ent., November, 1880 [v. 3], n. s., v. 1, p. 278.

Answer to letter of J. Schenck; galls of Cynips q. decidua? found on leaves of Quercus nuhlenbergii at Mount Carnel, Ill.

1926. [RILEY, C. V.] Insects from stomach of lark, robin, and sunfish. <Amer. Ent.. Norember, 1880 [ . 3], n. s., v. 1, p. 278.

Answer to letter of S. A. Forbcs; Diplotaxis sordicla from stomach of meadowlark; egg of a reduviid from that of a robin; larva of an ephemerid (Polymitarcys alba?) from the stomach of a sunfish.

1927. [Riley, C. V.] Supposed hibernating Aletia chrysalis. <Amer. Ent., November, 1880 [v. 3], n. s., v. 1, p. 278.

Answer to letter of $\mathrm{J}$. W. Davidson; pupa resembling that of Achatodes zece found in stalk of maize at Uniontown, Ala.

1928. Riley, C. V. On the natural history of certain bee-flies (Bombyliida). <Amer. Ent., December, 1880 [v. 3], n. s., v. 1, pp. 
1928. Rilfi, C. V.-Continued.

279-283, figs. 147-151. Review : <Ent. Mo. Mag., February, 1881, v. 17, pp. 206-207.

Advance print of pp. 262-267 and a general abstract of pp. 267-269 of the section entitled "Bee-fly larvæ, family Bombyliide," in $2 d$ Rept. U. S. Entomological Commission. See No. 1959 for synopsis of contents.

1929. RlLEY.C.V. On a new pyralid infesting the seed-pods of the trumpet-vine. <Amer. Ent., December, 1880 [v. 3], n. s., v. 1, pp. 286-288, figs. 152-153.

Description, with figures, of Clydonopteron n. g. [p. 287] and of larva, pupa, and imago of C. tecome n. sp. [p. 288], and of the abode of this insect in pods of the trumpet-vinc; habits of the insect.

1930. [RILEY, C. V.] Experiments with yeast-ferment on various in. sects. <Amer. Ent., December, 1880 [v. 3], n. s., v. 1, pp. 289, 290.

Reports by J. E. Willet and A. J. Cook upon their experiments in the application of beer and yeast to various insects; no infection communicated to the insects by these applications.

1931. Riley, C. V. Notes on the imported elm leaf-beetle. <Amer. Ent., December, 1880 [v. 3], n. s., v. 1, pp. 291-292.

Answer to letter of J. L. Leconte; seasons, transformations, enomios, and ravages of and means against Galeruca xanthomelana; hibernation of Chrysomeliäa.

1932. [Riley, C. V.] Synonyms of parasites' mistakes corrected. $<$ Amer. Ent., December, 1880:[v. 3], n. s., v. 1, p. 293. Review : <Ca. Ent., February, 1881, v. 13, pp. 31-33, fig. 3.

Review of paper by L. O. Howard; comparison of the alleged characters of Antigaster and Eupelmus to show grounds for the founding of the former; Didictyum synonymous with Hexaplasta; H. zigzag not a parasite of Aletia argillacea [=xylina], but of Phora aletia; habits of $H$. zigzag.

1933. [RILEY, O. V.] "A mystery in reference to Pronuba yuccasella." $<$ Amer. Ent., December, 1880 [v. 3], n. s., v. 1, p. 293.

Critical review of paper by H. A. Hagen, who confounded Prodoxus decipiens with Promuba yuccasella.

1931. [RIley, C. V.] Mandible of Lithocolletis guttifinitella. <Amer. Ent., December, 1880 [v. 3], n. s., v. 1, p. 294, fig. 138.

Figurc, with explanation, of the mandible of Lithocolletis guttifinitella.

1935. [RILey. C. V.] Excessive injury by a beetle in Russia. <Amer. Ent., December, 1880 [ . 3], n. s., v. 1, p. 294.

Ravages of Anisoplia austriaca in sonthern Russia; description of the same; its habits and vernacular name.

1936. [RILEY, C. V.] Chemical change in the color of butterfly-wings. $<$ Amer. Ent., December, 1880 [v. 3], n. s., v. 1, p. 294.

Note on paper by W. H. Edwards and J. M. Wilson.

1937. [RIley, C. V.] Fungus foes. <Amer. Ent., December, 1880 [v. 3], n. s., v. 1, p. 297.

Answer to inquiry of J. J. Brown; Cis fuscipes and all Cioidce infest fungi growing on old trees and logs. 
1938. [RILey, C. V.] The twig-girdler. <Amer. Ent., December, 1880 [v 3], u. s., v. 1, p. 297, figs. 155-156.

Answer to letter of W. R. Maxwell; figures of larva, pupa, and imago of Oncideres cingulata and of twig injured by the imago ; food-plants, habits, and transformations of this insect.

1939. [Riley, C. V.] The bedeguar of the rose. <Amer. Ent., Decem. ber, 1880 [r. 3], n. s., r. 1, p. 298, fig. 154.

Answer to lettcr of L. C. Bryan; account of the gall of Rhodites rosa ; figure of the same.

1940. [RILEY, C. V.] Minute borers in cherry, peach, and plum-trees. <Amer. Ent., December, 1880 [v. 3], 1. s., v. 1, p. 298.

Answer to letters of J. L. Bennett and M. H Boye ; ravages, food-plants, and distribution of Scolytus rugulosus; food-habits of the species of Scolytus.

1941. [RILey, C. V.] Smilax injured by cut-worms. <Amer. Ent., December, 1880 [v. 3], n. s., v. 1, p. 298.

Answer to letter of G. Thommen; habits, ravages, and food-plants of Agrotis sancia.

1942. [RILEY, C. V.] Honey-producing oak-gall. <Amer. Ent., December, 1880 [v. 3], n. s., v. 1, p. 298.

Answer to letter of H. C. McCook; secretion of saccharine matter by galls growing on Quercus undulata; description of these galls, Cynips quercusmellaria n. sp.; Myrmccocystus hortus-deorum [= melliger $]$ collects the saccharine matter from these galls.

1943. [Riley, C. V.] Dr. Hagen's mystery. <Ca. Ent., December, 1850, v. 12, pp. 263-264.

Review of paper by H. A. Hagen; Prodoxus decipiens confounded with Pronuba yuccasella

1944. Riley, O. V. Acorn-gall. <Trans. Acad. Sci. St. Louis, 1880, v. 4, p. 1 Proc.

Gall mistaken for abortive acorn, by G. B. Emerson, in his "Trees and shrubs of Massachusctts."

1945. Riley, C. V. Silk.culture in the United States. Condensed account of the silk-worm and how to inaugurate a new source of wealth. <Western Farmer's Almanac for 1881, 1880, pp. 3539, 4 figs. S.-b.. No. 23, p. - .

Practicability and desirability of the culture of Scricaria mori in the United States; requisites to its success; superiority of $S$. mori over all other insects for silk-culture; brief illustrated natural history of the same; directions for silk-culture.

1946. Riley, C. V. Legislation to control insects injurious to vegetation. <Farmer's Review, 20 January, 1881. S.-b. No. 23, p. 148. Reprint: <Amer. Nat., A pril [25 " arch], 1881, v. 15, pp. 322-323. <Indiana Farmer, 16 April, 1881. S.-b. No. 23, p. 149. Notice: <Farmer's Review, 20 January, 188ı. S.b. No. 23, p. 170.

Appointment of C.H.Dwinelle, by the California State Horticultural Society, on a committee to consider what legislation is desirable to check.the spread of noxious insects and to force land-owners to destroy the same; notice of the previous passage of such laws and of anticipated objections to them. 
1947. Riley, C. V. Larval habits of bee-flies, Bombyliide. <Amer. Nat., February [25 January], 1881, v. 15, pp. 143-145, tigs. 1-3. Notice: <Western Stock Journ. and Farm, March, 1881, r. 11, p. 58 .

Habits of Systochus and Triodites as parasites on eggs of Acridide; notiee of paper by T. A. Chápman; figures Jarva, pupa, and inago of Systochus oreas and compares its larve aud pupa with those of Bombylius major.

1918. Riley, C. V. Experiments with pyrethrum: Safe remedies for cabbage-worms and potato-beetles. <Amer. Nat., February [25 January], 188ı, v. 15, pp. 145-147.

Details of experiments made by A. J. Cook and W. R. Hubbert upon the effeet of a dusting of pyrethrum powder upon larva of Pieris rapa, larva and imagos of Doryphora 10-lineata, and upon Eriosoma [=Pemphigus] tessellata, Coreus [-Anasa] tristis, and flies and mosquitoes.

1949. Riley, C. V. Insect enemies of the rice-plant. < Amer. Nat., Febrnary [25 January], 1881, v. 15, pp. 148-149.

Chalepus trachypygus feeds on roots of the riee-plant; eonjectures as to other enemies of the rice-plant; Cecidomyia oryzo injurious to the same in India.

19:0. [RILey, C. V.] The "yellow-fever fly." <Amer. Nat., February [25 January], 1881, v. 15, p. 150.

Review of paper by H. A. Hagen; food-habits of Jarvæ of Sciara sp. ; occurrenee of swarms of imagos of the same.

1951. [RILey, C. V.] An aquatic Sphinx larva. < Amer. Nat., February [25 January], 1881, v. 15, p. 151.

Abstraet of paper by H. A. Hagen.

1952. Riley, C. V. Notes on the grape Phylloxera and on laws to prerent its introduction. <Amer. Nat, Mareh' [24 February], 1881, v. 15, pp. 23S-241. Notice with extracts : <Pacific Rural Press, 23 April, 1881. S.-b. No. 42, p. 17.

Remarks upon letter of I. Bush; preeantions to be adopted against the introduetion of Phylloxera vastatrix; summary of the life-history of the same.

1953. Riley, C. V. Hibernation of the cotton-worm moth: Ease with which mistakes are made. <A mer. Nat., March [24 February], 1881, v. 15 , pp. 244-245, figs. $1-3$.

Extraet fiom letter of I. A. Wimbish; Leucania unipuncta mistaken for Aletia argillacea [-xylina]; eharaeters of Aletia; figures'ovipositor and eggs of L. unipuncta aurl imagos of both speeies.

1954. [Riley, C. V.] On some interaction of organisms. <Amer. Nat., April [25 March], 1881, v. 15, pp.323-324.

Review of paper by S. A. Forbes, with extraets; relative unimportanee of speeial parasites as eompared with predaeeous animals of varied tastes in the limitation of the numbers of any species of animals; need of eonservative aetion and exhaustive inquiry in the attempt to interfere with the order of nature.

1955. [RILex, C. V.] Insect locomotion. <Amer. Nat., April [25 March], 1881, v. 15, p. 325.

Results of $G$. Carlet's studies on the order in whieh the feet are moved in the walking of Hexapoda and Arachnida. 
1956. [RILey, C. V.] Plant-feeding habits of predaceous beetles. <Amer. Nat., April [25 March], 1S81, v. 15, pp. 325-327.

Citation of evidence from nnmerous sources proting that certain Carabida and Coccinellide occasionally feed on plants, seeds, and spores.

1957. Rruex, C. V. Notes on Papilio philenor. <Amer. Nat., April, [25 March], 1Ss1, v. 15, pl. 327-329, figs. 1-3.

Description of egg and newly-hatched larva of Papilio philenor; figure of larva, chrysalids, and imago of the same; food-plants, distribution, and its occurrence in swarms.

1958. [RIlex, C. V.] Entomological notes. <Amer. Nat., April [थ5 March], 18s1, v. 15, pp. 330-331.

Notice of H. A. Hagen's paper on Simulium pictipes, with additional notes; abstracts and minor notices of other papers and items of news.

1959. [Rrmex, C. V.] Second report of the United States Entomological Commission for the years 1878 and 1879, relating to the Rocky Mountain locust and the Western cricket, and treating of the best means of subduing the locust in its permanent breeding grounds, with a view of preventing its migrations into the more fertile portions of the trans-Mississippi country in pursuance of appropriations made by Congress for this purpose, with maps and illustrations. <Washington: 1 s80 [4 April, 1881], pp. $18+322+80,10$ figs., 17 pl., 9 maps.

TABLE OF CONTENTS.

LETTER OF TRANSMTTAL ................................ IX

Preface ............................................... XIII

Chapter I: By A. S. Packard and C. V. Riley.

Additions to the chronology of locust ravages...................

The locust in 1878 in Minnesota and Iowa, 1; in Nebraska, Texas, and Indian Territory, 2; in Kansas, 2-3; in Dakota, 3-4; in Colorado, 4; in Wyoming, 4-5; in Utah and Idaho, 5-7; in eastern Oregon and Nevada, 7 ; in Montana, 7-9-Summary, 9The locust in 1879 in Nebraska, Washington Territory, Dakota, and Texas, 10; in Colorado, 10-11; in Wyoming, 11-12; in Utah, 12-13; in Montana, 13-14.

CHAPTER Ir: By C. Thomas.

The relation of the locust and its ravauges to agricnlture and the settlement of the Territories.............................

Character of the permanent region, 15-Importance of subdning the locusts in the permanent region, 15-16-Difficulties of burning over, 16-18-Extermination impossible, but subjection possible, 19-20-Settlement of the permanent region the best romedy, 19-20-Sonrce of the moro destructive swarms, $20-R a i l-$ road necded in the permanent region, 21-Agricultural, 'not pastoral, popnlation wanted, 22-Difficulties of constructing railroads in the permancnt region, $22-C$ Climatic character of the permanent region, 23-Disturbing and fighting the locusts in the permanent region, 24-25-Other proposed plans, 25-Plowing not feasible, 25-26-The locust question solved in the temporary region, 26-New definition of the temporary regrion, 27-28-The locist problem a national one, 29-31. 
1959. [Riley, C. V.]-Continued.

Chapter III : By C. Thomas.

Facts concerning and laws governing the migrations of locusts in all countries ...............................................

Most species of Acrididoe not migratory, 31-Migratory disposition not caused by anatomical differences, 31-32-Writers on locust flights, 32-33-Earliest accounts of locnst flights in Europe, 3334-Locnst flights in Europe in the middle ages, 34-37; in the seventeenth centnry, 37-38-The locnst invasion of 1693 in Enrope, 38-39-Locust flights in Europe in the eighteenth and nineteenth centuries, 40-41-Locusts in Asia and adjacent islands, 11 ; in Cyprns, 42 ; in Arabia and Syria, 43-44; in Persia, 44; in the Steppes, 45; in China, 46; in Manila, 46; in India, 46-47; in Australia, 47; in New Zealand, 47-Locust flights in Africa, 48; in northern Africa, 48-49; in Egypt, 49in Algiers, 50-51; in Abyssinia, 51; in central Africa, 51; in eastern Africa and the Canary Islands, 52-53-Locusts in South America, 53-54-Prevalence of locusts in deserts and dry regions, 54-55-Locust flights not governed by laws of periodicity, 5556-Permanent breeding grounds of locusts, 56-57-Their geographical distribution, 58-Caloptenus spretus not in Mexico, 58Migratory locusts in Yncatan and the West Indies, 58-59-In Nicaragua, 59-Geographical limits of Caloptenus spretus, 59; of Pachytylus migratorius, 59-60-Difficnlty of deterwining species, 60-61-Definition of permanent home of migratory locnsts, $62-$ Range of Pachytylus migratorius, 62-63; of Acridium peregrinum, 63-64-Comparison with the laws of geographical zoölogy, 6566-Meeting point of three sub-regions, 67-Each species has its permanent breeding ground, 6s-General character of the permanent brceding grounds, 68-69-Breeding ground of Caloptenus italicus, 69; of Pachytylus migratorius, 69-70; of Acridium peregrinum, 70; of Caloptenus spretus, 70-71.

Chapter IV : By C. Thomas.

Habits and characteristics of locusts in all countries within their areas of permanent distribntion, so far as these rclate to their movements ...........................................

Caloptenus spretus always migratory, $72-73-$ Flights of C. spretus, 73-74-Invading swarms come from northwest, 74-75-Other opinions eliminated, 75-76-Swarms in 1875 and $1876,76-77-\mathrm{Di}$ rection of returning swarms of $C$. spretus, 78 ; of other migratory locusts, 78-79-Direction of local flights, 79-81-Returning swarms do little injnry, 81-82-Distance to which swarms may migrate, 82-84-Length of a single flight, 84-85-Swarms able to cross large bodies of watcr, 85-86-Swarms carried far by winds, 86-87-The mode of flight, 87-Position of the locust while fly. ing, 87-88-Locnsts flying with the wind, 88-89-Method of falling of swarms, 89-Formation of $\mathrm{s}$ warms, 89-91-Movements of swarms of C. spretus, as reported by Dr. Child, 91-93-Other reports, 94-Movements of swarms in other countries, 95-96Swarms usually alight at night, 96-97-The height at which swarms move, 98-100-Different directions of swarms at the same time and place, $100-$ Fall of locusts into the sea, 100-102-Great flying power of locnsts, 102-Geueral causes of migration, 103Excessive numbers, 103-104-Want of food, 104-Excessive heat, 
1959. [Rrizer, C. V.]-Continued.

Chapter IV-Continued.

105-Dry coudition of the atmosphere, 105-106-Arid condition of the mountain region, 106-107-Immediate causes of migration, $107-108$.

- Cifapter V: By C. Thamas.

Influence of meteorological conditions on the development aud migrations of locusts ......................................

Influence of heat and dryness, 109-110-Packard's table of locust sears, 111-112-Table of rain-falls for 1860 to 1866, 112-Inflnence of the rainfall, especially in $1864,112-113-$ A verage monthly temperature for 1864 and $1866,113-115$-Rain-fall of the years 1863 to 1867, 116-Temperature of the years 1863 to 1867, 117-Extreme variations of monthly mean temperature from 1863 to 1867 , 118-119-Monthly and annial mean temperatnre from 1872 to $1876,119-121$-Monthly and annual rain-fiall from 1872 to $1878,122-$ 124-Extreme fluctuations between monthly mean temperature, 125-126-Greatest variations between monthly mean temperatures, 126-Variations of temperature between mouths of consecutive years, 127-128-Daily temperature at Fort Sully from 1872 to 1875, 129-134-Relation of temperatnre to the development of the eggs, 135-136-Professor Riley's experiments, 137Professor Abbe's theory on the subject discussed, 13i-140-Table showing temperatnre and direction and velocity of wind at Westeru stations, 141-154-Relation of temperature and winds to locust flights, 155 .

Chapter Vi: By A. S. Packard.

The southern limits of the distribution of the Rocky Mountain locust.

Fow locusts permaneutly breeding in New Mexico and none in Arizona, 156-Caloptenus spretus probably not in southern Now Mexico, central and southern Arizona, etc., 156-History of locust iuvasions in New Mexico from 1864 to 1879, 157-159-Sonthern rauge of the locust in Mew Mexico, 159-Changes in the map in the Report I, showing the distribution of the locust, 159-160.

Cilapter VII: By A. S. Packard.

Summary of locnst flights from 1877 to $1879 . . . . . . . . . . . . . . . .$.

Gencral remarks on maps Nos. 2 to 4, 160-161-Flights of locusts in 1878, 161-162-Flights in 1879, 162-163.

(Yhapter VIII : By A.S. Packard.

The western cricket.

Difference in habits between the western cricket and the locnst, 163-Occurrence of Anabrus purpurascens, 163-164; of A. simplex, 164-Mode of egg-laying, 164-Movements of au army of the western cricket, 164-165-Its ravages, 165-166-Its food, 166-Its enemies and parasites, 166-Its breeding habits, 166-167-Remedies, 167-168-Geographical distribution of the species of Anabrus, 168-169-Synopsis of the species of Anabrus and its allies, 169170-External anatomy of Anabrus, 170: the hedd, 170-17\%; the thorax, 172-174; the abdomen, 174-175-Internal anatomy of Anabrus purpurascens, 175 ; the digestive system, 175176 ; the nervous system, 176-177; the breathing apparatus, 177-178.

Chapter IX: By A. S. Packard.

The air-sacs of locusts with reference to their powers of flight ......

History of the study of the air-sacs, 178-Air-sacs in different insects, 178-179-The air-sues of the Acridii, 179-Use of the air. sacs in flight, 179-18:- Their origin, 18:-183. 
1959. [RILEY, C. V.]-Continued.

Chapter X: By C. S. Minot.

Histology of the locnst (Caloptcnus) and the cricket (Anabrus)......

Study of histology of insects, 183-184-Explanations of Figs. 1 and 2, Plate II, 185-186-The cuticula, 186-188-The epidermis, 188189-Sense organs, 189-Nervous system, 190-Tracheæ, 191-195Air-sacs and spiracles, 195-Mnscles, 195-196-Organs of circulation, 196-Connective tissue, 196-198-Ovary, 198-201-Anterior cæcum of the oviduct, 201-Uterus of locusts, 201-203-Male organs, 203-Testis, 203-204-Developinent of the spermatozoa, 204, 207-Vasa deferentia, 207-Ductus ejaculatorius, 207-Vesicula seminales, 207-208-Digestive canal, 208-210-Crop, 210-211Proventriculus, 211-212-Stomach, 212-214-Diverticula, 214215-Gastro-ileal folds, 215-217-Ileum, 217-Colon, 217-218Rectum, 218-219-Summary on the digestive canal, 219-221Malpighian vessels, 222 .

Chapter XI: By A. S. Packard.

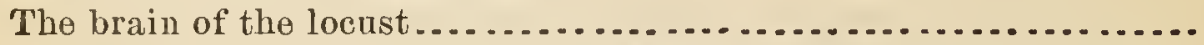

The nervous system in gencral, 223-224-The brain of insects compared with that of vertebrates, $224-226$-The brain of the adult locust, 226-Histological elements of the brain, 226-228-The sections of the brain, 228-230-Internal topography of the brain, 230--The central body, 230, 231-The mushroom bodies, 231-234The optic lobes, 234--The optic ganglion, 234-The antennal or olfactory lobes, 235-The commissural lobes, 235-The brain of locusts compared with that of other insects, 235-236-Structure of the brain in the enibryo locust, 236-The brain of the embryo locust compared with the first thoracic ganglion, 238-'The brain in the sccond embryonic stage, 238-239-Structure of the subossoplageal ganglion, 239-The brain of the freshly-hatched larva of Caloptenus spretus, 239; of the third larval stage of $C$. bivittatus, 239 ; of the second or last pupal stage of C. spretus, 240-241Bibliography of the internal structure of the brain of crustacea and insects, 241-242.

Chapter XII : By C. V. Riley and C. Thomas.

Locust ravages in California ...............................

Position of the genus Cammula in the Edipodini, 242-243-Description of the genus Camnula, 243; of Edipoda,pellucida, 243; of Edipoda atrox, 243-244; of Cammula pellucida, 244-246-'The locust in California in 1878, 246; in Sierra Valley, 247; in the vicinity of Loyalton, 247-248; of Sicrraville, 249-History of locust devastation in California, 250-Enemies of the Californian locust, 251-Protective measures, 251-252-Life history of Camnuta atrox, 252-253-The red or locust mite, 253-Damage done by the locust in Sierra Valley, 254-255-The locust in California in 1879, 255-257-Description of Edipoda obliterata, 257-259-Remarks on Cratypedes Putnami, 259.

Chapter XIII: By C. V. Riley.

Further facts about the natural enemies of the locust ..............

Blister-beetle larva feeding on the eggs of the Californian locust, 259-260-Retardation in the development of blister-beetles, as shown in Epicauta vittata, 260-Philosophy of such retardation, 260-261-Eggs of Chauliognathus pennsylvanicus, 261-Habits of the joung larva, 261-262-Egg-laying of asilid-flies, and particularly of Irallophora orcina, 262-Bee-fly larvæ common among the 
1959. [RILEY, C. V.]-Continued.

Chapter XIII-Continued.

eggs of Camnula pellucida, 263-Habits of bee-fly larvæ, 263-264Observations on the larval habits of Bombylii, 264-265-Larval habits of Argyramceba, 265-266-Abundance of bec-flies and blister-beetles in the Western country, connected with the abundance of loensts, 266-Life history of Systrechus oreas, 266-267-Description of its larva, 267; of the pupa, 267-268; of the imago, 268Description of Systcehus orcas, 268-Larva of Triodites mus, 268269-Imago of Triodites mus, 269-Dr. T. A. Chapman's observations on Bombylius major, 269-Hair-worms and red-mites abundant upon locusts in California, 270-Chalcid-fly parasitic on locnsts, 270-Synonymy of the locust-egg parasite, 270-Diggerwasps killing locusts, 270.

Chapter XIV: By C.V. Riley.

Conrses that may be adopted by the General Government to lessen

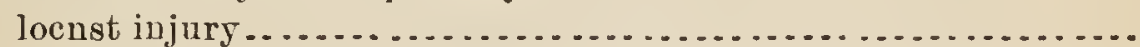

Importance of destroying the locusts in their native breedinggrounds, 271-Recapitnlation of means suggested in first report, 271-Importation of English rooks, 271-Inıportance of burning over the permanent brecding-grounds, 272-Breeding-grounds occupy comparatively small areas in the permanent region, 273Protection from invading swarms, 273-Locust warnings through the Signal Burean, 273-Diverting swarms by means of smoke, 274-Co-operation of governments and governmental institntions, 274-A pathy apt to resnlt from periods of immunity from locust invasions, 2\%4-How the Government can aid, 275-Surface characteristics of the permanent region and the proportion of burnable land, 275-Number of square iniles in the permanent region, 276 -The plains arca east of the mountains, 276-Its regetation, 276-Burnable land practically indentical with grazing-land, 277-The plains area in the British possessions, 278-In the United States, 279-The mountain area, 280-Timber-lands in the mountain arca dependent upon latitnde and altitude, 280Northern section of the mountain area, 280, 281-River vallcys in Montana, 281-Valley of the Yellowstone and its tribntaries, 281-Of the Madison River, 282-Of the Jefferson and Missouri Rivers, 28.3-The Wind River and the Bighorn Mountains, 283The Green River Basin, 28:3-Valley of the Snake River and its tributaries, 286, 289-Southern section of the monntain area, 289-In southern Wyoming, 290-291-In Colorado, 291-The San Luis Valley, 292-Mountain area in New Mcxico, 292-The platean area, 293-Its extent, 293-The Roan Plateau, 293-The Uinta Valley, 293-The Grand River Valley, 294-The Great Sage Plain, 294-The San Juan River Valley, 295-The Colorado River Platean, 235-The Great Basin area and the Wasatch Mountains, 296-Valleys of the Bear River and its tribntaries, 296-The Wasatch Range and its valleys, 298-Mountain Rauges in No. vada, 299-300-The Mojave Desert, 300-Preventive measures in the plains region, $300-$ Caloptenus spretus breeds, espccially in British America and Montana, 300-Fertile grass-land in the Territories, 300-Its extent, 302-Encou ra gement to settlement, 302Modification of climate by settlement and cultivation, 302-Professor Thomas' communication to Governor Pillsbury, 303-The settlenent of Dakota will benefit Minnesota, 304 - Forest planting 
1959. [RILEY, C. V.]-Continued.

Chapter XIV-Continued.

on the coteau of the prairies, 305-Preserving of lakes, ponds, and swamps in Minnesota, 306-Encouragements to railroads, 307Irrigation, 307-Extent of the arid region, 307-308-Only a small portion of the land irrigable, 308-Agriculturc in the arid West and in the Mississippi Delta require assistance of the National Government, 308-Prevention of floods by means of reservoirs, 309-Cost of irrigation, 310-Influence of irrigation on the locust question, 310-Mr. H. Gannctt's report on irrigation in the arid region, 310-Waste of water in irrigating, 311-Amount of irrigable land, 311-Amount of water necessary for irrigation, 312313-Irrigable land in Colorado, Utah, California, \&c., 313Arable land in the Territories, 314-Amonnt of land in actual cultivation, 314-Irrigation by means of artesian wells, 315Methods of irrigation, 315-316-Uselessness of rcservoirs and great irrigating canals in the arid region, 316-How irrigation should be regulated, 316-Preservation of forests; tree-planting, 317Judicious burning in spring, 317-Permanent establishment of locust signals and warnings, 318-Co-operation with the Dominion Government, 319-Preventive measures in the mountain and plateau areas, 319-Breeding-grounds of the locust in the mountain area, 319-Influcnce of settlement, 320-Replanting of forests, 320-Importance of locust signals to the farmer in Colorado and Utah, 321-Very destructive locust invasions not likely to recur in the future, 321-The locust has ceased to be an object of dread, 322.

APPENDix I:

Miscellaneous data and replics to Circular No. $1 . . . . . . . . . . . . .$.

Circular No. 1, [3]-Nebraska data, [4]—Data for Minnesota, [17]Data for Iowa, [20]-Data for Dakota, [21].

APpeNDIX II : By S. H. Scudder.

List of the Orthoptera collected by Dr. A. S. Packard, jr., in the western United States in the summer of $1877 . . . . . . . . . . . .$. Bradynotes opinus, Scudd., n. sp., [24]-Pezotettix pacificus, Scudd., n. sp., [24]-Gomphocerus shastanus, Scudd., n. sp., [25]Circotettix maculatus, Scudd., n. sp., [26]-Trimerolropis latifasciata, Scudd., n. sp., [26]-T. similis, Scudd., n.sp., [27]-T. caruleipes, Scudd., n. sp., [27]--Psinidia wallula, Scudd., n. sp., [27]. APPENDIX III:

Report of John Marten .....................................

Observations of John Marten, special agent, on locusts in Iowa, [29]-In Minnesota, [30]-In Daliota, [30]-In Nebraska, [31]. Appendix IV: By B. P. Mann and C. Thomas.

Bibliography of some of the literature concerning destructive locusts...............................................

Introductory and explanatory remarks, [33]-Bibliography on the destructive locusts of Europe, Asia, and Africa, [33]-Supplementary list to the bibliography on locusts in foreign countries, [50]-Additions to bibliography on the locusts in America, [55]. APPENDIX V:

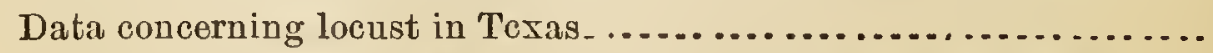

Notes furnished by Gen. A. J. Mver, U. S. A., Chief Signal Officer, on locusts in Texas, chiefly in the year 1877, [57]-Locust data from Indian Territory in 1877, [61]. 
1959. [Rrley, C. V.]-Continued.

\section{APPENDIX VI:}

On the flight of locusts..................................

Translation, by F. P. Spofford, of a memoir by Gaetano de Lucretus, [63]-Translation of d'Azara's paper on locust invasions in Spain from 1754 to 1757 , by F. P. Spofford, [66].

\section{APPENDIX VII :}

Notes of a journey made to Utah and Idaho in the summer of 1878 ,

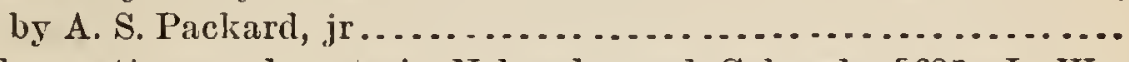

Observations on locusts in Nebraska and Colorado, [69]-In Wyoming, [69]-In Utah, [69]-In Idaho, [70]-Observations on the journey returning East, [₹1].

\section{APPENDIX VIII :}

Yersin's rescarches on the functions of the nervous system of the ar-

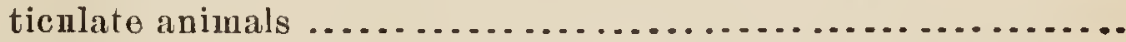

Translation, by Dr. A. S. Packard, jr., of Saussure's abstract from Yersin's Recherches sur les fouctions du système nerveux dans les animaux articulés, [73].

1960. Riley, C. V. Notes on North American Microgasters, with descriptions of new species. <Trans. Acad. Sci. St. Louis, 16 April 1881, vo 4, pp. 295-315, 9 figs. Separate: < [St. Louis, Mo.], 6 April, 1881, 20 pp., 9 figs.

Charactcristics aud babits of the Microgasters; description of larva of Apan. teles aletice; the cocoons and their construction; effect of the parasites upon the longevity of the host; secondary parasites; habits and descriptions of several new species and varieties, for a list of which see the Systematic Index; figures $A$. aletia, healthy and parasitized larva of Chcrocampa pampinatrix [= Ampelophaga myron]; also mass of Microgaster cocoons, and the formation of the cocoon by the larva.

1961. [RILey, C.V.] Exuviation in flight. .<Amer. Nat., Mav [16 April], 1851, v. 15, p. 395 .

Criticism of R. McLachlan's observations; process of casting subimaginal skin in Polymitarcys alba.

1962. Riley, C. V. The rascal leaf-erumpler in Georgia. <Amer. Nat., May [16 April], 1881, v. 15, p. 400.

Occurrence and ravages of Acrobasis nebulo [=indiginella] in Bryan County, Georgia.

1963. [Riley, C. V.] Vertical vs. horizontal insect boxes. <Amer. Nat., May [16 April], 1881, v. 15, p. 401.

Review of pamphlct by A. Preudhomme de Borre; reply of G. H. Horn to Preudhomme de Borre.

1964. [RILEY, C. V.] Insects affecting the China tree. < Amer. Nat., May [16 April], 1881, v. 15, pp. 401-402.

General immunity of the China tree from the attacks of insects and its consequent value as a shade tree; occurrence of a Lecanium and Ceroplastes $\mathbf{n}$. sp. upon it in Alabama; injuries to its leaves by Atta fervens in Texas.

1965. [Rrley, C. V.] Galls on Eucalyptus. <Amer. Nat., May [16 April], 1881, v. 15, p. 402.

Critical review of paper by R. McLachlan; the supposcd dipterous galls probably cecidomyidous; the supposed lepidopterous galls probably not lepidoptcrous, but inhabited by ạ lepidopteroụs ịnquiline, 
1966. [Riley, C. V.] North American Anthomyida. <Amer. Nat., May [16 April], 1881, v. 15, p. 402.

Notice and summary of paper by H. A. Hagen.

1967. [Rilex, C. V.] Galls and gall-insects. <Amer. Nat., May [16 April], 1881, จ. 15, pp. 402-403.

Review of paper by H. F. Bassett, with additional notes on the gall of Cynips [=Andricus $]$ quercus-californica found on Quercus douglasii and infested by Ozognathus cornutus; the Cynips produced from this gall all females; earlier accounts of the gall and of the habits of $O$. cormutus.

1968. RILEY, C. V. Scale insect on raspberry. <Farmer's Reriew, 21 April, 1881, v. 6, p. 243. S.-b. No. 23, p. 150. Reprint: <Amer. Nat., June [19 May], 1881, v. 15, p. 487.

Remarks on communication from R. B. Fulton; occurrence and ravages of a scale (Diaspis harrisii?) [=Chionaspis furfurus] on black-cap raspberry in Mississippi; mode of dissemination and means of extermination of Coccida.

1969. RILEY, C. V. Descriptions of some new Tortricidce, leaf-rollers. <Trans. Acad. Sci. St. Louis, May, 1882, v. 4, pp. 316-324. Separate: < [St. Louis, Mo.], 28 April, 1881, 9 pp.

Description of two (2) new genera and thirteen (13) new species of Tortricida; see the Systematic Indcx for a list of the same; mention of the food-plants of some of the species.

1970. RILEY, C. V. Larval habits of bee-flies. <Amer. Nat., June [19 May], 1881, v. 15, pp. 438-447, pl. 6. Separate: <pp. 438-447. Adapted from the 2d Rept. U. S. Ent. Commission, pp. 262-269; see No. 1959. for synopsis of contents.

1971. [RILEx, C. V.] The periodical Cicada alias "seventeen-year locust." <Amer. Nat., June [19 May], 1881, v. 15, pp. 479-482, fig. 1. Correction: <Ibid., July [22 June], 1881, p. 578.

Extract from 1st Rept. State Ent. Mo., with additional notes; figures eggs, pupæ, and imago of Cicada [=Tibicen] septendecim, and of twig punctnred by the imago for the deposition of her eggs.

972. RLLEY, C. V. A new species of oak coccid mistaken for a gall. <Amer. Nat., June [19 May], 1881, v. 15, p. 482.

Description of Kermes galliformis n. sp. [p. 482] occurring on Quercus palustris in the sonthern and central United States; the coccid infested by Euclemensia bassettella.

1973. [RILEY, C. V.] The "water-weevil" of the rice-plant. <Amer. Nat., June [19 May], 1881, v. 15, pp. 482-483. Extract: <Ann. Rept. [U.S.] Commissioner Agric. for 1881 and 1882, pp.130-133. Note on the injury done to rice plants by the larva of Chalepus trachypygus and by other larvæ, probably Lissorhoptrus simplex; letter from J. Screven; seasons, habits, and ravages of the last-mentioned species.

1974. [RILEY, C. V.] The impregnated egg of Phylloxera vastatrix. <Amer. Nat., June [19 May], 1881, v. 15, pp. 483, 484 . Reprint: <Amer. Wine and Grape Grower, 1 July, 1881, v. 3, p. 104. S.b. No. 42, pp. 12-13.

Verification by P. Graell of author's conclusion that the impregnated egg of Phylloxera vastatrix would generally be found to hatch in the same seasson in which it was laid, 
1975. Riley, C. V. Works on North American Microlepidoptera. <Amer. Nat., June [19 May], 1881, v. 15, pp. 484-486.

Review of works of T. de Grey [Lord Walsingham]; discussion of new genera; list of Tortricida of economic interest common to Europe and North America; additions to the synonomy of Tortricide.

1976. [Rrley, C. V.] Motbs mistaken for Aletia. <Amer. Nat., June [19 May], 1881, v. 15, pp. 486-487.

Platyhypena $[=$ Hypena $]$ scabra and Phoberia atomaris mistaken for Aletia argillacea $[=x y l i n a]$; hibernating habits of the first specics.

1977. [Riley, C. V.] Specific value of Apatura alicia Edw. <Amer. Nat., June [19 May], 1881, v. 15, p. 487.

Critical review of paper by W. H. Edwards.

1978. Riley, C. V. Antigaster vs. Eupelmus. <Ca. Ent., May, 1881, v. 13, p. 114.

Validity of L. O. Howard's reasons for considering Antigaster a synonym of Eupelmus.

1979. Riley, C.V. The periodical Cicada alias "seventeen-year locust." <Farmer's Review, 16 June, 1881, v. 6, p. 370. S.-b. No. 42, pp. 18 20 .

Extract from 1st Rept. State Ent. Mo., with additional notes and request for further information in regard to the chronology and geographical distribution of the broods of Cicada $[=$ Tibicen $]$ septendecim and $C .[=T$.$] tredecim$ which appear in 1881.

1980. [RILEY, C. V.] Dimorphism in Cynipida. <Amer. Nat., July [22 June], $18 s 1$, v. 15, p. 566.

Claim of author to have made the first record at least in North America of proof of dimorphism in Cynipida; notice of writings of B. D. Walsh, H. F. Bassett, and H. Adler on the subject; list of species of Cynipide in which the occurrence of aimorphic forms has been proven, and of closely allied species in which no alternate gencration seems to occur.

1981. [Rrley, C. V.] Blepharocerida. <Amer. Nat., July [22 June], 1881 , v. 15, pp. $567-568$.

Account of various investigations into the natural history of Blepharocerida; description of larvie and pupa of these flies.

1982. [R्Luex, C. V.] Braula caca not particularly injurious to the honey-bee <Amer Nat., July [22 June], 1881, v. 15, p. 568.

Notice of paper of $J$. Fedarb; ravages of Braula crea in hives generally overestimated at prescnt and formerly unknown.

1983. [RILEx, C. V.] Economic entomology in England. <Amer. Nat., July [22 June], 1881, v. 15, p. 568.

Notice of Miss E. A. Ormerod's report for 1880.

1984. [RILEY, C. V.] The cultivation of pyrethrum and manufacture of the powder. <Amer. Nat., 1881, v. 15. July [22 June], pp. 569-572; September [23 August], pp, 744-746; October $[23$ September], pp. 817-819. See: <Amer. Wine and Grape Grower, December, 1881, v. 4, p. 22. S.-b. No. 51, p. 149.

Partial history of the use of pyrethrum powder as an insecticide; directions for the cultivation of the plants and for the production and use of the powder 
1985. [RIley, C. V.] Hudson Bay Lepidoptera. <Amer. Nat., Jul.y [22 June], 1S81, v. 15, pp. 572, 573.

Review of paper of J. J. Weir; reprint of the list of Lepidoptera and of the remarks on the explanation of the relations of the fauna of Hudson's Bay to that of Curope; probability that the species identical with those of Europe are recent immigrants.

1986. [Riley, C. V.] Trade in insects. <Amer. Nat., July [22 June], 1881, v. 15, p. 573.

General declinc in prices of insects within sixty ycars or more; statement of some prices obtained for Coleoptera recently.

1987. [RILEY, C. V.] Ants injurious in Arizona. <Amer. Nat., July [22 June], 1881, v. 15, pp. 573, 574.

Statement by H. H. Rusby of ravages of Formicide, which occur in vast colonies.

1988. [RILEY, C. V.] Covering of egg-puncture mistaken for Dorthesia. <Amer. Nat., July [22 June], 1881, v. 15, p. 574.

Waxy material covering the egg-punctures of Enchophyllum [=Enchenopa] binotata, labeled Dorthesia viburni and D. celastri in collection of A. Fitch.

1989. [Riley, C. V.] [Dolerus unicolor.] <Amer. Nat., July [22 June], 1881 , v. 15 , p. 564.

Doubts the statement of H. Keenan that the imagos of Dolerus unicolor injure the fruit buds of pear-trees.

1990. [RILEY, C. V.] Supposed army-worm in New York and other Eastern States. <Amer. Nat., July [22 June], 1881, v. 15, pp. $574-577$.

Ravages of Nephelodes violans and Crambus vulgivagellus in New Jersey, Long Island, and northern New York; natural history, vernacular namcs, and description of the larva of the former species; previous accounts of this larva.

1991. [RILEY, C. $\nabla$.$] Migration of butterflies. <Amer. Nat., July [22$ June], 1881, v. 15, p. 577.

Report by J. H. Mellichamp of the eastward flight of thousands of Pieris monuste in snall groups of two, three, or more individuals, on 1 and 2 June, 1881, over Bluffton, S. C.; description of larva and pupa; food-plants of larva.

1992. [RILEY, C. V.] Classification of the mites. • < Amer. Nat., July [22 June], 1881, v. 15, 119. 577-578.

Abstract of letter of G. Haller; obscrvations on the appendages and systematic position of the Acarina.

1993. [RILEY, C. V.] Carrying out the law. <Amer. Nat., July [22 June], 1881, v. 15, p. 578.

A fine of $£ 5$ imposed upon a cnan in England for importing living Doryphora decemlineata into that country.

1994. Riley, C. V. Locusts and locusts. <N. Y. Tribune, 22 June, 1881. S.-b. No. 32 , pp. 55-56; No. 42, pp. 7-11.

Cicada $[=$ Tibicen] septendecim and $C .[T$.$] tredecim compared with Caloptenus$ spretus to explain and correct the confusion of the species by those who call them all "locusts"; differences in the habits and characters of these 
1994. RILEY, C. V.-Continued.

insects, their periodicity and distribution; no fear that $C$. spretus will commit great ravages this ycar; recommendation of a system of observations and warnings by the United States Signal Service to guard against unexpected inroads of $C$. spretus.

1995. RILEY, C. V. The caterpillar nuisance. <Evening Star [Washington, D. C.], 24 June, 1881, v. 57, No. 8802 , p. 3. S.-b. No. 23 , p. 152 ; No. 42 , p. 13 . Reprint: <Amer. Nat., September [23 August], 1881, v. 15, pp. 747-748, 1 fig.

Natural history of Hyphantria textor [=cunea]; means against it; methods of applying poisoned liquids to treos.

1996. RIEY, C. V. Directions for cultivating pyrethrum for insect powder. <Gardener's Mo. and Hortic., June, 1881, v. 23, pp. 172-173. S.-b. No. 23, p. 153.

Directions for raising Pyrethrum cinerariafolium from seed ; climate not favor. able to the growth of $P$ roseum; preparation of these plants for the destruction of insects.

1997. Riley, C. V. Cotton-worms and Cicadas. Prof. Stelle's logic! <Selma [Ala.] Times, 19 July, 1881. S.-b. No. 24, pp. 44-45; No. 39, p. 123.

Criticism of statements of J. P. Stellc; impossibility of exterminating Aletia xylina; waves of destructiveness; Cicada [= Tibicen $]$ tredecim abundant in sections of Alabama, as predicted.

1998. Riley, C. V. The Rocky Monntain locust, alias Western grasshopper. <Amer. Agric., July, 1881, v. 40, pp. 283-284, 6 figs. S.-b. No. 23, p. 142.

Summary of facts concerning the egg-lajing development, habits, food-plants, destructive powers, migration, flight, and enemies of and means against Caloptenus spretus; figures of the eggs of the insect in all stages, of the manner of oviposition, and of pans for the destruction of the locusts; prospects of future injury.

1999. Riley, C. V. Lepidopterological notes. <Papilio, July, 1S81, v. 1, pp. 106-110.

Advance print of extracts from Bull. No.6, U. S. Entomological Commission, pp. 56-58, 78, 82-83. Seo No. 2026 for synopsis of contents.

2000. Riley, C. V. Further notes on the pollination of Yucca and on Promuba and Prodoxus. <Proc. Amer. Assoc. Adv. Sci. for 1880, 14 October, 1881, v. 29, pp. 617-639, 16 figs. Separate: $<$ [Salem, Mass, July, 1881], 23 pp., 16 figs.

Recapitulation of publishcd observations on Pronuba yuccasella and Prodoxus dccipiens, with additional observations and references to literature; habits and functions of the two specics; descriptions and figures of the generic characters of Proniba, Prodoxus, and Hyponomeuta, and of the specific characters of Pronuba yuccasella, P. maculata n. sp., Prodoxus decipiens, $P$. intermedius n. sp., $P$. marginatus n. sp., $P$. cinereus n. sp., $P$. anescens n. sp., Hyponomeuta malinella, and $H$. multipunctella, especially tho structure of the ovipositor and the male characters, and the venation of the wings; discussion of the structure of the ovipositor in Lepidoptera characterization of the new family Prodoxida to comprise Pronuba and Prodoxus; generic and specific synonymy ; reply to criticism of T. Meehan ; lisi of insects frequent. ing Yucca; synonymical list of the described Prodoxio. 
2001. Rilex, C. V. Additional notes on the army worm, Leucania unipuncta. <Proc. Amer. Assoc. Adv. Sci. for 1880 [1t October], 1881, v. 29, pp. 640-612. Separate: <Salem, Mass., July, 1881, pp. 24-26. Abstract: <Boston Daily Advertiser, 2 September, 1880, v. 136, p. 4.

Number of annual generations of Leucania unipuncta; stages at which hibernation takes place; occasional immigration of moths into uninfested districts; preferred breeding-places; connection of wet and dry seasons with the abnndance of these insects.

2002. RrLey, C. $\nabla$. The hitherto unknown life-habits of two genera of bee-flies, Bombyliidce. <Proc. Amer. Assoc. Adv. Sci. for 1880 [14 October], 1881, v. 29, p. 649. Separate : <Salem, Mass., July, 1881, p. 33.

Food-animals and food-habits of Systcechus oreas and Triodites mus ; parallelism in the life-history of Bombyliide and Meloida; connection of the abundance of insects of these families in the western United States with the prevalence of Acridide there; retardation of development in the early stages of these parasites explained as a beneficial characteristic.

2003. Riley, C. V. A remarkable case of retarded development. <Sci. Amer., 20 August, 1881 [v.59], n. s., v. 45, p. 116. S.-b. No. 23, p. -

Report of a case in which eggs of Caloptemus spretus remaincd undeveloped for a period of four and one-half years after being laid; remarks upon the problems involved in the explanation of retarded development.

2004. [RILeY, C. V.] Blepharocerida. <Amer. Nat., September [23 August], 1881, v. 15, p. 748.

Discovery by J. Q. Adams of pupæ and imagos of Blepharoceride at Watertown, N. Y.

2005. [Riley, C. V.] Remarkable case of retarded development. <Amer. Nat., September [23 August], 1881, v. 15, pp. 748-749.

Eggs of Caloptenus sprctus, buried about $25 \mathrm{~cm}$. (10 inches) under ground, remained unhatched and alive for four and one-half years, and hatched upon being exhumed.

2006. [RILey, C. V.] Promotion of silk-culture in California. <Amer. Nat., September [23 August], 1881, v. 15, p. 749.

Answer to letter of Mrs. T. H. Hittell; popularization of silk-culture in California; preparation of the fiber for the market.

2007. [Riley, C. V.] Locust flights in Dakota. >Amer. Nat., September [23 August], 1881, v. 15, pp. 749-750.

Flights of Caloptenus spretus in Dakota on 7th and 16th July, 1881; large numbers of Diplax rubicundula accompanying the locusts.

2008. [Rrlex, C. V.] The Hessian fly. <Amer. Nat., September [23 August], 1881, v. 15, p. 750 .

Extensive damages done by Cecidomyia destructor in Illinois and Missouri ; its abundance in the western prairie States in 1881. 
2009. [RILey, C. V.] The genuine army-worm in the West. <Amer. Nat., September [23 August], 1881, v. 15, p. 750.

Occurrence and ravages of Leucania unipuncta in Illinois and Indiana in 1881; these larvæ either from eggs of hibernated moths or of a second brood; other insects mistaken for this in other States; periods of the Lencania and influence of the seasons upon it.

2010. [RILex, C. V.] A new imported enemy to clover. <Amer. Nat, September [23 August], 1S81, v.15, pp.750-751.

Clover injured by Phytonomus punctatus at Barrington, N. Y., in Júly, 1881.

2011. [RILEy, C. V.] Another enemy of the rice-plant. < Amer. Nat., September [23 August], 1881, v. 15, p. 751.

Rice-plants injured by the larva of Laphygma frugiperda in Georgia in the summer of 1831.

2012. [RILEy, C. V.] Canker-worms. <Amer. Nat., September [23 August], 18S1, v. 15, p. 751.

Exccssive ravages of Palcacrita vernata in Tazewell County, Illinois, in 1881. 2013. [Rrley, C.V.] Lepidopterological notes. <Amer. Nat., September [23 August], 18s1, v. 15, pp. 751-752.

Advance extract from Bull. No. 6, U. S. Entomological Commission, pp. 5556. See No. 2026 for synopsis of contents.

2014. Riley, C. V. The periodical Cicada. <Amer. Agric., August, 1881, г. 40, p. 132, 5 figs. S.-b. No. 23, p. 141.

Brief sketch of the natural history of Cicada $\lceil=$ Tibicen $]$ septendecim and $C$. $[=T$. $]$ tredecim, with figures of all stages and of punctured twigs; the reputed stinging by these insects probably done by Stizus grandis [= Sphecius speciosus] ; figure of the Stizus; recommends the substitution of the name "periodical Cicada" in place of the name "locust."

2015. Rruex, C. V. Entomological notes. <Farmer's Review, 22 September, 1881. S.-b. No. 42, pp. 54-55. Reprint: <Amer. Nat., [3] December, 1831, v. 15, pp. 1012-1013. See : <Sci. Amer., 11 February, 1882. S.-b. No. 38, p. 11.

Abstract and critical review of paper by M. Saint-André; attempted explanation of the immunity of grape-vines in sandy soil from the ravages of Phylloxera vastatrix.

2016. Riley, C. V. Notes on Hydrophilus triangularis. <Amer. Nat., October [23 September], 1881, v. 15, pp. 814-817, figs. 1-2.

Description and figures of egg-case and figures of eggs and of male imago, with structural details of Hydrophilus triangularis; characters and life-history of the larva and pupa ; figures of eggs, egg-case, larva, and pupa of $H$. piceus of Europe.

2017. [RILEY, C. V.] Migration of plant-lice from one plant to another. <Amer. Nat., October [23 September], 18\$1, v. 15, pp. 819-\$20.

Exposition of J. Lichtenstein's theory that most Aphidida, especially gallmaking Pemphigini, live upon two different plants in passing through their cycle of development ; cites instances in which the host-plants are of different families.

2018. [RILEy, C. V.] The chinch-bug. <Amer. Nat., October [23 September], 1881, v. 15, pp. 820-821.

The abundance of Blissus leucopterus is connected with the moisture of the season; extraordinary noxiousness of this insect in the dry season of 1881 in various parts of the United States. 
2019. [Rilex, C. V.] Phylloxera laws. <Amer. Nat., October [23 September], 1S81, v. 15, p. 821.

Snmmary of the existing laws regulating the traffic in plants, with a view of preventing the introduction of Phylloxera vastatrix into different countries.

2020. [RILex, C. V.] One half the vine area of France affected by Phylloxera. <Amer. Nat., October [23 September], 1881, v. 15, p. 821.

Statement that uearly onc-fourth of the area of vineyards in France is de. stroyed by Phylloxera vastatrix and as much more attacked; submersion the only sure remedy, and the use of American resistiug stocks the only available preventive.

2021. [Riley, C. V.] London purple and Paris green. <Amer. Nat., October [23 September], 1881, v. 15, p. 821.

London purple more than twice as efficacious and less expensive than Paris greeu as an insecticide; it needs to be well ground; composition of London purple.

2022. [RILey, Q. V.] Entomologist for the Pacific coast. <Amer. Nat., October [23 September], 1881, v. 15, pp. 821-822.

Notice of attempts made to have a State entomologist appointed in California.

2023. [RIlex, C. V.] 'Dilar in North America. <Amer. Nat., October [ะ3 September], 1881, v. 15, p. 822 .

Notice of paper by R. McLachlan.

2024. [Rilex, C. V.] Locusts in Nevada. <Amer. Nat., October [23 September], 1881, r. 15, p. 822.

Statement from Reno [Nev.] Journal that the countless locusts which hatched in western Nevada in the spring of 1881 flew toward the Sicrra Nevada without doing any iujury.

2025. [RIley, C. V.] Odor in butterflies. <Amer. Nat., October [23 September], 1881, v. 15, p. 822.

Notice of paper by Miss M. E. Mnrtfeldt.

2026. Rilex, C. V. General index and supplement to the nine reports on the insects of Missouri. <Bull. No,6, U .S. Ent. Commission [24 March], 1881, 178 pp.

Order of matter: (1) Introduction. (2) Table of contents. (3) Corrections. (4) Notes and additions. (5) Descriptious of new spccies and varieties. (6) List of descriptions of adolescent states. (7) List of descriptions, mostly amplified, of species not new. (8) List of illustrations by reports. (9) Classified list of illustrations. (10) General index. (11) Index to foodplants.

2027. [RILEY, C. V.] The permanent subsection of entomology at the recent meeting of the A.A. A. S. <Amer. Nat., 1881, v. 15, November [28 October], pp. 909-912; [3] December, Fp. 10081011.

Notice of the meeting at Cincinnati, Ohio, August, 1881, with abstracts and notices of papers read.

2028. Riley, C. V. The new imported clover enemy. <Amer. Nat., November [28 October], 1881, v. 15, pp. 912-914.

Occurrence and habits of Phytonomus punctatus in New York; description of the egrg and larva of the same; food-plants of the European species of Phytonomus. 
2029. Riley, C. V. Crambus vulgivagellus. <Amer. Nat., November [2S Uctober], 1881, v. 15, pp. 914-915.

Excessive abundance of this species in the eastern United States in 1881; description of the egg; method of oviposition.

2030. Riley, C. V. Larval habits of Sphenophori that attack corn. <Amer. Nat., November [28 October], 18s1, v. 15, pp. 915-916. Several species of Sphenophorus injurions to maize-plants in different parts of the United States; habits and ravages of S. robustus.

2031. [Riley, C. V.] Effect of drought on the Hessian fly. <Amer. Nat., November [ 28 October], 1881, v. 15, p. 916. See : $<$ N. E. Farmer, 10 December, 18s1. S.-b. No. 45, p. 39. <Farmer's Review, 15 December, 1881. S.-b. No. 45, p. 99.

Hot and dry weather dries up and kills Cecidomyia destructor and its parasites.

2032. [RIley, C. V.] Simulium from Lake Snperior. <Amer. Nat., November [2S October], 1881, v. 15, p. 916.

Notice of paper by H. A. Hagen; larvie and pupe from Lake Superior similar to those of S. pictipes, but the imagos from the same locality are different.

2033. [RIley, C. V.] Coleopterous cave fauna of Kentucky. <Amer. Nat., November [28 October], 1881, v. 15, pp. 916,917.

Notice of H. G. Hubbard's investigations; Adelops contains but one species, which seems to be equally common in all caves in the State; Ancphtíalmus contains several species, and more may be expected to be found.

2034. [Rilex, C. V.] Hemipterological studies. <Amer. Nat., November [28 Uctober], 1881, v. 15, p. 917.

Notice of paper of V. Siguoret.

2035. [Rilex, C. V.] Entomology in Buffalo, N. Y. <Amer. Nat, November [28 October], 1881, v. 15, p. 917.

Notice of Vol. 4, No. 1, of the Bulletin of the Buffalo Society of Natural Scieuce; list of entomological papers therein.

2036. [RIley, O. V.] Lampyriace. <Amer. Nat., November [28 October], 1881, v. 15, p. 917.

Notice of paper by J. L. Leconte.

2037. [Rrley, C. V.] Severe cold and hibernating apple-worms. <Amer. Nat., November [28 October], 1881, v. 15, p. 917.

According to A. J. Cook larvæ of Carpocapsa pomonella were killed in their cocoons where cxposed to the severe cold of the winter of 1880-1881.

2038. Riley, C. V. |Address delivered 4 November, 1881, at the cotton convention held in Atlanta, Ga., $2-4$ November, 1881.] $<[\mathrm{U}$. S. Department of Agriculture.] Address of Hon. George B. Loring... and other proceedings of the cotton convention, Washington, 18s1, pp. 19-35. Reprint: <Atlanta Constitution, 5 November, 1881. S.-b. No. 24, p. 34.

Beneficial and injurious inflnenco of inscets; methods of counteracting the same; ravages and natural history of and search for means against Aletia argillacea $[=x y l i n a]$; improved methods and contrivances for the application of poisons to plants. 
2039. Rilex, C. V. The chinch bug. <Amer. Agric., November, 1881, v. 40, p. 476, figs. 1-3. S.-b. No. 42, pp. 21-23.

Ravages, food-plants, and uatural history of Blissus lencopterus; descriptions and figures of its several stages and of dimorphic form of the imago; effect of wet weather upon it.

2040. [RlLex, C. V.] Retarded derelopment in insects. <Amer. Nat., [3] December, 1881, v. 15, pp. 1007-1008. Reprint: <Proc. Amer. Assoc. Adv. Sci. for 1881, [13 October], 1882, v. 30, pp. 270, 271. Notice : <Gardener's Chronicle, 27 May, 1882, v. 17, pp. 708-709. S.-b. No. 42, p. 31 .

Eggs of Caloptenus spretus retained their vitality four and one-half years under abnormal environment and then hatehed on exposure to normal conditions; speculations on the cause of the phenomena of retardation of development.

2041. [Rrlex, C. V.] Preparation of Diptera. <Amer. Nat., [3] December, 1881, v. 15, p. 1008.

Notice of paper of J. Mik.

2042. [RIley, C. V.] Another herbivorous ground-beetle. <Amer. Nat., [3] December, 1881, v. 15, p. 1011.

Anisodactylus confusus injuring strawberry-plants in California.

2043. [Riley, C. V.] A disastrous sheep parasite. <Amer. Nat., [3] December, 1881, v. 15, p. 1011.

A parasite (Trichodectcs ovis?) doing great injury to sheep in Illinois.

2044. [Riley, C. V.] Locusts in the West. <Amer. Nat., [3] December, 1881, v. 15, p. 1013.

Caloptenus spretus scarce in Colorado and Kansas; Camnula pellucida abundant on the Pacific coast; destructiveness of locusts in many parts of South America and of Pachytylus migratorius in Turkey; means adopted against the latter.

2045. [RrLex, C. V.] Structure of the claw in Psocina. <Amer. Nat., [3] December, 1881, v. 15, pp. 1013-1014.

Notice of paper of H. A. Hagen.

2046. [Rrley, C. V.] Insect collection for sale. <Amer. Nat., [3] December, 1881, v. 15, p. 1014.

Notice of the collection of Coleoptera left by C. Trabrandt.

2047. Rrley, C. V. Peach-tree bark-borer. Important note from Prof. C. V. Riley. <Rural New Yorker, 24 December, 1881, v. 40, p. 866. S. b. No. 42, p. 13.

Habits and ravages of Phlcotribus liminaris; means against bark-borers.

2048. Rrlex, C. V. The chinch-bug. <Amer. Agric., December, 1881, จ. 40, p. 515, figs. 1-4. S. b. No. 42, pp. 23-2

Figurcs Anthocoris [三Triphleps] insidiosus and Harpactor $[=$ Milyas $]$ cinctus as enemies of Blissus leucopterus and Nysius destructor [=angustatus] and Piesma cinerea as likely to be confounded with it; mentions other enemies of the chinch-bug; means against it; importance of irrigation.

2049. Rrley, C. V. On the oviposition of Prodoxus decipiens. <Amer. Nat., January, 1882 [30 December, 1881], v. 16, pp. 62-63. Re. print: <Proc. Amer. Assoc. Adv. Sci. for 1881 '13 October], 
2049. Riley, C. V.-Continued.

1882, v. 30, p. 272. Separate: < [Salem, Mass., February, 1882], p. 3.

Time and manner of oviposition of Prodoxus decipiens in stem of Fucca filamentosa.

2050.' [RILEy, C. V.] Clover insects. <Amer. Nat., January, 1882 [30 December, 1881], r. 16, p. 63.

Notice of paper of J. A. Lintner.

2051. Riley, C. V. Horn's classification of the Carabidoc. <Amer. Nat., January, 1882 [30 December, 18s1], v. 16, pp. 63-64.

Notice of paper of G. H. Horn.

2052. [RILey, C. V.] The butterfly-trees of Monterey again. <Amer Nat., January, 1882 [30 December, 1881], v. 16, p. 64.

Swarming and migrating habits of Danais archippus; hibernation of the same.

2053. [RILEY, C. V.] Interest felt in economic entomology in California. <Amer. Nat., January, 1882 [30 December, 1881], v. 16, p. 65.

Notice of a call issued by the Board of State Horticultural Commissioners of California for a State convention to consider horticultural subjects, including means against insects.

2054. [Rlley, C. V.] Obituary. <Amer. Nat., January, 1882 [30 December, 1881], v. 16, p. 65 .

Biographical notice of J. D. Putnam; announcement of the death of G. V. Mniszech.

2055. Riley, C. V. New insects injurious to agriculture. <Amer. Nat., February [25 January], 1882, v. 16, pp. 151-152. Reprint: <Proc. Amer. Assoc. Adv. Sci. for 1881, [13 October], 1882, v. 30, pp. 272-273.

The occurrcnce of previously unnoticed noxious insects dne to, 1 , the introduction of species from abroad; 2, previously existing unnoticed species; aud 3 , the acquisition of new habits by previously known innoxious species; in the last case the acquisition of new habits may be accompanied by the acquisition of new descriptional character, thus constituting a new species; new spccics thus become developed within bricf periods of time.

2056. [RILex, C. V.] New entomological periodicals. <Amer. Nat., February [25 January], 188: v. 16, pp. 152-153.

Notice of several prospective periodicals.

2057. [RIley, C. V.] Locust probabịlities for 1882. < Amer. Nat., February [25 January], 1882, v. 16, p. 153.

Favorable prospects of immunity from ravages of Caloptenus spretus in 1882.

2058. [Riley, C. V.] Entomological notes. <Amer. Nat., February [25 January], 1882, v. 16, p. 153.

Notice of J. J. Weir's paper on the "Lcpidoptera of the Outer Hebrides," etc.

2059. [RILEY, C. V.] Bibliography of gall literature. <Amer, Nat., March [24 February], 18s2, v. 16, pp, 246-247.

Notice of the record of F. Thomas, 
2060. Rilex, C. V. A new depredator infesting wheat-stalks. <Amer. Nat., March [24 February], 1882, v. 16, pp. 247-248, fig. 1.

Isosoma allynii French is a species of Eupelmus probably parasitic on some of the wheat-stalk feeders and on some species of Chlorops; habits and figures of larva and description of female imago of Isosoma tritici [p. 247]; comparisons between $I$. tritici and $I$. hordei; alleged habits of I. lineare of Europe; rclative conspicnonsness of the " humeral spot" in Europcan, American, and Australian species of Isosoma. Sce No. 2063.

2061. Riley, C. V. Further notes on the imported clover-leaf weevil (Phytonomus punctatus). <Amer. Nat., March [24 February], 1882 ; v. 16, pp. $248,249$.

Identity of Phytonomus opimus Lec. with P. punctatus Fab. ; instances in which injurious insects have been overlooked for a long time; probability that plant-feeding Coleoptera imported frow Europe will not spread far from the Atlantic coast; some species, injurious in Europe, are thus far innoxious in America; hibernation of and means against $P$. punctatus.

2062. [RILEY, C. V.] Silk-worm eggs; prices and where obtained. <Amer. Nat., March [21 Febrnary], 1882, v. 16, pp. 249-250.

Sources from which eggs of Sericaria mori can be obtained in the United States for purposes of silk-culture; prices at which eggs are sold by Crozier \& Co.

2063. Riley, C. V. The wheat Isosoma. A new depredator infesting wheat-stalks. < Rural New Yorker, 4 March, 1882. S.-b. No. 42, pp. 55-56. See: <Sci. Amer. Suppl, 17 June, 1S82. S.b. No. 37, p. 57.

Descriptiou of female imago of Isosoma tritici; habits, ravages, and distribution of and means against the same; comparison with related species; a probable parasite of it, described as Isosoma allynii by G. H. French, belongs to the genns Eupelmus. See No. 2060.

2064. Riley, C. V. Possible food-plants for the cotton-worm. <Amer. Nat., April [22 March, 1832], v. 16, pp. 327-329. Reprint: <Rept. [U. S.] Com. Agric. for 1881 and 1882, 1882 [January, 1883], pp. 164-166. Separate: <pp. 164-166.

Food-plants of Aletia xylina. See No. 2119 for synopsis of contents.

2065. [RIley, C.V.] Mode of feeding on the larva of Dytiscus. <Amer. Nat., April [22 March], 1882, v. 16, p. 330.

Notice of paper of E. Burgess ; structure of the mouth of the larva of Dytiscus; manner in which this larva feeds.

2066. [RIley, C. V.] Entomological notes. <Amer. Nat., April [22 March], 1882, v. 16, p. 330 .

Brief notices of screral articles recently published with items of news.

2067. [RiLEy, C. V.] Riley's researches. Orange insects and the cottonworm; how the orange insect operates and the cure for its ravages; the hibernation of the cotton-worm; settlement of a mooted question. <Florida Daily Times, 29 March, 1882. S.b. No. 42, pp. 28-29.

Report of interview with C. V. Riley; discovery by W. H. Ashmead that "orange rust" is caused by a mite; habits of and means against the same; 
2067. RILEy, C. V.-Continued.

successful application by H. G. Hubbard of an emulsion of kcrosene and milk as a means against this mite and against scale-insects; proof of the hibernation of Alctia argillacca $[=x y$ lina $]$ in the extrcme south of the United States; means against the Aletia.

2068. Riley, C. V. Prof. C. V. Riley and the Yucca moth. <Gardener's Mo. and Hortic., March, 1882, v. 24, p. 92. S.-b. No. 23, pp. 198-199.

Critical review and reply to editorial of T. Meehan.

2069. RILEY, C. V. The Noctuida in the Missouri entomological reports. $<$ Papilio, March, 1882, v. 2, pp.41-44. Separate: <N. Y., 1882, $4 \mathrm{pp}$.

Critical review of paper of A. R. Grote; discussion of the synonymy of the Noctuidoe in the Missouri entomological reports.

2070. Riley, C. V. Silk-culture in the United States. <Sci. Amer., 1 April, 1882 [r. 60], n. s., v.46, p. 193. S.-b. No. 42, pp. 93-96.

Statement of the dangers to be avoided and the obstacles to be overcome for the successful establishment of silk-culture in the Uniterl States.

2071. Riley, C. V. Little known facts about well known animals. A lecture delivered in the National Museum, Washington, D. C., April 8, 18\$2. <Washington, April, 1882, 32 pp., figs. See: $<$ National Farmer, 13 July, 1882. S.-b. No. 42, p. 15. <Prairie Farmer, 22 July, 1882. S.-b. No. 46, p. 99.

The entomological subjects include brief and popular illustrated accounts of the life-histories and transformations of the house-fly (Musca domestica) and mosquito (Culex pipren s); the development of Trombidium from Astoma; parasitism; truth of the theory of evolution; reasons for the prevalent ignorance of natural history; interest and value of a knowledge of natural history.

2072. Riley, C. V. Lichtenstein's theory as to dimorphic asexual fo. males. <Amer. Nat., May [24 April], 18s2, v. 16, p. 409.

Criticism of J. Lichtenstcin's theory that winged female Aphidida and asexual female Cynipidce are larve, and their eggs pupx; crrors in the comparison of these forms with the hypermetamorphotic stages of Mcloida.

2073. [RILEy, C. V.] Naphthaline cones for the protection of insect collections. <Amer. Nat., May [24 April], 1882, v. 16, pp. 409410.

Use of and objections to the use of naphthaline cones; formula of a preferable protective mixture.

2074. [RIlex, C. V.] Injurions insects in California. <Amer. Nat., May [24 April|, 1882, v. 16, p. 410.

- Notice of treatise of Mattherw Cooke.

2075. [RILEy, C. V.] Sarcophaga lineata destructive to locusts in the Dardanelles. <Amer. Nat., Hay [24 April], 1852, v. 16, pp. $410-411$.

Notice of communications, by F. Calvert, regarding the parasitic habits of Sarcophaga lineata, which preys upon Edipoda cruciata; egg-pods of the same locust destroyed by larro of Callostoma fascipennis. 
2076. [Rlley, C. V.] Parasitic Diptera. <Amer. Nat., May [24 April], 1882, v. 16, p. 411.

Dilophus parasitic in larvæ of Chcetoptria hypericana; the Bibionidae have hitherto been known only as vegetable feeders in the larval state.

2077. Riley, C. V. The cotton-worm. <Times-Democrat [New Orleans], 7 May 1882, v. -, p. 4. S.-b. No. 42, pp. 29-31; 112113 ; No. 63, pp. 47-4S. Reprint: <Rept. [U. S.] Com. Agric. for 1881 and 1882, 1882 [January, 1883], pp. 157-159. Separate: $<$ pp. 97-99.

See No. 2119 for synopsis of contents.

2078. Riley, C. V. The house-fly. <Prairie Farmer, 13 May, 1882. S.-b. No. 39, p. 122. See: <Colman's Rural World, 15 June, 1882. S.-b. No. 68, p. 194. <Times-Democrat [New Orleans], 24 June, 1882. S.-b. No. 42, p. 31. <N. E. Farmer, 5 August, 1882.

Wide distribution of Musca domestica; identity of $M$. harpyia with the species; description of eggs; habits, transformations, and hibernation.

2079. Riley, C. V. Habits of Cybocephalus. <Amer. Nat., June [20 May], 1882, v. 16, p. 514.

Cybocephalus nigritulus feeds on scales of Chionasp is pinifolii on Pinus elliottii in South Carolina, and C. californicus on a scalo on apple-trees in California.

2080. [Rrley, C. V.] One effect of the Mississippi floods. <Amer. Nat., June [20 May], 1882, v. 16, pp. 514, 515.

Probability that Ligyrus rugiceps will have been drowned out of the region submerged for months by the Mississippi River; liability of the importation of new foes with new seed-plants.

2081. [Riley, C. V.] Doryphora decemlineata in England. <Amer. Nat., June [20 May], 1882, v. 16, p. 515.

A living specimen carried from North America to London, England, in a barrel of potatoes.

2082. [RILEY, C. V.] Dr. Dimmock's inaugural dissertation. <Amer. Nat, June [20 May], 1882, v. 16, p. 515.

Review of G. Dimmock's paper on "The anatomy of the mouth-parts and of the sucking apparatus of some Diptera."

2083. [Riley, C. V.] The triungulin of Meloida. <Amer. Nat., June [20 May], 18s2, v. 16, p. 515.

The triungulin of Meloe proscarabceus was described by J. L. Frisch in 1727.

2084. [RIley, C: V.] Fossil tineids. <Amer. Nat., June [20 May], 1882, v. 16, p. 515 .

Notice of paper of $\mathrm{V}$. T. Chambers; occurrence of the supposed burrow of a tineid larva in a fossil leaf of Acer sp.

2085. [RIley, C. V.] Classification of North American Coleoptera. $<$ Amer. Nat., June [20 May], 1882, v. 16, pp. 515-516.

Notice of the approaching completion of the classification of the Coleoptera of North America by J, I, Leconte and G. H. Horn. 
2086. Riley, C. V. Hibernation of the army-worm. <Amer. Nat., June [20 May], 1882, v. 16, p. 516.

Confirmation of views in regard to the hibernation of the larva of Leucania unipuncta; places of oviposition; prospects of extensive injury by these insects in the more northern States in 1882.

2087. RILEy, C. V. Chinch-bug and army-worm prospects. <Rural New Yorker, $27 \mathrm{May}, 1882$. S.-b. No. 61, p. 27.

Blissus leucopterus abundant in dry weather; Leucania unipuncta in wet weather; the latter hibernates principally as a larva; its egges secreted in old grass and stubble; means against $L$. unipuncta.

2088. Riley, C. V. Successful management of the insects most destructive to the orange. <Sci. Amer., 27 May, 1882 [ $\mathrm{v} .60$ ], n. s., . 46 , pp. 335-336, 5 figs.

Treats of Coccida injurious to the orange; means against the same; use of kerosene emulsion; figures stages of Mytilaspis pomicorticis $[=$ pomorum $]$, M. gloveri, and M. citricola.

2089. Riley, C. V. The utilization of ants in horticulture. <Nature, $S$ June, 1882, v. 26, p. 126. Reprint: <Gardener's Chronicle, 17 June, 1882, v. 17, p. 805 . S.-b. No. 42, p. 32.

Abstract of paper of C. J. Macgowan; capture and sale of two species of ants which build nests in trees; colonization of these ants in orange orchards to destroy injurious insects.

2090. Rrley, C. V. The army-worm vs. the clover hav-worm. Remedies for the army-worm. <Rural New Yorker, 10 June, 1882. S.-b. No. 47, pp. 158-159; No. 61, pp. 32-33. Reprint: <Nat. Farmer, 22 June, 1882. S.-b. No. 37, p. 123. <Lancaster Farmer, July, 1882. S.-b. No.46, p. 104. "<Home and Farm, 1 July, 1882. S.-b. No. 37, p. 122.

Abundance of Leucania unipuncta and Asopia costalis in Alabama and Tennessee; confusion of the army-worm with the clover hay-worm; prevalence of enemies of and means against the former.

2091. Riley, C. V. Repelling insects by malodorants. <Amer. Nat., July [22 June|, 1882, v. 16, p. 596 .

Critical review of paper of J. A. Lintner; odorous substances repel insects more by their toxic properties than by their odor; failnre of attempts by the use of strongly smelling substances to prevent oviposition; sight, touch, and taste generally more important in inscet economy than smell.

2092. [RIley, C. V.] Habits of Bittacus apterus. <Amer. Nat., July [थ2 June], 1882, v. 16, pp. 596-597.

Notice of paper of C. R. Osten Sacken ; locomotion and food-habits of Bittacus apterus in California.

2093. Riley, C. V. Habits of Coscinoptera dominicana. <Amer. Nat. July [22 June], 1882, v. 16, p. 598.

Discovery by F. H. King that Coscinoptera dominicana is inquilinous in ants' nests in its earlier stages; similar habits of related species.

2094. [RILEY, C. V.] Sun-spots and insect life. <Amer. Nat., Jnly [22 June], 1882, v: 16, pp. 598-599.

Review of paper of A. H. Swinton; dependence of certain insect phenomena on the periods of sun-spots, through the determination by the latter of meteorological conditions. 
2095. Riley, C. V. The silk-worm. No. 1-3. <National Farmer, 13, 20, 27 July, 1882. S.-b. No. 35, p. 15; No. 48, pp. 32, 49.

Nature of the silk-worm; stages, enemies, diseases, races; wintering and hatching of eggs; feeding and rearing of larvæ; the cocoons; spinning and gathering, choking chrysalids; egg-laying, reproduction, reeling, foodplants.

2096. RrLEY, C. V. Change of habit; two new enemies of the eggplant. <Amer. Nat., August [28 July],.1882, v. 16, pp. 678679.

Sudden acquisition by Doryphora juncta and by Cassida texana of the habits of foeding on Solanum melongcna, these species having been found previously on S. carolinense and $S$. elaagnifolium respectively; occurrence of C. texana on $S$. carolinense; distribution of the two insects.

2097. Riley, C. V. Notes on Microgasters. <Amer. Nat., August [28 July], 1882, v. 16, pp. 679-680.

Critical review of paper of A. S. Packard; synomymical notes on Packard's specics.

2098. [RILEY, C. V.] A re honey-bees carnivorous? <Amer. Nat., August [28 July], 1882, v. 16, p. 681.

Observations of Fritz Müller on the carnivorous habits of Brazilian Apida.

2099. [RILey, C. V.] The "overflow bugs" in California. <Amer. Nat., August [28 July], 18s2, v. 16, pp. 681-682.

Extract from ietter of Mrs. A. E. Bush, with introductory remarks; occurrence of Platymus maculicollis in such abundance as to become a nuisance.

2100. [RILey, C. V.] Insects and drouth. <Amer. Nat., September [24 August], 1882, v. 16, p. 745.

Occurrence of excessive drouth in the spring and early summer of 1880 in New England; statement by S. Lockwood of the exceptional abundance of several insects in New Jersey in that year.

2101. Rifey, C. V. Probable sound organs in sphingid pupæ. <Amer. Nat., September [24 August], 1882, v. 16, pp. 745-746.

Occurrence of a peculiar structure on the abdominal joints of the pupæ of certain Sphingidae; genera in which this structure is observed; probable connection of this structure with the function of producing sound as observed in Sphinx atropos.

2102. RILEx, C. V. Is Cyrtoneura a parasite or a scavenger? <Amer. Nat., September [24 August], 1882, v. 16, pp. 746-747.

Cyrtoneura stabulans bred from pupæ of Aletia argillacea $[=x y l i n a]$ usual food of this species; doult whether the species is a parasite or is only a scarenger in decayed pupæ; Phora aletice merely a scavenger; great liability of pupæ of Aletia to decay

2103. [RILEx, C. V.] Habits of Polycaon confertus Lec. <Amer. Nat., September [24 August], 1882, v. 16, p. 747.

Polycaon confertus bores in twigs of apple- and pear-trees and grape-vines; the larvo probably live in the dead and dry wood of forest-trees.

2104. Riley, C. V. Dinoderus pusillus as a museum pest. <Amer. Nat., September [24 August], 1882,.v. 16, p. 747.

Dinoderus pusillus feeds on cork and paper lining in an insect box; they occur usually in drugs and other stored and dry vegetal products. 
2105. Riley, C. V. Myrmecophilou's Coleoptera. <Amer. Nat., September ['24 Augnst], 1882, v. 16, pp. 747-748.

Larvis and imagos of Euphoria hirtipes live in hills of Formica rufa; pupæ of Hymenorus rufipes in nests of Formica fusca and of $H$. obscurus in nests of another species of ant; known myrmecophilous habits of Cetonia, (remastochilus, Euparia castanea (in nests of Solenopsis xyloni [= geminatu]), Tenebrionide, and Anthicus.

2106. [RILEY, C. V.] Discontinuance of publication. < Amer. Nat., September [24 August], 1882, v. 16, p. 748.

Announcement of the discontinuance of publication of "Revue Coléopterologique;" critical review of the same.

2107. Rrley, C. V. Buffalo tree-hopper injurious to potatoes. <Ámer. Nat., October [28 September], 1882, v. 15, p. 823.

Habits, food-plants, and ravages of Ceresa bubalus.

2108. [RILEy, C. V.] Moths attracted by falling water. <Amer. Nat., October [28 September], 1882, v. 16, p. 826.

Notice of paper of J. S. Garùner; gleaming water-fallsin Iceland as attractive to moths as artificial light would be.

2109. [Riley, C. V.] A new museum pest. <Amer. Nat., October [28 September], 188", r. 16, p. 826. Reprint: <Psyche, September-October, 1882 [1 March, 1884], v. 3, p. 408.

Perimegatoma variegatum as a pest in collections of insects.

2110. [RILey, C. V.] Fleas feeding on lepidopterous larvæ. <Amer. Nat., October [28 September], 1882, v.,16, p. 826.

Notice of paper of C.J. Boden; abundance of fleas (Pulex sp.) where few or no ' warm-blooded animals occur may be explained by the feeding of the fleas on insects.

2111. [RILEx, C. V.] [Gasteracantha cancer.] <Gonzales [Tex.] In. quirer, 30 September, 1882. S.-b. No. 42, p. 15.

Habits of Gasteracantha cancer; the male unknown.

2112. Rulex, C. V. Cicada septendecim. <Gardener's Mo. and Hortic., September, 1882, v. 24, pp. 274-275. S.-b. No، 38, p. 42 ; No. 39 , p. 6 ; No. 42, pp. $2-4$.

Orthography of the names $C .[=T i b i c e n]$ septendecim and $C$. $[=T$.$] tredecim;$ natural relations of the sane; indistinguishability of the species of certain genera; dimorphic forms more numerons than usually recognized; Massospora cicadina parasitic on Cicada.

2113. Riley, C. V. Remarkable felting caused by a beetle. <Rural New-Yorker, 14 October, 1882, v. 41, pp. 699-700. S.-b. No. 42, p. 16. Reprint, with changes: <Amer. Nat. [2] December, 1882, v. 16, pp. 1018-1019.

Description of the felting of the interior of a pillow-ticking with fragments of feathers formed by the ravages of Attagenus megatoma within a feather pillow.

2114. Riley, C. V. The buckeye-leaf stem-borer. <Amer. Nat., November [28 October], 1882, v. 16, pp. 913-914. See: <Sci. Amer. Suppl., 16 December, 1882. S.-b. No. 47, p. 145.

Sericoris instrutana $\ddagger$ Claypole $=S$. [= Steganoplycha $]$ claypoleana n. sp.; habits and food-plants of this species and of Proteoteras asculana; distinctions between these two species. 
2115. [RILEY, C. V.] Efficacy of chalcid egg-parasites. <Amer. Nat, November [28 October], 1882, г. 16, pp. 914-915. See: <Prairie Farmer, 2 Decomber, 1882. S. b. No. 60, p. 123.

Beneficial influence and occasional vast abundance of egg-parasitic Chalcidida and especially of Trichogramma pretiosa and of Telenomus sp.

2116. [RILEY, C. V.] On the biology of Gonatopus pilosus Thoms. <Amer. Nat., November [2S October], 1882, v. 16, p. 915.

Notice of paper of J. Mik; parasitism of Gonatopus pedestris on Aithysanus maritima, and of $G$. pilosus on Deltocephalus xanthoneurus; transformations and habits of G.pilosus; probable parasitism of a Gonatopus (G. contortulus?) on Amphiscepa bivittata.

2117. RILEY, C. V. Species of Otiorhynchida injurious to cultivated plants. <Amer. Nat., No vember [28 October], 1.882, v. 16, pp. 915-916. See: <Sci. Amer. Suppl., 16 December, 1882. S.-b. No. 47 , p. 145 .

Aramigus fullevi the only species of N orth American Otiorhynchide whose development and earlier stages are known; food-plants of several species; discovery by G.P. Peffer of the injuries of Anametis grisea upon roots of apple- and pear-trees.

2118. [RILEY, C. V.] Bombyliid larvæ destroying locust eggs in Asia Minor. <Amer. Nat., November [28 October], 1882, v. 16, pp. 916-917.

Notice of and extract from communications of F. Calvert; parasitic habits of Callostoma fascipemis; similarity of habits of Bombyliida in Asia and in North America; probability that the larva of Cantharis vesicatoria and of other Meloidce will be found to feed on eggs of Acridida.

2119. Riley, C. V. Report of the Entomologist. <Ann. Rept. [U.S.] Commissioner Agric. for 1881 and 1882, 1882 [January, 1883], pp. 61-214, $20 \mathrm{pl}$. Separate: <Washington, 1 December, 1882, pp. $8+167,20 \mathrm{pl}$.

CONTENTS.

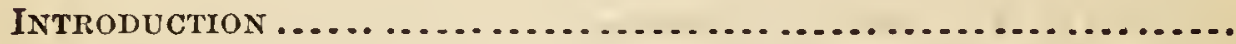

Plan of the report, 1-Insufficiency of former appropriations to the Entomological Division, 1-Reorganization of the Division, 1Great increase in the correspondence of the Division, 2-Preparation of special bulletins, 2-Periodical bulletins desirable, 2Special reports in preparation, 2-Work of the United States Entomological Commission, 3-The United States National Museum in connection with the Entomological Division, 3-Assistants, agents, and observers of the Division, 3-The illustrations to the report, 4.

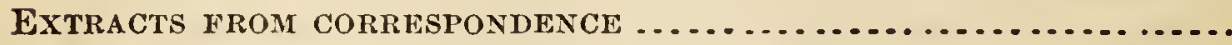

Miscellaneous correspondence on various insects injurious to vegetation in 1881-'8z, 4.

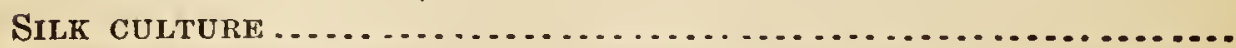

Distribution of eggs by the Department, 7-Mr. L.' S. Crozier's opinion as to the value of American silk products, 7-Mr. E. Fasnach on the importance of a home market for silk products, 8-Associations, 8-Ladics' Association at Spring Hill, Ala., 8-Women's Silk Culture Association of California, 8-Women's Silk Culture Association of the United States, 8-American Silk Exchangc in New York, 8-Sales of eggs and cocoons in the 


\section{Riley, C. V.-Continued.}

SilK CUlTure-Continucd.

United States, 9-Various reports from correspondents of the division, 9-Expcrience in 1882 at the Department in raising worms fed on osage orange or mulberry, 11-New nulberry tree from southern Russia, 13-Business ventures in the United States in connection with silk-producing industr5, 13-Salé of eggs, 13Second edition of the manual of silk culture, 14-Preface thereof, 14-Reasons why the growing interest in silk culture in the United States should be checked at the present time, 15-Import duty on raw silk demanded, 16.

Pyrethrum: Its USE as an InSECTICIDE ...................... Circular in reference to Pyrethrum, 16-Distribution of seed by the Department, 16-History of Pyrethrum in Asia and Dalmatia, 17-Experience in growing Pyrethrum roseum in America, 17Soil best adapted for raising the plant, 18-The Dalmatian plant in California, 18-Experience with raising the plant at Washing. ton, 18-Preparation of the plant for use, 18-Gathering and drying the flowers, 18-Pulverizing, '19-Keeping the powder, 19Advantages and disadvantages of the powder as an insecticide, 19-How Pyrethrum affects different insects, 19-Modes of application, 19-Pyrethrum as dry powder, 19-Pyrethrum applied in fumes, 20-Alcoholic extract, 20-The powder stirred up in water, 20-Tea or decoction, 21-Reports from persons to whom Pyrethrum seed was sent, 21-Success in raising the plant at Washington, 24-Miss M. E. Murtfeldt's experiments with powder on various insects, 25.

Chinch-bug notes, Blissus leucopterus ..........................

Professor Thomas' predictions for 1881, 27-1881 a chinch-bug year, 27-Injury in spring of 1882 in the western States, 27-Irrigation as remedy, 28-Use of kerosene emulsions, 29.

The ARMY worm, Lencania unipuncta........................

Habits and natural history, $30-$ Histors of investigation in America, 30 - Where the eggs are laid, 30-When the eggs are laid, 31Mode of oviposition, 31-Prolificacy of the moth, 32-Duration of the egg state, 32-Habits of the joung worms, 32-Guenée's characterization of Lencania larve, 32-Marching of the worms abnormal, 33-The marching worn not a distinct race, 33-Duration of worm life, 34-Remedies, 34-Burning old grass, 34Predictions of army-worm years unreliable, 35-Mcteorological influences on the species, 35-Ditching and fencing as remedies, 36-Use of arsenical poisons, 36-Kerosene and coal tar, 36Hcavy rolling not to be recommended, 37-"Drawing the rope" of little avail against the worm, 37-Mr. L. O. Howard's report on army-wornı iujury, 1881, in Illinois and Indiana, 37-Reports from correspondents, spring of 1882, 39-Rov. Samuel Lockwood's account of the invasion of 1880, in New Jerses, 44.

Scale insects of the orange, By H. G. Hubbard ..............

Characterization of the species, 46-Comparative destructiveness of the three species trcated of, 47 -Pcriods of migration, growth, and incubation, 47-Scalc inscets easily assailable only during a brief period of their development, 48-The hatching process and its maximum periods, 48-Great vitality of the eggs, 49-The work of enemies and parasites, 49-Lady-bugs, lace-wings, and lepidopterous enemies, 48 -Importance of mites as external 


\section{RILey, U. V.-Continued.}

SCALE INSECTS OF THE ORANGe-Continued.

enemies of scale insects, 49-Hyinenopterous parasites the most efficient destroyers, 49 -Sudden outbursts of the pest, 50-Destruction of the scales by their own undne increase, 51-Injury inflicted on young trees, and faulty methods of destroving the scales, 51-Recapitulation, 51-Remedies, 52-Danger in applying undiluted volatile oils, $5 \%-$ Kerosene, when properly applied, not injurious to the tiee, 52-Process of preparing kerosene butter, 52-Nature of kerosene butter, 53-How it slionld be applied, 54-The kerosene butter a sure remedy, 54-How it affects the scales and the eggs, 54-The aquapult force-pump very convenieut for applying kerosene einulsions, 54-Effect of kerosene emulsion on the tree, 55-Kerosene emulsions experimented with, 55-Whale oil soap as remedy, 56-Oil of creosote, its effect on scale insects and on the trees, 56-Saponaceous componnds of creosote, 57 -Creosote inferior to kerosene as insecticide, 57-Various other substances as remedies, 57-Tables of experiments, 60-Note on more recent discoveries in producing kerosene emulsions, by C. V. Riley, 67.

INSECTS AFFECTING THE RICE-PLANT . . . . . . . . . . . . . . . . .

Rice prodnction in the United States in 1879, 67.

The rice-grub, Chalepus trachypygus .........................

Mr. L. O. Howard's observations on the occurrence and habits of the insect, 68-It can easily be kept in check, 68-Structural characters and geographical distribution of the genns Chalepus, $69-$ Description of imago and larva, 69.

The water-weevil, Lissorhoptrus simplex......................

Colonel Screven ou the specific identity of "the inaggot" and "the water-weevil," $70-\mathrm{Mr}$. L. O. Howard's report on the occurrence of larva and beetle in rice-fields, 70-Habits of the beetle, 71Remarkable shape of the larva, 71 -Characters of the genus Lissorhoptrus, 72-Description of the imago, 72-Description of the larva, 72.

The rice-stalk borer, Chilo oryzcellus.......................

Mr. Howard's account of the work of the larva and the damage caused by it, 73-Enemies, 74-Preventive measures, 74-Difficulties in the specific determination of the insect, $74-$ Characteristics of the genus Chilo, 75-Description of the moth, 75-Description of larva and pupa, 75 .

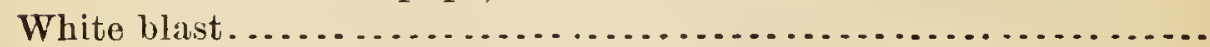

Colonel Screven's account of the disease, 76-Mr. Howard's observations on the insects found on the diseased plants, 77-The blast possibly caused by insect work, 7 .

Other insects injurious to growing rice ......................

The "grass-worm" and its injury, 78-The "lnbber grasshopper," 78-Acridium obscurum and various Heteroptera, 78.

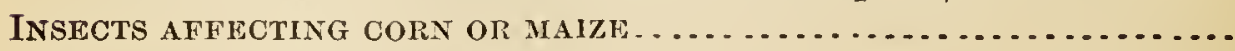

The corn-bill bug, Sphenophorus robustus ....................

Species of Sphenophorous injurious to agriculture, 78-Nature of damage done by the beetles, 79-Mr. Howard's report on the work of the larva and its development, 79-Preventive measures, $80-$ Burning the stubble in winter time to be recommended, 80 -Generic characters of Sphenophorus and its natural groups, 80-Diagnosis of the imago, 81-Description of the larva, 81-Larva of 
2119. Riley, O. V.-Continued.

INSECTS AFFECTING CORN OR MAIZE-Continued.

Rhodobcenus 13-punctatus and Rhynchophorus zimmermanni, 82-

Description of the pupa, 82.

The smaller corn-stalk borer, Pempelia lignosella ................

First appearance of the pest, 82-Geographical distribution in the

United States, 83-Habits and natural history, 83-Work of the larva, 83-Transformation, 83-Habits of the moth, 83-Prevent ive measures, 84-Color variations of the moth, 84-Mouth parts of the moth, 84-Description of the larva, 84-Description of the pupa, 85 .

The boll-worm, alias corn-worm, Heliothis armigera ...............

Injury to corn in 1881, 85-Food-plants, 85-Identity of the cornworm and boll-worm, 85-Number of broods in the northern States, 86-Nature of damage done to corn, 86-The worm also feeding on hard corn, 87-Corn-fceding broods in the southern States, 87-Damage done to tomatoes, 88-Food-plants of the families Solanacere and Leguminosæ, 88-Cucurbitaceous and malvaceous food-plants, 39-Various other food-plants, 89-List of food-plants probably still incomplete, 89-Carnivorous habit of the worm, 89-Report upon Heliothis armigera, by Judge Lawrence Johnson, 90.

The cotton-woru, Aletia xylina ..........................

Address by C. V. Riley before the Atlanta cotton convention, 93-

Past work on the practical side of the cotton-worm question, 93Obstacles and difficulties of the investigation, 93-Natural history, 94-The insect in its different stages, 94-Time of development and first appearance of the worms, 94-Poisons best applied from beneath, 95-Improvements in machinery for applying poisons, 95-Nozzles of various forms, 96-Machincry for poisoning from below, 96 .

Protection from injury in regions overflowed by the Mississippi.....

Poisons should be applied to the under surface of the leaves, 98Paris green and London purple, 98-Sprinkling and sifting, 98Device for mixing poisons and diluents, 98-Arsenic and arseniate of soda, 98-Early poisoning, 99.

Poisoning devices-machine for spraying from below ..............

The skid, 99-Device for thorough mixing and filling the barrel, 100-Details of barrel, pump, and stirrer, 100-Inserting and extricating the stirrer-bar, 100 -Fork of the descending pipe, 100The nozzles, 102.

Damage in 1881 .

Loss of cotton by worms by States and counties, 102 - Loss of cotton by worms in 1881, tabulated, 104.

Possible food plants of the cotton-worm ......................

No other food-plant than cotton yet found, 104-Eggs of Anomis erosa found on Urena lobata, 104-Eggs and young larva of Anomis erosa distinguished from those of Aletia xylina, 105-Plants upon which eggs related to Aletia were found in the Department herbarium, 105-Localities for malvaceous plants, with possible food-plants of Aletia indicated, 105.

The question of hibernation scttled..........................

Theories of hibernation, 106-Eggs deposited early in March, 106The early brood of worms, 106-Where the moth hibernates, 106-Value of fall and winter preventive work, 106. 
2119. Riley, C. V.-Continued.

Miscellaneous insects . . . . . . . . . . . . . . . . . . . . . . . . ...

The Urena anomis, Anomis erosa .............................

Habits and natural history; resemblance to the cotton-worm, 107Distribution, 107-Its eggs nistaken for those of Aletia, 108-Distinguishing characters, 108-Habits of larvæ, 108-Characters of moth, 109-Descriptive, 109.

The clover leaf-beetle, Phytonomus punctatus .....................

Habits of the genns Phytonomus, 111-Ph. punctatus an Enropean insect, 111-Food-plants of Europcan species, 111-History of $P h$. punctatus in N.A., 111-Specific identity of Ph.punctatus and $P h$. opimus, 112-When first noticed as destructive, 112-Damage in Yates County, N. Y., in 1881, 112-Mr. Schwarz's observations in Jnne, 1882, 113-Life history of the species, 113-The eggs, 113The newly-hatched larrx, 113-Method of locomotion of larvæ, 114-The cocoon, 114-Method of spinning, 115-Its method of spinning differs from that alleged of the European Ph.rumicis, 115-Principal damage done in the beetle state, 115-Feeds on white and red clover, 115-Length of life in the different states, 115-Number of annnal broods, 116-A second brood exceptional, 116-Remedies, 117-Will it spread?, 117-Natural enemies, 117Description of earlier states, 118.

The vagabond Crambus, Crambus vulgivagellus ....................

History of its injury and ideutification, 119-Correspondence with Professor Lintuer, 119-Abundance of the moths in the eastern States in 1881, 119-Habits and natural history, 119-The eggs, 120-The larva and its tube, 120-Habits of the moth, 120-Damage done by the worms, 120-Parasites, 121-Similarity of habit in an Enropean species, 121-Remedies, 121-Descriptive, 121Specimens from Vancouver's Isłand compared, 121-Descriptions of earlier states, 122-Bibliographical list, 122.

The wheat Isosoma, Isosoma tritici . ...........................

Past history and habits, 123-When first studied, 123-Professor Thomas finds it in Illiuois and Dr. Packard in Virginia, 123-Its work differs from that of the joint-worm, 123-Its injuries in Missouri, 124-Professor Freuch's o uservations, 124-Comparisons with the joint-worm and other allied species, 124-Errors corrected, 125-Its relationship to the Enropean I. linearc; habits of latter, 125-Number of broods, 125-Remedies, 125-Parasites, 126-Descriptive, 126-Bibliographical list, 126.

The sorghum web-worm, Nola sorghiella.....................

Its iujuries, 127-Letter from J. P. Stelle, 127-Habits, 128-Method of work, 128-Systcmatic position, 128-Descriptive, 1.28-Earlier stages, 129 .

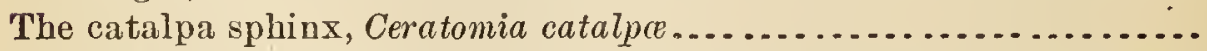

Valne of the catalpa tree, 129-Its usual excmption from insect attacks, 129-Past history of Sphinx catalpce, 129-Its larvæ used as fish bait, 130-Its distribution, 130-Extracts from correspondence concerning the larva, 130-Characters and natural history: The eggs, 131-The larvæ, 131-The pupa, 131-Description of the moth, 131-Number of broods, 132-Remedies, 132-Descriptive, 132-Pecnliarity of structure of pnpa, 133.

The osage orange sphinx, Ceratomia hageni .....................

Value of the osage orange, 133-Ita comparative exemption from insect attack, 133-Rarity of the osage orange sphinx, 133-Its generic place, 133-Characters of the species, 134-Its affinities, 134-Description of larva, 134. 
2119. Riley, C. V.-Continued.

Report on miscellaneous insects, by Prof. J. Henry Comstock.

The apple-maggot, Trypeta pomonella .......................

Its importance compared with the codlin moth, 135-Method of work, 135-Food-plants, 135-Its sprcad, 136-Extracts from correspondence, 136-Early apples principally infested, 136-Technical descriptions of different states, 137-Remedies, 138-Manner of distinguishing it from codlin-moth larva, 138.

The vine-loving pomace-fly, Drosophila ampclophila..............

Reasons for popular name, 139-Reasons for trcating of the species, 139-Where found, 139-Rapidity of multiplication, 139Destructive to grapes, 139-Tcchnical descriptions of different stages, 140-Remedies, 141.

The pretty pomace-fly, Diosophila am $\propto n a . . . . . . . . . . . . . . . . . .$.

Technical descriptions of diffcrent stages, 141-Remedies, 142.

The ocellate leaf-gall of the red-maple, Sciara ocellaris..............

Distribntion, 14.2-Description of gall, 14\%-Description of larva, 143-Its cocoon, 143-Number of generations, 143-Gall described as cecidongid by Osten-Sacken, 143-Another gall-making Sciara, 143-Description of adult male, 144.

Ladybirds, Coccinellide................................

General remarks on habits, 144-The ashy-gray ladybird, 144-Deseription of larva, 144-Description of pupa, 145-'The adult, 145The blood-red ladybird, 145-Description of pupa, 145-The ladybird of the cactus, 145-Descriptions of larva and pnpa, 145-The ambiguons Hippodamia, 146-Descriptions of larva and pupa, 146-Other species observed at Los Angeles, Cal., 146.

Methods of destroying scale insects..........................

Note by the Entomologist, dissenting from the conclusions of this article, 146-Letter from S. F. Chapin, 147-Lettcr from Matthew Cooke, 148-Method of spraying trees in groves, 148-Mr. Chapin's contrivance, 148 .

Lac insects, Carteria . ...................................

General remarks, 149-The genus Carteria of Siguoret, 49-Carteria lacca (Kerr); general appearance, 149-Preparation for study, 150-Technical deseription, 150-Remarks on Mr. Carter's description, 151-Carteria larrew n. sp., 151-Remarks on the creosote plant, 151-Mr. J. M. Stillman's papcr, 151-Differs from C. lacca, 151-Technical description of C. larrea, 152-Carteria mexicana sp., 152-Where fonnd, 152-General appearance, 152-Technical description, 152.

A new wax insect, Cerococcus quercus..........................

General description, 153-Can it be utilized?, 153-Cerococcus new genus, 153-Cerococcus quercus n. sp., 153-Female sac, 153-Female, 154-Male sac, 154.

Note on the strncture of mealy bugs .........................

The anal and genital openmgs distinct, $154-$ 'Two pairs of opcnings homologous with the honey tubes of Aphididx, 154.

2120. [Rrley, C.V.] A new rice stalk-borer: Genus-grinding. <Amer. Nat., [2] December, 1882, v. 16, pp. 1014-1015.

Extract from Rept. [U. S.] Commis. Agric. for 1881 and 1882, pn. 134-135, with additional remarks; Chilo oryzaellus = Diphryx prolatella; Diphryx Grote fonnded on a mutilated specimen, with mistake of maxillary for labial palpi. 
2121. [RILey, C.V.] A butterfly larva injurious to pine-trees. <Amer. Nat., [2] December, 1882, v. 16, pp. 1015-1016.

Habits and ravages of Pieris menapia on yellow-pine and tamarack in Washington 'Territory.

2122. [Riley, O. V.] The army-worm in $1882 .<$ Amer. Nat., [2] December, 1882, v. 16, p. 1017.

Occurrence of Leucania unipuncta in great abundance and with disastrous effects, especially in southern United States in 1882.

2123. [Rilex, C. V.] The wheat-stalk worm on the Pacific coast. $<$ Amer. Nat., [2] December, 18s2, v. 16, pp. 1017-1018.

Isosoma tritici injuring wheat-stalks in Washington Territory; reference to prior notices of this insect.

2124. [RIley, C. V.] Deserved honor. <Amer. Nat., [2] December, 1882, จ. 16, p. 1018.

Notice of the appointment of Eleanor A. Ormerod to be consulting entomologist to the Royal Agricultural Society of Great Britain.

2125. [RILEY, C. V.] Important work on Cynipidce. <Amer. Nat., [2] December, 1852, r. 16, p. 1018.

Notice of G. Mayr's "Die europäischen Arten der gallenbewohnenden Cyni. piden."

2126. Riley, C. V. Emulsions of petroleum and their value as insecticides. <Rural New Yorker, 9 December, 1882, v. 41, pp. 833, 834. S.-b. No. 42, pp. 17-18.

Results of experiments niade upon methods of using petroleum as an insecticide without injury to plants; soap and milk emulsions the most available; methods of preparing the same.

2127. Riley, C. V. The bean-weevil. < Rural New Yorker, 9 December, 1882, v. 41, p. 835 . S.-b. No. 42 , p. 18.

Answer to inquiry of R. J. B.; habits of and means against Bruchus faba.

2128. Riley, C. V. The "cluster-fly." < Prairie Farmer, 23 December, 1882, v. 54, p.7. S.-b. No.42, pp. 16-17. Reprint:<Amer. Nat., [5] January, 1883, v. 17, pp. 82-83.

Habits and synonyuy of Pollenia rudis; notice of other accounts of the swarming of Diptera. See No. 2174.

2129. Riley, C. V. Darwin's work in entomology. <Proc. Biol. Soc. Wash., 1882, v. 1, pp. 70-80.

Analysis of the interest shown by C. R. Darwin in entomology and of his contributions to the same.

2130. Riley, C. V. The cotton-worm. <Western Farmer's Almanac for 1883,1882, p. 40 . S. b. No. 42, p. 71.

Various theories hitherto held in regard to the hibernation of Aletia argillacea $[=x y l i n a]$; proof of its hibernation; seasons and conditions of development of the first brood of the year, precautionary measures to be adopted.

2131. Rilex, C. V. Pfrethrum, an important insecticide. <Western Farmer's Almanac for 1883, 1882, pp. 41-42. S.-b. No. 42, p. 49. See: <Prairie Farmer, 27 January, 18̄3. S.-b. No.42, pp. 56-58.

Condensed account of the history of the use of prrethrum flowers as an insecticide; cultivation of the plants and preparation of the powder; methods of its application; experiments in the cultivation of the plants. 
2132. [Riley, C. V.] New lists of North American Lepidoptera. <Amer. Nat., [5] January, 1883, v. 17, pp. 80-\$2.

Reriews of lists of Brooklyn Entomologieal Soeiety, of C. H. Fernald and A. R. Grote.

2133. [Rilex, C. V.] Naphthaline cones. <Amer. Nat., [5] January, 1883, v. 17, pp. 83,84 .

The cones stain the paper lining of boxes; they seem to destroy mites and Psoci very soon, but have little effeet on Dcrmestida.

2134. Rrley, C. V. Emulsions of petroleum as insecticides. <Sci. Amer., 6 January, 1883 [v. 62], n. s., v. 48, p. 3. S.-b., No. 42 , pp. 4-7.

Notice of experiments made, under author's direetion, in 1852, in tho use of emulsions of kerosene oil ; report of H. G. Hubbard upon experiments made by him; eritieal review of S. F. Chapin's "Seale inseets on deeiduous and ornamental trees;" effeet of pure kerosene, of emulsions, and of lye upon trees.

2135. Rilex, C. V. Entomological notes. <Rural New Yorker, 13 January, 1883. S.-b. No. 42, p. 78. See: <Amer. Nat., 1883, v. 17, pp. 198-199.

1. A new enemy to wax-beans; extraet from letter of G. H. Stone, on the food-plants, habits, and ravages of Epilachna corrnpta; distribution of the same. 2. Spread of the 12-punetured asparagus beetle; inereasing noxiousness of Crioceris 12-punctata reeorded fiom near Baltimóre, Md., by O. Lugger ; eomparative deseription of this speeies with C. asparagi. 3. An internal mite in fowls; presenee of Cytoleichus sarcoptoides in lungs and other parts of diseased ehickens.

2136. [Riley, C. V.] The "lignified snake of Brazil." <Evening Star [Washington, D. C.], 20 January, 1883, v. 61, p. 2. S.-b. No. 42, pp.59-60. Reprint: <Sci. Amer. Suppl., 17 February, 1883. See : <Science, 23 February, 1883, v. 1, p. 84 .

Diseussion of a speeimen of problematical eharaeter, supposed to be the burrow of a larva under bark; notice of writings upon the subjeet; frequeney with whieh the true nature of natural objeets is mistaken; letter from $J$. H. Hutehins aceompanying a gall of Cecidomyia vitis-pomum mistaken for a hybrid fruit.

2137. Rilex, C. V. Utilization of ants in horticuiture. <Sci. Amer., 27 January, 1883 [v. 62], n. s., v. 48, p. 49 . S.-b., No. 42, pp. $65-66$.

Abstraets of papers of C.J. Maegowan and H. C. MeCook, with additional notes; the introduetion of ants might involve objeetionable eonsequences; probability that they would not bo of service against Coccida.

2138. Rilex, C. V. Natural sugaring. <Amer. Nat., February [31 January ], 1883, v. 17, pp. 197-198. Reprint: <Country Gentl., 31 May, 1883, †. 48. S.-b. No. $42 a$, p. 297.

Lachmus platanicola n. sp. [p. 198], abundant in 1882 on syeamore trees; deseription of the speeies; attraetion of great numbers of insects to its saccharine exudations, and growth of Fumago salicina upon these exudations.

2139. [RILey, C. V.] Trogoderma tarsale as a museum pest. <Amer. Nat., February [31 January], 1883, v. 13, p. 199.

Notiee of paper of F. H. Snow; remarks on the abundance and ravages of Trogoderma tarsale; habits of its larva. 
2140. [RIley, C. V.] Phylloxera in California. <Amer. Nat., February [31 January], 1883, v. 17, pp. 199-200.

Phylloxera vastatrix in California is most injurious in moist soils.

2141. Riley, C. V. The hibernation of Aletia xylina [Say] in the United States a settled fact. <Sci. Amer., 3 February, 1883, v. 48, p. 68. S.-b. No. 42, pp. 66-67. Reprint: <Proc. Amer. Assoc. Adv. Sci. for 1882, 1883, v. 31, pp. 468-469. Separate: <Salem, Mass., July, 1883, pp. 46S-469. Abstract: <Amer. Nat., April [15 March], 18s3, v. 17, pp. 420-421. <Nature, 28 December, 1882, v. 27, p. 214.

Proof of the hibernation of Aletia xylina as a moth and of the perpetual existence of the species in Florida.

2142. [Riley, C. V.] Fostering the study of economic entomolog5. <Rural Now-Yorker, 12 February, 1883. S.-b. No. 42, p. 58. Reprint: <Amer. Nat., A pril [15 March], 1583, v. 17, p. 420. Efforts of the French for the promotion of economic eutomology.

2143. [RILEY, C.V.] Diseases of the chinch-bug. <Rural New.Yorker, 17 February, 1883. S.-b. No. 42, p. 58.

Note coneerning paper of S. A. Forbes on two fungus parasites of Blissus leucopterus.

2144. R[IIEY], O. V. [Instinct of Cicada [= Tibicen] septendecim.] $<$ Amer. Nat., March [21 February], 1883, ₹. 17, p. 322.

Remarks on note of $\mathrm{E}$. W. Claypole; sense of direction in insects.

2145. [RILex, O. V.] Food-habits of Megilla maculata. <Amer. Nat., March [21 February], 1883, v. 17, pp. 322-323.

Summary of S. A. Forbes' observations npon the food of Megilla maculata; results of other observations on this subject.

2146. [Rrley, C. V.] Clothes-moths observed in the United States. <Amer. Nat., March [21 February], 1883, v. 17, p.323. .

Notice of papeŕ by C. H. Fernald.

2147. Riley, O. V. Entomological notes. <Rural New Yorker, 27 February, 1883. S.-b. No. 42, p. 58. See: <Amer. Nat., April [15 March], 1883, v. 17, pp.419-420.

Abstract of the rules of the international convention at Berne for the pre. vention of Phylloxera ravages; their adoption by Belgium.

2148. Riley, U. V. Notice of an illustrated essay on the Noctuida of North America. <Bull. Brooklyn Ent. Soc., February, 1883, v. 5, pp. 77-79. Separate: <[Brooklyn, N. Y., 1883], 4 pp. Critical review of A. R. Grote's essay.

2149. Riley, C. V. Concerning canker-worms. <Indiana Farmer, 3 March, 1883. S.-b. No. 56, p. 69. <Prairie Farmer, 3 March, 1883. S.-b. No. 56, p. 69. <Pacific Rural Press, 10 March, 1883. S.-b. No. 54, p. 15. <Lancaster Farmer, Mareh, 1883. S.-b. No. 56, p. 72. <Gardener's Mo. and Hortic., April, 1883, v. 25. S.-b.No. $42 a$, p. 631.

Description of Paleacrita vernata and Anisopteryx pometaria; ravages of the former; request for information; method of observation. 
2150. Riley, C. V. Dipterous enemies of the Phylloxera vastatrix. <Oa. Ent., February [9 March], 1883, v. 15, p. 39.

Critical review of paper of T. W. Fyles; the characters given of Diplosis grassator are insufficient to distinguish the species; galls of Phylloxera vastatrix inhabited by Leucopis phylloxerce Riley MS.; conparison of the early stages of these two Diptcra.

2151. [RILey, C. V.] The food relations of the Carabidae and Coccinellidee. < Amer. Nat., A pril [15 March], 1883, v. 17, pp. 417-419.

Summary of S. A. Forbes's observations on the food relations of the Carabida and Coccinellide.

2152. [RIley, C. V.] Relations of the Carabide and Coccinellidce to birds. <Amer. Nat., April [15 March], 1883, v. 17, p. 419.

Reprint of S. A. Forbes's summary, with note; Coccinellide not caten by birds; Carabide eaten in proportion as they have phytophagous habits.

2153. [RILEY, C. V.] Viviparity in a moth. <Amer. Nat., April $\lceil 15$ March], 1883, v. 17, p. 420.

Notes Fritz Miiller's discovery of a moth seen to deposit living larvæ.

2154. [Riley, C. V.] Damage to silver-plate by insects. <Amer. Nat., April [15 March], 1883, v. 17, p. 420.

Holes in silver-plate said to have been made by Niptus hololencus.

2155. Riley, C. V. Possible food-plants of the cotton-worm. <Amer. Nat., April [15 March], 1883, v. 17, pp. 421-422.

Notice of paper of J.S. Bailey; nccurrence of newly issued imagos of Aletia xyliva at Karucr, N. Y., 7 and 8 October, 1882, proving that the larva of this insect feeds upon soue genus of pliuts other than Gossypium.

2156. [RrLey, C. V.] Agrotis messoria Harr. vs. Agrotis scandens Riley. <Amer. Nat., April [15 March], 1883, v. 17, p. 422, 2 figs.

Critical review of views of A.R. Grote; Agrotis lycarum, A. repentis, and $A$. cochranii $=A$. messoria $; A$. scandens is a distinct species; comparison of the imagos; figures larva and imagos of the two species.

2157. [RILey, C. V.] An internal mite in fowls. <Amer. Nat., April [15 March], 1883, v. 17, pp. 422-423.

Lungs, bronchia, and linings of thoracie and abdominal cavities of a sick chicken covered with Cytoleichus sarcoptoides Mégnin; habitat of the same in fowls in Europe; diseases caused by it.

2158. [RIley, C. V.] Prevalence of the screw-worm in Central America. <Amer. Nat., April [15 March], 18 3, v. 17, p. 423.

Extract from letter of J. C. Zeledon on the abundance and ravages of Lucilia macellaria and related flies in Costa Rica.

2159. R[ILEY], C. V. Dried leaves as food for lepidopterous larvæ. <Amer. Nat., April [15 March], 1883, v. 17, pp. 423-424.

Review of paper of A.H. Mundt; larvæ successfully fed upou fresh leaves trausported from a distance under pressure; chopping the leaves would possibly permit of more rapid curing and more couvenient packing.

2160. [RIley, C. V.] Lepidopterological notes. <Amer. Nat., April [15 March], 1883, v. 17, p. 424.

Duplication of descriptions of the early stages of Lepidoptera to be avoided; notice of Mrs. C. H. Fernald's list of Noctuida taken in Orono, Me. 
2161. [RILeY, C. V.] Obituary. <Amer. Nat., April [15 March], 1883, v. 17, p. 424 .

Obituary notices of G. W. Belfrage and F. W. Mrklin.

2162. R[ILEY], C. V. Mosquitoes vs. malaria. <Sci. Amer., 14 April, 1883, v. 48, pp. 224-225. S.-b. No. 42, pp. 63-64; No. 67, p. 8. Abstract: <Amer. Nat., May [18 April], 1883, v. 17, p. 549.

Criticism of the views of Dr. A.F.A. King in support of the thesis that malarial disease is the result of inoculation of the body with malarial poison by the bites of insects; citation of twenty correspondencies in the conditions affecting the prevalence of mosquitocs [Culicide] and malarial disease.

2163. Rruer, C. V. Jumping seeds and galls. <Sci. Amer., 14 April, 1883, v. 48, p. 228, fig. S.b. No. 42, pp. 61-63; No. 67, p. 2.

Figures of larra, pupa, and imago of Carpocapsa saltitans, with figures and description of seeds inhabited by the larva of this moth, and description of the plant bearing these seeds; vernacular names of plant and inscet; movements imparted to the seeds by the insects and by Cynips q.-saltatorius to the galls of the same.

2164. RrLey, C. V. Reports of experiments, chiefly with kerosene, upon the insects injuriously affecting ! he orange-tree and the cotton-plant, made under the direction of the entomologist. $<$ Bull. No. 1, Div. Eut. U.S. Dept. A gric., [17 A pril], 1883, 62.pp.

CONTENTS.

Letter of submittal ....................................... 3

Introductiou........................................ 5

Miscellaueous notes on orange insects. By H. G. Hubbard .......... 9

Experiments upon scale insects affecting the orange. By Jos. Voyle.. 19

Report of observations and experiments. By J. C. Neal ........... 31

Report of observations and experimeuts on the cotton-worm (Aletia

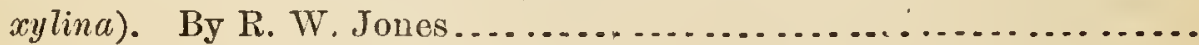

Report upon the cotton-worm, boll-worm, and other insects. By Law-

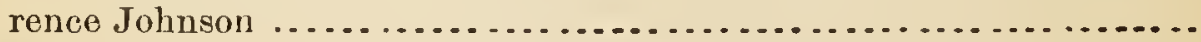

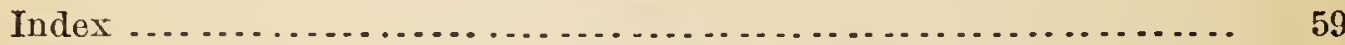

2165. Riley, C. V. Reports of observations on the Rocky Mountain locust and the chinch-bug, to gether with extracts from the correspondence of the division on miscellaneons insects. $<$ Bull. No. 2, Div. Ent. U. S. Dept: Agric., [17 April], 1883, 36. pp. Second edition, 16 September, 1883.

- CONTENTS.

Letter of submittal ....................................... 3

Iutroduction ........................................ 5

Report of observations in the Northwest on the Rocky Mountain locust, by Lawrence Bruner .................................. 7

Experiments on chinch-bugs. By S. A. Forbes ................. 23

Extracts from correspondeuce ................................ 27

Iudex................................................. 35

2166. [RILEY, C. V.] Insects as food for man. <Amer. Nat., May [18 April], 1883, v. 17, pp. 546-547.

Summary of Max Buchner's observations on the insects used as food by the Bantus tribe of negroes. 
2167. Riley, C. V. Number of molts and length of larval life as influencea by food. <Amer. Nat., May [18 April], 1883, v. 17, pp. 547-548.

Variability in habits and characters of insects; periods and number of molts observed in larva of Tenebrio niolitor, T. obscurus and Trogoderma tarsale; conclusion that insufficient food retarls development and occasions frequent molting.

2168. [Riley, O. V.] Entomological notes. <Amer. Nat., May 「18 April], 1883, v. 17, pp. 549-550。

Brief notes on recent publications.

2169. Riley, C. V. Larval stages and habits of the bee-fly Hirmoneura. <Science, 27 April, 1883, v. 1, pp. 332-334, figs. 1-3. S.-b. No. 42, p. 52 .

Summary of the life-history of Hirmoneura obscura condensed from Handlirscb, and from Braner; figures the several stages; corrcspondences of the structure and early history of the larva; predictions in reference to the larvio of Bombyliide.

2170. Riley, O. V. The eapitalizing of specific names. <Papilio, March [April], 1883, v. 3, p. 62.

Inquiry as to the use and purpose of capitalizing specific names.. See No. 2257.

2171. Riley, C. V. Observations on the fertilization of Yucca and on structural and anatomical peculiarities in Pronuba and Prodoxus. <Gardener's Mo. and Hortic. A pril, 1883, v. 25, pp.118119. S.-b. No. 51, p. 1221. Reprint: <Proc. Amer. Assoc. Adv. Sci. for 1882, 1883, v. 31, pp. 467-468. Separate: <Salem. Mass., July, 1883, pp. 467-463. Abstract: <Amer. Nat., February [31 January], 1883, r. 17, p. 197.

Description of the manner in which Pronuba yuccasclla gathers the pollen in flowers of Fucca; the work of this species necessary for the fertilization of the capsular species of Yucca, the irregularity of whose fruit is due to its punctures; description of the egg and of the manner of oviposition of this species.

2172. Rilex, C. V. The potato-stalk borer. <Rural New Yorker, 12 May 1883. S.-b. No. $42 a$, p. 213.

Answer to inquiry; life-history and means against Baridius [= Trichobaris] trinotata.

2173. Rilex, C. V. Jumping seeds and galls. <Proc. U.S. Nat. Mus., 12 May, 1883, r. 5, p]. 632-635, fig. Separate: < [Washington, 1884], pp. 632-635, fig.

Description of secds of "arrow-weed"; their motions cansed by larvo of Carpocapsa saltitans; figures of the seeds and of the larva, pupa, and imago of the Carpocapsa; habits and seasons of the same; description of the plant bearing these seeds; character and motions of the gall of Cynips q.-saltatorius.

2174. Riley, C. V. Note on cluster-flies. <Proc U. S. Nat. Mus., 12 May, 1883, v. 5, pp. 636-637.

Habits of Pollenia rudis; notice of recorded cases of swarming among the Diptera. See No. 2128. 
2175. [RILEY, C. V.] The new classification of the Coleoptera of North America. <Amer. Nat., June [17 May], 1883, v. 17, pp. 660661.

Notice of work of J. L. Leconte and G. H. Horn.

2176. RILEY, C. V. A pretty and unique gall-making tortricid. <Amer. Nat., June [17 May], 1883, v. 17, p. 661, fig. 1.

Description and figure of imago of Grapholitha ninana n. sp. reared from galls on stems of Acacia filicina in Arizona.

2177. [Rilex, O. V.] Simulium feeãing on other insects, <Amer. Nat., June [17 May], 1883, v. 17, pp. 661-662.

Comment on note of H. A. Hagen.

2178. [Rilex, C. V.] Synopsis of the N. A. Heliothince. <Amer. Nat., June [17 May], 1883, r. 17, pp. 662-663.

Review of paper of J. B. Smith; nature of the generic characters of Noctuida.

2179 [Riley, C. V.] Death of Professor Zeller. < Amer. Nat., June [17 May], 1883, v. 17, p. 663.

Obituary notice of P. C. Zeller.

2180. [RILEY, O. V.] Protection of insect collections. <Amer. Nat., June [17 May], 1883, v. 17, pp. 663-664.

Power of the larva of Dermestide to endure the effects of certain insecticides; prerequisites more important than insecticides; seasons when collections are most endangered.

2181. [RIlex, C. V.] Cocoon of Telea polyphemus. <Amer. Nat., June [17 May], 1883, v. 17, p. 664.

Answer to inquiry of H. Morris; cocoon of Telea polyphemus usually falls to the ground with the leaves, yet quite frequently it is attached to twigs and does not fall to the ground.

2182. [RILEY, C. V.] The sucking organs of bees, wasps, and flies. $<$ Amer. Nat., June [17 May], 1883, v. 17, pp.664-665.

Notice of paper of K. Kraepelin.

2183. [RILEY, C. V.] The "pine moth of Nantucket." < Amer. Nat., June [17 May], 1883, v. 17, pp. 665-666.

Critical review of paper of S. H. Sculder.

2184. [RILEx, O. V.] Entomological notes. <Amer. Nat., June [17 May], 1883, r. 17, pp. 666-667.

Brief notes on recent publications.

2185. Riley, C. V. Elephantiasis or Filaria disease. <Science, 18 May, 1883, v. 1, pp. 419-421, fig. S.-b. No. 42, p. 51, fig.

Criticism of the views of Dr. A. F. A. King; notice of the writings of P. Manson and others on the connection of Culex musquito with the life-history of Filaria sanguinis-hominis and on the production of elephantiasis and related diseases by Filaria.

2186. Rilex, C. V. Nemestrinidc. <Science, 8 June, 1883, v. 1, p. 513. Note on papers concerning Nemestrinidee; supplementary to No. 2169.

2187. Riley, C. V. The corn-root Diabrotica. <Rural New-Yorker, 9 June, 1883. S.-b. No. 54, p. 42.

Increasing distribution of Diabrotica longicornis; means against it. 
2188. Riley, C. V. Elm-leaf beetle. <Sci. Amer., 16 June, 1883, v. 48. S.-b. No. $42 a$, p. 265.

Reply to inquiries concerning Galeruca xanthomelcena.

2189. Rilex, C. V. A unique and beautiful noctuid. <Amer. Nat., July [20 June], 1833, v. 17, pp. 788-790, fig.

Fignre of imago of Cirrhophanus triangulifer; description of its generic characters; its affinities, synonyms, and probable habits.

2190. [RIley, C. V.] Insects affecting stored rice. <Amer. Nat., July [20 June], 1883, v. 17, p. 790.

Lists of insects, chiefly Coleoptera, found in a lot of damaged rice from the Chinese centennial exhibit; two species are carnivorous.

2191. Riley, C. V. Hypermetamorphoses of the Meloida. <Amer. Nat., July [20 June], 1883, v. 17, pp. 790-791.

Proposal of simpler and more natural terms to designate the stages of development of larva of Meloida.

2192. [Riley, C. V.] Entomological notes. <Amer. Nat., July [20 June], 1883, v. 17, pp. 792-793.

Comments on recent entomological publications; items of news.

2193. Rilex, C. V. The grape Phylloxera in France. < Science, 22 June, 1883, v. 1, pp. 576-578.

Review and criticism of the report of the Commission superieure du Phylloxera.

2194. Riley, O. V. Fig insects. <Science, 29 June, 1883, v. 1, p. 599. Review of S. S. Saunders's views on fig insects.

2195. Riley, O. V. Egg-punctures on raspberry-and grape-vines, etc. $<$ Rural New-Yorker, 30 June, 1883, v. 42, p. -. S.-b. No. 42, p. 56 .

Answer to inquiry of T. H. G.; oviposition of Eccuthus nivens in stems of raspberry-and grape-vines, and of Ceresa bubalus in twigs of apple-trees; habits and ravages of and means against the former; the latter seldom very injurious.

2196. Rilex, C. V. Silk culture in the United States. < Rural NewYorker, 14 July, 1883, r. 42 , p. - - S.-b. No. $42 a$, p. 531.

Revival of interest in silk culture in the United States; experience of the year; relation of silk culture to import đuties; warning against too high expectations as to profits; notes on manuals of silk culture.

2197. Riley, C. V. Economic entomology of Iowa. <Sci. Amer., 14 July, 1883, v. 49, p.-. S.-b. No. 53, p. 147.

Review of work done in Iowa, especially of papers of J. N. Dixon, H. Osborn, and A. B. Walton.

2198. [Riley, C. V.] Insect plagues. <Boston Herald, 22 July, 1883, p. -. S.-b. No.42, pp. 53-54; No. 67, p. 11. Extract: <Mirror and Farmer, $26 \mathrm{July}, 1883$, v. 35. S.-b. No. 42, pp. 126-127.

Newspaper interview; seasons, habits, ravages of and means against Caloptenus atlanis, Nematus erichsonii, and Orgyia Tencostigma.

2199. Riley, C. V. Report by C. V. Riley. <Proc. U. S. Nat. Mus., 27 July, 1883, v. 6, pp. 104-105. Reprint: <Sci. Amer. Suppl., 13 October, 1883, r. 16, p. 6486.

Note to F. Humbert's Lucilia macellaria iufesting man; references to other mentions of it; its distribution and means against it. 
2200. Rilex, C. V. Emulsions of petroleum and their value as insecticides. <Proc. Amel. Assoc. Adv. Sci. for 1882, 1883, v. 31, pp.469-470. Separate: <Salem, Mass., July, 1883, pp. 469-470. Reprint: <Kansas City Rev. of Science and Industry, November, 1883, г. 7, pp. 447-448. S.-b. No. 42, p. 124. Extract: <Sci. Amer., 19 November, 1883, v. 49, p. 294 . S.-b. No. 51, p. 153.

Description of modes of making emulsions of petroleum for use against ingects.

2201. [Riley, C. V.] The old, old question of species. <Amer. Nat., September [15 August], 1883, v. 17, p. 975.

Comments upon the discussion between H. A. Hagen and W. H. Edwards; views of both parties extreme; views as to the true nature of spccies.

2202. [RILey, C. V.] Myrmecophila. <Amer. Nat., September [15 August], 1883, v. 17, pp. 975-976.

Record of recent captures of Myrmecophila in Oregon and District of Columbia; record of former captures in the United States; habits of the gcnus.

2203. [RIley, C. V.] Salt-water insects used as food. <Amer. Nat., September [15 August], 1883, v. 17, pp. 976-977.

Occurrence of Ephydra (hians?) in Lake Tetscoco, Mexico; E. gracilis found in Great Salt Lake, Utah, and $E$. californica in lakes in California; account by W. H. Brewer of the manncr in which the last-named species is collected and used for food by the Indians living near Mono Lake.

2204. [RILey, C. V.] Food-plants of Samia cynthia. <Amer. Nat., September [15 August], 1883, r. 17, P. 977.

Review of paper of H. H. Birney; list of plants on which Samia $[==$ Attacus $]$ cynthia has hitherto becn found feeding; some of these are the favorite food-plants of Callosamia [ = Attacus $]$ pronethea.

2205. [Rilet, C. V.]. Bitten by an aphid? <Amer. Nat., September [15 August], 1883, v. 17, p. 977.

Letter of S. Swan, with answer; Siphonophora $[=$ Nectarophora $]$ rudbeckice common on Solidago and Rudbeckia; the biting was probably caused by ants or some other insect that escaped notice at the time.

2206. Riley; C. V. Steganoptycha claypoleana. <Amer. Nat., September [15 August], 1883, v. 17, p. 978. Reprint: <Papilio, September-December, 1883, v. 3, p. 191.

Comparative description of Steganoptycha claypolcana with Proteoteras asculanum; habits of the former.

2207. R[ILEY], C. V. Extermination and restriction of Phylloxera in Switzerland. <Rural New-Yorker, 25 August, 1853, v. 42. S.-b. No. 49 , p. 74 .

Notice of report of Valery-Mayet.

2208. Rilex, C. V. Hackberry psyllid galls. <Ca. Ent., August [5 September], 1883, v. 15, pp. 15i-159, figs. 6, 7 .

Critical review of paper of 'T. W. Fyles; Phylloxera vastatrix has many parasites and Celtis is attacked by many specics of gall-insccts; characters of Pachypsylla n. g. [p. 157]; figures of galls of $P$. celtidis-venusta and $P$. c.-mamma; derivation and orthography of the generic term Celtis. 
2209. Riley, C.V. Some recent discoveries in reference to Phylloxera. <Science, 7 September, 1883, r. 2, p. 336 . S.-b. No. 42, pp. 68, 69. Reprint: <Proc. Amer. Assoc. Adv. Sci. for 1883, 1884, v. 32, p. 320. Separate: <Salem, Mass., July, 18s4, p. 320. <Amer. Nat., December [2S November], 18s3, r. 17, p. 1288.

Summary of the cycle of development of the genus Phylloxera; character of the gall of $P$. spinosa and location of the impregnated egg of the species.

2210. Rrley, C. V. The Psyllide of the United States. <Science, 7 September, 1883, v. 2, p. 337. S.-b. No. 42, pp. 67-68. Reprint: <Proc. Amer. Assoc. Adv. Sci. for 1883, 1884, v. 32, p. 319. Separate: <Salem, Mass., July, 1884, p. 319.

Characteristics and economic importance of Psyllide; status of the present knowledge of this family in the United States; list of new genera and species; food plants of the same; characteristics of the eggs and young of Psyllider.

2211. Riley, C. V. Improved method of spraying trees for protection against insects. <Science, 14 September, 1883, v. 2, p. 378. S.-b. No. 42, p. 68. Reprint: <Proc. Amer. Asoc. Adv. Sci. for 1883,1884, v. 32, pp. 466-467. Separate: <Salem, Mass., July, 1884, pp. 466, 467.

Description of apparatus, especially of "cyclone nozzle" and adjustable hose; mention of insecticide substances.

Note.-Nos. 2209-2211 were issued as a separate, Salem, 1884.

2212. [Rrley, C. V.] Entomology at Minneapolis. <Amer. Nat., 1883, v. 17: October [17 September], pp. 1068-1070; November [19 October], pp. 1169-1174.

Minutes of the meetings of the entomiologists at the session of the American Association for the Advancement of Science; reorganization of the entomological club; election of .officers and change in the constitution; abstracts of papers read.

2213. Rrlex, C. V. Notes on Pedisca scudderiana. <Amer. Nat., October [17 September], 1S83, v. 17, pp. 1069-1070.

Habits and variation of Pedisca scudderiana; difference between the gall of this inscet and that of Gelechia gallosolidaginis.

2214. Riley, C. V. A myrmecophilous lepidopteron. <Amer. Nat., October [17 September], 1883, v. 17, p. 1070.

Larva of Helia americalis found in nests of Formica rufa; this species the only one of the Lepidoptera known to devclop in ants' nests.

2215. [RIley, C. V.] Enemies of the egg-plant. <Amer. Nat., October [17 September], 1.883, v. 17, p. 1070.

Extract from a lotter of A. Cimler, proving that the occurrence of Cassida texana and Doryphora juncta on Solanum melongena is not accidental or temporary.

2216. [RrLer, C. V.] The periodical Cicada in southeastern Massachusetts. <Amer. Nat., October [17 September], 1883, v. 17, p. 1071.

Note to paper of C. E. Bessey; Cicada [= Tibicen] septendecim at Martha's Vineyard, Mass., in June, 1883, the precursor to septendccim Brood XXI which will appear in North Carolina and Virginia as well as Martha's Vineyard in 1884; accelerated specimens of the same brood received from Loudoun County, Viı., recently. 
2217. Riley, C. V. Habits of Murmidius. <Amer. Nat, October [17 September], 1883, v. 17, p. 1071.

List of insects fonnd in a lot of damaged rice from Sonth America; occurrence of Murmidius ovalis in vast nnmbers in this rice; its probable food-habits; description of its cocoon; list of families of beetles some of whose larva spin cocoons; habitat of Mychocerus.

2218. [RILey, C. V.] Obituary. <Amer. Nat., October [17 September], 1883, v. 17, p. 1072.

Notices of V. T. Chambers and Townend Glover.

2219. [RILEy, C. V.] Entomological notes. <Amer. Nat., October [17 September], 1883, v. 17, pp. 1072-1073.

Notes on recent entomological publications; items of news.

2220. [Rlley, C.V.] Economic notes. <Amer. Nat., October [17 Séptember], 1883, v. 17, pp. 1073-1074.

Comments on the ravages of several injurions insects during the past season.

2221. Riley, C. V. A parasite of the cabbage-worm. < hural NewYorker, 6 October, 1883 , ง. 42 . S.-b. No. 42 , p. 58.

Answer to letter of J. H. B.; parasitism of Pteromalus puparum in larva and pupæ of Pieris rapæ.

2222. Rilex, C. V. The handmaid moth. <Rural New Yorker, 13 October, 1883, v. 42 . S.-b. No. 42 , p. 77.

Answer to inquiry of H. B. S. ; description of larva, pupa, and imago of $D a$ tana ministra from hickory- and walnnt-trees, and of a phytophagic variety of the larva from apple and other trees; habits of the larvæ; the larvæ unusually abundant in $\mathbf{1 8 8 3}$.

2223. Riley, C. V. Remarks on Arzama obliquata. <Amer. Nat., No. vember [19 October], 1883, r. 17, p. 1169.

Description of the egg-mass of Arzama obliquata; colors and habitat of the larva; variations of the imago ; nnmber of annual broods.

2224. [RILey, C. V.] Rare monstrosities. <Amer. Nat., November [19 October], 1883, v. 17, p. 1175 .

Notice of monstrosities recorded in Melanippe montanata and Zygana minos.

2225. [RILey, C. V.] The nervous system of insects. <Amer. Nat., November [19 October], 1883, จ. 17, pp. 1175-1176.

Snmmary of the observations of Ed. Brandt.

2226. [RILEy, C. V.] Hymenorus rufipes as a myrmecophilous species. <Amer. Nat., November [19 October], 18s3, v. 17, p. 1176.

Imagos of Hymenorus rufipes raised from larvæ found in nests of Formica fusca; character of the nests of the Formica; food-habits of the Hymenorus unknown.

2227. [RILey, C. V.] Recent publications. <Amer. Nat., November [19 October], 1883, v. 17, p. 1177.

Notice of J. H. Comstock's work on Diaspina and of other recent publications.

2228. [Riley, C. V.] Entomological notes. <Amer. Nat., November [19 October], 1883, г. 17, pp. 1177-1179.

Review of "General Index of the Entomological Reports of the Province of Ontario ;" recent publications and items of news. 
2229. RILEY, C. V. The potato-stalk borer. <Rural New-Yorker, 20 October, 1883 . S.-b. No.42, pp. 78-79.

Answer to letter of S. C. R.; description, habits of, and means against Gortyna nitela; means against Paria aterrima, Graphops pubescens, and other larvæ of Chrysomelide injurious to the roots of strawberry-plants.

2230. [RILEY, O. V.] Recent advances in horticultural entomology. $<$ Rural New-Yorker, 20 October, 1883, v.42. S.-b. No. 42, pp. 79-81. Reprint: <Proc. 19th Sess. Amer. Pomol. Soc., 1884, p. 45. <Trans. Wisc. State Hortic. Soc., 1886, v. 17, p. - .

Report of address delivered; discussion of measnres recommended for adoption to prevent the ravages of insects injnrions to horticnlture, especially of Carpocapsa pomonella and Conotrachelus nenuphar; correction of statements in regard to the oviposition of Seperda bivittata [= candida] and ? Bembex marginata; advance in knowledge of the life-history of Aphidide and in the development of machinery for the application of poison sprays to plants; relative value of the principal insecticides.

2231. Riley, C. V. On a gall-making genus of Apionince. <Bull. Brooklyn Ent. Soc., October, 1883, v. 6, pp. 61-62. Separate: $<$ Brooklyn, N. Y., 1883, 2 pp.

List of North American gall-making Coleoptera; description of Podapion n. g. [p. 62] and of the gall and imago of P. gallicola n. sp., found on twigs of Pinus inops; probable life-habits, inqnilines, and parasite of this species.

2232. Riley, C. V. Report of the Entomologist. <Ann. Rept. [U.S.] Commissioner Agric. for 1883, pp. 99-180, 13 pl. Separate: $<$ Washington, 31 October, 1883, pp. 5+pp. 99-180+pp. 7, 13 pl.

TABLE OF CONTENTS.

INTRODUCTION . . . . . . . . . . . . . . . . . . . . . . . . . . . . . . . .

Scope and limitations, 99-Cabbage insects, 99-Lesser locust, 99-

Protection of frnit and shade trees, 99-Office force, assistants and agents, 99-Observations and report on insects injurions to forest-trees, by Dr. A. S. Packard, jr., 99-Special report on insects affecting the orange, by H. G. Hnbbard, 99-Work of agents, 100Monographs in preparation, 100-Commission sent to Brazil to stndy certain insects, 100-Publication of third report of the United States Entomological Commission, 100-Pnblication of special bulletins, 100 -Correspondence and work of the division, 101-The illustrations to the report, 101.

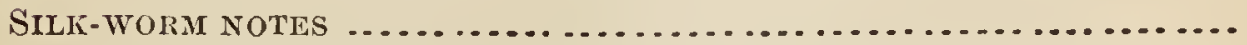

Legislation, 101-California State Board of Silk Culture, 101-Preminms offered in California, 101-Home cnlture, 102-Guaranty of egg supply, 102-Woman's Silk Cnlture Association of California, 102-California Silk Cultnre Association, 102-Reports from correspondents of the division, 102-104-Issne of "Silk Culture Directory," 104-Establishment of school in New Jersey, 105-Organization of Sonthern Silk Industrial Association, 105A new machine patented, 105-Report on the future of silk culture in the United States, by United States Consul Peixotto, of Lyons, France, 105-Silk culture by the Mennonites, 106-Work at the Department, 106. 


\section{RILEY, C. V.-Continued.}

Cabbage worms .

Interest in and importance of the subject, 107-Accurate estimate of loss impossible, 107.

Imported cabbage-worm, Pieris rape..........................

History of its spread, 108-Ravages, 109-Cliaracters, 110-Habits, 1.10-Food-plants, 111-Seasons of appearance, 111-Natural enemies, 111.

Southern cabbage-butterfly, Pieris protodice....................

Range, 114-Ravages, 114-Characters, 114-Food-plants, 115Parasites, 115.

The potherb-butterfly, Pieris oleracea ........................

Range, 115-Characters, 116-Habits, 116-Number of broods, 116Food-plants, 117-Enemies, 11\%.

The larger cabbage-butterfly, Pieris monuste...................

Range, 11\%-Characters, 117-Food-plants, 118-Parasites, 118Description of early states, 118.

The cabbage plusia, Plusia brassice .........................

Its range, 119-Food-plants, 119-Habits and natural history, 119Close relation to an European species, 120-Natural euemies, 120-Botrytis rileyi, a new species of fungus, 121-Remedies, 121.

The cabbage mamestra, Mamestra trifolii .....................

Its habits and natural history, 123-Remedies, 124-Description, 124.

The zebra cabbage-worm Mamestra picta......................

History, 124-Description, 125-Habits, 125-Broods, 125-Remedies, 125.

The cabbage pionea Pionea rimosalis .........................

Its past history, 126-Notes by Prof. Cyrus Thonıas, 126-Habits and natural history, 127-Parasites, 127-Remedies, 127-Descriptive, 128.

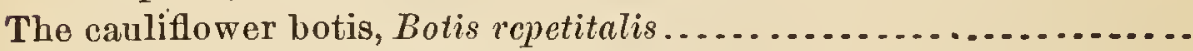

Past history, 128-Rauge, 128-Descriptive, 129.

The cabbage plutella, Plutella cruciferarum .....................

Its past history, 129-Habits and natural history, 130.

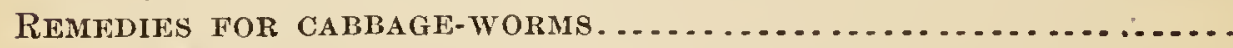

Hot water, 131--Pyrethrum, 131-Kerosene emulsions, 131-Other substances, 131-Paris green, London purple, and white hellebore, 132-Prcventive measures, 132-Report of Capt. R. S. Lacey, 133-Report of Col. Wright Rives, 134-Poisoning devices, 136.

Causes of Destruction of evergreen forests in New England aNd New York, BY $A$. S. PaCKard, JR ...................

The larch saw-fly, Nematus erichsonii .........................

History of its ravages, 138-Its devastations in Maine, 139-Its ravages in New Hampshire, 141-Its appearance in Massachusetts, 141-In northern New York, 142-History of the species and its habits, 142-Description of egg, larva, cocoon, and imago, 145-Remedies, 146-Parasites, 146.

The spruce-bud tortrix, Tortrix fumiferana.....................

Its ravages in Maine, 146-Habits and transformations, 147-Description of different stages, 148.

The spruce nematus, Nematus integer .........................

Range, 149-Description of different stages, 150. 
2232. Riley, C. V.-Continued.

Causes of destruction of inergreen forests, etc.-Continued.

The hemlock gelechia, Gelechia "bietisella....................

Habits, 151--Description of larva, pupa, and moth, 151.

Experinents on scale insects, with practical suggestions, BY

H. G. HubBard . . . . . . . . . . . . . . . . . . . . . . . . . . .

Report of progress in experiments, 152-Soap emulsions, 152-Kerosene and soap emulsions, formula, 152-Receipt for making emulsions of kerosene and soap, 152-Introduction and use of the cyclone nozzle, 152-Effects of kerosene emulsions upon plants, 153-Effects of kerosene emulsions varied by change of weather, 153-Most favorable season for applying kerosene emulsions, 153-Application of liquid insecticides, 153-The cyclone nozzle, 154-Cost of kerosene wash, 154.

Recent experiments.......................................

Potash compared with soda as an insecticide, 155-Details of experiments with potash, 155-156-Experiments with soda, 156.

Introduction and spread of scale insects .....................

Great vitality of bark-lice, 156-Importation on live trees, 157Precautionary measures; infection from nursery stock, 157-Protection afforded by hedges and forest trees, 158.

Miscellaneous inseCts ... . . . . . . . . . . . . . . . . . . . . . . . . .

The imported elm-leaf beetle, Galeruca xanthomelcna..............

Range, 159-An importation from Europe, 160-Habits and natural history, 160-Remedies, 161-Natural enemies, 163-More recent experiments at the Department, 164-Past history of the elms on Department grounds, 164-Condition and characteristics of the grove in 1882 and 1883, 164-Extent of injury in 1882 and 1883, 164-Preferences of the elm-beetle for certain varieties and species of clms, 165-Effects of arsenical poisons on insect and plant, 165-Preventive effects of the poison, when best applied, 166-Trentment with London purple, 166-Preparation of the poison, 166-Effects of the mixture, 167-Treatment with Paris green, 167-Mechanical means of applying the poison, 168-The eddy-chamber nozzle, 168-Hose and bamboo combination, 169.

The lesser migratory locust, Caloptems atlanis ...................

Its ravages in the Merrinac Valley, 170--Historical, 170-Characters, 172--Range and life-history, 173-Natural enemies, 174-. Remedies, 175-Destruction of eggs, 175-Destruction of young, 175-Coal oil, 175-Machines, 175-177-Coal tar, 177-Catching or bagging, 178-Protection of vegetable gardens, 179-Necessity for co-operation, 180.

2233. Riley, C. V. The imported orchard Scolytus (Scolytus rugulosus Ratz.). <Thomasville [Ga.] Times, 10 November, 1883. S.-b. No. 56, p. 182.

Answer to inquiry; S. rugulosus bores in twigs of pear; means against it.

2234. Riley, C. V. Osage orange vs. mulberry for the silk-worm. <Sci. Amer., 17 November, 1883, v. 49, p. 305. S.b. No. 42, p. 91. Reprint : <Amer. Nat., 5 January, 1884, ₹. 18, pp. 7879. <Prairie Farmer, 22 March, 1884, v. 56, p. 187. S.-b. No. 42, p. 118.

Comparative value of leaves of Maclura aurantiaca and of Morns as food for

'Sericaria mori; critical review of V. des Lauriers's conclusions. 
2235. RiLEY, C. V. Entomological notes of the sear. <Prairie Farmer, 24 November, 1883, v. 55. S.-b. No. 42, pp. 86-87.

Progress of experiments for the destruction of scale insects, Coccida; introduction of Aspidiotus rapax into California on apples from New Zealand; strawberries injured by Capsus oblineatus [= Lygus pratensis] and a myriapod in Illinois; occurrence of Leucania unipuncta in several places, and of Cecidomyia destructor in Illinois; extension of culture of Pyrcthrum cinerariafolium in California; occurrcnce of Anarsia lineatella on strawberryplants in Illinois; of Doryphora juncta and Cassida texana on Solanum melongena in Georgia; of Ceresa bubalus on potato-plants in Pennsylvania; of Epilachna corrupta on wax-beans, etc.

2236. RILEy, C. V. A satisfactory remedy for melon bugs, flea-beetles, etc. < Rural New-Yorker, 3 November, 1883, v. 42. S.-b. No. $42, \mathrm{pp} .77-78$.

Quinn's method of sprinkling the vines with a mixture of tobacco water and soft soap and then powdering with lime is probably, the best general preventive against Diabrotica vittata and Halticida; description of $\mathrm{J}$. $\mathbf{M}$. Nicholson's siphon arrangement by which to keep the vines constantly moist with the liquid.

2237. Riley, C. V. The chinch-bug in New York. <Science, 9 No. vember, 1883, v. 2, p. 621. Extract: <Sci. Amer., 22 December, 1883 , v. 49, p. 384 . S.-b. No. 42, pp. 122-123.

Present outbreak of Blissus leucopterus in New York the result of an increase due to favorable conditions rather than an invasion.

2238. R[ILEY], C. V. Insects in relation to agriculture. <Stoddart's Encylopædia Americana, 1883, v. 1, pp. 135-142, figs. 1-29.

Chapter 9 of article "Agriculture." Brief accounts with numerous illustrations of the insects named below, and of means against them, witl cross-references to accounts of other insects in other portions of the work. The headings and subjects of the sub-chapters are as follows:

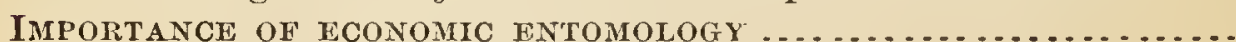
135

INSECTS INJURIOUS TO FRUIT AND FRUIT TREES:

Apple curculio (The), Anthonomus quadrigibbus Say, p. 135, fig. 1-Apple-maggot (The), or "railroad-worm," Trypeta pomonella Walsh, p. 135-Whitc-marked tussock-moth (The), Orgyia leucostigma Sm. and Abb., pp. 135-136, fig. 2-Apple-tree tent-caterpillar (The), Clisiocampa americana Harr., p. 136, figs. 3-4-Fall webb-worm ('The), Hyphantria textor Harr. [= cunea], p. 136, fig. 5-Oyster-shell bark-louse of the apple (The), Mytilaspis pomicorticis Riley [= pomorum], pp. 136-137, fig. 6-Round-headed appletree borer (The), Saperda bivittata Say [= candida], p. 137, fig. 7Flat-headed apple-tree boler (The), Chrysoboihris femorata Fabr., p. 137-Spring canker-worm (The), Paleacritavernata Peck, p. 137, figs. 8-9-Fall canker-worm (The), Anisopteryx pometaria Harris, p. 137, figs. 10-11-Peach-tree borer (The), Egeria [=Sannina] exitiosa Say, pp. 137-138, fig. 12-Currant-stalk borer (The), AEgeria tipuliformis L., p. 138-Imported currant-worm (The), Nematus ventricosus Klug. [= ribesii], p. 138, figs. 13-14-Native currant-worm (The), Pristiphora grossularia Walsh, p. 138Snowy tree-cricket (The), Ecanthus niveus Harr., p, 138, figs. 15-16. 
2238. R[ILEY], C. V.-Continued.

INSECTS INJURIOUS TO CEREALS AND FORAGE-CROPS:

White-grub (The), Lachnosterna fusca Froh., pp. 138-139, fig. 17-

Clover-seed midge ('The), Cecidomyia leguminicola Lintner, p. 139-Joint-worm (The), Isosoma hordei Harr., p. 139, tig. 18Wheat midge (The), Diplosis tritici Kirby, p. 139-Cut-worms, family Noctuide, genera Agrotis, Mamestra, Hadena, and Prodenia, p. 139-Wire-worms, family Elateride, p. 139.

INSECTS INJURIOUS TO GARDEN VEGETABLES:

Imported cabbage-worm (Thc), Pieris rape Schrank, p. 139, figs. 19-20-Southern cabbage buttertly (The), Pieris protodice Boisd., p. 140 - Potherb butterfly (The), Pieris oleracea Boisd., p. 140-Cabbage plnsia (The), Plusia brassica Riley, p. 140, fig. 21-Harlequin cabbage-bug (The), Murgantia histrionica Hahn, p. 140, fig. 22-Pea-weevil (The), Bruchus pisi Linn., p. 140, fig. 23-Bean-weevil (The), Bruchus fabce Riley, p. 140, fig. 24Blister-beetles, meloid genera Macrobasis, Epicauta, etc., p. 140, fig. 25-Striped cucumber-beetle (The), Diabrotica vittata Fabr., pp. 140-141, figs. 26-27.

INSECTS INJURING MISCELLANEOUS FIELD-CROPS:

Cotton-boll worm (The) or corn-ear worm, Heliothis armigera, Hübn., p. 141, fig. 28-Tohacco-worm (The), Sphinx $[=$ Protoparce] carolina L., p. 141.

INSECTS INJURIOUS TO THE VINE.

INSECTS INJURIOUS TO LIVE-STOCK:

Bot-fly of cattle (The), Hypoderma bovis Latr., p. 141-Sheep bot-fly (The), Estrus ovis Linn., p. 141, fig. 29-Horse bot-fly (The), Gastrophilus cqui Fabr., pp. 141-142.

List of PRINCIPAl AMERICAN WRITERs AND WRITINGS UPON INSECTS

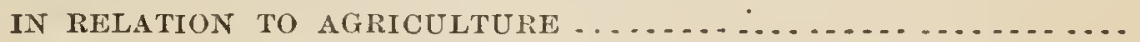

2239. R[ILFX], O. V. Army-worm, Leucania unipuncta, Haw. <Stoddart's Encylopadia Americana, 1883, v. 1, pp. 317-318, 2 figs.

Distribution, scasons, habits, and food-plants of and means against Lcucania unipuncta; refcrences to the more important articles on this insect; figures of larva and imago.

2240. RILey, C. V. An epidemic disease of Caloptenus differentialis. <Amer. Nat., December [28 November], 1883, v. 17, p. 1287.

Note to communication of H. Osborn ; the Entomophthor a calopteni a result rather than the cause of disease.

2241. Rrlex, C. V. The growth of insect eggs. < Imer. Nat., December [28 November], 1883 , v. 17, p. 1289.

Notice of paper of J. A. Osborne; swelling of the eggs of Phaneroptera [= Scudderia] curvicauda probably connected with embryological development.

2242. [RILex, C. V.] Protective device employed by a glancopid caterpillar. <Amer. Nat., December [थ\& November],1883, v. 17, p. $12 \measuredangle 9$.

Notice of paper of F. Müller; general use of shcd hairs by larva of Arctiidce in the construction of their cocoons; description of method in which the larva of Eunomia eagrus arranges its shed hairs to form a protection for the pupa.

2243. [RILey, C. V.] Saw-fly larva on the quince. <Amer. Nat., December [2S November], 1S\$3, v. 17, p. 1289.

Notice of paper of J.A. Lintner; food-plants of Selandria [=Eriocampa]cerasi. 
2244. [Riley, C. V.] Entomology in New Tork. <Amer. Nat, December [28 November], 1883, v. 17, pp. 1289-1291.

Review of J. A. Lintner's first annual report as State entomologist; list of subjects treated in the report.

2245. [RILey, C. V.] Fruit insects in California. < Amer. Nat., Decem. ber [28 November], 1883, v. 17, p. 1291.

Review of M. Cooke's "Injurious Insects of the Orchara.."

2246. [RILEx;C. V.] Death of Dr. J. L. Leconte. <Amer. Nat., Decem. ber [28 November], 1883, v. 17, p. 1291.

Notes the loss to entomologists occasioned by the death of J. L. Leconte.

2247. [Riley, C. V.] Entomological notes. < Amer. Nat., December [28 November,] 1883, v. 17, pp. 1291-1292.

Brief notices of published articles with items of news.

2248. [RILex, O. V.] Economic notes. <Amer. Nat., December [28 November], 1883, v. 17, p. 1292.

Effect of Phylloxera laws in Europe; use of lime as a means against Macrodactylus; award of the Le Brun prize for the most valuable improvement relating to the silk industry.

2249. RILEx, C. V. [Raspberry canes punctured by Orchelimum glaberrimum.] <Fruit Recorder, Purdy, 1 December, 1883, v. 15. S.-b. No. 42 , p. 92.

Description of and means against Orchelimum glaberrimum.

2250. [RILEY, C. V.] The Phylloxera in sandy soil. < Rural NewYorker, 1 December, 1883, v. 42. S.-b. No. 42, p. 97. Reprint: <Amer. Nat., January, 1884 [29 December, 1883], v. 18, p. 78.

Condition of the grape crop in France; favorable account of the use of Anerican grape-stocks; Phylloxera vastatrix harmless in sandy soils.

2251. Riley, C. V. Bacterial disease of the imported cabbage-worm. $<$ Sci. Amer., 1 December, 1883, г. 49, p. 337. S.-b. No. 42, pp. 91-92. Reprint: <Amer. Nat., January, 1884 [29 December, 1883], v. 18, p. 80.

Notice of observations of S. A. Forbes on the death of larve of Pieris rapce from infection by Bacterium; previous mention of this disease.

2252. RÆLEy, C. V. The chinch-bug in New York State. < Sci. Amer., 8 December, 1883, v. 49. p. 359. Reprint: < Amer. Nat., 5 January, 1884, v. 18, pp. 79-80.

Critical review of papers of J. A. Lintner; the occurrence of Blissus leucopterus in Now York in unusual abundance in 1882 and 1883 is not. warrant for great alarm. See No. 2271.

2253. Riley, C. V. Reports of observations and experiments in the practical work of the division, made under the direction of the entomologist. <Bull. No. 3, Div. Ent. U. S. Dept. Agric., 「8 December], 1883, 75 pp., 3 pl.

\section{CON'TENTS.}

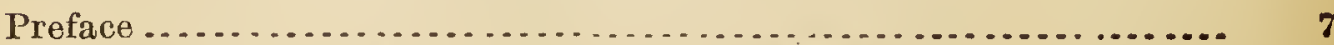

Further notes on the army worm (Lencania unipuncta)............ 9

Experiments with pyrethrum............................. 16 
2253. Riley, O. V.-Continued.

\section{CON'IENTS-Continued.}

Notes on forest-tree insects. By A. S. Packard, jr............... 24

The cotton-worm in South Texas in 1883. By E. H. Anderson........ 31

Test of inachinery for destroying the cotton-worn. By W.S. Barnard. 39

The tree-borers of the family Cossidw. By J. S. Bailey ............ 49

Tests of silk fiber from cocoons raised at the Department. By W. Mc-

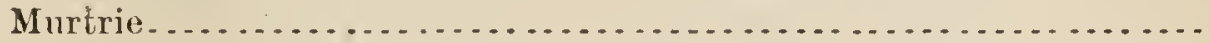

2254. Rilex, C. V. Entomology in New York. <Rural New.Yorker, 15 December, 1883 . S.-b. No. 42, pp. $85-86$.

Revicw of J. A. Lintner's first report (for the year 1881) as State entomologist of New York.

2255. Riley, O. V. Incilia macellaria. <Sci. Amer., 15 December, 1883, จ. 49, p. 373. S.-b. No. 42, p. 93.

Critical review of paper of $F$. Humbert.

2256. Riley, C. V. Dipterous larrie in the human body. <Sci. Amer., 22 December, $18 \varepsilon 3$, v. 49 , p. 385 . S.-b. No. 42 , p. 90.

References to and notices of several articles on the occurrence of larva of Diptera in the human body; synonymy and distribution of Compromyia [=Lucilia $]$ macellaria; myasis cansed solcly by larvæ of Sarcophagide and Muscide; Getride occur rarely and exceptionally in the human body.

2257. Riley, C. V. Capitalizing specific names. <Papilio, Septem. ber-December, 1883, v.3, pp.164-166. Separate: $<[\mathrm{N} . \mathrm{Y}],$.3 pp.

Comments on reasons given by W. H. Edwards and others for the uniform capitalizing of spccific nanes. See No. 2172.

2258. R[ILEX], C. V. Townend Glover. <Papilio, September-Decem. ber, 1883 , v. 3, pp. 167-168.

Obitnary notice.

2259. [Riley, C. V.] The genus Colias. <Amer. Nat., [5] January, 1884, v. 18, pp. 74-76.

Reriew of paper of H. A. Hagen; discussion of the species of Colias in North America; plastic nature and classificatory characters of the genus.

2260. [RILEy, C. V.] Larral habits of the dipterous family Dexida. <Amer. Nat., [5] January, 1854, v. 18, pp. 76-77.

Notice of paper of $\mathrm{l}$. Braner; parasitism of Dexia rustica and of Phorostoma latum on the larra of Rhizotroyus and of Melanophora? diabrotica on Dia. brotica vittata.

2261. [Riley, C. V.] Entomological notes. <Amer. Nat., [5] January, 1884, r. 18, pp. $80-81$.

Carpocapsa pomonella has been introduced into Australia, New Zealand, and Tasmania; occurrence of Myrmicoccla ochraceclla in ants' nests.

2262. Riley, C. V. Recent outbreaks of the army-worm. <Rural NewYorker, 12 Januar5, 1884, v. 43, 1. 19. S.b. No. 56, p. 145.

Rare occurrence of Lcucania unipuncta in 1852 and $188: 3$, following its last abundance in 1881; occurrence of its larva at East Windsor, Vt., in June, 1883.

2263. [RILEY, C. V.] The harlequin cabbage-bug, etc. <Rural NewYorker, 2 February, 1884, г. 43, p. 70. S.-b., No. 63, p. 41.

Habits of and incans against Hurgantin histrionica; effect of chemicals applied to the soil npon the colors of flowers. 
2264. Riley, C. V. Tribute to the memory of John Lawrence Leconte. $<$ Psyche, November December, 1883 [11 February, 1884], v. 4, pp: 107-110. Separate: < CUambridge, Mass., 11 February, 1884\}, pp. 107-110. Notice: <Psyche, loc. cit., p. 119.

Biographical notice of J. L. Leconte; his work and writings; his personal character; disposition of his entomological collection.

2265. [RILEY, C. V.] Fruit culture in the South. <Washington Post, 26 February, 1884. S.-b. No. 42, pp. 119-120.

Interview with a reporter; means against insects infecting the orange.

2266. Riley, C. V. Oviposition of the round-headed apple-tree borer. <Rural New-Yorker, 1 Miarch, 1884, v. 43, p. 132, fig. 73 . S.-b. No. 42 , p. 85 ; No. 67, p. 3 .

Notice of paper of C. G. Atkins; confirmation of the account of the method of oviposition of Saperda candida; description of this method; correction of several statements by W. Sannders in regard to the oriposition of different insects; description and figure of the egg of $S$. candida; figures of the burrows and hole of exit of this bectle; figures of the pupa and of the position of the egg when deposited.

2267. [Rilex, C. V., et al.] Third report of the United States Ento. mological Commission, relating to the Rocky Mountain locust, the Western cricket, the army-worm, canker-worms, and the Hessian fly; together with descriptions of larvæ of injurious forest insects, studies on the embryological development of the locust and of other insects, and on the systematic position of the Orthoptera in relation to other orders of insects; with maps and illustrations. <Washington: 1883 [6 March, 1884], pp. $14+347+12+92,18$ figs., 64 pls., 4 maps.

LETTER of SUBMITTAL ................................. XI

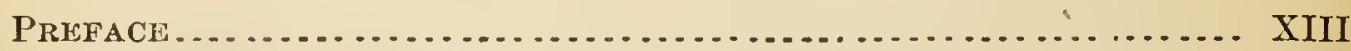

Part I.-In Reference to the Rocky Mountain locust (Caloptenus spretus).

Chapter I :

Additions to the chronology of locust ravages in 1880 and $1881 . . . .$.

'The locust in 1880 in Texas, 3 ; in Colorado, 4 ; in Utah. 4 ; in 1881, in Texas, 6 ; in Utah, 7.

Chapter II:

The Rocky Mountain locust in Montana in 1880. By Lawrence Bruner ...........................................

The country from St. Paul to Montana, 8-Between Bismarck and Fort Keogh, 9-Burning often impracticable, 9-Destroying locusts by ditches and kerosenc eddies, 13-Ropes dragged to drive them, 15-"Drifts of hoppers," 16-Shooting against locust swarms, 16-Destroying by ditches and burning straw, 17-No more damage for three or four years, 17-Encmies of the locust in the Nortliwest, 17-Topography- of western Dakota and Montana, 19.

Chapter III :

The Rocky Monntain locust in Wyoming, Montana, etc., in 1881. By Lawrence Bruner...................................

Letter of submittal of report by Lawrence Bruner, 21 - General report, 22-Brief history of depredations, 22-The earlier 
2267. [RILEY, C. V., et al.]-Continued.

Chapter III-Continued.

ones, 23-Characteristics of the permanent region, 24-Settlement and other checks against locusts, 25-Distribution of the permanent regions, 25-Their physical peculiarities, 28-Tho arid region, 29-Permanent breeding grounds, 29-Their locations and relations, 30-The sources of locusts, 30-Interchange of swarms, 31-Regular migratory routes, 31-Agencies controlling migration, 32-Disadvantages of the temporary regions, 33-Period of hatching, :34-Period of growth, 35-Habits of the Joung, 36Habits at maturity, 36-Causes of occasional over-increase, 37Checks, enemics, 3\&-The efforts of experts baftled, 42-Tree culture, 42-Climatic checks, 43-Tree planting, 43-Flights affected by storms, 45-Number of aunual broods, 46-Sub-permanent region, 46-Its relations, 47-Locust movenents thereiu, 48-How to fight this insect, 49-Locust probabilities, 49-Recent swarms, 50.

Chapter iv:

Notes on other locusts and on the Western cricket, Anabrus. Вy Lawrence Bruner ... . . . . . . ....................... . . .

Other locusts, 53 - List of North Auerican locusts north of Mexico, 55-The Western cricket, 61.

Chapter V:

Data obtained frou solar physics and carthquake commotions applied to elucidate locust multiplication and migration, by $\mathrm{A} . \mathrm{H}$.

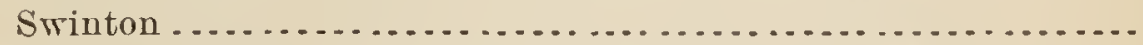

Importance of the central luminary, wide effects of variation in its potential energy, 65-On the tides, on chemical and organic activities, on the physical forces, on cpidcmics, etc., 65, 66-Periods of sun-spots, electrical effects of, 66-Thermometric effects of, 67-Volcanic effects of, 68-Entomological effects of, 68-A new sun-spot table, 69-Statenient and tabulation of suu-Epot dates, 69-Comparison of sun-spot periods and insect periods, 73American locusts diminisher by the spots, 73-European confirmative examples of locusts and other insects, 74-'Tabulation of rare insect captnres, 79-Explained, 81-Migration and distribntion affectcd, 81-Locusts again predicted in four or ten years, 83-Conclusions, 84.

PART II.-THE ARMY-WORM, CANKER-WOLMS, AND THE IIESSIAN FLY.

Chapter VI: By C. V. Riley.

The army-worn, Leucania unipuncta. By C. V. Riley .............

Nomenclaturc, 89-Other army-worms, falsely so called, 89-Geographical distribution, 91-Injurics by, 92-Past history of, 92Descriptive characters of, 101-The egg, 101-The larva, 102The pupa, 103-Adnlts and sexual differences, 103-Habits and natulal history, 105-Oviposition, 105-Habits when young, 108Duration of larval life, 109-Traveling habits, etc., 1:0-Time of appearance, 112-Sudden appearance aud disappearance, 114Foot-plants, 116-The pupa state, 117-Habits of the moth, 117Flight, 118-Position at rest, 118-Number'of bloods yearly, 118Hibernation, 122-Natural enemies, 125-Remedies, 128-Burning old grass, etc., 128-Predictious, metcorological influences on the species, 129-Ditching, coal-tar, poisoning, 130-Rolling, fencing, roping, 131 -Report of observations by L. O. Howard, 132-Ex- 


\section{7. [Ruex, C. V., et al.]-Continued.}

Chapter VI-Continuer.

tent of country injured, 133-Crops injured, 133-Amount of damagc, 133-Previous scason and crop, 134-Number of broods, 134-An accompanying cut-worm, 125-Natural enemies, 135Army-worm correspondence in spring of 1882, 136-The invasion of 1880 in New Jersey, by Rev. Samuel Lockwood, 139-Performances of the worms, 139-The direction of travel, 141-Origin, eggs, etc., 143-Breeding spots, 143--Recapitulation, habits, and remedics, 145-Notes from Prof. C. V. Rilcy, the number of broods, hibernation, seasonal influences, 147-Bibliography, 148.

Chapter Vil: By C. V. Riley.

Canker-worms, Paleacrita vernata, Anisopteryx pomctaria. By C. V. Riley .............................................

Classification, 157-Two distinct insects concerncd, 158-Differences between them, 159-Nomenclature, 162-Past history, 165-The spring canker-worm, 170-Range of the species, 170-Characters, 171-Habits and natural history, 172-A ppearance of the worms, 173-Food-plants, 174-Modes of distribution, 175-Enemies, 175Destructiveness of canker-worms, 178-Thc fall canker-worm, 179-Range of this species, 179-Its characters, 180-Habits and natural history, 181-Oviposition, 182-Season of appearance, 182-Pupation, 183-Food-plants, 18.3-Remedies and preventive measures applicable to both species, 183-Sticky substances, 183Hanging tin band, 185-Troughs of oil, 186-Precautions and classification of contrivances, 189-Jarring and burning, 191Washes and dustings, 191-Paris grcen, 192-Muriato of limc, 192-Sulphur plugged in trecs, 193-Fall plowing, 193-Birds and parasites, 195-Different measures against the species, 196.

\section{Chapter ViII:}

The Hessian fly-Cecidomyia destructor, its ravages, habits, and the neans of preventing its increase. By A. S. Packard, jr.........

Introduction, 198-Losses occasioned by the Hessian fly, 199-Description of the fly, 207-Ilabits, 210-Mode of egg-laying, 211Effects of the larra, 213-Weather and seasonal influences, 215Parasites, 216-Remedies, 220-Late sowing, 221-Early sowing, 223-Advantage of high culturc, 225-Pasturing with shcep, 225Sowing hardy varictics, 227-Special remedies, 229-Application of lime, 229-Rolling the ground, 229-Close cutting, 229-Burning stubble, 230-Periodicity of the fly, 230-Chronological table of fly years, 232-Distribution of the fly, 234-Its origin in America, 234-History of its distribution in the old World, 234-In Americta, 240-Summary of habits and remedies, 244-List of works and articles on the Hessian fly, 245.

\section{Chapter IX:}

\section{P.ART III.-Schentufic Results.}

Descriptiuns of larve of injurious forest insects. By A. S. Packard, jr . Buprestida, 251-The flat-hearled apple-borer, Chrysobothris femorata, 251-Chalcophora virginica, 252-Melanophila sp., 253-The flat-beaded spruce-borer (Helanophila?), 254-The flat-headed peach-and cherry-borer, Dicerca divaricata Say, 255-Buprestid under hemlock bark, 255-Cerambycide, 256-Longicorn larva under hemlock bark, 256-Saperda on the willow, 256-The lesser pine-borer, Asemum mostum Haldcman, 256-The oak-borer, Elaphidion parallelum Newman, 25t-The common cak clytus, 
2267. [Rrley, C. V., et al.]-Continued.

Chapter 1X-Continued.

Xylotrechus colonus Fabr., 257-C7ytus (?) larva on blaek-birsh, 259-The ribbed rhagium, Rh. lineatum Oliver, 259-The lesser prionus, Orthosoma brunneum. De Geer, 260-Unknown longicorn borer from an oak log, 261- Unknown longicorn borer in sycamore, 262.

\section{Chapter X:}

The embryological development of the locnst. By A. S. Packard, jr. Formation of the blastoderm, 263-Origin of the primitive amaboid eells, 264-The blastodermic dise or primitive band, 264-The germinal groove, 264-Origin of the eellular or germinal layers, 264-Diagrammatic view of the origin of these layers, from Graber, 265-Embryonal membranes, 265-Serous nembrane, 265Annion, 265-Tabular view of the eight embryonal layers, 265Division of the embryo or primitive band into body segments, 266-Development of the appendages, 266 ; of the nervous system, 266; of the alimentary canal. 266-The stomodieum, 266The proctodxum, 26\%-The inesenteron or stomach, 267 -The pyloric appendages of the stomach, 267-The Malpighian tubes, 267 -The genital glands, 267-The trachere and salivary glands, 267-Spinning glands, 267-Development of the wings, 268-Critieism of Gegenbaur's views, 269-Fritz Miiller's views, 269Speculation on the prinlary origin of wings, 270 -Correlation of metamorphosis with the acquisition of wings, and of the latter with the ripening of the sexual organs, 271-Differentiation of mesonotum and metanotum dependent on the presence of wings, 271-Developunct of a pupal stage, 271-Genealogy of the order's of insects, 271.

The embryological development of orthopterous inseets. By A. S.

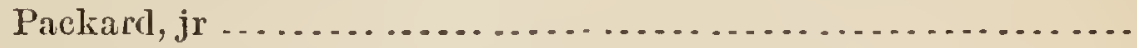

Rapid development of the embryo in autumn, 272-Embryology of Gryllotalpa vulgaris, 272-Formation and eontraction of the embryonal skins, 272-Formation of the digestive caual, 272-Funetions of the mid-gut and hind-gut, 273-Origin of the Malpighian vessels, salivary glands, trachere, and ovaries, 273-The sections of eggs studier by the anthor, prepared by N. N. Mason, 273.

Development of Caloptenus allanis. By A. S. Packard, jr...........

Rapidity of development in locust egrs laid in antumn, 273-Requisites for the observation of stages carlier than those studied, 273Method of preparation of the eggs studied, $274-$ Structure of the nervous system and cyes, 274; of the heart, 274-Mode of origin of the heart, 274-Contents of the heart, 274-Structure of the trachea, 275; of the digestive eand, 275-Relations of the proctodrum to the amnion, 275-Structure of the Malpighian tubes, 276-The yolk cclls and yolk granules, 276.

Development of Caloptemus spretus. By A. S. Packard, jr..........

The primitive segments, 277-The nervous system, 277-The traehex, 278-The digestive canal, 278-Details of structure in more arlvanced embryos, 278-Structure of eyes, 278-Origin of ocelli, 278-Relations of antemne, eyes, clypens, and labrum to the proeelaphic lobes, 279-Structure of braiu and other ganglia, 279Relations of mancibles and the two pairs of maxille, 279-Relative development of legs, 279-Sections of embryo about ready to hateh, 279 . 
2267. [RILey, C. V., et al.]-Continued.

Chapter $\mathrm{X}$-Continued.

The development of the bark-boring beetles Bylurgops and Tyleborus. By A. S. Packard, jr............................

Breeding habits of Xyleborus calatus, 250-OYiposition of Hylurgus pinifex, 280-Egg of the Xyleborus, 24 hours after impregnation, 280-More developed egg, 280-Threads connecting the amnion with the serous membrane, 281 -Dorsal view of the embr $50,281-$ Later stage in Hylurgops, 281-Later stage in Xyleborus, 281Number of pairs of spiracles, 281-Structure and habits of freshly hatched Hylurgops, 281.

The number of segments in the head of winged insects. By A. S. Packard, jr . .......................................

Views generally entertained on this subject, 282-Head composed of four segments, 283-The procephalic lobes form the antennal segment, 284-The clypeus and labrum are the tergal portion of this segment, 284-The epicranium is the pleural portion, 284The occiput is the tergal portion of the labial segment, 284-The gnlar region probably the base of the labium, 285 .

\section{Chapter XI:}

The systematic position of the Orthoptera in relation to other orders of insects. By A. S. Paskard, jr ........................

Review of the characteristics of the four lowest orders of winged insects, 286-Probable descent of Orthoptera, Pseudoneuroptera, and Dermatoptera from a Thysanuran form, 286-Method of the present study, 286-Characters of the Phyloptera, 287-Mouthparts, 287-Thorax, 287-Wings, 288-Abdomen, 288-Metamorphosis, 288-Nomenclature of external parts of Arthropoda, 288Sequence of orders of Phyloptera, 288-Charactcrs of Dermatoptera, 289; of Orthoptera, 289; of Pseudoneuroptera, 290-Want of uniformity in eharacters of Psendoueuroptera, 290-The diagnostic characters superficial, 290--Structure of labium, 291Relative proportions of hoad-parts, 291 -Subdivisions of the order, 292-Characters of Platyptcra, 292 ; of Odonata, 292-Of Ephemerina, 203-Characters of Nenroptera, 293-Lignla, 293-Thorax, 293-Wings, 293-Abdomen, 294-Subdivisions of the order, 294'Tabular' view of the grand divisions of winged insects, 294-Diagrammatic view of the genealogy of the insects, 295-Genealogy of the Hexapoda, 295; of Thysanura, 295; of Dermatoptera, 295; of Orthoptera, 296; of Psendoneuroptera, 296; of Hemiptera, 297; of Nenroptera, 297-Derivation of cruciform larvæ, 297 ; of Sialidx, 297; of thysanuriform larvi, 297-Diversity of Neuropterous larve, 297-Larvæ of Sialidie, 297; of Hemerobiidæ, 297; of Trichoptera, 298; of Panorpidæ, 298-Significance of the abdominal legs of Panorpid larva, 299-The hypermetaniorphosis of Mantispa a key to the origin of a complete metamorphosis, 299-The aspect of the Nenroptera comparatively specialized and modern, 299-The Neuroptcrous labinm a secondary product, 299-Origin of the Coleoptera, 299-The free, active larve of the carnivorons gronps most nearly allied to the primitive form, 300-The scavenger and phytophagous larva show increasing degradation of devclopment, 300-The relative form of the maxille a good index of the gencral development of the bods in Coleoptera, 300-Structure of maxillx in the several families, 300-Close resemblance of the mouth-parts of Elaterid 
2267. [Riley, C. V., et al.]-Continued.

\section{Chapter XI-Continued.}

larva to those of Carabid larra, 301-The hypermetamorphosis of Meloidx furnishes a clew to the probable origin of the different types of Colcopterous larva, 301-Brief description of the metamorphoses of Meloe, 301-Of Epicanta, 302-Comparison of the larval stages of Meloid:s with the different types of Coleopterous larve, 302-Origin of the Diptera, Lepidoptera, and Hymenoptera, 303-Presence of temporary abdominal appendages on each segment of Lepidopterons, Coleopterous, and Orthopterous embryos, 304-Description of the structure of Dermatoptera (Forficula), 304-Labia,308-Larva of Forficula, 308-Orthoptera, 309-Blattaris, 309-Close relation of Blatta and Termes, 310Structure of Mantidie, 310-Blatta the stem-form of the Ortboptera, 312-Mantis connects the Acrydii and the Blattarix, 312Strueture of Phasmida, 312-Diapheromera, 312-Prisopus, 313This genus connects the Phasmida with the Acrydii, 314-Structure of Acrydii, 314-Calopten us, 314-Proscopia, 316-Conocephalus, 318-Locustariso (Anabrus), 318-Gryllidie, 319-Gryllus, 319-Gryllotalpa, 320-CEanthus, 322-Sequence of families of Orthoptera, 32:2-Structure of Pscudoneuroptera, 322-Corrodentia, 322-Perlidæ (Pteronareys), 322-Psocidæ (Psocus), 325Termitidæ, 326-Odonata, 329-Ephemerina, 333-Neuroptera, 335-Planipennia, 335-Sialide, 335-Hemerobiidæ, 338-Panorpidæ (Panorpa), 342-Trichoptera (Linınophilus), 344.

\section{Chapter XII :}

Note on the geographieal distribution of the Rocky Mountain locust, illustrated with a colored zoü-geographical map of North Ameriea. By A. S. Packard, jr............................

APPENDICES.

APPENDIX I:

Early references to the occurren ce of the ILessian fly in North America.

Early newspaper references, [3]-In 1784-'85, at Long Island and West Chester, [3]-In 1788, in Long Island, Delaware, New Jersey, and Pennsylvania, [3]-The fly resisted by certain varieties of wheat, [3-5].

\section{APPENDIX II:}

A. Deseription of the rye gall-gnat. By Dr. Herman Loew ......... Views as to the original conntry of the Hessian fly, [6]-The rye gall-gnat and the Hessian fly may not be the same species, [6]Description of the rye gall-gnat, C. secalina, [7].

B. Observations of the new crop gall-gnat. By Dr. Balthasar Wagner, Fulda, 1861. Translated by Carl F. Gissler...............

Literature, [8]-Preliminary consideration of the subimago and imago stages, [8]-Occurrence at Fulda, [8]-Breeding under nets, [9]-Seasonal and sexual differences, [9]-The fly short lived, [10]-Deseription of the adult, [10]-Of the male, [12]Of the female, [13]-The winter generation, [14]-The egg, [15]The maggot, [16]-The pupa or ehrysalis, [19]-The perfeet insect, [20]-Sensonal and scxual differences, [21]-Only the maggots hibernate, [22]-Single and double brooded, [23]-Summer generation, [23]-The new cercal gall-gnat as compared with Cecidomyia secalina Loew, [24]-Comparison of C. secalina Loew with C. destructor Say, [24]-Views of Loew, Fitch, and Herrick. 


\section{7. [Riley, C. V., et al.]-Continued.}

APPENDIX II-Continued.

- discussed, [25]-The rye gall-gnat, C. secalina and.C. destructor, all of one spccies, [28]-The name Hessian fly not justified, [28]Historical evidence thereon, [28]-Attempt at a new theory of the origin of the insect, [31]—Of Asiatic origin?, [31]-Carried to North America from France or Spain, [32]-Parasites, [33]Remedies, [34]-The removal of the barley after-growth, [34]Picking by hand, [35]-Grazing, [35]-Mowing, etc., [36]-Sowing grain as bait, [36]-Plowing, burning, rolling, [37]-Richness of soil, $[3 \%]$-Resistive varieties of wheat, $[38]$-Sowing late or early, [38].

APPENDIX III :

The Hessian fly in Silesia in 1869. By Professor Dr. Ferd. Cohn....

The Hessian fly, Cecidomyia destructor, and other Diptera observed destroying grain in Silesia, [39].

APPENDIX IV :

Koeppen's account of the Hessian fly. By F. T. Koeppen, St. Peters-

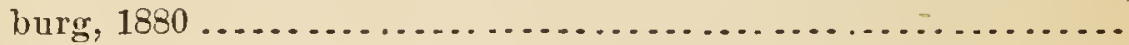

The Hessian fly recently detected extensively distributed in Russia, [41]-Two generations each season, [41]-Number of eggs at each deposition, [41]_Parasites, [41]-Doubtful species of Cecidomyia, [42]-Descriptions of species, [42].

APPENDIX V:

The Hessian fly not imported from Europe. By Dr. H. A. Hagen,

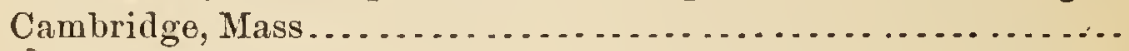

Conclusions of the author and others as to the nativity of Cecidomyia destructor, [43]-Not imported by the Hessian troops, [43]Probably here before the war, [45]-Not known in Germany before 1857, [46]-Mistakes corrected, [46]-A critical review of its history, $[47]$--Marked difference between $C$. destructor and $C$. secalina, [49].

APPENDIX VI:

Report on the Rocky Mountain locust in 1880. By Johu Marten...

Report to Dr. Cyrus Thomas of observations, [50]-Damages from locusts and wheat flies in Minnesota, [50]-Previous damages from locusts in Dakota, [51]-In Montana, [52].

APPENDIX VII:

Report of notes made in 1880. By A. J. Chipman .................

Nolocusts in Kansas, [55]—Suffering from drought, [55]-Favorable climatic changes, [55]-The locusts in Colorado, [56].

APPENDIX VIII :

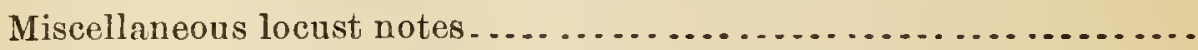

Dates and localities of locust swarms that have atiained the coast of Great Britain. Notes by A. H. Swinton, [57 $\hat{]}$-Occurrence of the migratory locust in Japan, [59]-Early uoticcs of locusts in North America, [59]-Locnsts at Fort Frontenac or Cataraqui, Canada, [59]; at Puerto Seguro Harbor, Californı, [60]-The locust in California in 1880, [60]; in Nevada, [60]-Locusts and coffee-trees in Guatemala, [60]-History of locusts in other countries, [61]-Locusts probably never will do so much damage again in North America, [61]-Utilization of locnsts as food, [61]; of crickets as manure, [6\%]-Ravages of locusts in Russia in 1879 and 1880, [62]; in the Caucasus, [63]; in Elizaretopol, [63]; in the district of Rassachs, [64]_-Plowing as a means of killing the 
2267. [RILEY, C. V., et al.]-Continued.

APPENDIX VIII-Continued.

locnsts, [64]-Destruction of locnsts in the district of Gori, [64]-Locusts in China in 1878, [65]-Oil as a means of destroying them, [65]-2,000,000 catties of eggs collected, [65]-Articlo on the extermination of the locust in China, [65-68]-Chinese bibliography of the subject, [65]-Chinese regulations regarding the extermination of locusts, [67]-Locusts in Cape Colony, South Africa, [68]-Ravages of nnfledged locusts, [68]-Locusts as food, [69]-Barriers as means of warding off and captnring locusts, [69]-Egg laying aud hatching, [72]-Protection against flying locusts, [72] -Locusts in the Philippinc Islands in 1878-'79, [72]-The locust plague in Bolivia, [72]-Locusts in India, [73]; in the Ottapidaram Taluq, [73]; in Sattur, [7:3]-Reqnest of the Madras Government for information as to the movements of the locusts, [74]-Locnsts in Kulapurum, Comaralingum, Kolumam, and in the Pulni Taluq, [74]-Difficulties in coping with locusts in southern India, [74]-Means against unfledged locusts, [ 75$]$ Locusts driven into the sea at Tuticorin and Trichendur, [76]Recommendation of rewards for gathering locnsts, [76] - Locusts at Peryapatty, [76]; in the Bellary district, [77]-Recommendation of means against locusts, [78]-Locusts at Madura, [78]Destruction of young locusts by fire at Pothanore, [78]-Locusts at Tiroomoorthypovil, Dhully, and Jellipatty, [79]; in various parts of the Punjab, [79]-Means against the locusts, [79]-Remuneration for destruction of locusts, [80]-Locusts in Coddapah district, [81].

APPENDIX IX:

Expericnce with the spring canker-worm. By Martin A. Howell, jr . .

Means employed to save an orchard from the ravages of cankerworms, [82]-Pruning, mannling, and washing of the trees, [82]-Spraying of the leaves with soft soap and arsenite of soda in water, [83]-Belting the trees with sulphnr and adhesive mixtures, [83]-Endurance of the moths, [84]-Variation of color in eggs, [85]-Most practical means of relief, [85]-Adulterations of Paris green, [85]-Good force-pumps, [85.]-Distribntion of canker-worms by the wind, [85].

2268. [RILex, C. V.] The silk industry in the United States. <Sci. ence, 7 March, 1S84, v. 3, pp. 290-292. S.-b. No. 42, pp. 82-84-

Review of article of W. C. Wyckoff; early history and present status of silk culture in North America; criticism of the estimates of the amonnt of silk raised in early times; relations of silk-culture and silk-manufacture to free trade and protection in the United States.

2269. Riley, C. V. The army-worm. <Washington, 1883 [20 March, 1884], pp. 89-152, pl. 1-2, with 1 p. expl. of pl. Advance reprint of principal portions: <Rept. [U. S.] Com. Agric. for 1881-1882, January, 1883, pp. 89-106.

Chapter 6 of the Third Report U. S. Entomological Commission. See No. 2267 for synopsis of contents.

2270. Riley, C. V. Canker-worms. <Washington, 1883 [20 March, 1884], pp. 157-198, pl.3, with 1 p. expl. of pl. Extract: <Amer. 
2270. Rrley, C. V.-Continued.

Cult., 1884, v. $46: 29$ March, p. 1; 5 April, p. 1. S.-b. No. 42, pp. 118-119; No. 57, pp. 86-87.

Chapter 7 of Third Report U. S. Entomological Commission. See No. 2267 for synopsis of contents.

2271. [Rrley, C. V.] The chinch-bug. Another entomologist expresses his views regarding the farmers' pest. <Watertown $[\mathrm{N} . \mathrm{Y}$. Daily Times, 27 March, 1884, v. 24. S-b. No. 57, pp. 42-43. Reprint: <Ogdensburg Jourual, 1884.

Notice of articles of J. A. Lintner; the occurrence of Blissus leucopterus in New York State in unusual abundance in 1882 and 1883 not a cause for great alarm; means against this insect. See No. 2252.

2272. Riley, C. V. Notes on North American Psyllide. <Proc. Biol. Soc. Wash., 1884, v. 2, pp. 67-79. Separate: $<$ [Washington], 10 April, 1884, pp. 67-79.

Notice of earlier studies of European and North American Psyllida; list of 18 nominal species described from North America; systematic and synonymical list of the same; descriptions of Pachypsylla n. g. [p. 71], $P$. venusta, $P$. celtidis-mamma, and $P$. [Blastophysa n. s-g., p. 75] celtidis-gemma n. sp. [p. 74]; dichotomic table of the thrce species of Pachypsylla; descriptions of Ceropsylla n. g. [p. 76] sideroxyli n. sp. [p. 76], Rhinopsylla n. g. [p. 77] schwarzii n. sp. [p. 78].

2273. Riley, C. V. Remarks on the bag-worm, Thyridopteryx ephemeraformis. <Proc. Biol. Soc. Wash., 1882-1884, 1884, v. 2, pp. 80-83, figs. 1-3. Separate: < [Washington], 10 April, 1884, pp. 80-83, figs. $1-3$.

Explanation of the more important and less known facts in relation to the life-history of Thyridopteryx ephemeraformis, especially in reference to the act of coition; figures of all stages and of the external male genitalia.

2274. Riley, C. V. The use of naphthaline as an insecticide. <Science, 11. A pril, 18s4, v. 3, pp. 455-456.

Review and summary of article of E. Fischer.

2275. Riley, C. V. Entomography of Hirmoneura. <Science, 18 A pril, 1884, v. 3, p. 488.

Review of F. Brauer's observations on the life-history of Hirmoneura obscura.

2276. Rrley, C. V. Orthoptera. <Standard Natural History (The) ... Boston, Cassino, 1 May-27 July, 1884, v. 2, pp. 167-203, 1 pl., figs. 243-285. Reprint: <Riverside Natural History (The) ... Boston and New York, Houghton, Mifflin \& Co., 1888, v. 2, pp. 167-203, 1 pl., figs. 243-285.

Systematic position, limitations, classificatory characters, transformations, molts, and geographical and geological distribution of the order; characters, habits, and distribution of the several familics; mention of the principal North American and of some forcign species, with more particular accounts of many specics, especially in regard to their stridulation and oviposition, with figures of a fow species and of their eggs. Ectobia germanica, Phasmomantis carolina, Diapheromera femorata, Ecanthus niveus, E.latipennis, Orocharis saltator, Camptonotus scudderi, Cyrtophyllus concavus, Microcentrum retinerve, and Caloptenus syretus are particularly mentioned.

2277. RrLey, C. V. Reports of observations and experiments in the practical work of the division, made under the direction of the 
2277. Riley, C. V.-Continued.

entomologist, together with extracts from correspondence on miscellaneous insects. <Bull. No. 4, Div. Ent. U. S. Dept. Agric. [3 May], 1884, 102 pp., 4 figs.

\section{CONTENTS.}

Introduction

Report upon cranberry and hop insects. By John B. Smith ..........

Observations on the Rocky Mountain locust and other insects in the Northwest during the summer of 1883. By Lawrence Bruner......

Preliminary report of observations upon insects injurious to cotton, orange, and sligar-cane in Brazil. By John C. Branner ...........

Report on the effects of cold on the scale insects of the orange in

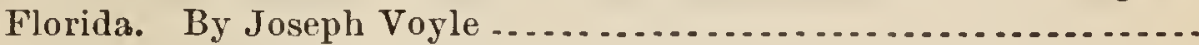

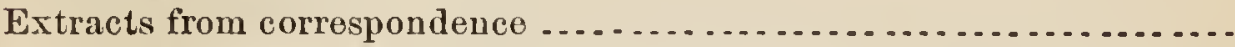

Additional notes ou the cultivation of pyrethrum in the United States.

2278. Rilex, C. V. Silk-culture in the colonies. <Science, 9 May, 1884, v. 3, pp. 562-563.

Explanation of several technical terms used in silk-culture.

2279. Riley, C. V. Maple-tree insects. <Sci. Amer., 24 May, 1884, v. 59, p. 325 . S.-b. No. 63, p. 45.

Answer to inquiry of R. H. Cntler; food-plants of and means against Pulvinaria innumerabilis.

2280. Riley, C. V. Acronycta betule n. sp. <Bull. Brooklyn Ent. Soc., May, 1884, v. 7, pp. 2-3, fig.

Description of Acronycta betule u. sp. [p. 2], reared from Betula nigra; seasons and habits of larva; comparison with related species.

2281. Riley, C. V. Recent advances in economic entomology. <Proc. Philos. Soc. Washington, 1884, v. 7, pp. 10-12. Separate: <Washington, 1884, pp. 10-12. Reprint: <Kansas City Review of Science, May, 1884, pp. 13-15. S.-b. No. 63, pp. 43-44.

Characteristics of economic entomology as a science and difficulties of its prosecution; the chief insecticide substances and thcir applicability; recent progress in mechanical appliances.

2282. Riley, C. V. Department of insects. <Ann. Rept. of Regents Smith. Inst. for 1882, 1884, pp. 215-216.

List of accessions to the U. S. National Museum, with comments; note on the Glover plates and manuscripts.

2283. RILEY, C. V. Quelques mots sur les insecticides aux Etats-Unis et proposition d'un noureau remède contre le Phylloxera. Communication faite à la Société d'Agriculture de l'Hérault à la seance du 30 Juin, 1884. <Montpelier, 1884, t.p. cover+8 pp. Reprint: <Messager Agricole, $10 \mathrm{July}, 1884$, ser. 3, v. 5, pp. 255-265. <La Vigne Amer., July, 18s4, v. 8, No. 7, p. 207.

Resistant vines better than the best insecticides as a means against Phylloxera vastatrix; principal insecticides in use, esprecially arsenical substances, potrolcum and pyrethrum; method of action and mode of application of these insecticides, especially application by the cyclone nozzle, and the subterranean application of kerosene cmulsion as a means against Phylloxera vastatrix; tobacco vapor, under favorable conditions, would probably kill this insect. 
2284. [RILEY, C. V.] Remedies for varions insects. <Prairie Farmer, 26 July, 1884, v. 56, p. 470 . S.-b. No. 59, p. 36.

Comparative efficacy and other qualities of several insecticides, especially arsenical substances, tobacco vapor, petroleum emulsions, and pyrethrum.

2285. Riley, C. V. Habits of Grapholitha olivaceana. <Ent. Mo. Mag., August, 1884, v. 21, p. 67.

Grapholitha olivaceana bred from curled tips of Solidago.

2286. Riley, C. V. Rhyssa not lignivorous. <Science, 28 November, 1884, v. 4, p. 4866 .

Parasitic habits of Rhyssa $[=$ Thalessa $]$ upon Tremex columba.

2287. Riley, C. V. The apple-root borer. <Rural New-Yorker, 13 De. cember, 1884, v. 43 , p. 831 . S.-b. No. 63 , p. 50.

Means against the larva of Prionus laticollis.

2288. Riley, C. V. A new insect injurious to wheat. < Bull. Brooklyn Ent. Soc., December, 1884, จ. 7, pp. 111-112. Separate: $<$ [Brooklyn, N. Y., December, 1884], p. 111.

Description of larva, pupa, and female imago of Isosoma grande n. sp. [p. 111] reared from wheat stems in Indiana.

2289. Riley, C. V. The insects of the year. <Science, 26 December, 1884, จ. 4, pp. 565-568.

Entomological calendar for each month of the year.

2290. Riley, C. V. On the care of entomological specimens. <Science, 9 January, iSs5, v. 5, p. 25.

Reply to editorial comments on the care of entomological specimens in the National Museum.

2291. Riley, C. V. Report of the entomologist. <Amn. Rept. [U.S.] Commissioner Agric. for 1884, 1885, pp, 285-418, 10 pl. Separate: <Washington: 31 January, 1885, pp. 9+pp. 285-418+ pp. $9,10 \mathrm{pl}$.

InTRODUCTION............................................

Scope of the report, 285-Climate and insect phenomena during the year, 285-Silk-culture, 286-Field force of the Bureau, 286-Suggested additions to field force, 287-Office force and its work, 287-Trip to Europe, 28\%-International Forestry Exhibition at Edinburgh, 287-Phylloxera in France, 288-Exhibit of the Bureau at the New Orleans Exposition, 288-'Third report of the United States Entomological Commission, 288Special reports, 288-Suggestions, 288-Illustrations, 288.

Carbage rnsects .... . . . . . . . . . . . . . . . . . . . . . . . . . . . . .

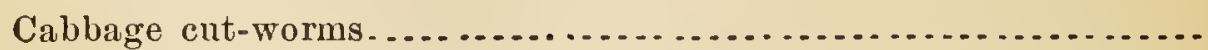

General characters, habits, and natural history, 289-Natural enemies, 290-Damage to cabbage, 290.

The dark-sided cut-worm, Agrotis messoria .....................

Synonymy, 290-Spread, 290-Climbing habits, 290-Natural history, 290-Larva and moth popularly described, 290.

The granulated cut-worm, Agrotis annexa...................

Spread; 291-Number of anuual generations, 291-Hibernation, 291-Eggs and early states described, 292.

The shagreened cut-worm, Agrotis malefida..................

Distribution, 29:-Points of difference from Agrotis annexa, 293Early states described, 293. 
2291. Riley, C. V.-Continued.

Cabbage insects-Coutiuned.

The W-marked eut-worm, Agrotis clandestina..................

Food-plants, 293-Habits, 294-Larva and moth popularly deseribed, 294.

The greasy eut-worm, Agrotis ypsilon ........................

Synonyny, 294-Distribution, 294-Habits, 294-Eood-plants, 294-Hibernation, 295-Larva and moth popularly described, 295-Deseription of egg, 295.

The speekled eut-worm, Mamestra subjuncta...................

Distribution, 296-Habits, 296-Appearance, 296.

The glassy eut-worm, Hadena devastatrix...................

Past history, 297-Natural history, 297-Charaeters, 297.

The variegated eut-worm, Agrotis saucia......................

Distribution, 297-Food-plants, 297-Egg and early states de. scribed, 298-Rapidity of development, 298.

Remedies for eabbage ent-worms...........................

Unsatisfaetory remerlies, 298-Wrapping the stem, 298-Trapping the worms, 299-Ditching, 299-Fall plowing, 299-The great value of poisoned bait, 299 .

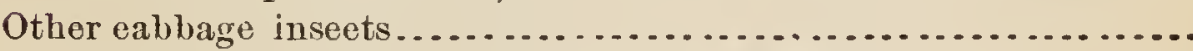

The imbrieated snout-beetle, Epicarus imbricatus...............

Distribution, 300-Food-plants, 300-Habits, 301-Remedies, 301-An allied imported insect, said to injure eabbage, 301.

The wary-striped flea-beetle, Phyllotreta vittuta................

Food-plants, 301-Habits, 301-Injury, 302-Early states, 302Remedies, 302.

Zimmermaun's flea-beetle, Phyllotreta zimmermanni...............

Food-plants, 304-Habits of larva, 307-Charaeters as eompared with the wavy-striped flea-beetle, 305-Early states deseribed, 306-Other speeies of the group, 307-Their habits, 307-Natural enemies, 307-Pleurotropis phyllotreta n. sp. deseribed, 308.

The Colorado eabbage flea-beetle, Phyllotreta albionica............

How it differs from the preeeding speeies, 308-Mention of a Paeific eoast speeies, 308.

The Colorado potato-beetle, Doryphora 10-lineata...............

Mentioned as soluetimes eating eabbage, 308 .

The harlequin cabbage-bug, Murgantia histrionica ................

Distribution, 309-Its spread to the Nortb aud East, 309-Foodplauts, 310-Natural history, 310-Amount of damage, 311Natural enemy, 311-Remedies, 311-Applieations, 311-Clean eultivation, 311-Destroyiug the early broods, 311-Kerosene, 312.

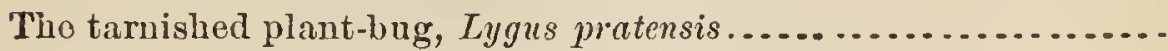

Distribution, 312-Food-plants, 312-Synongmy, 312--Supposed earnivorous habit, 312-Effeets of its puneture, 313-Variation in eolor, 313-Habits, 313-As an enemy to strawberries, 314Remedies, 314-Prevontive measures, 315-Applieations, 315.

The false ehinch-bug, Nysius angustatus .....................

Synonymy, 315-Food-plants, 316-Habits, 316-Reruedies, 316.

The eabbage plant-louse, Aphis brassica .....................

An imported inseet, 317-Damage, 317-Habits, 317-Life-history, 318-Natural enemies, 318-Remedies, 318.

The eabbage Authomyia, Anthomyia brassica ..................

Introduced from Europe, 319-Life-history, 320-Natural ene. mies, 320-Remedies, 321. 


\section{RILEY, C. V.-Continued.}

CABBage INSECTS-Continued.

The cabbage Oscinis, Oscinis brassica ........................

First found at St. Louis, 322-Habits, 322-Descriptive, Oscinis brassicae n. sp., 322.

The Rocky Mountain locust, Caloptenus spretus ..................

Successful introduction of a parasite (Apanteles glomeratus) of the imported cabbage-worm ...............................

GENERAL TRUTHS IN APPLIED ENTOMOLOGT .....................

Introductory, 323-Benefits derived from insects, 324-Influence of civilization upon insect increase, '324-Losses from insects, 324-Knowledge which the economic entomologist should possess, 325-Habits of the grape phylloxera, 325-Number of species of insects, 326-The different insecticides, 326-Arsenical compounds, 327-Petrolenm, 327-Kerosene emulsions, 328-Pyrethrum, 3:28-Its cultivation in California, 328-Its influence on mammals, 329-Insecticides to be used against root-feeding insects, 329-Mechanical contrivauces, 329-The eddy-chamber or cyclone nozzle, 330.

Kerosene EMulsions

Their importance as insecticides, 330-Use in orange. groves, 330 -Warning against imperfect emulsions, 331-Formula for kerosene and soap emulsions, 331-Importance of a stable emulsion, 3:31-Use of a force-pump in making emulsions, 331Trees injured by unemulsified oil, 332-The use of ley washes in California, 333.

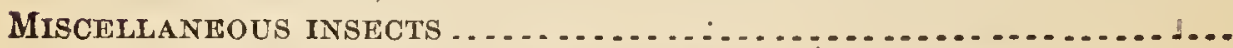

The American Cimbex, Cimbex americana....................

Injury to willows, 334-A new habit, 334-Eggs and mode of oviposition, 335-Habits of young larva, 335-Remedies, 336Other willow enemics, 336.

The streaked cottonwood leaf-beetle, Lina scripta ...............

Value of the cottonwood in the West, 336-Damage by the beetle in 1884, 336-Other food-plants, and former injuries, 337Natural history, 338-Remedies, 338-Apparatus for poisoning, $339-$ Varieties of the beetle, 340 .

The Southern buffalo-gnat, Simulium. pecnarum ...............

Losses in former years, 340-Damage donc by European species, 341-Early states of European species, 342-Early states of American species, 342-Recent ravages in the Southwest, 343Remedies, 344-Smudges, 344-Body applications, 344-Suggestions, 345 .

The angoumois grain-moth, Gelechia cerealella .................

Abundance, 345-Origin, 345-Past history, 346-Natural history and method of work, 346-Number of annual generations, 347Results of its work, 347-Parasites, 348-Remedies, 348Baking and concussions, 348-Quarantine, 348-Bisulphide of carbon, 349-Preventive measures, 349-Description of egge, 350 .

The cottony naple scale, Pulvinaria innumerabilis ................

Distribution, 350-History and synonymy, 350-Lifo history, 351Food-plants, 352-Mode of spreading, 353-Natural enemies, 354-Remedies, 355.

The cranberry fruit-worm, Acrobasis vaccinii..................

Natural history, 355-Remedies, 356-Descriptive, Acrobasis vaccinii n. sp., 356-Systematic position, :35\%. 
2291. Ruley, C. V.-Continued.

Miscellanfous insects-Continued.

The larger wheat-straw Isosoma, Isosoma grande.................

The phytophagic habits of the genus, 357-Mr. Webster's observations, 357-Descriptive, Isosoma grande n.sp., 358-Oviposition, 358-Ouly fernales known, 358.

Silk CULTURF

Sending out eggs, 359-Reports, 359-The manual of instructions, 359-Appointment of Philip Walker as special agent, 359Diseases, 359-Pasteur's process, 35y-A Government reeling establishment, 360-Correspondence; 360-The Serrell reel, $360-$ Home reeling, 361-Herbelin's filature, 361 .

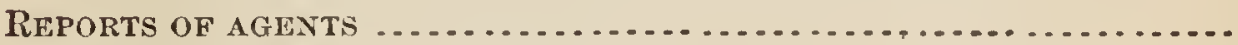

Rust of the orange. By H. G. Hubbard ........................

Discoloration of the fruit, 361-Time of appearance, 361-It is not a fungus, 362-The mito on the leaves, 362-First appearance of mites on the fruit, 363-Attacks of mites always followed by rust, 363-Interval between disappearance of mites and appearance of rust, 363-Description of the mite, 363-Life history, 364-Food, 364-Wandering habits, 365-Numerical abundance, 365-Rings of rust on fruit, 366-Influence of weather, 366-Agencies which assist in the distribution of the mites, 366-Food-plants, 367-Effects of attacks on foliage, 367Rusted fruit, 367-Introduction and spread of the mite, 367Periods of increase, 368-Gcographical distribution, 368-Remedies, 368-Influence of soil and methods of cultivation, 368Preventive measures, 368-Application of insecticides, 369Whale-oil soap, 369-Sulphur, 370-Kicrosene, 372-Creosote, 372-Potash, 372-Pyrethrum, 373-Lime, 373-Ashes, 373Cantion, 373.

Second report on the causes of the destruction of the evergreen and other forest trees in northern New England and New York. By A. S. Packard, jr ..........................................

Localities visited, 374-Destruction of spruces in northërn New York, 374-Probably caused by bark-boring beetles, 375-Destruction of spruces in northern Maine, 376-Discussion of causes, 376-Condition of the hackmatack in 1884, 377-The reddish-yellow spruce-bud worm, 378-Its injuries, 378-Its classification, 378-Its halits, 378-Remerlies, 379-The common longicorn pine-borer, 379-Abundance, 379-Mode of oviposition, 380-Description of egg, 380-Habits and damage done, 381-The sugar-maple borer, 38?-Its burrows, 382-Its eggs and larvix, 38:-Kerosene as a remedy, 383.

Insects affecting fall wheat. By F. M. Webster .................

The wheat-straw Isosoma, 383-Oviposition, 384-Description of its egg, 385-Number of generations, 385-Effect of its work on wheat-straw, 386-Table o position of larva in straw, 386Natural enemies, 387 Wheat and grass saw-fly, 387-Appearance, 388-Parasites, 388-Wheat midge; 389-Natural enemies, 389-Dates, 339-American Meromyza, 389-Dates, 390-The flca-like negro-bug, 390-Dates, 390-Description of egg, 390The tarnished plant-bug, 391-The soldier-bug, 391-The fieldcricket, 391-Cuttiug off wheat, 391-Insects affecting rse, 392Insects affecting oats, 392-The stalk-borer, 392-Dates, 393. 


\section{9i. Riley, C. V.-Continued.}

REPORTS OF AGENTS-Continued.

Report upon insects affecting the hop and the cranberry. By J. B. Sinith ..............................................

The hop Aphis, 393-Its first appearanee, 393-The cranberry fruit-worm, 394-'The fire-worm, 395-Cranberry leaf-folder, 395-Its dimorphism, 396-A cecidomyid larva infesting pears at Meriden, Conn., 396-Deseription of larva and infested fruit, 396-Pupation, 397-Distribution, 397-Varieties of pear infested, 397-Probably an imported pest, 398-Remedy, 398.

Notes from Nebraska. By Lawrence Bruner ....................

The Rocky Mountain locust in 1884, 398-Other species of locusts, 399-The snowy tree-cricket, 399-The chinch-bug, 399-Cutworms, 400-The imported cabbage-worm, 400-Its natural enemies, 400-Other cabbagc-worms, 401-False caterpillars on grass and scdge, 401 - Cimbex americana on willow hedges, 401injury to cotton woods by the striped beetle, 402 -The Colorado potato-beetle, 403.

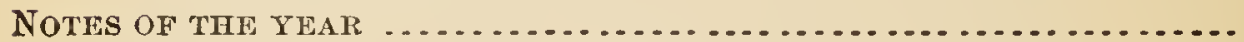

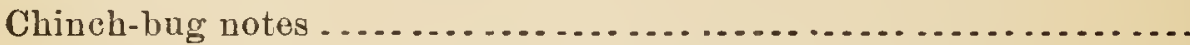

The so-called "invasion" of St. Lawrence County, New York, in 1883, 403-Mr. Lintner's prediction and his reasons therefor, 403-Reasons for dissenting from this view, 404-The result in $1884,405$.

Notes on the grape Phylloxera .............................

Regarding the grape Phylloxera in Russia, 405-In reference to the treaty of Berne and the prohibition of the introduction of bulbs and cuttings from the United States into Germany, 407The grape Phylloxera in graperies; legal questions arising, 408.

Miscellaneous notes ...................................

The box Psylla found in the United States, 410-The dwarfing of oaks by Mallodon melanopus, 410-The clover-seed midge, 411The potato-stalk weevil, 411 -The red-humped prominent, 411The varying anomala, 412-Whitc-lined morning-sphinx, 412The apple-tree tent caterpillar, 412-Corn bill-bugs, 413-A swarming mite, 413-A new enemy to white roses, 413-A beetle eating peach-leates, 413-Effect of cold on the eggs of barklice, 413-Ravages of grain-weevils in Florida, 414-Fuller's rose-beetle, 414-The blood-sucking Conorhinus, 414-The catalpa sphinx, 415-Notes on cotton worms, 415-Pyrethrum, 416.

Notes from Missouri. By M. E. Murtfeldt...................

'The striped flea-beetle, 416-The Colorado potato-beetle, 416The imported cabbage-buttcrfly, 416-The cottony maple scale, 417-The stalk-borer, 417-Grapho7itha prunivora, 418-The grape saw-fly, 418-A saw-fly on plum, 418-A saw-fly on ash, 418.

2292. Rilex, C. V. General truths în applied entomology. Essay. <Trans. Ga. State Agric. Soc., 1884, v. -, pp. 153-159. Separate: <Macon, Ga., 1884, t.-p. cover, pp. 153-159. Reprint: <Rept. [U. S.] Commissioner Agric. for 1884, pp. 323330. <Gardener's Chronicle, 1885, г. 23; 20 June, pp. 785-786; 27 June, p. 818. S.-b. No. 61, p. 6; 10-11. See: <Ga. Crop 
2292. RrLey, C. V.-Continued.

Rept., June, 1884, p. $33 . \quad<$ Sci. Amer. Suppl., 7 February, 1885, v. 19, p. 7588. S.-b. No. 61, p. 12.

See No. 2291 for synopsis of contents.

2293. R[ILEY], C. V. Codlin moth. <Suppl. Encyclopxdia Britannica, 9th ed., 1884, v. 2, p. 281, fig.

Natural history, remedies, and tigures of Carpocapsa pomonella.

2294. R[ILEY], C. V. Colorado potato-beetle. <Suppl. Encyclopædia Britannica, 9th ed., 1884, v. 2.p. 311, fig.

Summary of the eastward spread of Doryphora 10-lineata; natural history, enemies, remedies, and figures of the same.

2295. R[rLey], C. V. Cotton-worm. <Suppl. Encyclopædia Britannica, 9th ed., 1884, v. 2, pp. 432-433, figs.

History, ravages, life-history, remedies, and figures of Aletia xylina.

2296. R[rLey], C. V. Curculio, plum. < Suppl. Encyclopædia Britannica, 9th ed., 1884, v. 2, p. 494.

Natural history and means against Conotrachelus nenuphar.

2297. Rrley, C. V.' Insect named. 'Daily Gate City [Keokuk, Iowa], 18 February, 1885. S.-b. No. 63, p. 31.

Brief notes of Olfersia americana.

2298. Riley, C. V. A new remedy for the imported cabbage.worm. $<$ Rural New-Yorker, 28 February, 1885, v. 44, p. 132. S.-b. No. 63, p. 50. See: <Colman's Rural World, 5 March, 1885, v. 38, p. 76. S.-b. No. 63, p. 8. <Prairie Farmer, 7 March, 1885, v. 57, p. 153 . S.-b. No. 61, p. 26. <Amer. Farmer, 1 April, 1885, v. 4, p. 105. S.-b. No. 67, p. 60. <Sci. Amer., 23 May, 1885, v. 52, p. 322. S.-b. No. 61, p. 19. <Indiana Farmer, 30 May, 1885. S.-b. No. 61, p. 22.

Ice-cold water applied during the heat of the day causes the death of the larva of Pieris rapa.

2299. Rrley, C. V. The collection of insects in the National Museum. <Science, 6 March, 1885, v. 5, pp. 188-189. S.-b. No.61, pp. 7-8. Answer to criticisms of C. H. Fernald; the insects in the National Museum cared for by the entomologist of the Department of Agriculture.

2300. Rrley, C. V. Ants and aphides. <Rural New-Yorker, 14 March, 1885, ₹. 44, p. 171 . S.-b. No. 61, p. 19.

Answer to inquiry of J. McFarland; habits of ants in relation to plant-lice; subterranean plant-lice attended by ants; ants in northern States beneficial rather than injurious; ground can be cleared of them by injection of bisulphide of carbon or a strong kerosene emulsion.

2301. Rrley, C. V. Parasites of the larva of Lachnosterna fusca. $<$ Psyche, 1884 [16 March, 1885], r. 4, p. 224.

Criticism of statements of $O$. Lugger; larval habits of Tiphia inornata and Rhipiphorus sp.

2302. Rrley, C. V. Jumping spiders. <Rural New-Yorker, 11 April, 1885, v. 44, p. 250 . S.-b. No. 63, p. 33.

Answer to inquiry of H. B. S. ; habits of Attus sp. 
2303. Rilex, C. V. Circular No.9 [U. S. Department of Agriculture, Dirision of Entomology]. < [Washington:] 1 May, 1885, 1 p., fo:, 1 fig. Reprint : <Pacific Rural Press, 16 May, 1885. S.b. No. 63, p. 27. <Weekly Times-Democrat [New Orleans], 23 May, 1885. S.-b. No.61, p. 23. <Rural Californian, June. 1885, จ. 80, p. 122. <S.-b. No. 61, pp. 20-21. . <Sci. Amer. Suppl., 6 June, 1885, v. 19, p. 7859 . S.-b. No. 63, pp. 25-26. < $<$ Pacific Rural Press, 16 May, 1885, v. 29, p. 469. S.-b. No. 63, p. 27. See : <Farmer's Review, 21 May, 1885, v. 14, p. 362 . S.-b. No. 63, p. 29. N. Y. Weekly Sun, 27 May, 1855. S.-b. No.63, p. 29. N. Engl. Farmer, 16 May, 1885. S.-b. No. 63, p. 29.

Conditions under which the Government will buy silk-worm eggs; how to select moths to produce eggs.

2304. Rilex, C. V. The imported elm-leaf beetle. Its habits and natural history and means of counteracting its injuries. <Bull. No. 6, Dir. Ent. U. S. Dept. Agric. [14 May], 1885, 20 pp., 1 pl., $1 \mathrm{fig}$.

Treats of Galemca xanthomelcena; its habits and natural history; description, figures, remedies, and methods of application of insecticides.

2305. Riley, C. V. Destroying Cicadas: Scurfy apple bark-louse. $<$ Rural New-Yorker, 23 May, 1855, v. 44, p. 353 . S.-b. No. 61, p. 24.

finswer to inquiries of J. A. K.; means against Cicada $[=$ Tibicen $]$ septendecim and Chionaspis furfurus.

2306. Riley, C. V. [Poisonous spider.] <Rural New.Yorker, 23 May, 1885, v. 44, p. 354 . S.-b. No. 61, p. 23.

Reply to statements of Dr. W. H. G.; no spider known whose foot-tracks kill leaves or trees.

2307. [Riley, C. V.] Expected advent of the locust. <Sci. Amer., 23 Maj, 1885, v. 52, p. 320. S.-b. No. 61, p. 9. <Farmer's Home Journ., 13 June, 1885. S.-b. No. 63, p. 18. <Orange Co. [N. Y.] Farmer, 28 May, 1885. S.-b. No. 63, p. 23. <See: <Sci. Amer., 20 June, 1885, v. 52, p. 389. S.-b. No. 63, p. 28. Simultaneous appearance of a 17-ycar (Cicada $[=$ Tibicen $]$ septendecin) and a 13-year ( $C .[=T$.$] tredecim) brood; localities of the two brools; life-history$ and habits.

2308. Rilexy, C. V. Rust of orange. < Rural New-Yorker, 16. May, 1885 , v. 44, p. 355 , figs. 196,197 . S.-b. No. 61 , pp. 18-19, figs. 196-197. Reprint: <Colman's Rural World, 18 June, 1885, v. 38, p. 195, 2 figs. S.-b. No. 61, pp. 31-32, 2 figs.

Description, habits, and means against Phytoptus gleivorus; figures the same and its eggs; figure of a rusty orange.

2309. [Riley, C. V.] Red-ants. <Sci. Amer., 21 May, 1855, v. 52, p. 183 . S. b. No. 66, p. 35.

Recommends pyrethrum, kerosene, hot water, and naphthaline as means against red-ants in honses. 
2310. [RILEy, C. V.] Ridding the ground of cut-worms. <Rural NowYorker, 30 May, 18s5, v. 44, p. 368. S.-b. No. 63, p. 22.

Answer to inquiry of V. R. R.; means against the larva of Agrotide.

2311. [RILEY, C. V.] An entomological breakfast. <N. Y. Times, 2 June, 1885. S.-b. No. 63, p. 1. See: <Belvidere [Ill.] Standard, 23 June, 1885 . S.-b. No. 63, p. 7.

Cicadas and Acridida as food.

2312. Riley, C. V. The periodical or seventeen-year Cicada. <Harper's Weekly, 6 June, 1885, v. 29, p. 363, 4 figs. S.-b. No. 61, pp. 24-26, 4 figs.

Recolds and map showing distribution of brood XXII (septendecim) and of brood VII (tredecim); habits, enemies, and figures, with details of structure of Cicada [= Tibicen] septendecim; figure of twig punctured by the same and of twig healed after the puncture.

2313. [RILEY, C. V.] The winged pests of the West. <St. Louis Globe-Democrat, 9.June, 1885. S.-b. No.61, p. 11.

Prediction that the northern States of the Mississippi Valley will escape serious damage from locusts this year; reasons for this opinion; ravages of Camnula pellucida in California.

2314. Riler, C. V. The periodical or serenteen.year Cicada. <Amer. Grange Bulletin, 11 June, 1885. S.-b. No. 63, pp. 16-17.

Chronological record, natural history, and popular names of Cicada $[=$ Tibicen? septendecim.

2315. Rlley, C. V. The periodical Cicada. An account of Cicada septendecim and its tredecim race, with a chronelogy of all broods known. <Bull. No. 8, Div. Ent. U. S. Dept. Agric., [17 June], 1885,46 pp., 8 figs. Second edition, 13 July, 1885.

2316. Riley, C. V. Notes on joint worms. <Rural New-Yorker, 20 June, 1855, v. 44, p. 418, figs. 215-218.

Habits, means against, and figure of Isosoma hordei; criticism of A. J. Cook's views on $I$ sosoma; figures $I$. tritici and $I$. grande.

2317. Riley, C. V. Beetles in the corn-fields. <Daily Gate City [Keokuk, Iowa], 23 June, 1885. S.-b. No. 61, p. 17.

Answer to letters of J. M. Evans and J. M. Schaffer; Agonoderus pallipes injurious to seed corn; recommends soaking the seed corn in Paris green or London purple.

2318. Riley, C. V. Notes'on the periodical Cicada. <Science, 26 June, 1885, v. 5, pp. 518-521. Reprint: <Sci. Amer. Suppl., 27 June, 1885, r.19, pp. 7905-7906. S.-b. No. 61, pp. 47, 48; No. 63, p. 74. Record showing distribution of brood XXII (septendecim) and of brood VII (tredecim) in 1885 ; the specific value of the different forms; long period of underground development; its life-history; food of the larva, methods of burrowing, and transformations; the Cicada versus civilization.

2319. Kiley, C. V. The Chester onion pest. <Orange County [N. Y.] Farmer, 2 July, 1885. S.-b. No.61, pp.1-2. See: <Rural New Yorker, 5 December, 1885, v. 44, p. 829. S.-b. No. 61, p. 151.

Extract from Rept. U.S. Eut. for 1884 ; remedies against cabbage cut-worms; the poisoned ball system and kerosene cmulsion effective against the onion cut-worm; formula for a soap-kerosene emulsion. 
2320. Rluey, C. V. Premature appearance of the periodical Cicada. <Science, 3 July, 1855, v. 6, pp. 3-4.

Criticism of L. F. Ward's record of the occurrence and song, of Cicada [=Tibicen ] septendccim. See No. 2326.

2321. Riley, C. V. Periodical Cicada in Massachusetts. <Science, 3 July, 1885, v. 6, p. 4.

The occurrence of Cicada $[=$ Tibicen $]$ septendecim in southeastern Massachusetts needs confirmation.

2322. RILEx, C. V. Destructive insects of the year. <Rural New Yorker, 11 July, 1S85, v. 44, p. 464 . S.-b. No. 61, p. 8.

Injurics and means against Agrotis malefida, Anthonomus musculus and Eurycreon rantalis; localities and food-plants of the last.

2323. [Riley, C. V.] [Grasshopper ravages in California.] <Rural New-Yorker, 11 July, 1885, v. 44, p.470. S.b. No. 61, p. 2.

Ravages cominitted by Melanoplus [= Caloptenus $]$ devastator and Caloptenus differentialis; recommends the use of coal-oil pans against them.

2324. Rilex, C. V. Pests of the strawberry. <Rural New-Yorker, 18 July, 1885, v. 44, p. 484 . S.-b. No. 61, p. 17.

Answer to inquiry of J. H. J.; means against Agrotis tricosa, Phoxopteris fragarie, Eccopsis permundana and Emphytus [= Harphiphorus] maculatus.

2325. Rilex, C. V. The imported elm-leaf beetle. <Harper's Weekly, 18 July, 1885, v. 29, p. 463, 1 fig. S.-b. No. 61, pp. 21-22, fig.

Natural-history descriptions and tigures of all stages of Galeruca xanthomelcena; means against the same.

2326. Riley, C. V. Premature appearance of the periodical Cicada. <Sci. Amer. Suppl., 15 August, i885, v. 20, p. 8021.

Criticism of L. F. Ward's record of the occurrence and song of Cicada $[=$ Tibicen $]$ scptendecim; an introductory note states that this article was prepared for Science, but that it appeared in that jourual in a mutilated and weakened form. See No. 2320.

2327. Riley, C. V. The cyclone nozzle. <Rural New-Yorker, 22 August, 1885 , v. 44 , p. 567 . S.-b. No. 61 , p. 34 .

Facts relative to the invention of the cyclone nozzle.

2328. Riley, O. V. A new remedy against destructive locusts. $<$ Rural New-Yorker, 29 August, 1885, v. 44, p. 577. S.-b. No. 61, p. 33 .

Recommends the use of poisoned bait; formula of the same.

2329. Riley, C. V. The influence of climate on Cicada septendecim. $<$ Entom. Amer., August, 1885, v. 1, p. 91.

Records the transfers of eggs of brood XXII (septendecim) of Tibicen septendecim to the extreme southern States where no septendecim brood is known to oc cur, and of brood VII (tredecim) to northern States where no tredecim brood is known to occur.

2330. Riley, C. V. Department of insects. <Ann. Rept. of Regents Smith. Inst. for 1883, 1855, pp. 239-244.

Brief mention of work accomplished in the U. S. National Museum; list of . accessions to the collection. 
2331. Riley, C. V. Insects of the rear. <Prairie Farmer, 3 September, 1885 , r. 57 , p. 567 . S.-b. No. 63, p. $37 ; 134$. See: <Entom. Amer., December, 1855, v. 1, pp. 176-177.

Ravages of Agrotis messoria, Anthonomus musculus, Eurycreon rantalis, Cecidomyia destructor, and Acridide on the Pacific coast.

2332. Rrlex, C. V. On the parasites of the Hessian fly. <Proc. U. S. Nat. Mus., 14-17 September, 1855, v. S, pp. 413-422, pl. 23. Abstract: <Proc. Amer. Assoc. Adv. Sci. for 1885, [August], 1886, v. 34, pp. 332-334. <Amer. Nat., November, 18S5, v. 19, pp. 1104-1105.

Description, synonymy, habits, and figures of Merisus destructor (Say); $M$. subaptcrus n. sp. [p. 416, pl. 23, f. 2: p. 333]; Eupelmus allynii French; Tetrastichus productus n. sp. [1. 419, pl. 23, f. 5: p. 333]; and Platygaster herrickii Packard.

2333. Riley, C. V. Enemies of the black-walnut and willow. <Rural New-Yorker, 19 September, 1885, v. 44, p. 632. S.-b. No. 61, p. 35.

Habits, description of eggs, larva, and adult of Datana ministra; description of eggs, larva, and adult of Cimbex americana; means against both species.

2334. Riley, C. V. The song-notes of the periodical Cicada. <Science, 25 September, 1885, v. 6, pl. 264-265. Reprint, with additions: <Proc. Amer. Assoc. Adr. Sci. for 1885, [August], 1886, v. 34, pp.330-332. Translation: < Stett. Ent. Zeit., 1886, jahrg. 47. pp. 158-160. See : <Science, 11 September, 18s5, v. 6, p. 225. <Kansas City Review, October, 1885, p. 171.

Description of the three prevalent notes of Cicada $[=$ Tibicen $]$ septendecim.

2335. Rilex, C. V. The probabilities of locust or "grasshopper" injury in the near future, and a new method of counteracting their injury. <Colman's Rural World, 29 October, 1855, v. 38, p. 348. S.-b. No. 63, pp. 32-33. Reprint: <Proc. Amer. Assoc. Adv. Sci. for 18S5, [August], 1SS6, v. 34, pp. 519-520. <Proc. 6th Meeting Soc. Prom. of Agric. Sci., Manhattan, Kans., 1Ss6, pp. 38-39. See: <Mich. Christian Herald, 3 September, 1885. S.-b. No. 63, p. 39. <Amer. Grange Bull., 5 Norember, 1885. S.-b. No. 63, p. 34. <Prairie Farmer, 10 October, 1885, v. 57, p. 669. S.-b. No. 61, pp. 34-35.

The advance of settlement and cultivation will prevent such widespread injuries of Caloptemus spretus as occurred between 1874 and 1877; use of poisoned baits.

2336. RrLey, C. V. The present status and future prospects of silkculture in the United States. <Entom. Amer., October, 1885, v. 1, pp. 139-140. Reprint: <Proc. Amer. Assoc. Adv. Sci. for 1885, [August], 1886, v. 34, p.516. See: <Science, 11 September, 1885 , v. 6 , p. 236.

Abstract; headıngs under which the subject is discussed; summary of conclusions. 
2337. Rilfey, C. V. The grain moth. <Rmral New-Yorker, 7 November, 1885, v. 44, p. 744 . S.-b. No. 63, p. 56.

Habits, deseriptions, ravages, and means against Asopia farinatis.

2338. [RILEy, O. V.] Profits of silk-culture. <Rural New-Yorker, 26 December, 1885 , v. 44 , p. $\$ 85$. S.-b. No. 63 , pp. 50-51.

Answer to inquiry of J. M. S. ; aetual eost of produeing silk in different parts of the United States.

2339. Riley, C. V. Aletia xylina rs. A. argillacea. <Entom. Amer., December, 1855̃, v. 1, pp. 161-163.

Rcasons for eonsidering Aletia xylina the correct name for the cotton-worm; advanee print from No. 2343.

2340. [Rrley, C. V.! [Euphanessa mendica, ete.] <Entom. Amer., December, 1885, v. 1, pp. 170-171, 173, 176.

Remarks on papers real at the A. A. A. S.; Euphanessa mendica eonsidered a geometrid ; some charaeters of the Lepidoptera; life-habits of Egerida.

2341. Riley, O. V. On the hitherto unknown mode of oviposition in the Carabidee. Abstract: <Proc. Amer. Assoc. Adv. Sci. for 1884, 1855, v. 33, pp. 535-539.

History of Chalcenius impunctifrohs traced from egg to imago; eggs laid singly on leaves of trees inclosed in mud or clay.

2342. Riley, C. V. [Report of the Edinbargh International Forestry Exhibition.J <Rept. U. S. Dept. Agric. for 1884, 1885, pp. 167179.

Brief mentiou of some of the insect collections ex hibited.

2343. RILEY, U. V. Fourth report of the United States Entomological: Commission, being a revised edition of Bulletin No. 3, and the final report on the cotton-worm, together with a chapter on the boll-worm, with maps and illustrations. <Washington: 1885, [3 Febrnary, 1886], pp. $38+399+147,45$ figs., 64 pl., 2 maps.

LetTer of SUbMitTaL .................................. xvii

Preface ....................................................

INTRODUCTION .......................................... xxii

Chapter I:

Classification and nomenclature. Destructiveness................

Popular and scientifie uames, 1-Most desirable popular name, 1Different technical numes, 1-History of these names, 1-The name Aletia xylina the eorrect one, 1-Synonomy of the insect, 2-Classificatory position, 2-Importance of the family Noetuidæ, 2-Dcstruetiveness of the worm, 2-Causes which increase this destructiveness, 2 - Regions where losses are greatest, 2 ; and least, 3-Tabular statement of losses, 3-Previous statements, 3-Statement of loss in 1881, 4.

Chapter II:

Charaeters, habits, and natural history.................

Distinct states of growth, 5-The worm must hatch from an egg, 5 -Description of egg, 5-Where the cgg is laid, 5-Number of eggs to a leaf, 6-Time elapsing before hatching, 6-Unhatched eggs perish when frozen, 6-Inseets' and other eggs mistaken for eggs of Aletia, 6-Charaeters of worm, 6-Description of newlyhatched worm, 6-Number of molts, 7-Different colors of worm, 


\section{Riley, C. V.-Continued.}

\section{Chapter II-Continued.}

7-Habits of worm at different stages, 7-Jumping habit, 7Only known to feed on cotton and one another, 8-Odor of the worm, 8-Migrations of worm, 8-Method of pupation, 8Formation of cocoon, 8-The worm never burrows in the ground, 8-Distinctive characters of the chrysalis, 9-Duration of chrysalis state, 9-Distinctive characters of the moth, 9-Sexual differences in the nioths, 9-Different habits of the moths at night and by day, 10-Thcir strong flight, 10-Their position at rest, 10-How soon the female begins to lay, 10-Her prolificacy, 10Food of the moth, 10-It injures fruits, 11-Structure of the tongue, 11-Mention of other Noctuide which injure fruits, 11Time elapsing from one generation to another, 11-This will average abont one month, 12-Time of year when the first worms appear, 1\%-Former opinions erroneous, 12-Dates of earlicst appearance variable, 12-Worms of all sizes found in Florida and southern Georgia in the latter part of March, 12First worms always fow and scattered, 12-They multiply and spread irregularly, 12-Their progress governed by the season and latitude, 13-The third gencration often called the first, 13Number of annual generations, $13-$ There are at least seven in southern Texas, 13-Gradual progress and succcssion of broods, 14-The second generation exceptionally very injurious, 14Why not usually sn, 14-Extent of migratory flights of the moths, 15-Probable existence of northern food-plants, 15Causes and seasons of migration, 15-Behavior of migrating moths, 15-The question of hibernation, 15-Different former opinions and beliefs concerning hibernation, 16-Discussion of these opinions, 16-The chrysalides are killed by a temperature below 220 F., 16-Parasited chrysalides can bcar greater cold, 16-Fallacy of the belief that the chrysalis winters underground, 16-Ease with which erroneous conclusions can be drawn from mistaken identity, 17-The chrysalis of Aspilavirescens mistaken for that of the Aletia, 17-Chrysalides of other cotton larvie found underground in abundance, 17-The chrysalis of Aletia killed by burial, 17-Ability of the moth to survive the winter, 18-Unreliability of most testimony as to the hibernation of the moth, 18-Other moths easily mistaken for it, 18-Hypena scabralis, 18-Phoberia atomaris, 19-Leucania unipuncta, 19-Absence of testimony to the survival of the moths beyond March, 19-Theory of annual introduction of the species from some southern foreign country, 19-Statement and discussion of Grote's arguments and of others in support of this theory, 20-Arguments in favor of the hibernation of the moth, 21Both immigration and hibernation may occur, 21-Summary of the evidence, 22-Aletia hibernates only as a moth and only in the extreme south, especially in Texas, 22.

\section{Chapter III :}

Past history of the cotton-worm in the United States............. From 1793 to $1825,23-F r o n ~ 18: 26$ to $1846,24-F r o m ~ 1847$ to 1866 , 25-From 1867 to 1869, 26-From 1869 to 1872, 27-In 1872 and 1873, 28-In 1873 and 1874, 29-In 1875 and 1-76, 30-In 1877 and 1878, 31-In 1879 and 1880, 32-In 1880 and 1881, 33-History of remedies, 34-Hund-picling. and poultry, 34-Fires, 35-Other 
2343. Riley, C. V.-Continued.

Chapter III-Contioued.

remedies, 35, 36-Arsenic, 36-Paris green, 36-38-Planting jute, 38-Machinery, 38-London purple, 38-Pyrethrum, 38.

CHAPTER IV:

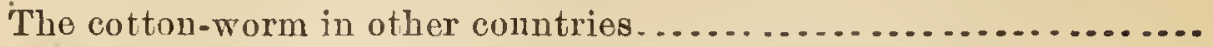

Geographical distribution of Aletia xylina, 39-Other insects injurious to cotton in the Eaștern Hemisphere, 39-Occurrence of Aletia xylina on the Pacific const of Mexico, 39-40-Ou the Gulf coast of Mexico, 40-41-In Yucatan, 41-In the West Indies, 42-In the northern countries of South America, 42-43-In Brazil, 43-44.

Chapter V:

On the anatomy of Aletiu. By Edward Burgess and C. S. Minot....

Circumstauces under which this chapter was prepared, 45-External anatomy of larva, 45-True legs, 45-Prolegs, 46-Colored markings, 46-Stigmata, 46-Internal anatomy of larva, 47Head, 47-Ganglia, 47-Digestive canal, 47-Malpighian vessels, 47-Salivary głands, 47-Dorsal vessel, 47-Stomach, 48-External anatomy of imago, 48-Method of preparing the exoskeleton for examination, 48-Head and appendages, 48-Prothorax, 48, 49-Mesothorax, 49-Metathorax, 49, 50-Supposed organ of hearing, 50-Abdomen, 50-51-Spiracles, 51-Legs, 51-Scales, 51-52-Scale-pores, 52-Proboscis, 52-Spines, 53-Interual anatomy of imago, 53-Digestive canal, 53-Pharynx, 53-54-Salivary glands, 54-Csophagus, 54-Food reservoir, 54-55-Stomach, 55Malpighian vessels, 55-Intestines, 55-Aorta, 55-Nervous system, 55-Ganglia, 55-Terminal body segments and organs of reproduction, 56-Brush-sac, 56-Male organs of reproduction, 56Testes, 57-Vasa defercntia, 57-Penis, 57-Female organs of reproduction, 57-Ovaries, 57-Sebaceous glands, 57-Vagina, 58Copulatory pouch, 58-Terminal abdominal segments of the femalc, 58.

Chapter VI:

The cotton belt. By Prof. E. A. Smith ........................

A. General features of the cotton States...................... Region included in the cotton belt, 59-Climate, 59-Winds, 59Rainfall, 59-61-T'cmperature, 61-62-Geological sketch, 62-63Topography, 63-64-Soils, 64-65-Agricultural subdivisions, 65Regions of forest growth, 66-67.

B. Description of the agricultural-subdivisions............... The all uvial region, $67-68$-The lower prairie region, $68-69-$ The long-leaf pine region, 69-71-The oak uplands region, 72-73-The npper prairie region, 73-75-The red and brown loam region, 7577-The sandy and siliceous lauds of the older formations, 77-79The gneissic region, 79-80.

Chapter VII:

Terrestrial and meteorological influences affecting the worm........

Condition of soil and plant connceted with the appearance of the first worms, 81-The earliest worms are confined to the "low, lands," 81; and to luxuriant plants, 82; and to the vicinity of winter shelters, 82; and to the same localities, 82-Influence of wet weather on the developmeut of the worms, 83-Severe rains with gales destroy both worms aud crop, 83-Late cold rains do the same, 84-Frequent summer rains favor the development of the worms, 84-Hot, dry weather destructive to them, 84-Artifi. 
2343. Riley, C. V.-Continued.

\section{Chapter VII-Continued.}

cial drought produces the same effect, 84-Indirect influences of wet weather in favoring the development of the worms, 85- Immunity of the worms from their enemies in wet weather, 85Drowning of ants by heavy showers, 85-Wet weather prevents poisoning and working the cotton, 85-Letter from J. W. Du Bose on the influence of winds on Aletia, 85-86.

\section{Chapter VIII :}

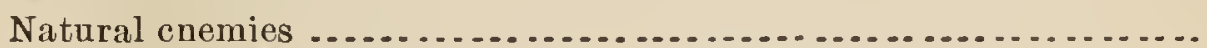

General remarks, 87-Importance lessened by the use of arsenical poisons, 87-Vertebrate enenies. 87-Quadrupeds, 87-Birds, 87English sparrow, 88-Toads and lizards, 89-Invertebrates, 89Spiders, 89-Ants, 90-Species of ants destroying Aictia, 90Hubbard's observations on ants, 92-The leaf-cutting ant, 94Wasps, 94-Coleoptera, 95-Tiger-beetles, 95-Ground-beetles, 95-Lady-birds, 96--Soldier-beetles, 96-Heteroptera, 97-List of species, 97-Diptera, 99-Orthoptera, 99-Neuroptera, 100-Lepidoptera, 100-Parasites, 101-List of specics, 101-The Trichogramma egg-parasite, 102-Tho cotton-worm Microgaster, 104-. Comstock's Euplectrus, 105-Elachistus euplectri, a secondary parasite, 106-The common flesh-fly, 107-Cyrtoneura stabulans, 108-Is it parasitic ?, 108-Tachina-flies, 109-Their habits, 109The watchful Pimpla, 111-The ring-legged Pimpla, 113-Cryptus nuncius, 113-The ovate Chalcis, 114-The devouring Tetrastichus, 115-Species that are easily mistaken for parasites of Aletia, 115-Hexaplasta zigzag, 115-Phora aletia, 116.

\section{Chapter IX:}

Preventive measures .......................................

Mode of cultivation, 120-Inlproving cotton seed, 120-Forcing the young plants, 120-Transplanting from hot-beds, 120-Objections, 121-Frequent cultivation, 121-Topping the cotton, 121Fertilizers, 121-Sulphuric acid on seeds, 121-Late planting, 121-"Worm-proof cotton," 121-Diversified agriculture, 122Rotation of crops, 122-Jute as a protection, 122-Other supposed protective plants, 123-Protection oi natural enemies, 123 -Immunity of cotton under trces, 124-Preventing oviposition of the moth, 124-Futility of decoctions for this purpose, 125Road dust, 125-Early application of direct remedies, 126-Conccrted action, 126-Early poisoning and hand-picking, 126Cotton-worm warnings, 127-Destroying chrysalidẹs accidentally carried into gin-houses, 127-False theories, 127 -Burning the stalks, 127-Winter plowing, 127-Salt, 127.

Chapter $\mathrm{X}$ :

Remedies; means of coping with the insect; substances used for its destruction ..........................................

Destruction of the eggs, chrysaides, and moths, 128-Destruction of the eggs impracticable, 128-Little chance for successful destruction of the chrysalides, 128-Destruction of the moth, 129Lights and fires for attracting the moths, 129-Indifferent success with lamps used at Columbus, Tex., 130-Importance of using lamps carly in the season, 130-Apparent success with lamps near Hearne, Tex., 131-Great at tractivcness of the electric light, 131Movable lights, 131-Poisoned sweets and fluids, 131-Fonduess of the moths for ripe fruit, 132-Killing moths by poisoned fruit, 
2343. Riley, C. V.-Continued.

Chapter X-Continued.

132-Method of using poisoned liquids, 132-No results from using poisoned baits late in summer, 133-Poisoning the glands of the plant, 133-Cotton-leaf essence and its attraction to the moth, 134-Hand-picking, 135-Mechanical mcans of killing the worms, 136-Shaking off the worms, 136-Poisoning the worms, 136Progress in the nse of insecticides, 137-Classification of insecticides, 137-Importance of preparing materials in advance, 138Arsenical compounds, 138-Safety in their use, 138-Difficulty in determining minimnm quantities, 139-Overdoses of poisons, 139 -General rules in dry applications, 140-Mixing devices, 141Ingredients, 141-Wet application, 142-Principles to be followed and ingredients to be used, 142-Comparison of dry and wet applications, 142-Paris green, 143-Historical data, 143-Liquid application, 143-Dry application, 144-Minimum quantities, 144 -Patents on Paris-green combinations, 146-Arsenic, 147-Commercial arsenic, 147-Arseniate of soda, 147-Fowler's solution, 148-Johnson's dead-shot, 148-Texas cotton-worm destroyer, 149 -London pnrple, 149-Manufactnce and analysis, 149-History of its use, 150-Expcricnce in Alabama in 1880, 150-Advantages and disadvantages, 151-Dry application, 151-Wet application, 152-Other mineral substances, 153-Salt and saltpeter, 15:3-Snlphur, 154-Red lcad, 154-Road dust, 154-Oils and allied substances, 155-Kerosene, 155-Former nethods of application, 155 -Invention and perfection of emulsions, 156-Mcthod of preparing emulsions, 157-Formula for perfected emnlsion, 158-Experiments with imperfect emnlsion in 1880, 158-Experiments with perfected emulsions, 160-Oil of creosote, 162-Oil of tar, 162Gas-tar water, 162-Carbolic acid, 163-Cotton-seed oil, 163Vegetable insecticides, 164-Pyrethrum, 164-History, 164-Modo of cultivation, 165-Success in cultivating the plant in America, 166-Preparation of the powder, 167-Its use as an insecticide, 168- $\Lambda$ dvantages and disadvantages, 168-Active principle in Pyrethrum, 169-Its effects on cotton-worms, 169-Imported vs. Californian powder, 170-Dry application, 170-Minimum quantitics of dry powder, 171-Dry powder mixed with flour and other ingredients, $172-\Lambda$ pplication in fumes, $174-\Lambda$ lcoholic extract, 174-Experiments with extract obtained by distillation, 174Expcrience with extract obtained by repercolation, 176-Use of the powder in simple water solution, 17\%-Tea or decoction of Pyrethrum, 178-Effect of Pyrethrum upon other inscets, 179Prospects for the nse of Pyrethrum for the cotton-worm, 180Ox-eye daisy powder and its nselessness as an insecticide, 180Extracts and clecoctions from various plants, 181-Difficnlties in the way of discovering new vegetable insecticides, 182-Mode of preparing the extracts and diffusions, 183-Tist of the plauts $\mathrm{ex}$ perimented with, 184-Effect of alcohol upon the worms, 187Yeast fermont and fungns infection, 183-Dr. Hagen's recommondations of the nse of yeast as an insecticide, 188-Objections to Dr. Hagen's plan, 189-Negative results obtained by the Commission, 190.

Chapter XI:

Machinery and devices for the destruction of the worm. By W. S.

Barnard, Ph. D 
2343. RILEY, C. V.-Continued.

Chapter XI-Continued.

I. Spray nozzles, classification, preferred kinds, 191-Many-punctured nozzles, 191-196-Plefcrred construction, 191-193-Straining and cleaning $v s$. clogging, 192-Eddy-roses, their opcration, construction, and leading importance, 192-193-Plug-roses, action and construction unsatisfactory, 193-194-Johnson's, Melcher's, Dawson's, Foster's, 193-Lynch's, 194-Colliding jets, gas-jets, superiority, Daughtrey's, Wcbcr's, Prouty's, 194-T-roscs, 194Yeager's, Warner's, improvements, 195-Divided rosc-heads, clutch-head of Mast, Foos \& Co., Foss', Fox's, Rarrows', Vose's, 195-Peripheral roses [divided], Mclcher's, Yeager's, Ruhmann's, 196-Rosc-combinations of Barry, Prentice, etc., 196-Slot nozzles, 196-205-Opcration, 196-Preferred construction, 196-201-Disadvantages, improvements made, 197-201-Eddy-chambered, 197199-Lip construction, 198-199-Inside cleaner, 199-Simple slotnozzles, Fowler's, Mallory's, Iske's, 201-202-Plug slot-nozzles, Allen's, Rubmann's, Jolunson's, "The Niagara," Pinter's, 202-Removable slots of Long, Vestal, and Merigot, 203-Jawer slots, "The Boss Nozzle," Raymond's and Perkiu's, Smith's, Moffet's, 203-Willians', Ruhmann's, Pinter's, 204-Stanton's, 205-Side slots, Schier's, Melcher's, 205-Deflector nozzles, 206-211-Definition, use, applicability, relative merits, 206-Drip-waste, clogging, 206-Simple constructions made, 206-208-Conformations for narrow, wide, and even sprays, 206-207-Removable deflectors, 207-Hóllings', Douglas's, Nickerson's, 208-Hayden's, Killam's, Lewis', Schier's, Bar'ett's, 209-Rulımann's, Binkley's, Schier's compound, 210-Schier's and Polansky's, 211-Centrifugal nozzles, 211-221-Operation, kinds, choice, 211-The new and most perfect sprayers, 212-Eddy-chambered, 212-219-Conformation and operation, 212-Clogging, cleaning, construction principles, 213-Forms described, 214-Whistle-jets, 215-216-For blast-atomizers, 216-Eddy-jets proper, 216-219-Involute form, cone form, 216-Convex and concave forms, 217-Dircet discharge, proximal. diagonal discharge, 217-Distal diagonal discharge, 218-Centrifugal uose-pieces, double-cone or doublechambered form, and chambered plug form, 218-Direct spray and solid jot, 219-Fistulur spray nozzles, hose-pipes, 219-With rotary segment, Hotz's, Clifford's, Gielow's, Jobuson's, Hoyer's, Clarke's, 220-With cross-plug, McGaffoy's, Jolinson's, Gray's, Gielow's, Hosford's, 221-Sprap-wheels, 221.

II. Centrifugal throwers, 2:1-226-Their cliaracter and opcration, 221-Rotated orifices, pronger recls, brush poison-throwcrs, 222Brush fibers, 222-223-Rotary polishiug brushes, improved construction, fiber strength, spring and density, 223-Feeding the brushes with liquid, 22:3-225-With porvder, 224-A simple brush thrower of powder, 224-225-Advantages over-sifters, velocity of rotation, 225-Wisewull's, 225-226-Whisps and brooms, rotated recesses, 226 .

III. Blowers of poison, 226-252-Rotary blowers, 226-235-Kinds and success of, 226-227-For blowing powder, 227-232-Hoppers and adjustable fecders, 227-228-Blower encascments and blast.pipcs, 228-229-Blast forks and deflectors, 229-Improved light rotary blowers, 229-230-Hauled blowers, compound rotary blower, Aframe and legged swivel wheels, 230-Rotary velocity, 231- 
2343. Riley, C. V.-Continued.

Chapter XI-Continued.

Hurd's rotary powder blower, 231-232-For blowing liquids, 232235-Iniproved feeders of liquid to rotary blower, 232-233-Dripcatcher, forked blast spray, 233-Darnell's rotary liquid-blower, 233-234-Hurd's ditto, and Perl's rotary fume-blower, 234Force-blast rotary blowers-Oscillating blovers, 235-251-Bellows power, construction, durability, improvements, 235-236-For blowing powders, 236-243-Hermetic powder-box, 236-Feeders of powder to blasts, 236-237-Pipes, forks, and nozzles for these powder blasts, 237-238-Hauled compound bellows powderer, to wagon, with motor, etc., 238-Cultivator bellows-blower, 238239-Knapsack and horse-back bellows powderers, 239-Improved small "hand-bellows powderers, 239-241-With forks, 241-Allen's powderer, 241-Common powder bellows, Woodason's, Hendley's improved, 242-Stelle's, etc., 243-For blowing fluids, 243-249-Importance, resuction, feeding by blast-suction, blast-pressure, gravitation, ganges, 243-244-Blast spray conductors and nozzles, reverberatory, 244-Whistle-jets and agitation chambers, 245-Common blast atomizers, 245-Improved automatic-feeding blast sprayers, 246-249-Rcatomizing, reverberatory nozzles, 247-Nether blast sprays, directing pipes and nozzles, 248-Compound combinations, 249--Peck's blast sprayer, and Wallace's, 249-Reciprocating or pistoned blowers, 249-251Improved air-pump apparatus, 249-250-Air-pumps of Humphryville, Rumsey, ctc., 251-Generator blowers, 251-252-Steinmann's vaporizer, 251.

\section{Chapter XII :}

Machinery and devices for the destruction of the worm-continued.

IV. Pneumatic compression squirters, 253-261-Kinds, advantages, available fire-extinguishers, 253-254-Carbonic anhydride, apparatus, practicability, 255-Danger, antidotes, safety constructions, 255-256-Simple generators, 257-Rotary force-blast, compression ejectors, 257-Oscillating bellows, pneumatic compression ejectors, 257-Reciprocating or pistoned ditto, 258-261-Simple kind to construct, beer forcers applicable, Worswick Co.'s, Weindel's, Rumsey's, Douglas's, 258-Daughtrey's underspray theory and machine, 258-261-The author's devices, 259-Weber's nozzles, 260.

V. Solid compression squirters of poison, 261-283-Kinds, 261Rotary force-pumps, 261-262-Hydraulic bellows, 262-Oscillating force-pumps, 262-Reciprocating force-pumps, 262-283-Kinds, 262Hydronettes and fountain pumps, 262-269-May's patent, Tyler's, Servants', Staples', Whitman's fountain pump, 263-Hydronettes, äouble-acting, Deakin's, Rumsey's, cost, 264-Author's improvements in knapsack apparatus, 264-265-In knapsack fireextinguishers, Condict's and Doty's, 265-In horseback apparatus, Warner's, author's, 265-In cart or wagon, 265-268-Calahan's carts, legged wheels, tongue or shafts, 266-Wagon use, Trelease's report, 266-268-More economic devices, 268-Othe. pumps not in trade, 268-269-Aquapults, aquajects, aquarius, excelsior, hydropult, 269-271-Opcration, cost, 269-Aquapult, Johnson's patents, Douglas', Prouty's, 269-270-Johnson's syringe, Douglas' aquarius, Rumsey's aquaject, 270-Dcakin's excelsior, Vose's hydropult, 271-Bucket pumps and knapsack 
2343. Riley, C. V.-Continued.

Chapter XII-Continned.

pumps, 271-274-Lewis's, 271-Korth's and less desirable kinds, Stoner's, Mallory's Kaiser's, Dix's, 272-Crandal's, Hollaud's knapsack extınguishers, Donglas's, Stanton's, 273-Bucket poisoners, McDonald's, Allen's watering-pot improvements, 273Amor's and Lane's can-syringe, Hull's, Wisner's, 274-Barrcl and tank pumps and appurtenances, 274-283-Single acting, discharging bclow the piston, Melcher's, 274-Voglesang's, Rubmann's, 275Polansky's, Schier's, Butman's, Ball's agitator, 276-Evcnden's, Hclnecke's, 277-Ycager's pump and nozzle, 277-278-Pinter's, 278-Single-ncting, discharging from above the piston, Chipley's, Weith's, 278-Available cistern or well pumps, 278-279-Barrow pumps, truck pumps, garden engine pumps, windnill pumps, Blunt's Lotus pump, the Pendulum and Index pumps, couter pumps, 279-Double-acting, force-punips proper, 279-283-The best, 279-Kinds characterized, Vose's hydropult, the Champion, 280-Ransdeu's, reduction-cyliuder pumps, patentees aud manufacturers, 281-282-Anthor's agitator barrel pump, found most satisfactory, 282-283-Conduits, frames, portage, and combinations of appurtenances, 283-Johnson's cotton-spraying machine, 284Jones', Binkley's, '285-Goodi u's, Wolfram's, 286-Author'suuderspraying accessories, 288-Plan, skid, mixing, and straining funncl, 288-Adjustments of pipes, forks and nozzles, 289-297; fork modifications, 290-292-Pendent pipes, 292, conformability, lightnoss, cheapness, 292-293-'Tube substances, 293-Anthor's Aframe machines, 293-297-Maximum width undersprayed, 295Pipe adjustments to row widths, flexible systems superior, 296297.

VI. Gravitational distributors, 297-309-For liquid,297-302-Kinds, author's tripod autonatic sprinkler, 297-298-Schank's sprinkler, Taylor's, 298-Robinson's, 299-Suction force-pumps and windlass elevators, 299-Bilge-pumps, 300-Horseback automatic sprinklers, watering-pot method, Willio's sprinkler, 300-Ransey's, 301-Knapsack automatic sprinklers, 301-Gray's _ Ruggle's, Townsend's, 302-Antomatic hand-sprinkler's, watering-pots a foot and on horseback, 302-For dry poisons, sifters, kinds, 302-309Disadvantages, reciprocating sievo machines, hand-sieves, 303304-Sifting bag, Hurd's sifter and blower, Goodheart's duster and sprinkler, 304-Rotary-sieve machines, 304-307-Robinson's duster and sprinkler, Davis' duster, Levy's, 305-Taylor's duster and sprinkler, 306-Reciprocating-stirrer sifters, Willie's, 307Rotary-stirrer sifters, Young's, 307-Smith's, 308-Eldridge's, 309.

\section{Chapter XIII :}

Machinery and devices for the destruction of the worm-concluded.

VII. Insect manipulators, mechauical treatment, dislodging, crushing or stifling the worms or chrysalids, 310-Swecping, knocking, or jarring off the worms; frictiou drags, fringes; beatcrs, 310Collecting and despatchiug means, 311-Crushing, Helm's swceper and crusher, 311-Ewing's sweeper and stifler, 312moths, Wood-Smith's, 313-Iske's catching trays, 314-Traps for the 314-321-Kinds of lures, lighttraps, 314-Lenis's, McQueen's, Rigel's, 315-Walker's and others, 315-.316-Lamps in motion, Leblanc's, Fordtran's, 316-Bait traps, Heard's, Garrett's, 317Traps combining light and bait, author's net trap, 317-319, thought 


\section{Rilex, C. V.-Continued.}

Chapter XIII-Continued.

the best, 318-Indiscriminate killing wrong, the best bait, 319-

Stith's trap, 319-Pugh's, Garrett's, 320-Binkley's, 321.

Chapter XIV:

. History of the literature and bibliography ....................

History of the literature, 322-From 1802 to 1828 , 322-From 1829 to 1847 , 323-From 1848 to 1854 , 324-From 1855 to $1871,325-$ From 1869 to 1874 , 326-From 1874 to 1878 , 327-From 1878 to 1880, 328-From 1880 to 1881, 329-Bibliography up to and including the ycar 1881, 329-344.

\section{Chapter XV :}

Insects liable to be mistaken for Aletia..........................

Confusion of Alctia with other moths, 345-With Aspila virescens, 345-Characters of the most important of these moths to be illustrated in this chapter, 345-List of these moths, 345-Account of Anomis erosa Hübner, 345-Its geographical distribution, 346Structure of itseggs, 346-Distinguished from egg of Aletia xylina, 346-Its seasons, 346-Habits of larva, 346-Characters of moth, 347-Detailed description of egg, 348-Larva, 348-Pupa, 349Scasons and food-plants, 349-Account of Anomis texana n. sp., 350-Habitat of A. exacta, 350-Of A. texana, 350-Larva distinguished from that of Alctia xylina, 350-Pupa distinguished, 350-Account of Leucania unipuncta Haworth, 350-Reference to discussions about this species, 350-Its geographical distribution, . 351-Oviposition, 351-Food-habits of worms, 351-Pupation, 351 -Number of broods, 351-Hibernation, 351-Account of Aspila virescens, 351-Synonymy, 351-Confounded with Aletia xylina only in pupa state, 351-Pupæ of the two species distinguished, 352-Food-plants of $A$. virescens, 352-Moth distinguished from that of Aletiaxylina, 352-Account of Drasteria erechtea (Cramer), 352-Its geographical distribution, 352-Variations in size of moth, 352-Food-plants of larva, 352-Habits of moth, 352-Number of broods, 352-Oviposition, 353-Colors of larva, 353-Account of Laphygma frugiperda, 353-Its food-habits, 353-Synonyms, 353-Account of Platyhypena scabra (Fabr.), 354-Geographical distribution, 354-Food-plants, 354-Number of broods, 354 -Reference to descriptions of larva, 354-Euplectrus platyhypence Howard, bred from larva, 354-Account of Phoberia atomaris (Hiibner), 354-Reference to descriptions and figures of moth, 354 -Food-plant of moth, 354.

Chapter XVI:

The boll-worm (Heliothis armigera Hïbner) .................... Introductory, 355-One of the foremost of our injurious insects, 355-Extent of its ravages, 355-Nomenclature, 357-Syıonyms, 358-Popular names, 358-Geographical distribution, 358-Foodplants, other than cotton, 359-Corn, 359-Tomato, 361-Tobacco and other Solanacex, 362-Leguminose, 362-Cucurbitacew, 363Malvacece, 363-Other food-plants, 363-Characters and transformations, 364-The egg, 364-The larva, 365-The pupa, 370-The imago, 371-Number of broods, 372-Hibernation, 373-Summary of the distinguishing points compared with Aletia, 374-Egg, 374-Larva, 374--Pupa, 374--Adnlt, 374-Natural cnemies, 375Remedies, 377--Early planting, 378-Low corn vs. high corn, 378-Fall plowing, 378-Destruction of the moths, 379-Lights 
2343. Riley, C. V.-Continned.

Chapter XVI-Continued.

and poisoned sweets, 379-Hand-picking, 380-Poisoning, 381Pyrethrum, 381-Bibliography, 382.

Explanation to plates ...................................

Plate I-III, 385-IV-VII, 386-VIII-XI, 387-XII-XVI, 388-XVIIXX, 389-XXI-XXV, 390-XXVI-XXVIII, 391-XXIX-XXXII, 392-XXXIII-XXXVIII,393-XXXIX-XLII, 394-XLIII-XLVII, 395-XLVIII -LIII, 396-LIV-LVII, 397 -LVIII-LXI, 398LXII-LXIV, 399 .

APPENDICES ................................................

Preface to appendices ......................................

APPENDIX I:

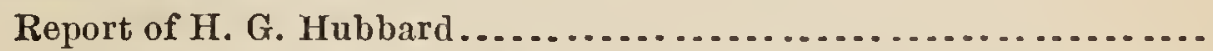

Report of observations made in 1881 upon Aletia and other insect enemies of cotton, in the State of Florida, [5]-Cotton injureci more by Dysdercus suturellus than by Aletia xylina, [6]-And more by rust-mite than by either, [7]-Great destruction of Aletia eggs by Trichogramma pretiosa, [7]-Successions of broods of Aletia, [7]-Distribntion of worms on plant, [8]-Tabular statement of periods of time occupied in eacli stage of growth, [10]-Locality of deposition of eggs on plant [12]-Proportions of light and dark colored worms, [12]-Effect of shade in protecting cotton, [12]-Periods of different stages, [13]-Copulation, [13]_Position of moths at rest, [13]-Experiments with poisons, [14]-Pyrethrum, [14]-London purple, [15]-Poisoning the moths, [15]-Yeast, [16]-The boll-worm, Heliothis armigera Huibn., [16].

APPENDIX II :

Report of Prof. R. W. Jones ................................

The cotton boll-worm, Heliothis armigera, [17]-Its importance, [17] -Food-plants, [17]-Natural history, [18]-The egg, [18]-The larva, [18]-Chrysalis, [19]-The moth, [19]-Weather, [19]Natural enemies, [19]-Cotton army-worm, Aletia xylina, [19]First appearance observed in 1880, [19]-Experiments with poisoned sweets, [20]-With adhesive swects, [20]-Gradual disappearance of moths in October, [20]-Preparation of vegetable substances as insccticides, [20]-Pyrethrum, [21]-Experiments with Pyréthrum, [22].

\section{APpendix III :}

Report of J.P. Stelle

First appearance of Aletia xylina and Heliothis armigera in Texas in 1880, [25]-Cotton blight, [25]-Its symptoms, [25]-Its causes, [26]-Boll rot, [26]-Its symptoms, [.27]-Its cause [27] -The flare, [27]-Its symptoms, [27]-Its probable canse, [27] -Other food-plants than cotton for Aletia, [2\%]-Nowe found for the larva, [27]-Many for the moth, [27]-Food of larva of Heliothis armigera, [28]-Annoyances to the cotton-worm, [28]Common salt, [28]-Saltpeter, [28]-Roaid dust, [28]-Open spaces, [28]-Trees, [29]-Shade, [29]—Natnral enemics, [29]Birds, [29]-Ants, [29]-Other insects, [30]-The yeast ferment remedy, [31]-Pyrothrum powder, [31]-Other vegetahle poisons, [32]-Arsenical poisons, [32]-London purple, [32]-Paris green, [33]-Arsenic, [33]. 
2343. Rilet, C. V.-Continued.

APPENDIX IV:

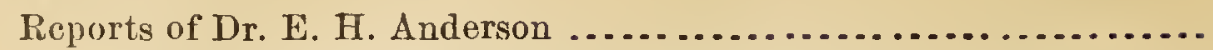

For 1880, [37]-Seasons and habits of A.xylina, [37]-Of Heliothis armigera, [37]-Localities of first appearance of $A$. xylina in the season, [37]-Reasons for this first appearance, [3\%]-[38]-Hibcrnation of this insect in some form, [38]-Causes of undue multiplication of the worms, [38]-Inflnence of ants on the nnmber of worms, [38]-Habits of ants, [38]-Other insects gathering sweets from the cotton-plant, [39]-Jnte growing amidst cotton has no effect on the wornis, [39]-Saturnia io fonnd eating cotton, [39]-An enemy of the cotton-worm found, [39]-Experiments with London purple, [39]-With Pyrethrum extract, [39] -With veast, [40]-Eggs of insects found on cotton-leaf, [40]Characteristics of season of 1880, [40]-Report for 1881, [40]Diary of observations on issuance, egg-laying, and hibernation of moths, and on weather, from October 3 to December 31, [40][44]-Observations of Heliothis armigera, [41]-[43]-Report for 1882, [44]-Observations on ants and aphides, [45]-Abundance and sudden disappearance of Laphygma frugiperda, [45]-Scarcity of cotton-worms, [45]-Experiments with Pyrethrum, [45][48]-Weather in September, [46]-[47]-Scarcity of Heliothis armigera in cotton, [46]-[47]-Its preferred food-plants, [47].

APPENDIX V:

Cotton caterpillars in Brazil. By John C. Branner ................

Historical accounts of the occurrence of cotton caterpillars in Brazil, [49]-[51]-Influcnce of weather on the appearance and abundance of cotton-worms, [51]-Localities in which worms first appear, [51]-Young cotton-plants most injured, [51]-Two species of cotton caterpillars have been confonnded, [52]-Seasons and relative abundance of the two, [52]-Duration of their pupa state, [52]-Time of issue of moths, [53]-Number of broods, [53]-Enenies of the caterpillars, [53]-Preventive measures, [53]-Losses caused by caterpillars, [53]-[54]-Heliothis armigera scarcely known to attack cotton in Brazil, [54].

APPENDIX VI:

Report of Judge William J. Jones...............................

Obstacles to investigation in 1880, [55]-Exemption of scattered patches of cotton-plants from depredation, [55]-Answers to questions in Circular No. 7, [55]-[56]-Cotton killed by a fungus, [56]-Application of poisons to cotton, [56]-Effect of poisons upon eggs and larvæ, [56]-No other insects observed to be injurious, [56]-Use of lights recommended to destroy moths, $[56]-[5 \%]$.

APPENDIX VII:

Reports of consuls and consnlar agents on the cotton crop and its enemies in Mexico, Central and Sonth America, and the West Indies ............................................

Introdnction, [59]-Circnlar letter of inquiry, [59]-Replies: from Merida, Mexico, [60]-From Tampico, Mexico, [60]-From Martinique, W. I., [60]-From Trinidad, W. I., [61]-From Manzanillo, Mexico, [61]-From Mazatlan, Mexico, [62]-From Bahia, Brazil, [63]-From Maricaibo, U. S. of Colombia, [64]From Vera Cruz, Mexico, [65]-From Pernambuco, Brazil, [67]-From Bogotá, U. S. of Colombia, [68]-Notes on insects 
2343. Riley, C. V.-Continued.

APPENDIX VII-Continued.

injurious to the cotton-plant in the Republic of Mexico, by D.

H. Strother, U. S. consul-general, [70].

APPENDIX VIII :

Answers to Circnlar No. 7

From D. M. Hamilton, St. Francisville, West Feliciana Parish, La., [71]-From R. A. Lee, Evergreen, Ala., [73]-From J. M. Wolkom, Henderson, Tex., [74]-From P. S. Clarke, Hempstead, Waller Co., Tex., [75]-From L. D. Hoyt, Livingston, Sumter Co., Ala., [77]-From F. S. Shields, Lake Concordia, Concordia Parish, La., [79]-From G. E. Gillespie, M. D., Natchitoches, La., [81]-From H. O. Dixon, Jackson, Miss., [84]-Froin F. L. Yoakum, Larissa, Cherokee Co., Tex., [85]-From O. H. Perry, Perry Co., Ala., [86]-From J. IV. Grace, Walterborough, Colleton Co., S. C., [86]-From F. M. McMeekin, Jamcstown, Alachua Co., Fla., [87]-From H. P. Bee, San Antonio, Tex., [88]-[89]From E. H. Anderson, Kirkwood, Miss., [90]-Condensed summary of the habits of the worm, from Dr. D. L. Phares, Wood. ville, Miss., [92].

Notes.............................................

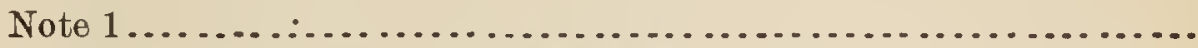

Hiibner's description of Aletia argillacea, with translatiou, [95].

Note 2

Reasons for rejecting Hiibner's description of Aletia argillacea, [95] -Wherein this descriptiou and the figures differ from A. xylina, [95]-Doubts of authors concerning A. argillacen, [95]-Search for the type of $A$. argillacea, $[96]$-Condition of the Somner collection, [96]-How specimens of $A$. xylina are labeled therein, [96].

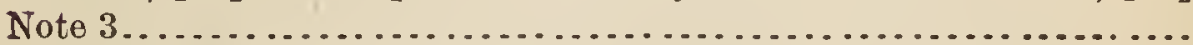

No published, full, and complete description of the earlier states of A. xylina extant, [96]-Reprint of descriptive portion of Dr. C. W. Capers' article "On the cotton caterpillar," [97]-History of ravages of $A$. xylina prior to $1828,[97]$-Sudden abandonment of cotton-plants, [97]-His description of moth, [98]-Egg, [98] -Larva, [98]-Smell of larva, [98]-Habits, [98]-Food-plant, [98]-Pupation, [98]-Description of pupa, [98]-Remedies, [99]-Detailed description of egg, [99]—Six stages of larva, [99]-Pupa, [100].

Note 4 .............................................

Difference in structure of prolegs, distinguishing Aletia xylina from Anomis texana, [100].

Note 5

Resemblance of larva of Plusia dyaus to that of Aletia xylina, [100]Proportion of light and dark specimens early and late in the seasoll, $[100]$.

Note 6

Cotton leaves blotched by young larva of Spilosoma acrea, [100].

Note 7 ..............................................

Larva of Aletia xylina fed on Ipomoca eommutata, [100]-Abutilon and Phytolacca defoliated by different larvw, [100]-Said to feed on "salve bush," [100].

Note 8 . . .............................................

Structure of male genitalia of Aletia xylina, [100]. 
2343. Riley, C. V.-Continued.

Notes-Continued.

Note 9

Notice of Wm. Trelease's "Nectar: what it is and some of its uses," [101]-Teleology and dysteleology. of nectar glands of cottonplant, [101].

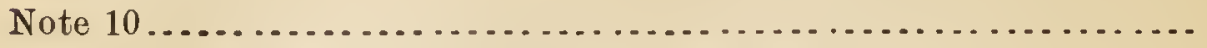

Rapidity with which the broods of A.xylina follow one another in midsnmmer, [101]-Time of first appearance of worms, [101]Number of broods, [:101]-Prolificacy of moth, [101]-Importanee of natural checks upon its increase, [101].

Note 11

Influence of winter temperature on time of first appearance of worins, [101].

Note 12

Theories of hibernation of A. xylina, [101]-Proof of hibernation of moth, [102]-importance of this proof, [102].

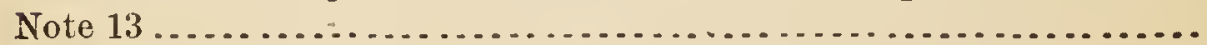

Inflnence of latitude upon time of hatching of insects, [102].

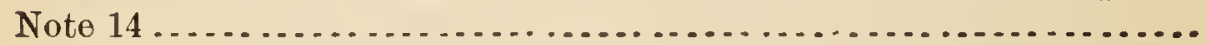

Number of broods of $A$. xylina previously recognized, [102].

Note 15 ..............................................

Possible food-plants of larva of $A$. xylina, [102]-There must be some besides cotton, [102]-Failure to find any other, [102]Feeding of larva of Anomis erosa on Urena lobata, [102]-Value of fiber of $U$. lobata, [102]-Geographical distribution of U. lobata, [103]-Eggs and larva of Anomis erosa distingnished from those of Aletia xylina, [103]-Examination of malvaceous plants in herbarinm of U. S. Department of Agricultnre, [103]-Disadvantages of such an examination, [1037-Plants on which eggs were found in the herbarinm, [103]-Petition for aid in obtaining evidence of the food-plant of $A$. xylina in the more northern States, [103]-List of malvaccons plants growing in these States, with localities, [103].

Note 16

Description of larva of Aspila vireseens, [104]

Note 17

Travels of E. A. Schwarz in 1878 and 1879, [104]-Reference to pnblished accounts of the results of his investigations and those of others on hibernation of $A$. xylina, [104].

Note 18

Platyhypena seabra, [104]-Cliaracters of larva, [1.04]-Food-plants of larva, [104]-Pnpation and hibernation, [104]-Characters of pupa, [104].

Note 19

Seasons of larva of Phoberia atomaris, [104].

Note 20

Criticism of paper by A. R. Grote on hibernation of $A$. xylina, [104]-Grote's arguments against hibernation, based on experience gained in the same regions which furnish argnments against the theory of annual immigration, [105]-Possibility of hibernation admitted by Grote, [105].

Note 21

Definition of northern and southern portions of cotton belt, [105]. 
2343. Riley, C. V.-Continued.

Notes-Continued.

Note 22

References to discussion of J. P. Stclle's claim to have first recommended publicly the use of Paris green for A. xylina, [105].

Note 23

Refercuccs to descriptions and figures of brush-sacs of nıoths, [105].

Note 24

Worms worse in wet weather than in dry, because more protected from cnemies, [105]-Localities of first appcarance of worms are those of least molestation, [105].

Note 25

Appetite of swiue for cotton-worms, [106]-Worms eaten by dogs and cats, [106].

Note 26

Refercuce to list of birds of southern Statcs, [106].

Note $2 \gamma$

Range of English sparrow in Uniter States, [106]-In hotter portions of the conntry it is confined to towns and villages, [106].

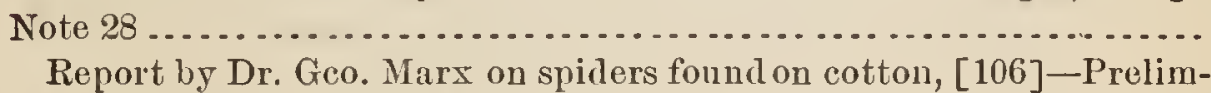
inary list of spiclers which destroy insects noxious to agriculture, [106]-List of spiders observed to devour larva of Aletia xylina, [106]-How they capture their victims, [106]-Food-habits of Theridula spherula, [107]-Observations on habits of Oxyopes viridans, by H. G. Hubbard, [107]-Ants captured ly larva of a Cicindela, [10ð].

Note 29

Description of imago of Trichogramma pretiosa, [107].

Note $29 a$

Metamymar n. g. and $M$. aleurodis n. sp., provisionally named, [107].

Note 30 .

Description of imago and larva of Apanteles aletice, [108].

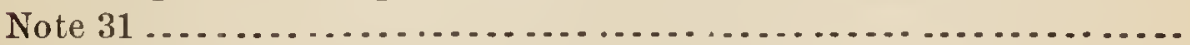

Apanteles aletice parasited by Eupelmus sp., [108].

Note 32

Description of imago of Euplectrus comstockii, [108].

Note 33 .

Description of imago of Elachistus euplectri n. sp., [108].

Note 34

Sarcophaga sarraceniop distinct from s. carnaria, [109]-Points of difference between the Sarcophagce of America and Enrope generally, [109]-Additional specific characters of S. sarracenice, [109].

Note 35 ..............................................

Description of imago of Tachina aletia, [109].

Note 36

Description of imago of Tachina fraterna, [109].

Note 37 .

Differences between tachinid larva and that of Sarcophaga, [109]Differcuces of puparia, [109]-Reference to description of larra of Senometopia atropitora, [110]; of larva and pupa of Tachina villica, [110]-Description of larva and puparium of Sarcophaga sarracenice, [110]; of larva of Belvoisia bifasciata, [110]-Difference of larva of $B$. bifasciata from that of Tachina concinnata, 
2343. Rilex, C. V.-Continued.

NoTEs-Continued.

[110]-Structure of spiracles in normal form of tachinid puparium, [110]-Description of the puparium, [110]; of puparium of Belboisia bifasciata, [111].

Note 38

Synonymy of Cryptus conquisitor, [111] -C. pleurivinctus erroneously given as a synonym of C. annulicornis, [111].

Note 39

Synonymy of Cryptus samia, [111].

Note 40

Description of larva and pupa of Chalcis ovata, [111]-List of Lepidoptera parasited by $C h$. ovata, [111]-Variations in size or imago, [111].

Note 41

Synonymy of Tetrastichus esurus, [111]-Description of imago, [111].

Note 42

Description of imago of Hexaplasta zigzag, [111]-Diffculty of defining the families Chalcidide, Proctotrupidee, and Cynipide, [112]-Food-habits of these families, [112].

Note 43

Phor a aletice not a true parasite, [112]-Habits of this species, [112].

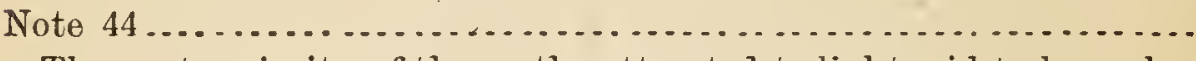

The vast majority of the moths attracted to light said to be males, [112]-If this is so, the usefulness of fires and lights as a remedy is almost nothing, [112].

Note 45.

Antidotes for arsenical poisoning, [112].

Note 46

Non-fertilized blossoms destroyed by morning showers or spraying, [112]-When to make wet applications of poison, [112].

Note 47

Test of purity of Paris green, [113].

Note 48

Proportions of Paris green mixture, [113].

Note 49 .

Effect of kerosene and kerosene emulsion on cotton-plants, [113].

Note 50

Pyrethrum willemoti probably a synonym of $P$. roseum, [113]-Reference to Willemot's paper on $P$. willemoti, [113].

Note 51 ...............................................

Growth of productive pyrethrum industry in California, [113] Effect of pyrethrum on warm-blooded animals, [113]-Pyrethrum recommended as a disinfectant and germicide, [113].

Note 52

Cost of production compared with price of pyrethrum, [113].

Note 53

Enemies of Aletia xylina killed by poisoning the worms, [113].

Note 54

Positiveness with which various plants have been recommended as insecticides, [113].

Note 55

Insects injuring dog-fennel, [114]. 
2343. Riley, C. V.-Continued.

Notes-Continued.

Note 56

Tests of spraying maehinery, by Dr. W. S. Barnard, [114]-Diffieulties in the use of maehinery in irregularly-planted fields, [114]-Means of overeoming these diffieulties, [114]-Conveyances for underspraying apparatus, [115]-Management of apparatus, [115]-Rapidity of service, [115]-Quantity of poison required, [115]-Sueeess of stirrer-pump deviee, [115]-Construetion of stirrer-pump, [115]-Construetion of nozzle-pipes, [116]-Adjustment of these pipes, [116]-Suecess of Erldy-chamber nozzles, [116]-A elosed system of pipes advisable, [116]High pressure shonld alwags be used, [117]-Adjustment of deseending pipes, [117]-Flexile joints reeommended, [117]-Advantages of flexile pipes, [117]-Lifting of deseending pipes in turning, [118]-Devices for lateral shifting of pipes, [118]Summary of eonelusions from experiments, [118].

Note 57 ............................................

Reeommendation to use Paris green in 1872, [119]-Extraet from report made on this subject by $J$. P. Stelle, in 1880, [119]-Comment on the same, [120].

Note 58

Deseription of imago of Anomis texana n. sp., [120].

Note 59

Deseription of egg and pupa of Drasteria trcchtea, [120].

Note 60

Reprint of J. W. Boddie's deseription, in 1850, of imago of I'halcena zea (Heliothis armigera), [121].

Note 61

Reprint of A. R. Grote's deseription of Heliothis umbrosus, [121].

Note 62

Remarks on speeimens sent from Bahia, by R. A. Edes, in 1880, [121]-Charaeters of egg, larva, and pupa of Anomis sp., [121]Inseets found in eotton bolls, [121].

Note 63

Probably Macrosila rustica stated to feed on cotton, [121].

Note 64

Larvio of Aletia xylina reeeived from Vera Cruz, [121]-Recurrence of eotton-worms at irregular periods, [122].

2344. RILEY, C. V. Reports of experiments with various insecticide substances, chiefly upon insects affecting garden crops, made under the direction of the entomologist. <Bull. No. 11, Div. Ent. U. S. Dept. Agric., [February 26], 1886, 34 pp.

\section{CONTENTS.}

Experiments with insectieides.............................. 5

Report of experiment sat La Fayette, Ind. By F. M. Webster ....... 9

Report of experiments at. Ames, Iowa. By H. Osborn ............. 23

Report of experiments at Trenton, N. J. By T. Bemnett ............. 27

2345. [RILEY, C. V.] [The study of entomology.] <Entom. Amer., March, 1886, v. 1, pp. 225-227.

Remarks made at a meeting of the A. A. A. S.; books useful for beginuers, 
2346. [RILEY, C. V.] [Habitat of Mezium americanum.] <Proc. Ent. Soc. Wash., [30 March], 1886, v. 1, p. 14.

Occurrence of Mezium americanum in old hay.

2317. [RIlex, C. V.] [Arctic insects.] <Proc. Ent. Soc. Wash., [30 March ], 1886, v. 1, pp. 14-15.

Remarks on collection of insects made at Point Barrow, Alaska; prevalence in Arctic regions of spccies common to America and Europe; occurrence of Urocerus flavicornis in Alaska.

2348. [Riley, C. V.] [Habits of Isosoma.] <Proc. Ent. Soc. Wash., [30 March], 1886, v. 1, p. 15.

Phytophagic haluits of the genus Isosoma ; I. grande observed ovipositing.

2349. [Rrley, C. V.] [Cranberry fruit-worm.] <Proc. Ent. Soc. Wash., [30 March], 1886, v. 1, p. 15.

Names Acrobasis vaccinii as the well-known cranberry fruit-worm.

2350. [RIley, O. V.] [Rhyssa lunator.] <Proc. Ent. Soc. Wash., [30 March ], 1886, v. 1, p. 15.

States that Rihyssa [ = Thalessa] lunator is parasitic and not lignivorous.

2351. [RIley, C. V.] [Tiphia and Rhipiphorus.] <Proc. Ent. Soc. Wash., [30 March], 1886, v.1, p. 15.

Refers to O. Lugger's statements in regard to the habits of Tiphia and Rhipiphorus as inanifestly incorrect.

2352. [RILEY, C. V.] [Insects attracted to light.] <Proc. Ent. Soc. Wash., [30 March], 1886, v. 1, pp. 15-16.

Disfigurement of buildings by the insects and spiders attracted to the electric light ou the dome of the Capitol.

2353. [Rrley, C. V.] [Parasitic Coleoptera.] <Proc. Ent. Soc. Wash., [30 March], 1886, v. 1, p. 16.

Parasitic habits of Aleochara unthomyice $[=$ nitida $]$.

2354. [Riley, C. V.] [Scenopinus.] <Proc. Ent. Soc. Wash., [30 March], 1886, v. 1, p. 16.

Larva of Scenopinus sp. infesting the blanket of a Navajo Indian.

2355. Rilex, C. V. Annual address of the president. <Proc. Ent. Soc. Wash., [30 March], 1886, v. 1, pp. 17-27.

Bricf comments upon the histories or injuries of Agrotis fennica, Hadena devastatrix, Nematus erichsoni, Phytonomus punctatus, $P$. nigrirostris, Pulvinaria innumerabilis, Systochus lencophceus, and Phylloxera vastatrix; notes on the egg parasites of the Acridida; mode of oviposition of some Carabida; advantages of Washington from an entomological standpoint.

2356. [Rilex, C. V.] [Gall-making moths.] <Proc. Ent. Soc. Wash., [30 March], 1886, v. 1, p. 30.

Walshia amorphella, previously known as a gall-maker on Amorpha fruticosa, bred from roots of loco weed; Euryptychia saligneana distinct from Pcdisca scudderiana.

2357. [RIlex, C. V.] Sphida, Grote.] <Proc. Ent. Soc. Wash., [30 March], 1886, จ. 1, p. 30.

Considers S. obliquata synonymous with Arzama densa. 
2358. [RILey, O. V.] [Food of Calopteron and Photinus.] <Proc. Ent. Soc. Wash., [30 March], 1886, v. 1, p. 31.

Larva of Calopteron terminale gregarious and lignivorous; Photinus pyralis feeds on snails.

2359. Riley, C. V. A carnivorous butterfly larva. <Science, 30 A pril, 1886, v. 7, p. 394.

Distribution and recorded food-habits of Feniseca tarquinius; Aphidida the normal food of the same.

2360. Rilex, C. V. Entomology. Professor Riley to Dr. Shaffer. <Daily Globe [Keokuk, Iowa], 2 May, 1886. S.-b. No. 63, p. 30. Injuries of and means against Abia caprifolium $[=$ Zarcea inflata $]$.

2361. RILEy, C. V. A carnivorous butterfly larva.-Plant-feeding habit of Feniseca tarquinius. <Amer. Nat., June, 1886, v. 20, pp. $556-557$.

Supposed food-plants of the larva of Feniseca tarquinius; first publication of proof that it feeds on plant-lice; Schizoneura tessellata, Pemphigus fraxinifolii, and $P$. imbricator the spccies preyed upon.

2362. Riley, C. V. Thrips-Leaf hoppers. <Gardener's Mo. and Hortic., June, 1886, v. 28, p. 174. S.-b. No. 61, p. 56.

Letter to Duncan Rhind; remedies against Erythroneura vitifex $[=T y p h l o c y b a$ vitis].

2363. Riley, C. V. Report of the entomologist. <Ann. Rept. [U. S.] Commissioner Agric. for 1885, 1886, pp. 207-343, 1 map, 9 pl. Separate: <Washington: June, 1886, pp. $10+137+10$.

TABLE OF CONTENTS.

INTRODUCTION

Silk-culture, 207-Review of the divisional work in silk-culture, 207-Necessity for a home market for cocoons, 205-Proposed establishment of a filature at Washington, 203-Silk culture in France, 209-Destructive locusts, 209-Injurious insects of the year, 209-Correspondence of the Division, 210-Work of the Division in economic ornithology, 210-Establishment of an apicultural station, and the work of the Division in apiculture, 211Work of other divisional agents, 212-Relations of the Division to the National Museum, 213-Publications of the Division, 213Office force, 213.

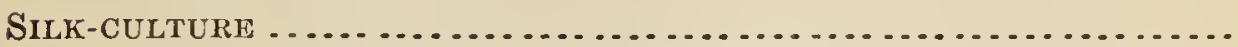

General work of the division, 214-Distribution of eggs, 214-States in which greatest interest is felt, 214.

Distribution of mulberry trees.............................

Number distributed, 214-Danger of indiscriminate distribution, 214-Osage orange, 214-Russian mulbcrry, 215.

Distribution of eggs .................................

Variety distributed, 215-Designation of races, 215.

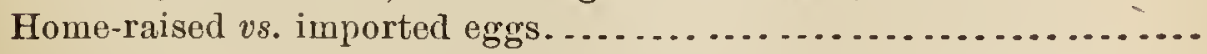

Feeling against importation, 215-Reasons for importation last year, 215-Provisions for the next distribution, 216-Eggs rejected, 216-Labor involved in silk-culture, 216.

Establishing of filatures-Cost of producing reeled silk............ 


\section{Riley, C. V.-Continued,}

SILK-CULTURE-Continued.

Importance of filatures, 216-Establishing of stations, 217-Work at Philadelphia station, 217-Work and results at New Orleans filature, 217-The Serrell automatic silk reel, 218-Application of the saving of this recl to New Orleans figures, 219.

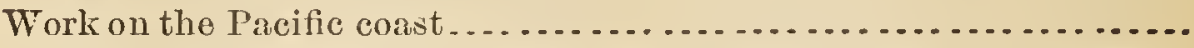

Last season's experimental crop, 219-Incorporation of the Ladies' Silk-Culture Socicty of California, 219-The station at Piedmont, 219-Proposed work at the station, 220-Work of the State board, 220 -Attempt to form a stock company, 220.

On the precantions necessary in the production of pure silk-worm

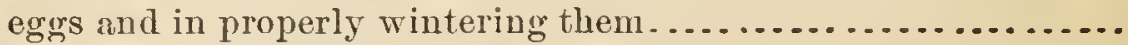

Pasteur's classification of diseases, 221.

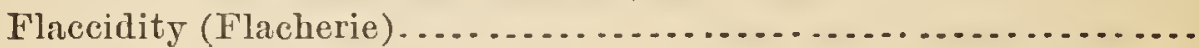

Symptoms and consequences, 221-Action of worms, 221-Color, 221-Odor, 221-Nature and treatment, 222-Microscopic diagnosis, 222-The bacillus of flaccidity, 222-Examination of the chrysalis, 222.

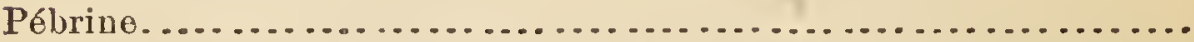

Symptoms, 223-The black spots, 223-Microscopic diagnosis, 223Appearance of chrysalis, 224-Tests for the determination of pébrine, 224-Difficul ty of using the w orm for test, 224-Advantage of using the moth, 224-Isolation and examination of the moths, 224-Maillot's method, 224-Examination of chrysalides, 224Selection of cocoons, 225-Moth cells, preparation, 225-Fastenings for cells, 225-Preparation of moth for examination, 226The corpuscle of pébrinc, 226.

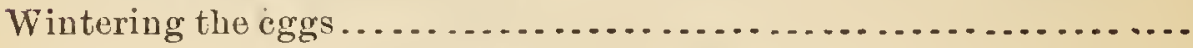

Colors of eggs, 227-The inicropyle, 227-Proper temperature and humidity, 227-Hibernating boxes, 228-Acknowledgments, 228.

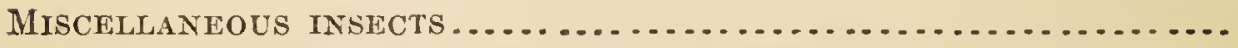

Destructive locusts or "grasshoppers," Acridida ..................

Unusnal damage, 228-The Rocky Mountain locnst, 228-Probabilities for 1886, 229-The California migratory locust, 229Abundance the present Jear, 2:9-The destructive species in previons years, 230-Geographical range, 230-Characters of the species, 2:1-Remedies, 232-New remedy, 232-Non-migratnry species, 232-The red-legged locnst, 232-The differential locust, 233-The two-striped locnst, 233-The lesser locust, 233.

The periodical Cicada, Tibicen septendecim.....................

Preparation of a Bulletin, 233-A seventeen-year and a thirteenyear race, 234-Our announcement in 1868, 234-Dr. Smith's manluscript, 234-Dr. Phares's earlier discovery, 234-Two distinct forms or varieties; specific value of the different forms, 234First discovery, 234-Points of difference, 235-How the species should be catalozued, 235-The long period of underground development, 235-The food of the larva, 236-Method of burrowing of the larva, 237-The transformations, 237-Rising of the pup: 237-Five phases of eclysis, 238-Time required for transformation, 238-The Cicada vs. civilization, 238-Influence of domestic animals, 238; of building of towns, 238; of the English sparrow, 238-Song notes of the Cicada, 239-Notes of other insects, 239-First or phar-r-r-r-aoh note, 239-Second note or "screech," 240-Third or "chirping" note, 240-Other notes, 
2363. Riley, C. V.-Continued.

Miscellaneous inseCts-Continued.

240-Variation in time of appearance, 240-Enemies of the Cicada, 241-Supposed sting of the Cicada, 241-Oriposition, 242-Injury caused to fruit trees; remedies and preventive measures, 242-Small injury in larva state, 243-Destrnction of the insects as they issue from the gronnd, 243; by Pyrethrmm powder, 243 ; by Pyrethrum water, 243 ; by kerosene cmulsion, 244Experiments with substances that kill by thwarting exuviation, 244-Carbolic acid, 244-Acctic acid, 245-Alcohol, 245-To prevent ovipositing, 245-Kerosene emulsion, 245-Consideration of the two 1885 broods, 246-Circular letter, 246-Brood VII, 247Brnod XXII, 248-Points of contact of the two broods, 249Geographical distribution of Brood VII, 250-Distribution of Brood XXII, 251-Summary of distribution and future appearance of different broods, 252-Influence of climate upon the races, 254-Experiment in the transfer of eggs, 255-Persons assisting, 255-Description of the placing of the different lots of eggs, 256-The Cicada in 1886, $25 \%$.

The leather beetle, or toothed Dermestes, Dormestes vulpinus........

Injury to boots and shoes, 253-History of its occurrence at St. Louis, 258-Unrecorded points in its habits and natural history, 259-Food of larve, 259-The eggs, 259-Growth of larva, 260'The pupa, 261-The beetle, 261-Litigation growing' out of its injuries, 261-History of the Savannah case, 262-Remedies, 263-Care and clcanliness, 263-Use of poisons, 263-Descriptive, 264-Mature larva, 264-Differences between young and old larvæ, 264.

The garden web-worm, Eurycreon rantalis.....................

Great damage the present year, 265-A wide-spread species, 265Popular descriptions of different statcs, 265-Former injuries, 266-Localities of damage in 1885, 266-Food-plants, 267-Habits and natural history, 267-Number of annual generations, 267Habits of larva, 268-Cocoon; 269-Natural cncmics, 269-Remedies, 269-Arsenical poisons, 269-Machine for jarring the worms from the plants, 270 .

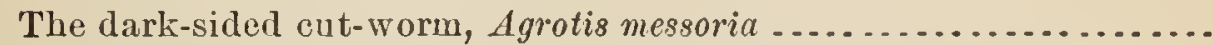

Injury to onions; new habit, 270-Habits and natural history, 270 - Number of broods, 270-Hibernation, 271-Remedies, 272Treatment of land in spring, 27\%-Poisoned balls, 27:2-Korosene emulsions, 272-Report of John B. Smith, 273-Report of Thomas Bennett, 274 .

The strawberry weovil, Anthonomus musculus...................

Past history, 276-In Maryland, 276-In Missouli, 276-In Michigan, 276-Injury in 1885, 276-Damage on Staten Island, 276Habits and natural history, 277-Mr. Smith's observitions, 277Diversity of habit in the genus, 278-Natural history of other species of Anthonomus, 270-Inquilinous species, 279-Speices haviug aifferent habits, 279-Remedies, 279-IVolf's soap, 279Kerosenc emulsion, 280-Pyrethrum, 280-Repellants, 230-Characters and syuonomy, 280-Descriptive, 281-Variations of $A$. musculus, 282-Comparative diffcrences between $A$. musculus aud A. suturalis, 282.

The pear midge or pear Diplosis, Diplosis pyrivora............... 


\section{Riley, C. V.-Continued.}

Mrscellaneous Inșects-Continued.

Decisive steps for eradication recommended, 283-Life-history and habits, 283-Laying of eggs and growth of larva, 283-Habits of larvæ, 284-The cocoon, 284-One annual generation; dates of issuance of adults, 284-Parasites, 285-Remedies, 285-Is it an introduced species?, 285-Reasons for so considering it, 285Schmidberger's account of the European pear midge, 286-Dr. Joseph Mik's opinion, 287-Descriptive, 287-Imago, 287-Larva, 288-Pupa, 288-The classificatory value of the genitalia, 288.

RePorts of AGENTS...................................

Report on the locusts of the San Joaquin Valley, Cal. By D. W. Coquillett .......................................

Letter of transmittal, 289-Letter of instructions, 289-Location, 290 - Work of the locusts in general, 290-Species most destructive, 291-The devastating locust, 291-The ash-colored locust, 296292-Where did these locusts hatch ?, 292-Consideration of surroundiug topography, 293-How the young locusts may be distinguished, 293-Influence of submersion on hatching, 294-Cause of the abundanec in this valley in 1885, 294-Early hatching, 294Lack of rain, 294-The differential locust, 295-A bundance, 295Egg-pod, 295-Oviposition, 296-Flight, 296-'The yellow locust, Abundance, 296-Flight, 296-Camnibalism, 296-Oviposition, 297-Other species of locusts, 297-Table showing relative abundance, 297-Injury committed by the locusts, 297-To grape-vines, 298-To grain-fields and vegetablc-gardens, 298-Natural enemies, 298-Birds and poultry, 298-Wasps, 298-Mites, 299-Flies, 299Remedies, 299-Collccting in winflows of dry stems and then burning, 299-Rolling, 300-Kerosene emulsion, 300-Burning sulphur, 300-Horse troughs, 300-Bran, arsenic, and sugar trappoisouing, 300-Buhach, 302.

Report on the abundance of the Rocky Mountain locust in 1885. By L. Bruner . . . . . . . . . . . . . . . . . . . . . . . . . . . . .

Letter of submittal, 303-The great abundance of native specics, 303-Direction of flight of the Rocky Monutain species, 304Probabilities for 1886, 305-Effect of weather upon probabilitics, 305-Scarcity of parasites, 305-Abundance of Melanoplus atlanis and Camnila pellucida, 306-List of locusts noticed in larger num-" bers than usual, 307.

Notes on locusts at and about Folsom, Cal. Bv A. Koebcle... .....

Methods adopted by the Natoma Company, 308-Manner of Hight, 309-Time of appearance, 309-Losses, 310-Parasites, 310-Ponltry, 310 .

Insects affecting fall wheat. By F. M. Webster ................. Isosoma tritici Riley and I. grande Riley,311-Notes of breeding, 312Selection of plants, 314-Facts concerning oviposition, 314Influence of temperature, 314-No males found, 315-The grain Sphenophorus, 315-Found in rye and wheat, 315-Oviposition, 316-Damage to straw and roots, 316-The pupa, 316-Dates of emergence, 316-The white-grub, 316-Distinguishel from Sphenophorus, 317-The tarnished plant bug, 317-Found feeding on kernels of wheat, 317-Euschistus fissilis, 317-Dercoocoris [ =Calocoris ] rapidus, 317-Diedrocephala flaviceps, 318-Th̀e eggs, 318Injurious to oats, 318-The chinch-bry, 318-Abundance in fall wheat, 318-On bottle-grass, 318-Parisitized by Mermis,318-The wheat midge, 318-Breeding notes, 318-Date of emergence, 319. 
2363. Riley, C. V.-Continued.

Reports of Agents-Continued.

Third report on the eauses of destruetion of the evergreen and other forest trees in northern New England. By A. S. Packard ...... General review, 320-Condition of the spruce on the eoast of Maine, 321-Exemption from inseet attack, 321-Condition of the haekmatack in 1885, 321-Verification of last year's predictions, 322The white-pine weevil, 322-Eggs, 322-Larva, 323-Pupa and its cell, 323-Distinguished from other species, 323-Life-history in brief, 324-Effeets of its work, 324-Prevention, 325-The spruee Epizeuxis, 325-Diseovery of food-plant, 325-Compared with otherspecies, 325-Deseriptive, 326-The spruee plume-moth, 326Habits, 326-Deseriptive, 326-The pine Phecesma, 327-Tho evergreen Cleora, 327-Habits, 327-Deseriptive, 327-The fir Paraphia, 328-Descriptive, 328-The spruce Therina, 328-Deseriptive, 329-The pine Therina, 329-The pine Amorbia, 329The V-marked Cacœeia, 329-Habits, 329-Deseriptive, 330-Tho hiekory Eecopsis, 330-Habits, 330-Descriptive, 331-The variegated Eccopsis, 331-Déseriptive, 331-The white-heart hickory Geleehia, 331-Habits, 332-Deseriptive, 332-The willow Teras, 332-Deseriptive, 332-The purple willow Gracilaria, 332-Habits, 332-Deseriptive, 333 .

Report on experiments in apieulture. By N. W. MeJain .......... Letter of submittal, 333-Economy in the prodnction of wax, 334Experiments in wax-feeding, 334-Device for feeding sugar syrup and for other purposes, 334-Deseription, 334-Wintering bees, 335-Loss from thirst, 335-" Roaring in the hive," 336-Deviee for furnishing water, 336 -Bees vs, fruit, 336 - House built for experiment, 336-Details of experiments, 337-Conclusions, 338Fruits used, 339-Experience of Richard Rees, 339-Artifieial fertilization, 339-Desirability of accomplishing it, 339-Reent experiments, 340-Experiments with larval and pupal queens unsuecessful, 340-Experiments with imago quecns, 341-Conelusions and ground for hope, 342-Bee forage, 342-Inproved raees, 342-Importanee of apiculture, 342-Statistics, 343-Necessity and seope, 343-Desirability of aeeurate erop reports of apiarian produets, 343 .

2364. Rilex, C. V. Miscellaneous notes on the work of the Division of Entomology for the season of 1885, prepared by the Ento. mologist. <Bull. No. 12, Div. Ent. U. S. Dept. Agric. [13 July], 1886, 46 pp. 1 plate.

\section{CONTENTS.}

Report on the production and mannfacture of Buhaeh. By D. W. Co-

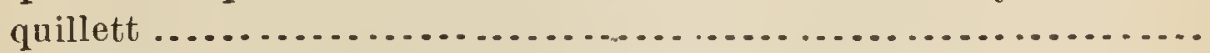

Additions to the third report on the eauses of the destruetion of the evergreen aud other forest trees in northern Ner England. By A. S.

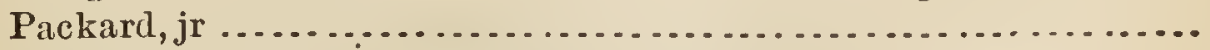

The periodical Cicada in sontheastern Indiana. By A. W. Butler......

Notes of the year.................................... 32

2365̃. R[LEE], C. V. Hessian-fly. <Suppl. Encyclopædia Britannica, 9th Ed., 1886, v. 3, p. 324, fig.

Natural history, remedies, and figures of Cecidomyia destructor. 
2366. R[ILEY], O. V. Locust. <Suppl. Encyclopædia Britannica, 9th Ed., 1886, v. 3, pp. 626-628, fig., map.

Ravages, life-history, enemies of, and means against Caloptenus spretus; migrations and their canse; map of the region overrun; figure of adult.

2367. Riley, C. V. Some popular fallacies and some new facts regarding Cicada septendecim L. <Proc. Amer. Assoc. Adv. Sci. for 1885, [August], 1886, v. 34, p. 334.

Varicty cassinii is not the race tredecim of Tibicen septendecim; twigs with eggs do not necessarily break off or die to insure the hatching of the larva.

2368. Riley, C. V. Report of the curator of the department of insects in the U. S. National Museum for 1S84. <Ann. Rept. of Regents of Smith. Inst. for 1884, 1885 [1886], pp. 185-188.

List of accessions, with notes; recommendations for utilizing the Glover plates; needs of the Dcpartment.

2369. Riley, C. V. Notes on Feniseca tarquinius, Fabr. <Ca. Ent., October, 1886, v. 18, pp. 191-193.

Comments on article by W.H. Edwards; records made at the Department of Agriculture proving the carnivorous habits of the larva of Feniseca tarquinius.

2370. Riley, C. V.' Two useful lives. <Sci. Amer., 29 January, 1887, v. 56, p. 64. S.-b. No. 63, p. 122. See: <Wine and Fruit Grower, January, 1887, v. 9, p. 10. S.-b. No. 61, pp. 55-56.

Brief obituary notices of Louis Bazille and Jules Lichtenstein.

2371. Riley, C. V. Mr. Hulst's observations on Pronuba yuccasella. <Entom. Amer., March, 1887, v. 2, pp. 233-236.

Criticism of the observations of G. D. Hulst; summary of the method of oviposition of Pronuba yuccasella; pollination of Yucca by the same.

2372. [Rilex, C. V.] Fruit pest extermination. <San Diego Mirror, 5 April, 1887. S.-b. No. 63, pp. 88-89.

Mcans against Coccida.

2373. [Riley, C. V.] [Californian orange insects.] <Daily Herald . [Los Angeles], 9 April, 1887. S.-b. No. 63, p. 88.

Means against Coccida.

2374. [Riles, C. V.] Our bugs. <San Francisco Daily Examiner, 16 A pril, 1887. S.-b. No. 63, p. 80;86-87.

Food-plants, ravages, and means against the white-scale.

2375. [RILe $\mathrm{Y}, \mathrm{C} . \nabla$.$] [Remedies and appliances.] < Press and Horti-$ culturist, 16 April, 1887 . S.-b. No. 61, pp. 82-84.

Replies to inquiries made at the annual convention of the State Board of Horticulture of California; means against the codlin-moth; methods of spraying; differences between allicd scales; thcir methods of dispersal and means against them.

2376. Riley, C. V. Bumble-bees vs. red-clover. <Rural New-Yorker, 23 April, 1887, v. 46, p. 270 . S.-b. No. 61, pp. 36-37.

Revival of unsettled questions; red-clover sterilc in the absence of bumblebees in New Zealand; some fertilization by other insects probable; introduction of bumble-bees into New Zealand; their rapid propagation there; beneficial effects on red-clover. 
2377. Riley, C. V. Young grasshoppers. <San Francisco Examiner, 25 April, 1887. S.-b. No. 63, p. 85.

Interview with reporter; ravages of and means against Melanoplus $[=$ Caloptenus] devastator.

2378. Ruley, C. V. Our shade trees and their insect defoliators. Be. ing a consideration of the four most injurious species which alfect the trees of the capital; with means of destroying them. <Bull. No.10, Div-Ent. U. S. Dept. Agric. [7 May], 1887, 69, pp. 27 figs.

\section{CON'TEN'TS.}

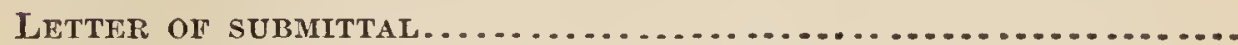

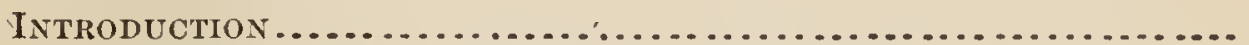

FotrR PRINCIPAL LEAF-EATERS. . . . . . . . . . . . . . . . . . . . .

The imported elm leaf-beetle, Galevica xanthomelana............. An importation from Europe ............................

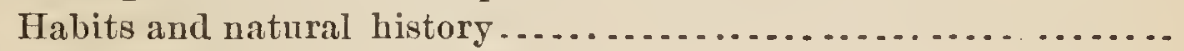

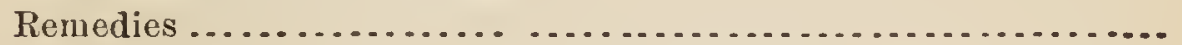
More recent experience at the Department...................

Past history of the clrns in question, 14-Condition aud characteristics of the grove in 1882 and 1883, 14-Extent of injury in 1882 and 1883, 14-Preferences of the elm beetles for certain varieties, 15 -Effects of arsenical poisons on insect and plant, 15-Preventive effects of the poison, 16-Treatment with London purple, 17-Preparation of the poison, 17-Effects of the mixture, 17-Treatment with Paris grcen, 18-Mechanical means of applying the poison, 19.

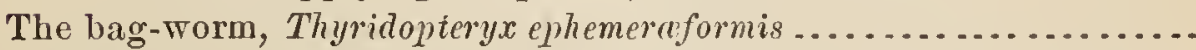

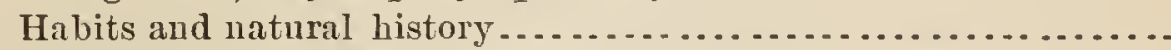

The eggs, 22-The larva and its bag, 23-Pupation, 25-The inago or perfect insect, 25.

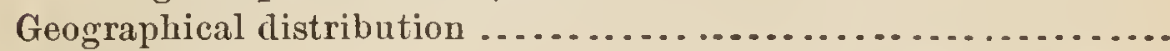

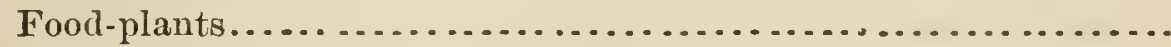

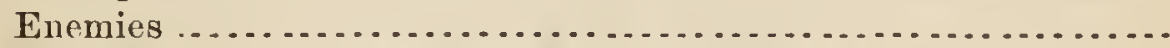

The whitc-marked tussock-moth, Orgyia leucostigma..............

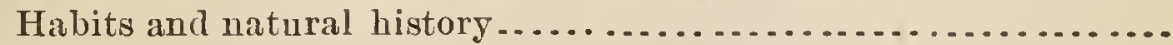

The eggs, 29-Development and characters of the larva, 29Habits of the larva, 30-Pupation, 30-The imago, 30-Hibernation, 31-Number of annual generations, 31 .

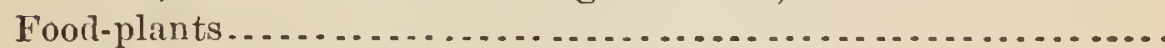

Natural enemies and parasites. . . . . . . . . . . . . . . . . . . . . .

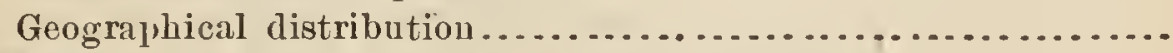

The fall web-worm, Hyphantria cunea ........................

Natural history ........................................

Limitation of broods, 33-The eggs, 34-The larva, 35-Pupa and cocoon, 36-The moth, 36.

Injury done in 1886

Proportionate injury to diffcrent plants and shade trecs ..........

Peculiar effect of defoliation upon some plants .................

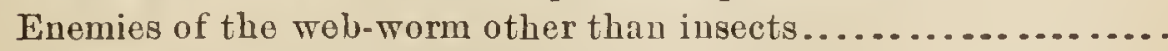

Predaceous insect cucmies. . . . . . . . . . . . . . . . . . . . . . . . . .

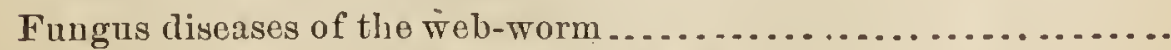

Experiments to obtain percentage of diseased caterpillars, 47. 
2378. Rilex; C. V.-Continued.

Contents-Continued.

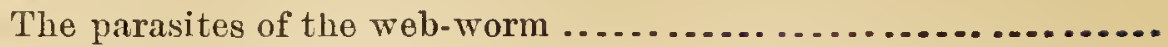

Telenomus bifidus Riley, 48-Meteorus hyphantric Riley, 49-Apanteles hyphantrice Riley, 50-Limneria pallipes Prov., 51-Tachina sp., 52.

SUMMARY OF THE HABITS OF THE FOUR SPECIES. . . . . . . . . . . . . 53

ReMEdies AND PREVENTIVE MEASURES $\ldots \ldots \ldots \ldots \ldots \ldots \ldots \ldots \ldots \ldots . .65$

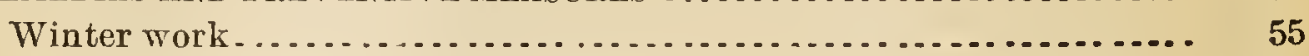

One simple preventive remedy for all ....................... 55

Pruning and burning..................................... 59

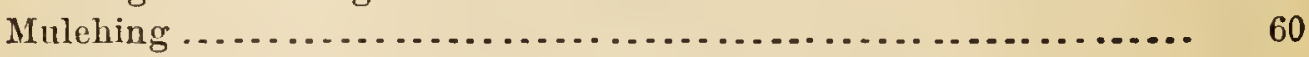

Influenee of tree-boxes .................................... 60

Whitewashing of trunks ................................. 61

Bitids: THE Englisir SPARrow ............................ 62

The future of our trees. Pruning ........................ 63

TRELS WHICH ARE UNINJURED ............................... 64

GOOD AND BAD EFFECTS OF OUR TREES . ....................... 64

Prospects the coming season. Conclusion ................. 65

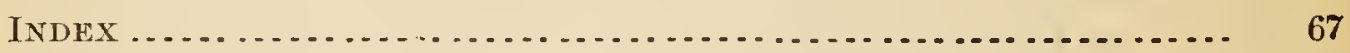

2379. Riley, C. V. Remarks on the insect defoliators of our shadetrees. <New York, 1887, t-p. +12 pp.

Report of address made before the New York farmers, $10 \mathrm{March}, 1887$; ravages and means against Galeruca xanthomelana, Thyridopteryx ephemeraformis, Orgyia leueostigma and Hyphantria eunea.

2380. Riley, C. V. Variable moulting in Orgyia. <Ent. Mo. Mag., May, 1887, v. 23, p. 274.

The female of Orgyia leueostigma undergoes four molts, the male undergoes three; tendency of individual larvæ of all orders to vary from the normal number in the species; whenever there is a discrepancy in size of the sexes the smaller undergoes a less number of molts; number of molts when not sexual dependent on food supply; molting correlated with rate of growth and nutrition.

2381. Riley, C. V. Pedigree moth-breeding. <Ent. Mo. Mag., May, 1887, v. 23, pp. 277-278.

Recommends Seriearia mori as the most favorable inscet to experiment with; its tendency to vary under new conditions.

2382. Rilex, C. V. Reports of observations and experiments in tho practical work of the division, made under the direction of the entomologist. <Bull. No. 13, Div. Ent. U. S. Dept. Agric. [3 June], 1887, 78 pp., 4 figs.

\section{CON'TENTS.}

Introduetion

Report on loeusts in Texas in the spring of 1886 . By L. Bruner. .....

Fourth report on insects injuring forest and shade trees. By A. S. Packard, jr ..................................................

Report on Nebraska insects. By L. Bruner.....................

Tests with insectieides on garden inseets. By W. B. Alwood.........

Report on Uhio insects. By W, B. Alwood...................... 
2382. Riley, C. V.-Continued.

Contents-Continued.

A record of some experiments relating to the effect of the puncture of some hemiptcrous insects upon shrubs, fruits, and grains, 1886. By

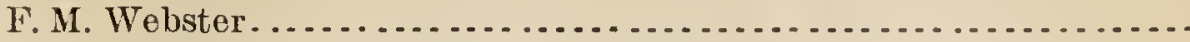

Notes from Missouri for the season of 1886. By M. E. Murtfeldt........

Apicultural experiments. By N. W. McLain.....................

2383. Riley, C. V. A new apple pest. <Sci. Amer., 18 June, 1887, v. 56, p. 384. S.-b. No. 61, p. 50. <Colman's Rural World, 23 June, 1887, v. 40, p.185. S.-b. No. 61, p. 112. <Garlener's Mo. and Hortic., July, 1887, v. 29, p. 216. S.-b. No.61, p. 111; $138 ; 148$.

Food-plants, habits, description of larva and adnlt of Haltica punctipennis; the species subdued by arsenical poisons.

2384. Riley, C. V. A destructive cricket in Louisiana. <Florida Dispatch, 20 June, 1887, v. 7, p. 576. S.-b. No. 61, pp. 64-65. Reprint: < Insect Life, 2 October, 1888,. . 1, pp. 87-88.

Ravages and means against Gryllus sp., destructive to cotton, peas, tobacco, sweet and Irish potatoes.

2385. Riley, C. V. Strawberry borers. <Pacific Rural Press, 25 June, 1887, v. 33, p. 559 . S.-b. No. 61, p. $90 ;$ No. 63, p. 110.

Letter to I. A. Wilcox; recommends bisulphide of carbon as a means against Egeria impropria.

2356. Riley, C. V. Life-history of the Icerya. <Pacific Rural Press, 25 June, 1887, v. 33-34, p. 565; 2 July, p. 9. S.-b. No. 61, pl. $60-64,9$ figs.

From advance proof of Report of U. S. Commissioner of Agriculture for 1886. See No. 2394 for synopsis of contents.

2387. [Riley, C.V.] Cut-worms. <Pacific Rurail Press, 25 June, 1887, v. 33 , p. 578 . S.-b. No. 63 , p. 108.

Means against cut-worms.

2388. Riley, C. V. Reports of observations and experiments in the practical work of the division made under the direction of the entomologist. <Bull. No. 14, Div. Ent. U. S. Dent. Agric. [3 August], 1887, 62 pp., 1 pl., 4 figs.

\section{CONTENTS.}

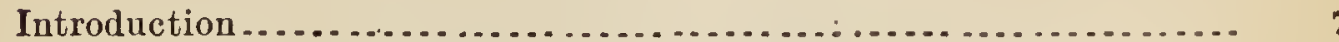

Report on insects injurious to garden crops in Florida. By W. H. Ash-

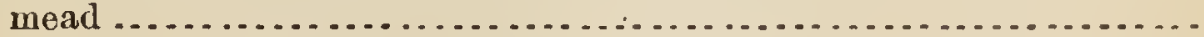

Report on buffalo gnats. By F. M. Webster .....................

Native plums. How to fruit them. They are claimed to be practically

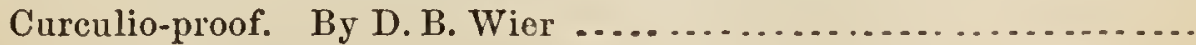

The Serrell automatic silk-reel. By P. Walker .................. 52

2389. Riley, C. V. The Icerya or fluted scale, otherwise known as the cottony cushion-scale. <Bull. No. 15, Div. Ent. U. S. Dept. Agric. [18 August], 1887, 40 pp. <San Diego Union, 16 April, 1887. S.-b. No. 61, pp. 90-97. <Los Angeles, 13 April, 1887. 
2389. RILEY, C. V.-Continued.

S.-b. No. 61, pp. 97-104. <Los Angeles Tribune, 14 April, 1887. S.b. No. 61, pp. 104-111. See: <Pacific Rural Press, 23 April, 1887, v. 33, pp. 361.362; 364. S.-b. No. 61, p. 48 ; No. 63, p. 76. <Riverside Daily Press, 12, 13 April, 1887. S.-b. No. 61, pp. 65-6s; No. 63, pp. 98-105. <Press and Horticulturist, 16 April, 1887. S.-b. No. 61, pp. 74-82. <Florida Dispatch, 2 May, 1887, v. 7, pp. 385-388. S.-b. No. 63, pp. 75; 77. $<$ Pacific Rural Press, 2 July, 1887, v. 34, p. 9.

\section{CONTENTS.}

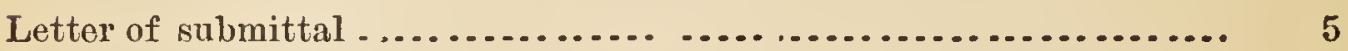

Introduction.......................................... 7

The scale-insects of the orange in California, and particularly the Icerya or fluted scale, etc............................... 9

Notes on Icerya-Its probable origin the Islands of Bourbon and Mauritius............................................. 27

The use of gases against scale-insects........................ 35

2390. [RILEY, C.V.] [Classification of insects.] <Entom. Amer., September 1857, v. 3, p. 102.

Comments on the address of J. H. Comstock before the A.A.A. S.

2391. [RILey, C. V.] [Pronuba and its connection with the pollination of Yucca.] <Entom. Amer., September, 1887, r. 3, pp. 107-108.

Record of the results of recent experiments on the pollination of Yucca and the agency of Pronuba in this work.

2392. Rilex, C. V. Beschreibung einer den Birnen schädlichen Gallmuicke (? Diplosis nigra Meig.). <Wiener Entomol. Zeit., September, 1887, v. 6, pp. 201-206, 3 figs.

Discovery of the species in America; its habits and life-history; detailed description of all stages; possible difference between Enropean and American specimens; suggests $D$. pyrivora for the latter, if distinct.

2393. Rrley, O. V. Some important discoveries in the life-history of the hop-plant louse (Phorodon humuli Schrank). <Soc. for - Prom. Agric. Sci., September, 1887, 1, No. 9, p. 205. Reprint: <Sci. Amer. Suppl., 24 September, 1887, v. 24, p. 9781. S.b. No. 61, pp. 117-119. <Gardener's Mo. and Hortic., October, 1887, v. pp. 309-311. S. b. No. 61, p. 124.

Résumé of recent discoveries in the life-history of Phorodon humuli; proof of its migration from plum to hop ; life of the egg on plum in winter ; spring migration to hop; number of broods thus far observed; probable course of later broods.

2394. RILEy, C. V. Report of the entomologist. <Ann. Rept. [U. S.] Commissioner Agric. for 1886, 1887, pp. 459-592, 11 pl. Separate: $<$ Washington, September, 1887, pp. 459-592+6+9, 11 pl.

TABLE OF CONTENTS.

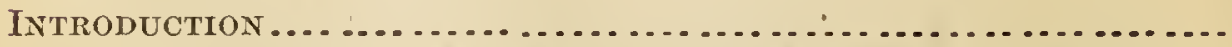

Fruit interests of the Pacific coast, 459-Cottony cushion-scale (Icerya purchasi), 459-Kerosene emulsions, 459-Caustic soda 


\section{Riley, C. V.-Continued-}

Table of Contents-Continned.

and canstie potash, 459-Remedy for the California red-seale (Aspilliotus aurantii), 460-Experiments made by Mr. Coquillett and Mr. Koebele, 460-Emulsifying oil, 460-Southern bnffalo gnats, 461-Results of investigations made on the Soutbern bnffalo guat and the turkey gnat, 461 -Common fall web-worm (Hyphantria cunea), 461-Imported elm-leaf beetle, 461-Spraying applianees, 461-Alternation of generation with the jointworms, 462-Injurions inseets of the year, 462-Hop Aph is (Phorodon humuli), 462-Serrell antomatie reel for silk, 462-Apicultural station at Anrora, Ill., 462-Work of the Division of economic ornithology, 46:-International exhibition of maehinery and eontrivanees for applied remedies against fungi and inseets at Florenee,464-Publieations of the Division during the jear, 464-Proposed publications, 464-Work of field agents, 465-Office foree, 465 .

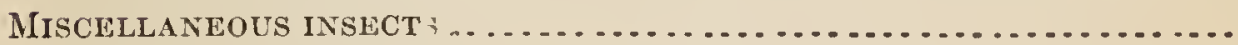

The eottony eushion-seale, Icerya purchasi ....................

Introduetory, 466-Geographieal distribntion, 466-In Australia, 466-In Cape Colony, 467-In New Zealand, 467-Importation of the speeies into California, 468-Its spread and present limitation in California, 469-Food-plants, 471-Original food-plant of Icerya purchasi, 4;1-Its food-plants in Sonth Africa, 471Its food-plants in New Zealand, 472-Its food-plants in California, 472-Characters and life-history, 474-The egg, 475The female larva, first stage, 475-Female larva, seeond stage, 476-Female larva, third stage, 476-The adnlt female, fonrth stage, 47\%-The egg-sae, 478-The male larva, probable seeond stage, 478-Male larva, third stage, 479-The male pnpa and eoeoon, 479-The adult male, 480-Rate of growth of the different stages, 481-Habits, 481-Exndation of the honeydew, 482-Mode of spread and distribution, 483-Natural enemies, 484-Birds, 484-Predaeeous inseets, 484-Parasites, 487Remedies and preventive measures, 488-Importation of parasites, 488-Preventive aetion, 489-Spraying with inseeticides, 489-Fumigating, 491-Bandages aronnd the trunk, 491-Conclusion, 491.

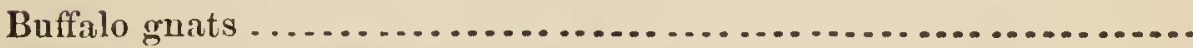

The Sonthern bnffalo gnat, Simulium pecuarum ................

Geographieal distribution, 493-Early history, 493-Time of appearanee, 494-Duration of an invasion, 494-Charaeter of a swarm, 495-Mode of attaek, 496-Animals injired, 497-Effeet of the bites, 497-How animals proteet themselves, 498-Preventives, 499-Remedies for the bites, 501-Attaeking man, 501Damage done in varions years, 501-Popular opinions about the early states of the buffalo gnats, 502-Habits and natural listory, 503-The egg, 503-The larva, 505-Habits of the larvæ, 505-Food of the larvie, 507-Pu pa and eoeoon, 508-The imago, 509-Number of brools, 509-Enemies of the buffalo gnat, 510Deseriptive, 511-Simulium pecuarum n. sp., 512-Simulium meridionale $\mathrm{n} . \mathrm{sp} ., 5 \hat{\mathbf{i}}$-Remedies tried and proposed against the larvæ, 514-Overflows and buffalo gnats, 515 . 
2394. Riley, C. V.-Continued.

TAMLE- OF CoNTENTS-Continned.

The fall web-worm, Hyphantria cunea......................

Natural history, 518-Limitation of broods, 518-The eggs, 519-

The larvæ,519-Pupa and cocoon, 520-The moth, 520-Injnry done in 1886, 521-Proportionate injury to different plants and shade trees, 522-Pcculiar effect of defoliation upon some plants, 525-Enemies of the web-worm other than insects, 525-Predaceons insect enemies, 526-Fnngus disease of the web-worm, 527-Experiments to obtain percentage of discased caterpillars, 529-True parasites of the web-worm, 530-Secondary parasites, 530-The Telenomns egg-parasite, 531-The Meteorus parasite of the web-worm, 531-The Microgaster parasite of the web-worm, 533-The Limneria parasite of the webworm, 534-The Tachina parasite of the web-worm, 534-Remedies, 535-Pruning and burning, 535-Mnlching, 536-Arsenical poisons, 536-Emulsions of kerosene, 538-Naphtha, 538.

Joint-worms, Isosoma sp ...................................

The common joint-worm, 539-Its occurrence in Virginia in $\mathbf{1 8 8 5}$, 539-Other recent appearances, 540-Its identity with $I$. nigrum Cook, 541-Parasites, 542-The wheat-straw Isosoma, 542Dimorphism of $I$. tritici and $I$. grande, 543-Occurs in Califoruia, 544-In Kansas, 545-Parasites, 546.

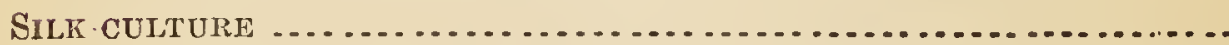

Appropriations for the current year, 546-Establishment of a filature at Washington, 546-Osage orange $v s$. mulberry, 546Rendition of osage cocoone, $547-\mathrm{Mr}$. Serrell's opinion, 547Satinage, 547-The Serrell reel; cost of work up to the present time, 548-Expenses tabulated, 548-Chances for improvement, 549-Distribution of eggs, 549-Reasons for purchasing foreign eggs, 549-Improper choking of cocoons, 550-A simple apparatus for choking, 551-Cocoons produced in the United States in 1886, 551-Tabnlated by States, 552.

REPORT OF AGENTS

Report on remedies for the cottony cushion-scale. By D.W. Co-

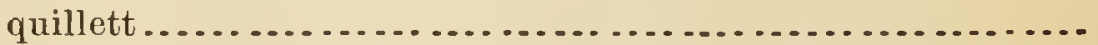

Letter of transmittal, 552-General considerations, 553-Canstic potash, 554-Caustic soda, 5.55-Hard soap, 555-Soft soap, 555Kerosene emulsions, 556-Tobacco, 556-Sheep dip, 557-Tobacco soap, 557-Vincgar, 557-Paris green, 557.

Report upon supplementary experiments, on the cottony cushionscale, followed by a report on expériments on the red-scale. By A. Koebclo .......................................

Lettcr of transmittal, .558-Introductory, 558-Soap solntions, 558-Preparation of soap, 559-Resin compounds, 559-Lye soIntion, 560-Bisulphide of carbon, 560-Kerosene emnlsion, 560-Experiments, 560-Experinents on fumigation with bisulphide of carbon, 569-Experiments on red-scale (Aspidiotus aurantii), 569.

Insects affecting small grains and grasses. By F. M. Webster.......

Letter of transmittal, 573.

Insects affecting fall wheat..................................

The wheat-straw Isosoma (Isosoma tritici, Riley), 573-The American Meromyza (Meromyza americana, Fitch), 574-The companion wheat fly (Oscinis sp.), 574. 
2394. Riley, C. V.-Continued.

TABLE of Contents-Continued.

Insects affecting barlcy.

The white-grub (Lachnosterna fusca, Frohl.), 575-Tlie barley root-louse (Schizoneura sp.), 575-The grain A phis (Siphonophora avena, Fab.), 576 .

Insects frequenting or depredating upon buckwheat.............

Supposed exemption from insects, 576-Mode of observation, 576 -Siguification of symbols, 576-List of insects, 576 .

Insects affecting timothy, 578 .

The glassy cut-worm (Hadena devastatrix, Brace), 578-Outbreak in Indiana in 1886, 578-Doubt as to species concerned, 578Method of work, 579-Traveling, 579-Parasites, 579-Damage, $580-$ Condition of fields in October, 580-The grain Sphenophorus (Sphenophorus parvulus, Gyll.), 580.

Insects affecting white-clover..............................

The flavescent clover weevil (Sitones flavescens, Allard), 580Infests alsike, 580-Mode of attack, 580-Distribution, 580Eggs and larva, 580-Hibernation, 580-Summary of life-history, 581-The clover-stem maggot (Oscinis sp.), 582-Descriptive, 581-Time and place of oviposition, 581-Number of broods, 581.

Report on experiments in apiculture. By N.W. McLain ............

Letter of transmittal, 583-The "quaking disease," 583-Nature of the disease, 583-Odor of infested hives, 583-Treatment with brine and soda, 583-Another form of the disease, 584The foul-brood disease, 584-It is contagious, 584-Live pollen the medium, 584-Treatuent, 584-Results of treatment, 585How the disease spreads, 587-The control of reproduction, 587-Difficulties, 587-Experiments in 1885, 588-Device for holding the queen, 588-Differences in drones, 589-Proportion of impotent individuals, 589-Mr. Baldwin's experiments at Clarksville, Mo., 589-Comments, 590-Fertilization in confinement, 590-Apparatus, 590-Results of expcriments, 590Proposed experiments, 591.

2395. Riley, C. V. The Hessian-fly in England; its origin; its past; its future. <London Times, 17 October, 1887. S.-b. No. 61, pp. 144-147.

Date of the introduction of Cecidomyia destructor into England; probability that it has been introduced from continental Europe since the time of Curtis; conditions in Great Britain unfarorable for its increase.

2396. Riley, C. V. The problem of the hop plant louse fully solved. <Gardener's Chronicle, 22 October, 1887. S.-b. No. 61, pp. 133-135. Reprint: <Mark Lane Express, 31 October, 1887, v. 57, pp. 135-137. S.-b. No. 63, pp. 136-140.

Life-history, migrations, and mode of hibernation of Phorodon humuli.

2397. Riley, C. V. On the luminous larviform females of the Phengodini. <Ent. Mo. Mag., [December], 1887, v. 24, pp. 148-149.

Structural characters of the larval Phongodini; food of Zarhipis; characters of eggs, young larva, and female larve of Zarhipis and Phengodes; female Phengodini considered an archetspal hexapodal form; rolations between phosphorescence and differentiation of the scxes. 
2393. Riley, C. V. [Introduction of the Hessian-fly into Englaud.] $<$ Trans. Ent. Soc. London, [December], 1857, pp. 45-48, Proc.

Discussion of the date of introduction of Cecidomyia destructor into America and England; concludes from a study of the historical evidence, the distribution and parasites of the insect, that it was probably introduced into England abont three or four years ago.

2399. Rilety, C. V. Poisonous insects. <Reference Handbook of the Medical Sciences, 1887, v. 5, pp. 741-760, figs. 2971-3020.

An exhanstive illustrative review of the Arachnida, Myriapoda, and Hexapoda which secrete a poison injurious to man ; descriptions of their life-histories; the manner in which the injury is inflicted and the remedies for the same.

2400. Riley, C. V. The problem of the hop-plant louse [Phorodon humuli, Schrank] in Europe and America. <Rept. Brit. Assoc. Adv. Sci., 1887, pp. 750-753. Separate: <pp. 1-3. See: $<$ Nature, 13 October, 1857, v. 36, pp. 566-567. <Gardener's Chronicle, 17 September, 1887. S.b. No. 61, pp. 333-334.

Life-babits of Phorodon humuli; effects of extreme heat and of meterological conditions; natural enemies and means against the Phorodon.

2401. Riley, C. V. On Icerya purchasi, an insect injurious to fruit trees. <Rept. Brit. Assoc. Adv. Sci., 1857, p. 767. Separate: $<$ p. 1. See: <Nature, 20 October, 1887, v. 36, p. 592.

Summary statement of food-plants, original home, synonomy, and means agaiust Icerya purchasi.

2402. Riley, C. V. On the lumiuous larviform females in the Phengodini. <Rept. Brit. Assoc. Adv. Sci., 1887, pp. 760-761. Sep. arate: <pp. 1-2. See: <Entom. Amer., September, 1857, v. 3, p. 107. <Proc. Amer. Assoc. Adv. Sci., 1887 [May, 1888], v. 36, p. 262.

R6sumé of facts relating to the history, characters, and life-habits of the luminous larviform females in the Phengodini; bearing of these facts on the theory of evolution.

2403. Riley, C. V. [Seale on \$2uonymus latifolia?] <Sci. Amer., 14 January, 1888, v. 58, p. 27. S.-b. No. 61, p. 148.

Means against Chionaspis euonymi and other Coccida; formulæ of kerosene emulsions.

2404. [RILey, C. V.] [Larval habits of Lixus.] <Proc. Ent. Soc. Wash., [13 March], 1888, จ. 1, p. 33.

Lixus macer bred from stems of Chenopodium hybridum and fron Helianthus; larva of $L$. parcus a gall producer on stems of Amelanchier.

2405. [RILey, O. V.] [Girdling habits of Pcedisca obfuscata.] <Proc. Eint. Soc. Wash., |13 March], 18s8, v. 1, p. 33.

Larva of $P$. obfuscata spins a web over the orifice at the amputated end.

2406. [RILEY, C. V.] [Early stages of Aphorista vittata and Epipocus punctatus.] <Proc. Ent. Soc. Wash., [13 March], 18ss, v. 1, p. 37.

Comparative characters between corresponding stages of the two species. 
2407. [RILEy, C. V.] [Food-habits of Feniseca tarquinius.] <Proc. Ent. Soc. Wash., [13 March], 1Sss, v. 1, p. 37.

List of Aphidide preyed upon by larva of $F$. tarquinius.

2408. [Rrley, C. V.] Notes on.Phengodes and Zarhipis. <Proc. Ent. Soc. Wash., [13 March], 18ss, v. 1, pp. 62-63.

Structural eharacters of the luminous larve of Phengodes and Zarhipis and of an unnamed form from Nevada; differenee between the perfeet female and the larva.

2409. [Rrley, C. V.] [Trees injured by spiders.] <Proc. Ent. Soc. Wash., [13 March], 18ss, v. 1, 1. 84.

Growth of trees retarded by spider-webs.

2410. [RILey, C. V.] [Remarks on exhibited specinens.] <Proc. Ent. Soc. Wash., [13 March], 18ss, v. 1, pp. S1-86.

1. Notes on the life-habits of Ageriide. Habits and early stages of Melittia gloriosa, Sciaptcron robinia, Phemonoe 5-caudata, Egeria impropria, A. albicornis, and A. pyri.

2. Color variation in the larva of Agraulis vanille. Colorational variation between eastern and western larvie of $A$. vanillo.

3. Miscellaneous inseets. Food-plants of Eumenia atala and Cloantha dernpta; habitat of Dendrotettix quercus n. g. et sp.

2411. Rrley, C. V. Further notes on Phengodes and Zarhipis. <Proc. Ent. Sor. Wash., [13 Mareh], 1888, v. 1, pp. 86-87.

Comparative charaeters of the larvie of Phengodes and Zarhipis; life-habits and metanorphoses of the same; eolorational and struetural characters of the larva and larviform female of Zarhipis; description of the eggrs of Zarhipis.

2412. [Riley, C. V.] [Remarks on exhibited specimens.] <Proc. Ent. Soc. Wash., [13 Mareh], 1888, v. 1, pp. S7-89.

1. Notes on the eversible glands in larve of Orgyia and Parorgyia, with notes on the synonony of species. Presence of glands, probably scent organs, in the larvo of Orgyia and Parorgyia; synonomy and food-plants of solne species of Parorgyia.

2. Further remarks on Phengodes. Comparative characters of larva and larviform females of Phongodes laticollis.

3. Interesting Lepidoptera. Characters of Syntomeida sp., and of an undetermined inoth.

2413. Riley, C. V. The British pest. Worthlessness of the sparrow as an insect-killer. <National Tribune, 26 April, 1888.

Result of the examination of the stomach contents of 522 sparrows, of which 92 only, or $1 \tau{ }_{10}^{6}$ per cent., contained iusects, a large proportion of these being innoxious or actually beneficial species; review of recorded observations in North America.

2414. Riley, C. V. Elm-tree depredators. <Newark [N. J.] Press and Register, 10 May; 1888.

Report of an address before the Newark Board of Trade; life-history and incans against Galcruca xanthomelena.

2415. Rrley, C. V. On the original habitat of Tcerya purchasi. <Pacific Rural Press, 12 May, 1888, r. 35, p. 425.

Australia probably the true home of Icerya purchasi; its distinctness from I. sacchari. 
2416. Riley, C. V. The buffalo-gnat problem in the lower Mississippi Valley. Abstract: <Proc. Amer. Assoc. Adv. Sci. for 1887, [May], 188s, v. 36, p. 362.

Result of late investigations on species of Simulium.

2417. Rilex, C. V. Systematic relations of Platypsyllus, as determined by the larva. <Sci. Amer. Suppl., 2 June, 1388, v. 25, pp. 1035(j10358, 4 figs.

Review of the literature concerning the systematic position of Platyps!yllus castoris; additional facts confirming G. H. Horn's view of the coleopterous nature of the insect.

2418. RILEY, C. V. Report of the entomologist. <Ann. Rept. [U. S.] Commissioner A gric. for 1887, 1888, pp. 48-179, 8 pl. Separate: $<$ Washington: June, 1888, pp. 48-179+6, 8 pl.

\section{TABLE OF CONTENTS.}

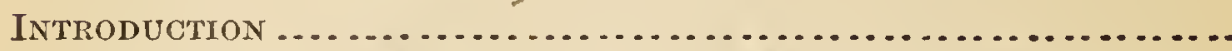

Damage by the ehinch-bug, 48-Codling-moth, 48-Hop Aphis, 48-Work of Division in regard to silk-culture in the past year, 49-Recent experiments on the fluted or cottony cushion-scale of California, 49-Hydrocyanic acid gas and arseniuretted hydrogen, 49-Possible introduction into California of the parasites of Icerya from Australia, 50-Recent experiments on other scaleinscets, 50-Professor Osborn's report on the more important insects of the season in Iowa, on the chinch-bug, on hop insects in Wisconsin, 50-Mr. Bruner's rcport, 50-Mr. Webster's report on the sonthern buffalo-gnat, 50-The year as a whole one of comparative immunity, 50-Apiculture, 50.

The Chinch-Bug, Blissus leucopterus. By L. O. Howard............

Introductory, 51-Past history, 51-Earliest appearance, 52-First described by Say, 52-Called "Mormon louse" in Illinois in 1840, 52-First recorded appearance in Missouri, Iowa, Indiana, and Wisconsin, 52-Its damage in the years 1864 and 1868, 52-Estinates of loss in 18\%1, 52-Great injury in $1874 \mathrm{in}$ Missouri and adjoining States, 52-First injurious appearance in New York in 1882, 53-Damage in succeeding years, 53-Geographical distribntion, 53-Indigenous east of the Rocky Mountains, north and south, 53-States in which it does the greatest damage, 53-In Cuba, 54-West of the Rocky Mountains, 54-Specimens from California and Mexico, 55-Injury during 1887, 55-Review of localities and damage this season by the statistician of the De. partment, 55-Table showing losses in States most dawaged, 56Summary of counties in these States, 57-Food-plants, 57-Cultivated grains and cultivated and wild grasses, 57-Rice, 58-Pólygonum, 58-Stages of growth-Descriptive, 59-Egg, 59-Larval stages, 59-Pupa, 59-Imago, 59-Original description, 59-Lo Baron's description, 59-Fitch's varieties, 60-Riley's variety melanosus, 60-A new variety, 60-Number of broods and hibernation, 60-First accurate statement, 60-Hibernation, 60-Influence of severe cold, 61 -Odor reveals hiding places, 62-Habits, 62-Flight, 62-Oviposition, 62-Young larvæ, 63-Growih, 63Migration, 63-Habits on corn, 64-Preparations for hibernation, 64-Erroneous statement as to oviposition, 65-Exceptional habits, 65-Natural enemies and diseases, 65-Insect enemies, 65No true internal insect parasite yet known, 65-A possible hair- 
2418. Riley, O. V.-Continued.

THE chinch-BUG-Continued.

worm parasite, 65-Lady-bird enemies, 65-Weeping lacewinged fly, 66-True bugs which prey upon it, 66-Inefficacy of lady-bugs when plant-lice are present, 66 -Vertebrate enemies, 67-Common quail; 67-Other birds, 67-Quail laws, 67-Diseases, 68-Dr. Shimer's account of his observations on the epidemic in 1865, 68-Professor Forbes' investigations, 69-His studies of bacterial diseases of other inscets, 70-Professor Riley's commonts, 70Wet weather and ehinch-bug, 71-Professor Forbes' experiments, 71-Comments, 71-Wet weather and the disease, 72-Dr. 'Thomas' theory, 72-Professor Riley's eomments, 73-An anonymous prediction, 73-Table of temperature and rain-fall in North Carolina, 74-Official records of precipitation in chinch-bug States for 1885, 1886, and 1887, 74-Remedies and preventives, 75-Earlier recommendations,75-Preventions, 75-Clean cultivation, 75-Diversified farming, 75-Rotation of crops, 76-Early sowing and manuring, 76-Rolling, 76 -Sowing an unattractive crop with wheat, 76-Direet winter remedics, 77-Burning, 77-Fall plowing and harrowing, 77-Gas lime, 77-Trapping, 77-Trampling, 77-Direct summer remedies before migration, 77-Irrigation, 78-Burning, 78-Prevention of migration-Direct remedies during and after migration, 79-Ditching, 79-Tarred boards or tar alone, 80-Sowing strips of plants distasteful to the bugs around the fields to be protected, 80 -Sowing strips of favored food around the fields to be protected, 80-Hot water and soap-suds, 80-Kerosene emulsion, 80-Professor Forbes' experiments, 81Mr. Hubbard's formula, 81-Professor Atkinson's test, 81-Professor Osborn's experiments, 82-Mr. Warren's letter, 83-Bogus chinch-bugs, 83-Falso chinch-bug, 83-Insidious flower-bug, 84Ash-gray leaf-bug, 84-Flea-like negro-bug, 84-Bibliographical list, 84.

The Codling-мотH, Carpocapsa pomonella. By L. O. Howard......

Introductory, 88-Remarks on the bibliography, 83-Geographical distribution, 89-Date of introduction into Amcrica, 89-The insect popularly described, 89-Larva, 89-Cocoon, 89-Moth, 90Habits and natural history, 90-Broods, 90-Its round of life, 90Irregularity of development, 91-Number of larvæ in a single apple, 91-Larvie of the second generation, 91-Hibernation in the larval state, 92-Apparent exception to this rule, $92-$ Cocoons found in apple barrels, 92-Habits of the insect in the North of Germany, 92-Food-plants, 92-Stone fruits of the Rosacen less infested, 22-European records of its occurrcnce in walnuts and oak-galls, $92-A$ closely alliod species known to fced upon walnuts, 94-Natural enemics, 94-Birls, 94-A hair-worm parasite, 94-True hymenopterous parasites, 94-Predaccous insects which feed upon the larve and pupæ, 95-Remedies, 95-The destruction of windfalls-feeding and trampling-the use of sheep and hogs, 96-Jarring or picking infested fruit from the trces, 96Killing the moth, 97-Miss Walton's observations, 97-Mr. De Long's observations, 97-Capture of the moth with baits, 98Insect-catching flowers, 98-Sunımary of the question of attracting the moth, 98-Quotations from Professor Riley's Fourth Missouri Report, 99-Attraction of moth impractical, 99-'Trapping the worm-bandages, shingle traps, etc, 100-"Trimble hay 
2418. RILEY, O. V.-Continued.

The CODLING-Moth-Continued.

band system," 100-Professor Riley's rules concerning this system, 100-The Wier shingle trap, 101-Cloth bands, 101-Dr. Chapin's work in California in 18:2, 102-Spraying the trees with arsenical mixtures, 103-Professor Cook's statements, 103-Professor Forbes' conclusions from his expcriments in 1885, 104-Mr. Goff's experiments at Gencva, N. Y., during 1885, 106-Supple. mentary conclusions by Professor Forbes, 106-Mr. Alwood's experiments in Obio the past season, 109-Results, 110-Mr. Cushman's letter, 111-The consideration of these poisons in California, 111-Time of day for spraying, 112-Notice of Mr. Dixon's paper, 113-Apparatus for applying the arsenical mixtures, 114.

SilK-CUlture-Report of THe Year's operations. By Philip Walker

Distribution of silk-worm eggs, 115-European egg-producers, 115The establishment of Signor Susani, of Milan, 115-Deydier establishment at Aubenas, France, 117-Mulberry trees, 117-The Cattaneo nurseries, 117-Experimental stations, 118-The Royal Sericultural Experimental Station at Padua, 118-Experimental silk filature at Washington, 119-Production and purchase of cocoons, 120-Co-operating organizations, 122.

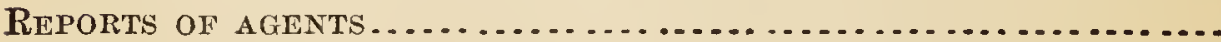

Report on the gas treatyent For scale-insects. By D. W.

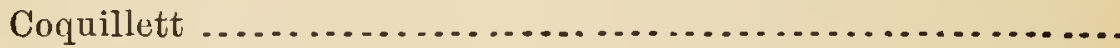

Letter of transmittal, 123-The gas treatment for scale-insects, 123-Extract from Mr. Craw's paper, 124-Results of Dr. Dim. mock's experiments on various insects with pure gases, $125-$ The tent, 126-Apparatus for operating the tent, 126-The McMullen tent, 126-The Wolfskill fumigator, 12\%-The Titus fumigator, 128-The Culver fumigator, 129-The gas, 129-The dry cyanide process, 129-The dry gas process, 130-The cyanide and soda process, 131-Remarks, 132-Agitating the air in the tent, 133Experiments, 134-Index to experiments, 142.

REPORT ON EXPERLMENTS AGAINST SCALE-INSECTS. By Albert Koebele

Letter of submittal, 143-The value of arsenic as an addition to the kerosene emulsion, 143 -Results of various experiments with rosin compound, 143-Experiments with resin cumpound, 146Experiments on Aphididee with resin compound, 146.

REPORT ON THE SEASON'S OBSERVATIONS IN INDIANA, AND ESPECIALLY UPON CORN INSECTS By F. M. Webster..............

Letter of transmittal, 147-The twelve-spotted Diabrotica, 148-The corn plant-louse, 148-Corn bill-bug, 149-Myochrous denticollis, 150-Flea-beetles, 150-The greasy cut-worm, 150-Ants, 150Drasterius dorsalis (?), 151-Chinch bug, 151-Corticaria pumila, 151-Calathus gregarius (Say) versus the Colorado potato-beetle, 151-A new enemy to the bean and cow-pea, 152-The strawberry saw-fly, 152-Wheat wire-worm, 153.

Report upon the insects of the season in Iowa. By Herbert Osborn

Letter of transmittal, 154-The turf web-worm or sod-worm, 154Extracts from crop report, 155-Habits and life-history, 156-- Description of different stages, 153-Remedies, 159-Natural enemies, 160-Other mention of the species and related forms, 160The wheat-head army-worm, 160-Extracts from Iowa crop report, 160 -Blister beetles, ${ }^{`} 161-$ The false chinch-bug, 162Notes on miscellaneous insects, 162. 
2418. Riley, C. V.-Continued.

Report on the season's observations in Nebraska. By Lawrence Bruner.......................................

Letter of submittal, 164-Introduction, 164-Colorado potatobeetle, 164-Chinch-bug, 165-Causes of increase, 165-Locusts, 167-Cabbage insects, 168-The codling-moth, 168-Forest-tree inscets, 168-The American Cimbex, 169-Other insects, 170.

REPORT ON EXPERIMENTS IN APICULTURE. By N. W. McLain.......

Letter of submittal, 170-Diseases of bees, 171-Bacillus alvei (Cheshire), 174-Quotations from Professor Cheshire, 172-Treatment, 174-Starved brood, 174-Symptoms, 175-Remedy, 175The control of reproduction, 175. 

U.S. DEPARTMENT OF AGRICULTURE.

DIVISION OF ENTOMOLOGY.

\section{BIBLTOGRAPHY}

OF

THE MORE IMPORTANT CONTRIBUTIONS

TO

\section{AMERICAN ECONOHIC ENTOHOLOGY.}

PREPAREI, BY ALTHORITI OF THE SECRETARY OF AGRICULTURE,

135

SAMUEI, HENSHA W.

\section{INDEX}

TO

Parts I, II, and III.

WASHINGTON:

GOVERNMENT PRINTING OFFICE.

1890 . 



\section{INDICES T0 PARTS I, II, AND III.}

\section{SYSTEMATIC INDEX OF THE NEW NAMES PROPOSED BY B. D. WALSE AND BY WALSH AND RILEY.}

[The Walsh and Piley names are followed by W. \& R. The first number following the name refers to the number of the paper in the list, the second to the page where tho species is first described. As is well kitown, the Walsh collection was destroyed in the Chicago fire in October, 1871. A few of the types sent to Drs. Hagen and Riley are in the collections of the Museum of Comparative Zoology at Cambridge and the National Museum at Washington. Those at Cambridge are indicated by $\mathbf{a}^{*}$, those at Washington by **.]

ARACHNIDA.

ACARINA.

Acarida.

Acarus pruni-crumena, $373 ; 43$.

s.-ronigma (Cecidomyia), $46 ; 608$.

s. -scmen (Cecidomyia), 46; 606.

\section{MYRIAPODA.}

\section{Chilogratha.}

Iulidac.

Cambala multistriatus (Inlus), $193 ; 34=$ anuu. Iata, Say.

\section{HEXAPODA.}

Pseudoneuroptera.

Procider.

Psocus amaluilis, 24; 362.* bifasciatus, 39 ; 183. . confluons, 39 ; 185 . conterminus, 39 ; 185. * geologus, 24 ; 302.*1 lichenatus, 39 ; 183.* madesccns, 39 ; $186 . *$ permadidus, 39 ; 185.* perplexus, 24; 361.* pollutus, $24 ; 361$ * $^{*}$ purus, 24 ; 361 .* rufus, $39 ; 185$.

Perlidae. semistriatus, 24; 361 .*

Acroneura rupinsulensis, 24 ; 363.*

Chloroperla brunnipennis, 24 ; 367.* fumipennis (Perla), 21 ; 366.* nana, 24; $367 . *$
Perlida-Continued.

Perla decipiens, 24; 364 ** elongata, 24; $366 . * 1$ flavescens, 24; $363 . * 1$ producta, 24 ; 365. * varians, $24 ; 364 . *$

Ephemerida.

Batis sicca, 24 ; $371.0^{\star 1}$

Bxtisca, 24 ; 378 .

Cloe dubia, 24 ; $380 . * 1$ ferrnginea, 24 ; 379.* fluctuans, 21 ; $379 . *$ mendax, 24 ; 381 . *

Ephemera flavcola, 24; 377.* myojs, 39 ; 207.*

Ephemerella, 24; 377.

consimilis, $24 ; 378$. excrucians, 24 ; $377 . \star 1$

Heptagenia, $39 ; 197$.

cruentata, 39 ; 205.*

maculipennis, 39 ; 206. simplox, 39 ; 204.*

Hexagonia, 39 ; 197.

Palingonia flaroscens, $24 ; 373 .{ }^{* 1}$ pulciella, $24 ; 375 .{ }^{* 1}$ terminata, $2 t ; 376 . * 1$ vittigera, 24 ; $373 . *$

Pentagenia, $39 ; 196$. quadripunctata, 39 ; 198.

Potamanthus? odonatus, $24 ; 372$.

Siphlurus interlineata (Batis), 39; $190=$ femorata, Say. Odonata.

Agrion binotatum, 24 ; 387.*

dentiforum, 39 ; 236.*

Lageni, $24 ; 386 . \quad 39$; $234 . * 1$ 
Odonata-Continned.

Cordulia? molesta, $39 ; 254$.

Gomphus amnicola, 24; 396.*? consobrinus, $39 ; 242$.* flnvialis, $24 ; 394 . * 1$ grasilinellus, 24 ; 394 . $^{* 1}$ quadricolor, $39 ; 246$. vastus, $24 ; 391 . * 1$ ventricosus, $39 ; 249$.

Herpetogomphus? rupinsulensis, 24 ; 388.

Hetærina psendamericana, 39 ; 223 .* $^{*}$ rupamnensis, $39 ; 230 . * 1$ rupinsnlcnsis, 24; 383. scelerata, $39 ; 267$. texana, $39 ; 227$.

Lestes inæequalis, $24 ; 385$.

Macrogomphus? spiniceps, 24 ; 389.

Macromia flavipennis, 24 ; 398. illinoiensis, 24 ; 397.

Ophiogomphus mainensis, $39 ; 255$. ORTHOPTERA.

Phasmidee.

Diapheromera velii, $45 ; 410$.*

HEMIPTERA.

Coccidae.

Chionaspis harrisii (Aspidiotus), $2 ; 308^{\star *}=$ furfurus, Fitch.

salicis-nigra (Aspidiotus), 373; $40=$ salicis, Linn.

Pnlvinaria acericola (Lecanium) W. \& R., 389 ; $14^{* *}=$ innumerabilis, Rath. macluræ (Lecanium) W. \& R., 389 ; 14 =innnmerabilis, Rath.

Aphidida.

Aphis bella, 27; 299.*

carduella, 27 ; 300.

queroifoliæ, 27 ; 298.

Byrsocrypta psendobyrsa, 27 ; 306. vagabunda, $27 ; 306 . * 1$

Calaphis, 27; 301.

betulella, 27 ; $301 . *$

Pemphigus formicarius, $27 ; 308$. formicetorum, 27 ; 308.* ulmi-fusus W. \& R., 518; 109.*

Phylloxera caryæ-globuli, 27 ; 309.** caryæ - s в m өn (Dactylosphæra) $373 ; 23 . *$

Schizoneura cornicola (Eriosoma ?), 27 ; 304. fungicola (Eriosoma?), 27; 304.

Jassida.

Chloroneura, 22; $4^{2}=$ Empoasca, Walsh.

Etmpoa albicans, $22 ; 4$.

Empoasca, 22 ; 3.

abnormis (Chloroneura), $22 ; 4$.

consobrina, $22 ; 4$.

malefica (Chloronenra), 22; $4=$ viridescens, Walsh.

maligna (Chloronenra), $22 ; 4=0 \mathrm{~b}$. tusa, Walsh.

obtusa, 22 ; 4.

viridescens, $22 ; 3$.

Erythroneura australis, $22 ; 4$. octonotata, $22 ; 4$ ziczac, $22 ; 4$.

Jassido-Continued.

Typhlocyba anrea, 22; 3. binotata; 22 ; 3 . pallidula, $22 ; 3$.

Tingitida.

Gargaphia amorph» (Tingis), $45 ; 409 . * *$ tilix (Tingis), 45 ; 408. ${ }^{\text {** }}$

\section{Coleoptera.}

Scolytidoe.

Scoly tus fagi, $220 ; 58$.

Calandridae.

Sphenophorus $\quad$ zeæ, $337 ; 117^{*+}=$ sculptilis Uhler.

Curculionida.

Antionomus cratæogi, $197 ; 266$. syncophanta, $197 ; 265$.

tessellati, 197 ; 267.

Apion languinosum, 197; 269=walshii, Smith. Coccotorns prnnicida (Anthonomus), 33 ; 373 = scutellaris, Lec.

Conotrachelus cratægi, $35 ; 37$. puncticollis, 34 ; 21.

Ohrysomelidae.

Fidia viticida, 272 ; 87.**

Physonota 5-punctata (Cassida) W. \& $\mathbf{R}$. $767 ; 4^{\star *}=$ unipunctata, Say.

DIPTERA.

Trypetida.

Trypeta pomonella, $373 ; 33 .{ }^{* *}$

Anthomyidce.

Homalomyia leidyi, 382; 138. prunivora, $382 ; 138$. wilsoni, 382 ; 138.

Tachinidoe.

Nemoræa militaris (Senometopia) 0; $367^{\star \star}=$ leucaniæ Kirkp.

Syrphida.

Pipiza radicum W.\& R.., 495; $83^{\star \star}=1$ fomo. ralis Loew.

Midaidoe.

Midas fulvipes, $46 ; 306$.

Cecidomyidae.

Cecidomyia albovittata, $40 ; 621$.* $^{*}$

cornuta, $46 ; 625$.

cratægi-bedeguar, $376 ; 79$.

orbitalis, 46 ; 623 .

q.pilulao (Cynips), 41 ; 481.

s.-batatas, $46 ; 601 . \star \star 1$

s.-brassicoides, 46 ; 577 . ${ }^{\star \star 1}$

s.-cornu, 46; 570. 197; 224 .

s.-coryloides, 46 ; 588.*

s.-gnaphaliodes, 46 ; 583.*

s.-hordeoides, 46 ; 599.

s.-nodulus, 46 ; 599.*

s.-rhodoides, 46 ; 586.*

s.-siliqua, $46 ; 591 . * 1$

s.-strobiliscns, $46 ; 582.197 ; 223$.

s.strobiloides, $46 ; 580$.

s.-triticoides, 46 ; 598. *1

s.-verruca, $46 ; 606$.

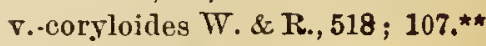

v.-pomum W. \& R., 518; 106.**

Diplosis annulipes, $46 ; 629$. atricornis, $46 ; 628$. 
Midaidae-Continued

atrocularis, $46 ; 626$.

decem-maculata, 46; 631 .

helianthi-bulla, $197 ; 228$.

septem.maculata, $46 ; 631$.

\section{LEPIDOPTERA.}

\section{Tortricidoe.}

(irapholitha prunivora (Semasia), $373 ; 80$.** $^{* *}$

Phoxopteris fiagarix (Anchylopera), W.\& R. $499 ; 90 . \star \star$

\section{Pyralida.}

Acrobasis nebulo (Phycita), 2; 308 =indigi nella, Zeller.

Geometrida.

A plodes venustus (Hipparchiscus), 40;31**= mimosaria, Guen.

Hipparchiscus, $40 ; 300=$ Aplodes, Guen.

Bornbycida.

Malesidota antiphola, $40 ; 2 \varsigma 8=$ tessellata, S. \& A harrisii, $45 ; 430^{\star *}=$ tessellata, S.\& A

Limacodes? tetradactylus, $40 ; 300$.

Phobetron hyalinnm (Limacodes ?), $40 ; 300{ }^{*}$ Sphingicampa, $40 ; 290$.

distigma, $40 ; \quad 290=$ bicolor, Harris.

Egeriada.

无geria hospcs (Trochilium), 197; 270.

\section{HyMenoptera.}

\section{Tenthredinidoe.}

Euura perturbans, 197 ; 254.

s.-gemma; $197 ; 250=$ orbitalis, Nort.

s.-nodus, $197 ; 253$.**

s.-ovin, $197 ; 251$.

Nematus fur, 197; 263.

hospes, $197 ; 261$.

inquilinus, 197; 260.

mendicus, 197 ; 261.

s.-desmodioides, $197 ; 257$.**

8.-pisum, 197; 258.**

s.·pomum, $197 ; 255$.*夫

Prístiphora grossulária, $140 ; 123 . * *$ sycophanta, $197 ; 263$.

\section{Cynipida.}

Acraspis q.-erinacei (Cynips), $41 ; 483$.

Amphibolips pruuus (Cynips) W.\& R., 518; $104 .^{* *}$

Ancistrophus, $821 ; 74$.

1.-pisum, $821 ; 74 . * *$

Andricus q.-flocci (Суnips), $41 ; 482, * *$

q.-podagræ (Cynips), $41 ; 491 .^{* 1}$

Biorhiza q. forticornis (Cynips), 41 ; 490.*

Ceroptres ensiger (Amblynotus), 41; $496^{*}=$ petiolicola, O. S.

inermis (A mblynotis), 41; 498.

Holcaspis namma (Cynips), 518; 102.**

Synergusalbipes (Syuophrus), $41 ; 496^{\star}=$ lana,

Fitch.

mendax, $41 ; 498$.

rhoditiformis, $41 ; 499^{*}=$ lignicola,

O.S.

Tribalia, $41 ; 470$.

batatorum, $41 ; 471$.
Ichneumonide.

A cænitns rnpinsnlensis, $385 ; 144$.

Bassus bicapillaris, 385 ; 88 .

ruficrus, 385 ; 86 .

semifasciatus, $385 ; 86$.

tripicticr11s, $385 ; 85$.

Catocentrus, $385 ; 98$.

Chorinæus cariniger (Polyrhabdus), 385; 98.

Crsptocentrus, $385 ; 156=$ Mesoleins, Holmg.

Cryptus albicaligatus; $385 ; 82$.

albisolcatus, $385 ; 80$.

atricollaris, 385 ; 72 . **

cinctipes, $385 ; 74$.

nigricalceatus, $385 ; 77$.

picticoxus, 385 ; 8 .

rhomboilalis, $385 ; 74$.

rufifrons, $385 ; 75$.

Cteniscus albilineatus, $385 ; 107$. ornatus (Exeuteron), 385; 105.

Echthrus annnlicoruis, 385; 159.

Ephialtes gigas $385 ; 110$. pusio, 385 ; 111. pygmæus, 385; 111.**

Exetastes illinoiensis (Leptobatus), $385 ; 148$. suareolens, 3 -5; 146

Exochiscus, $385 ; 96=$ Orthocentrus, Grav.

Exochus albiceps, $385 ; 96$. annulicrus, 385 ; 95 . atriceps, $385 ; 95$

Glypta alboscutellaris, 385; 127.

diversipes, 385 ; 125.

ruficornis, 385 ; 129.

rufiple uralis, $385 ; 127$.

Hemiletes finscatus, $380 ; 12=$ var. of nema tivorns, Walsh. nemativorus, 380 ; 11.

Joppidium, $385 ; 67$. ruficeps, $385 ; 70$.

Lampronota amphimilana, 385 ; 117. brevivontris, $385 ; 120$. imitatrix, $385 ; 121$. interpellata, $385 ; 118$. pictiventris, 385; 119.

Mesochorus vitreus, 6 ; 368.**

Orthocentrus pusillus (Exochiscus), 385 ; 97. stigmaticus, $385 ; 101$. trifasciatus, $385 ; 100$.

Pararbyssa, 385; $109=$ Rhyssa Grav.

Pezomachus minimus, 6 ; 368.**

Pimpla colebs, $385 ; 141$.

investigatrix, $385 ; 142$.

pictipes, 385 ; 135. vidua, 385 ; 140.

Polyrhabdus, 385 ; $98=$ Chorinæeus Holmgr. Polysphincta nigriceps, 385 ; 144. nigrita, 385 ; 144. pimploidos, 385 ; 144.

Tryphon atricoxus, 385; 104. Braconidee.

Apanteles militaris, $6 ; 369 .^{* *}$ Chalcididee.

Antigaster, 384 ; $368=$ Eupelmus, Dalm .

Decatoma dubia, $384 ; 300=$ var. of varians, Walsh. 
Chalcidida-Continued.

exerucians, $384 ; 300=$ var. of nigriceps, Walsh.

hyalipennis, $384 ; 300$.

nigriceps, $384 ; 300$.

nubilistigma, $381 ; 300$.

simplicistigma, $381 ; 300$.**

varians, $384 ; 300$.**

Enpelmus mirabilis (Antigaster), 384; 369.**

- Eurytoma abnormicornis, $384 ; 299$.

auriceps, $384 ; 2990^{+*}$

bicolor, $384 ; 298$.

diastrophi, 381; 299.

gigantea. $384 ; 300$.

globulicola, 384 ; $299=$ var of prunicola, Walsh.

prunicola, 384 ; 298 **

punctiventris, 384 ; 299.

\section{Chalcidide-Continned.}

seminatrix, $384 ; 299=$ var. of auri. ceps, Walsh.

Glyphe viridascens, 6 ; 370 .**

Haltichella perpulchra (Hockeria), 11 ; 258.

Hockeria, 11; $258=$ Haltichella, Spin.

Semiotellus chalcidephagus, $384 ; 369$ **

Smicra albifrons (Chaleis), 6 ; 369.**

Formicidos.

Formica aphidicola, $27 ; 310$.

Lasius latipes (Formica), 27 ; 311.

Pompilido.

Agenia subcorticalis, $375 ; 162$.

Ceropales rufiventris, $375 ; 163$.

Sphecidae.

Ammophila pictipennis, $375 ; 164 .^{\text {** }}$

Bembecido.

Megastizus brevipennis (Stizus), 375; 162.** 


\section{SYSTEMATIC INDEX OF THE NEW NAMES PROPOSED BY C. V. RILEY.}

[The types, without exception, are preserved in the collection of the National Maseum, Washington, D. C.]

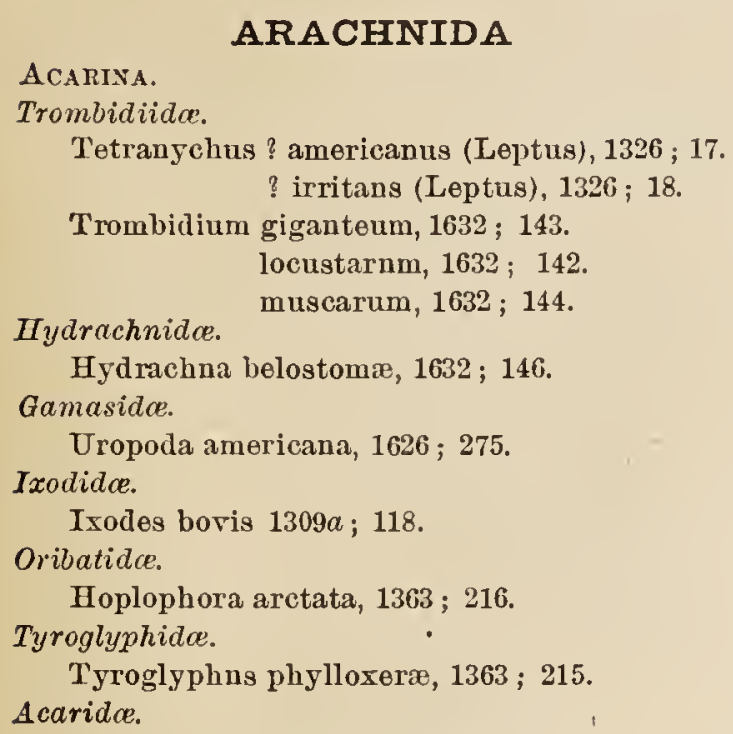

ACARINA.

Trombidiida.

Tetranychus? americanus (Leptus), $1326 ; 17$. ? irritans (Leptus), $1326 ; 18$.

Trombidium giganteum, $1632 ; 143$. locustarnm, $1632 ; 142$.

Hydrachnidoe. muscarum, $1632 ; 144$

Hydrachna belostomæ, $1632 ; 146$.

Gamasida.

Uropoda americana, $1626 ; 275$. Ixodidoe.

Ixodes bovis $1309 a ; 118$.

Oribatidce.

Hoplophora arctata, $1363 ; 216$.

Tyroglyphida.

Tyroglyphns phylloxeræ, $1363 ; 215$.

Acaridoe.

Acarus aceris-crumena, $1265 ; 339$.

\section{HEXAPODA.}

\section{ORTHOPtera.}

\section{Acridiidae.}

Caloptenns atlanis, $1423 ; 169$.

Dendrotettix, $2410 ; 80$.

Gryllido. quércus, $2410 ; 86$.

Ecanthus latipennis, 2026 ; 61.

\section{HEMIPTERA.}

Coccidce.

Kermes galliformis, 1972 ; 482.

Mytilaspis pomicorticis, 1329 ; 96 . = pomorum, Bonclé.

Aphidido.

Lachnus platanicola, 2138 ; 198.

Pemphigus acerifolii, $1678 ; 16$. fraxinıfolii, $1678 ; 17$. populi-monilis, $1678 ; 13$. populi-ramulorum, $1678 ; 16$. populi-transversus, $1678 ; 15$.

Phylloxera caryæ-avellana, 1901; 230. caryæ-fallax, 1423 ; 118. caryæ-gummosa, 1423 ; 118. caryæ-ren, $1423 ; 118$. caryæ-scissa, $1901 ; 230$.

Schizoneura americana, 1678 ; 4. ulmi (Eriosoma), 1059; 124.

\section{Psyllidoe.}

Blastophysa, 2272; 75.

- ccltidis-gemma, $2272 ; 74$.

- Calophya nigriponnis, 2272; 69.

Ceropsylla, 2272; 76. sideroxyli, $2272 ; 76$.

Pachypsylla, 2208; 157 : 2272; 71. celtidis-mamma, 2208 ; 157 . 2272 . 73.

Rhinopsylla, 2272; 78. schwarzii, $2272 ; 78$.

Jassida.

Diedrocephala flaviceps, $1767 ; 78$.

Lygoida.

Nysius destructor, $1329 ; 113$. = angustatus, Uhler.

Coleoptera.

Scolytida.

Scolytus caryæe, $938 ; 69 .=4$-spinosus, SaJ. Curculionidce.

Ampeloglypter vitis (Madarus), 1059; 132. = sesostris, Lec.

Podapion, $2231 ; 62$

$$
\text { gallicola, } 2231 ; 62 \text {. }
$$

Tyloderma fragariæ (Analcis), 1301; 44. Meloida.

Horniá, 1601. minutipennis, 1601 .

Bruchide.

Bruchus fabæ, 1301; 55.

Diptera.

Oscinida.

Oscinis brassicx, $2291 ; 322$.

Anthomyida.

Anthomyia var. calopteni, 1557. = angustifrons, Meig. zeas, $1059 ; 155$.

Sarcophagida.

Sarcophaga sarracenia, 1390 ; 238.

Tachinidae.

Exorista cecropix, 1112 ; 101. doryphorw (Lydella), 1059 ; 111. flavicauda, 1127 ; 51.

Masicera archippivora, 1301; 150.

Tachina aletiæ, $1712 ; 162$. anonyma, 1311; 129. 
A silidoe.

Proctacanthus missouriensis (Asilus), 1127; $122=$ milberti, Macq.

\section{Simulidee.}

Simulium mcridionale, 2394 ; 513. pecuarum, 2394 ; 512.

Mycetophilide piscicidium, $1174 ; 228$

Mycetophila persica, 963 ; 397.

Cecidomyidce.

Cecidomyia cupressi-ananassa, 1180; 244.

Diplosis pyrivora, 2392.

\section{LEPIDOPTERA.}

Pterophoridoe.

Platyptilus carduidactylus (Pterophorus), $1059 ; 180$.

Tineida.

Blastobasis iceryæella, 2394 ; 485.

Coleophora malivorella, 1721 ; 254.

Gelechia gallasolidaginis, $1059 ; 175$.

Holocera glandulella, 1310 ; 18 .

Prodoxus, $1830 ; 155$.

ænescens, 2000 ; 636.

cinereus, $2000 ; 636$.

decipiens, $1830 ; 155$.

intermedius, 2000 ; 635 .

marginatus, $2000 ; 635$.

Pronuba, $1329 ; 150$ : $1336 ; 55$.

maculata, $2000 ; 633$.

juccasella, $1329 ; 151: 1336 ; 56$.

Tortricidae.

Conchylis erigeronana, 1968; 316.

œnotherana, $1968 ; 316$.

Eccopsis ferrugineana (Exartema), 1968; 317. monetiferana (Exartema), 1968; 317.

Grapholitha gallæ-saliciana, 1968; 320. ninana, $2176 ; 661$. olivaceana, $1968 ; 320$.

Mellisopus, 1969 ; 322. aurichalceana 1969 ; 323.

Pædisca celtisana, 1968; 319 giganteana, $1968 ; 318$.

Penthina fullerea.* $=$ hebesana, Walk.

Phoxopteris cornifoliana, 1968; 324. murtfeldtiana, 1968 ; 323.

Proteoteras, 1968 ; 321. æsculana, 1968 ; 321.

Semasia helianthana, 1968 ; 319.

Steganopijcha claypoleana (Sericoris), 2114; 914.

Teras cinderella (Tortrix), $1311 ; 47$.

Pyralida.

Acrobasis nebulella (Phycita), 1311; 42. $=$ var. of indiginella Zeller. vaccinii, 2291.

Chilo oryzællus, 2119 ; 133.

Clydonopteron, 1929 ; 287.

tecomæ, $1929 ; 288$.

Pempelia hammondi, $1311 ; 46$.

Geometridoe.

Paleacrita, 1438 ; 278.

Synchlora rubivora (Aplodes). 1059; 140.

\section{Noctuidce.}

Acronyeta betulæ, $2280 ; 2$. populi, $1127 ; 120$.

Agrotis cochranii, 964; 414. morrisoniana, 1409 ; 286 . scandens, $1059 ; 78$.

Anomis texana, $2343 ; 350$.

Exyra ridingsii (Xanthoptera), 1411; 240.

Laphygma autumnalis (Prodenia), 1301; 116. fulvosa (Prodenia), 1301; 117. obscura (Prodenia), $1301 ; 117$.

Lithophane cinerea (Xylina), $1301 ; 135$.

Plusia brassicæ, 1127 ; 111.

Pyrophila conspersa (Amphipyra), 1301; 74.

Bombycida.

Cerura multiscripta, $1411 ; 241$.

Nola sorghiella, $2119 ; 187$.

Aigeriadoe.

Bembecia rubi (Egeria), 1363; 113. = marginata, Harris.

HYMENOPTERA.

Oynipida.

Cynips q.-glandulus, $1606 ; 578$. q.-mellaria, $1942 ; 298$.

Didactyum, 1749; 52 = Hexaplasta, Forst.

Hexaplasta zigzag (Didictyum), $1749 ; 52$.

Ichneumonidae.

Hemiteles cressonii, $1059 ; 177$.

thyridoptery gis, $1059 ; 150$.

Ichneumon obsoletus, 1570 ; 55. = rar. of brevipennis, Cress.

Limneria lophyri, $1570 ; 32$.

Thersiloch us conotracholi (Porizon), 1301; 28. Braconidce.

Apanteles acrony்ctæ, 1960 ; 312. aletiæ, $1960 ; 306$. cacoecia, $1960 ; 305$.

cassianus, 1960 ; 307 .

flaviconchæ, 1960 ; 308.

hemilencx, 1960 ; 309.

hyphantrix, $2394 ; 533$.

limenitidis (Microgaster), 1301; 158.

megathymi, $1960 ; 304$.

paleacritæ, 1960 ; 313.

pieridivora, $2097 ; 679$. = var. of congregatus, Say.

politus, $1960 ; 307$.

rufocoxalis, $1960 ; 310$.

scitulus, 1960 ; 310.

smerinthi, $1960 ; 311$.

theclæ, $1960 ; 308$.

Bracon charus, 1423 ; 75 .

Exothecus prodoxi, $1831 ; 156$.

Meteorus hyphantriæ, 2394 ; 532.

Microgaster gelechiæ, 1059; 178.

Microplitis ceratominæe, $1960 ; 303$. gortynæ, 1960 ; 304.

Perilitus indagator, $1311 ; 43$.

Sigalphus rufus, $1301 ; 27 .=$ var. of curcu. lionis, Fitch.

Spathins trifasciatus, $1329 ; 106$.

*Describcd and figured in A. S. Fuller's "Injurious insects." <Tilton's Journ. of Hortic. and Florist's Companion, October, 1868, v. 4, pp. 207-209. 
Chalcididce.

Cirrospilus flavicinctus. ${ }^{1}$

Eurytoma bolteri, $1059 ; 177$. = var. of dias. trophi, Waish.

Isosoma grande, 2285; $111.2291 ; 358$. tritici, $2060 ; 24 \%$.

Merisus subapterus, 2332 ; 416.

Pentarthron ${ }^{2}=$ Trichogramma.

Pleurotropis phyllotretæ, 2291; 308.

Spilochalcis ma:izo (Chalcis), 1112; 101.

Stictonotus isosomatis, $2119 ; 186$.
Chalcidida-Continued.

Tetrastichus esurus (Cirrospilus), $1712 ; 162$. productus, $\dot{3} 32 ; 419$.

Trichogramma minutum, 1301; $158.2026 ; 68$. pretiosa, $1712 ; 161$.

Proctotrupida.

Caloptenobia, $1643 ; 306=$ Scelio, Latr.

Scelio ovivora (Caloptenobia), 1643; 3c6 $=$ famelicus, Say.

Telenomus bifidus, 2378 ; 48. 2394 ; 531.

\footnotetext{
${ }^{1}$ Describer and figured in Lintner's First Report N. Y. State Entomologist, p. 159.

${ }^{2}$ Proposed (Record of Amer. Ent., 1871, p. 8) for Trichogramma minutum. Pentarthron has, however, been used for a genns of beetles.
} 



\section{INDEX.}

Abbot Sphinx, 1127.

\author{
larva, 1248, 1277. \\ Parasites on its larva, 1277.
}

Abia caprifolia, 2360.

Abuormal cocoon, 1797 .

Abroad. Colorado potato-beetle, 1364.

Abutilon. Aletia feeding on, 2343.

Acacia filiaria. Galls on, 2176.

ACACIA. INSECTS AFFECTING.

Dorthesia characias, 1730.

Grapholitha ninana, 2176.

Lytta cinerea $=$ Macrobasis unicolor.

Macrobasis unicolor, 1290.

Acacias. Large white scalo on, 1730.

Acarleny of Science. Address of presilont St.

Louis, 1564, 16:9.

Acænitus rupinsulensis $n . s p ., 385$.

A canthia lectularia, 497, 1502, 1741.

Acaridons gall on Cratregus, 376 .

Acarina, 412, 1444, 1639, 1710, 1739, 1992.

Acarus aceris-crumona $n . s p ., 1265$.

pruni-crumena n. $s p ., 373$.

salicis-ænigma, 46 .

salicis-semen, 46 .

scabiei, 497.

Accusation. Unjust, 1537.

Acer dasycarpum. Scale on, 1575.

sp. Supposed tineid larva on leaf of fossil 2084.

Achatodes zer, 311.

Achemon Sphinx, 1127.

Acheta abbreviatus = Gryllus abbreviatus.

A chetida $=$ Gryllida .

Achorutes nivicola, 608.

Acoloithns falsarius, 124.

Acorn cups. New oak gall on, 1606. gall, $19 \pm 4$. moth, 1310, 1311.

Acraspis q.-erinacei, 41.

Acrididse, 391, 431, 433, 929, 1446, 1452, i548, 1645, $1947,1959,2002,2118,2267,2311,2331$, 2363.

Dimorphism in, 1889.

Effects of winter on tho eggs of, 1550 .

Egg parasitos of, 2355 .

Acridium amoricanum, 1413, 1549, 1570 .

eaten out by ants, 1413.

obscurnm, 2119.

perigrinum, 1959 ,
Acrobasis oonsociella, 1311.

hammondi $=$ Pempelia hammondi.

indiginella, 2, 341, 373, 511, 574, 810, 949, $975,998,1012,1069,1151,1232,1311$, $1580,1962$.

juglandis, 1311.

nebulella $n . v ., 1311=\mathbf{A}$. indiginella.

nebulo $=\mathrm{A}$. indiginolla.

vaccinii $n . s p ., 2291,2349$

Acroneura rufinsulonsis $n . s p ., 24$.

Acronfeta acericola $=\mathrm{A}$. americana. americana, 571, 841

betulio n.sp., 2280 .

lepusculina, 1127.

oblinita, 1208, 1276, 1301.

populi $n . s p ., 1127$.

xylinoides, 1329.

Acrosoma spinea, 813. stellata, 1869

Acrydii, 1959, 2267.

Actias luna, 776, 1311.

selene, 1311.

Ad interim committeos, 394.

Adalia bipunctata, 2452 .

Address at Atlanta Cotton Convention, 2038.

on entomology, 1454.

St. Louis Academy Science. President's, $1564,1629$.

Washington Entomological Society. President's, 2355.

Adelops, 2033.

Adimonia rufosanguinea, 156.

Ecidium borberidis, 1605 .

Egeria acerni, 743, 1063, 1360, 1363.

albicornis, 2410.

candatum = Alcatho canlatum.

oxitiosa = Sannina exitiosa.

hospes, 197.

impropria, 2385, 2410.

polistiformis = Sciapteron polistiformis. 1 yri, 2410.

rubi $n . s p ., 1363=$ Bembccia marginata

sp., 30 ?.

syringa $=$ Podosesia syringæ.

tipuliformis, 55, 340, 481, 974, 1642, 2238.

Egeriidæ, 302, 576, 2341.

lifoluabits, 2410 .

Egerian maple borer. A now, 1360.

Xogialo cofaqui = Megathymus yucco. 
Eschna constricta, 759.

Agassiz, L. Criticism of entomological state. ments, 44.

Agave. New use of American, 1498.

Agenia architecta, 375 .

bombycina, 375,543 .

cupida, 375 .

subcorticalis $n . s p ., 375$.

Agnomia anilis, 785 .

Agonoderus comma $=$ A. pallipes . pallipes, 3, 1825, 2317.

Agraulis,vanillæ, 2410 .

Agricnltural advancement in the United States, 1750.

editorial excursion, 1349.

Agriculture and its advancement. Entomology and its relation to, 1329.

American writers on insects in relation to, 2238.

Entomological work at the Depart. ment of, 1892

Insects in relation to, 2238 .

Legislation in regard to insects injurious to, 1468.

New insects injurious to, 2055.

Agrilus ruficollis, 821, 1124, 1771.

Agrion binotatum $n .8 p ., 24$.

dentiferarum $n .8 p ., 39$.

hageni $n . s p ., 39$.

Agrotidæ, 3, 868, 901, 964, 1504, 1522, 2310.

Agrotis, 2238.

annexa, 2291.

clandestina, $901,2291$.

cochranii $n . s p ., 964=$ A. messoria, Harris. Description of a new species of, 1409 . devastatrix $=$ Hadena devastatrix.

fennica, 2355.

herilis, 964, 1059.

inermis $=$ A. saucia.

lycarum, 2156.

malefida, 2291, 2322.

messoria, 901, 964, 1059, 1873, 2156, 2291 , $2331,2363$.

Harr. vs. Agrotis scandens Riley, 2156.

morrisoniana n. $s p ., 1409$.

repentis $=\mathbf{A}$. cochranii.

saucia, 607, 1059, 1095, 1775, 1.826, 1941, 2291.

scandens $n . s p ., 1059,1408,2156$.

Riley vs. Agrotis messoria Harr., 2156.

sp., 281.

subgothica, 964, 1059.

telifera $=\mathbf{A}$. ypsilon.

tricusa, 964, 2324.

ypsilon, 626, 658, 964, 1059, 1504, 2291.

AILANTHUS. INSECTS AFFECTING, 1343.

Attacus cynthia, 899, 1179, 1343, 1460, 1718.

Eta compta $=$ E. punctella. punctella, 1059, 1343.

Samia cythia $=$ Attacus cynthia.

Ailanthus silk-worm, 899, 1311, 1718.

in Missouri, 1460.

naturalized, 1179.

Air-holes not needed in sending insects, 655 .
Alabama. May beetles swarming in, 1812.

Moths caught in, 1774.

Spread of Picris rapæ into, 1720.

Alaria florida $=$ Rhodophora florida.

Alcathos caudatum, 481.

Alcohol. Bugs in, 605.

Aleochara anthomyia $=\mathrm{A}$. nitida. nitida, 2353.

Aleocharini, 1729.

Aletia argillacea $=$ A. $x y$ ylina.

Aletia xylina $v \delta ., 2339$.

Migrations and hibernation of, 1689.

chrysalides. Not, 1826.

Chrysalides supposed to be those of, 1775 .

Moths mistaken for, 1976.

xylina, 328, 636, 1127, 1338, 1353, 1363, 1369, $1649,1657,1689,1702,1712,1719,1721,1722$, $1728,1736,1749,1758,1769,1814,1826,1831$, $1845,1852,1882,1888,1903,1914,1932,1953$, $1976,1997,2038,2064,2069,2102,2119,2130$, $2141,2155,2164,2295,2343$.

Aletia xylina. (See also Cotton-worm.)

Anatomy, 2343.

Annual generations, 1736 .

Bibliography, 2343.

Bulletiu No. 3,U.S. Ent.Com., 1763.

Characters, 1736, 2343.

Classification, 2343.

Destruction of the moth, 1763.

Destructiveness, 1763, 2343.

Devices for the destruction of, 2343.

Flight (powers of), 1763.

Habits, 2343.

Hibernation, 1763.

History of literature of, 2343.

Insects liable to be mistaken for, 2343.

Invertebrate enemies, 1763.

- Machinery for the destrnction of, 2343.

Mechanical means of killing, 1763.

Meteorological influence upon, 2343.

Migrations, 1763.

Natural enemies, 1763, 2343.

Natural history, 2343.

Nomenclature, 2343.

in other countries, 2343.

Past history in the United States, 2343.

Poisoning the worm, 1763.

Preventive measures, 1763, 2343.

Remedies, 1763, 2343.

Stages, 1763.

Terrestrial influences, 2343.

in the United States. Hibernation of, 2141.

Vertebrate enemies of, 1763.

$v s$. Aletia argillacea, 2339.

Wet weather (effects of), 1763.

Aleurodes, 221

on Oxalis, 1791.

Allorhina nitida, 54, 718. 
Alpine flowers. Fertilizers of, 1838.

Alwood, W. B. Report on Ohio insects, 2382.

Tests with insecticides on garden insects, 2382.

Alypia octomaculata, 3\$3, 1059,1127, 1130, 1208, 1363.

Amara, 1643.

Ambiguous Fippodamia, 2119.

Amblycorspha oblongifolia, 569, 1060, 1157, 1329, 1363.

Amblynotas ensiger $n . s p ., 41=$ Ceroptres petiolicola.

inermis $n . s p ., 41=$ Ceroptres inermis.

Amelanchier. Lixus parvus on, 2404.

America. Problem of the hop-plant louse in Eu. rope and, 2400.

American Agave. New use of, 1498.

A. A. S. Entomology at the 1880 meet. ing of, 1893.

Permanent subsection of entomolog $5,2027$.

bean Bruchus, 1301.

Cimbex, 2291, 2418.

Entomological Society, 621.

Entomologist, 1309.

Salutatory, 386.

insects. Imported and native, 1115, 1127. lackey moth, 1301.

Meromyza, 1058, 1059, 2291, 2394.

Procris, 1127.

Staphylinidre wanted, 1786 .

tent caterpillar. Eggs of the, 1329.

Ames, Iowa, Osborn, H. Experiments at, 2344.

$\Delta$ mmophila pictipennis $n . s p ., 375,543$.

Amorbia. Pine, 2363.

Amorpha fruticosa. Walshia amorphella on, 1127, 2356.

Ampeloglypter ater, 821 .

$$
\text { sesostris, } 821,1059 .
$$

vitis $=\mathbf{A}$. sesostris.

Ampelophaga myron, 837, 1056, 1086, 1127, 1247, 1290,1960 .

Ampelopsis. Swellings in roots of, 1428 .

Amphibolips aciculata $=$ A. $q$,-spongifica.

q.-inanis, $45,518,1448$.

q.-prunus, 518, 1606 .

q.-spongifica, $41,45,518,1448$.

Amphicerus, 1747.

bicaudatus, $2,55,249,485,517,633,839$, $893,1163,1185,1311,1329,1747,1776$, 1820.

Amphipyra conspersan. $8 p ., 1301=$ Py rophila con spersa.

pyramidea = Pyıophila pyramidea.

pyramidoides $=$ Pyrophila pyramidoides.

Hibernation of, 1471.

Amphiscepa bivittata, 2116.

Amputating insects, 1556.

Anabrus, 2267.

purpurascens, 1959.

simplex, 1959

Analcis fragarix $n .8 p ., 1301=$ Tyloderma fraga riæ.

Anametis grisea, 2117.

Anaphora, 2536.
Anarsia lineatella, 2235.

Anasa tristis, 409, 825, 867, 1858, 1948.

Anatis 15-punctata, 959, 127 $₫, 1450,1672$.

Ani2x junius, 1851, 2455.

Anchylopera fragarix n. $s p ., 499=$ Phoxopteris fragarix.

Ancistrophus $n . g ., 821$

$$
\text { 1.-pisum n. sp., } 821 \text {. }
$$

Anderson, E.H. Cotton-worm in south Texas in 1883, 2253.

Andrena, 800.

Report on cotton insects, 2343.

Andricus q. -californica, 1967.

q. flocei, 41.

q.-operatola, 1352.

q.-operator, 1352.

q. podagro, 41, 45.

q.-punctata, 45, 1822.

seminator, 739, 821, 1037

Angoumois grain-moth, 2291 .

Angular winged katydid, 1363.

Eggs of, 1518.

Animal kingdom, 393.

dniseed and grain-weevil, 1742.

Anisodactylus baltimoreusis, 627 . confusus, 2042.

Anisoplia austriaca, 1935.

Anisopteryx, 91, 96, 27t, 717, 902, 910, 1391 . mscularia, 1604 .

Differences between Ani. sopteryx pometaria and, 1604.

pometaria, 1127, 1363, 1423, 1438, 1482, $1539,1540,160 \pm, 2149,2238,2267$.

Variation in imagos, 1540.

Venation of wings, 1540.

vernata $=$ Paleacrita vernata.

Anisota $=$ Dryocampa.

rubicunda $=$ Dryocampa rubicunda.

Anomala lucicola, 113.

Varying, 2291.

Anomis erosa, 2343 .

exacta, 1651, 2343.

texana $2.8 p ., 2343$.

urena, 2119.

$\mathrm{xylin} a=$ Aletia $x y l i n a$.

Anonymous Tachina.fly, 1423, 1625 .

A nophthalmus, 2033.

Ant-hill. Hemispherical larva at bottom of, 1789.

Antheræa pernyi, 1311.

yama-mai, 1311.

as a silk-producer, 1346.

Anthicus, 2105.

Anthocoris insidiosus $=$ Triphleps insidiosus.

Anthomyia, 1643.

angustifrons, 1541, 1557.

brassicæ, 2291.

Cabbage, 2291.

calopteni $n . s p ., 1541,1557=$ angusti

frons, Meig.

ceparum, 225.

Egg parasite, 1570, 1625, 1643

zeas $n . s p ., 657,1059,1065$.

Anthomyida. North American, 1966.

Anthonomus cratrogi $n .8 \% ., 197,376,1244$.

musculus, 2322, 2331, 2363 . 
Anthonomns prunicida $n . \quad s p ., 33=$ Coccotorns scutellaris.

quadrigibbus, $42,254,1088,1173,1176$, $1228,1301,1358,2232$.

suturalis, 2363.

sycophanta n. sp., 197, 821.

tessellata $n . s p ., 197$.

Anthophora abrupta, 372, 1601, 1651.

sponsa $=\Lambda$. abrupta.

Anthreni, 483.

Anthrenus musæorum, 492, 572.

scrophulariæ, 1659, 1663, 1699, 1752. varius, 5772.

Antigaster n.g., $384=$ Eupelmus. mirabilis n. $s p ., 384=$ Enpelmus mira bilis.

vs. Enpelmus, 1932, 1978.

Antiopa butterfly, 1234.

Autistrophus $n$. g., 821, 1131. lygodesmiæ-pisum n. sp., 821.

Ants, 1278, 1736, 2418.

Acridium eaten out by, 1413.

and aphides, 520, 2300.

4 in Arizona. Leaf-stripping, 2532.

gardens. Destroying black, 438.

horticulture. Jtilization of, 2089, 2137.

injurious in Arizona, 1987.

nests in gardens, 496.

Red, 2309.

A panteles acronyctæn. sp., 1960.

aletiæ $n . s p ., 1960,2343$.

сасœcia n. sp., 1960.

cassianus $n . s p ., 1960$.

congregatus, 1247.

flaviconchæ n. v., 1960 .

glomeratus, 2291.

hemilencæ n. $s p ., 2378,2394$.

limenitidis n. sp., 1301.

megathymi $n . s p ., 1960$.

militaris n. $s p ., 6,1$, $, 1059,1357,1442$, 1670 .

- paleacritro $n .8 p ., 1960$.

pieridivora $n . v ., 2097$.

politus n. sp., 1960.

rufocoxalis $n . v ., 1960$.

scitulus n. v., 1960.

smerinthi $n . s p ., 1960$.

theclæ n. sp., 1960 .

A patura alicia, 1363, 1977.

celtis, 1356, 1363.

clyton, 1356, 1363.

herse $=$ A. clyton.

Ijcaon $=\mathrm{A}$. celtis.

Apnelinus mytilaspis, 1329.

Aphid. Bitten by an, 2205.

Aphides, 952, 1736.

Ants and, 520, 2300.

Aphididæ, 58, 198, 265, 518, 5ะ0, 1883, 2017, 2072, 2119, $2230,2359,2407$.

Means against, 80, 102, 198, 508, 644, 678, $1148,1184$.

of the United States. Gencra of the, 27. Notcs on the, 1678.

A phis, Apple borer and root, 1038, grenp $=$ Neotarophora granaria
Aphis, Bad work of the grain, 1638.

bella $n . s p ., 27$.

brassica, 1365, 2291.

carduella $n .8 p ., 27$.

cerasi $=$ Myzus cerasi.

Cherry, 960.

Grain, 2394.

Grape-vine, 170.

Hop, 1001, 2291, 2394, 2418.

maidis, $23,27$.

mali, 59, 198, 201, 270, 291, 325, 413, 507, 539,

$550,579,591,883,952,996,1056,1139,1429$, 1899.

prunifoliæ, 678 .

quercifoliæ $n .8 p . .27$.

ribis $=$ Myzus ribis.

Root, 990, 1038.

rudbeckix $=$ Nectarophora rudbeckiæ.

solani, 1679.

vitis, $27,102,170$.

v8. rust. Grain, 1806.

Aphodius inquinatus, 1445.

Aphorista vittata, 2406.

Aphrophora, 93.

quadıangularis, 691 .

Apiaries. Floating, 1785.

Apiculture. McLain, N. W. Experiments in, 2394.

Report on expert. ments in, 2363, 2418.

Apidx, 2098.

Apion languinosum n.sp., $197=$ A. walshii.

Apioninze. Gall-making genus of, 2231.

Apis mellifica, 13, 372, 411, 782, 833, 1455, 1774.

Aplodes, 40.

mimosaria, 40.

rubivora $n . s p ., 1059=$ Synchlora rubj. vora.

venustus $=\mathrm{A}$. mimosaria.

Apple bark-lice on pear's, 973 . louse, 1552.

Scurf., 2305.

borer and root Aphis, 1038. remedy, 1023.

borers, 870, 1583 .

Coleophora, 1721.

Curculio, 1176, 1301, 1441, 2238.

go under ground to transform

Does the, 1228.

gall. Grape-vine, 1329, 1898.

growing on a grape-vine, $403,436$.

Apple. Ixsects AFFECTING.

Acrobasis hammond $i=$ Pempelia hammondi.

Amphicerus bicaudatus, 249, 485, 517, 633, 839 , $893,1163,1311,1329,1747,1776,1820$.

Anametis grisea, 2117.

Anthonomus cratægi, 1244. quadrigibbụs, 42, 1088, 1176, 1228 , $1301,2238$.

Aphis mali, 201, 270, 335, 507, 539, 550, 579, 591. $883,996,1139,1429$.

Arctia virginica $=$ Spilosoma virginica.

Aspidiotus conchiformis $=$ Mytilaspis pomo. rum.

harrisii $=$ Chionaspis furfurus. rapax, 2235.

Attacus cecropia, 139, 1028, 1070, 1215, 
APPle. Insecta AFFECTING-Continued.

Bostrichus bicaudatus $=$ Amphicerus bicaudatus.

Brochy mena annulata, 684 .

Bucculatrix pomifoliella, 92, 1311, 1733.

Buprestis fermorata $=$ Chrysobothris femorata.

Capsus oblinoatus $=$ Lygus pratensis.

Carpocapsa pomonella, 330, 373, 467, 523, 565, $769,1010,1022,1059,1311,1320,1334,1373,1398$, $1666,1677,1682,1721,2037$.

Caterpillars, 1054.

Catydid, 29.

Cecidornyia sp., 963.

Ceresa bubalus, 2195.

Chrotochilus pomonellus, 874 .

Chilocorus bivulnerus, 731.

Chionaspis furfuras, $69,345,373,579,951,1061$, $1152,2305$.

Chloroneura malefica = Empoasca viridescens. maligna $=$ Empoasca obtusa.

Chrysobothris femorata, 20,379, 537, 555, 634, $870,1059,1423,1475,1513,1640,2238,2267$.

Clisiocampa americana, 66, 77, 336, 1301, 2238.

Coccus harrisii $=$ Chionaspis furfurns.

Colodasys unicornis, 749 .

Coleophora malivorella, 1721.

Conotrachelus nenuphar, 1214.

Corycia vestaliata, 744 .

Cybocephalus californicus, 2079.

Datana ministra, 467, 922, 2222.

Diaspis harrisii $=$ Chionaspis furfurus.

Dipteron, 548.

Elaphidion parallelum $=$ E. villosum. villosum, 839

Empoasca malefica $=$ E. viridescens. maligna = E. obtusa. obtusa, 22. viridescens, 22, 30 .

Epicaras imbricatus, 296.

Eriosoma psri=Schizoneura lanigera.

Euphoria melancholica, 842.

Euryomia melancholica $=$ Euphoria melan. cholica.

Galls, 552.

Gastropachua americana, 812. velleda $=$ Tolvpe velleda.

Haltica punctipennis, 2383.

Helops micans, 963.

Homipteron, 243.

Hyphantria cunea, 112, 2238. textor $=\mathrm{H}$. cunea.

Ithycerus noveboracensis, 869, 1033, 1085, 1188. Iulng marginatus = Spirobolus marginatus.

Ixodes unipunctata, 1133.

Lagoa opercularis, 145,796 .

Larva, 758, 1054.

Lepidopteron, 243, 602.

Limacodes pithecium $=$ Phobetron pithecium. sp., 847 .

Limenitis ursula, 145.

Lygua pratensis, 2.

Lytta cinerea $=$ Macrobasis unicolor.

Macrobasis unicolor, 38 .

Macrodactylus subspinosus, 748.

Minings, 532.

Mycetophila persicm, 963.
APPLE. INsECTS AFFECTLNG-Continued.

Mytilaspis pomicorticis = M. pomorum.

pomorum, 69, 201, 345, 373, 423, 565, $951,973,98: 2,1059,1061,1329,1552$, $1772,2238$.

Notodonta concinna $=$ Edemasia concinna. unicornis = Cœlodasys unicornis.

Oberea sp., 1850.

Ecanthus niveus, 1691.

CEdemasia concinna, 922.

Orgyia leucostigma, 1000, 1151, 2238.

Papilio glaucus, 1048. tarnus, 1048.

Pempolia hammondi, 810 .

Pemphigus pyri = Schizoneura lanigera.

Phobetron pithecium, 127\%.

Phoxopteris nubeculana, 1721.

Phycis indiginella, 511, 574, 810, 949, 975, 998, $1069,1151$.

Phycita nebulo = Phycis indiginella.

Polycaon confertus, 2103.

P'rionus laticollis, 2287.

Psenocerus supernotatus, 1458.

Psocus venosus, 1263, 1526.

Reduvius raptatorius = Sinea diadema.

Saperda bivittata $=S$. candida.

calcarata, 963.

candida, 20, 67, 379, 421, 870,962, 1023, $1038,1059,1213,1332,1441,1513,1608$, $1630,2238,2266$.

Schizoneura lanigera, $373,467,495,963,997,1038$, $1059,1187$.

Sciara mali, 211.

Sinea diadema, 638, 731 .

Solenobia, 38.

Spilonota oculana = Tmetocera ocollana.

Spilosoma virginica, 296.

Spirobolus marginatus, 963.

Teras cinderella, 1311. malivoraua, 1311.

Tettigonia sp., 951.

Tineid, 77.

Tmetocera ocellana, 747.

Tolypo velleda, 972 .

Tortricid, 847.

Tremex columba, 1126.

Trypeta pomonella, 177, 373, 1320, 1553, 2119, 2238.

Urocerid, 893.

Xyluborus obesus, 1583.

Apple. Lappet caterpillars on the, 972.

Large green caterpillars on the, 1076.

leaf Bucculatrix, 1311.

crumpler, 574, 949, 975, 998.

mistaken for Curculio, 1069.

folder. Tho lesser, 1311.

sewer. Chapin's, 1721.

skeletonizer, 1311, 1322.

tyer. I'he green, 1311.

worm, 1322.

Small, 747.

maggot, 1553, 2119, 2238.

fly, 373,1320 .

and mountain ash. Plant-louse eggs on, 579. 
A pple. Oak, 1448.

Oyster-shell bark-Jouse of the, 1329, 2238. and peach borers, 1475,1513 .

pear. Two new foes of the, 22 . pest. New, 2383.

Pigeon Tremex in, 1126.

plant-louse, 883 .

Plnm Curculio breeds in, 1214.

root-blight, 997.

borer, 2287.

plant-louse, $373,495,1059$.

scions. Swellings on, 548 .

Small reddish snout-beetle in, 1244.

snout-beetle or four-humped Curcnlio,

1088.

treo bark-lice, 345, 1059.

Native, 1152.

louse, 255.

borer, 1332, 1640.

Flat-headed, 1059, 1423, 2238, 2267.

in horse chestnut. Flat. hcaded, 1316.

Insect foes of the, 421.

New facts about the roundheaded, 1630.

Oviposition of the roundheaded, 2266.

Round-headed, 1059, 1608, 2238.

Variations in the two-striped 1213.

borers, 20, 67, 379, 962, 1059.

bugs, 685 .

on south side of trees, 634 .

caterpillar. Unicorn, 749 .

caterpillars, 66, 874, 922, 1054.

cocoons, 139.

Egg-masses and cocoons on, 1000 .

Insect focs of the, 467 .

insects, $77,145,201,276,296,514,731$ 1056, 1151, 1733.

Lappet caterpillar on, 812.

Large moth 011, 1028.

worm on, 1048

leaf crumpler, $574,1311$.

plant lice, 270, 335, 591, 996, 1429 .

in Oregon, 1899

Scab in apple vs., 1139. louse, 1127.

again. Eggs of, 550 .

Eggs of the, 507,539 .

roots caused by root-lice. Knots in 1187.

Insects affecting, 963 .

scales, 69 .

Tent caterpillars of the, 336,1301 , $2238,2291$.

tineid, 92.

web-caterpillar, 112.

worms, 511, 744, 810.

trees. Bark lice on, 423 .

Eggs on, 638 .

Injured, 537.

Insccts clustered on, 1263.

Native bark-lice on, 1061.
Apple treos. New York woevil on, 1085.

Scarred, 951.

Secd ticks under bark of, 1133.

South. Muscle-shaped bark louso on, 1774 .

twig. Borer in, 839.

borer's, $249,485,517,633,1163,1311$, $1329,1747,1776,1820$.

Flat-headed, 555 .

Small borer in, 1458.

twigs. Catydid eggs on, 29.

Eggs on grape canes and, 1323.

Larva boring a long the axis of, 1850 .

Small galls and minings in, 552 .

v8. apple-tree plant lice. Scab in, 1139.

Woolly, slug-like worm on, 796 .

. worm, 211, 330, 376, 1022, 1059, 1666.

in, 177.

natural histor 5 , remedies, 1373.

Notes on, 1682, 1721.

trap. Thomas Wier's, 1312.

worms, 523, 1010.

by machinery. Killing, 769 .

Severe cold and hiberuating, 769.

Apples and codling-moth. Michigan, 1677.

Melancholy chafer in, 842 .

Rose bug on, 748 .

Appliances. Remedies and, 2375.

Applied entomology. General truths in, 2291, 2292.

Apply soap, 1367.

Appropriations for United States Entomological

Commission, 1843.

Aquatic larvæ, 1851.

Sphinx larva, 1951.

A rachnida, 1955

Characters, 59.

Poisonous, 2399.

Aragnomus grisens, 2428.

Aramigus fulleri, 1708, 1721, 1740, 2117.

Habits of, 1708.

Archippus butterfy, 1301.

$$
\text { Pupa of, } 1235 .
$$

Architects. Galls and their, 518, 821.

A retia isabella = Pyrrharctia isabella." virginica $=$ Spilosoma virginica virgo, 674 .

Arctic insects, 2347.

Arctiidæ, 2242.

Argiope riparia, 830, 1299.

Argynnis, 1301.

$$
\text { bellona, } 1410 \text {. }
$$

Argyramaba, 1959.

Arhopalus = Cylleno.

infaustus $=$ C.yllene decorus.

pictus $=$ Cyllene pictus

robinix $=$ Cyllene robiniæ.

speciosus = Plagionotus speciosus.

A ristolocbia. Papilio philenor fecding on, 1774 .

Arizona. Ants injurious in, 1987.

Arma spinosa $=$ Podisus spinosus.

Army-worm, 11, 17, 120, 670, 876, 906, 1127, 1442, 1482, $1551,1570,2119,2239,2267,2269$.

Additional notes, 2001.

and canker. .rorm, 910.

Complete life-history of the, 1670 . 
Army-worm. Eggs of the, 1484.

and its enemies, 10.

The fall, 1256, 1267. 1282, 1301, 1482.

Further notes on the, 2253.

Further notes and observations on the, 1856.

Hibernation of, 7, 8, 2086.

How it comes and goes, 1442.

Important point yet to ascertain in its bistory, 1442.

Ichneumon fly, 1127.

and its insect foes, 12 .

Natural enemies, 1442.

bistory complete, 1551.

in New York and other Eastern

States. Supposed, 1990.

Northeru, 1835.

notes and inquiries; its work in clover, $187 \%$.

in $1882,2122$.

Parasites, 6, 10, 1670 .

Prospects. Chinch-bug and, 2087. question, 8, 9.

Recent outbreaks, 2262 .

remedies, 2090.

Supplementary notes, 1482 .

True, 647.

vs. the clover hay worm, 2090.

in the West. Genuine, 2009.

Wbeat-head, 1570, 2418.

worns. Canker-worms not, 1304.

Prof. Riley on, 1800.

Tbree so-called, 328.

Wbat are, 1400 .

A rrow-weed. Carpoeapsa saltitans on, 2173.

ARTEMESIA, INSECTS AFFECTING.

Cochylis bilaraua, 1059 .

Galls, 1347.

Articulates, Yersin. Function of the nerrous system of, 1959.

Arzama densa, 2357. ohliquata, 2223.

Asaphes inemnonius, 1874.

Aselepias. Latva on, 1535.

A semum mcestum, 2267.

A sexual females. Lichtenstein's theory as to dimorphic, 2072.

Ash. Borers in black, 1733 .

Cocoons on the flowering, 950.

colored locust, 2363.

destroyers. Linden and, 1847.

gray blister beetle, 1209,1558 .

leaf-bug, 1127, 1423, 2418.

pinion, 1301.

Ash. Insects nFFecting.

Attacus promethea, 950 .

Fatua denudatum, 1733.

Hspbantria cunea, 1733. textor $=\mathbf{H}$. cunea.

Neoclytus capræa? 1849.

Parandra brunnea, $1733,1876$.

Trochilium denudatum = Fatua denudatum.

Xyloryctes satyrus, 471.

Ash larva. Prickly, 1914.

and mountain ash, 705 .

Plant-louse eggs on apple and mountain, 579.
Asb root-borer, 1876.

saw-Hy, 2:91.

trees in the nursery. Holes around the roots of, 471 .

Ashmead, W. H. Report ou insects injur:ous to garden crops in Florida, 2388.

Ashy-gray lally-bird, 2119.

Asia Minor. Bombylid larva destroying locust eggs in, 2118.

Asilid larva, 1643.

Asilidæ, 1543 .

Asilus, 660, 668, 1127.

flies, 1127, 1543, 1558, 1643, 1959.

Ay. Large, $668,1269$.

missouriensis $n . s p ., 1127==$ Proctacanthus milberti.

sericeus, 668,1543 .

Asopia costahs, 83, 675, 948, 993, 1132, 1363, 2090.

farinalis, 980,2337 .

olinalis, 1363

Asparagus beetle, 524 .

ASPARAGUS. INSECTS AFFECTING.

Crioceris aspar"ai, 524, 2135.

12-punctata, 2135.

A spidiotus, 1, 389.

anrantii, 2394.

conchiformis = Mytilaspis pomorum. harrisii $n . s p ., 2=$ Cbionaspis furfurus. pinifolii $=$ Chionaspis pinifolii.

ratpax, 2235.

salicis-nigra $n . s p .=$ Chionaspis salicis.

Aspidoglossa subangulata, 372.

Aspila viresceus, 1689, 2343.

Aster. Instects AFFECTING.

Diabrotica vittata, 148

Epicauta peunsylvanica, 38.

Gortyna nitela, 75, 940.

Lytta atrata = Epicauta pennsylranica.

Aster stalk borer. Dahlia and, 940.

Astoma gryllarium = Trombidium locustarum. locustarun = Trombidium locustarum. Trombidinm dereloped from, 2071.

Athysanus maritima, 2116.

Atlanta cotton convention address, 2038.

A tonizers. Sprinklers and, 1857.

Atlantic migratory locust, 1423, 1625.

Atta forrens, 1964, 2532 .

Attacus angulifera, 1311.

cecropia, 139, 209, 238, 277, 287, 297, 542, 629 . $635,786,832,841,911,1028,1029,1076$, $1112,1215,1249,1311,1533$.

cynthia, $542,899,1179,1311,1343,1460,1718$, 2204.

Iuna $=$ A ctias luna.

polyphemus = Telea polyphemus.

promethea, 259, 268, 604,629, 950, 1311, 1486 , 1797,2204

ricini, 1718.

Attagenus injurng featbers, 56. megatoma, 2113.

Attractive but untrue, 1644 .

Attus, 2302.

Aulax, 318

Austrian pines. False caterpillar's on Scotch and, 1011. 
Azalea. Beetles on, 156.

Prasocuris varipes on, 156.

Bacillus alvoi, 2418.

Back-rolling wonder, 1363.

Bactcrial disease of the imported cabbage-worm 2251.

Bacterium, 2251.

Bad packing, 837 .

Bætis femolata = Silpblurus femoratus. interlineata $n . s p ., 39=$ Silphlurus femoratus.

sicea $n . s p ., 24$.

Bietisca $n . g ., 24$.

obesa. Prpa of, 43.

Bag-worm, 1059, 1090, 1189, 1650, 2378.

New, 1441.

at South Pass, Ill., 1156.

Thyridopteryx ephemeraformis. Remarks on, 2272.

worms, 182, 266, 538, 641, 738, 1036.

again, 815.

and borers, 1472 .

Ways of, 1424.

Bahia, Brazil. Cotton culture ana the insects af. fecting the plant at, $1788 \alpha$.

Bailey, J.S. Tree borers of the family Cossille, 2253.

Balaninus rectus, 1310,1311 .

Balsam fir. Lachnus strobi on, 1039.

Bamboo Sinoxylou, 2454.

Banded Ips in calyx of pear, 1239.

Baridius sesostris = Ampeloglypter sesostris. trinotata $=$ Trichobaris trinotata.

Bark beotles, 295.

borer. Hickory, 938, 1329.

Peach-tree, 2047.

borers, 220.

boring beetles. Packard on the derelop. ment of, 2267.

lice, 1, 264, 935, 944, 989, 994, 1007.

again, 1040.

on apple-trees, $423,1059$.

Curculio and, 487.

Natire, 1061.

eggs in Missouri. Supposed, 1084.

on grape-rine, 1212.

Maple, 1004.

Means against, 104.

Native apple-tree, 1152.

on the pear, 982.

pears. Apple, 973.

Preveutice of, 1012.

remedy, 896.

on rose bushes, 1303.

louse, 987, 1397, 1583.

Apple, 1552.

on apple-trecs South. Muscle. shaped, 1774.

enemy, 154.

Imported apple-trec, 255.

Insect focs of the, 417.

in Missouri. Oyster-shell, 1169.

on Osage orange, 389.

Oyster-shell apple, 1127, 1329, 2238.

Scurfy apple, 2305.

Tulip-tree, 271.
Barlet. Insects affecting.

Laehnosterna fusca, 2394.

Nectarophora gravaria, 2394.

Schizoneura sp., 2394.

SipLonophora avenæ= Nectarophora granaria.

Barley-root lonse, 2394.

F. M. Webster. Insects affecting, 2394.

Barnard, W.S. Machinery for destroying Aletia, 2343.

Tests of machinery for destroying the cotton-worm, 2253.

Basket-worm, 271, 1059, 1090, 1650.

Bass. Insects from stomach of rock, 1793.

Larve in stomach of black, 1792.

Bassus bicapillaris n. $s p ., 385$.

luficrus $n . s p ., 385$.

semifasciatus $n . s p ., 385$.

tripieticrus n. $s p ., 385$.

Bass-wood. Dipteron on, $5 \pm 8$.

Batrachedra salicipomonella, 821 .

Bazille, Louis, Obituary, 2370.

$\mathrm{Be}$ on the guard, 708.

BEAN. INSECTS AFEECTING.

Bruchus fabr, 1201, 1631, 2127, 2238. granarius, 1120. obsoletus, 1155, 1232, 1296.

Epilachna corrupta, 2235.

Lytta cinerea = Macrobasis unicolor.

Macrobasis unicolor, 38.

Bean. A new enemy to, 2418.

Weevil, 1155, 1296, 2127, 2238.

American, 1301.

Beans. Buggs, 1631

Beautiful wood nymph, 1127, 1363.

Bed bugs, 1502.

Lepidium vs., $17 \pm 1$.

Bedleguar of the rose, 1939.

Bee bread deroured by worms, 1293.

Bug preying on honey, 13.

disease. Possible cause of the, 704.

enem $5,1186$.

fly, 1959.

killer. Nebraska, 1127, 1311.

killers, 1543.

Bcetle named, 627.

Remarkable felting caused by a, 2113.

in Russia. Excessive injury by, 1935.

on sugar maple, 1014.

in thistle, 169.

Bectles, 1736

around peach-trees, 751 .

Food-habits of ground, 1760.

in dried English currants, 1260 . .

in flouring-mills, 1261.

injuring cabbages and fuchsias, 1868.

in stomach of meadow lark, 1013.

in the corn-field, 2317.

Mites parasitic on, 315 .

nimed, 732, 802, 806, 1172, 1187.

on buttercup and azalea, 156.

Plant-feeding habits of predaceous, 1956.

supposed to be foeding on wheat, 1746. swarming about the lawn, 718 .

under dead fish, 817.

working in wlieat, oats, and rye, 1259.

Belated individuals of the periodical Cicada, 648 . 
Belfrage, G. Tr. Obituary, 2161.

Belostoma americantum, $473,534,733,1570,1584$. grandc $=$ B. americanum.

Belvoisia bifasciat., 1329, 2343.

Bembecia marginata, 576, 1363, 1454. rubi $=$ B. ńarginata.

Bembex fasciata, $5 \pm 3$. marginata, 2230.

Bombidium 4-macnlatnm, 3.

Bennett, T. Ieport of experiments at Trenton, N. J., 2344.

Berberry. Aphididx on, 644.

Berne. Phyllosera convontion at, 2147.

Berry and cherry twiga, 1503.

Beschreihung einer den Birnen schädlichen Gallmücke, 2392.

Bezt's fruit.tree invigorator again, 530. invigorator once $m$ orc, 545 .

Betula nigra. Aeronyeta on, 2280 .

Bibio alhipennis, 257, 683 .

Bibioniảx, 2076.

Bihliography of gall literature, $\mathbf{2 0 5 9 .}$

Bidens chrysinthemoides. Syrphus sp. caught by, 1761 .

Bill bug. Corn, 2291, 2118.

Biorhiza forticornss, 41,745 .

Birch. Clytus sp. ? on, 2267.

Bird question dispassionately considered, 1768.

Birds. Professor Riley in fav"or of the, 1675.

Relatiou of Carahide and Coccinellida to, 2152.

vs. insects, 199. 369.

Bittacus apterus. Hahits of, 2092.

Bitten by an aphed, 2205.

Bitter-sweet. Enchenopa binotata on, 1913.

White waxy secretion on stems of 1913.

Black ants in gardens. Destroying, 438.

asli. Borers in, 1733.

bass. Larva in stomach of, 1792 .

blister beetle, 1059,1558 .

beetles on potatoes, 1381 .

breeze fly, 1127.

bug, 314.

currant. Currant.worms and, 1079.

grape-vine caterpillar's, 1018.

knot oneo mole, 930.

legged tortoise beetle, 1127.

potato heetles. Large, 1206 .

rat blister beetle, $1059,1558$.

walnut. Inspets feeding on sap of, 1195 .

and willow. Enemies of the, 2333.

Blackberry borers, 302 .

cane borers, 576 .

gall insects, 318 .

Pithy, 1131.

Galls on, 263.

Blackberry. Insects affecting.

Ageria rubi = Bembecia inarginata. sp., 302.

A grilus ruficollis, 1771.

Bembecia marginata, 576, 1364, 1454.

Diastrophus cuscu taeformis, 609. nebulosus, $263,610,1131$. sp., 318.

Eudemis botrana, 1232 .
BLACKBERRY. IxSECTS AFFECTING-Continued.

Lecanium sp., 117.

Lobesia botrana $=$ Eudemis botrana.

Oherea bimaculat:a, 302, 783, 1363. perspicillata $=0$. bimaculata. tripunctata, 1503.

Ecanthus niveus, 1503.

Psylla rubi = Trioza tripunctata.

Trioza tripunetata, 669.

Blackberry. New insect foe of the, 669 . and raspberiy cancs. Gouty galls on, 1771.

scale, 117 .

twig. Fuzzy galls on, 609.

Pithy galls on, 610 .

Blastobasis iceryxella n.sp., 2394.

Blastophysa $n .89 ., 2272$.

celtidis.gremma n. $s p ., 2272$.

Blatta, 2267.

germanica $=$ Ectobia germanica.

Blattidæe, 573, 1858 .

Blennocampa pygmaa, 1056, 1252.

Blepharida rhois, 849, 1363.

Blepharoceridi, 1981, 2004.

Blight. Apple.root, 997.

Blind.cyed Smerintlius, 1912.

Going it, 588 .

as those who shut their eyes. None so, 275.

Blissus lencopterns, $6,90,180,398,548,886,888,890$, $891,894,895,1068,1127,1357,1402,1423,1432,1453$, $1508,1538,1681,2018,2039,2048,2087,2119,2143$, $2237,2252,2271,2418$

Blister beetle. Asli-gray, 1059, 1209, 1558 .

Biack, 1059, 1558.

rat, 1059,1558 .

Margined, 1059, 1558.

on potatoes. Black, 1381 .

Retarded dovelopment in, 1860.

Striped, 1059, 1558.

beetles, 134, 289, 301, 362, 1059, 1558, 2238, 2118.

Larval characters and habits of, 1600.

from New Mexico, 1796.

Notes on life-history of, 1651.

Pear leaf, 1739.

Blcod-red lady-hird, 2119.

sucker and pear slug, 1253.

sucking cone-nose, 795,854 .

Conorhinus, 2291.

Blow-fly. Cheese-fly and, 1266.

Bluebird. Ichneumonid from stomach of, 1878 .

Larvo from stomach of, 1871.

Bluebirds feeding on parasitic and predaceous insects, 1885.

Blue caterpillars of the vine, 1127, 1363.

syangled peach-worm, 1301.

Bogus chinch.hug, 1127, 1423.

Colorado potato-beetle, 1558.

\section{bug, 519}

Thrips. True Thrips and, 203.

Yucca moth. True and, 1804.

Boll-worm, 821, 1301, 1353, 2119, 2164, 2343.

Report on, 2164.

worms feeding on cabbage, 1915.

Bombardier bcetle, Kansas, 1311. 
Bombus, 800, 1032, 1226.

Hibernation of the queens of, 1032. pennsylvanicus, 800 . virginicus, 1774.

Bombycidx, 1718.

Bombylid larvæ destroying locust eggs in Asia Minor, 2118.

Bombylii, 1959

Bombyliidæe, 2118.

Larval habits, 1947, 2169.

Life-habits, 2002.

Natural history of certain, 1928.

Bombylitis major, 1947, 1959.

Bombyx arrindria, 899.

mori $=$ Sericaria mori.

Bordered soldier bug, 1059 .

Borer, 47.

Borers, 55, 141, 233, 967, 1083.

Bag-worms and, 1472

Brimstone for, 931.

Canker-worms and, 941.

Tansy for, 1016.

Boston. Entomologists at, 1894.

Bostrichus = Amphiccrus.

bicandatus $=$ Amphicerus bicaudatus.

Botis. Cauliflower, 2232. repctitalis, 2232 .

Bot flies, 114

fly. Cattle, 2238 .

Horse, 2238 .

Sheep, 2238.

Squirrel, 526.

Botrytis rilevi, 2232.

Bots, 1563.

Bow ols. Larvæ in human, 382.

Box Psylla, 2291.

Brachinus, 802.

$$
\text { americanus, } 802 .
$$

Brachyrhynchus, 553.

Brachytarsus rariegatus, 18, 1461, 1479.

Bracon charus n. sp., 1423.

Cherished, 1423.

scolytivorus $n . s p ., 1329$.

Bradynotes opimus n. $s p ., 1959$.

Brandt on nervous system of insects, 2225.

Branner, J. C. Cotton-catelpillars in Bi'azil, 2343.

Preliminary report of observations upon insects injurious to cotton, orange, and sugar-cane in Brazil, 2277.

Braner on Hirmoneura. Review of, 2275.

Braula coeca not particularly injurious to the honey-bee, 1982.

Brazil. Branner, J. C., on cotton-caterpillars in, 2343 .

insects injurious to cotton, orange, and sugar-caue in, 2277.

Lignified snake of, 2136.

Breakfast. Entomological, 2311.

Breeding-cages, 695 .

silk-worms, 1648

Breeze-fly. Black, 1127.

Brenthian. Northern, 1363.

Brimstone for borers, 931 .

British pest, 2413.
Broad-necked Prionus. Eggs of, 1329.

winged katydid, 1329, 1363.

Brochymena annulata, 684 .

Brown mantispian, 1243.

Brown's answer to inquiries about Colorado po

tato-beetle. Mayor, 1491:

Bruchus of Europe just imported. Grain, 1120 .

fabæo n. sp., 1301, 1631, 2127, 2238.

Grain, 1301.

granarius, 1120, 1301.

obsoletus, $1155,1232,1296$.

pisi, 434, 1120, 1301, 1357, 1916, 2238.

Bruner, L. Additions to the chronology of locust ravages in $1880-81,2267$.

List of North American locusts, 2267.

Notes on other locusts and the west-

ern cricket, 2267.

from Nebraska, 2291.

Observatious in the Northwest on the Rocky Mountain lo. cust, 2165.

on the Rocky Mountain locust and other insects in the North. west during the sum. mer of $1883,2277$.

Report on the abundance of the Rocky Mountain locust in $1885,2363$.

locusts in Texas in spring of $1886,2382$.

Nebraska insects, 2382.

of the season's observations

in Nebraska, 2418.

on the Rocky Mountain locust in Montana in 1880, 2267.

the Rocky Mountain locust in Wyoming and Montana, otc., in 1881 2267.

Bucculatrix. Apple-leaf, 1311 pomifoliella, 92 . 1311, 1733 . thuiella, 1311.

Buck fly, 595 . moth, 1329 .

Buckeye leaf. Sericoris claypoleana on, 2114. stem-borer, 2114.

Buckwheat to destroy insects. Use of, 1744

Webster on insects affecting, 2394.

Bad-eating insects, 1408.

Buffalo. Eutomology in, 2035.

gnat problem in the Lower Mississippi Valley, 2416.

Southern, 2291, 2394, 2418.

gnats, 2394.

Webster on, 2388.

treo hopper, 415, 1329.

injurious to potatoes, 2107.

Bug. A most precious, 575 .

Buggy beans, 1631. peas, 1916.

Bug-hunter in Egspt, 372.

hunters. Cruel, 440.

Bugs, 354.

in alcohol, 605 . 
Bugs. Hogs v8., 387.

Our, 2374.

Toads vs., 1103.

Bubach. Coquillett on the produetion and manu. facture of, 2364.

Bulletin Div, Ent. U.S. Dept. Agric., No. 1, 2164.

$$
\begin{array}{r}
2,2165 \\
3,2253 \\
4,2277 \\
6,2304 \\
8,2315 \\
9,1724 \\
10,2378 \\
11,2344 \\
12,2364 \\
13,2382 \\
14,2388 \\
15,2389
\end{array}
$$

Michigan Agrie. College, No. 39 (Review), 2501.

United States Entomological Commis. sion, No. 1, 1577.
2,1578 .
3,1736 .
$6,2026$.

Bumble-bees $v 8$. red-clover, 2376.

What becomes of, 1032 .

Bundle of entomological queries, 556.

Buprestidæ, 821, 2267.

Buprestis divaricata $=$ Dicerea divaricata feniorata = Chrysobothris femorata.

Burr-oak. Insects stripping the, 966 .

Burgess, E. Anatomy of Aletia, 2343.

Burying beetles, 315,845 .

Bushels of butterflies, 238.

Butalis cerealella, 1232.

Buteo pennsylranicus, 643.

Buthus carolinianus, 453, 1119.

Butler, A. W. The periodical Cicada in south. eastern Indiana, 2364.

Buttercup. 'Beetles on, 156.

INSECTS AFFECTING.

Adimonia rufosanguinea, 156.

Galeruca rufosanguinea = Adimonia rufosan. guinea.

Butterflies. Bushels of, 238.

caught by the torgne, 1761 .

Controlling sex in, 1352 .

Effects of cold applied to the chrys. alids of, 1778 .

Hackberry, 1356, 1363.

Imitative, 613.

Migrations, 1770, 1991.

Migratory, 1622, 1635.

named, 461.

of New England. Notice of Scudder's, 2164

North America. Review of Edward's, $395,479,623,827$.

Odor in, 2025.

Philosophy of the pupation of, 1711. Swarm of, 406,1050 .

Butterfly chrysalis, 1535.

Goat-weed, 1117, 1127, 1329.

larva. Carnivorous, 2359.
Butterfly larva injnrious to cotton squares, 1872. pino-trees, 2121.

larræ. Summer dormancy of, 1410. named, 666.

tongue, 1815 .

trees of Montercy again, 2052.

wings. Chemical change in color of, 1935.

Brrsocrypta pseudobyrsa n. $s p ., 27$. vagabunda $n . s p ., 27$.

Cabbage Anthom yia, 2291.

bug. Harlequin, 1099,1311, 1534, 2238, 2263, 2291.

butterfy. Imported, 1127, 2291.

Larger, 2232.

Southern, 1127, 2232, 2238.

cut-worms, 2291.

Remedies for, 2291.

flea-beetle. Coloradu, 2291.

insects, 1297, 2291, 2418.

Cabbage. Ixsects affecting.

A grotis annexa, 2291.

clandestina, 2291.

nalefida, 2291.

messoria, 2291.

sancia, 2291.

tolifera $=$ A. ypsilon.

ypsilon, 626, 2291.

Anthomyia brassica, 2291.

A phis brassicæ, 1365, 2291.

Botis repetitalis, 2232.

Calontenus spretus, 2291.

Doryphora 10-lineata, 2291.

Elaterid, 740.

Epicxus imbricatus, 1868.

Hadena devastatrix, 2291.

Heliothis armigera, 1915.

Lygus lineolaris $=$ L. pratensis. pratensis, 2291 .

Mamestra chenopodi $=$ M. trifolii. picta, 1127, 2232. subjuncta, 2291 . trifolii, 2232.

Murgantia histrionica, 1097, 1297, 1311, 1534, 2238, 2263, 2291.

Nysius angustatus, 2291.

Oscinis, 2291.

Phyllotreta albionica, 2291. vittata, 2291 . zimmermani, 2291.

Pieris monuste, 2232. oleracea, $835,1127,2232,2238$. protodice, 1127, 2232, 2238.

rapx, $1127,1257,1279,1294,1694,1721$, $2221,2232,2238,2251,2298$.

Pionea rimosalis, 1915, 2232 .

Plusia lirassiex, 1127, 2232, 2238.

Plutella cruciferarum, 1291, 1297, 2232.

Strachia histrionica = Murgantia histrionica. Cabbage-lice, 1365.

Mamestra, 2232.

Oscinis, 2291.

pest. Our now, 1257.

pests, 740 .

Pionea, 2232.

plant-louse, 2291 
Cabbage plants. Cut-worms severing, 626 . Plusia, 1127, 2232, 2238.

Plutella, 1291, 2232.

worm. Bacterial disease of the imported, 2251.

Imported, 2232, 2238, 2291.

A new remedy for the imported, 2298.

parasite, 2221.

in the South. The imported, 1714.

Successful fntroduction of a parasite of the imported, $229 \mathrm{i}$.

The westward progress of the im. ported, 1694, 1721.

Zebra, 2232.

worms, $835,1127,1279,1915,2232$.

upon gillyflowers, 614 .

Remedy for, 1920,2232 .

Safe remedies for, 1948 .

Cabbages and fuchias. Beetles injuring, 1868.

Cabinet pests. Means against, 1057.

Cacocia fractivittana, 2475.

rileyana, 1059, 1192

rosaceana, 735 .

$\checkmark$-marked, 2363.

Cactus lady-bird, 2119.

Caddis-worms. Carnivorous habits of, 1839

Calandra granaria, 510, 586, 1259, 1673, 1683, 1742.

oryzæ, $510,1673,1683$,

remotepunctata, 15 .

Calaphis n. g., 27.

betulella $n . s p ., 27$.

Calathus gregarius, 2418.

California. Chinch-bug, 2431.

Fruit insects in, 2245.

Fuller's rose-beetle in, 1740 .

Grape Phylloxera in, 1727.

Grasshopper ravages in, 2323.

Injurious insects in, 2074.

Interest in economic entomology in, 2053.

Introduction of Lestophonus iceryæ into, 2522.

- Locust ravages in, 1959.

migratory locust, 2363.

Overflow bug in, 2099.

Phylloxera in, 2140.

Promotion of silk-culture in, 2006.

red scale, 2394.

Winged Phylloxera in, 1895.

Californian locust, 1959.

orange insects, 2373.

Callidium antennatum, 50, 319.

janthinum, 50, 319.

Callidryas philea, 1271.

Secondary sexual characters of, 1784 .

Callimorpha fulvicosta $=$ C. lecontei.

lecontei, 1301 .

sp., 1871.

Calliphora, 1390

vestalis $=$ C. lecontei.

Callipterns, 1678 .

vomitoria, 1266.

Callochlora viridis $=$ Parrasa chloris

Callosamia angulifera $=$ Attacus angulifera.
Callosamia promethea $=\Delta$ ttacus promethea.

Callostoma fascipennis, 2075, 2118.

Calocoris chenopodi, 2458.

rapidus, 2363.

Calomicrns. Characters of, 1799 .

Calophya nigripennis $n . s p ., 2272$.

Caloptenobia $n . g ., 1643=$ Scelio.

ovivora $n . s p ., 1643==$ Scelio famelicus.

Caloptenus, 2267.

atlanis $n . s p ., 1423,1549,1643,2198,2232$, 2363.

Packard on the development of, 2267.

bivittatus, 1959.

devastator, $2323,2377$.

differentialis, 1423, 1549, 2323.

Epidemic disease of, 2240

Dimorphism in, 1889.

femur-rubrum, 147, 475, 1423, 1437, 1451, $1549,1598,1643,2471$.

Mite infesting, 146.

spretus, $147,368,373,475,536,926,929$, $1423,1433,1434,1437,1451$, $1452,1456,1473,1481,1482$, $1488,1492,1493,1494,1495$, 1501, 1521, 1527, 1532, 1538, $1541,1549,1555,1557,1562$, $1564,1565,1566,1567,1570$, $1571,1572,1573,1575,1576$, $1577,1578,1582,1585,1588$, $1596,1598,1612,1613,1614$. $1615,1617,1643,1669,1674$. $1693,1959,1994,1998,2003$, 2005, 2007, 2040, 2014, 2057, 2267, 2276, 2291, 2395, 2366. (See also Locust; Rocky Mountain locust.)

Agricultural bearingsof, 1643 . Aid of animals against, 1643 . Air-sacks of, 1959.

Anatomy of, 1643.

Animals as foes to, 1643 .

Autumn flights in 1877, 1643.

Birds that feed on, 1643.

Brain of, 1959.

Breeding-grounds of, 1643 .

British-American data, 1643.

Characters, 1625.

Chronological history, 1625.

Chronology of ravages, 1643, 1959.

Classification, 1643.

Colorado data for $1877,1643$.

Crops as affected by, 1643.

Dakota data, 1643.

Destruction(devices for), 1643 . (means of), 1643.

Development of, 2267.

as influenced by meteoro. logical conditions, 1959.

Devices for destruction of, 1643. 
Caloptenusspretus. Distribution of, 1625,1643 , 1959. (southern lim its of), 1959.

Effects that follow severe injury, 1643.

Eggs, 1613.

in samo ground for two consecutive years, 1643.

Enemies (invertebrate), 1643. (natural), 1625, 1959. (vertebrate), 1643

Fires (influence of prairie), 1648.

Flight, 1959 . (powers of), 1959.

Flightsin 1877 (autumn), 1643. from 1877 to $1879,1959$.

General considerations, 1625.

Habits, 1625, 1643. (at night), 1643

Histology, 1642, 1959.

Injury (effects that follow severe), 1643.

Tnvertcbrate encmies of, 1643. Iowa data, 1613.

for $1877,1643$.

Kansas data for $1877,1643$.

Losses caused by, 1643.

Means against, 1959.

Metamorphoses, 1643.

Meteorological conditions (influence of, on migrations), 1959.

Migrations, 1643 , 1959 .

(intluence of meteorological conditions on), 1959 .

in 1877,1643 .

Minnesota data, 1643. for 1877,1643 .

Missouri data for $1877,1643$.

Native home, 1625.

Natural enemies, 1625, 1959.

Natural history, 1625, 1643.

Nebraska data, 1643.

for 1877,1643 .

New Mexico data, 1643.

Night habits of, 1643.

Nomenclature, 1643.

Parasites on eggs, 1612.

Permanent breeding-grounds of, 1643 .

Powers of injurs, 1625.

Practical considerations, 1625.

Prairie fires and, 1643.

Previons visitations of, 1643.

Ravages of (chronology of), $1643,1959$.

(east of the Mississippi), 1625.

(relative to agriculture), 1959.
Caloptenus spretus. Remediess, 1643.

Statisties of losses caused by, 1643.

in the temporary region after the departure of the return swarms, 1613 .

Texas data, 1957. for $1877,1643$.

Trausformations, 1625 .

travel. Direction in which young, 1643 .

Uses of", 1643.

Utah data, 1643.

Vertebrate enemies of, 1643.

Visitation of, 1643.

Weathor (effects of), 1643.

Wings (time of year when acquired), 1643.

Young in country where they hatch, 1625.

Calopteron and Photinus. Food of, 2358. reticulatun, 806 .

terminale, $806,2358$.

Calosona calidum, 721, 1274, 1314, 1357, 1672. scrutator, 1226, 1898.

Calves, Lice on, 889.

Cambala annulata, 193, 236. inultistriatus $=$ C. annulata.

Camel cricket, 1059.

Camnula atrox, 1959 pellucida, 1959, 2044, 2313, 2363.

Campoplex fugitiva = Limneria fugitiva

Camptonotus scudderi, 2276.

Campyloneura vitripennis, 1301.

Canadian Eutomologist (Reviuw), 395, 479, 827.

Canker-tworm, 86, 172, 1021, 1066, 1127, 1363, 2012. again, 173.

Army-worm and, 910 .

Cure for, 1426 .

Fall, 1423, 1482, 2238.

Howell, A. J. Experience with the Spring, 2267.

once more, 274.

parasite, 717.

Spring, 1423, 1482, 2238.

worms, 91, 96, วิ02, 1482, 2267, 2270.

not army-worms, 1304

Borers and, 941.

Concerning, 2149.

Remarks on, 1438.

at the West, 1539 .

Canna flavida. Pamphila etlilius feeding on, 1897.

Hesperid larva fecding on, 1897.

Cannibal mites, 624 .

Cantharis cinerea = Macrobasis unicolor. vesicatoria, 2118 .

Cauthon chalcites, 1172.

hudsonias $=-\mathrm{C}$. lavis.

lævis, $1172,1386$.

Cape. Grape Phylloxera not at the, 1841.

Capitalizing specific names, $2170,2257$.

Capnia minima, 1141.

Capsus oblineatus $=$ Lygus pratensis.

4. vittatus $=$ Poecilocapsus lineatus

Carabidœ, 1537, 1726, 1738, 1760, 1956. 
Carabidæ and Coccinellidø to birds. Relations of, 2152.

Fool relations of, 2151.

Curculio-feeding habits of, 372.

Horn's classification of, 2051.

Mode of oviposition of, 2341, 2355.

Care of entomological specimens. On the, 2290.

Carnivorous. Are honey-bees, 2098.

butterfly larra, 2359, 2361.

habits of caddis.worms, 1839.

Carolina sphinx, 1262.

propensities of plant-feeders, 1867.

Carpet-beetle. The imported, 1699.

bug, 1659 .

Trapping the, 1752.

pests, 1663.

Carpets in Texas. A tineid on, 2531.

Carpocapsa, 934.

poinonella 57, 307, 330, 367, 373, 377. $387,454,467,523,565,769,977,1010$, $1022,1056,1059,1254,1301,1311,1320$, $1329,1334,1363,1373,1394,1398,1476$, $1496,1609,1666,1695,1721,1887,2037$, $2230,2261,2293,2418$.

saltitans, 1496, 1609, 2163, 2173.

Carrying out the law, 1993.

Carteria laccæ, 2119.

larreæ, 2119.

mexicana, 2119.

Case-bearer. Dominican, 1363.

Lepidopterous, 260.

Walnut, 1311.

Cassida, 94, 1238.

aurichalcea $=$ Coptocycla aurichalcea.

bivittata, 681, 993, 1127, 1510.

clavata = Coptocycla clavata.

nigripes, 1127, 1510, 1697.

pallida $=$ Coptocycla aurichalcea.

5-punctata $n . s p ., 767=$ Physonota unipunctata.

texana, 2096, 2215, 2235 .

Cassididæ, 105, 767, 973, 1056, 1082, 1510.

Castor bean. Locusts eat the, 1645 .

Catalogues and monographs, 1765.

Catalogus coleopterorum, 1866.

Catalpá sphinx, 2119, 2291.

Cat-bird. Tipula eggs in stomach of the, 1735, 1745.

Catcher. Dr. Hull's Curculio, 651.

Caterpillar nuisance, 1995.

Caterpillars named, 857, 1276. Stinging, 1748.

Catocentrus n.g., 385.

Cattle bot-fly, 2238.

Catydia eggs, 29, 247.

as an enemy to Doryphora 10-lineata, 313.

Catydids. Food of, 143, 241.

Cauliflower Botis, 2232.

Cause of variation in organic forms, 2460 .

Cave fauna of Kentucky. Coleopterous, 2033.

Cecidomiyia, 107, 1461.

albovittata $n . s p ., 46$.

carbonifera, 1924

cornuta $n . s p ., 46$.

Cranberry, 194.

cratægi-bedeguar n. sp., 376.
Cecidomyia cupressi-ananassa n. $s p ., 1180$.

destructor, 6, 62, 122, 150, 157, 250, 426,

494, 711, 1506, 1581, 1587, 1665, 1690, $1721,1787,2008,2031,2235,2267,2331$, $2365,2395,2398$.

impatientis, 852 .

leguminicola, 1690, 1721, 2238.

orbitalis n. sp., 46.

oryzæ, 1949.

q.-pilulæ n. sp., 41, 799.

q.-symetrica, 799.

s.-ænigma n.sp., $46=\Delta$ carus s.-ænigma.

s.-batatas n. $s p ., 46$.

s.-brassicoides n.sp., 46, 518 .

s.- coruu n. sp., 46, 197.

s.-coryloides $n . s p ., 46,518$.

8.-gnaphalioides $n$. $s p$., 46.

8.-Iordeoides $n . s p ., 46$.

s.-nodulus n. sp., 46.

s.-rhodoides n. sp., 46.

s.-semen $n . s p ., 46=$ A carus s.-semen.

s.-siliqua $n . s p ., 46,1170$.

s.-strobiliscus $n$. $s p ., 46,197$.

s.-strobiloides $n . s p ., 46,518$.

8.-triticoides n. sp., 46.

8.-verruca $n . s p ., 16$.

secalina, 2267.

solidaginis, 798 .

sp., $799,963$.

tritici $=$ Diplosis tritici.

tubicola, 1232.

v.-coryloides $n$. $s p ., 518,1329$.

v.-Jituus $=$ C. v. - viticola.

- v.-pomum n. $s p ., 403,518,1281,1329$, $1898,2136$.

v.-viticola, 791, 1077, 1116, 1329.

Cecidomyid gall on Cratregus, 376.

in wheat, 18.

Cecidomyidæ, 294, 518, 799.

on grape. Galls of, 111 .

salix. Galls of, $46,197$.

new species, 46.

Cecil's books of natural history (Review), 506.

Cecropia Cryptus, 1301.

moth, 1112.

caterpillars, 786.

cocoon, 635

silk-worm, 1311.

Remarkable abundance of, 2511.

Tachina $\mathrm{fl}_{y}, 1311$.

worm, $1215,1249$.

on elder, 1533 .

Cenar. Insects afFectinc.

Callidium anteunatum, 319 . janthin um, 319.

Cerambycid, 1324.

Thyridopteryx ephemeræ formis, 427.

Cedar longicorns, 319.

Celæna renigera = Hadena renigera.

Celert. Ixsects AFFecrixg.

Buprestís divaricata $=$ Dicerca divaricata .

Dicerca divaricata, 1063.

Tettigonid, 452.

'Trochilium sp., 1063.

Celery. Leaf-hoppers on, 452. 
Celtis, 2208.

Centennial insects, 1611.

Those, 1511.

Central America. Prevalence of screw-worm in, 2158.

Report on cotton crop and its enemies in, 2343.

Cephalomyia ovis = CEstrus ovis.

Cerambycida, 1324, 2267.

Food habits of, 1902.

Cerastophorus cinctus $=$ Chion cinctus.

Ceratina dupla, 1171.

Ceratocampa imperialis = Eacles imperialis. regalis $=$ Citheronia regalis.

Ceratomia catalpæ, 2119. hageni, 2119.

Cercopididæ, 882.

Cercopsylla n. g., 2272. sideroxyli $n .8 p ., 2272$.

Cereals. Insects injurious to, 2238.

Ceresa bubalus, 415, 1323, 1329, 2107, 2195, 2235.

Cermatia forceps, 752, 764, 1154.

Cerococcus quercus, 2119.

Ceropales rufiventris $n . s p ., 375,543$.

Ceroplastes cirripediformis, 2450. n. $s p ., 1964$

Ceropsylla $n . g ., 2272$. sideroxyli $n . s p ., 2272$.

Ceroptres ensiger, 41 . ficus, 745 .

inermis, 41. petiolicola, 41.

Cerotoma caminea, 2418.

Cerura multiscripta n. $\delta p ., 1411$.

Cetonia, 2105. inda $=$ Euphoria inda

Chærocampa pampinatrix = Ampelophagamyron

Chætochilus pometellus, 874 .

Chætophorus, 1678.

Chatoptria hypericana, 2076.

Chafer. Melancholy, 522.

Rose, 1329.

Chalcid egg parasites. Efficacy of, 2115. fly $y, 1643,1959$.

Chalcididæ, 128, 384, 2115, 2343.

Joint-worm not one of the, 49.

Chalcis albifrons $n . s p, 6=$ Smicra albifrons. fly, 1059.

Inflating, 1059 .

mariæ n. $s p ., 1112=$ - Spilochalcis mariæ.

Mar, 1311.

ovata, 2343.

Chalcophora virginiensis, 2267.

Chalepus trachypygus, 273, 1911, 1949, 1973, 2119.

Chambers, V. T. Obituary, 2218.

Change of habit, 2096.

in vegetation caused by locusts, 1495 .

Chapin's apple-leaf sowcr, 1721.

Chariesterus antennator, 847.

Chauliodes. Larval characteristics of, 1652 . pectinicornis, 712 . rastricornis, 712 .

Chauliognathus pennsylranicus, 372, 374, 1959.

Cheese-fly and blow-fly, 1266.

Other insects affectirg, 1703,

ekipper, 1700.
Chelifer cancroides, 1884.

Chelymorpha argus, 767.

cribraria $=$ C. argus.

Chemical changes in the color of butterfly wings, 1936.

Chenopodium hybridum. Lixus macer bred from, 2404.

Cherished bracon, 1423 .

Chernetidæ, 1884

Cherry aphis, 960 .

borel. Flat-headed, 2267.

Caterpillars ncst on wild, 242.

Cocoon on wild, 259.

Cherry. Insects affecting.

Acarid, 1265.

Aphis ccrasi $=$ Myzus cerasi.

Attacus polyphemus, 1164 . promethea, 257.

Dicerca divaricata, 2267 .

Eriocampa cerasi, 1222.

Hyphantria cunca, 242.

$$
\text { textor }=\text { H. cunea. }
$$

Myzus cerasi, 960, 1067, 1207, 1251.

Ceanthus niveus, 1503.

Scolytus rugulosus, 1940.

Selandria cerasi $=$ Eriocampa cerasi.

Telea yolyphemus = Attacus polyphemus.

Cherry plant-lice. Destroying, 1207. and their foes, 1251.

tree borers, 1063 .

plant lice, 1067.

trecs. Minute borers in, 1940. Slug on pear and, 1222.

twigs. Berry and, 1503.

Chester onion pcst, 2319.

Chestnut. Gall ou, 353.

Gregarious worms ou horse, 1192.

Phylloxera sp. on, 353.

Chicken mite, 1308.

Chickweed. Geometer, 1059, 1154.

Hrmatopis grataria on, 1059, 1154.

Chilo oryzeell us $n . s p ., 2119,2120$.

Chilocorus bivulnerus, 38, 188, 301, 417, 730, 731 ,

1554, 1798, 1883.

China-TREe. INseCts AFFeCtiNg, 1964.

Atta fervens, 1964.

Ceroplastes sp., 1964.

Lecanium sp., 1964.

Chinch-bug, 584, 886, 891, 894, 1127, 1423, 1508, 1681, $2018,2039,2048,2271,2363,2418$.

and army-worm prospects, 2087.

Bogus, 1127, 1423.

Bug allied to, 90.

Bugs on grape-vines mistaken for, 398.

Diseases of, 2143.

False, 1329, 1423, 2291, 2418.

in New York, 2237, 2252, 2271.

not in seed grain, 888 .

notes, 2119, 2291 .

once more, 890,894 .

bugs, S. A. Forbes. Experiments on, 2165. Genuine vs. bogus, 1402.

Locusts $v 8 ., 1432$.

Chion cinctus, 55.

Chionaspis euronymi, 2403. 
Chionapsis furfurus, $2,188,264,345,372,373,579$, $951,1008,1040,1061,1152,1554,1968$, 2305.

pinifolii, 97, 1329, 2079.

salicis, 373 .

nigræe $n . s p ., 373=\mathrm{C}$. salicis.

Chipman, A. J. Locust notes in 1880, 2267.

Chiro: omus, 167, 625.

Chlænius impunetifrons, 2340.

Chlamys plicata, 1363.

Chlorion cæruleum, 543.

Chloroneura $2 . g ., 22=$ Empoasca.

abnormis $n . s p ., 22=$ Empoasca abnormis.

malefica $n . s p ., 22=$ Empoasca viridescens.

maligna $n . s p, 22=$ Empoasca obtusa

Chloroperla brunnipeunis $n, s p ., 24$.

fumipennis, 24.

uana $n . s p ., 24$.

Chlorops, 1461, 2060.

Chorinaus cariniger, 385.

Chortophaga viridifasciata, 1566.

Chronology of locust ravages iu 1880-'81, 2267.

Chrysididæ, 375.

Chrysobothiis, 934.

femorata, 2, 6, 55, 352,377, 379, 537 $555,578,634,870,1059,1227, \cdot 1250$ $1316,1367,1423,1454,1472,1475$, $1513,1610,2267$.

Chrysochus anratus, 735, 790.

Chrysomela bigsbyana, 323 .

cyanea $=$ Gastroidea cyanea

iniladelphica, 323.

scalaris, 45 .

Chrysomelidæ, 323, 2229.

Chrysopa plorabuuda, 584, 1127.

$$
\text { sp., 372, } 533 \text {. }
$$

Cicada, 189, 213, 372, 431.

alias the strenteen-year locust. Periodical, 1159, 1971, 1979.

Belated individuals of the periodical, 648 . canicularis = C. tibicen.

cassini $=$ Tibicen cassini.

Fungus in, 1809.

in Iowa. Seventeen.year, 1737.

Little, 1242.

in Massachusetts. Periodical, 2321.

Note on the periodical, 2318.

our first brood established. Periodical, 707.

parvula = Melampsalta parvula.

Periodical, 474, 527, 619, 1059, 1159, 1489 , $1624,1836,2014,2216,2312,2314,2315,2318$, $2320,2363$.

Premature appearance of the periodical, 2320. 2326 .

pruinosa $=$ C. tibicen.

in savin-twigs. Eggs of the periodical, 698.

septendecim $=$ Tibicen septendecim.

Iufluence of climate on 2329.

Instinct of, 2144.

Some popular fallacies re. garding, 2367.

Seventeen-Jear, 1034, 1093, 1698, 2312, 2314.
Cicada. Song notes of the periodical, 2334. in southeastern Indiana, Butler, A. W. The periodical, 2304.

Massachusetts. Period. ical, 2216.

Sting of the, $371,372,407$.

tibicen, 920, 1034, 1546.

tredecim = Tibicen tredecim.

Twigs puuctured by periodical, 1055. rears, 51.

Cicadas, 26, 2311.

Cotton-wor'ms and, 1997.

Destroyiug, 2305.

and walling-sticks, 920.

Cicadidice, 431.

Cicadula exitiosa, 1766.

Cicindcla l'cpanda, 1763.

6-guttata, $34 \%$.

vulgaris, 628 .

Cicindelidæ, 719 .

Cimbex amcricana, 699, 1380, 1514, 2291, 2333, 2418. laportei $=$ C. americana.

Cioidæ, 1937.

Circotettix maculatus n. sp., 1959.

Circular No. 1, United States Entomological Commission, 1575.

2, United States Entomological Com. mission, 1576.

9, U. S. Dept. Agric., Div. Ent., 2303.

Cirrhoplianus triangulifer, 2189.

Cirrospilus esurus $n . s p ., 1712=$ Tetrastichus csurus.

flavicinctus $n . s p$. , in Lintner's first report. (See foot-note 1, p. 379.)

Cis fuscipes, 1737.

Citheronia regalis, $425,629,702,775,803,860,1087$, 1275.

Clemens, B. Obituary 223.

Cleonus $s p ., 1755$.

Cleora. Evergreen, 2363.

Clerid $x, 1363$.

Clerus nigripes $=$ C. 4-guttatus.

4-guttatus, 200.

Click-beetle larva, 1643 .

beetles, $84,351,1625$.

Climate on Cicada septeudecim. The influence of 2329.

for Doryphora, 1412.

on prolongation of life of insects. Effects of, 1129.

Climbing cut-worms, 1059.

Clisiocampa americana, $66,77,112,240,277,336,350$, $363,642,819,1181,1301,1352 ; 2238$.

disstria, $210,291,328,363,645,616,688$, 1127, 1181, 1200, 1301, 1331.

sylvatica $=$ C. disstria.

Cloantha derupta, 2410.

Clœ dubia n. $s p ., 24$.

ferrnginea $n . s p ., 24$.

fluctuans $n . s p ., 24$.

mendax $n . s p, 24$.

Close of the filst rolume, 701.

Clostera americana = Ich thyura inclusa.

Clothes moths, 70, 1633 .

observed in the United States, 2146. 
Clover. Army-worm notes and inquirics, its work on, 1877.

beetle. Flarescent, 2394.

Bumble-becs vs. red, 2376.

enemy. New imported, 2028.

hay-worm, 1363.

Army-worm vs., 2090.

Clover. Insects AFFecting, 1690, 2050.

A sopia costalis, 83, 675, 948, 1132, 1363, 2090.

Cecidomyia leguminicola, 1690, 1721, 2238.

Drasteria ercchtea, 1459.

Hylesinus trifolii, 1690, 1721, 1777, 1846.

Leucania nnipuncta, 1877.

Oscinis sp., 2394,

Plytouomus punctatus, 2010, 2028, 2061, 2119.

Pyralis olinalis =- A sopia costalis.

Sitones flavescens, 2394.

Clover-leaf beetle, 2119.

weevil. Furtler uotes on, 2061.

New imported enemy to, 2010.

root borer, 1721, 1846, 2512.

secd midge, 1721, 2238, 2291.

stem maggot, 2394.

Webster, F.M. Insects affccting white, 2394.

weevil, 1777.

worms, 83, 675, 948, 1132.

Clnbberl tortoise beetle, 1127,1558 .

Lal'va of, 1238.

Clnster flies. Notes on, 2174. t1 $y, 2128$.

Clydonopteron n.g., 1929. tecomse $n . s p ., 1929$.

Clytus capræa $=$ Neoclytns capræa. Oak, 2267.

pictus $=$ Cyllene pictus.

robiniæ $=$ Cyllene robinix.

speciosus $=$ Plagionotus speciosus

Coccid mistaken for a gall, 1972.

Coccidæ, 1329, 1883, 1968, 2088, 2137, 2235, 2520.

Means agrainst, 104, 218, 264, 301, 487, 508,

944, 2372, 2373, 2403.

Monograph of, 1828.

Coccinella mnnda $=$ C. sanguinca . sanguinea, 6 .

Coccinellid $x, 69,322,323,639$, 894, 1883, 1956, 2119. to birds. Relations of Carabidæ and, 2152.

Food relations of Carabidas and, 2151.

Habits of, 125.

Coccotorus scntellaris, $33,34,42,254,373,377,1301$, 1378.

Coccns, 159.

harrisii $=$ Chionaspis furfurus.

Cochylis hilarana, 1059.

Cocklebnr. Rhodobaenus 13-punctatus on, 1301. Sphenophorus, 1301.

Cockroach eggs, 573.

Cockroaches. Means against, 1197.

Cockscomb elm gall, 1384:

Codling moth, 57, 307, 373, 1022, 1059, 1127, 1254, $1329,1334,1363,1476,1677,2119$, $2293,2418$.

again, 1301, 1311.

heresies, 1398.
Codling moth, jarriug down infested frnit, 1318.

\section{Michigau apples and, 1677.}

Wier's trap, 1334.

Coliodes inxqualis = Craponins inæqualis.

Cœlodasys unicornis, $749,880,1280$.

Coffee-borer, 498.

Cohn, F. The Hessian $\mathrm{Ag}$ in Silesia in 1869, 2267.

Colaspis, 372.

barbara, 1301.

flavida, 129, 133, 135, 231,993, 1301, 1311. 1904.

Grape-vine, 231, 1301.

Cold appliod to chrysalids of butterflies. Effects of, 1778 .

on Curculio. Influence of extreme, 1335.

and hibernating apple-worms. Severe, 2037.

on insects. Effects of severe, 1818.

the scale insects of the orange in Florida. Voyle, J. Effects of, 2277.

Coleophora. Apple, 1721.

mali rorolla $n$. sp., 1721.

Coleoptera, 1329, 1904, 2267.

Classification of North American, 2085.

Myrmicophilons, 2105.

of North America. The new classif. cation of, 2175 .

Parasitic, 2353.

Willow-galls made by, 46.

Coleopterorum. Catalogus, 1866.

Coleopterous cave fauna of Kentucky, 2033. larva. Remarkable, 40.

Colias. The genus, 2259 .

philodice, 461 .

Collectiug and prescrving insects, 881, 1057.

Colonies. Silk-culture in the, 2278.

Colopha ulmicola, 27, 137, 151, 518, 1384, 1678.

Colorado beetie poisonous? Is the, 1405 .

cabbage flea-beetle, 2291.

glasshopper, 502.

potato-beetle, 21, 991, 1059, 1311, 1329 , $1363,1423,1482,1558$, $1570,2291,2294,2418$.

abroad, 1364, 1407, 1431 .

again, 1301.

Bogus, 1558.

in Europe, 1597.

Experieuce with the, 1518.

Inquiries coucerning the, 1491.

Insect euemies of the, 411.

Mite parasite of the, 1505 .

Native home of the, 1462.

in New Hampshire, 1859.

Now York, 1379.

Onward march of the, 1218.

poisonorts? Is the, 1483.

Poisouous qualities of the, 1425.

Specific for, 1490 .

potato-bug, 293, 334, 366 .

Bogas, 519. 
Colorado potato-bug. Poisonous qualities of the, 1101.

bugs. To destroy, 650 .

Coloration in insects. Unity of, 50.

Come. Still they, 908.

Common Curculio and its allies, 254.

flesh-fly, 1423, 1570, 1625, 1643.

longicorn pine-borer, 2291.

Mas beetle. Eggs of , 1329.

Commoner insects. Notes on our, 1802.

Companion wheat-fly, 2394.

Complimentary, 504.

Compositæ. Antistrophus confined to the, 1131.

Compsomyia macellaria, 2256.

Comstock on the classification of insects, 2390 .

Diaspinæ, 2227.

J.H. Report on miscellaneous insects, 2119.

Conchylis erigeronana $n . s p ., 1968$.

wotherana $n .8 p ., 1968$.

Conclusions. Jumping at, 253.

Cone-nose. Blood-sucking, 795, 854.

Confessing the corn, 256.

Coufounding friend with foe, 1378.

Conocephalus, 2267.

Conorhinus. Blood.sucking, 2291.

sanguisugus, $497,795,854$.

Conotrackelus, 934 .

$$
\begin{aligned}
& \text { anaglypticus, } 372 . \\
& \text { cratægi } n . s p ., 35,358,1301,1358 . \\
& \text { geminatus, } 34 . \\
& \text { nenuphar, } 6,33,42,50,98,188,237,254 \text {, } \\
& 290,329,367,372,373,377,387,439, \\
& 487,501,566,589,620,649,680,703, \\
& 873,930,958,978,1056,1059,1062, \\
& 1069,1071,1129,1135,1173,1177, \\
& 1201,1214,1258,1301,1325,1357, \\
& 1358,1372,1477,1685,2230,2296 . \\
& \text { puncticollis } n . s p ., 34=\text { C. gemina. } \\
& \text { tus. }
\end{aligned}
$$

Controlling sex in butterflies, 1352.

Convolulatex, Insects, 1238.

Cook on insecticides. Review of, 2501.

Coolse's injurious insects of the orchard. Review of, 2245.

Copidryas gloveri, 2486.

Copper underwing. Spattered, 1301.

Copris carolina, 416.

Coptocycla, 1238.

aurichalcca, 681, 736, 802, 1127, 1510.

bivittata = Cassida bivittata.

clavata, $693,742,767,1238,1558$.

guttata, 1127, 1510.

nigripes $=$ Cassida nigripes

Coquillett, D. W. Remedies for cottony cushion. scale, 2394.

Report on the gas treatment for scale insects, 2418.

locusts of the San Joaquin Val. ley, California, 2363.

prodnction and manufacture of buhach, 2364 .
Cordulia? molesta n. $s p ., 39$.

Cordjceps, 332, 478.

rasenelii, 594, 640 .

Coreus tristis = Anasa tristis

Corimelæna pulicaria, 354, 637, 741, 1046.

Corn bill-bug, 2119, 2291, 2418.

borer, 754 .

Confessing the, 256.

Curculio, 1042.

cut-worm, 1059 .

ear-worm, 2238.

foeding Syrphus-fir, 2422.

fields. Beetles in, 2317.

Corn. Insects AFFECTING, 2119.

A gonoderus pallipes, 2317.

Anthomyia zeas, 657, 1059, 1066.

A phis maidis, 23.

Butalis cerealella, 1232.

Calandra granaria, 1683 oryza, 1683.

Cetonia inda $=$ Euphoria inda.

Cut-worm, 1073.

Diabrotica longicornis, 1905, 2187.

Empretia stimulea, 754 .

Euphoria inda, 1655.

Gortyna uitela, 754. sp., 138.

Hadena sp., 1047.

Heliothis armigera, 192, 1301, 1664, 2119, 2238.

Ips fasciatus, 4 . 4 -signatus $=I$. fasciatus.

Lepidopteron, 162.

Mesograpta polita, 2422 .

Noctuid, 181.

Pempelia lignosella, 2119.

Sphenophori, 2030.

Sphenophorus robustus, 2119. sculptilis, 337, 1042, 1301. zeas $=$ S. sculptilis.

Corn insects. Potato and, 138.

Larval habits of Sphenophori that attack, 2030.

A new'enemy to, 1905. foe of the, 337.

insect foe of green, 1655.

pest. Unknown, 1073.

plant louse, 2418.

root Diabrotica, 2187.

louse, a new enemy to the corn, 23.

rustic, 1059 .

Serious injury to stored and cribbed, 1683.

Sphenophorus, 1301.

stalk borer. Smaller, 2119.

Webster, F. M. Insects affecting, 2418.

worm, 192, 820, 1301.

Worm in 181.

worms, 162, 1047, 1664, 2119.

The war on, 1522.

Corrccted. A few errors, 977.

Correction, 939 .

Entomological, 1328.

Phylloxera, 1355.

Corrodentia, 2267.

Corticaria pumila, 2418.

Corycia vestaliata, 744 . 
Corydalus cornutus, $130,308,473,1329,1570$, 1584 . $1627,1652$.

Larral characters of, 1652.

Corynetes rufipes = Necrobia rufipes.

Corythuca ciliata, 200, 400.

Coscinoptera dominica, 1363, 2093.

Cossidie, Bailey, J. S. The tree borers of the family, 2253.

Cossus robiniz, 37, 245, 967, 1003, 1121.

Cotalpa lanigera, 40.

Cotton belt. Smith, E. A., 2343.

boll-worm, 2238.

bolls. Euryomia melancholica vs., 2451.

in Brazil, Branner, J. C. Insects injurious to, $227 \%$.

caterpillar, 1353, 1801.

caterpillars in Brazil, Branner, J. C., 2343. convention. Address at Atlanta, 2038.

crop and its enemies in Mexico, Central and South America, and the West Inlies. Report on the, 2343.

culture and the inscets affecting the plant at Bahia, Brazil, 1788a.

destroyers, 1886.

field mistaken for those of the cotton. worm. Chrysalids dug up in, 1790.

insects, 636.

CotTon. Insects AFFECTIN.

Aletia argillacea $=\mathbf{A}$. xylina.

xylina, 646, 1127, 1338, 1353, 1363, 1369, $1649,1657,1702,1719,1721,1722,1736$, $1758,1769,1814,1845,1852,1882,1886$, $1997,2038,2064,2067,2119,2130,2155$, $2164,2295,2343$.

Anowis xylina = A lotia xylina.

Euphoria melancholica, 2451.

Enryomiá melancholica $=$ Euphoria melan. cholica.

Gryllus sp., 2384.

Heliuthis armigera, 646, 1353, 2238, 2343

Hyperchiria io, 2343.

Saturnia io $=$ Hyperchiria io.

Spilosoma acræa, 2343.

Theclapeas? 1872.

Cotton inscets, Jones, R. W. Report on, 2343.

TV.J. Report on, 2343.

Kcrosene as a means against, 2164 .

moth. Habits of, 1758 .

Hibernation, 1728.

plant. Insects affecting, 1721 .

planters. Sugrestions to, 1832.

Plums and, 1477.

seeds in hot-beds. Sowing, 1772.

squares. Butterfly larvæ injurious to, 1872.

Cottouwood borers, 1525.

dagger, 1127.

A foe to, 1834 .

CotTowwood. INseCts AFFECTING.

Acronycta lepusculina, 1127.

Aphid, 495.

Drasteria ercchtea, 1459.

Lina scripta, 1654, 1834, 2291.

Pemphigus populicaulis, 446, 713.
CotTonwood. Insects AFFECTING-Continued.

- Pemphigus ragahundus, 446.

Plectrodera scalator, 1525.

Saperda calcarata, 71.

Cottonwood killer, 1654.

leaf beetle. Streaked, 2291, galls, 713 .

Unsightly galls on, 446.

Worms on, 1459.

Cotton-worm, 1127, 1363, 1619, 1702, 1719, 2077, 2119, 2130, 2164, 2295.

articles in tho News, 1719.

Barnard, W.S. Tests of machinery for destroying, 2253.

Bulletin on the, 1736.

Chrysalids dug up in corn-fields mistaken for those of the, 1790 .

damage in 1881, 2119.

To destroy the, 1338.

destroyer. Best, 1882.

Early appearance of, 184.

Facts about, 1657.

How to manage the, 1831. use Paris green for the, 1544.

injury in regions overflowed by Mississippi. Protection from, 2119.

investigation, 1833.

Jones, R. W. Obserrations and ex. periments on, 2164.

moth hibernation, 1953.

Not the, 1773.

notes from Vera Cruz, Mexico. In. teresting, 1845.

Orange insects and, 2067.

parasites, 1712.

Parasites bred from, 1722 .

Poisoning devices for the, 2119.

Possille food-plants for, 2064, 2119, 2155.

in prairie bclt. First appcarance of, 1852.

question of hibernation settled, 2119.

A remedy for the, 1369.

Report on, 2164.

in-south Texas in 1883. Anderson, E. H., 2253.

Sowing cotton-seeds in hot-beds as a nieans against the, 1772 .

in the United States, 1769.

Cotton-worms, 2291.

and Cicadas, 1997.

Cottony cushion-scale, 2394, 2418.

Coquillett, D. W. Reme. dies for, 2394.

Koebele, A. Remedies for, 2394.

maple-scale, 1816, 2:91.

scale insect on maples, 1515.

Couper's thorn-leaf gall. Mr., 376.

Crab-apple borers, 602.

Crack-jaw names, 592.

Crambus. Vagabond, 2119.

vulgivagellus, 1990, 2029, 2119.

Cranberry fruit wolm, 2291, 2349.

galls, 194. 
CRANBERRy. INEECTS AFFECTING,

Acrohasis vaceinii, 2291.

Cecidomyia sp., 194 .

Phytopus sp., 2493.

Cranberry leaf-folder, 2291.

Smith, J.B. Report on insects affect.

Crane-flies, 1278. ing the hop and the, 2277, 2291.

fly larva, 512.

Craponius inæqualis, $367,373,1059$.

Cratægus. Insects on, 376.

Cratonychus incertus $=$ Melanotus incertus.

Cratypedes pntnami, 1959.

Cremastochilus, 2105.

Creophilus villosus, 805.

Crepidodera brevis, 1782

cucumeris, $357,401,1056,1059,1558$, 1782.

Distribution of species of, 1782 .

helxines, 358 .

parvula, 1782.

Crescent. The little Turk and his, 329 .

Cribbed corn. Serious injury to, 1683.

Cricket. Grapes cut by a tree, 414 .

in Louisiana. Destructive, 2384.

in raspberry canes. Eggs of tree, 2195.

Tree, 251, 953, 961, 999.

Snowy tre日, 2291.

Western, 1959, 2267.

Bruner, L. Report on, 2267. Histology of, 1959.

Crickets, 143, 1363.

Mole, 1270.

Crioceris asparagi, 524, 2135.

12-punctata, 2135

Crippled moths, 729 .

Critic criticised, 222, 942.

Criticism. Fliendly, 1307.

Crop gall-gnat, Wagner, B. Observations on the new, 2267.

Croton-bug as a library pest, 1717 .

Cruel bug.hunters, 440.

Crumpler. Apple-leaf, 949.

in Georgia. Rascal, 1962.

mistaken for Curculio. Apple-leaf 1069.

Rascal leaf, $311,373,1311,1580$

Cryptocentrus $n \cdot g ., 385=$ Mesoleius.

Cryptorhopalum, 1746.

Cryptus albicaligatus $n . s p ., 385$.

alhisoleatus n. sp., 385 .

annulicornis = Pimpla annulicornis.

cecropia, 1311.

cinctipes $n . s p ., 385$.

conquisitor $=$ Pimpla conquisitor.

inquisitor = Pimpla inquisitor.

junceus = Linoceras junceus.

nigricalceatus $n .8 p$., 385.

nuncius, 1112

picticoxus, 385 .

pleurivinctus $=$ Pimpla conquisitor

rhomhoidalis $n . s p ., 385$.

rufifrons $n .8 p ., 385$.

samiæ, 2343.

Cteniscus alhilineatus n. $s p ., 385$.

ornatus, 385.
Ctenucha latreilliana $=$ C. virginica virginica, 1241.

Cucumber beetle. Striped, 773, 1127, 2238 . bug. Striped, 148. flea-beetle, 1059, 1558.

Cucumber. Insects AFFEcting.

Diabrotica vittata, 148, 773 .

Eudioptis nitidalis, 808, 843 .

Phakellura nitidalis =Eudioptis nitidalis.

Cucumber. Worm boring in, 808,843 .

Cucnibitaceous vines. Insects affecting, 1127.

Culex, 625.

mosquito, 2185.

pipiens, 2071.

Cnlicidæ, 603, 2162.

Cupulifere. Cynips confined to, 1131.

Curculio, 958, 978, 1062, 1080, 1127.

again. Comparative scarcity of the, 703. and its allies. Common, 254.

Apple, 1176, 1301.

leaf crumpler mistaken for the, 1069.

snout-beetle or four-humped, 1088.

and bark-lice, 487.

hroeds in apple. Plnm, 1214.

Carabidæ feeding on, 372.

catcher, 875 .

$$
\text { Hull's, 372, 651, } 875 .
$$

Corn, 1042.

extermination possible. Great discov. ery, 1173.

Fighting the, 237.

Flea-beetles and, 873 .

flies by night. How the, 706 .

Four-humped, 1088.

Gas-waste vs., 549.

go underground to transform? Does the apple, 1228.

humbug. Another new, 589.

A new, 680 .

Influence of extreme cold on the, 1335.

injurious to grape, 267.

Means against the, 290 .

natural history and how tó catch him.

Plum, 1372.

parasite. Porizon, 1301.

Sigalphus, 1301.

Parasites of the plum, 1751, 1795.

Paris green for the, 1258.

Plum, 1059, 1129, 1301, 2296.

To protect plums from the, 1071 .

Quince, 1301.

remedies, 566 .

remedy. The new, 1177.

Ransom, 1201.

scarcer than last year, 620 .

Is the, 649 .

trap. Smith's patent, 969.

Use of the word, 1069 .

Curculionidae. Monograph of, 1828.

Curcnlios on pears, 1358.

Currant bolers, 481 .

bush borer, 974 . 
Currant, Currant-worms and black, 1079. Four.lined leaf.bug o11, 715. and gooseberry worms, 1570.

Currayt. Insects afFecting.

IEgeria tipuliformis, 340, 481, 974, 2238.

Alcathco caudatum, 481.

Amblycorypha oblongifolia, 1157.

Aphis ribis $=$ Myzus ribis.

Capsus 4-vittatus = Pnecilocapsus lineatus.

Ellopia ribearia $=$ Eufitchia ribearia.

Eufitchia ribearia, 176, 364, 772, 877, 1224.

Mytilaspis pomicorticis= $\mathbf{M}$. pomorum.

Myzus ribis, 304 . pomorum, 973

Nematus ribesii, 78, 340, 364, 380, 381, 772, 1031, $1224,1570,1696,2238$.

ribis $=\mathrm{N}$. ribesii.

ventricosus $=\mathrm{N}$. ribesii.

Phylloptera oblongifolia = Amblycorypha ob. longifolia.

Pocilocapsus lineatus, 715.

Pristiphora grossulariæ, 176, 364, 772, 1570, 2238.

Prosopis affinis, 1171.

Psenocerus sipernotatus, 481.

Silvanus surinamensis, 1260.

Tenthredinid, 136.

Trochilium tipuliformis= Ageria tipnli . formis.

caudatum = Alcatho caudatum .

Carrant plant-lice, 304.

louse, 322.

stalk-borer, 2238.

worm, 877, 1204 .

Imported, 1127, 1570, 2238.

Native, $1570,2238$.

Pear-slug and, 1031.

worms, 361, 882, 1696.

Destructive, 78.

Gooseberry and, 772.

Currants. Beetle in dried English, 1260.

Green wormas on gooseberries and, 136.

Cnshion-scale. Cottony, 2394, 2418.

Coquillett, D. W. Reme dies for, 2394.

Koebele, A. Remedies for, 2394.

Cushions. Ravages of moths in, 1731.

Cussed red-leg, 1598.

Cuterebra buccata, 526.

Cut-worm, 868,992.

Climbing, 1059.

Corn, 1059.

Dark-sided, 281, 1059, 2-91, 2363.

Ding $5,1059$.

eggs, 1095.

Glass, 1059, 2291, 2394.

Granulated, 2291.

Greasy, 1059, 2291, 2418.

lion, $1059,1314$.

moth. Eggs of, 607.

Shagreened, 2291.

Small whito bristl 5,1059 ,

Speckled, 1059, 2291.
Cnt-worm. Variegated, 1059, 2291.

W-marked, 1059, 2291.

Westeru striped, 1059.

Wheat, 1059.

Fellow-headed, 1059.

Cut-worms, 3, 85, 321, 658, 914, 1059, 1315, 2238, 2291.

Cabbage, 2291.

A chapter on, 964.

Climbing, 321, 359.

destroying recently sown wheat, 455 .

Means against, 226, 312, 1059, 2387.

Novel facts about, 901.

originate? How, 787 .

and other insects? Can land be in. sured against, 801.

parasites, 349 .

Remedy for cabbage, 2291.

Ridding the ground of, 2310.

severing cabbage-plants, 626 .

Smilax injured by, 1941.

from the stomuch of a robin, 1873.

Tree, 228, 281.

Cybister fimbriolatus, 750,816 .

Cybocephalus californicus, 2079.

Habits of, 2079.

nigritulus, 2079.

Cyclocephala immaculata, 1236.

Cyclone nozzle, 2327.

Cylindrical Orthosoma, 1059.

Cyllene, 560.

decorus, 50.

pictus, $45,50,55,89,269,308,560,828,941$, 1516.

robinire, $37,45,50,55,141.308,472,560,828$, $921,941,967,1196,1250,1288,1516$.

Cynipid gall on oak twigs, 1822.

Cynipidæ, 518, 799, 821, 2072, 2343.

Dimorphism in, 41, 1980.

Illinois, 41.

Important work on, 2125.

List of, 41.

New classification, 41.

Synoptic table of genera, 821.

Cynips, 1131, 1559.

aciculata $=$ Amphibolips spongifica.

bicolor = Rhodites bicolor.

confined to Cupuliferæ, 1131.

Dimorphism in, 41.

fecundatrix, 1606.

galla-tinctorix, 1560.

in. sp., 1822.

q.-califormica $=$ Andricus q.-californica.

q.-lecidua, 1925.

q.-erinacei $n . s p ., 41=$ Acraspis q.-eriracei.

q.-flocei $n .8 p ., 41=$ Andricus q.-flocci.

q.-forticornis $n . s p ., 41=$ Biorhiza forticor. nis.

q.-frondosa, $821,774,1666$.

q.-glandulus n. $8 p$., 1606.

q.-inanis = Amphibolips q.-inanis.

q. mamma n. sp., $518=$ Holcaspis mamma.

q.-mellaria n. $s p ., 1842$.

q.-operator $=$ A udricus operator.

q.-operatula, 1352 . 
Cynips, q. pilulæn. sp., 41=Cecidomyia q. $\cdot$ pilulæ. q.-podagræ $n . s p \cdot, 41=$ Andricus $q \cdot \cdot$ poda græo.

q.-pruuus 2ъ. sp., $518=$ A mphibolips q.-prunus.

q.-punctata $=$ Andricus q.-punctata.

q.-sal tatoring $=$ Neurcterus q.-Saltatorius. q.-spongifica $=\Delta$ mphibilops q.-spongifica. seminator $=$ Andricus seminator.

sp., 799.

terminalis, 1448.

Cynthia atalanta $=$ Pyrameis atalanta. cardui $=$ Pyrameis cardui.

Cypress. Cecidomyia cupressi-ananassa on, 1180. galls, 1180 .

Cyrtoncura a parasite or a scavenger? Is, 2102. stabulans, 2102, 2343.

Cytoleichus sarcoptoides, 2135, 2157.

Cytophyllus concavus, 516, 569, 1005, 1157, 1363, 2276.

Dactylosphæra caryæ-semen $n . s p ., 373=$ Phylloxera carya-semen.

vitifolire = Phylloxera vastatrix.

Dactylosphæridre, 1301.

Dagger. Cottonwood, 1127.

Smeared, $13 \sim 1$.

Dahlia and aster stalk-borer, 943.

Gortyna nitela injuring, 862, 940, 1009 .

stalk-borer, 862, 1009.

Daisy as an insecticide. Ox-eye, 1861.

Dilkota. Locust flights in, 2007.

Daliruma convolutella, 1059.

Dana, J. D. Criticism of the eutomelogical views of, 44 .

and his entomological speculations. Professor, 82.

Danaidæ, 613, 1301.

Danais archippus, $406,461,613,1235,1301,1340,1535$, $1622,1635,1711,1756,1770,2052$.

Dangerous looking, 814.

Dapsilia rutilana, 1713, 1721.

Darapsa myron = Ampelophaga myron.

Dardanelles. Sarcophaga lineata destructive to locusts in, 2075.

Dark grape-worm, 763.

sided cut-worm, 1059, 2291, 2363.

Darning-needle. Devil's, 1709.

1) arwin's work in entomology, 2129.

Dascyllid in atomarl of black bass, 1792.

Dasyllis thoracica, 1226.

Datana contracta, 50 .

ministra, 50,132,151, 165, 467, 922, 1045, $1229,2222,2333$.

Decatoma dıbia $n . s p ., 384=$ var. of rarians. excrucians $n . s p ., 384=$ var. of nigri. ceps.

byalipennis $n . s p ., 384$.

ni uriceps $2 . s p ., 384$.

uubilistigua n. $s p,, 384$.

simplicistigma n. $s p ., 384$.

sp., 536.

varians $n . s p ., 384$.

Defense. Inexpert, 2476.

Delicate long-sting, 1329.

Deloyala $=$ Coptocycla.

clavata $=$ Coptocycla clavata.
Deltocephalus xanthoneurus, 2116.

Delusion. A popular, 5:5.

Dendrotettix n.g., 2410.

quercus $n . s p ., 2410$.

Derseocoris rapidus $=$ Calocoris rapidus.

Dermanyssus avinm, 1308. gallina, 1308.

Dermatobia hominis, 497.

Dermatoptera, 2267.

Dermestes lardarius, 72, 726, 1190, 1240, 1703. Toothed, 2363. vulpinus, 2363.

Dermestid $x, 1746,2133,2180$. Means against, 56, 246, 462 .

Deserved honor, 2124.

Desmia maculalis, 468, 993, 1056, 1158, 1301, 1569 1579.

Desmocerus palliatus, 358 .

Uestructive larvæ, 722 .

locusts. Literature of, 1959.

Devastating locust, 2363.

Devil's darning-needle, 1709. riding-hor $\$$ e, $457,1059$.

Dexia rustica, 2260.

Dexidæ. Larval habits of, 2260 .

Diabrotica. Corn-root, 2187.

12-punctata, 123, 687, 2418.

Long-horned, 1905.

longicornis, 169, 1905, 2187.

Twelve-spotted, 687, 1127, 2418.

vittata, $123,148,175,355,772,897$, $2230,2238,2260$.

Diapheromera, 2267.

femorata, 144, 448, 920,1111, 1395, $1701,1709,1721,2276$.

relii $n . s p ., 15$.

Diaspinx. Comstock on the, 2227.

Diaspis harrisii $=$ Chionaspis furfurus.

rosæ, 1303 .

Diastrophus, 318, 1131.

cuscutæformis, 609.

nebulosus, 263, 610, 1121 .

Dicerca divaricata, 871, 1063, 2267.

Didictyum $n . g ., 1749==$ Hexaplasta. zigzag $n . s p .=$ Hexaplasta zigzag.

Diedrocephala flavipes $n . s p ., 1766,1767,2363$.

Differential locust, 1423, 2363.

Digger wasps, 309, 1643, 1959.

Dilar in North America, 2023.

Dilophus, 2076.

Diminished Pezomachrus, 1127.

Dimmock's inaugural dissertation, 2082.

Dimorphic asexual females. Lichtenstein's theory as to, 2072.

Dimorphism in Cynipidæ, 1980.

Cynips. 41.

Dytiscidæ, 28.

locusts, 1889.

Dingy cut-worm, 1059.

Dinoderus pusillus, 2104.

as a museum pest, 2104 ,

Dionea, $1499,1688$.

Diphryx prolatella, 2120.

Diplax rubicundula, 2007.

Diplodns luridus, 372.

Diplosis anuulipes n. sp., 46, 
Diplosis atricornis $n . s p ., 46$.

atrocularis $n . s p ., 46$.

decem-macnlata n. sp., 46.

found in phylloxera galls, 1901.

grassator, 2150 .

helianthi-bulla $n . s p ., 197$.

nigra, 2363, 2393.

Pear, 2363 .

- pyrivora $n$.sp., 2393.

septem-maculata $n . s p ., 46$.

tritici, $109,110,142,216,280,292,372,428$ $711,1512,1690,1721,2238$.

Diplotaxis not a vesicant, 1796 . sordida, 1926.

Diptera, 1329, $1736,2267$.

Parasitic, 2076.

Preparation of, 2041.

Swarming of, 2128, 2174.

Willow-galls marle bs, 46.

Dipterous enemies of the honey.bee, 704 .

Phylloxera vastatrix, 2150. galls of the willow, 46 .

larva on swallow, 153.

larve in human body, 2256.

Remarkable. 40.

Discontinuance of publication [of Am. Ent.], 2106.

Disease. Infesting Phylloxera with fungus, 1808.

Diseases of beneficial insects. Fungus, 1813. chinch-bug, 2143.

Disippus buttertly, 1301.

Pupa of, 1193.

Microgaster, 1301.

Disonycha alternata, 45 .

flaviventris, 1506.

Dissosteria carolina, 667.

Ditching for young locusts, 1488 .

Dobson, 780 .

Dock. Galls on supposed, 1165.

Dock. INSECTS AFFECTING.

Gastroidca cyanea, 1165.

Gistrophysa cyanea= Gastroidea cyanea.

Doctoring fruit-trees again, 230 .

Doctors differ, 98.

Dog-day harvest.fly, 1546.

Dolerus arvensis, 358 . unicolor, 1989.

Dollars. That hundred and fifty million, 1647.

Jomesticated katydils, 1536.

Dominican case-bearer, 1363.

Dorthesia celastri, 1988.

characias, 1686, 1730.

Covering of egg-puncture mistakeu for, 1988.

viburni, 1988 .

Dol'yphora, 1639.

Climate for, 1412

10-lineata, 21, 32, 48, 50, 88, 94, 119, 171, $275,276,293,313,334,347$, $365,401,411,565,650,708$, $709,760,866,905,908,919$, $925,946,968,977,983,991$, $995,1019,1027,1044,10.56$, $1059,1068,1096,1101,1218$, $1301,1311,1325,1329,1363$, $1364,1379,1391,1405,1407$,
Doryphora, 10-lineata, 1412, 1423, 1425, 1431, 1447, $1450,1462,1469,1480,1482$, $1490,1491,1505,1519,1524$, $1528,1558,1564,1570,1593$, $1597,1610,1639,1672,1714$, $1859,1948,1993,2081,2235$, $2291,2294$.

Fire cure for, 121.

juncta, 48, 50, 372, 401, 519, 1056, 1059, $1431,1450,1558,1672,2096,2215$.

Dotted-legged plant bug 1311.

Double cocoons. The shedding of trachex, $171 j$. Dragon-flies, 1707.

Dragon-fly. Large, 759.

Drasteria erechtea, 631.1459, 2343.

Drasterius anabilis, 1798, 1905. dorsalis, 2418.

Drepanosiphum, 1678.

Dried leares as food for lepidopterous larva, 2159.

Driving nails into fruit-trees, 87. potato-beetles, 1044.

Drones to death? Do worker bees sting, 1145.

Drop of gold, 775 . wor'm, 1059, 1090, 1650 .

Drosera, 1499, 1688.

Drosophila amøena, 2119. ampelophila, 2119. nigricornis, 1607. sp., 1607.

Drought. Counection of locust invasion with the occurrence of, 1422.

on Hessian-fly. Effects of, 2031.

Insects and, 2100 .

Drug-store pests, $510,551$.

Dryobins sexfasciatus, 583 .

Dryocampa, 1352.

bicolor $=$ Sphingicampa bicolor.

pellucida $=$ D. virginiensis.

rubicunda, 244, 841, 915, 1329, 1352, $1357,2490$.

senatoria, 151, 783.

stigna, 488.

rirginiensis, 488.

Dutchman's pipo. Papilio philenor on, 1321, 1774. Worms on, 1321.

Dynastes tityrns, 580, 1216, 1292.

Dysdercus suturellus, 2343.

Dytiscid in stomach of black bass, 1792.

Dstiscid\%. Dimorphic, 28.

Dytiscus. Modo of feoding of the larva of, 2065.

Eacles imperialis, 1087, 1268.

Sarthqualie commotion and locust multiplication and migration, Swinton, A. H., 2267.

Eastern States. Supposed army-worm in New Tork and, 1990.

Eburia 4-geminata, 1014.

Eccopsis ferrugincana, 1968.

Hickory, 2363 .

monetiferana, 1968.

permundana, 2324.

Variegated, 2363.

Echthrus annulic rnis n. $8 p ., 385$.

Economic entomology, $1357,: 362$.

in California. Interest in, $20 \% 3$, 
Economic entomology in England, 1983.

Fostering the study of, 2142.

Importance of, 2238.

Iowa, 2197.

Recent advances in, 2281. inrestigations in the South and West, 1864

notes, $2220,2248$.

Ecpantheria scribonaria, 1140, 1153, 1311, 1802.

Ectobia germanica, 573, 1717, 2276.

Edema albifrons, 422, 913.

Edinburgh International Forestry Exhibit. Ro. port of, 2342.

Edwards' butterflics of North A merica (Review), $395,479,623,827$.

Egg-fecding mites, 1637

parasite. Anthomyia, 1570, 1625, 1643.

parasites of Acrididæ, 2355.

Efficacy of chrlcid, 2115.

plant. Enemies of, 2096, 2215.

EGG-PLANT. INSECTS AFFECTING.

Cassida texana, 2096, 2215, 2235.

Doryphora 10-lineata, 21. juncta, 2096, 2215, 2235.

Egg puncture mistaken for Dorthesia. Covering of, 1988.

punctures in rasplerry and grape-rines, 2195. sack of some unknown spider, 1144. slits made by Homoptera, 79.

Eggs in or on canes or twigs, 1329.

Experiments with locust, 1572. growth of insect, 2241.

'hatch? Will unimpregnated, 1029.

in maple twigs. Rows of, 665 .

Mass of, 65, 240.

of moth, 611 .

but parasitic cocoons. Not, 1290 .

in peach twigs, 554 .

pear twigs. Rows of, 577.

on su gar-maple, 350 .

in sumach, 18.

Egypt. Bug-hunter in, 372

Eight-spotted forester, 343, 1059, 1127, 1363.

Eighth Report State Entomologist of Missouri, 1482.

Einige unserer schädlicherer Insekten, 1325.

Elachistus enplectri, 2343.

Elaphidion parallelum $=$ E. villosum. putator $=$ E. villosum

tectum, 1602.

villosum, 288, 793, 839, 1556, 2267.

Elateridæ, 3, 224, 430, 740, 846, 892, 932, 1030, 1504 $1522,1866,2238$.

Monograph of, 1828.

Elder. Attacus cccropia on, 1533.

Cecropia worm on, 1533.

Elephantiasis or Filaria disease, 2185.

Ellopıa ribearia $=$ Eufitchia ribearia.

Elm. Enemics of the 1350.

enemy, 1520.

gall. Cockscomb, 1384

ELM. INSECTS AFFECTING.

Cimbex americana,

$$
\text { Liporteı }=\mathrm{C} \text {. amểricana }
$$

Colopha ulmicola, 1384,
Elm. Insects AfFeCting -Continued.

Dryobius sexfasciatus, 583.

Galeruca calmariensis = G. xanthomelæna xanthomelæna, 1350, 1520, 1931, 2188, 2232, 2304, 2325, 2378, 2394.

Monocesta coryli, 1721.

Pemphiginæ, 1653 .

Physocnemum brevilineum, 696.

Saperda lateralis, 583.

Schizoneura rileri, 1059.

Tremex columba, 928.

Elm-leaf beetle, 2188.

Great, 1721.

Imported, 2232, 2304, 2325, 2378, 2394.

Notes on the imported, 1931.

and pcar-tree borer, 928 .

tree borer, 583, 696

depredators, 2414

louse. Woolly, 1059 .

saw-fly, 699

Emmon's New York report, 84.

Emperor. Eyed, 1363.

Tawny, 1363.

Emphrtns maculatus = Harpiphorus maculatus.

Empoa albicans $n . s p ., 22$.

Empoasca n. g., 22.

abnol'mis, 22.

consobrina $n . s p ., 22$.

malefica $=$ E. viridescens.

maligna $=$ E. obtusa.

obtusa n. $s p ., 22$

viridescens $n . s p ., 22,30,79$.

Empretia stimulea, 60, 161, 424, 811, 829, 837, 1092.

Emulsions. Kerosene, 2291.

of petroleum as insecticides, 2134.

and their value as insecticides, 2126,2200 .

Enchenopa binotata, 725, 1913, 1988.

Enchophyllum binotatum = Enchenopa binotata

Endrosa quercus = Lachnosterna quereus.

England. Doryphora 10-lineata in, 2081.

Economic entomology in, 1983.

Hessian-fly in, 2395.

Introduction of the Hessian-fly into, 2398.

English currants. Beetles in, 1260.

sparrow. Anent the, 1667.

Ennomos alniaria, 75.

magnaria $=\mathrm{E}$. alniaria.

subsignaria = Eudalimia subsignar ia

Entilia concara $=$ Publilia concava.

sinuata, 163.

Entomography of Hirmoneura, 2275.

Entomological, 371, 869, 893, 1411.

breakfast, 2311.

cabinet. Walsh, 1107.

circular. A recent British, 2509.

collection, 1328.

commission. Appropriation for, 1843 . Bulletin No. 1, 1577.

2,1578

3,1736 .

6, 2026 .

Circular No. 1, 1575.

$2,15 \pi 6$, 
Entomological commission. Report. First, 1643. Second, 1959. Third, 2267.

Fourth, 2343.

Reports of the U.S. 1757.

correction, 1328.

ignorance in the North, 431.

information, 1351.

South, 390 .

notes, 2, 1396, 1554, 1609, 1610,1681, $1958,2015,2058,2066,2135$ $2147,2168,2184,2192,2219$, $2228,2247,2261$.

of the year, 2235 .

papers read at A. A. A. S., 1893.

periodicals. New, 2056.

quackery, 439.

queries. A bundle of, 556 .

question, 1463.

reports. Index to Ontario, 2228.

Missonri, 1680.

Society. American, 621 . Address of president before WVashington, 2335.

specimens. Care of, 2200.

speculations of the N.E. school of naturalists, 44 .

Professor Dana and his, 82.

work at the Department of Agriculture, 1892.

works, 831 . wanted, 1529.

Entomologist. American, 1309.

Salutatory, 386 .

Canadian (Review), 395, 479, 827. caught napping, 1110. of Illinois. State, 327.

for Minnesota. A State, 1108. of Missonri. First report of State, 1059 .

Second, 1127. Third, 1301.

Fourth, 1311.

Fifth, 1329.

Sixth, 1363

Seventh, 1423.

Eighth, 1482.

Ninth, 1570.

Index to reports of State, 2026.

for New York. State, 1863.

New York without an, 1330.

One day's journal of a State, 383.

for the Pacific coast, 2022.

Report U. S., 1878, 1721.

$1881-' 82,2119$.
$1883,2232$.
$1884,2291$.
$1885,2363$.
$1886,2394$.
$1887,2418$.

in the South. Field for the, 1109.

Entomologists at Boston, 1894.

Death of noted, 1285 .
Entomoligists in Europe. Number of, 1865.

Self-taught, 276.

Entomology. Address on, 1454

all a humbug, 63 .

Best works on, 418.

Books useful for the study of, 418 .

in Buftalo, N. Y., 2035.

- California. Iuterest of economic, 2053.

Darwin's work in, 2129.

Descriptive, 1199.

Discussion on, 1391.

Economic, 1362.

in England. Economic, 1983.

Fostering the study of economic, 2142.

General truths in applied, 2291, 2292.

Importance of economis, 2238.

indeed run mad, 227, 1224.

in Iowa. Economic, 2197.

Lecture on, 1394.

at Minneapolis, 2212.

in Missonri, 1361.

New York, 2244, 2254.

Permanent subsection of, 2027.

and the phonograph, 2481.

Professor Riley to Dr. Schaffer, 2360. in reality. Practical, 914.

Tiecent advances in economic, 2281. horticultural, 2230.

its relation to agriculture and its adrancement, 1329.

Report Mliuois State Horticultural Society on, 1056.

Missomri, 1113, 1127.

Study of, 2345.

Work in, 202.

Entomophthora, 1813.

calopteni, 2240 .

Epeira, 1847.

riparia = Argiope riparia

sp., 1144.

spinea, 813.

Ephemera flaveola n. $s p ., 24$.

flies. A hard story, 1043.

myops n. sp., 39 .

Ephemerella n.g., 24. consimulis $n . s p ., 24$.

excrucians $n . s p ., 24$.

Ephemeridæ, 283, 525, 1043, 1205.

Ephemerina, 2267.

Ephemerinous genus Bætisca. Pupa of, 43.

Eplemeron, 283.

Ephestia interpunctella, 325, 1293, 1896. zeas $=$ E. interpunctella.

Ephiaites gigas n. sp., 385 . pusio n. sp., 385 . pygmæns n.sp., 385 .

Ephydra californica, 2205. gracilis, 2203. hians, 2203.

Epicærus imbricatus, 35, 296, 1301, 1868, 2291.

Epicauta, 1600, 1643, 1651, 2238, 2267. atrata $=\mathrm{E}$. penusylvanica. cinerea, $134,185,401,1056,1558,1600$. 
Epicauta corvina, 1206.

Larval characters and habits of, 1600. habits, 1387.

pennsylvanica, $38,134,185,284,362,401$, $732,1056,1558,1600$.

puncticollis, 1381.

vittata, $38,134,185,401,470,794,1056$, $1230,1558,1600,1860,1959$.

Epidemic disease of Caloptenus differentialis, 2240.

Epilachna borealis, 125, 417, 1289.

corrupta, 2135, 2235.

Epimeris. Grape-vine, 1301, 1363.

Epipocus punctatus, 2406.

Epitrix brevis = Crepilodera brevis. " cucumeris = Crepidodera cucumeris.

Distribution of species of, 1782.

hirtipennis = Crepidodera parviula.

Epizenxis. Spruce, 2363.

Erax, 1127.

bastardi, 1127, 1269.

Eriocampa cerasi, 1031, 1222, 1953, 1382, 2243.

Eriosoma cornicola n. sp., $27=$ schizonoura cornicolá.

fungicola $n .8 p ., 27=$ Schizoneura fungicola.

lanigera $=$ Schizoneura lanigera.

pyri = Schizoneura lanigera.

tessellata $=$ Pemphigus tessellata.

ulmi $n . s p ., 1059=$ Schizoneura nlmi.

Eristalis, 986.

Errors corrected, A few, 977.

Erynnis alce:e boring in stems of Malva sylvestris, 1602.

Erythroneura, 164.

australis $n .8 p ., 22$.

octonotata $n . s p ., 22$.

tricincta $=$ Typhlocyba tricincta.

vitifex $=$ Typhlocyba vitis.

vitis $=$ Typhlocyba vitis.

ziczac $n . s p ., 22$.

Eucalyptus. Galls on, 1965.

Enchætes egle, 413.

Euclemensia bassettella, 1972.

Eudalimia subsignaria, 75.

Eudamus tityrus, 787, 857.

Eudemis botrana, 557, 585, 792, 1059, 1232 .

Endioptis nitidalis, 808, 843, 1127.

Eudryas grata, 1127, 1363.

unio, 831, 1127, 1363.

Eufitchia ribearia, 176, 364, 772, 877, 1068, 1224, 1570.

Eumenes fraterna, 543, 1357, 1847.

Eumenia atala, 2410.

Eumenidæe, 770 .

Eunomia eagrus, 2242.

Euonymus latifolia? Chionaspis euonymii on, 2403. Scale on, 2403

Euparia castanea, 2105.

Eupelmus, 384, 1932, 2343.

allynii, 2060, 2063, 2332.

mira bilis, 384, 563, 1363.

ขs. Antigaster, 1978.

Euphanessa mendica, 2340.

Euphoria hirtipes, 2105.

inda, 447, 1655.

melancholica, 372, 522, 842 .
Euplectrus comstockii, 2343.

platyhypenæ, 2343.

Eupsalis minuta, 1363.

Enrope and America. Problem of the hop-plant louse in, 2400.

The Colorado potato-beetle in, 1597.

Grain Bruchus just imported from, 1120.

Hagen, H. A. The Hessian-fly not imported from, 2267.

Number of entomologists in, 1865.

European natural encmies of the asparagus beetle. I.ew, 2458.

parasites. Importing, 208.

Eurycreon rantalis, 2322, 2331, 2363.

Euryomia melancholica =Euphoria melancholica.

Euryptychia sa!igneana, 180, 1127, 2356.

Eurytoma abnormicornis $n .8 p,, 384$.

auriceps n. sp., 384 .

bicolor $n . s p ., 384$.

bolteri $n . s p ., 1059=$ var. of E. diastro. phi.

diastrophi n. sp., 384, 1131.

gigantea n. sp., 384 .

globulicola $n . s p ., 384=$ var. of prunicola prunicida n. $s p ., 38 t$.

punctiventris n. $s p ., 384$.

seminatrix $n . s p ., 384=$ var. of auriceps. sp., 62, 563 .

Eurytomid from stomach of Ohio shad, 1853.

Eurytomides, 384, 1223.

Euschistas fissilis, 2363.

Euthyrhynchns floridanus, 2472.

Euura orbitalis, 821.

perturbans $n . s p ., 197$.

s.-gemma n. sp., 197, $821=$ E. orbitalis.

s.-nodus n. sp., 197.

s. -ovum n. sp., 197, 821 .

Evagoras viridis = Diplodus luridus.

Evarthrus orbatus, 872.

Evergreen cleora, 2363.

and other forest trees in Now England and New York. Packard, A. S. Causes of destruction of, 2232,2291 , $2363,2364,2382$.

plant.lice, 1039.

Evergreens. Borers in, 1324.

Insects affecting, 271, 527, 1039, 1324, 2232, 2291, 2363

Exartema ferruginearum $n . s p ., 1968=$ Eccopsis ferruginearum.

montiferarum $n . s p ., \quad 1968=$ Eccopsis montiferarum.

Excursion. Agricultural editorial, 1349. to Rocky Mountains, 988.

Exenteron ornatus $n . s p ., 385^{\circ}=$ Cteniscus ornatus.

Exetastes illinoiensis, 385 .

suarcolens $n . s p ., 385$.

Exochiscus $2 . g ., 385=$ Orthocentrus. pusillas $n . s p .=$ Orthocentras pasil. lus.

Exochus albiceps $n . s p ., 385$.

aunulicrus n. sp., 385 .

atriccps $n .8 p ., 385$.

Exolista cecropiæ n. sp., 1112.

doryphoræ, 1059, 1431, 1450, 1672.

flavicauda $n . s p ., 1127,1442,1670$. 
Exorista lencanix $=$ Nemoræa leucanix. militaris $=$ Nemorrea lcucanire.

- osten-sackeni = Nemoræa Ieucanix.

Exothecus prodoxi $n .8 p ., 1831$.

Expected adrent of tho Iocust, 2307.

Extensilo penetrating organ in a gamasid mite, $16: 26$.

Fxterminator. Fruit.pest, 2372.

Extinguisher. Treat's insect, 531.

Extrene cold on the Curedio. Influence of, 1335.

Exuviation in flight, 19:1.

Exyra ridiugsii, 1411. semicrocea, $1385,1390$.

Eyed empcror, 1363.

Eyes and luminosity of fire-flies. Development of, 1840 .

None so blind as thoso who shut their, 275 .

Fagopsrum. Acrididse that eat, $16 \pm 5$.

Failure of tea-roses, 1708 .

Fall army-worm, 1256, 1267, 1282, 1301, 1482.

canker.worm, 1423, 1482, 2238.

web-worm, 1301, 1733, 2238, 2378, 2394.

on hickory, 460 .

Tent caterpillars and, 819.

wheat, Webster, F. M. Insects affocting, 2291, 2363, 2394.

Falling water. Moths attracted to, 2108.

False caterpillars on the pine, 985.

\section{Scotch and Anstrian pines, 1011.}

chinch-bug, 1329, 1423, 2291, 2418.

indigo gall-moth, 1127.

Walshia amorphella on, 1127.

Fatherless and mothcrless race. That, 1650. race. Somo further facts regarding that, 1658

Fatua denudata, 1733.

Fear. A gromudless, 284.

Foathers. Attagenus injuring, 56 .

Folting caused by a beetlc. Remarkable, 2113.

Feniseea tarquinius, 2359, 2361.

\section{Food-habits of, 2407.}

Notes on, 2369

Plant-feeding habit of, 2361.

- Fertilization of Yncca, 1329, 1336, 2171.

Furtilizers of alpine flowers, 1838.

Fertilizing plauts, 324.

Few errors col'ected, 977.

Fidia. Grape-vine, 1231.

longipes, 339 .

sp., 102.

viticida n. sp., 272, 339, 1059, 1231.

Field cricket, 2291.

crops. Insects injurious to, 2238.

for the entomologist in the South, 1109.

Fiory grouucl-bcetle, 1059.

Fifteen-spotted laris-bird, 959, 1311.

Fifth report State Entomologist of Missouri, 1329.

Fifty million dollars. That hundred and, 1647.

Fig insects, 2194.

Fighting the Carculio, 237.

Hessian-tly, 1587.

Fignier's Insect World (reviow), 408.

Filaria disease. Elephantiasis or, 2185. sanguinis-hominis, 2185.
Filbert grape. Grape-vine, 1329.

Fir Paraphia, 2363.

Fire blight, 22, 30, 149, 285

cure fur potato-beetles, 121.

flies, $396,1705$.

Development of eyes and luminosity of, 1840.

Intermittenco of phosphoresc snce, 1805. worm, 2291.

First report noxious insects of tho State of Iliinois, 373.

State entomologist of Missonri, 1059.

U. S. Entomological Commission, 1613.

rolume. Close of the, 701.

Fischer on naphthaliue as an insocticido. Review ot, 2274 .

Fish-fly. Large, 712, 903

Fitch. Dr. Asa, 1781.

Flat-headed apple-treo borer, 1059, 2238, 2267.

in horse-chestnut, 1316.

twig borer, $555,1423$.

borer in soit maples, 1250.

cherry-borer, 2267.

peach-borer, 2267.

spruce-borer, 2267.

Flavescent clover-beetle, 2394.

Flea-beetle, 1583.

Colorado cab bage, 2291.

Cucumber, 1558.

Grapo-vine, 298, 1252, 1301.

Larra of grape-vine, 10+1, 107t.

Striped, 2291.

Wary-striped, 348, 564, 2291.

in soung tobacco-plants, 1782

Zimunerinan's, 2291.

beetles, 636, 2418.

and Curculio, 873.

Moans against, 133.

Satisfactory remedy for, 2236.

like negro-bug, 1127, 1423, 2291, 2418.

Fleas foeding on lepidopterous larvæ, 2110.

Flesh-flies, 1643, 1736.

fly. Common, 1423, 1570, 1625, 1643.

Flesh-worms, 459.

Flies in rooms. Swarms of minute, 596 .

Sucking organs of, 2182.

Flight. Exuviation in, 1961.

in inseets is directer. How, 1891.

Flights east of tho Mississippi. Locust, 1549, 1613.

Locnst, 1590.

Floating apiaries, 1785.

Floods. One effect of the Mississippi, 2080.

Florida, Ashnead, W.H. Iieport on insocts in. jurions to garden erops in, 2388.

Voyle, J. Effects of colit on the scale in. insects of the oramgo in, 2277 .

Flour. Poisonous, 586.

and rye. Worms ill, 72.

Flouring-mills. Beetles in, 1261.

Flower-bng. Insidinus, 1127, 1423, 2418.

Flower-gardm. Insects in, 936.

Flowering ast. Coconns on, 950 .

Flowers. Fertilizers of alpine, 1838. 
Fluted-scale, 2389, 2418.

Recent California work against the, 2519.

Flying bug, 157.

locusts in Illinois, 1437, 1443.

Foe. Confounding fricnd with, 1378 .

to coru. A new, 337 .

cotton wood, 1834.

green corn. A new insect, 1655 .

Scarenger mistaken for a, 416.

Foes. Cherry plant.lico and their, 1251.

Some friends and, 1274.

Folsom, Cal., Koebele, A. Notes on locustsabout, 2363.

Food of Calopteron and Photinus, 2358.

habits of Feniseca tarquinius, 2407. ground-beetles, 1760.

longicorn beetles, 1902 .

Megilla maculata, $21 \$ 5$.

thrushcs, 1726.

of insectivorous plants, 1499 .

for lepidopterous larvæ. Dried leaves as, 2159.

man. Locusts as, 1481.

Number of molts and length of larval life as influenced by, 2167.

plants for the cotton-worm. Possible, 2064 2119,2155 .

of Samia cynthia, 2204.

relations of Carabidæ and Coccinellidæ, 2151.

Salt-water insects used as, 2203.

tor silk-wormś, 1319.

tront, 1142.

Forage crops. Insects injurions to, 2238 .

Forbes, S. A. Experiments on chinch-bugs, 2165.

For'Les' in restigations on the food of fresh-water fishes. Professor, 2515.

Forest insects. Larre of injurious, 2267.

Tent caterpillar of the, $645,688,1181,1200$, $1301,1331$.

tree insects, 2418.

Packard, A. S. Notes on, 2253.

trees in northern New England and New York, Packard, A. S. Causes of the destruction of evergrecn and other, 2232, 2291, 2363, 2364, 2382.

and weeds of Germany. Ratzeburg. Review, 1110.

Forester. Eight-spotted, 343, 1059, 1127, 1363.

Forestry exhibition. Report on the Edinburgh

international, 2342.

Forficula, 1798, 2267.

Formica aphidicola n. $s p ., 27$.

fusca, 2105, 2226.

latipes $n . s p ., 27=$ Lasius latipes.

rufa, 2105, 2114,

Formicidæ, 438, 1278, 1594, 1987.

Fossil tineids, 2084. .

Four-humped Cnrculio, 1088.

Apple-snont beetle or, 1088.

lined leaf-bug on currant, 715.

Fourth report State entomologist of Missouri, 1311.
Fourth report U. S. Entomological Commission, 2343.

Fowls. Internal mite on, 2157

Parasites on, 1308.

France affectod by Phyllosora. Half the vine area of, 2020.

Grape Phylloxera in, 2193.

Fraternal potter-wasp, 1127.

Friend. Another insect, 879 . with foc. Confounding, 1378. unmasked, 374 .

Friendly criticism, 1307. notes, 1306.

Friends and foes. Some, 1274.

Inquiring, 1642, 1656.

and insect foes. Insect, 38 .

Frog-spittle insects, 691 .

Frogs, 217.

Frosted lightning hopper, 1329.

Fruit culture in the South, 2265.

foe. A new, 35 .

and fruit trees. Insects injurious to 2238 .

Trimble's cnemies of, 187.

growers. Insects of interest to, 367 . in northern Illinois. Six worst enemics of, 37 .

insects in California, 2245.

invigorator agaiu. Best's, 530 .

Jarring lown infested, 1318.

pest exterminators, 2372.

Snout-beetles injurious to, 1302 .

trees again. Doctoring, 230

Driving nails into, 87.

Icerya purchasi, an insect injurions to, 2401 .

Fruit trees. Insects affecting.

Epicærus imbricatus, 35.

Ithycerus noveboracensis, 16.

Lytta ænea = Pomphopœa ænea.

Oncideres cingulata? 442, 443.

Pomphopœa ænөa, 1056.

Fruit trees. Insects injurious to, 16, 31 .

Tarred paper for, 1568 .

worm. Cranberry, 2291.

Tomato, 1136

Fruits and grains, Wobster, F. M. Experiments on the effect of punctures of Hemiptera on shrubs, 2382.

Fuchsia beotles, 133.

Fuchsias. Beetles injuring cabbages and, 1868

FuCHSIAS. INSECTS AFFECTING.

Haltica carinata, 133, 1868. exapta $=$ H. carinata.

Fulgoridæ, 737.

Fuller. Retirement of $\mathrm{Mr}$., 1910.

Fuller's rose-beetle, 1708, 1721, 2291.

$$
\begin{aligned}
& \text { in California, } 1740 . \\
& \text { Habits of, } 1708 . \\
& \text { Not, } 1825 .
\end{aligned}
$$

Fumago salicina, 2138.

Fumigation against orange scales, 2520 .

Fungoid growths, 500 .

Fungus in Cicada, 1809

diseasos of beneficial inserts, 1813.

Infecting Phylloxera with, 1808. 
Fungus foes, 1937.

glowths to destroy iusects. Cse of, 1808.

Remarkable parasitic, 1313.

White-grub, 594.

Fuzzy galls on blackberry twigs, 609.

Garl-fly. Shcep, 887 .

Galerita janus, 1824.

lecontei, 1824.

Galeruca calmariensis $=\mathrm{G}$. xanthomelæna. rufosanguinea - Adimonia rufosan gninea.

xanthomelæna, $1135,1350,1520,1931,2188$, 2232, 2304, 2325, 2378, 2379, 2414.

Gall on acorn-cups. A new oak, 1606.

blackberry, 263.

and raspberry canes. Gouty, 1771.

chestnut, 353.

Coccid mistaken for a, 1972.

Cockscornb elm, 1384.

flies, 294.

guat, Loew. Description of the rye, 2267.

Waguer. Observations on the new crop, 2267. .

on grape-vine. Large compound, 720 .

Grape-vine apple, 1329, 1898.

insects, 1559 leaf, $724,840,1716$

Galls and, 1967.

Leafy oak, 774.

literature. Ribliography of, 2059 .

louse. Hickory-stem, 685 .

making senus of A piouinæ, 2231.

moths, 1127, 2356.

Pemphiginx. Biological notes on, 1653.

tortricid. A pretty and unique, 2176.

Mossy-rose, 570, 1166.

nuts, 1560.

Oak-fig, 745.

leaf, 799.

on oak twigs. Cynipid, 1822.

P'elargonium, 1764.

Pithy blackberry, 1131.

Pod-like willow, 1170.

Prickly rose, 119t, 1245.

Raspberry gonty, 1124.

$$
\text { root, } 1149 .
$$

Rose, 1235.

on Solidago leaves, 1924.

spotted touch-me-not, 852 .

Sugar-maple mite, 1265.

Trumpet grape, 791, 1116.

Gaileria cereana, 581, 716, 904, 1059, 1293, 1357, 1508, 1723 .

Gallmitcke. Beschreibung einer den Birnez sclüdlichen, 2392.

Galls, 137, 1561.

on blackberly, 263.

cottonwood leaf, 713.

Cypress, 1180.

Unsightly, 446.

on Eucalyptus, 1965.

aurl gall insects, 1967.

Golden-rod, 798

Grape, 111, 160.
Galls ou the grape-vine. I,eaf, 724, 840, 1716.

growing on wild sage, 1347.

Hackberry psyllid, 2208.

Jumping seeds and, 1496, 2163, 2173.

on leaves of soft maple, 445 .

wild grape-viue. Conical, 1077.

made by moths, 1127.

Phylloxera. New hickory, 1901.

and mining in apple-twigs. Small, 552.

Oak and rose, 1037.

Production ot, 1056.

on sugar-berry, 762 .

supposed dock, 1165 .

and their arcbitects, $518,821$.

on white oak. Woolly, 739.

Gamasid mite. An extensile penetrating organ in a 1626.

Gamasus juloides infesting Inlus marginatus, 963.

Garden crops. Experiments with insecticides npon insects affecting, 2344.

in Florida, Ashmead, W. H. Report on insects injurious to, 2388.

insects, Alwood, W. B. Tests with insectici tes on, 2388.

Insects in the flower, 936.

vegetables. Insects injurious to, 2238.

web-worm, 2363.

Gardens. Ants' nests in, 496.

Destroying black ants in, 438

Toads in, 822

Gargaphia amorphæ, 45 .

tiliæ, 45,400 .

Gas treatment for scale insects. Coquillett, D. W., 2418 .

waste vs. Curculio, 549.

Gases against scale insects. Use of, 2389 .

Gasteracantha cancer, 2111.

Gastroidea cyanea, 316, 1165 .

Gastropacha americana, 812 . velleda $=$ Tolype velleda.

Gastrophilus equi, 1391, 1563, 2238.

Gastrophysa cyanea = Gastroidea cyanea.

Geelong, Victoria. Grape Phylloxera at, 1732.

Gelechia abietisella, 2232 .

cerealella, 2291.

galle-solidaginis $n . s p ., 1059,1165,2213$.

glandulella $n . s p ., 1306$.

Hemlock, 2232.

White-heart hickory, 2363.

Gemminger and Harold's Catalogus Coleopterorum, $1866^{\circ}$.

General index and supplement to the Missour reports, 2026.

truths in applied entomology, 2291, 2292.

Gennine army-worm in the West, 2009.

vs. bogus chinch-bugs, 1402.

Genus grinding, 2120 .

Geographical distribution of the Rocky Mountain locust, 2267.

range of snecies, 1614.

Geometer. Chickweed, 1059, 1154.

Knot-weed, 1059.

Geometra catenaria = Zerene catenaria.

Geometridie. Larval characters, 165 
Georgia. Rascal leaf-crumpler in, 1962.

German aster's. Diabrotica vittata on, 148. thoroughness, 1597.

Gigantic rhinoceros beetle, 580, 1216, 1292. water-bng, 534, 733 .

Gilly-flower's. Cablage-worms upon, 614. Plutella cruciferarum injuring, 614.

Gilt gold-beetle, 790.

Girdled pear-twigs, 848 .

Girdler. Twig, 476, 1938 .

Girdling habits of Prdisca obfuscata, 2405.

G]assy cut-worm, 1059, 2291, 2394.

Mesochorus, 1127.

winged soldior-bug, 1301 .

Glaucopid caterpillar. Protective devico employed by a, 2242 .

Glorified squash-bug, 262.

Glossina morsitans, 1467.

Glover, Townend. Obituary, 2218, 2258.

Glow-worm, 1917.

$$
\begin{aligned}
& \text { Nature of the phosphorescence of, } \\
& \text { 1810. } \\
& \text { That, } 1097 \text {. }
\end{aligned}
$$

Glyphe viridascens $n . s p ., 12$.

Glypta al boscutellaris $n . s p ., 385$.

diversipes $n . s p ., 385$.

ruficornis $u . s p ., 385$.

rufiplearalis $n .8 p ., 385$.

Gnats, 625.

Groat-weod buttertly, 1117, 1127, 1329.

Paphiaglycerinm feeding on, 1329 .

Going it blind, 588 .

Gold-beetle. Gilt, 790 .

Drop of, 775 .

Golden-rod galls, 798 .

GOLDEN-ROD. INSECTS AFFECTING.

Cecidomyia carbonifera, 1924. solidaginis, 798 .

Euryptychia saligineana $=$ Podisca scudderiana.

Gelechia gallæ-solidaginis, 1059, 1165.

Graphtholitha olivaceana, 2285.

Nectarophora rudbeckiæ, 2205.

Predisca sculderiana, 180.

Siphonophora rudbeckiæe =: Nectarophora rud. beckix.

Trypeta solidaginis, 180, 798, 1059.

Golden-rod tortoise-beetle, 1127.

Gomphocerus shastanus n. sp., 1959.

Gomphus amnicola n.sp..24.

consobrinns n.sp., 39.

fluvialis $n . s p ., 24$.

grasiliuellus $n . s p ., 24$.

quadricolor $n . s p ., 39$.

vastus $n . s p ., 24$.

ventricosus $n . s p ., 39$.

Gonatopus contortulus, 2116.

pedestris, 2116.

pilosus. Biology of, 2116.

Goniocotes hologaster, 1094.

Groed words. More, 532.

Gooseberries and currants. Green worms on, 136. Gooseberry and currant worms, 772.

fruit-worm, 1059
GoOSEBERRY. INSECTS AFFECTING.

Dakruma convolutella, 1059.

Ellopia ribearia $=$ Eufitchia ribearia.

Epicrerus imbricatus, 35.

Eufitchia ribearia, $772,1068,1570$.

Nematus ribesii, 140, 228, 333, 756, 772.

ventricosus $=\mathbf{N}$. ribcsii.

Pristiphora grossularia, 4€, 189, 772.

Tenthredinid, 136.

Gooseberry saw-fly, 140 .

Imported, 228, 333.

span-worms, 1068, 1570.

worm, 189.

worms. Currant and, 1570.

Imported, 756.

Gordiacæa, 612 .

Grordius, 861.

aquaticus, 447, 1143.

varius, 1143 .

Gortyna nebris, 1646.

nitela, 331, 401, 632, 694, 734, 754, 820,862, $940,976,993,1009,1056,1059,1210,1558$, 1589, 1595, 1646, 1870, 2229.

sp., 138.

Gonty gall on blackberry and raspberry canes, 1771.

Governor of Kansas on the grasshopper question. Report to, 1573.

Governors of Western States on the Rocky Mount. ain locust, 1557.

Gracilaria. Purple willow, 2363.

Grain A phis, 2394.

Barl work of, 1638

vs. rust, 1806 .

Bruchus, 1301.

of Europe just imported, 1120.

Chinch-bug not in seed, 888.

GraIx. Ixsects AFFECTING.

A phicl, 99.

Asopia farinalis, 2337.

Bruchus granarius, 1301.

Gelcchia cerealella, 2291.

Noctarophora granaria, 126.

Grain moth, 2337.

Angoumois, 2291.

A now leaf-hopper injurious to small, 1767. plaut louse, 99, 126, 1127.

Silvanus, 1259.

Sphenophorns, 2363, 2394.

weevil, 15, 2291.

weevils. A niseed vs., 1742.

Grains. Calandra granaria in, 1259. and grasses, Webster, F. M. Insects af. fecting, 2394.

Webster, F. M. Experiments on the cffect of punctures of Hemiptera on shrubs, fruits, aun, 2382.

Granddaddy long-legs, 838.

Granulated cut-worm, 2291.

Grape-bark louse, 106.

berry inoth, $557,585,792$.

cano-gall Curculio, 1059.

canes and apple-twigs. Eggs in, 1323.

Egg on, 855 .

punctured, 513, 1333 . 
Grape Curculio, 373, 1059.

disease, 1311.

fruit worm, 1059.

gall. Trumpet, $791,1116$.

galls, 111, 160.

insects, 164, 267, 1056, 1569.

lèaf-folder, 1301, 1579 .

folders eaten hy spiders, 468. Hairr, 664.

gall-lonve, 373, 1301, 1311.

galls, 127, 1295, 1435, 1531.

Leaf-hopper's of the, 399.

leaf-louse, 916.

Phylloxera enemy, 1530.

Phylloxera, 1329, 1363, 1373, 1482, 1721

in California, 1727.

France, 2193.

Geelong, Victoria, 1732.

New biological facts regard.

ing, 1421.

Newest facts of, 1404 ,

not at the Cape, 184 .

permaneutly destructive, 1907.

Notes on the, 1952, 2291. natural history of, 1439 .

Use of guano for, 1837.

root.borer, $373,1301$.

New, 1059, 1127.

rot. Phylloxera and, $1623,1628$.

saw. $\mathrm{Hy}, 2291$.

scale insect, 1706 .

seed Curculio, 1059.

Insect infesting, 482 .

maggot, 1127.

vine Aphts, 170.

apple-gall, 1329, 1898.

An apple growing on a, 403,436 .

Bark-lice on, $12 \mathrm{I} 2$.

hcetles, 113, 129, 133, 339, 354 .

borer, 429.

caterpillars, 124.

caterpillars. Black, 1018.

Colaspis, 231, 1301. again, 1311.

Conical galls on leaves of wild, 1077.

Epimeris, 1301, 1363.

Fidia, 272, 1059, 1231.

filhert-gall, 1329.

flea-heetle, 298, 1252, 1301, 1821, 1855. Larvæ of, 1041, 1074 .

and fuchsia heetles, 133.

a hickory. Hybrid hetween, 1284. hoppers, 1024.

Injured strawherry and, 682.

insects, 128, 725 .

GRAPE-VINE. INSECTS AFFECTING.

Acoloithus falsarins, 124.

A cronycta ohlinita, 1208, 1301.

Ageria polistiformis = Sciapteron polistifolmis.

Alypia octomaculata, 1059, 1127, 1130, 1208, 1363.

Amblycorypha oblongifolia, 1329.

A mpeloglypter sesostris, 1059.

Ampelophaga myron, 1086, 1127, 1247.
GrAPE.VINE. INSECTS AFFECTING-Continued.

Amphicerus bicandatus, 1185.

Anomala lucicola, 113.

Aphis vitis, 102, 170.

Apis mellifica, 441.

Blennocampa pygmæa, 1252.

Bostrichus bicaudatus = A mphicerus bicauda. tus.

Capsus ohlineatus $=$ Lygus pratensis.

Cecidom,yia vitis-corsloiles, 1329.

lituns, 791, 1116.

powum, 403, 1284, 1329, 1898.

viticola, 791, 1077, 1116, 1329.

Cecidomyid, 111.

Cerambycid, 429.

Ceresa buhalus, 1323, 1329.

Chrocampa pampinatrix $=\mathrm{A}$ m pelophaga myron.

Cœliodes inæqualis = Craponius inequalis.

Colaspis flavida, 129, 133, 135, 231, 1301, 1311.

Corimelæna pulicaria, 1016.

Craponius inæqualis, 373, 1059.

Curculio, 267.

Dactylosphera vitifoliæ $=$ Phylloxera vasta . trix.

Darapsa myron $=$ A mpelophaga myron.

Desmia maculalis, 468, 1158, 1301, 1569, 1579.

Drosophila ampelophila, 2119.

Eggs, 855.

Encheuopa binotata, 725 .

Enchophylinm binotatum = Enchenopa bino. tata.

Erythroneura sp., 164.

tricincta $=$ Typhlocyha tri. ciucta.

vitis $=$ Typhlocyba vitis.

Eudemis botrana, 557, 585, 792, 1059.

Eudryas grata, 1127, 1363. unio, $1127,1363$.

Fidia longipes, 339. sp., 102.

viticida, 272, 339, 1059, 1231 .

Galls, 128, 791.

Graptodera chalybea $=$ Haltica chalybea.

Haltica chalyhea, 203, 298, 1041, 1252, 1255, 1301. $1821,1855$.

Harrisiana americana, 164, 213, 1127, 1136.

Isosoma vitis, 482, 484, 1059, 1127.

Lasioptera vitis, 720, 1329.

Leaf-hopper, 484.

Lecanium vitis = Pulvinaria vitis.

Lygus pratensis, 682.

Macrodactylus suhspinosus, 373, 565, 1375.

Membracid, 286.

Membracis ampelopsidis, 1183.

CEcanthus niveus, 286, 414, 723, 1059, 1323, 1329, $1333,1691,2195$.

Oucometopia undata, 36, 79, 164, 399.

Orocharis saltator, 513, 1323, 1329.

Ortliosoma hrunneum, 397.

cylindricun $=0$. hrunneum.

Oxyptilus periscelidactylus, 664, 1059, 1175, 1301.

Pelidnota punctata, 113, 129, 354, 725, 1221, 1301.

Pemphigus vitıfolix = Phylloxera vastatrix.

Penthina vitivorana $=$ Eudemis botrana. 
Grape-vine. INSECTS AFFECTING-Continued. Plilampelus achemon, 1091, 1127. pandorus, 1102. satelliatia $=$ P. pandorus.

Phylloxera vastatrix, $127,160,373,565,724,840$, $916,1281,1295,1301$, $1311,1325,1329,1342$, $1363,1374,1376,1421$, $1423,1435,1439,1482$, $1530,1531,1023,1628$ $1716,1721,1727,1732$ $1837,1841,1895,1900$ $1907,1952$.

vitifoliæ $=\mathrm{P}$. rastatrix

Poeciloptera pruinosa, 1329.

Polycaon confertus, 2103.

Prionus imbricornis, 1127, 1274. laticollis, 561, 1059, 1081, 1127.

Proconia undata $=$ Oncometopia undata. Procris americana $=$ Harrisiana americana falsarius $=$ Acoloithus falsarius.

Psychomorpha epimeris, 1301, 1363.

Pterophorns periscelidactylns = Oxyptilus periscelidactylus.

Pulvinaria vitis, 106, 1212, 1706, 1716.

Pyrophila pyramidoides, 671, 1301.

Sciapteron polistiformis, 373, 1301, 1509.

Selandria vitis = Blennocampa pygmæa.

Sinoxylon basilare, 1311.

Smilia auriculata, 1183.

Spilosoma virginica, 1202, 1301.

Tettigonia coagulata, 1024.

$$
\text { vitis }=\text { Tsphlocyba vitis. }
$$

Thyreus abbotii, $763,1018,1127,1248$.

'Typhlocyba tricincta, 25.

$$
\text { vitis, } 203,686 .
$$

Grape-vine. Insects injurious to the, 267, 1059, $1081,1086,1091,1102,1118,1130,1137$ $1158,1175,1202.1221,1255,1281,1301$ $1311,1329,1363$

Large compound gall on, 720 .

leaf-galls, $724,840,1716$. hoppers, 484, 686 .

pest. More about the, 1376 .

plume, 1059, 1301.

Procris, 213.

root-borer, 1509.

roots. Wood-lice on, 1906.

tomato-gall, 1329

trumpet-gall, 132 \%.

worm. Dark, 763.

Green, 671.

Pyramidal, 1301.

vines. Bugs on, 1046.

Caterpillars on, 1208.

On the cause of deterioration in sume of our native, 1342.

Egg-puncture in raspberry and, 2195.

Eggs of the tree-cricket on, 723 .

mistaken for chinch-bug. Bugs on, 398.

to Phylloxera in sandy soil. Resistance of, 2250.

Rose-chafers on, 1375.

Grapes cut off by tree-cricket, 414 .

Honey-bees eating, 441.
Grapes spoiled bs something, 464 .

Grapholitha gallw-saliciana $n . s p ., 1968$.

Grapholitha ninana $n . s p ., 2176$. olivaceana $n . s p ., 1968$. Habits of, 2285. pruinirora, $367,373,1795$.

Graphops pubescens, 2229.

Grapta, 1301.

comma, 461, 1140 .

interrogationis, 420, 444, 1306.

Graptodera carinata $=$ Haltica carinata. chalybea $=$ Haltica chalybea. punctipennis = Haltica punctipennis.

Grass-bng and its habits, 882. insects, 541 .

Grass. InseCts AFFECTIXG.

Laphygma frugipcrda, 1127.

Leucania unipuneta, 1877.

Grasses, Webster, F. M. Tnsects affecting small grains and, 2394.

Grasshopper. The, 1588.

Colorado, 502.

eggs, 536, 667 .

Trombidium preying on, 624 .

Governors of Westerm States on the Rocky Mountain, 1557.

Hateful, 373,475 .

injuries. New method of coun. teracting, 2235.

injury in the near future. Probabilitics of, 2335 .

Outlook for locust or, 2461 machine. A satisfactory, 1592. A new enemy of the, 1541.

Parasite on hateful,-728. pest of the West. Important ob. servations on, 1571.

prospect, 1693.

question. Report to govcrnor of

Kansas, 1573.

ravages in California, 2323.

Rocky Mountain, 1557.

Western, 1998.

year? Is this a, 1565 .

Grasshoppers, 368, 391, 402, 433, 1363.

Destructive, 2363.

and locusts, 26, 147, 929.

Mites ou, 146.

Rear-horses vs., 590

Young, 2377.

Grass.worm, 2119.

Gray straight-horned snout-beetle. Large, 1033.

Gray. Personal reminiscences of Dr. Asa, 2419.

Greasy cut-worm, 1059, 2291, 2418.

Great discovery. Curculio extermination possible, 1173.

elm-leaf beetle, 1721:

Lebia, 1801.

lcopard inoth, 1311.

Groen apple-leaf tyer, 1311.

corn. A new insect foe to, 1655 .

grape-vine worm, 671.

hag moth, 1233.

striped maple-worm, 1329.

worms on gooseberries and currants, 136.

Greenhouse pests, 508.

plants, 508 
Gregarious worm on horse chestnut, 1192. walnut caterpillars, 1045. willow-worms, 856.

Ground-bectle. A nother herbivorons, 2042. Fier's, 1059.

Murky, 486 .

Pennsylvania, 1059.

Subangular, 372.

bcetles, 1127, 1558, 1625, 1613 .

Eggs of, 692.

Food-habits of, 1760.

Tegctal feeding, 1738.

Groundless fear, 284.

Growth of insect eggs, 2241.

Grub fungus. White, 594, 640, 1064, 1430, 1436, $1599,1803,1823$.

information wanterl. White, 1072.

White, 68, 410, 1020, 1059, 2238, 2363, 2394. worm, 51 .

Grubs and guess-work, 1440.

Gryllidæ, 929, 2267.

Gryllotalpa, 2267.

borealis, 562, 1270, 1798.

columbia, 562 .

longipennis $=\mathrm{G}$. columbia.

Gryllus, 2267, 2381.

abbreviatus, 143, 433.

Guano for grape Phylloxera. Use of, 1837.

Guard. Be on the, 708 .

Guess-work. Grubs and, 1440.

Guide to the study of insects. Review of Packard's, 395, 479, 623, 827.

Gymnetis nitida = Allorhina nitida.

Gyrinus larva in stomach of shad, 1853.

Habit. Cliange of, 2096.

Hackberry butterflies, 1356, 1363.

HACKBERRY. INSECTS AFFECTING.

Apatura alicia, 1363.

celtis, 1356, 1363.

clyton, 1356, 1363 .

herse $=\mathrm{A}$. clyton.

- $l_{\text {ycaon }}=\mathrm{A}$. celtis.

Galls, 791.

Pachy"psylla c.-mamma, 2208. c.-venusta, 2208.

Hackberry psyllid galls, 2208.

Hadena, 2238.

chenopodii = Mamestra trifolii.

devastatrix, 1056, !059, 2291, 2394, 2355.

juncta, 1056.

renigera, 964, 1059.

sp., 1047.

subjuncta, 901, 1059.

Hæmatopis gratariá, 1059, 1154.

Hag-moth. Green, 1233.

larra, 777, 1272.

Hagen, H. A. The Hessian-fly not imported from Europe, 2267.

Observations on certain North American Neuroptera, 39.

Hagen's mystery. Dr., 1943.

Halr snakes, 612, 861, 1143. worms, 861, 1643, 1959.

Hairy catcrpillar, 558 . grape-leaf folders, 664 .

Haldeman, S. S. Death of, 1909,
Halictus sp., 800 .

Halisidota antiphola $n .6 p ., 40=\mathrm{H}$. tessellata. caryse. 45.

harrisii $n . s p ., 45=\mathrm{H}$. tessellata. tessellata, 40, 45, 50 .

Haltica alternata $=$ Disonycha alternata. carinata, 133, 1868. chalybea, 203, 298, 1041, 1074, 1252, 1255,1301. $1583,1821,1855$.

cucumeris = Crepidorlera cucumeris. exapta $=\mathrm{H}$. carinata.

holxines $=$ Crepidodera helxines. punctipennis, 2383, 2468.

striolata $=$ Phrllotreta vittata

Haltichella perpulchra, 11, 12.

Halticidxe, 873, 1858, 2236.

Ham-beetle. Red-legged, 1363.

Hams. Skippers injuring smoked, 1734.

Hand-maid moth, 2222.

Hard story. Ephemera flies, 1043.

Harlequin cabbage-bug, 1099, 1311, 1534, 2238, 22fi3, 2291.

Harmless insects, 1526.

Harold's Catalogus Coleopterorum. Gemminger and, 1866.

Harpactor cinctus = Milyas cinctus

Harpalus, 1643.

caliginosus, 3,486 .

crraticus, 1537.

pennsylvanicus, 372

Harpiphorus maculatus, 499, 955, 965, 1056, 1264 $1570,1586,2324$.

Harris's bark-louse, 373.

correspondence (review), 623.

insects injurious to vegctation (review), 568.

Harrisina americana, 161, 213, 789, 1056, 1127, 1136.

Harvest bugs, 412.

fly. Dog-day, 1546.

mites, 1326.

Hatch pupx. How to, 509.

Will unimpregnated eggs, 1029.

Hatching? Are the locusts, 1566.

Hateful grasshopper, $373,475$.

Parasites on, 728.

locust, 1452

locusts. Prairie fires and, 1453.

Hawk's pellets, 601, 643.

Hawthorn. Worms on, 1051.

Hay. Worms under mulch, 1161 .

Head-maggot, 450,1059 .

of winged insects, Packard, A. S. Number of segments in the, 2267.

Hedge-hog caterpillar, 1153.

Helia americalis, 2414.

Helianthus. Lixus macer bred from, 2404.

Heliothina. Synopsis of (review), 2178.

Heliothis armigera, 192, 636, 820, 993, 1136, 1256 , $1301,1353,1664,1695,1886,1915,2119$, $2238,2343$.

marginidens $=$ Pyrrhia cxprimens. phlogophagus, 936, 945, 993, 1056. umbrosus, 2343.

Hellgramite, 1570,1584 . fly, 473, 1329 .

Helops ærous, 751. 


\section{INDEX.}

Helops micans, 963.

pullus $=$ H. æreus.

Hemaris thysbe, 879.

Hemerobilæ, 2267.

Hemileuca maia, 595, 722, 735, 760, 1329, 1352.

Hemiptera, 400, 1329, 2267.

upon shrubs, fruits, and grains. Webster, F. M., 2382.

Experiments of the effects of punctrires of, 2382.

Hemipterological studies, 2034.

Hemispherical larva at bottom of ant hill, 1789.

Hemiteles, 77,

cressoni $n . s p ., 1059$.

fuscatus $n . s p ., 380=$ var. of nemativorus.

nemativorus $n . s p ., 380$.

thyridopterygis $n . s p ., 1059$.

Hemlock Gelechia, 2232.

HEMLOCK. INSECTS AFFECTING.

Buprestid, 2267.

Ceramby cid, 2267.

Gelechia abietisella, 2232.

Hen. Death of a, 1094.

Henderson's experiments. Mr., 1688.

Henous, 1643.

confertus, 1600.

larral habits, 1387.

Heptagenia $n . g ., 39$.

cruentata n. sp., 39.

maculipcnnis $n . s p ., 39$.

simplex n. $s p ., 39$.

Herbivorous ground-beetle. Another, 2042.

Herpetogomphus rupinsulensis $n .8 p ., 24$.

Hesperid larva feeding on Canna, 1897.

Hessian-fly, 150, 250, 426, 1581, 1665, 2008, 2267, 2365.

Effects of drought on, 2031.

in England, 2395.

into England. Introduction of, 2398.

Fighting the, 1587.

half way around the world, 2440.

Koeppen's account of the, 2267.

in North America. Early references

to the, 226 .

Not the, 1445.

imported from Europe. Hagen, H. A., 2267.

Parasites of, 2332.

prior to the Revolution. Insects confounderl with the, 2470 :

Probabloparthenogenesis of the, 1787. in seed-wheat, 494.

Silesia. Cohn, F., 2267.

Wheat-rust and the, 1605.

Hetærina pseudamericana $n . s p ., 39$.

rupamnensis $n . s p ., 39$.

rupinsulensis $n . s p ., 24$.

scelerata n. sp., 39.

texana $n . s p ., 39$.

Heteronychus relictus = Ligyrus relictus.

Heteropelma datanæ 2 . sp., 2526.

Heteroptera, $173 \%$.

Defensive odors of the, 354 .

Hexagenia n.g., 39.

bilineata, $372,1043,1851$,
Hexaplasta, 1749, 1932.

zigzag n. $s p ., 1749,1932,2343$.

Hexapoda, 1955, 2267.

Poisonous, 2399.

Hibernating Aletia chrysalids. Supposed, 1927.

apple-wor'ms. Severe cold and, 2037.

Hibernation of Aletia xylina in the United States a settled fact, 2141 .

Anphipyra pyramidoides, 1471.

army-worm, $2 \dot{u} 86$.

the cotton-moth, 1728.

insects, 1129

worm moth, 1953.

Hickory-bark borer, 938.

borer, 269, 308, 1401.

Citheronia regalis on shell-bark, 775.

Eccopsis, 2363.

Fall web-worm on, 460 .

galls, 360 .

made by Phylloxera. New, 1901.

Gelechia. White heart, 2363.

Hybrid betwoen a grape and a, 1284 .

HiCKORY. InsECTS AFFECTING.

Arhopalus pictus $=$ Cyllene pictus.

Cecidomyia tubicola, 1232.

Citheronia regalis, 775.

Clytus pictus $=$ Cyllene pictus.

Cyllene pictus, 89, 269, 308, 1516.

Datana ministra, 2222.

Eceopsis, $236 \%$.

Galls, 791.

Geleclia, 2363.

Hyphantria cunea, 460.

$$
\text { textor }=\text { H. cunea. }
$$

Phylloxera carya avellana, 1901. caulis, 360,685 . globuli, 360 . scissa, 1901.

Scolytus carye $=$ S. 4-spinosus.

4-spinosus, 938, 1329, 1401, 1754.

Hickory Scolytus, 938.

stem gall-louse, 685 .

vs. lncust-borer, 1516.

Hipparchiscus $n . g ., 40=$ Aplodes.

venustus $n .8 p ., 40=$ Aplodes mi. mosaria.

Hipporlamı. Ambiguons, 2119.

convergens, 639, 1251, 1431, 1672

glacialis 849 .

maculata $=$ Megilla maculata.

Hirmoneura. Entomography of, 2275.

Larval stages and habits of, 2169 .

obscnra, 2169, 2275.

Hirundo amcricana, 1502.

fulva, 1502.

Hispa scutellaris = Odontota dorsalis.

Hitherto unknown life-habits of two gevera of

bee flies, 2002.

Hockeria $n . g ., 11=$ Haltichella.

perpulchra n. sp., $11=$ Haltichella per. pulcbra.

Hog caterpillar of the vine, 1127.

infested with para. sites, 1247 .

Hogs vs. bugs, 387.

Holoaspis mannma, 518, 
Holos around the roots of young ash-trees in the nursery, 471.

Bolocera glanduella $n .8 p ., 1310,1311$.

Homalomyia lcidyi n. sp., 382.

pruinivora n. $s p ., 382$.

wilsoni $n . s p ., 382$.

Home. Colorado potato-beetlo's native, 1462.

Homoptera. Egg-slits made by, 79.

Honoy-ant. Peculiarities of the Mexican, 1417.

beø. Braula cœea not particularly inju. rious to, 1982.

Bug preying on, 13.

Dipterous enemies of, 704 .

Discussion on, 1455.

Insect cnemies of, 1059.

bees carnivorous? Are, 2098.

eating grapes, 441.

locust seed weovil, 1026. weevil, 1474.

producing oak gall, 1942.

Too fond of, 764 .

Honor. Deserved, 2124.

Hop A phis, 1001, 2291, 2394, 2418.

and tho cranberry, Smith, J. B. Insects affecting the, 2291.

growing in the West, 235, 279.

insects, 1001.

plant louse in Europe and America. Prob-

lem of the, 2400 .

fully solved. I'roblem of the, 2396.

Life-history of the, 2393.

Problem of the, 2400.

vine caterpillars, 444, 979.

HOP-VINE. INSECTE AFEECTING.

Grapta interrogationis, 420, 444 .

Hylena humuli = H. scabra. scabra, 979, 1001.

Hyperchiria io, 420.

Phorodon humuli, 235, 279, 1001, 2393, 2394, $2396,2400$.

Saturnia io = Hyperchiria io.

Vanessa interrogationis = Grapta interroga tionis.

Hop-rine. Insect foes of the, 420 .

Hoplophora arctata n. sp., 1363, 1370.

Hopper in Iowa, 1585.

Horinus levis $=$ Merinus lævis.

Horizontal insect boxes, 1963.

Hormaphis spinosus, 1678.

Horn-bug, 1636.

Cocoon of, 784.

Horncd Passalus, 1311.

$$
\text { Egg of, } 1329 .
$$

Hornia $n . g ., 1601,1643$.

minutipenuis $n . s p ., 1601,1651$.

Structure and development of, 1651.

Horn's classification of the Carabidæ, 2051.

Horse bot-fly, 2238.

chestuut. Flat-headed applo-tree borer in, 1316.

Gregarious worms on, 1192.

Horse-chestnut. INGECTE AFFECTING.

Cacoeia rileyana, 1192.

Chrysobothris femorata, 1316.

Tortrix rileyana $=$ Caccoia rileyana
Horse-hair snakes, 612.

Horses. Lico on, 258.

Horticultural ontomology. Recent advancos in, 2230.

Horticalture. Utilization of ants iu, 2089, 2137.

Houghton's insects in the orchard, 188.

House-fly, 864, 2078.

Proboscis, 1783.

How great wits jump together, 567 .

to hatch pupæ, 509.

Howard, L. O. Chinch-bug, 2418.

Codling-moth, 2418.

Howell, M. A. Experience with the spring canker-worm, 2267.

Hubbard, H. G. Miscellaneous notes on orange insects, 2164.

Report on cotton insects, 2343.

Rust of the orange, 2201.

Scale insects of the orange, 2119.

Hudson Bay Lepidopter'a, 1985.

Hnll's Curculio catcher, 372, 651, 875.

Hulst's observations on Pronuba yuccasella, Mr. 2371.

Human aninal. Parasites of the, 497.

body. Larva in, 382.

lnngs. On a larva of Scenopinus from, $13 \pm 8$.

Humbert on Lucilia, 2255.

Humblebees, 800 .

Humbug. $\triangle$ nother, 195.

now Curculio, 589.

Entomology all a, 63 .

Now, 122.

Cureulio, 680.

Humming-bird moths caught by the tongue, 1388. Hundred and fifty million dollars. That, 1647 .

legged worms, 219.

Hybrid between a grape-vine and a hickory, 1284 .

Hydrachna belostom: n. sp., 1632.

HJdrophilus piceus, 2016. triangularis, 2016.

Notes on, 2016.

Hylecetus lagubris, 575 .

Hylesinus opaculus, 1656, 1721. trifolii, 1690, 1721, 1777, 1846, 2512.

Hylobius confusas, 700, 1168. stupichs, 845 .

Hylurgops, Packard, A. S. Devolopment of, 2267. Hylurgus pinifex, 2267.

Hymenoptera, 543, 1329, 1736, 2267.

Description of North American, 385. Parasitic, 310.

Willow galls made by, 46 .

Workers among, 311 .

Hymenorus obscurus, 2105. rufipes, 2105, 2226.

as a myrmecophilous spocies, 2226.

HJpena humuli, $9=\mathrm{H}$. scabra.

scabra, 979, 1001, 1976, 2343.

scabralis, 2343.

Hsporchiria io, 420, 809, 1264, 1329, 1352, 1389, 2343. varia $=$ H. io.

Hypermetamorphoses of Meloidra, 2191.

Hyphantria cunea, 112, 242, 454, 456, 460, 819, 1301, $1733,1819,1995,2238,2378,2379,2394$ toxtor $=H_{\text {, cuner }}$ 
Hypoderma bovis, 898, 1563, 2238

Hy ponomeuta, 2000.

malinella, 2000.

multipunctella, 2000.

5-punctella, 1603, 1804.

Hурорus, 1703.

Icerya. Bull. No. 15 on, 2389.

Life-history of, 2386 .

in New Zealand. Enemies of, 2479.

purchasi, 2386, 2394, 2400, 2401, 2415.

an insect injurious to fruittrees, 2401.

Original habitat of, 2415.

sacehari, 2415.

Ichneumon, 1541.

brevipennis, 1570 .

cærculeus, 1802.

Cocoons of, $63,183$.

flies, 662, 679, 1643, 1625.

Cocoons of, 851.

fly. Arm5-worm, 1127.

fly mistaken for a wasp, 477.

leucanix, 1670.

obsoletus $n . s p ., 1570=$ var. of brevi. pennis.

signatipes, 1802.

from stomach of bluebird, 1878.

wing, 50, 197, 38 .

Ichneumonidæ, 2516.

Descriptions of new, 385 .

Habits, 158.

Ichtłyura inclusa, 856 .

Icy lady-bird, 1311.

Identity. Mistaken, 1593.

Ignorance in the North. Entomological, 431.

South. Entomological, 390.

Illinois. Entomological tour in Southern, 372.

First report noxious insects of, 373.

Flying locusts in, 1437, 1443.

Natural History Society. Address be.

fore, 5 .

New Cynipidas of, 41.

Pseudonenropter'a, 24.

A rare captnre in, 1211.

Six worst insect enemies of the fraitgrowers in northern, 377 .

state entomologist of, 327.

Horticultural Society. Report of committee on entomology of, 1056.

Imbricated snout-beetle, 1301, 2291.

Imitative butterflies, 613 .

Impatiens fulva. Galls on, 852.

Imperial moth. Larva of, 1087, 1268.

Importation of insect parasites, 2461.

Lestophonus. Further on the, 2541.

Imported cabbage-butterfly, 1127, 2291.

worm, 2232, 2238, 2291.

Bacterial disease of the, 2251.

New remedy for, 2298.

in the South, 1714.

Successful introdaction of a parasite of the, 2291.
Imported carpet.betle, 169 .

cnrrant-worm, 1127, 1570, 2238.

fly and its parasite, 380

- 381.

elm-leaf beetle, 2232, 2304, 2325, 2378, 2394.

gooseberry saw.fly, 228, 333 . worms, 156.

insects, 140,225 .

and native American insects, $1115,1127$.

orchard Scolytus, 2233.

plauts and insects, 1339.

Importing Enropean parasites, 208.

Improved method of spraying trees for protection against insects, 2211.

In memoriam B. D. Walsh, 1098.

Index to reports State entomologist of Missouri, 2026.

Indian-corn insects, 23, 138.

Indiana, Butler, A. W. The periodical Cicada in southeastern, $236 \overline{4}$.

Webster, F. M. The season's observa. tions in, 2418.

Indigo. Walshia amorphella on false, 1127.

Industry in the United States. Silk, 2268.

Inexpert defense, 2476.

Inflating Chalcis, 1059.

Information wanted, 1111.

Injurious caterpillars, 151.

insects, 126.

in California, 2074.

Inquilines in galleries of common white ant, 1729. and Psenides. Relations of, 41.

Inquiries answered, 180.

Inquiring friends, 1642, 1656.

Insect boxes. Vertical vs. horizontal, 1963, catching habits of Sarracenia variolaris, $1385,1390$.

changes, 388.

collection for sale, 2046.

collections. Naphthaline cones for, 2073.

Protection of, 2180.

damage to the corks of wine-bottles, 2477.

defoliators. Shade-trees and their, 2378, 2379.

destroyer. Paris green as an, 1447.

eggs, 243, 286, 291.

Grow th of, 2241.

enemies, 1583.

of the Colorado potato-beetle, 411. growing rice, 1911 .

to the rice.plant, 1949. .

extinguisher. Treat's (review), 531.

foe of the apple-tree borer, 421.

to green corn. A new, 1655.

foes of the apple-tree, 467.

army-worm, 12.

bark-louse, 417 .

hop-vine, 420.

jea, 14.

potato, 1558 .

found about orange-trees, 1798.

friend. Another, 879.

friends and insect foes, 38.

on grape, 1569. 
Insect injurions to junipers, 1713. wheat. A new, 2288.

killer. Worthlessness of the sparrow as an, 2413.

life, 5 .

and sun spots, 2094.

locomotion, 1955.

named, 2:97.

pest. A new, 1686 .

plagues, 2198.

A plant growing out of an, 332, 478.

powder. Directions for cultirating pyrethrum for, 1996.

Persian, 1485.

powders and their use, 3692.

ravages, 1464.

Trade in, 1986.

world, $1466,1467$.

Figuier's (review), 408.

Remarkable peculiarity in the, 622 .

Insecticide. London purple as an, 1725.

Oxeye daisy as an, 1861.

Pyrethrum an important, 2131. its use as an, 2119.

Use of naphthaline as an, 2274. Paris greell as an, 1497.

Insecticides. Emulsions of petroleum as, 2134. and $t h \theta i r$ value as, 2126, 2200.

on garden insects, Alwood, W. B.

'Tests with, 2382.

upon insects affecting garden crops.

Experiments with, 2344.

Quelques mots sur les, 2283.

Two valuable, 1743.

Insectivorous plants. Food of, 1499.

Insects attracted to light, 178, 2352.

Bill providing for the extermination of, 1842.

Birds vs., 199, 369 .

Bluebirds feeding on parasitic and preda. ceous, 1885.

in Califoruia. Injurious, 2074.

Californian orange, 2373.

Catalogues and monographs of, 1765 .

Centennial, 1511, 1611.

clustered on apple-trees, 1263.

coflecting and preserving, 881, 1057.

Comstock's classification of, 2390.

Damage to silver plate by, 2154.

Deatl of mules caused by, 1811 .

is directed. How flight in, 1891.

Directions for collecting and preserving, 881.

rearing, 14 .

and drought, 2100.

effects of serere coid on, 1818.

enemies of fruit and fruit-trces. Review of 'Trimble's, 187.

in northern Illinois. Six wor'st, $3 i 7$.

the honey-bee, 1059.

rice-plant, 1949.

feeding on sap of black-walnut, 1195 .

in the flower garden, 936.

27 ENT
Insects as food for man, 2166.

found on apple-trees, 731.

Fungus diseases of beneficial, 1813.

Harmless, 1526.

Imported, 140.

plants and, 1339.

Improved method of spraying trees for protection against, 2211.

Injurious, 126.

injurions to agriculture. Legislation in regard $t o$, 1468.

New, 2055.

cereals and forage crops, 2238.

cotton in Brazil, 2277.

field crops, 2238.

fruit and fruit trees, 2238 . trees, 16,31 .

garden regetables, 2238.

grape-rine, 267, 1081, 1086,

$1091,1102,1118,1127,1130$,

$1158,1175,1202,1221,1255$ 1281. 1301, 1311, 1229, 1363.

livo-stock, $22: 38$

orange in Brazil, 2277.

sugar-cane in Brazil, 2277.

regetation. Reviow of Har. ris's, 568.

in Illinois, 6, 52 .

Legislation to control, 1946.

the vine, 2238

of interest to fruit-growers.

Introduction and spread of scale, 2232.

by malodorants. Repelling, 2091.

Maple-tree, 2279.

Mind how you pack your, 435 .

most destructive to the orange. Success.

ful managenicut of the, 2088.

named, $163,200,316,358,359,413,447,463$,

$490,540,560,562,582,631,673,714,721,736$,

$743,746,785,789,805,832,847,849,858$,

$1140,1147,1183,1226,1273,1287$.

to be named, $488,514,598$.

in the National Museum. The collection of, 2299 .

Report on the collection of, 2282,2330 , 2368.

and native American insects. Imported, $1115,1127$.

Nervous system of, 2225 .

Notes on our commoner, 1802.

on the oleander, 730.

in the orchard. Review of Houghton's, 188.

Packard, A.S. Larve of injurions forest, 2267.

Notes on forest, 2253.

Number of segments in the head of winged, 2267.

around peach.trees, 660 .

Pitcher-plant, 1385. 
Insects. Poisoning noxious, 205.

Poisonous, 2399.

Popular remedies for noxious, 73 .

Preserving, 881, 1057.

Regulation of sex in, 1415.

in relation to agriculture, 2238 .

Remedies for varions, 2281.

Retarded development of, 2040.

Salt and vinegar for; 937 .

Simulium feeding on other, 2177.

Some interesting, 1232.

Stings of, 116.

from stomach of lark, robin, and' sunfish, 1926. rock-bass, 1792.

stripping the burr-oak, 966 .

in timber, 918 .

Trade in, 1986.

Transformation of, 528 .

Unity in coloration of, 50 .

Use of buckwheat to destroy, 1744. fungus growths to destroy, 1918 . poisons to destroy, 1887.

used as food. Salt-water, 2203.

White willow, 907

of the year, 2289, 2331

Destructive, 2322

Insekten. Einige unserer schällicherer, 1325.

Insidious flower-bug, 1127, 1423, 2418.

Instinct of Cicada septendecim, $21 \pm 4$.

Instructions to agents of the U.S. Entomological

Commission. Supplementary, 1888.

Interaction of organisms, 139, 1954.

Interest felt in economic entomology in California, 2053.

Interim committees. $A d, 394$.

Intermittance of phosphorescence in firc-flies, 1805.

Internal mite in fowls, 2157.

Introduction of Phylloxera. Laws to prevent the, 2019

Invigorator again. Best's fruit-tree, 530 . once more. Best's, 545.

Io moth, 1329, 1389 .

caterpillar, 809.

Iowa. Econonic entomology in, 2197

The hopper in, 1585.

Osborn, H. Report upon the insects of the season in, 2418.

The seventeen-year Cicada in, 1737.

Ipomæa commutata. Aletia feeding, 2343 .

Ips in caly $x$ of pear. Banded, 1239.

fasciatus, 4, 214, 1239.

4. signatus $=\mathrm{I}$. fasciatus.

Isabella tiger $\operatorname{moth}, 1311$.

Isosoma, 2394.

allynii, 2060, 2063

grande n. sp., 2288, 2291, 2316, 2348, 2363, 2394

Habits of. 2348 .

hordei, 563, 923, 2060, 2238, 2316, 2394.

Larger wheat-straw, 2291.

lineare, 2060, 2119.

nigrum $=\mathrm{I}$. hordei.

tritici n. $s p, 2060,2063,2119,2123,2316$, $2363,2394$.
Isosoma vitis, 482, 1059, 1127.

Wheat, 2119.

straw, 2291, 2394.

Ithycerus noveboracensis, 16, 306, 652, 659, 869, 1033, $1085,1188,1301$.

Inlus, 430 .

coeruleo-cinctus, 236.

marginatus = Spirobolus marginatus.

infested with Gamasus juloides, 963.

multistriatus $n . s p ., 193=$ Cambala annulata virgatus, 261.

Ixodes bovis, 404.

sp., 834 .

unipunctata, 1133.

Jaeger's North A merican insects, 84 .

Japanese mode of packing silk-worm egga, 1016 .

Jarring down infested frut. Colling-moth, 1318.

Jassidæ, 737.

Jassus, 1766.

sexnotatus, 1766

Jiggers, 412.

Johnson, L. Report on cotton.worm, boll-worm, and other insects, 2164.

Joint-worm, 49, 62, 563, 923, 2238. Appendix to article on, 1223. fly, 1127.

Joint-worms, $2119,2394$.

Notes on, 2316.

Joints of wheat. Worm in, 1848 .

Jones, R. W. Ooserrations and experiments on cotton-worm, 2164.

Report on cotton insects, 2343.

TI.J. Report on cotton insects, 2343.

Joppidium $n . g \cdot, 385$. ruficeps $n . s p ., 385$.

Journal of a State entomologist. One day's, 383.

Jumping to conclusions, 253.

seeds and galls, 1496, 2163, 2173.

spiders, 2302.

sumach beetle, 1363 .

tree.cricket, 1329.

Juniper. Dapsilia rutilans on, 1713,1721 . web-worm, 1721.

Junipers. Insects injurious to, 1713

Juniperus sabina. Insects injurious to, 698 .

Junonia lavinia, $\mathbf{7 5 3}$.

Kansas bombardier-beetle, 1311.

The locust in, 1591

and Missouri this fall. No locust injury in, 1433.

Report on grasshopper question to the governor of, 1573 .

Scorpion in, 1119.

Silk culture in, 1542.

Kartoffel-Käfer. Nene, 919 .

Katydid. Angular-winged, 1363.

Broad-winged, 1329, 1363.

Domesticated, 1536.

Eggs of the, 516, 1005 angular, 1518. oblong, 569 .

Narrow-winged, 1363.

Oblong-winged, 1329, 1363

Ste Catydid.

Katydids, 1363. 
Kentucky. Coleopterous cave fauna of, 2033.

Kermes galliformis $n . s p ., 1972$.

Kerosene emulsion, 2291.

as a means against cotton insects, 2164 . orange insects, 2161

Kiesenwetter. Obitnary, 1819.

Killer. Cottonwood, 1654 .

Killers. Bee, 1543.

Killing apple-worms by machinery, 769.

Kinglow. Animal, 393.

Klippart's wheat plant (review), 186.

Knot once more. Black, 930.

Kuots on apple-tree roots caused by root-lice, 1187.

Knotweed geometer, 1059.

Hænlatopis grataria on, 1059.

Knowledge useless ? Is any, 1135.

Koobele, A. Experiments on cottony cushionscale, 2394 .

the red scale, 2394.

Notes on locusts about Folsom, Cal., 2363.

Report of experiments against scale iusects, 2418.

Koeppen, F. T. A ccount of the Hessian-fly, 2267.

Labena. Useful, 1423.

Labia, 2267.

Lae insects, 2119

Lace-wing fly; $533,1423$.

Lace-wing larva, 1059.

Weeping, 1127.

Lachnosterna fusca, 3, 54, 68, 300, 332, 410, 478,500, $594,640,865,1020,1059,1064,1072$, $1307,1313,1329,1436,1440,1522$ 1803, 1812, 2238, 2394.

pilosicollis $=\mathbf{L}$. tristis. quercina $=$ L. fusca. quercus, 372. tristis, 966 .

Lachnus caryæ, 27. plantanicola $n . s p ., 2138$. strobi, 265, 320, 1039.

Lackoy moth. Amcrican, 1301.

Lacordaire, J. T. Death of, 1285.

Ladiler spider, 1293.

Lady-bird. Ashy-gray, 2119.

Blood-red, 2119.

Cactirs, 2119.

Fifteen-spotted, 959, 1311.

Icy, 1311.

and its larva. Northern, 1289.

Spotted, 599.

Twicc-stabbed, $38,1883$.

Lady.birds, 1059, 1127, 1423, 1558, 2119.

Swarms of, 824.

Lafayette, Ind., Webster, F. M. Experiments at, 234.

Lagon opercularis, 145, 796, 1748.

Lake Superior. Simulinm from, 2032.

Lamellicorni:a, 1440.

Lampronota, 1878.

armplimilaua $n . s p ., 385$.

brevivontris $n .8 p ., 385$.

imitatrix n. $s p ., 385$.

interpellata n. $s p ., 385$.

pictiventris n. $s p ., 385$.
Lampyridæ, 1705, 1805, 2036.

Revision of the, 1819.

Lampyris noctiluca, 1097, 1917.

Laphria thoracica $=$ Dasyllis thoracica.

Laphygma autumnalis = L. fra giperda.

frngiperda, 1127, 1256, 1267, 1282, 1301, $1400,2011,2343$.

fulvosa $n . v ., 1301=$ var. of L. frugiperda.

obscura, $n . v$., $1301=$ var. of $\mathbf{L}$. frugi. perda.

Laporte. Obitualy, 1817.

Lappet caterpillars on the apple, 972.

apple-trees, 812 .

Larch. Nematus erichsoni on, 2232. saw-fly, 2232.

Large Asilus ty, 1269.

black potato-bectles, 1206.

compound gall ou grape-vine, 720 .

d ragon.fly, 759 .

fish-fly, 712, 903.

gray straight-liorned snont-beętle, 1033.

green caterpillars on the apple, 1076. worms in a poich, 661.

moth on apple-trees, 1028 .

phosphorescent Iarva, 1874

saw-fly, 1514.

silken cocooll, 604 .

watcr-bectlc, 750,816 .

white-scale on Acacias, 1730

willow-worm, 1380.

worm on apple-trees, 1048.

Larger cablage-butterfly, 2232.

wheat.straw Isosoma, 2291.

Lark. Insect from stoniacl of a, 1926.

Larva boring along tho axis of applo twig, 1850. injurious to cotton squarcs. Butterfly, 1872 . Large phosphorescent, 1874.

Moth issuing from a, 1779.

Larvæ. Aquatic, 1851.

Habits of, 346 .

in the human bowels, 382 .

of injurious forest insects, 2267.

named, 1264.

Preserring, 1300.

in stomach of black-hass, 1792

blut-birk, 1871.

Larval characteristics of Corydalus and Chanlio. des, 1652

characters and haluits of blister-beotles, 1600 Epicanta, 1600.

Macrobasis, 1600.

habits of hoe-tlies. Bombylida, 1947, 1970. Dexillac, 2260.

Epicauta and Henous, 1387.

Sphenophori that attack coru, 2030.

lifo as influcheed by food. Number of molts and length of, 2167 .

stages and habits of bee-fly. Hirmonenra 2169.

Larviform females in the Phengodini. Luminous, $2397,2402$.

Lasils latipes, 27.

Lasioderma serricorue, 551 .

Lasioptera vitis, 720, 1329. 
Law. Carrying out the, 1993.

Lawn. Beetles swarming about, 718.

Laws to prevent the introduction of Phylloxera, 2019.

Leaf-beetle. Streaked cottonwood, 2291.

bug. Ash gray, 1127, 1423.

bugs, 400 .

crumplex. Apple, 574,1580 .

in Georgia. Rascal, 1962.

Rascal, 341, 373, 1311.

folder. Cranberry, 2291.

Grape, 1301, 1579.

galls and catcrpillars on sugar berry, 762 .

hopper, 36. on the grape-vine, 1716 .

injurious to small grains. A new, 1767.

hoppers, 2362.

on celery, 452.

of the grape, 399.

Grape-vine, 484.

injuring wheat, 1766 .

miner on white-oak, 1879.

miners of the locust, 451.

roller. Strawberry, 1574.

rollers. Descriptions of new, 1969.

tyer. The green, 1311.

Leafy oak-gall, 774.

Leather-beetle, 2363 .

Lebia grandis, $365,1218$. Great, 1301.

Lecanium, 1.

acericola $n . s p ., 389=$ Pulvinaria innu merabilis.

maclura n. $8 p ., 389=$ Pulvinaria innu merabilis.

olex, 1303.

rose $=$ L. olex

sp. on blackberry, 117.

cbina-tree, 1964.

magnolia, 1377.

plum, 107.

sugar-maple, 1004

vitis $=P$ ulvinaria vitis

Leconte, J. L. Deatb of, 2246.

Tribute to the memory of, 2264.

Leconte's pine-worm, 1570.

Lederer, J. Death of, 1285.

Le Duc, W. G. Letter to, 1684.

Legged maple-borer, 1363.

Legislation to control insects injurious to vegetation, 1946.

in regard to insects injurious to agri cuiture, 1468.

Lema trilineata, 119, 126, 135, 136, 138, 185, 401, 565 $925,1059,1328,1558,1593$

Length of larval lifo as influenced by food. Num. ber of molts and, 2167 .

the thread of the silk-worm, 1359.

Leopard moth. Great, 1311.

Lepidinm vs. bed-bugs, 1741.

Lepidoptera, 1329, 2267, 2340.

Hudson Bay, 1985.

Migrations of, 1770.

New lists of North American, 2132.

Notes on Soutb American, 1784.
Lepidoptera of the Outer Hebrides, 2058.

Lepidopterological notes, 1999, 2013, 2160.

Lepidopteron. A myrmecophilous, 2214.

Lepidopterous case-bearer, 260.

larræ. Dried leares as food for, 2159.

Fleas fecding on, 2110 .

Remarkable, 40.

Lepidosaphidæe, 1301.

Lepiopomus pallidns. Insects from the stomach of, 1792.

Lcptobatus illinoiensis $n . s p ., 385=$ Exetastes illinoiensis.

Leptostylus aculiferus, 673 .

Leptura capitata, 200.

Leptus americauus $n$. $s p ., 1326=$ Tetranychus americanus.

irritans $n . s p ., 1326=$ Tetranychus irri tans.

Lesser apple-leaf folder, 1311.

locust, 2363.

migratory locust, 2232 .

pine-burer, 2267.

Prionus, 2267.

Lestes inæqualis $n . s p ., 24$.

Lencania albilinea, 1507, 1570, 1610.

unipuncta, $6,7,8,9,10,11,12,17,52,328$, $647,670,879,906,1127,1267$, $1282,1400,1442,1482,1481$, $1551,1570,1670,1800,1835$ $1856,1877,1885,1886,1953$, $2001,2009,2086,2087,2090$, 2119, 2122, 2235, 2239, 2253, $2262,2267,2343$.

Additional notes on, 2001.

Completc life-history of, 1670 .

Hibernation, 7, 8, 2086.

Parasites of, $6,10,17,1670$.

Leucopis, 154, 160, 174, 1530.

Phylloxera, 2150.

Libellulidse, 1707, 1709.

Library pest. Croton bug as a, 1717 .

Lice on calves, 889.

horses, 258 .

pigs, 900 .

snow-balls, 1184

Lichtenstein, J. Obituary, 2370.

Lichtenstein's theory as to dimorphic asexual fe. males, 2072.

Life. Tenacity of, 1755 .

Ligbt. Insects attracted to, 178, 2352.

Lightning-hopper. Frosted, 1329. hoppers, 737.

Lignified snake of Brazil, 2136.

Lignivorous. Rhyssa not, 2286.

Ligyrus relictus, 3, 54, 68, 1440. rugiceps, $1794,2080$.

Lilac-borer, 844 .

LILAC. INSECTS AFFECTING.

Egeria syringæ $=$ Podosesia syringæ.

Podosesia syringæ, 844 .

Limacodes, 847, 1150.

byalinus $n_{0} s p ., 40=$ Pbobetron $_{\text {hyali- }}$ num.

pithecium $=$ Phobetron pithecium. scapba, 40 . 
Limacodes tetradactylus $n . s p ., 40$.

Limenitis disippus, 613, 1193, 1217, 1301, 1305, 1306, 1340. ursula, 145, 1217, 1305, 1306, 1340.

Limneria fugitiva, 413, 1311. lophyri n. sp., 1570 . pallipes, 2378.

Limnophilus, 2267.

Lina lapponica, 1834. populi, 1834. scripta, 1654, 1834, 2291. tremulæ, 1834.

Liuden and ash destroyers, 1849.

LIN1)EN. INSECTS AFFECTING.

Hsphantria cunea, 1849. textor $=\mathrm{H}$. canea.

Odontota rubra, 1849.

Linoceras junceus, 543, 1827.

L'insectologie agricole, (review), 506, 568.

Liutner's first report, 2244, 2254.

Linnu. Acrididæ that eat, 1645.

Lissor hoptrus simplex, 273, 1911, 1973, 2119.

Listotrophus cingulatus, 805 .

Lithocolletis cincinnatiella, 1879. guttifinitella. Mandible of, 1934.

Lithophane antenuata, 1182.

Littlo Cicada, 1242.

$$
\text { cinerea, } 1301 .
$$

known factsabout well.known animals, 2071.

Turk and its crescent, 329.

Live-stock. Insects injurious to, 2238.

Lives. 'Two useful, 2370.

Lisus. Larval habits of, 2404.

niacer, 2404.

parcus on Amelanchier, 2404.

Lolusia botrana $=$ Eudemis botrana

Loco weed. Walshia amorphelia bred from, 1127, 2356.

Loconotion. Insect, 1955.

Locust, 2366 .

Ash.colored, 2363.

A tlantic migratory, 1423, 1625.

borer, 921, 1121, 1196, 1288.

Hickory v8., 1516.

borers, 37, 472.

Bruner, L. Observations in the North. west on the Rocky Mountain, 2165 .

California migratory, 2363.

Californian, 1959.

Devastating, 2363.

Difforential, 1423, 2363.

eggs, 1548.

in Asia Minor. Bombylid larvæ destroying, 2118.

Condition of, 1567.

Experiments with, 1572.

Expected advent of the, 2307.

experience, 1617.

flights, 1590.

in Dakota, 2007.

east of the Mississippi, 1549, 1613.

Geographical distribution of the Rocky

Mountain, 2267.

or grasshopper. Governors of Western States on tho Rocky Mountain, 1557.
Incust, important observations on the Rocky Moun tain, 1571.

injuries. New method of connteracting, 2335.

injury in Kansas and Missouri this fall, 1433.

the near future. Probabilities of, 2355 .

injury next spring, 1555 . summer. Anticipated, 1615.

LOCUST. INSECTS AFHECTING.

Arhopalus robinix $=\mathrm{Cyllcno}$ robinix.

Cossus robiniæ, $37,1121$.

Clytus robiniæ $=$ Cyllen e robinis.

Cyllene robiniæ, 37, 472, 827, 921, 1196, 1250 , $1288,1516$.

Hispa scutellaris = Odontota dorsalis.

Nitidulida, 37.

Odontota dorsalis, 451.

Spermophagus robinia, 1026, 1474.

Xyleutes robinix $=$ Cossus robinix.

Locust invasion with the occurrence of drought. Connection of, 1422.

Leaf miners of the, 451.

Lecture on the Rocky Mountain, 1493.

Lesser' migrator $5,2232,2363$.

mite, 1423, 3625, 1643, 1959 .

in Montana in 1880, Bruner, L. Rocky Mountain, 2267.

multiplication and migration, Swinton, A. H. Solar phssics and earthquake commotion applied to, 2267.

Natural history of the Rocky Mountain, 1578.

notcs. Miscellaneous, 2267.

in 1876,1521 .

1880, Martin, J. Rocky Mountain, 2267. 1885, Bruner, L. Abundance of the Rocky Mountain, 2363.

and other insects in the Northwest during the summer of 1883, Bruner, L. Obserrations on the Rocky Mountain, 2277.

Packard, A. S. Development of the, 2267.

The periodical Cicala alias the seventeen. year and the thirteen-jear, 1159.

pest, 1501.

Philosophy of the morements of the Rocky Mountain, 1669.

plague, 1473.

in the Unitcd States, 1625.

probabilities for 1882, 2057.

prospccts, 1527, 1562, 1582.

in sonthwest Missouri this fall, 1596.

ravages in California, 1959.

1880 and 1881. Chronology of, 2267.

Red-legged, 2363, 1423, 1625.

report to governor of Kansas, 1573.

Rocky Mountain, 1423, 1451, 1452, 1482, 1538,

$1557,1570,1625,1613,1959,2267,2291$.

sconrge. Rocky Mountain, 1629.

seed-weeril. IIoney, 1026.

Seventeen-year, 370, 884, 1489.

swarms that derastato tho trans-Missis. sippi country, 1674.

theory wauted. Now, 1532. 
Locust. Two-striped, 1423, 2363.

wervil. Honey, 1474.

in Wyoming, Montana, ctc., in 1881, Bru. ncr, L. Thu Iocky Mountain, 2267.

Yellow, 2363.

Locustida, 929,1453

Locusts, 926, 1349, 1363, 2418.

agaill, 1550.

Bruner, L. List of North American, 2267.

Changes in regetation caused by, 1495.

in Dardanellcs. Sarcophaga lineata do. structive to, 2075.

Destruction of young or anfledged, 1577.

Destructive, 2363.

Dimorphism of, 1889 .

Ditching for young, 1488.

eat the castor-bean, $\mathbf{1 6 4 5}$.

about Folsom, Cal., Koebole, A. Notes on, 2363 .

as food for man, 1481 .

Grasshoppers and, 26, 147, 929 .

Habits of young or unfledged, 1578.

hatching? Are the, 1566 .

Mistaken identity. Are the, 1593.

How to destrov, 1446.

in Illinois. Flying, 1437, 1443.

in Kansas, 1591.

Literaturc of destructive, 1959.

and locusts, 1994.

in Nevada, 2024.

New remedy against destructive, 2328 .

next spring. Injury by, 1555 .

Notes on, 1456.

1880. Chipman, A.J. Notes on, 2267.

Prairie fires and hateful, 1453.

Professor Riley and the, 1434.

of San Joaquin Valley, Cal. Coquillett,

D. W. Report on the, 2363.

sting? Do, 371 .

in Texas in spring of 1886, Bruner, L.

Report on, 2382.

in the West, 2044.

and the Western cricket, Brnner, I.

Notes on other, 2267.

in westcrn Missouri. Ravages of yonng, 1492.

Loew, H. Description of the rye gall.gnat, 2267.

Lombardy poplars. Caterpillars on, 571.

London purple as an insecticide, 1725. and Paris green, 2021.

Long.borned Diabrotica, 1905.

legs. Grand-daddy, 838.

sting. Delicate, 1329.

tailed Ophion, 1311.

Longicorn beetles. Food of, 1902.

borers, 95 .

Longicorns in pine and cedar, 319.

Longitarsus, 636 .

Look out for the eggs of the apple-tree plant. louse, 507.

Lopha 4-maculata =.Bembidium 4-maculatum.

Lophyrus abbotii, 465, 927, 956, 1057, 1570. abietis, 115 .

lecontei, 985, 1011, 1057, 1570.
Louisiana. Destructive cricket in, 2384.

Lozotænia rosaceana $=$ Cacœeia rosacerne.

Lubber grasshopper, 2119.

Lucanus dama, 781. elaphus, 305, 755, 957, 1517.

Lucidota atra, 358.

Lucilia macellaria, 209, 1880, 1921, 2158, 2199, 2255.

Ludius attennatus, 224.

Lumbricus, 1304.

Luminosity of fire-flies, 1840 .

Luminous larviform females of Phengodini, 2397, 2402.

Luna moth, 776 .

silk-worm, 1311.

Lungs. Larva of Scenopinus from human, 1348.

Luperus brunneus, 1799. morulus, 1799.

noxins $=\mathbf{L}$. brunneus

Lure for moths, 1695.

Lyda $8 p ., 656$.

Ljdella doryphoræ n. $s p ., 1059=$ Exorista dory. phora.

Lygus lineolaris $=$ L. praténsis.

pratensis, $2,31,76,682,1127,1213,1219,2235$, 2291,2363

Lymexylida, 575 .

Lymexylon navale, 575,1135 .

Lytta ænea $=$ Pomphopœa ænea. atrata $=$ Epicauta pennsylvanica. cinerea $=$ Macrobasis unicolor.

fabricii = Mar;robasis unicolor. marginata = Epicauta cinerea. murina $=$ Macrobasis uniculor: sayi $=$ Pomphopcea sayi.

tarsalis $=$ Pomphopcea tarsalis vittata = Epicauta vittata.

Machine. A satisfactory grassholper, 1592.

Machinery for destroring the cotton-worm, Barnard, W.S. Tests of, 2253.

Killing apple-worms br, 769.

McLain, N. W. A picultural experiments, $23 \delta 2$.

Experiments in apiculture, 2394.

Report on experiments in apiculture, 2363 .

Maclura aurantiaca as food for Sericaria, 2234. Silk-worms fed on, 1341, 1542, 1609.

McMurtrie, W. Tests of silk-fiber from cocoons raised at the Department, 2253.

Macrobasis, $1600,1643,1651,2238$.

albida, 1796

Macrobasis, Larval characters and habits, 1602. murina $=\mathbf{M}$. unicolor.

'Inicolor, 38, 134, 185, 347, 3́62, 401, 470, $736,912,1044,1209,1558,2248$.

Macrocentrus delicatus, 1334.

Macrodactylus subspinosus, $249,361,373,565,748$,

$1075,1278,1329,1357,1375,1478,1583,2248$.

Macrogomphus? spiniceps $n . s p ., 24$.

Macromia flavipennis $n . s p ., 24$.

illinoiensis $n . s p ., 24$.

Macronema zebratum, 372.

Macrosila carolina $=$ Protoparce carolina. cluentins, 1784

5-maculatus $=$ Protoparce celeus rustica $=$ Protoparce rustlca. 
Mad. Entomology indeed run, 227, 1224.

Madarus ampelopsidos $=$ Ampeloglypter ater. vitis $n . s p ., 1059=$ Ampeloglypter sesos. tris.

Madras. "Coffee-borel' in, 498.

Macklin, F. W. Obituary, 2161.

Maggots in sauce, 1607. .

Magnolia. Lecanium on, 1377. Scale-insect $01,1377$.

Mail moth, 1329.

Mails. Quecn becs in the, 1762 .

Maine. Now potato-bug in, 119.

MAIZL, INSECTS AIFECTING, 2119.

Achatodes zere, 1927.

Agrotidae, 1522.

Elaterida, 15:2.

Lachnostorna fusca; 1522. quercina $=\mathbf{L}$. fusca.

Malaria. Mosquitoes vs., 2162.

Mallodon melanopus, 2291.

Mallophaga, 258, 497.

Mallophora orcina, 1959.

Malodorants. Repelling insects by, 2091.

Malva sylvestris. Ersnnis alcex boring in stems of, 1602 .

Mamestra, 2238.

Cabbage, 2232.

chenopodi $=$ M. trifolii.

picta, 179, 1056, 1127, 2232 .

subjuncta, 2291 .

trifolii, 229, 281, 2232.

Man. Effect of Paris green on, 1427.

Insects as food for, 2166.

Locusts as tood for, 1481 .

Mautidæ, 2267.

Mantis, 2267.

carolina $=$ Phasmomantis carolina

Preying, 457.

or 1ear-horse. Eggs of, 1060.

Supposed eggs of preying, 1002.

ITantispa, 2267.

brunnea, 1243.

Mautispian. Brown, 1243.

IIany-banded robber, 1059, 1423.

Maple-bark lice, 1004.

$$
\text { lonse, } 344 .
$$

Boetlo on sirgar, 1014

borer. Logged, 1363.

$$
\text { A new (?) regerian, } 1360 .
$$

Eqgs on sugar, 350 .

Iaple Galls on leaves of soft, 445.

MALLE. INSECTS AFFECTING.

Acarus aceris-crumena, 1265.

A cronyeta amoricana, 841 .

Ageria accrui, 743, 1063, 1360, 1363.

Anisota l'ubicunda = Dryocampa rubicunda.

1 rachnid, 445 .

Attacus cecropia, 841.

Catydid, 665.

Ccratocampa imperialis = Eacles imperialis.

Chrysobothris femorata, 1250.

Clisiocampa americaua, 350.

Clytus speciosus = Plagionotus speciosus

Coccid, 344.

Dryocampa rubicunda, 841, 915, 1329.

Eacles imperialis, 1268.
MAPLE. INsECTS AFFECTING-Continued.

Eburia 4-geminata, 1014.

Lecaninm acericola $=$ Pulvinaria innnmera. bilis.

sp., 1004.

Orggia antiqua, 1797.

Plagionotus speciosus, 215 .

Pyendococus aceris, 1890.

Pulviuaria innumerabilis, 1515, 1816, 2279.

Sciara ocellaris, 2119.

Telca polyphemus, $8+1$.

Trochilium acericolnm = Egoria acerni. acerni $=$ Egeria acorni.

Maplo. Mite-gall on surar, 1265.

Ocellate leaf-gall of the red, 2119.

scale. Cottony, 1816, 2291 .

Scale insect on, 1890.

troe inscets, 2279 .

twigs. Rows of cgrss 011,665 .

worm. Green striped. 1329.

worms, 841.

Maples. Cottony scrilo on, 1515.

Flat-headed borer in soft, 1250 .

Mare's ncst. Finding a, 86 .

Margined blister-beetle, 1059, 1558.

Martin, J. Report on tho Rocky Mountain 1ocust, 1959 .

Roport oll the Rocky Mountain locust in 1880,2267 .

Mary Chalcis-1ly, 1311.

Masicera archippivora $n . s p ., 1301$.

Mason-bee cells. Remarkable new gonus of Me

loida iufesting, 1601.

Mass of eggs, 240.

mistakes, 234.

Massachusetts. Periodical Cicada in, 2321.

southeast

ern, 2216

Massospora cicadiua infesting Cicada, 1809, 2112.

May-beetle, $300,865,1020$

Egg of the common, 1329.

beetlcs swarming in Alabama, 1812.

fly, 283.

Meadow enemy, 1368.

lark. Boetles in stomach of, 1013.

worms, 947.

Mreal sack. Worm infesting, 1896.

worms, 191.

Mealy hugs. Structure of, 2119.

Measurin $\underline{\mathrm{g}}$-worms, 75 .

Megastizils brevipennis, 375 .

Megathymus coloradeusis n. var., 1602.

yuccre, $1420,1465,1482,1570,1602$.

Additional notes, 1602 .

Note on, 1465 .

Megatoma serra, 1352.

Megilla maculata, $6,51,188,599$.

Food-habits of, 2145 .

Melampsalta parvula, 1242.

Melancholy chafor, 522

Melanactes, 1874.

in apples, 842.

Melanippe montanata, 2224 .

Melanolestes picipes, 314, 1253 .

Melanophila sin., 2267.

Melanophora? diabrotica, 2260. 
Melanoplus atlanis = Caloptenus atlanis. destructor $=$ Caloptenus destructor. devastator $=$ Caloptenus devastator.

Melanotus communis, 351,358 . incertus, 40, 846 .

Melasoma lapponicum = Lina lapponica populi = Lina populi. scriptum = Lina scripta. tremulæ = Lina tremulæ.

Melissopus $n \cdot g \cdot, 196 y$. aurichalceana n. sp., 1969 latiferreana, 1969.

Melittia ceto, 125, 126, 248, 377, 1083. gloriosa 2410.

Meloe, 1500, 1600, 2267.

angusticollis, 1387 .

barbarus, 1600.

proscarabæus, 2083.

Meloidæ, 912, 1230, 1396, 1600, 1601, 1651, 1858, 2002 $2072,2118,2267$

Fire cure for, 121

Hy permetamorphoses of, 2191.

infesting potato, 48 .

Means against, 794 .

Remarkable genus of, 1601.

Remarks on, 1600 .

Triungulin of, 208 .

Meloini, 1601

Melılontha philophaga = Lachnosterna fusca

Melon. Bug on, 897.

bugs. Satisfactory remedy for, 2236.

Diabrotica vittata on, $897,2236,2238$.

Membracidæ, 737.

Membracis ampelopsidis, 1183.

Memoriam B. D. Walsh. In, 1098.

Meracantha contracta, 1871.

Merinus levis, 1153.

Merisis destructor, 1581, 2332.

Mermis, 2363. subapterus $n . s p$., 2332.

Meromyza, 1461. americana, 727, 1058, 1059, 1506, 1589 $1848,1875,2291,2394$.

Mesochorus. Glassy, 1127. vitreus $n . s p ., 6,1670$.

Mesoleius, 385.

Metamymar $n . g ., 2343$. aleurodis $n . s p ., 2343$.

Metapodius femoratus, 373,775 . vasulus $=$ M. femoratus.

Meteorus hyphantriæ n. $s p ., 237 \dot{8}, 2394$.

Methods of destroying scalc-insects, 2119.

Mexican honey-ants. Peculiarities of, 1417.

Mexico. Report on cotton crop and its enemies in, 2343.

Mezinm americanum, 2346.

Michigan apples and codling-moth, 1677.

Microcentrum-retinervis, 241, 247, 1363, 1518, 1536 2276.

Microdon go obosua, 1789.

Microgaster, $77,158,183,490,662,679,717,851,1217$, 1290.

Disippus, 1301.

gelechiæ n. sp., 1059.

Life-habits of, 64 .

limenitidis $n . s p ., 1301=$ Apanteles limenitidis.
Microgaster, Militar $5,1127$.

Notes on North American, 1960.

parasitic on Protoparce celeus, 155, 1261.

sp. parasitic on Thecla (poes?), 1872.

Microgasters. Notes on, 2097.

Microlepidoptera. Works on North American, 1975.

Microplitis actnosus, 1125, 1134 .

ceratomiæ n. sp., 1125, 1134,1960.

gortynæ n. sp., 1960.

Micropterus salmoides. Larvæ in stomach of, 1792.

Micropus leucopterus = Blissus leucopterus.

Mirlas fulvipes $\imath . s p ., 40$.

Midge, 167.

Clover-seed, 2291.

Pear, 2363.

Wheat, 109, 110, 142, 216, 280, 292, 428, 711, $1512,2238,2291,2363$.

Migration of butterflies, 1770, 1991.

and hibernation of Aletia argillacea. 1689.

of plant-lice from one plant to another, 2017.

Migratory butterfies, 1622, 1635.

locust. Atlantic, 1423

Lesser, 2232.

Military Microgaster, 1127.

Milkweed. Danais archippus on, 1535. weevil, 711.

Million dollars. That hundred aud fifty, 1617.

Plums for the, 501.

Mills. The same in flouring. 1261.

Milyas cinctus, 777, 1294, 1431, 1450, 1672, 2048.

Mimicry and protective resemblances, 1301, 1340.

Mind how you pack your insects, 435.

Minings on apple-twigs. Galls and, 552.

Minneapolis. Entomoloy at, 2212.

Minnesota. A State entomologist for, 1108.

Minot, C. S. Anatomy of Aletia, 2343.

Minute borers in eherry, peach, and plum tries, 1940.

Miscellaneous, 735 .

Miscellaneous notes on orange insects, 2164.

Misnamed gall-moth, 1127.

Mississippi country. Tle locust swarms that devastate the trans, 1674.

Deseription of Aphididre from west of the, 1678.

floods. One effect of the, 2080.

Locust flights east of the, 1549, 1613.

valley. The Buffalo-gnat problem in the lower, 2416

Missouri. Ailanthus silk-worm in, 1460.

bee-killer, 1127.

entomological reports, 1680.

Noctuida in the, 2069.

Entomology in, 1361.

this fall. Locust prospects in southwest, 1596.

No locust injury in Kansas and, 1433.

Mnrtfeldt, M. E. Notes from, 2291. 
Missouri. Murtfeldt, M. E. Notes for 1886 from, 2382.

Oyster-shell bark-lonse in, 1169 .

Ravages of young locusts in western, 1492.

Report State entomologist of, 1, 1059.

2,1127 .

3,1301 .

4,1311 .

5,1329 .

6,1363 .

7,1423 .

8,1482 .

9,1570 .

Index, 2026.

State Horticultural Society. Report committee on entomolog $5,1113,1127$.

Mistaken identit, 1593.

Supposed bark.lice eggs in, 1084.

Mistakes. A mass of, 234.

Mite. On an extensile penetrating organ in a gamasid, 1626.

in fowls. Internal, 2157.

gall on sugar-1naple, 1265.

Locust, 1423, 1625, 1643, 1959.

parasites of the Colorado potato-beetle, 1505.

Phylloxera, 1363.

lied, 1959 .

Scarlet, 1470.

Silk $5,1423,1625$.

transformations, 1618.

Mites, 356.

Cannibal, 624.

Classification of, 1992.

Descriptions of new subterranean, 1370.

Egg-infesting, 1637 .

on grasshoppers, 146.

mistaken for plant-lice, 59 .

parasitic on beetles, 315 .

- Transformations of the red, 1632.

Mniszech, G. V. Ohituary; 2054.

Mold and Phylloxera, 1807.

Mole crickets, 1270.

Molts and length of larval life as influenced by food. Nimber of, 2167.

Monell, J. Notes on Aphididæe, 1678.

Monocesta coryli, 1721.

Monocrcpidius vespertinus, 351.

Monographs again, $1765,1828$.

Monobammus titillator, 1324.

Monophadnus rubi, 663, 761, 1212, 1641.

Monostegia rosæe, 672, 984, 1780.

Monstrosities. Rare, 2224.

Montana in 1880, Bruner, L. The Rocky Mountain locust in, 2267.

1881, Bruner, L. The Rocky Mountain locust in W yoming and, $\subseteq 267$.

Monterey again. Butterfly-tree of, 2052.

More good words, 532 . universal remedies, 278.

Morning.glory. Coptocycla aurichalcea on, 1510. Sphinx. White-lined,630, 1198, 1301, 2291. Morns as food for Sericaria, 2234.

Mosquitoes, 603 . vs. malaria, 2162.
Mossy rose-gall, 570, 1166.

Most precious bug, 575 .

Moth on apple-tres. Large, 1028.

Bee, 716, 904, 1059, 1508, 1723 .

hreeding. Pedigree, 2381.

eggs, 611 .

Handmaid, 2222.

issuing from a larva, 1779.

named, $807,1241$.

Viviparity of a, 2153.

Motherless race. That fatherless and, 1650 .

Moths attracted by falling water, 2108.

and hutterflies canght by the tongne, 1761.

caught in Alabama, 1774.

in cushious. Rarages of, 1731 .

Descriptions of two ncw, 1411.

Galls made by, 1127 .

Lure for, 1695.

mistaken for Aletia, 1976.

by Physianthus albens. Capture of, 1388, $1419,1761$.

Sugaring for, 1300 .

Mottled tortoise-heetle, 1127.

Moulting in Orgyia. Variable, 2379.

Monnding peach-trees, 587. again, 617,653 .

Mountain ash. Ash and, 705 .

Mountain ash. Insects afFecting.

? Aphis mali, $5 i 9$.

Aspidiotus harrisii $=$ Chionaspis furfurns.

Chionaspis furfurus, 579 .

Mountain ash. Plant-louse eggs on apple and, 579.

IInd-wasp and parasites, 1827. spider eg'g-nest, 1847.

Mulberry. Sericaria mori on, 1311, 1341, 2234. silk-worm, 1311.

Osago olange for the, 1220 , 1286.

for the silk-worm. Osage orange v8., 2234.

Mulch has. Worms under, 1161.

Mules cansed by insects. Death of, $18 \mathbf{i 1}$.

Hurgantia histrionica, 849, 1099, 1297, 1311, 1534, $2238,2: 63,2291$.

Murky ground-beetle, 486.

Murmidius. Hahits of, 2217.

Murmidius ovalis, 2217.

Murtfe]dt, M. E. Notes from Missonri, 2291.

for the season of 1886,2382 .

Musca, 1390.

domestica, 815, 864, 2071, 2078.

harpyia $=\mathbf{M}$. domestica.

Muscid, 459.

from stowach of Ohio shad, 1853.

Muscidæ, 153, 1880, 2256.

Musclo shaped bark-louse on apple.trees South, 1774.

Museum pest. Dinoderus pusillns as a, 2104 .

A new, 2109.

once more, 492.

Trogoderna tarsale as a, 2139.

pests, $246,462,572,726$. again, 483 .

Mutilla coccinea = Sphrepophtbalma occidentalis. Mycetophila persica $n . s p ., 653,660,963,1056$. 
Mr cetophila sp., 410.

My chocerus, 2217.

Mygale leutzii, 466, 493, 521, 823, 1178. and Pepsis formosa, 1619.

Mrochrous denticollis, 2418.

Myriapoda, 219, 224

$$
\text { Poisouons, } 2399 .
$$

Mryriapods, 1025.

Myrmecocystus hortusdeorum, 1942. mexicanus, 1417.

Myrmecophila, 2202.

Myrmecophilous coleoptera, 2105. lepidoptera, 2214. species. Hymenorus rufipes as

Mylmica minuta, 1413. a, 2226.

Mrrmicocela ochracclla, 2261.

Mysia 15-punctata = Anatis 15-punctata

Mystery. Dr. Hagens', 1943.

in reference to Pronuba yuccasella, 1933.

Mytilaspis, 1.

conchiformis $=$ M. pomorum.

pomicorticis n. $s p$., $1329=$ M. pomo rum.

pomol'um, 188, 201, 345, 372, 373, 377,423, $565,896,944,951,973,982,989,994$ 1007, 1008, 1012, 1040, 1056, 1059, 1084 $1169,124 h, 1329,1362,1397,1552,1583$ $1774,2088,2238$

M) zus cerasi, $678,960,1067,1207,1251$. l'ibis, 304, 322, 735, 970.

Nails into fruit-trees. Driving, 87.

Nanodes tamarisci, 1496.

Nantucket. Pine-moth of, 2183.

Naphthaline cones, 2133.

for insect collections, 2073.

as an insecticide. Use of, 2274.

Napping. An entomologist caught, 1100.

Nirrow-winged katydid, 1363.

Natioual MIuseum. The collection of insects in $2299,2390$.

Reports on the department of insects in the, 2282,2330 2368.

Native American insects. Imported and, 1115, 1127.

apple-tree bark-lice, 1152.

bark-lice on apple-trees, 1061.

clurrant-worm, 1570, 2238.

grape-vines. Cause of deterioration in some of our, 1342.

home. Colorado potato-beetles, 1462.

plums. Wier, D. B., 2388.

Naturaliste Cauadien. Le (review), 546.

Naturalists. Entomological speculations of the New England school of, 44.

Neal, J. C. Observations and experiments, 2164.

Nebraska bee-killer, 1127, 1311.

Bruner, I. Notes from, 2291.

Report of the season's observations in, 2418 .

insects, Bruner, L. Report on, 2382.

Necrobia ruficollis, 1363

rufipes, 1363, 1367, 1703.
Necrological, 1817.

Neerophorus marginatus, 315,845 .

Nectarophora granaria, 126, 1806, 2394 . rudbeckiæ, 27, 2205.

Needle. Devil's darning, 1709.

Negro bug. Flea-like, 1127, 1423, 2291, 2418.

Nematus erichsoni, 2198, 2232, 2355.

fur n. $s p ., 197$.

hospes n. sp., 197.

inquilinus $n . s p ., 197$.

integer, 2232.

mendicus n. $s p ., 197,821$.

ribesii, $78,140,228,333,340,364,380,381$ $756,772,1031,1224,1570,1696,2238$.

ribis $=\mathrm{N}$. ribcsii.

s.-desmodioides n. sp., 197.

s.-pisum $2 . s p ., 197$.

s.-pomum n. sp., 197.

Spruze, 2232.

vontralis, 907, 917, 924, 1211.

ventricosus $=\mathrm{N}$. ribesii.

Nemestrinida, 2186.

Nemobius vittatus, 1287.

Nemoræa leucaniæ, 6, 12, 647, 1112, 1127, 1670.

Neoclytus capræa, 560,582, 1849.

erythrocephalus, 1798.

Nephelodes violans, 1885, 1990.

Nephila plumipes, 830 .

Peculiarities of, 1416.

Nepidx, 797

Nerium oleander. Moths caught by, 1419, 1761.

Nerrous system of articulates. Fersin. Function of the, 1959.

insects, 2225 .

Phylloxera, 1687.

Neuroptera, 1329, 1736, 2267.

North American, 24, 39.

Neuroterus q.-saltatorius, 1496, 2163, 2173.

Nevada. Locust in, 2024.

New Curculio humbug, 680.

New England and New York. Packard, A. S. Causes of destruction of ever. green and forest trees in, 2232, 2291, 2363, 2364, 2382.

school of naturalists. Entomolog. ical speculations of the, 44 .

entomological journal, 2056.

Hampshirc. Colorado potato-beetle in, 1859. humbug, 122.

Mexico. Blister beetics from, 1796.

philosophy. Old and, 322.

York. Chinch-bug in, 2237, 2252, 2271.

Colorado potato-beetle in, 1379.

and Eastern Statcs. Supposed army. worm in, 1990.

Entomology in, 2244, 2254.

Packard, A. S. Causes of destruction of evergrcen and forest trees in New England and, 2232, 2291, 2363, 2364, 2382.

State entomologist for, 1863 . weevil, 306, 652, 659, 1301. in apple trees, 1085.

without a State entomologist, 1330.

News. Recent cotton-worm articles in the, 1719. Nicotiana tabacum. Flea-beetle eating, 1782. 
Night. How the Curculio flies by, 706.

Nintl report State entomologist of Missouri, 1570.

Niptus hololeucus, 2154.

Nitidula bipustulata, 214.

Nitidnlidæe, 37, 214.

Noctnid. A unique and beautiful, 2189.

- Noctuidæ, 455, 787, 1419, 1761.

of the Missouri l'cports, 20 r.

North America. Notice of Grote's

iliustrated essay on the, $214 x$.

Parasites of, 349 .

taken at Orono, Me., 2160.

Nula sorghiella n.sp., 2119.

Nomenclatnre. Scientific, 303,768 .

None so blind as those who shut their eyes, 275.

Nonsense about the Pliylloxera, 1457.

North America. Dilar in, 2023.

Early references to the Hes. sian $\mathrm{fly}$ in, 2267.

Notes on Psyllidie of, 2272.

Packard, A. S. Zoo-geograplical map of, 2267.

Americau Anthomyilac, 1966.

Coleoptera. Classification of, 2085.

Hymenoptera. Descriptions of, 385.

Lepidoptera. New lists of, 2132.

Microgasters. Notes on, 1960.

microlepidoptera. Works on, 1975.

Entomological ignorance in the, 431.

Nortliern army-worm, 1835.

brenthian, 1363 .

Illinois. Six worst enemies of fruitgrowers in, $37 \%$.

larly-bird and its larra, 1289.

Northwest in 1883. Irmner, L. Rocky Mountain locust in the, 2277.

ou the Rocky Mountain locust. Bru. ner, L. Report of observations in

Note, $184,954$. the, 2165 .

Notes. Entomological, 2, 1396, 1554, 1609, 1610, $1681,1958,2015,2058,2066,2135,2147,2168$, 2184, 2192, 2219, 2228, 2247, 2261.

by B. D. Walsh, 174 .

Nothrus orivorus, 1357.

Notices, 196.

Notodonta concinna $=$ Edemasia concinna. unicornis $=$ Colodasys unicornis.

Nuttiglossa undata = Oncometopia undata.

Noxious insects increase upon us. Why, 766 . named, 454.

Poisoning, 205.

Popular remedies for, 73 .

Nozzle. Cyclone, 2327.

Nuisance. Caterpillar, 1995.

made useful, 983.

Number of entomologists in Europe, 1865. molts and length of larral life as in. fluenced by food, 2167.

segments in the head of winged in. sects. Packard, A. S., 2267.
Nursery. Holes around the roots of young ash trees in the, 471 .

Nuts. Gall, 1560.

Nymphalidæ, 1301.

Pupation of, 1704.

Nysins angustatus, 1329, 1357, 1402, 1453, 2048, 2291. destructor n. sp., $1329=-\mathrm{N}$. angustatus. n. $811 ., 1317$.

Oaik apple, 1448 .

bark louse, 159.

lorer, 2267.

Clytns, 2267.

coccid mistaken for a gall, 1972.

fig gall, 745 .

rall, 212, 1925.

on acorn crips. A new, 1606.

Honey-producing, 1942 .

Leafy, 774 .

OAK. INGECTS AFFECTING.

Antphibolips q.-inanis, 1448.

q.-prinus, 1606.

q.-spongifica, 1448.

Andricus q. californicus, 1967.

q.-punctat 11s, 1822.

seminator, $739,1037$.

Balaninus l'ectus, 1311.

Biorhiza forticornis, 745 .

Cocidomyia q.-pillulæo, 799.

q.-symmetrica, 799.

Cecidomyidæ, 799.

Cerambycid, 2267.

Ceroptres ficus, 745.

Coccus, 159.

Cossus robiniæ, 1003.

Cynipid, 212.

Cynipilæe, 41, 799.

Cynips fecundatrix, 1606 .

forticornis = Biorhiza forticornis.

gallæ-tinctoriæ, 1560 .

q.-californıcus = Andricus q.•(alifor.

nicus.

q. decirlua, 1925.

q.-frondosa, 774, 1606 .

q.-glandulus, 1606.

q.inanis = Amphibolips q.-inanis.

q.-mellaria, 1942.

q. prumus $=$ Amphibolips q. prumus.

q. $\cdot$ punctata $=$ Andricus q. $\cdot$ punctatus.

q. $\cdot$ spongifica $=$ A mphibolips q $\cdot$-spongi-

- fica.

seminator $=$ Andricus seminator.

sp., 799 .

telmiualis, 1448 .

Edema albifrons, 422.

Elaphidion parallelum $=$ E. villosum. putator $=\mathbf{E}$. villosum. rillosum, 288, 793, 2267.

Euclemsis bassetella, 1972.

Galls, 1269.

Holocera gland nella, 1310, 1311.

Ithycerus norebolacensis, 1033.

Kermes galliformis, 1972.

Lachnnsterna fusca, 1812.

pilosicollis $=\mathbf{L}$. tristis.

quercina $=$ L. fnsca.

tristis, 966 . 
OAK. InseCts AFFECTING-Continued.

Lithocolletis cincinnatiella, 1879.

Mallodou melanopus, 2291.

Myrmecocystus hortus-dcorum, 1942.

MIJ tilaspis pomicorticis $=$ M. ponorum. pornorum, 973.

Ozognathus cornutus, 1967.

Plyylloxera lichtensteini, 1421.

Tenthredinid, 108.

Xylotrechus colonus, 2267.

Oak. Inscets stripping the bur, 966 .

leaf gall, 799.

Leaf-miners on white, 1879.

Phylloxera, 1363.

pruner, 793.

and rose galls, 1037.

tree borer, 1003 .

caterpillars, 422.

twigs. Cynipid galls on, 1822.

Woolly galls on white, 739 .

OATS. INSECTS AFFECTING.

A phis avenæ = Nectarophora granaria.

Nectarophora granaria, 1806.

Silvanus surinamensis, $12 \div 9$.

Oats and rye. Beetles working in wheat, 1259.

Oberea bimaculata, $302,783,1363$.

perspicillata $=0$. bimaculata. sp., 1059.

? boring in apple twigs, 1850 .

tripunctatá, 1503.

Obituary. Bazille, L., 2370.

Belfrage, G. W., 2161.

Chambers, V. T., 2218.

Clemers, B., 223.

Glover, T., 2218, 2258.

Lichtenstein, J., 2370.

Maeklin, F. W., 2161.

Mniszech, G. V., 2054

Putnam, J. D., 2054.

Oblong winged katydid, 1329, 1363.

Eggs of the, 569, 1157.

Ocellate leaf gall of the red-maple, 2119.

Odonata. Venation of, 39.

Odontota, 2267.

dorsalis, 451.

rubra; 1849, 1876.

Supposed eggs of, 1876.

Odor in butterflies, 2025.

Odynerus, 770, 1827.

birenimaculatus, 1827.

flavipes, 770,1827 .

Ccanthus, 2267.

\section{latipennis n. $s p ., 2026,2276$.}

nivens, $143,251,286,414,554,723,953$, $961,999,1006,1059,1122,1323$ $1329,1333,1503,1691,2195$, $2238,2276$.

Habits of, 207.

Ecodoma fervens $=$ A tta fervens.

Edemasia concinna 61, 413, 454, 779, 788, 922, 1545 .

Cdipodáa atrox, 1959.

carolina $=$ Dissosteira carolina.

eruciata, 2075.

obliterata, 1959.

pellucida, 1959.
CEdipodini, 1959

Enothera grandiflora. Moths caught by, 1419, 1761.

Cistridie, 114, 153, 290, 2256.

CEstrus hominis = Dermatobia hominis. ovis, $450,887,914,1057,1059,1357,1563$, 2238.

CEta compta $=$ CE. punctella. punctella, 1059, 1343.

Ohio insects. Alwood, W. B. Report on, 2382.

Oil-beetles, 1053, 1643 .

Old-fashioncd potato-bugs, 185.

and new philosophy, 392.

question of species, 2201.

Oleander. Chilocorus bivulnerus on, 730 .

Coccid on, 218.

Insects on, 730 .

Olfersia amcricana, 2297.

Omaha. Conference of western governors at, 1557.

Oncideres amputator, 1556.

cingulata, 442, 443, 476, 489,746, 848, 1556, 1938.

putator, 1556.

Oncometopia undata, 36, 79, 164, 399, 1013.

One day's journal of a state entomologist, 383.

effect of the Mississippi floods, 2080.

half the rine area of France affected by Phyl. loxera, 2020.

Onion-fly, 225.

ONION. INSECTS AFFECTING.

Anthomyia ceparum, 225.

Cambala annulata, 236.

Iulus multistriatus = Cambala annulata.

Ortalis flexa = Tritoxa flexa.

Tritoxa flexa, 225.

Onion-maggot. Means against the, 12. pest. Chester, 2319.

Ontario. Index to the entomological reports of the province of, 2228.

Onward march of the Colorado potato-beotle, 1218.

Ophiogomphus mainensis n. $8 p ., 39$.

Ophiou. Long-tailed, 1311.

macrurum, 1112, 1802 .

purgatum, 1442, 1670.

Purged, 1127.

Opsicotus personatus, 497.

Orange. Bark-louse on osage, 389.

in Brazil. Branner, J. C., insects injuri. ous to the, 2277.

California. Scale-insects of the, 2389.

Experiments upon scale-insects affecting, 2164.

in Florida. Voyle, J., the effects of cold on the scale-insects of the, 2277.

IInbbard, H. G. Rust of the, 2291.

ORANGE. INSECTS AFFECTING.

Coccid, 218.

Mite, 2291.

Phytopus oleivorts, 2308.

Orange insects. Californian, 2373.

and cotton-worm, 2067.

Kerosene as a means against, 2164.

Miscellaneons notes on, 2164. 
Orange insects. Successful management of the most destructive, 2088.

for the nuulberry silk.worm. Osage, 1220, 1286.

Rust of tho, 2308 .

Scale.insects of tho, 2113.

seed. Torms in osage, 597.

Silk-worms fed with osage, 1341, 1542.

Succossful management of insects most destructive to the, 2088.

trees. Insocts found about, 1798 .

Orchard giving out. An, 578 .

Injured, 1594.

Scolytus. Imported, 2233.

Houghton's insects in the, 188.

Orchelimum, 118, 861

\section{glaberrimum, 1329.}

gracile, 447.

Oregon. Apple.plant lice in, 1899.

Organisms. Interaction of, 139,'1954.

Orgyia, 872 .

antiqua, 1797.

Glands in, 2412.

lencostigma, $65,480,535,600,762,1000,1059$, $1151,1227,1352,2198,2238,2378,2379,2380$.

moth issuing from a larva, 1779

Orilatidæ, 1363.

Original habitat of Icerya purchasi, 2415.

Orocharis saltator, 513, 1287, 1323, 1329, 2276.

Ortalis flexa = Tritoxa flexa.

Orthoccntrus pusillus, 385 .

$$
\begin{aligned}
& \text { stigmaticus } n . s p ., 385 . \\
& \text { trifasciatus } n . s p ., 385 .
\end{aligned}
$$

Orthoptera, 1329, 2267, 2276.

Orthoptera, Packard, A. S; systematic position of the, 2267.

Orthopterous insects. Packard, A. S., embryo. logical development of, 2267.

Orthosoma brunneum, $95,397,2267$.

Cylindrical, 1059.

cylindricum $=0$. brunnenm

unicolor $=0$. brunneum.

Osage orange. Bark-louso in. 389.

OSAGE ORANGE. INSECTS AFFECTING.

Dipteron, 597.

Lecanium acericola $=$ Pulvinaria innumerabilis.

maclure $=$ Pulvinaria innumer abilis.

Pulvinaria innumerabilis, 389.

Sericaria mori, 1341, 1542, 1609, 2234.

Sphinx hageni, 2119.

Osage orange for the mulbcrry silk-worm, 1220, 1286.

soed. Worms in, 597.

Silk-worms fod with, 1341, 1542.

Sphinx, 2119.

$v s$. mulberry for the silk.worm, 2234.

Osborn, H., report of experiments at Ames, Iowa, 2344.

upon the insects of the season in Towa, 2418.

Oscinis, 2394

brassica n.sp., 2291
Oscinis. Cabbage, 2291.

Other insects affecting cheese, 1703.

Otiorhynchida injurions to cultivated plants, 2117.

Otiorhynchns piclpcs, 1788.

Our: bugs, 2374

tablo. On, 395, 408, 506, 546, 568, 623, 827, 1110 .

Ont of evil cometh good, 618 .

Outbroaks of almy worms. Recent, 2262.

Overcrowded, 654

Orerflow bugs in California, 2099.

Oviposition in Carabidie. Mode of, 2341.

Prodoxus decipiens, 2049.

round headed applo-tree borer, 2266.

Saperda bivittata, 1621.

Tortricidie, 1922 .

the Yucea moth, 1354.

Owlet moth. Spider-wort, 1301

Owls' pellets, 601.

Ox insects, 290.

Oxalis. Aleurodes on, 1791.

Ox-oye daisy as an insccticide, 1861.

Oxjopes viridans, 2343.

Oxyptilus periscelidactylus, $1059,1175,1301$.

Oyster-shell bark-louse, 373, 1059, 1127. of the apple, 1329,2238 in Missouri, 1169.

Ozoguatius cornutus, 1967.

Pachylobins picivorus, 845 .

Pachypsylla n.g., 2208, 2272.

$$
\begin{aligned}
& \text { c.-gemma n. } s p ., 2272 . \\
& \text { c.-mamina } n . s p ., 2208,2272 . \\
& \text { renusta, } 2208,2272 .
\end{aligned}
$$

Pachytylus migratorins, 1959, 2044.

Pacific coast. Entomologist for the, 2022.

Whoat-stalk worm on the, 2123.

Pack your insects. Mind how you, 435.

Packard, A.S. Additions to the third report on the causes of the destruction of the evergreen and other forest trees in northern New England, 2364.

Causes of destruction of evergreen forests in Now Englard and New York, 2232.

Descriptions of larve of injurious forest insects, 2267.

Development of the bark-boring beetles Hylurgops and $\mathrm{Xyle}$. borus, 2267.

Embryological development of Caloptenus atlanis, 2267.

Fmbryological development of Caloptenus spretus, 2267.

Embryological development of the locust, 2267.

Embryological derelopment of orthopterous insects, 2267.

Fourth report on insects injuring forest and shade trees, 2382.

The Hessian-fly, 2267.

Narrative of the first journey in 1877,1613

a second journey in $1877,1643$.

Notes on forest-tree insects, 2253 
Packard, A.S. Notes of a journey to Utah and Idaho in $1878,1959$.

Number of segments in the head of winged insects, 2267.

Second report on the causes of the destruction of the evergreen and other forest trees in northern New England and New York, 2291.

Systematic position of the Or. thoptera in relation to the other orders of insects, 2267.

Third report on the causes of the destruction of the evergreen and other forest trees in worth ern New England, 2363.

Packard's Guide to the study of insects (Review), $395,479,827$.

Pædisca celtisana n. sp., 1968.

giganteana $n . s p ., 1968$

obfuscata. Girdling habits of, 2405. scudderiana, 2356.

Notes on, 2213.

Painted borer, 89.

lady-hird, 1329.

Pale thighed tortoise heetle, 1127.

Paleacrita n. g., 1438.

vernata, $75,86,172,173,377,1021,1066$ $1127,1357,1363,1423,1438,1482,1539$ $1604,1847,2012,2149,2238,2267$.

Palingenia bilineata $=$ Hexagenia bilineata flavescens $n . s p ., 24$. pulchella $2 . s p ., 24$. terminata $n . s p ., 24$. vittigera $n . s p ., 24$.

Pamphila ethlius, 1897.

Paniscus geminatus, 1059.

Pangus caliginosus = Har'palus caliginosus.

Panorpa, 2267.

Panorpidæ, 2267.

Paper-makers, 505.

Paphia glycerium, 1117, 1127, 1329, 1704, 1711.

Papilio, 1352.

asterias, $453,804,863,1272,1276,1512$. cresphontes, 1237, 1300, 1914.

glaucus, 28, 1048.

marcellus, 666 .

philenor, 1127, 1321, 1774, 1957.

thoas $=$ P. cresphontes.

troilus, 469,857 .

turnus, 28, 361, 1048.

Parandra brunnea, 1733, 1876.

Paraphia. Fir, 2363.

Pararlyssa n. g. , $385=$ Rhyssa.

Parasa chloris, 1233.

Purasito of cabbage-worm, 2221. canker-worıu, 717.

the imported cabbage-worm. Introduction of a, 2291.

Imported currant-worm fly and its, 380 , 381.

Mud-wasp and, 1827.

Phora not a, 1923.

on Prodoxus decipiens, 1831.

or a scavenger? Is Cyrtoneura a, 2102.

Sheep, 2043.
Parasitee, 66.

on hees, 1500 .

hred from cutton-worm, 1722.

of Colorado potato-beetle. Mite, 1505.

cotton-worm, 1712.

cut-worms, 349.

Efficacy of Chalcid $\operatorname{egg}, 2115$

on eggs of Caloptenus spretus, 161 fowls, 1308.

the hateful grasshopper, 728.

Hessian-fly, 2332.

Hog-caterpillars of the vine infesterl with, 1247.

of the hnman animal, 728 .

Inporting European, 208.

on its larva. The Ahhot Sphinx, 1277. of the larva of Lachnosterna fusca, 2301. Loucania unipuncta, $6,10,17,1670$.

of the plum Curculio, 1751, 1795.

Synonyms of, 1932.

Parasitic cocoons, 158, 1125, 1134.

Not eggs but, 1290 .

coleoptera, 2353.

diptera, 2076.

flies, 310 .

fungus. Remarkahle, 1313.

Parasitized tomato-worm, 155.

Paria aterrima, 1887, 1904, 2229.

Paris green absorhed? Is, 1487.

for cotton-worms. How to use, 1544.

the curculio, 1258.

its effects on plants, soil, and mav, 1427.

as an insect destroyer, 1447.

insecticide. Use of, 1497.

Paris green, London purple and, 2021.

purple, 2021.

Parorgyia. Glands in, 2412.

Synonyms and food-plants, 2412.

Parsnip caterpillars, 453, 804 .

Parsnip. INsECT AFFEC'TING.

Papilio asterias, 453, 804, 863, 1273.

Parsuip worm, 863.

Parthenogenesis of the Hessian-fly. Probable, 1787.

in insects Occurrence of, 1029.

of Mytilaspis pomicorticis, 1056.

Passalus cornutus, 1311, 1329, 1636.

Horned, 1311.

$$
\text { Egg of, } 1329 .
$$

Passer domesticus as an insect destroyer, 1667.

Pra. Insects affecting.

Bruchus pisi, 434, 1120, 1301, 1916, 2238.

Cerotoma caminea, 2418.

Gryllus sp., 2383.

Pea and its insect foes, 14.

weevil, 1301, 2238.

Peach borer, 1017, 1059.

Flat-headed, 2267. .

horers, $871,1366$.

Apple and, 1475, 1513.

Means against, 121.

Peach. Insects affecting, 514.

Egeria exitiosa $=$ Sannina exitiosa.

Asilus sp., 660.

Callimorpha lecontei, 1301 . 
Peach. Insects affecting-Continaed.

Carpocapsa pomonella, 1334.

Cetonia inda = Euphoria inda.

Dicerca divaricata, 871, 2267.

Ephestia interpunctella, 325. zeæ = E. interpunctella.

Eriocampa cerasi, 1253.

Euphoria inda, 447.

Gortyna nitela, 632, 1210.

Helops æreus, 751. pullus $=$ H. æreus.

Larva, 661.

Lepidopteron, 697, 1210.

Lithophane antennata, 1182.

Mycetophila persica, 653,660 . sp., 419.

Ecanthus niveus, 554.

Plulcetribus liminaris, 2047.

Saunina exitiosa, 587, 617, 871, 1017, 1059, 1070, $1475,1513,2238$.

Scolytus rugulosus, 1940.

Selandria cerasi = Eriocampa cerasi.

Thyridopteryx ephemeræformis, 1189.

Xyliua cinerea $=$ Lithophane antennata.

Peach. Large green worm in a, 661 .

tree bark borer, 2047.

borer, 1070, 2238.

borers, 871 .

trees again. Mounding, 617, 653.

Beetlo around, 751.

Insects around, 660 .

Minute borers in, 1940 .

Mounding, 587.

Sulphur cure for, 176 .

Supposed canse of yellows in, 515 .

twig borer, 632,697 .

twigs. Eggs in, 554.

worm, 325 .

Blue spangled, 1301 . boring into, 1182.

Pear. Applo-bark lice on, 973.

Banded Ips in calyx of, 1239.

Bark-lice on the, 982.

and cherry trees. Slug on, 1222.

Diplosis, 2363.

Pear. Insects affecting.

A nametis grisea, 2117.

Anthonomns quadrigibbus, 1358.

Aragnomus griseus, 2428.

Aspidiotus harrisii = Chionaspis furfurus.

Capsus oblineatus = Lygus pratensis.

Carabid, 692.

Carpocapsa pomonella, 1334 .

Cerambycid, 288.

Chionaspis furfurus, 372.

('hloronoura malefica $=$ Empoasca viridescens.

Clisiocampa americana, 363 . maligna $=$ Empoasca obtusa.

Conotrachelus cratægi, 1358. nenuphar, 1358.

Corimelæna pulicaria, 741 .

Diplosis nigra $=$ D. pyrivora. p.rivora, 2363, 2392.

Dolerus unicolor, 1989.

Empoasca obtusa, 22 . viridescens, 22.
Pear. Insects affecting-Continued.

Eriocampa cerasi, 1031, 1382.

Euphoria melancholica, 372.

Euryomia mclancholica = Euphoria melancholica.

Ips fasciatus, 1239 .

Lygus pratensis, 2, 31 .

Mytilaspis pomicorticis $=M$. pomorum. poino1'um, 973. 982 .

Notodonta concinna $=$ Eilemasia concinua

Edemasia concinna, 779.

Oncideres cingulata, $\varepsilon+8$.

Platycerus quereus, 116?.

Poljcaon confertns, 2103.

Prionus laticollis, 561.

Rhopalus sp., 372.

Scolytus rugulosns, 2233.

Selandria cerasi $=$ Eriocampa cerasi.

Tremex columba, 928.

Typhlodromus pyri, 1739, 1759.

Pear leaf blister, 1739.

midge, 2363.

root-borer, 561 .

shoots. Bng gathering on, 741.

slug. Blood-sucker and, 1253.

- Currant worm and, 1031.

tree borer. Elw and, 928.

insect. A new, 1162.

insects, 277.

Rows of eggs in, 577 .

slug, 1382 .

worms, 779 .

twigs. Girlled, 848.

Two new foes of the apple and, 22.

Pearl wood nymph, 1127. 1301, 1363.

Pears. Curculios on, 1358.

Peas. Buggy, 1916.

from bugs. To keep seed, 434 .

Pecan trees girdled by Oncider'es cingulata.

Young, 489.

Pediculina, 258, 497.

Pediculus capitis, 497.

cervicalis $=$ P. capitis.

humanus $=$ P. vestimcriti.

pubis $=$ Pthirius pubis.

vestimenti, 497.

Pedigree moth breeding, 2381.

Pelargonium. Galī on, 1764.

Pelidnota punctata, 40, 113, 129, 354, 358, 725,1221 , 1301.

Spotted, 1301.

Pelopæus cementarins, 543, 1371 .

Habits of Polistes and, 1371.

lunatus $=$ P. comentarins.

Pempelia hammondi $n . s p ., 810$, i311, 1322.

lignosella, 2119.

Pemphiginæ. Biological notes on gall-making, $1653,1678$.

Pemphigini, 2017.

Pemphigus acerifolii $i . s p ., 1678$.

formicarins $n . s p, 27$.

formicetorum $n .8 p ., 27$.

fraxiuifolii $n . s p ., 1678,2361$.

imbricator, 449, 1396, 2361.

populicanlis, 446, 713.

populi-monilis $n .8 p ., 1678$. 
Pemphigus populi.ramulorum n. sp., 1678. populi.transversus n. $s p ., 1678$. pyri $=$ Schizoneura lanigera. rhois, 518.

tessellata, 1948.

ulmifusus $n . s p ., 518$.

vagabundus, 446, 518 .

vitifoliw = Phylloxera vastatrix.

Penetrating organ in a gamasid mite. On an extensile, 1626.

Pennsylvania ground beetle, 1059. soldier beetle, 1059 .

Pentagenia $n . g ., 39$. quadripunctata $n . s p ., 39$

Pentarthron n.g. (Seep.379) = Trichogramma.

Penthina fullerea n. sp. (See f. 378) $=$ P. hebesana.

vitivorana $=$ Eudemis botrana.

Pepsis formosa, 466, 521, 543, 823 .

Mygale hentzii and, 1619

Periclistus sylvestris, 1131.

Perilitus indagator, 1311.

Perimegatoma variegatum, 2109.

Periodical Cicada, 474, 527, 619, 1059, 1311, 1489, 1624, $1836,2014,2312,2314,2315,2363$.

alias the seventeen-year loc ust, $1971,1979$.

alias the serenteen-year and thirteen-year locust, 1159.

Belated individuals of the, 648 . in Massachusetts, 2321.

Notes on the, 2318 .

Our first brood established, 707.

Premature appearance of the, $2320,2326$.

insavin trigs. Eggr of the, 698 .

Song notes of the, 2334 .

Periodical Cicada in southeastern Indiana. Butler A. W. 2364

Massachusetts, 2216.

Twigs punctured by, 1055. or seventeon-year Cicada, 2312, 2314.

Perla decipiens $n . s p ., 24$. dorsata, 903 .

elongata $n . s p ., 24$.

flavescens $n . s p ., 24$.

fumipennis $n . s p ., 24=$ Chloroperla fumi. pennis.

producta $n . s p ., 24$.

varians $n . s p ., 24$.

Perlidæ, 2267.

Perny silk.worm, 1311.

Persian insect powder, 1485.

Persimimon. Insects AfFecting.

Ceratocampa regalis $=$ Citheronia regalis.

Citheronia regalis, 1275.

Pests. Carpet, 1663.

Drug-store, 510.

Museum, 246, 462, 572.

Potato, 1554 .

of tho strawberry, 2324.

West. Winged, 2313.

Petrolenm as insecticides. Emulsions of, 2134. and their value as insecticides. Emulsions of, $2126,2200$.
Pezomachus, 158.

Diminished, 1127.

minimus $n . s p ., 12,1442,1670$.

Pezotettix, some species dimorphic forms of (a] optenus, 1889.

pacifica $n . s p ., 1959$.

Phakellura nitidalis = Eudioptis nitidalis

Phalæna zea, 2343.

Phalænidæ. Description of a new genus of 1138 . Phalangide, 838.

Phaneropteracurvicauda $=$ Scudderiacur ricanda. Phasmida, 2267.

Phasmomantis, 457, 590, 859, 971, 979, 1059, 1060 , 2276.

Phengodes, 1874, 2397.

laticollis, 2412 .

and Zarbipis. Further notes on, 2411 , 2412.

Notes on, 2408.

Phongodina. On the luminous larviform fomales iu the, 2397, 240?

Phenomena. Vegetable, 436.

Pheocyma. Pine, 2363.

Phemonone 5-caudata, 2410 .

Philampelus achemon, 1991, 1127.

pandorus, 1102, 1127.

satellitia $=$ P. pandorus.

Philenor swallow tail, 1127.

Philonthus, 1311.

Philosophy of the inovement of the Rocky Mountain locust, 1669 .

Old and new, 392.

of the pupation of butterflies, 1711.

Phloeotribus liminaris, 2047.

Phlox. Heliothis phloxiphaga injuring, 936, 915. worm, 945.

Phoberia atomaris, 1976, 2343.

Phobetron hyalinum, 40.

pithecium, 777,1272 .

tetradactylus, 40 .

Phora aletiæ, 1923, 1932, 2102, 2343.

a scavenger, not a parasite, 1923.

Phorodon humuli, 235, 279, 1001, 2393, 2394, 2396 2400.

Phorostoma latum, 2260.

Phosphorescence of fire-flies. Intermittence of the, 1805.

the glow-worm. Nature of the, 1810 .

Phosphorescent larve. Large, 1874.

Photinus. Food of Calopteron and, 2358. psralis, 396, 1097, 1705, 1917, 2358 .

Photuris pennsylvanica, 1097, 1705, 1917 :

Phoxopteris cornifoliana n. sp, 1968.

fragariæ, 499, 984, 1059, 1574, 2324.

murtfeld tiana $n .8 p ., 196 \%$.

nubeculana, 1721.

Phryganeidæ, 1138.

Phyciodes nycteis, 1410 ,

Phycita nebulella $n . v ., 1311=$ var. of Acrobasis indiginella.

Phycita nebulo $n . s p ., 2=$ Acrobasis indiginella.

Phyllobrotica longicolnis $=$ Diaurotica lungi . cornis.

Phylloptera oblongifolia $=$ Amblycorypha oblon. gifolia. 
Phyllotreta albionica, 2291.

striolata $=P$. vittata.

vittata, 348, 564, 2291 .

zimmermanni, 2291.

Phylloxera, 1355, 1396, 1404, 1406, 1428, 1449, 1644, 1671.

in California, 2140.

Grape, $172 \%$.

Winged, 1895.

carya-avellana n. $s p ., 1901$. caulis, 360, 685, 1439.

-fallax n. $8 p ., 1423$.

-foliæ, 1311, 1363.

-globuli $n .8 p ., 27,360$.

-gummosa, n. sp., 1423.

-ren n. sp., 1423.

-scissa p. sp., 1901.

-semen, 373 .

on chestuut, 353 .

congress in Spain, 1907.

conrention at Berne, 2147.

correction, 1355.

enemy. Grape-leaf, 1530.

in France. Grape, 2193.

with fungus disease. Infesting, 1808 .

in Geelong, Victoria. Grape, 1732.

Grape, 1329, 1363, 1373, 1423, 1482 , 1721.

and grape-rot, $1623,1628$.

Half the vine area of France affected by, 2020 .

laws, 2019.

in Europe, 2248.

German, 2432.

lichtensteni, 1421.

mite, 1363.

Mold and, 1807.

Nervous system and salivary glands of, 1687 .

New biological facts regarding the grape, 1421.

hickory galls made by, 1901 .

Newest facts of grape, 1404.

Nonsense about the, 1457.

not at the Cape. Grape, 1841.

permanently destructive. grape, 1907.

notes, 1406 .

Notes on the grape, 1952, 2291. in the natural history of, 1439.

Nouveau remède contre, 2283.

Oak, 1363.

One-half the vine area of France affected by, 2020.

quercus, 1363.

Remedies tor, 1403 .

rileyi, $1363,1423,1530$.

in sandy soil, 2250 .

Some recent discoveries in reference to, 2209.

spinosa, 2209 .

in Switzerland. Extermination and restriction of, 2207.

Use of guano for the grape, 1837.
Phylloxera vastatrix, 127, 373, 565, 724, 810, 916, 1281, 1295, 1301, 1311, 1325, $1329,1342,1353,1363,1373$, $1376,1394,1403,1421,1423$, $1435,1439,1449,1454,1457$, $1469,1482,1530,1531,1564$, $1623,1671,1716,1721,1727$, $1732,1808,1841,1900,1906$, $1907,1952,2015,2019,2020$, $2140,2150,2208,2250,2283$, 2355.

Dipterous enemies of, 2150. vitifoli $x=P$, vastatrix Impregnated egg of, 1974.

Phyloptei'a, 2267. work, 1900 .

Ph yloscia, 1900.

Phymata erosa, 778, 1660.

Physianthus albens, 1418, 1419.

Capture of moths by, 1388 , $1419,1761$.

Peculiarities of, 1418.

Physiantilus. Ixsects Affecting, 1388.

Deilephila lineata, 1419.

Noctnidæ, 1419, 1761.

Sphingidæ, 1418, 1419, 1761.

Physicians. Quacks or, 282.

Physocnemum brevilinellm, 696.

Physonota quinquepunctata $n . s p .767=$ P. unipunctata.

unipunctata, 767.

Phytocoridae, 1301.

Phytolacea not fed on by Aletia, 2343.

Phytonomus nigrirostris, 2355.

$$
\text { opimus }=\text { P. punctatus. }
$$

punctatus, $2010,2028,2061,2119,2355$. Further notes on, 2061. rumicis, 2119.

Phy tophagic species, 45, 50 .

Phytophagis varieties, 45,50 .

Phytopus, 1739. oleirorus, 2308.

Pickle-worm, 1127.

Pieridæ, 613, 1301.

\section{Dimorphic, 28.}

Pieris menapia, 2121.

monuste, 1991, 2232.

oleracea, 835, 1127, 2232, 2238.

protodice, 836, 1127, 2232, 2238.

rapæ, 1127, 1257, 1279, 1294, 1469, 1694, 1714, $1720,1721,1867,1948,2221,2232,2238$, $2251,2298$.

into Alabama. Spread of, 1720 .

vernalis, 1634 .

Piesma cinerea, 398, 2048.

Pigeon Tremox, 458.

in apple, 1126.

Pigs. Lice on, 900 .

Pimpla annulicornis, 2343. annulipes, 1334. atrata $=$ Thalessa atrata. ccelebs $n . s p ., 385$. conquisitor, 2343. inquisitor, 1059. 
Pimpla investigatrix n. $s p ., 385$. pictipes $n . s p ., 385$. pleurivinctus $=P$. conquisitor. Red-legged, 1329.

sp. on Parandra brunnea, 1876. vidua $n . s p ., 385$.

Pine Anorbia, 2363.

borer. Common longicorn, 2291.

Lesser, 2267.

Caterpillars on the, 927.

and cedar. Longicorns in, 319.

False caterpillars on the, 985 .

Pine. Insects affecting.

Amorbia, 2363.

Asemum mœstum, 2267.

Aspidiotus pinifolii $=$ Chionaspis pinifolii.

Borers, 1049.

Callidium antennatum, 319. janthinum, 319 .

Chionaspis pinifolii, 97, 1329, 2079.

Cybocephalus nigritulus, 2079.

Hylobins confusus, 1168.

Lachnus strobi, 320.

Lophyrus abbotii, 465, 927, 956, 1570. lecontei, 985, 1011, 1570.

Mowohammus titillator, 1324.

Pheocyma, 2363.

Pieris menapia, 2121.

Pissodes strobi, 781, 2363.

Podapion gallicola, 2231.

Ptinus brumeus, 191.

Therina, 2363.

Pine-leaf scale insect, 1329.

moth of Nantucket, 2183.

Pheocyma, 2363.

Therina, 2363.

trees. Butterfly larvæ injurious to, 2121. killed by borers. White, 1049.

worm. Leconte's, 1570.

White, 465,956

Pinion. Ash-gray, 1301,

Pinus elliotii. Chionaspis pinifolii on, 2079.

inops. Gall on, 2231.

strobus. Insects affecting, 97,320 .

Pionea, Cabbage, 2232.

rimosalis, 1867, 1915, 2232.

Piophila casei, 1141, 1266, 1700, 1734. radicum, 1357.

Pipiza femoralis, 495. radicum $n . s p ., 495=$ P. femoralis.

Pirates biguttatus $=$ Rasahus biguttatus. picipes $=$ Melanolestes picipes.

Pissudes strobi, 781.

Pitcher-plant. Insects affecting, 1385.

Sarcophaga sarracenia, 1385, 1390.

Xanthoptera semicrocea, 1385, 1390.

Pichy blackberry gall, 1131. galls on blackberry-twigs, 610.

Pityophthorus micrographis, 295. minutissimus, 295.

Plagionotus speciosus, $547,915$.

Plagues. Insect, 2198.

Planipennia, 2267.

Plant-bug. Dotted legged, 1311.

Tarnisled, 1127, 1219, 2291.

feeders, Carnivorous propensity of, 1867.
Plant-feeding habit of Feniseca tarquinius, 2361. habits of predaceous beetles, 1956. growing out of an insect, $332,478$. lice, $23,80,265$.

again, 1008.

Apple tree, 270, 335, 591, 996.

on berberry, 644 .

Cherry-tree, 1067.

Culrant, 304.

To destroy, 1148.

Destroying cherry, 1207.

enemies, 151.

Evergreen, 1039.

Mites mistaken for, 59 .

from one plant to another. Migration of, 2017.

in Oregon. Apple-tree, 1899.

Plum-tree, 678.

on potatoes, 1679 .

Scab in apple vs. apple-tree, 1139.

and their foes. Cherry, 1251.

their friends and foes, 198.

louse again. Eggs of the apple-tree, 550.

A pple, 883.

root, $373,495,1059$.

tree, 1127.

Cabbage, 2291.

Corn-root, 23.

Currant, 322 .

eggs on apple and mountain ash, 579.

Eggs of the apple-tree, 507, 539.

enemy, 301.

Grain, 99, 126, 1127.

Look out for the eggs of the apple. tree, 507

White-pine, 320.

Plants. Fertilizing, 324.

Food of insectivorons, 1499.

and insects. Imported, 1339.

Otiorhynchida injurious to cultivated, 2117.

soil and man. Effects of P'aris green on, 1427.

Platamodes unicolor, 573.

Platycerus qnercus, 1162.

Platygaster herricki, 2332 .

Platylypena scabra = Fy pena scabra.

Platynus aruginosus, 1013.

excavatus, 1013.

maculicollis, 2099.

punctiformis, 1798.

Platyphyllum concavum $=$ Cyrtophyllus con . cavus.

Platypsyllus castoris, 2417.

as determined by the lawa. Sys. tematic relations of, $241 \%$.

Platyptera, 2267.

Platyptilus carduidactylus, 1059.

Plectrodes scalator, 1330, 1525.

Plenty of specimens. Send, 593.

Pleurotropis phyllotreta $n . s p ., 2291$.

Plug-ugly theory, 233, 1383.

Plum bark-louse, 107.

Curculio, 373, 1059, 1129, 1301, 2296.

breeds in the apple, 1214 . 
Plum Curculio, natual history and how to eatch him, 1372.

Parasite for the, 1751, 1795.

gouger, 33, 34, 373, 1301.

gum. Larvo in, 419.

Plum. Insects affecting.

Acarid, 1265.

Ageria exitiosa = Sannina exitiosa.

Anthonomus prunicida $=$ Coccotorus scutel. laris.

A phis cerasi = Myzus cerasi.

prunifolia, 678.

Attacus cecropia, 1249.

Bibio albipennis, 683 .

Carpocapsa pomonella, 1334.

Cerambycid, 559.

Coccotorus scutellaris, 33, 373, 1301, 1378.

Colaspis sp., 372.

Conotrachelus geminatus, 34 . nenuphar, 33, 372, 373, 501, 566, $1059,1071,1301,1372,1477,1685$, 2296.

puncticollis $i . s w ., 34=\mathrm{C}$. geminatus.

Dipteron, 419.

Elaphidion parallelum $=\mathbf{E}$. villosum. villosum, 606 .

Elaterid, 81.

Grapholitha jrunivora, 373.

Hylobins stupidus = Pachylobius picivorus.

Lecanium sp., 107.

Lyda 811., 656.

Mytilaspis pomicorticis = M. pomorum. pomorum, 973 .

Myzus cerasi, 678.

Pachylobius picirorus, 845 .

Phorodon humuli, 2393, 2394.

Sannina exitiosa, 81.

Scoly tus rugulosus, 1940.

Semasia prunivora = Grapholitha prunivora.

Telea polyphemus, 765 .

Plum leaf worms, 656.

moth, 373.

saw- $\mathrm{Hy}, 2291$.

tree insects, 683 .

Minute borers in, 1940.

plant lice, 678.

twigs. Borer in, 559, 606.

Plume. Grape vine, 1059, 1301. moth. Spruce, 2363.

Plums and cotton, 1477.

from Curculio. To protect, 1071.

for the million, 501.

Preventing rot in, 1685.

Wier, D. B. Native, 2388.

Plusia brassica $n .8 p ., 1127,1867,2232,2238$, Cabbage, 1127, $2232,2238$. dyaus, 2343.

Plutella. Cabbage, 1291, 2232.

. cruciferarum, 614, 1291, 1297, 2232.

Pod-like willow gall, 1170.

Podabrus modestus, $358,673$. rugulosus, 359.

Podapion $n \cdot g ., 2231$. gallicola $n .8 p ., 2231$.

Podisus spinosus, $372,456,1378,1431,1450,1672$.
Podosesia syringæ, 844.

Poduræ, 1764.

Podura nivicola, 608.

Poduridæ, 317.

Precilloptera prunosa, 737, 1329.

Poecilocapsus lineatus, 715 .

Poison. Potato pest, 1521.

Poisoning noxious insects, 205.

Poisonous Arachnida, 2399.

Is the Colorado potato-beetle, 1483 .

flour, 586.

Hexapoda, 2399.

insects, 2399.

Myriapoda, 2399.

qualities of the Colorado potato-beetlo, 1425.

qualities of the Colorado potato-bug, 1101.

spider, 2306.

Tomato-worm not, 771 .

worm, 710 .

Poisons to lestroy insects. Use of, 1887.

Polistes fuscatus $=$ P. metricus.

metricus, 1371.

and Pelopæus. Habits of, 1371 ,

rubiginosus, 543.

Pollenia rudis, 2128, 2174

Pollination of Yueca, 1603, 2000.

Polycaon confertus. Habits of, 2103.

Polydesmus, 261.

complanatus, 215.

serratus, 342 .

sp., 834.

virginiensis, 219.

Polymitarcys alba, 1926, 1961.

Polyphemus moth, 542 .

\section{Caterpillar of, 765}

Cocoon of, $116 \pm$.

silk-worm, 1311.

Polyrhabdus $n .9 ., 385=$ Chorinaus. cariniger $n . s p ., 385=$ Chorinæus cariuiger.

Polysphineta nigriceps $n .8 p ., 385$. nigrita $n . s p ., 385$.

pimploides $n . s p ., 385$.

Pomace-fly. Pretty, 2119.

Vine-loving, 2119.

Pomphopor ænea, 289, 301, 1056. say $\mathrm{i}, 188,301$.

Synoptic table of, 289.

tar'salis, 289.

Pomphilus formosus $=$ Pepsis formosa.

Poplar borer, 71.

Poplar. Insects afFecting.

Acronyeta acericola $=\mathrm{A}$. americana americana, 575.

Saperda calcarata, 1849.

Poplars. Caterpillar's on Lombardy, 571.

Popular delusion, 525.

names, 100, 430.

remedies for noxious insects, 73.

Populus monilifera. Insects on, 1459.

Porcelio, 1900.

Polizon conotracheli $n . s p \cdot, 1751=$ Thersilochus conotracheli.

Curcalio parasite, 1301. 
Potamanthus? odonatus n. sp., 24.

Porato beetle, 946, 968, 995, 1019, 1027.

abroad. The Colorado, 1364, 1407.

again. Colorado, 1301.

Colorado, 21, 334, 991, 1059, 1311, 1329.

$1363,1423,1431,1558,1570,2291$, 22942418.

enemies, 313, 365 .

in Europe. Colorado, 1597.

New Hampshire. Colorado, 1859.

Experience with, 1519.

Inquiries concerning, 1491

Insect enemies of the Colorado, 411.

Mite parasites of the Colorado, 1505.

in New York. Colorado, 1379.

The onward march of the, 1218.

poisonous? Is the Colorarlo, 1483.

Poisonous qualities of the Colo. rado, 1425.

progress, 1480 .

Specific for the Colorado, 1490.

Sweet, 1697

Ten-lined, 925.

Th ree-lineã, 1059, 1558.

beetles, $247,470$.

Driving, 1044

Fire cure for, 121.

Large black, 1206.

natico home. Colorado, 1462.

Safe remedies for, 1948

Some notes on, 1528.

Sweet, 681, 1510.

Potato-bug, 742, 905, 1450, 1672.

Bogua Colorado, 519.

Colorado, 293, 334, 366.

in Maino, 119.

New, 48, 88, 171, 293.

Poisonous qualities of the Colorado, 1101.

bugs, 401, 794, 1096.

To destroy Colorado, 650 .

old-fashioned, 185.

and corn insects, 138.

Insect foes of the, 1558 .

Potato. InseCts AFFECTING, 767, 1059.

Acarina, 1444.

A phis solani, 1679 .

Baridius trinotata $=$ Trichobaris trinotata

Cassida clavata $=$ Coptorycla clavata.

Ceresa bubalns, 2107, 2235.

Coptocycla aurichalcea, 1510. clavata, $693,742,1558$.

Crepidodera brevis, 1782. cucumeris, 401, 1056, 1059, 1558. parvula, 1.882

Doryphora 10-lineata, 21, 48, 121, 138, 171, 293, $334,347,365,366,401,565,760,905,925,946,968$, $995,1019,1027,1044,1059,1218,1301,1311,1329$, $1363,1364,1379,1105, i 407,1423,1425,1431$, $1450,1462,1480,1482,1483,1490,1491,1505$, $1519,1524,1528,1558,1570,1597,1672,1859$, 2081, 2294.

Epicauta cinerea, 401, 1056, 1558. corvina, 1206. pennsylvanica, 38, 401, 1056, 1558. puncticollis, 1381.
Potato. Insects a FFeCTIN $r_{2}$-Continuod.

Epicauta vittata, 401, 470, 794, 1056, 1230, 1558.

Epitrix brevis = Crepidodera brevis. hirtipennis = Crepidodera parvula.

Gortyna nitela, 401, 1059, 1558, 2229.

Gryllus sp., 2383.

Haltica cucumeris = Crepidodera cucumoris. Lema trilineata, 138, 401, 565, 9:5, 1059, 1558.

Lepidopteron, 794.

Lytta atrata = Epicanta pennsylvanica. cinerea $=$ Macrobasis unicolor marginata $=$ Epicauta cinerea. murina $=$ Macrobası unicolor. vittata $=$ Epicauta vittata.

Macrobasis unicolor, 38, 347, 401, 470, 1044, 1558 . Melanotus incertus?, 846 .

Mcloidæ, 48, 121, 794, 1059, 1230.

Nysius sp., 1317.

Protoparce ccleus, 1059, 1558. 5-maculata, 401

Sciara sp., 239.

Sphinx 5-maculata $=$ Protoparce 5-maculata.

Trichobaris trinotata, 401, 1059, 1558, 2172.

Potato. Meloida injurious to, 48, 121, 794, 1059, 1230.

New insect foe of the, 693 .

pest poison, 1524.

pests, 1558.

Scab on, 239.

stalk-borer, 1059, 2172, 2229. wuevil, 1059, 1558, 2291

worm, 1059, 1329, 1558 .

Potatoes. Black blister beetles on, 1381 .

Buffalo tree-hopper injurious to, 2107.

Plant-lice on, 1679 .

Scabby. 1444.

Wirc-worms in, 846

Pot-herb butter'fy, 1127, 2232, 2238.

Potter wasp, 770.

F'raternal, 1127.

Powder: Manufacture of pyrethrum, 1984.

Persian insect, 1485.

Powders aud their use. Insect, 1692.

Practical entomology in reality, 914.

Prairie belt. First appearance of the cotton-worm in, 1852.

fires and hateful locnst, 1453.

Prasocuris. Table of species, 156. raripes, 156.

Predaceons bectles. Plant-feeding habits of, 1956. Predictions relified, 1494.

Prematme appearance of the periodical Cicada $2320,2326$.

Preparation of Diptera, 2041.

Preserving insects, 881, 1057.

Directions for collecting and, 881.

larvæ, 1300 .

President. Washington Entomological Society. Address as, 2355.

Presidential address to St. Louls Academy of Sciences, 1564, 1629.

Pretty pomace-fiy, 2119.

and unique gall-making tortricid, 2176.

Preying Mantis, 457.

Supposcd eggs of, 1002. 
Prickly ash larva, 191t.

Papilio cresphontes on, 1914.

rose gall, 1194, 1245.

.Primrose. Insects affecting.

Alaria florida = Rhodophora florida.

Rlodophora florida, 1273.

Prionida. Food habits, 1902.

Prionilus cristatus, 262, 491.

Prionotus novenarius = Priouidus cristatns.

Prionus. Eggs of broul-neckerl, 1329.

inıbricornis, $95,1127$.

laticollis, 95, 561, 1059, 1081, 1127, 1329, 2287.

Lesser, 2267.

sp. 736 .

Tile horned, 1127.

Prisopus sp., 2267.

Pristiphora grossularias n. sp., 140, 176, 189, 364.772, 1570.

sicophanta $u . s p ., 197$.

Probabilities of locust or grasshopper injury in the near future, 2335.

Problem of the hop-plant louse in Europe and

A inerica, 2400. fully solved, 2396.

Proboscis of the cominon housc-fly, 1783.

Proconia undata = Oncometopia undata. from stomach of Sturnella magna,.1013.

Procris. Ämerican, 1127.

americana $=$ Harrisiana americana.

falsarius $=$ Acoloithus falsarins.

Grape rine, 213.

Protacanthus milberi, 1127, 1269, 1543. missouriensis $=P$. milberti.

Proctrotrupidæ, 2343. a new genus of, 1749.

Prodenia autnmnalis $n . s p ., 1301=$ Laphygma frusriperda.

commelinie, 850, 1282

fulvosa $=$ var. of Laphygma frugiperda.

lineatella, 1775 .

obscura = var. of Lałhygma frugiperda. sp., 2238 .

Prodoxida, 2000.

Prodoxus $n . g ., 1830,2000$.

ænescens $n . s p, 2000$.

cincreus $n . s p ., 2000$.

decipiens $n . s p ., 1804,1830,1854,1933,1943$, 2000, 2049.

mistaken for Pronuba yuccasella. 1804.

Oviposition of, 2049

A parasite on, 1831.

Erolution of, 1804.

Further notes on Pronuba and, 2000.

remarks on the difference between Pronuba and, 1854.

intermedius $u . s p ., 2000$.

marginatus $n . s p ., 2000$.

Pronuba $v 8,1844$.

Structural and anatomical pecnliarities of, 2171.

Profits of silk-culture, 2338.

Promachus, 1127.

apivorus, $668,1059,1543$

bastardii, 1269
Promachus vertebratus, 1269.

Promethea silk-worm, 1311.

Prominent. The red-hnmped, 2291. unicor'n, 1280.

Pronuba $n . g ., 1329,1336,2000$. and its connection with the pollination of Yncea, 2391.

Erolution of, 1804

maculata $2.8 p$., 2000.

A new tineid greuus allied to, 1830.

and Prodoxus. Further notes on, 2000. remarks on the differences be tween, 1854

Structural and anatomical pecnliarities of, 2171.

v8. Prodoxus, 1844.

yuccasella $n . s p ., 1329,1336,1337,1363$, $1603,1854,1933,1943,2000$, 2171.

Chrysalis of, 1414.

Further reluarks on, 1603.

Mr. Hulst's observations on, 2371.

mistaken for Prodosus decipiens, 1804

Mystery in reference to, 1933.

Supplementary notes on, 1337.

Prophecy fulfilled, 709.

Proscopia, 2267.

Prosopis affinis, 117i.

Prospects. Locust, 1527, 1562, 1582.

Protection of insect collections, 2180.

Protective device employed by a glancopid cater. pillar, 2242.

resemblances. Mimicry or, 1301, 1340.

Proteoteras $n . g ., 1968$

xeculana $n .8 p ., 1968,2114,2206$.

Protoparce carolina, 131, 933, 1089, 1262, 2238.

celens, 131, 152, 401, 490, 710, 815, 851, $885,993,1059,1089,1264,1329,1558$, 1661.

Prunus insects, 1503.

Psenides, 821.

and inquilines. Relations of, 41 .

Psenocerus supernotatus, 481, 1458 .

Pseudococcus aceris, 1890.

Pseudouenroptera, 2267.

of Illinois, 24.

New, 24, 39 .

Pseudoscorpion, 1884.

Psinidia wallula n. $s p ., 1959$.

Psoci, 2133.

Psocidax, 1147, 2267.

Psocina. Strncture of the claw ic, 2045.

Psocus, 1078.

amabilis $n .8 \%$., 24

bifasciatus $n . s p ., 39$

confluens $n . s p ., 39$.

conterminus $n_{.} s p ., 39$

geologns $u . s p, 24$.

lichenatus n. $s p ., 39$.

madescens $n . s p ., 39$.

pcrmadidus $n . s p ., 39$.

perplezus $n . s p ., 24$.

pollntrs $n . s p ., 24$. 
Psocus purus $n . s p ., 24$.

rufus $n . s p ., 39$.

semistriatus $n . s p ., 24$.

venosus, 176, 1078, 1147, 1195, 1263, 1526, 1798.

Psyche confederata, 1441.

Poychidæ, 1650.

Psychomorpla epimenis, 1301, 1363.

Psylla. Box, 2291. rubi, 669 .

Psyllid galls. Hackberry, 2208.

Psyllidx of North America. Notes on, 2272. . the United States, 2210.

Pteromalus puparum, 2221.

Pteronarc5s, 2267.

Pterophorus carduidactylus n.sp., 1059

periscelidactylus $=$ Oxyptilus peri scelidactylus.

Pthirius pubis, 497.

Ptinns brunneus, 191, 510, 1141.

Publication. Discontinuance of, 2106.

Publilia concava, 163.

Puccinia graminis, 1605.

Pulex irritans, 497.

penetrans $=$ Sarcopsylla penetrans.

sp. feeding on lepidopterous larva, 2110.

Pulvinaria acericola $=$ P. innumerabilis. innumerabilis, 3̊89, 1515, 1816, 2279, 2291. 2355.

maclura $=\mathbf{P}$. innumerabilis.

vitis, 106, 1212.

Punctured grape-canes, 513, 1333.

Punctures of Hemiptera upon slirubs, fruits, and grains. Webster, F. M. Experiments on the effects of, 2382 .

Punctures on rose twig, 1167.

Pupa of the disippus butterfl $5,1193$.

Pupa. Habits of, 346 .

How to hatch, 509.

Pupation of butterflies. Plilosophy of the, 1711. Nymphalidæ, 1704.

Purged Ophion, 1127.

Purple willow Gracilaria, 2363.

Purslane. Insect affecting.

Deilephila lineata, 1402.

Putnam, J. D. Obituary, 2054.

Pyralid infesting seed-pods of trumpet-vine, 1929.

Pyralis farinalis = Asopia fariualis. olinalis = A sopia olinalis.

Psrameis atalanta, 540. cardui, 1635,1770 .

Pyramidal grape-vine worm, 1301.

Pyrethrum. Additional experiments with, 1903. cinerariæ folium, 1996, 2235.

Cultivation of, 1984.

Directions for cultirating, 1996. raising, 1862 .

Experiments with, 1918, 2353.

an important insecticide, 2131.

powder. Manufacture of, 1984.

roselum, 1996, 2119, 2343.

for the screw-worm, 1921.

in the United States. Additional notes on the cultiration of, 2377.

The use of, 1858.

its use as an insccticide, 2119.
Pyrethrum willemoti, 2343.

Pyrophila conspersa, 1301. pyramidea, $785,1301$. pyramidoides, $671,785,1301,1471$.

Hibernation of 1471 .

Pyrrharctia isabelia, 244, 558, 909, 1153, 1311, 1802. Pyrrhia exprimens, 677.

Quackery. Entomological, 439.

Quacks and physicians, 282.

Quedins, 1311.

Queen bees in the mails, 1762.

Quelriues mots sur le insecticides, 2283.

Quercus acuminata. Cynips on, 1822. coccifera. Phylloxera on, 1421. douglassi. Gall on, 1967.

Galls on the prinus group of, 1606. infectoria. Gall on, 1560 . muhlenbergi. Cynips on, 1925. palustris. Coceid on, 1972. undulata. Galls on, 1942.

Queries answered, 217.

Bundle of entomological, 1463.

Questions answered, 1246.

Quick traveler, 752.

Quince Curculio, 1301.

QUINCE. INSECTS AFFECTING.

Capsus oblineatns = Lygus pratensis.

Conotrachelus cratægi, 1301.

Eriocampa cerasi, 2243.

Lygus pratensis, 2.

Selandria cerasi = Eriocampa cerasi.

Quince. Saw-fly on the, 2243.

Riabbit insects, 290.

Race. Some further facts regarding that fatherless, 1658.

That fatherless and motherless, 1650.

RAGWEED. INSECTS AFFECTING.

Epicauta pennsyl

Lytta atrata $=$ Epicauta pennsylvanica.

Railroad wor'm, 2238 .

Rauatra, 1709.

$$
\text { fusca, } 797,1191 .
$$

Range of the rear-horse, 859.

Ransom chip-trap for Conotrachelus, 1177.

Ranumculus acris. Insecte affecting, 156.

Curculio remedy, 1201.

Rapacious soldier-bug, 1059 .

Rape buttertly, 836, 1294.

our new cabbage pest, 1257.

Rare capture in Illinois, 1271.

monstrosities, 2224.

Rasahus biguttatus, 497.

Rascal leaf-crumpler, $341,373,1311,1580$. in Georgia, 1962.

Raspberries. Do bees injure, 529 . destroyed by weevils, 1788 .

Raspberry borer, 783 . brand, 676 . canes dying, 1035.

Eggs of snowy treo-cricket in, 1122.

tree-cricket in, 1006.

Gouty gall on blackberry and, 1771.

punctured by Orchelimum glaberrimum, 2249. 
Raspberry Geometer, 1059. gouty gall, 1124.

and grape-vines. Egg punctures in, 2195.

RAsprerry. INSFCtS AFFETING.

Ageria rubi = Bembecia marginata.

Agrilus ruficollis, 1124, 1771.

Bembecia marginata, 1363. 1453.

Chionaspis furfurus, 1968.

Diaspis harrisii $=$ Chionaspis furfurus.

Dipteron, 676.

Moliophadnus rubi, 663, 761, 1212, 1641 .

Oberca bimaculata, 783,1363 . perspicillata $=0$. bimaculata tripunctata, 1503.

CEcanthns niveus, 961, 1006, 1122, 1503, 1691 2195.

Orchelimum glaberrimum, 2249.

Otiorhynchus picipes, 1788

Rhodites radicum, 1149.

Selandria rubi = Monophadnus rubi.

Synchlora rubivoraria, 1059.

Raspberry-root boler, 1363. gall, 1149.

saw-Hy, 1212, 1641 .

Scale inscet on, 1968.

worms, 663, 761.

Rat-tailed larva, 168.

Ratzeburg. Forest trees and weeds of Germany (revicw), 1110.

Rear-horse, 1059.

Eggs of the Mantis or, 1060.

Range of the, 859 .

Rear-horses v8. grasshoppers, 590.

Record of Anierican entomology (review), 827.

Red ants, 2309.

cedar catcrpillars, 427.

clover. Bumble bees and, 2376.

humped caterpillar, 788 .

prominent, 61, 2291.

leg. The cussed, 1598 .

legged ham-lreetle, 1363.

locust, 1423, 1625, 2363.

maple. Ocellate leaf-gall of the, 2119.

mites, 1959.

Transformation of the, 1632.

scale. California, 2394.

Foehele, A., experiments on the, 2394.

shouldered Sinoxylon, 1311.

spider, 1146, 1225, 1710.

on roses, 1710.

tailed Tachina fly, 1127.

weevil, 711.

Reddish snout heetle on apple. Small, 1244. yellow spruce bud-worm, 2291.

Reduvius personatus $=$ Opsiccetus personatus. raptatorum = Sinea diadema.

Regal walnut caterpillar, 425 .

Regulating sex in insects, 1415.

Remarks, 206, 255.

Remedies and applianccs, 2375.

More uni rersal, 278.

Universal, 204, 503, 818.

Remed5. Another universal, 232.

Report of committee of cntomology, Ill. State Hortic. Soc., 1056.
Report of committce of entomology, Mo. State Hortic. Soc., 1113, 1127.

experiments, chietly with kcrosene, upon insects injuriously affecting the orauge-tree and cotton-plant, 2164.

to governor of Kansas on the glasshopper question, 1573.

on Lucilia macellaria, 2199.

of State entomologist of "Illinois, $1,373$.

Missouri, 1, 1059.

2,1127 .

3,1301 .

4, 1311 .

5,1329 .

6,1363 .

7,1423

8,1482 .

9,157 .

Index, 2026

U. S. Ent. Commission, 1, 1643.
2. 1959.
$3,2267$.
$4,2343$.

U. S. Entomologist for 1878,1721 .

1881-'82, 2119.

$1883,2232$.

$1884,2291$.

$1885,2363$.

$1886,2394$.

1887,2418 .

Reports. Missouri entomological, 1680.

U. S. Entomological Commission, 1757.

Resemblances. Mimicry or protective, 1301, 1340.

Resistance of grape-vines to Plylloxera in sandy soil, 2250 .

Retarded development in a blister-Leetle, 1860.

of insects, 2040.

Remarkable case of, 2003 , 2005.

Retirement of Mr. Fuller, 1910

Revision of the Lampyridæe, 1819.

Rhagium lineatum, 2267.

Rhenm rhaponticum. Asilus sericous feeding on, 1543.

Rhinoceros beetle. Gigantic, 580, 1216, 1292

Rhinopsylla $n . g ., 2272$. sch warzii $n, s p, 2272$.

Rhipiphorus sp., 2301.

Tiplia and, 2351.

Rhizotrogus sp., 2260.

Rhodites, 1235.

licolor, 1037, i194, 1245.

radicuni, 137, 1149.

rosæe, $570,1166,1939$.

Rhodobænus 13-punctatus, 1301, 2119.

Rhodophora florida, 807, 1273.

Rhopalocera, 1635, 1784.

Rhopalosiphum, 1678.

Rlopalus, 372.

Rhus glabra. Insects on, 320 .

Rhynchophora, 254, 1301.

Rhynchophorus zimmermanni, 2119.

Rhyssa, 385.

atrata $=$ Thlialessa atrata

not ligrivorous, 2286.

lunator $=$ Thalessa lunator. 
Ribes insects, 772.

Rice crop. Enewies of the, 273.

$$
\text { grub, } 2119 .
$$

Rice. INSECTS AFFECTING.

Acridium obsenrnm, 2119.

Cecidomyia oryza, 1949.

Chalepus trachypygus, $273,1911,1949,1973,2119$.

Chilo oryzæellus, 2119, 2120.

Laph,ygna frugiperda, 2011.

Lissorhoptrus simplex, 273, 1911, 1973, 2119.

Murmillus ovalis, 2217.

Rice. Insects affecting stored, 2190.

enemies of growing, 1911.

plant. Another enemy of the, 2011.

Insect enemies of the, 1949.

Insects affecting, 2119.

Water weevil of the, 1973.

stalk borer, 2119 .

$$
\text { New, } 2120 .
$$

weevil, 1683

Ricinis communis. Acrididæ feeding on, 1645 .

Ridding the ground of cut-worms, 2310.

1.iley to Dr. Schaffer. Entomology. Professor, 2360.

in favor of the birds. Professor, 1675 .

Letter from Prof. C. V., 1676.

and the locusts. Professor, 1434 .

Yucca moth. Professor, 2068.

Riley's report to the governor of Kansas. Professor, 1573 .

researches, 2067.

Ring-banded soldier-bug, 1311.

legged Pimpla, 1329.

Robber. Many.banded, 1059, 1423.

Robin. Cut.worms from the stomach of, 1873 . Insects from the stomach of, 1926.

Rock-bass. Insects from stomach of, 1793 .

Focky Mountain grasshopper, 1557.

locust, $1423,1451,1452,1482.1538$, $1557,1570,1625,1643$, 1959, 1998, 2267, 2291.

Bruner, L., observations in the Northwest on the, 2165 .

in 1880. Martin, J., on the, 2267 .

1885. Bruner, L., re. porton the abundance of the, 2363 .

Geographical distribution of the, 2267.

or grasshopper. Gover. nors of Western States on the, 1557.

Important observations on, 1575 .

Lecture on the, 1493.

in Montana in 1880. Bruner, L., 2267.

Natural history of the, 1578.

and other insects in the Northwest during the summer of 1883 . Bru. ner, L., observations on the, 2277.
Rocky Mfountain locust. Philosophy of the move ments of the, 1669 . scourge, 1629.

in Wyoming, Montana etc., in 1881. Brnner, L., the, 2267.

Rocky Mountains. Excursion to, 988 .

Rogas n. sp., 879 . sp., 1002.

Roller. Strawberry-leaf, 984, 1059, 1574.

Roman-nosed pupa, 1217.

Rooms. Swarms of minute flies in, 596.

Root Aphis, 990, 1038

Apple-borer and, 1038,

blight. Apple, 997.

borer, 981 .

Raspberry, 1363.

lice. Knots on apple-tree roots caused by, 1187.

louse. Barley, 2394.

Syrphus-fly, 1059.

Roots of Ampelopsis. Swellings on, 1428

Insects affecting apple-tree, 963

Rosaceæ. Diastrophus confined to, 1131. insects, 1149.

Rose. Bedeguar of the, 1939.

beetle, 361 .

in California. Fuller's, 1740.

Fuller's, 1708, 1721, 2291.

Habits of Fuller's, 1708.

Not Fuller's, 1825 .

bug, 373,1075 .

on apples, 748 .

Rose bug remedy, 1478.

bugs, 1278 .

bushes. Bark-lice on, 1303.

chafer, $1329,1583$.

chafers on grape-vines, 1375 .

gall, 1235.

Mossy, 570, 1166.

Prickl5, 1194, 1245.

galls. Oak and, 1037.

ROBE, INSECTS AFFECTING.

Aramigus fulleri, 1708, 1721, 1740.

Cynips bicolor = Rhodites bicolor.

Diaspis rosro, 1303.

Heliothis marginidens $=$ Pyrrhia exprimens

Lecanium oler, 1303. rosie, 1303.

Macrodactylus subspinosus, $361,373,1075,1329$, $1375,1478,1583$.

Monostegia rosæ, 672, 1780.

Pyrrhia exprimens, 677 .

Rhodites bicolor, 1037. rosæe, 570, 1037, 1166, 1194, 1245, 1939.

sp., 1235 .

Selandria rosæ $=$ Monostegia rosæ

Tetranychus telarius, 1710 .

Rose-slug, 672, 1780.

twig. Puncture on, 1167.

worms, 677.

Roses. Failuro of tea, 1708 .

The red spider on, 1710.

Rot in plums. Preventing, 1685.

Rotten root, 758 
Round-headed apple-tree borer, 1059, 1608, 2238.

New facts ahout the, 1630.

Oriposition of the, 2266.

Rove bcetle. Spotted, 1123.

beetles, 1558 .

Royal horned caterpiller, 702, 803, 860, 1275.

Rubus insects. 1503 ,

Rudbeckia. Aphid on, 2205.

RUDHECKIA. INSECTS AFEECTING.

Nectarophora rudbeckia, 2205.

Siphonophohra rudbecki $=$ Nectarophora Iudbeckias.

Rue. Papilio asterias on, 1512 . worms, 1512.

Rumexinscets, 1165 .

Russia. Excessive injury done by a beetle in, 1935.

Rust. Graik A phis vs., 1806.

and Ilessian-fiy. Wheat, 1605 .

of orange, 2308 .

Hubuard, H. G. Report on, 2291.

red social wasp, 1329,1558

Rustic. Corn, 1059.

Ruta graveolens. Insects on, 1512 .

Ryo. Beetle working in wheat, oats, and, 1259. gall-gnat, Loew, H. Description of, 2267.

Riye. IXISECTS AFEECTING.

Cccidlonyia secalina, 2267.

Silvanus surinamensis, 1259.

Tenebrio molitor, 72.

Ryc. Worms in flour and, 72.

Sack bearers, 1052.

Saddle-back caterpillars, 60, 161, 424, 829, 1092.

Sago. Galls growing on wild, 1347.

St. Louis Academy of Science. Presidential address, 1564,1629 .

Sale of silk-worm oggs, 1908.

Salivary glands of Phylloxera, 1687.

Salix. Galls of Cecidomyidas on, 46, 197. nigra. Vanessa antiopa on, 1609.

Salt and vinegar for insects, 937. water insects used as food, 2203 ,

Salutatory, 386.

Sania cecropia $=$ Attrcus cecropia. columbia $=\Delta$ ttacus columbia. cynthia = Attacus cynthia.

The ailanthus silk.worm, 1718.

Food-plants of, 2204.

ricini $=$ Attacus ricini.

San Joaquin Valley, California. Coquillett, D. W. Report on locusts of, 2363.

Sandy soil. The Phylloxera in, 2250.

Sannina exitiosa, 55, 587, 617, 871, 1017, 1059, 1070, $1475,1513,2238$.

Saperda, $379,934,2267$.

bivittata $=\mathbf{S}$. candida.

Oriposition of, 1621 .

calcarata, $71,963,1849$.

candida, 2, 6, 55, 57, 277, 377, 421, 578, 714, $870,939,962,1023,1038,1056,1059$, $1213,1227,1332,1367,1441,1513$, lateralis, 583.
Sapenda. Variation in the two-striped, 1213. on willow, 2267.

Sarco]haga, 1390.

carnaria, 1390, 1452, 2343.

lineata destructive to locnsts in Dar. danelles, 2075.

sarracenia n.sp., 1385, 1390, 2343.

Sarcophagida, 2256.

Sircoptes scabiei, 497.

Sadcopsylla penetrans, 412, 497.

Sarracenia variolaris. Description and natural history of two insects which brave the danger's of, 1390.

111sect-catching habits of, $1385,1390$.

Sarracenias, 1499.

Satellite Sphinx, 1127.

Saturuia io $=$ Пyperchiria io.

maia = Hemileuca maia.

Sauce. Maggots in, 1607.

Savin $\mathrm{twigs.} \mathrm{Eggs} \mathrm{of} \mathrm{periodical} \mathrm{Cicada} \mathrm{in,} 698$.

Saw-flies, 294.

Spruce-tree, 115.

Saw-fly. Ash, 2291.

eggs, 108 .

Eltin-tree, 699.

Gooseberr\%, 140.

Imported, 228, 333.

Grape, 2291.

Larch, 2232.

Large, 1514.

larrie on the quiuce, 2243.

Plum, 2291.

Raspuerly, 1212, 1641.

Strawberry, 2418.

Scab in apple vs. apple-tree plant-lice, 1139. potato, 239 .

Scabby potatocs, 144 .

Scale on acacias. Large white, 1730.

Cottony maple, 1816, 2291.

ou Euonymus latifolia, 2403 .

insect on maple, 1890.

Cottony, 1515.

Pine-leaf, 1329.

on raspberry, 1968.

Scale insects affecting the orange. Fxperiments on, 2164.

Coquillett, D. W., gas treatment for, 2418.

Experiments on, 2232

Introduction and spread of, 2232.

Koebele, A., experiments against, 2418.

on magnolia, 1377.

Mcthods of destroying, 2119.

New specics of, 1919.

of the orange, $2119,2369$.

ill Florida. Foyle, J., report on thie effects of cold, 2277.

Tho use of gases against, 2389 .

Whitc-pine, 97 .

Scales, 218

Applc-tree, 69.

Scarites subterraneus, 80\%. 
Scarlet mite, 1470.

Scarred apple trees, 951.

Scarenger? Is Cyrtoneura a parasite or a, 2102. mistaken for a foe, $\mathbf{4 1 6 .}$

Scelio orivora, 1643 . lot a parasite. Phora a, 1923.

Scenopinus from human lungs. Larva of, 1348. sp., 2354.

Schadlicherer Inseckten. Einige unserer, 1325.

Schizoneura americana $n . s p ., 1678$.

cornicola, 27.

fungicola, 27 .

lanigera, 58, 367, 372, 373, 467, 495, 963, $990,997,1038,1059,1187$.

rileyi, 1059.

tessellata, 2361.

ulmi, 1059.

Sciapteron polistiformis, 373, 1301, 1509 .

robiniæ, 2410.

Sciara, $239,596,1547,1662,1950$

mali, 211.

ocellaris, 2119.

Scientific names, 101, 430, 826. nomenclature, 303,768 . symbols, 405 .

Scolopendra castanipes, 834.

Scolytus caryse $n . s p ., 220,938=\mathrm{S} .4$-spinosus. destructor, $938,1329$.

fagi $n .8 p ., 220$.

Food-habits of, 1940.

Hickory, 1754.

Imported orchard, 2233.

pyri $=$ Xyleborus pyri.

quadrispinosus, 220, 938, 1329, 1401, 1754.

r'ugulosus, 1940, 2233.

Synoptic table of, 220.

Scorpion in Kansas, 1119.

Scorpions, 453 .

scotch and Austrian piues. False caterpillars on the, 1011.

Scrape our trees? Shall we, 1399.

Screw.worm, 209.

in Central America. Prevalence of the, 2158.

its parentage in doubt, 1880 .

Pyrethrum for the, 1921.

Scudderia curvicauda, 1363, 2241.

scurfy apple-bark louse, 2305.

Seymuus cerricalis, 1059.

l. æmorrhous, 151.

sp., 151.

Scyphophorus juccæ, 1602.

Second report State entomologist of Missouri, 1127.

\section{U. S. Entomological Commission,} 1957.

Secretion on stems of bitter-sweet. White, waxy, 1913.

Secd corn maggot, 657, 1059, 1065.

grain. Chinch-bug not in, 888.

peas from bugs. To keep, 434 .

ticks under bark of apple-trees, 1133.

wervil. Honey locust, 1026.

Seeds aud galls. Jumping, 1496, 2163, 2173.

Segments in head of winged insects. Packard, A.

S. Number of, 2267.
Selandria cerasi = Eriocampa cerasi

rosæ $=$ Monostegia rosæ.

rubi = Monophadnus rubi.

vitis = Blennocampa pygmæa.

Self-tanght entomologists, 276.

Scmasia helianthana $n . s p ., 1968$.

primivora $n . s p ., 373=$ Grapholitha pra. nirora.

Semiotellus chalcidiphagus n. sp., 384, 563 .

destructor, 1581.

Send pleuty of specimens, 592.

Senometopia atropivora, 2343.

militaris $n . s p ., 6$.

Serica iricolor, 74.

vespertina, 1140.

Sericaria mori, 45, 542, 1311, 1346, 1609, 1616, 1648, $1718,1721,1724,1753,1945,2062$, $2234,2381$.

Length and weight of thread of, 1359 ,

Sericornis claypoleana $n . s p ., 2114=$ Stcganoptycha claypo'eana.

instrutana $=$ Steganoptycha claypo leana.

Serrell automatic silk-reel. Walker, P., 2388.

Sesia pelasgus $=$ Hemaris thysbc.

Seventeen-year Cicada, 1034, 1093, 1698, 2312, 2314.

in Iowa, 1737.

Periodical or, 2312, 2314.

Sting of the, 407 .

locust, $370,881,1489,1971,1979$.

or thirteen-year locnst. Periodi. cal Cicada, alias the, 1159.

Seventh report State entomologist of Missouri, 1423.

Severe cold on insects. Effects of, 2037.

Scx in butterflies. Controlling, 1352.

insects. Regulating, 1415.

Shad. Terrestrial insects in stomach of, 1853.

Shade trees and their insect defoliators, 2378 , 2379

Shaffer. Entomology. Prof. Riley to Dr., 2360.

Shagrecned cut-worm, 2291.

Shall wo sciape our trees, 1399.

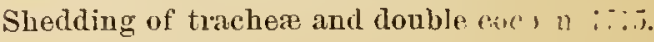

Sheep bot, 450 .

$$
\begin{aligned}
& \text { fly, } 2238 . \\
& \text { gad-fiy, } 887 .
\end{aligned}
$$

Sheldon's borer remedy, 195 .

Shell-bark hickory. Citheronia regalis on, 775 .

Shimer, H., criticised by B. D. Walsh, 174.

Shrubs, truit, and grains. Webster, F. M. Experiments on the effect of pupture of Hemiptera on, 2386.

Sialidx, 2267.

Sialis infumata, 39 .

Sigalphus Curculıo parasite, 1301. curculionis, 1751,1795 .

rufus $n . s p ., 1301=$ var. of curculionis.

Silesia in 1869. Cohn, F. Hessian-fly in, 2267.

Silk-culture, 1668, 1753, 2119, 2291, 2363, 2394.

in California. Promotion of, 2000.

the colonies, 2278.

- low to dispose of cocoons, 1881 .

in Kansas, 1542.

Profits of, 2338. 
Silk.culture in tho United States, 1668, 1945, 2070, 2196, 2336.

W alker, P., 2418.

fiber from coeoons raised at the Department. McMurtrie, W. Test of, 2253.

industry in the United States (Review), 2268. producer. Antheræa yama maia as a, 1346. reel. Walker P. Serrell's automatie, 2386. spiders, 830.

Silk-พorm, 2095.
Ailanthus, 899, 1311.
breeding, 1648
Ceeropia, 1311
Cireular, 2303.
cocoons, 1486.
eggs, 1114, 1753 .

Japanese mode of paeking, 1616 . priees and whore obtainerl, 2062. Sale of, 1908, 2303.

Length and weight of the thread of the, 1359.

Luna, 1311.

Manual ot the, 1721, 1724 .

in Missonri. Ailanthus, 1460 .

Mulberrs, 1311.

naturalized. Ailanthus, 1179.

notes, 2232.

Osage orange for the mulberry, 1220, 1286. ' vs. mulberry for the, 2234.

Perny, 1311.

Silk.worm. Polyphemus, 1311.

Promethea, 1311.

Tusseh, 1311.

Xamamai, 1311.

Silk.worms fed with osage orange, 1341.

Food for, 1318.

Nomenelature of Ameriean, 303.

Silky mite, $1423,1625$.

Silpha amerieana, 817, 1226 .

peltata $=$ S. americana.

surinamensis, 1259, 1260, 1261.

Silphurus femoratus, 39.

Silvauus. Grain, 1259.

in dried English enrants, 1260.

in flouring-mills, 1261.

Silver plate by insects. Damage to, 2154 .

Simulium, 1160, 2291, 2416.

attacking mules, 1811.

feeding on other insects, 2177.

from Lake Supcrior, 2032.

meridionale n.sp., 2394.

molestum, 1174.

peeuarum $n .8 p ., 2394$.

pietipes, 1958, 203:.

piseidium n. sp., 1174, 1283, 1345.

Siner diadema, $34,638,731$.

Singular caterpillar, 880 .

Sinoxylon basilare, 1311, 1747. .

Red shouldered, 1311.

Siphonophora, 1678.

aven $=$ Nectarephora granaria. rudbeckia = Nectarophora rind.

Sitaris, $1600,1643$.
Sitones flarescens, 2394.

Sitophilus granarius = Calandra granaria

oryza = Calandra oryzæ.

romotepunetata $=$ Calandra remotepunctrata.

Six worst inseet enemies of fruit-growers in northern Illinois, 377.

Sixth report State entomologist of Missonri, 1363.

Skeletonizer. Apple-leaf, 1311, 1322.

Skipper. Choeso, 1700.

Skippers injuring smoked ham, 1734 .

Slng un pear and eherry-trees, 1222.

Pear-tree, 1382.

Rose, 672, 1780.

worm. Spined, 1150.

Small apple-leaf worm, 747 .

borer in apple-twig, 1458.

galls and minings in apple-twigs, 552.

grains. A new leaf-hopper injurions to, 1767.

and grasses. Webster, F.M. In. seets affecting, 2391.

reddish snont beetle in apple, 1244.

white bristly cut-wor'm, 1059.

Smaller cormstalk bor er, 2119.

Smart bugs. Concerning eertain, 565 .

Smeared dagger, 1301.

Smerinthus. Blind:oyed, 1912.

exereatus, 1912

Smiera allifions, 6 .

Smilax. Agrotis saucia injuring, 1941.

injured by cut-worms, 1941.

Smilia anrieulata, 118 .

Smith, E. A. Tho cotton belt, 2343.

Smith, J.B. Report upon eranberry and hop in sects, 2277 .

Report upon insects affeeting the hop and the exanberry, 2291.

Smith's patent Cureulio-trap, 969.

Smoked hams. Skippors injuring, 1734.

Smut in wheat, 1479.

Cause of, 1461.

Snake of Brazil. Lignified, 2136.

worms, 1547.

Siakes. Hair, 612, 861, 1143.

Horse hair, 612.

Snellen von Vollenhoven. Obituary, 1817.

Snout bertle, 700, 1168, 1302.

on apple, Swall reddish, 1244.

Imbricated, 1301, 2291.

Large gray straight horued, 1033.

beetles injurious to fruits, 1302.

Snow-balls. A phididie on, 1184 .

Lieo on, 1184.

fleas, 608 .

Snowy treo-erieket, 1059, 1329, 2238, 2291.

in raspberry canes. Eggs of, 1122 .

So-caller army-worms. Three, 328 .

web-worm of young trout, 1283.

Scap. Apply, 1367.

against borers, 47 .

Social wasp. Rust-red, 1329, 1553.

Soeial wasps, 616 .

Soul.worm, 2418.

Soft maples. Flat-healed horer in, 1250. 
Soil. The Phylloxera in sandy, 2250.

Soils. Effects of Paris grcen on, 1427

Solanacere inscets, 1238.

Solanum cafolinonse. Cassida texana on, 2096.

Dorsplion'a juncta on, 2096.

elragnifolium. Cassida texana on, 2096. Flea-heetle eating, 1782.

insects, 1238.

melongena. Cassida texana on, 2215, 2235.

Doryphora juncta on, 2096 , $2215,2235$.

Solar physics and locust multiplication and migration. Swinton, A. H., 2267.

Soldier-beetle larrae, 1643.

Pennsylvania, 1059.

bng, 1558, 2291.

Bordered, 1059.

Glassy-winged, 1301.

Rapacions, 1059.

Ring-banded, 1311.

Spined, 456, 1059, 1311, 1329, 1523.

Solenohia, 38, 943.

Solenopsis geminata, 2105.

$$
\text { xylonii = S. geminata. }
$$

Solidago. Aplid on, 2205 .

gall moth, 1059.

Grapholitha oliraceana bred from, 2285.

leaves. Galls on, 1924.

nemoralis. Cecidomyia carbonifera on, 1924.

Song notes of the periodical Cicada, 2334.

Sorghum. Nola sorghiella on, 2119.

Sorghnm weh-worm, 2119.

Sound organs in sphingid pupæ. Probahle, 2101.

South America. Report on cotton crop and its enerties in, 2343.

American lepidoptera. Notes on, 1784.

Entomological ignoranee in the, 390.

Field for tho entomologist in the, 110 .

Fruit-culture in the, 2265.

The imported cabbagc-tworm in the, 1714.

Mnsclo-shape bark-louse on apple trees in the, 1774.

Notes from the, 1657.

Pass, Ill. The bag-worm at, 115 C.

side of trees. Apple-treo borers on, 634 .

west. Economicinvestigations in the, 1864.

Southerm buffalo-guat, 2291, 2394, 2418.

cabhage-butterfly, 1127, 2232, 2238.

grasi-wolm, 1127.

Illinois. Entomological tour in, 372 .

Sowing cotton secds in hot-heds, 1772.

Spaiu. Phylloxera congress in, 1906.

Span-worms. Goosebcrry, 1068, 1570.

Spariow. Anent the English, 1667.

as an insect killer. Worthlessness of the, 2413.

Spathius trifisciatus $n$. sp., 1329.

Spattered-copjer underwing, 1301.

Spearman. Larva of the ten-striped, 866 .

Ten-striped, 32.

Spocies. Goographical range of, 1614 .

- Ola question of, 2201.

of Otiorhynchida injurious to cultiva.

ted plants, 2117.

Phytopliagic, 45,50 .
Speries, T'licory of, 384.

Specific for the Colorado potato beetle, 1490. names. Capitalizing, 2170, 2257. value of A patura alicix, 1977.

Specimens lost, 1210.

Send plenty of, 593 .

Speckled eut-worm, 1059, 2291.

Specters. TValking-sticks or, 1395.

Speetrum hirittatum, 1298.

femoratum = Diapheromera femorata.

Specnlations of the New England school of naturalists. Entonoiogical, 44.

Professor Dana and his ontomological, 82.

Sperunophagus rohinix, 1026, 1474.

Sphreria n1orhosa, 930 .

Sphrerophthalma occidentalis, $814,832,858$.

Sphecidx. Table of genora of, 375 .

Sphecius speciosts, 371, 372, 407, 543, 858, 2014.

Sphenophori that attack corn. Larval habits of, 2030.

Sphenophorus. Cocklebur, 1301.

Corn, 1301.

Grain, 2363, 2394.

parvulıs, 2394.

robustus, 2030,2119 .

sculptilis, 337, 1042, 1301.

zeas n. sp., $337=$ S. sculptilis.

Sphex ichneumonca, 543.

Sphida obliquata. 2357.

Sphingicampa $n . g ., 40$.

bicolor, 40,45 .

Sphingicampa distigra $n . s p ., 40=$ S. hicolor.

Sphingid pupa. Probable sound organ in, 2101.

Sphingidæ, 771, 1089, 1277, 1418, 1419, 1761, 1784, 2101.

Sphinx. Ahhot, 1127, 1248, 1277.

Achemon, 1127.

atropos, 2101.

carolina $=$ Protoparco carolina

catalpre = Coratomia catalpre.

hageni = Ceratomia bagenj.

Larva of A b hot, 1248, 1277.

Aquatic, 1951.

Osage orange, 2119.

5. maculata = Protoparce coleus.

Satellite, $112 \%$.

White-lined morning, 630, 1198, 1301, 1643, 2291.

Sphyracephala brevicornis, 299.

Spider egg-nest. Mud-wasp and, 1847.

ligg sacks of some unknown, 1144.

Ladder, 1299.

and nest, 1869.

Poisonons, 2306.

Red, 1146, 1225, 1710.

on roses. Red, 1710.

wort owlet-moth, 1301.

Spiders, 217.

Grapre leaf-folders eaten bs, 468 .

Jumping, 2302.

Silk, 830.

Trees injured by, 2409.

Spilochalcis niarire, 1112.

Spilonota oculana =-Tmetocera ocellana.

Spilosoma acrea, 2343.

virginica, 296, 454, 1202, 1307. 
Spindle-worm 4331.

Spincd slug-worm, 1150. soldier-hug, 456, 1059, 1311, 1329, 1523. spider, 813.

Spirobolus marginatus, 166, 963, 1025.

Spittlo insect, 93.

Spotted lady-hind, 599.

Pelirluora, 1301.

lis re-beetle, 1123.

touch-mc-not. Cecidomyia impatientis on, 852.

Galls on, 852.

rumpet-leaf. Insects associated with, $1385,1390$.

Splaying treos for protection against insects. Im proved method of, 2211.

Spread of Pieris rape into Alahama, $\mathbf{1 7 2 0 .}$

scale insects. Introluction aud, 2232.

Spring canker-worm. 1423, 1482, 2238.

Howell, M. A. Experience with, 2267.

Locust injury next, 1555.

tails, 317 .

Sprinklers aud atomizor's, 1857.

Spruce-boler. Flat-hearled, 2267.

hucl. Tortrix, 2332.

worm. Reddish yellow, 2291.

Epizenxis, 2363 .

SPRUCE. INSECTS AFrecting.

Epizeuxis, $23 \mathrm{e} 3$.

Lopliyrus ahietis, 115.

Miclanopliila, 2267.

Nematus integcr, 2232.

Plume moth, 2363 .

Therina, 2363.

Tortrix fumiferana, 2332.

Spruce. Nematus, 2232.

plume-moth, 2363.

'Therina, 2363.

tree saw-flies, 115.

Squares. Butterfy Iarve injurious to cotton, 1872. Squash-borcr, 378, 1127.

bug, $409,867,1059$

does not tonch the white bush scol. lop, 825 .

Glorified, 262.

SUUASII. IXSECTS AFFECTING.

Anasa tristis, 409,825 .

Corcus tristis $=$ Anasa tristis.

Diabrotica vittata, 355 .

Epilachna borealis, 125 .

Melitria ceto, 125, 248, 378.

Trochilinn cnculloita = Melittia ceto.

Sipuash-vine lorer, 248.

Squirre!-bot, 526 . inserts, 125,355 .

Stag-beetle, 957, 1517.

Horns of the, 755 .

Stalk-borer, 1558, 1595, 1646, 2291.

Dahlia, 862, 1009.

Rice, 2119. aucl aster; 940

Tomato, 694, 976 .

weevil. Potato, 1558 .

Staphylinida wanted. Americau, 1786.

Staphylinus maeulosus, 1123, 1186.
State entomologist of Illinois, 327

for Minnesota, 1108.

New Tork, 1863.

One day's jonrnal of a, 383 .

Status and future prospects of sill-culture in the

United States, 2336.

Steelo, . P., report on cotton insects, 2343.

Steganoptycha claspolcana $n . s p ., 2206$.

Stick-bug, 448 .

Stictonotus isosomatis $n$. sp., 2119.

Still they come, 908 .

Sting? Do lorllst, 371.

of the seventeen-year, 407 .

Stinging hug, 778 .

caterpillats, 1748 .

larvie, 760, 811, 1329.

Stings of bees, 116 .

inscets, 116, 217

Stiretrus anchorago, 37\%.

fimhriatus $=\mathrm{S}$. anchorago.

Stizus hrevipenuis n. sp., $375=$ Megastizus brevipennis.

grandis $=$ Sphecius speciosus.

speciosus $=$ Sphocius speciosus.

Stock. Insect injurious to live, 2238.

Stomach of hlack-hass. Larva in, 1792.

bne-bird. Ichnenmon in, 1878.

Larva from, 1871.

cat.bird. Tipula cegs in, 1735, 1745 .

lark, rohin, and sun-fisl.. Insect from, 1926.

meadow-lark. Boetles in, 1033.

robin. Cut-worms fiom, 1873.

rock-hass. Iusects from, 1793

shad. Terrestrial insects in, 1853.

Stomoxys calcitrans, 864 .

Stored corn. Serions injury to, 1683.

rice. Inscets aftecting, 2190 .

Strachia histrionica $=$ Murgantia histriouica.

Straiglit-hornerl snout-beetlo. Large gray, 1033

Strango bug, 1078.

Strawiorry hels. Whitc-grub in, 1236.

boler.s, 2385 .

hugs, 637.

crown-horer, 1301.

Notes on, 1393.

destroyer: 689.

Eggs of bugs on, 690 .

enemy, 342.

and grape-vines. Injured, 682 .

STRAWWERY. INSECTS AFFECTING.

玨geria impropria, 2385.

A grotis tricosa, 2321.

Anarsia liueatella, 2235 .

Anchyluperi fiaguria = Phoxopteris fragarix.

Authonomus musculus, 2363

Cilpsus oblineatus = LJgus pratensis.

Chrysomelidre, 2235.

Colaspis flavida, 1904.

Corimelma pulicaria, 637 .

Cyclocephala immaculata, 1236.

Eccopsis permundana, 2324.

Emplytus maculatus = Farpiphorus macnatus.

Graphops, 2229. 
Strawberry. Insects AfFecting-Continued.

Harpiphorus maculatus, 499, 955, 964,1570,1586, 2324.

Julus sp., 834 .

Lygus pratensis, 682, 2235 .

Monostegia rosæ, 984.

Myriapod, 2235.

Paria aterrima, 1904, 2229.

Phoxopteris fragariæ, 499, 984, 1059, 1574, 2324.

Polydesmus serratus, 342.

$$
\text { sp., } 834 \text {. }
$$

\section{Saw-fly, 2418.}

Selanuria rosæ = Monostegia rosæ.

Tyloderma fragariæ, 1301, 1393.

Strawberry leaf-roller, 984, 1059, 1574.

$$
\begin{aligned}
& \text { A new enemy to, } 1904 . \\
& \text { Pests of the, } 2324 . \\
& \text { saw-fly, } 2418 . \\
& \text { weevil, } 2363 \text {. } \\
& \text { worm, } 955,965,1570 . \\
& \quad \text { and remedy, } 1586 . \\
& \text { worm, } 499 .
\end{aligned}
$$

Streaked cottonwood leaf-beetle, 2291.

Striped-beetle, 2291.

$$
\begin{aligned}
& \text { blister-beetle, } 1059,1230,1558 . \\
& \text { bug, } 123,175 \text {. } \\
& \text { cucumber-beotle, } 773,1127,2238 . \\
& \text { bug, } 148 . \\
& \text { flea-beetle, } 2291 .
\end{aligned}
$$

Sturnella magna. Contents of the stomach of, 1013. Subangular ground beetle, 1059.

Subscribers. To our, 1106.

Subterranean mites. Description of new, 1370.

Successful management of the most destructive orange insects, 2088.

Successor. Mr. Walsh's, 1105.

Sucking organs of bees, wasps, and flies, 2182.

Sugar-berry. Leaf-galls and caterpillars, 762. Orgyia lencostigma on, 762 .

cane in Brazil; Branner, J. C. Insects injurious to, 2277.

SUgAR CANE. INSECT AFFECTING.

Ligyrus rugiceps, 1794.

Sugar-maple. Beetle in, 1014.

$$
\text { borer, } 2291 .
$$

Eggs on, 350.

Mite gall on, 1265 .

treo-borer, 547.

SUGAR-TREE. INSECTS AFFECTING.

Arhopalus speciosus = Plagionotus speciosus .

Plagionotus speciosus, 547.

Sugaring for moths, 1300 .

Natural, 2138.

Sulphnr cure on peach trees, 176. in trees, 98, 228, 931, 1154, 1383.

Sumach-beetle. Jumping, 1363. Eggs in, 118.

SuMACH. INSECTS AFFECTING.

Blepharida rhois, 1363.

Coccid, 320.

Orcholimum sp., 118.

Xiphidium sp., 118.

Summer. Anticipated locust injury next, 1615. dormancy of butterfly larvæ, 1410. larva of Phyciodes nyc teis, 1410 .
Sunfish. Insects from stomach of, 1926.

Sunspots and insect life, 2094.

Supposed army-worm in New York and the eastern States, 1990.

bark-lice eggs in Missouri, 1084.

cause of yellows in peach trces, 515 .

dock. Galls on, 1165.

eggs of the preying Mantis, 1002.

hibernating Aletia chrysalids, 1927.

trout enemy, 1141.

Swallow-tail. Larva of thoas, 1237.

Philenor, 1.127.

Thoas, 1268.

Swallows, 878,1502 .

Dipterous larva on, 153.

Swarms of buttcrtlies, 406,1050 .

lady-birds, 824 .

minute flies in rooms, 596 .

that devastate the trans-Mississippi country. Locust, 1674.

Sweęt-potato beetles, 681, 1510, 1697.

SWEeT-POTATO. INSECTS AFFECTING.

Cassida bivittata 681, 1127, 1510. nigripes, 1127, 1510, 1697. sp., 94.

Cassididæ, 993, 1056, 1082, 1127, 1510.

Cojptocycla aurichalcea, 681, 1127, 1510. bivittata $=$ Cassida bivittata. guttata, 1127, 1510 . migripes = Cassida nigripes.

Gryllus sp., 2384.

Swellings in apple scions, 548 . roots of Ampelopsis, 1428.

Swinton, A. H., Solar physics and locust multiplication and migration, 2267.

Switzerland. Extermination and restriction of Phylloxera in, 2207.

SYCAMORE. INSECTS AFFECTING.

Cerambycid, 2267.

Lachnus platanicola, 2138.

Symbols. Scientific, 405 .

Synchlora rubivoraria, 721, 1059.

Synergus albipes $=\mathrm{S}$. lana.

lana, 41.

lignicola, 41.

mendax $n . s p:, 41$.

rhoditiformis $n . s p .41=$ S. lignicola

Synonyms of parasites, 1932.

Synophrus albipes $n . s p .=$ Synergus lana.

Synopsis of North A merican Heliothina (Review), 2178. मे.

Syntomeida sp., 2412.

Syringa. Citheronia regalis feeding on, 803 .

Syrphidæ. Larval habits of, 168 .

Syrphus-fly. Root-louse, 1059.

mellinus, 1813.

sp., 1251, 1798 .

caught by flower of Bidens chrysan. themoides, 1761.

Systematic position of the Orthoptera. Packard, A. S., 2267.

relations of Platypsyllus as deter. mined by the larva, 2417.

Systoechus leucophæus, 2355.

oreas, $1541,1947,1959,2002$.

Tabanus atratus, 1127 . 
Tabanus, sp., 40.

Table. On onr, $395,408,506,546,568,623,827$, 1110.

Taclina aletia $n . s p ., 1712,2343$.

anonyma $n . s p ., 1311$.

archippivora n.sp., $1301=$ Masicera ar-

chippivora.

concinnata, 2343.

flies, $1643,1736$.

fly, 1558.

Anonymous, 1423, 1625.

Cecropia, 1311.

Red-tailed, 1127.

Yellow-tailed, 1127, 1625.

fraterna, 2343.

pliycita, 1311.

sp., 2378.

villica, 2343.

Tachinid eggs, 1914.

Tachinide, 66, 1301.

Truiopteryx fasciata, 249.

Tamarack. Pieris menapia feeding on, 2121.

Tamariscus. Nanodes tamarisci on, 1496.

Tansy for borers, 1016.

Tarantula killer. Notes on the, 823. of Texas, $466,521,1178$. again, 493 .

Tarnisked plant-bug, 1127, 1219, 2291, 2363.

Tarred paper for fruit trees, 1568.

Tat. Tit for, 432 .

Tawney emperor, 1363.

Tea roses. Failure of, 1708.

Telea polyphemus, 244, 542, 629, 635, 841, 1164, 1311.

Caterpillar of, 765 .

Cocoons of, 2181.

Telenomus, 2115.

$$
\text { bifidus, } 2378,2394 .
$$

Telephorida, 374.

Telephorus bilineatus, 1311, $18 \varepsilon 5$.

Teanochila virescens $=$ Trogosi ta virescens.

Ten-lined potato beetle, 925 .

. striped spearman, 32.

$$
\text { Larva of, } 866 .
$$

Tenacity of life, 1755.

Tenebrio molitor, 72, 191, 980, 2167.

$$
\text { obscurus, 191, } 216 \text { \% }
$$

Tenebrionidre, 2105.

Tent caterpillar, 642.

of the apple tree, $336,1301,2238$, 2291.

Eggs of the Americall, 1329.

of the forest, $645,688,1181,1200$

caterpillars, 363 . $1301,1331$.

and fall web-worms, 819 .

Tenthredinidæ, 197, 294.

$$
\begin{aligned}
& \text { Descriptions of new, } 385 . \\
& \text { Larva of, } 108 .
\end{aligned}
$$

Tenthredo. Venation of, 197.

Teras cinderella, 1311.

malivorana, 1311.

Willow, 2363.

Terias, 1711.

Termes, 2267.

flavipes, $1620,1729$.

Terrestrial laryog in stomach of shad, 1853 .
Test of machinery for destroying the cotton. worm. Baruard, W. S., 2253.

Tests of silk-fiber from cocoons raised at the De. partment. McJurtrie, W., 2253.

Tetranjchus americanus, 1326.

irritans, 1326.

telarius, $1146,1225,1710$.

Means against, 508 .

Tetraopes femoratus, 323.

5-maculatus, 1140.

tetraophthalmus, 323.

tornator $=T$. tetraophthalmus.

Tetrastichus esnrus, 1712, 2343.

productus $n .8 p ., 2332$.

Tettigonia coagnlata, 1024.

sp., 951.

vitis $=$ Typhlocyba vitis.

Tettigonidie, 452.

Tettix granulata, 1566 .

Texas again. Tarantula of, 493 .

fever. 'Ticks and, 404.

in 1883. Anderson, E. H. Cotton-worm in south, 2253.

spring of 1886. Bruner, L. Locusts in, 2382.

Tarantula of, $466,521,1178$.

Thalessa, 2286.

atrata, $338,477$.

lunator, 1111, 1126, 2350.

Thecla poeas, 1872.

Thelares ulmicola $=$ Colopha nlmicola

Thelia bimaculata, 787 .

Theory. Plugr-ngly, 233.

wanted. New locust, 1532.

Theridula sphrerula, 2343.

Therina. Pine, 2363.

Spruce, 2363.

Thersilochus conotracheli $n . s p ., 1301,1751$.

Thick-thighed walking-stick, 1701, 1721.

Third report State entomologist of Missouri, 1301.

U. S. Entomological Commission, 2267.

Thirteen-year locust. The periodical Cicada alias the seventeen-year and the, 1159.

Thistle. Beetles on, 169.

THistle. INsects AFFeCting.

Diabrotica longicornis, 169.

Phyllobrotica longicornis = Diabrotica longicornis.

Platyptilus carduidactylus, 1059.

Thistle-plume, 1059.

Thoas swallow-tail, 1268.

Lar'va of the, 1237.

THORN. INSECTS AFFECTIN.

Anthonomus cratægi, 376 .

Cecidomyid, 376.

Thorn-leaf gall. Mr. Couper's, 376 .

Those centennial insects, 1511.

Thousand-legged worm, 193, 236, 261, 834, 1025.

Three-banded Spathius, 1529.

lined leaf-beotle, 1059, 1558.

so-called army-worms, 328.

worms' and their work, 1504.

Thrips, 1127, 2362 .

Food-habits of, $53,280,685$,

sp., 203 , 
Thrips. 'True and bogus, 203.

of the vine-grower, 53.

Thrushes. Food-habits of, 1726.

Thyreus abbotii, $763,1018,1118,1127,1248,127$.

Thyridopteryx ephemereformis, 182, 206, 266, 271, $427,538,629,641,738,815,1036,1059,1050,1156,1189$, 1352, 1424, 1472, 1650, 1658, 2272, 2378, 2379.

Thyridopteryx ephemeræformis. Remarks on, 2272.

Thysania zenobia, 1291.

Thysanoptera, 174 .

Thysanura, 2267.

Tibicen cassinii, 1057, 2367.

septendecim, 51, 189, 213,370,407, 474, 527, $618,619,648,698,707,746,884,920,1034$, $1037,1057,1059,1093,1159,1311,1489,1609$, $1624,1698,1737,1809,1836,1971,1979,1994$, 2014, 2112, 2144, 2216, 2305, 2307, 2312, 2314, 2315, 2318, 2320, 2321, 2329, 2334, 2363, 2367. tredecim, 474, 746, 1034, 1057,1159,1609,1624, 1809, 1836, 1979, 1994, 1997, 2014, 2112, 2307, 2312, 2329, 2367.

Ticks under bark of apple-trees. Seed, 1133. and Texas fever, 404.

Tiger beetle. Common, 1763.

larva, 719

Virginia, 1059.

beetles, 628,1643 .

moth. Chrysalis of the virgin, 674 .

Isabella, 1311.

Tilden tomato and tobacen-worm, 933.

Tile-horued Prionus, 1127.

Tilia gall, 1116

Odontota rubra on, 1849.

Timber borer's, 191.

oncourages apple-tree borers, 1441.

Insect in, 918.

TIMOTII. IXsECTS AFHECTING

Hadena derastatrix, 2394.

Sphenophorus parvulus, 2394.

Timothy: Webster, F. M. Insects affecting, 2394.

Tinea, 1633 .

Tineid. Apple-treo, 77, 92. genus allied to Pronuba. A new, 1830.

Tineida, 70.

New genus of, 1329, 1336.

Tineids in bee-hives, 252 Tossil, $\therefore 084$.

Tineina, 1246.

Tingis amorplix n. sp., $45=$ Gargaphia amorphx. ciliata $=$ Corvthuea cilia!a. tilie $n . s p ., 45=$ Gargaphia tilix.

Tiplia femorata, 1363.

inornata, 1363, 2301.

and Rhipiphorus, 2351.

Unadorned, 1363.

Tipula, 947, 1161, 1278, 1368 .

eggs in stomach of cat-bird, 1735,1745 .

sp., 512.

trivittata, 512,1735

'lit for tat, 432.

Tmetocera ocellana, 747 .

Toads, 217, 262.

eat worker bees? Do, 544 .

in gardens, 822 .

vs. bugs, 1103 .
Tobacco. INsECTS AFFECTING.

Crepidodera encumeris, 1782. parvula, 1782.

Epitrix eueumeris = Crepiclodera cacumeris. hirtipennis = Crepidodera parvula.

Gryllus sp., 2384.

Macrosila carolina = Protoparce carolina. $5 \cdot$ maculata $=$ Protoparee celens.

Protoparce carolina, 131, 933, 1262, 2238. celeus, 131, 771, 885, 933, 1329.

Sphinx carolina $=$ Protoparce carolina 5-maculata $=$ Protoparce celeus.

Tobacco moth, 131.

plants. Flea beetles on joung, 1782 .

worm, 885,2238 . moth, 1059.

Counterworking the, 1329.

'Tilden tomato and the, 933.

Tolype velleda, 972, 1773 .

Tomato feeding worm, 850 .

fruit worm, 1136.

gall. Grape-vine, 1329.

TOMATO. INSECTS AFFECTING.

Doryphora 10-lineata, 21.

Gortyna nitela, 694, 734, 976.

Heliothis armigera, 1136.

Prodenia commelinæ, 850.

Protoparce carolina, 933, 1089.

celeus, 152, 155, 933, 1089, 1661.

Sphinx 5-maculata = Protoparce celeus.

Tomato stalk boror, 694, 976.

and the tobacco worm. Tilden, 933 .

worm, 152, 1059, 1558, 1661. again, 1104.

Worm eating into green, 734.

worm. Parasitized, 155. 'That renomous, 1089

worns yot poisonous, 771 .

Tomicns pusilus = Pityophthorus minutissimus. ranulorum $=$ Pityophthorus nicrographus.

Tongue. Batterfly's, 1815.

Humming-bird moths caught by the, 1388.

Moths and butterflies caught by the, 1761.

'Too fond of honey, 764 .

Toothed Dermestes, 2363.

Torrubia, 1064

elongata, 1430, 1436.

ravenelii, 1803, 1823

Tortoise beetle. Black-legged, 1127.

Clubbed, 1227, 1558.

Golden, 1127.

Larva of clubbed, 1238

Mottled, 1127.

Pale thighed, 1127.

beetles, 105, 767, 1082, 1127.

Tortricid. A pretty new gall-making, 2176.

Tort ricidæ, 918, 1975.

Description of new, 1969.

Oriposition of, 1922.

Tortrix cinderella $n . \star p ., 1311=$ Teras cinderella. fractivittan $\mathrm{a}=$ Cacoecia fractivittana

fumiferana, 2232.

rileyana $=$ Cacneia rileyana. 
Tortrix. Sprnec bud, 2232.

$$
\text { Walnut, } 1059 .
$$

Touch-me-not. Cecidomyia impatientis on spotted, 852 .

Galls on spotted, 852 .

Tracher and donble cocoons. Sherding of, 1715.

Trado in insects, 1986.

Tragidion fulvipenne, 490.

'Tragocephala viridifasciata $=$ Chortophaga viridi fasciata.

Transformations of insects, 528 .

\section{Mite, 1618}

of red mites, 1632

the tumble bug, 1386 .

Trap. Thomas Wiers's apple-worm, 1312.

Trapping the carpet beetle, 1752.

Treat's insect extinguisher (Review), 531.

Tree borers of the family Cossidæ. I3ailey, $J$. S., 2253.

cricket, $251,953,961,999$.

on grape vines. Eggs of, 723 .

Grapes cut off by, 414

Habits of, 207.

Jumping, 1329.

in raspberry canes. Eggs of, 1006 . Snowy, 2238 .

Snowy, 1329, 2291.

cut-worms, $229,281$.

hopper. Buffalo, 415, 1329.

injurious to potatoes. Buffalo, 2107.

Trees. Apple-tree borers of the south side of, 634 . injured by spiders, 2409 .

for protection against insects. Improved method of spraying, 2211.

Shall we scrape our, 1399:

Tremвx columba, 458, 928, 1126, 2286.

Pigeon, 458, 1126.

Trenton, N. J. Bennett, T. Report of experiments at, 2344 .

Trichius delta, 372 .

Trichobaris trinotata, 401, 1059, 1558, 2172.

Trichodectes oris, 2043.

Trichogramma minutum n. $s p ., 1301$. pretiosa n. sp., 1712, 2115, 2343.

Trichopscnius lepressus, 1729.

Trichoptera, 2267.

Trifolium insects, 1459.

Trimble's insect enemies of fruit, etc. (Review).

187.

Trimerotropis cœeruleipes n. sp., 1959.

$$
\text { latifasciata } n .8 p ., 1959 .
$$

similis n. sp., 1959 .

Triodites, 1947.

mus, 1959, 2002.

Trioza tripunctata, 669

Triphleps insidiosus, 1853, 2048.

Triplax thoraeica $=$ Tritoma thoracica

Tritoma thoracica, 114 .

Tritoxa flexa, 225.

Triungulin of Meloida, 2083.

Trochilium acericolum = Egeria acerni. acerni = Egeria acerni caudatum = Alcathre candatum. cucurbita $=$ Melittia ceto. denudatum = Fatua denudata.

29 ENT
Trochilium hospes, 197.

sp., 1063.

tipuliformis = AEgeria tipuliformis.

Trogoderma tarsale, 2167

as a muscum pest, 2139.

Trogosita manritanica $=$ Tencbrioides manritanica.

virescons, 721 .

Trogus obsidianat or, 1802

Troilus butterfly cnterpillar, 469 .

Trombidium, 624.

developed from $\Lambda$ stoma, 2071.

giganteum $n . s p ., 1632$.

holosericeum, 1470 .

locustarmm n. $s p ., 146,728,1287,1451$, $1521,1598,1618,1632$.

muscarum $n . s p ., 1632$.

sericenm, 1451, 1470, 1598, 1618 .

tclarium $=$ Tetranychus telarius tiuctorium, 1470

Trout. Death-web of young, 1138, 1160, 1174 . cnemy. Supposed, 1141.

Food for, 1142.

So-called wcb-worm of young, 1283.

True army-worm, 647, $112 \overline{7}$.

and bogus Yucca moth, 1804.

Thrips and bogus Thrips, 203.

Trumpet grape-gall, 791, 1116, 1329.

leaf. Insects associated with the spotted, 1385,1390 .

vine. Clydonopteron tecomis in seedpods of, 1929 .

Pyralid infesting seed pods of, 1929.

Trupanea apivora = Promachus apirorus.

Truths in applied entomology. General, 2291, 2292.

Trypeta pomonella $n . s p ., 177,367,373,454,1320$, $1553,1654,2119,2238$.

solidaginis, 137, 180, 798, 1059.

Tryphon atricoxus n. $8 p ., 385$.

Trypoxylon albitarse, 543 .

Tulip-tree bark-louse, 271.

Tumble-dung. Transformation of the common, 1386.

Turf web-worm, 2418.

Turk aud its crescent. The little, 329 .

Turkey-gnat, 2394.

Turnip enemy, 215.

Polydesmus complanatus an enemy to, 215.

Tusseh silk-worm, 1311.

Tussock.moth. Caterpillars of the white-marked, 1227.

Eggs of the white-marked, 480 , 600 .

White.marked, 1059, 1363, 2238, 2378.

again, 535 .

Twelve-spotted Diabrotlca, 687, 1127, 2418.

Twice-stabbed lady-bird, 38, 1329, 1883.

Twig-borers, 1052, 1185. girdler, $476,1938$.

Twigs amputated by some unknowu animal, 442 Berry and cherry, 1503.

Eggs in or on cunes and, 1329. 
Twigs girdled by some animal, 443.

proners, 288.

punctured by periodical Cicada, 1055.

Two-striped locust, 1423, 2363.

Saperda. Variation in, 1213. swect-potato beetle, 1127. walking.stick, 1298.

Tyloderma fragariæ, 1301, 1393.

Typhlocyba aurea n.sp., 22,

binotata $n, 8 p, 22$.

pallidula n. $s p ., 22$.

tricincta, 25.

vitis, 203, 686, 1392, 1853.

Typhlocybini. New species of, 22 .

Typhlodromus pyri, 1739, 1759.

Tyroglyphus phylloxeræ n. sp., 1363, 1370. siro, 1703.

Uji parasitc, 1311.

Uloma impressa, 805 .

Tlmus. Gall-making Pemphiginse on, 1653.

Unadorned Tiphia, 1363.

Unfledged locusts. Destruction of young or 1577.

Habits of young or, 1578

Cnicorn apple-tree caterpillars, 749. prominent, 1280.

Unimpregnated eggs hatch? Will, 1029.

Unique and beautiful noctuid, 2189.

United States. Agricultural advancement in the, 1750 .

Clothes moths observed in the, 2146.

The cotton-worm in the, 1769

Department of Agriculture. Division of Entomology-

Bulletin 1, 2161; 2, 2165 ;

3,$2253 ; 4,2277$; 6, 2304;

8,2315 ; 10,2378 ; 11,2344 ;

12,$2364 ; 13,2382 ; 14,2388$; 15,2389 .

Entomological Commission. Appropriation for, 1843. Bulletin 1, 1577 ; 2, 1578; 3,$1736 ; 6,2026$.

Circular 1,$1575 ; 2,1576$

Report 1, 1643; 2, 1959; 3,$2267 ; 4,2343$.

Reports, 1757 .

Supplementary instructions to agents of the, 1888 .

U.S. Entomologist. Report for 1878, 1721 . 1881 -' $82,2119$. for 1883,2232 . $1884,2291$. $1885,2363$. 1886,2394 . 1887,2418

United States. New source of wealth to, 1668.

Notes on Aphidinæ of the, 27, 1678.

Psyllidx of the, 2210.

settled fact. Hibernation of

Aletia xylina in the, 2141.

Silk.culture in the, $1668,1945,2070$, 2196.

industry in the (Review), 2268.
United States. Status and prospects of silk. culture in the, 2336.

Unity of coloration in inscets, 50.

Universal remedies, 204, 503, 818.

More, 278.

remedy. Another, 232.

Unjust accusation, 1537.

Unknown corn pest, 1073.

- larræ, 853.

moth, 753 .

worm, 986 .

Unmasked. A friend, 374.

Unnatural secretion of wax, 782 .

Unsightly galls.on cotton-wood, 446.

Untrue. Attractive but, 1644.

Urena Anomis, 2119.

lobata. Anomis orosa feeding on, 2343.

Uroceridro injurious to apple-twigs, 893.

Urocerus flavicornis, 2347.

Uropoda americana $n . s p ., 1505,1626$. vegetans, 1626.

Useful Labena, 1423.

lives. Trro, 2370.

A nuisance made, 983.

Useless? Is any knowledge, 1135.

Dstilago segetum, 1461, 1479.

Utah in 1878. Packard, A. S. Notes of a journey to, 1959.

Utilization of ants in horticulture, 2089, 2137.

Vagabond Crambus, 2119.

Valedictory, 326.

Valery Mayet on Phyllozera, 2207.

Valuable insecticides. Two, 1742.

Vanossa antiopa, 540, 907, 1234, 1327, 1609, 1704, 1711. comma = Grapta comma.

interrogationis = Grapta interrogationis

Variable molting in Orgyia, 2379.

Variation in Anisopteryx, 1540.

the two-striped Saperda, 1213.

Variegated cut-worm, 1059, 2291.

Éccopsis, 2363.

Varieties. Phytophagic, 45, 50.

Varying A nomala, 2291.

Vegetable phenomena, 436.

Vegetal-feeding ground beetles, 1738 .

Vegetation caused by locusts. Changes in, 1495.

Harris. Insects injurious, to (Re. view), 568 .

in Illinois. Insects injurious to, 6, 52 .

Legislation to control insects injurious to, 1946.

Venation of wings of Anisopteryx, 1540.

Venomous tomato-worm. That, 1089.

Vera Cruz, Mexico. Interesting cotton-worm notes from, 1845.

Verified. Predictions, 1494.

Vertical insect-boxes, 1963.

Vesicants. Meloidæa as, 912 .

Vespa crabro, 616. maculata, 543

Vespidæ, 190, 505, 770.

Victoria. Grape Phylloxera in Geelong, 1732.

Vilfa vaginæflora, 402, 1495, 1538.

Vine area of France affecterl by Phylloxera. Helf the, 2020.

Blue caterpillars of the, $1127,1363$. 
Vine-growers. Thrips of, 53.

infester with parasites. Hog caterpillar of the, 1247.

Insects iujurious to the, 2238.

loving pomace fly, 2119.

Vinegar for insects. Salt and, 937.

Virgin tiger-moth. Chrysalis of the, 674 .

Virginia tiger-beetle, 1059.

Vitis lituus, 1116. rinifera. Phylloxera destructive to, 1727. viticola, 1116.

V-mar'red Cacoecia, 23E3.

Viviparity of a moth, 2153.

Volumc. Close of the first, 701.

Voyle, J. Experiments on orange scale insects, 2164.

Report on the effccts of cold on the scale insects of the orange in Florida, 2277.

Waguer, B. Observations on the new crop gall. gnat, 2267.

Walker, P. Serrell's au tomatic silk-reel, 2388. Silk-culture, 2418.

Walking-stick, 144. Thick-thighed, 1701, 1721.

Two-striped, 1298.

sticks. Cicadas and, 920 . or specters, 1395 .

Walnut case-bearer, 1311. caterpillars, 1229.

\section{Gregarious, 1045.}

Insect fecding on the sap of black, 1195.

WALNUT. Ixsects AFFECTING.

Cacœcia rileyana, 1059.

Clisiocampa disstria, 363. sylvatica $=\mathrm{C}$. disstria.

Datana ministra, 1045, 1229, 22222, 2333.

Notollontid, 757.

Phycis juglandis, 1311.

Psocus venosus, 1195.

Walnnt Tortrix, 1059.

tree. Worm on bark of, 757 .

and willow. Enemies of the black, 2333.

Walsh, B.D. Entomolomical collectiou of, 1107, 1203.

In memoriam, 1098.

Portrait of, 1128.

Posthumous paper by, 1344.

Successur to, 1105.

Walshia amorphella, 1127, 2356.

Wanted. Information, 1111.

War ou corn-worms, 1522.

IVarbles, 898.

Washington Entomological Society. Address as president, 2355.

Wasp. Ichneumon-fly mistaken for, 477. and parasites. Mud, 1827. spider-egg nest. Mud, 1847.

Wasps, 1736.

Digger, 309.

and their habits, $375,543,615$.

Social, 616.

Sucking organs of, 2182.

Water bug, 797, 1191 .

Girantic, 534 .

larva, 1205.

Water. Moths attracted by falling, 2108.

weevil, 2119. of rice-plant, 1973.

War5-striped flea-bectle, 348, 56t, 2291.

Wax-beans. Epilachna corrupta eating, 2135 .

inscet. New, 2119.

Unnatural secreticn of, 782 .

worm, 1059.

Waxy secretion on stem of bittcr-sweet. White, 1913.

Ways of bag-worms. 1424.

Wealth to the United States. A new source of 1668.

Web-worm. Fall, 1301, 1733, 2238, 2378, 2394.

Garden, 2363.

on hickory. Fall, 460 .

Juniper, 1721.

Sorghum, 2119.

Turf, 2418.

of young trout. So.called, 1283 .

of joung trout. Death, $1138,1160,1174$.

Webster, F.M. Insects affecting burley, 2394.

1
fall-wheat, 2291, $2363,2394$.
small graius and grasses, 2394.
timothy, 2391.
white clorer, 2391.

buckwbeat, 2394.

Record of experiments on the effect of puuctures of hemip. tera upon shrubs, fruits, aud glains, 2382.

Report on Buffalo guats, 2358.

of experiments at Lafasette, Incl., 2311.

upon the season's ubser. rations in Indiana, especially upon corn insects, 2418 .

Wreeping lacc-wing, 1127.

Weeril, 1673 .

on apple-trees, Now Tork, 1085.

Clover, 1777.

Eonej-locust seed, 1026.

Rice, 1683. plant water, 1973.

Strawberry, 2363.

Weerils. Aniseed $v \&$. grain, 1742 .

Raspberries destroyed by, 1788.

Well-known animals, Little known facts about, 2071.

Wells. White worms in, 1015.

West. Canker worms at the, 1539.

Economic investigations in the South and, 1864 .

Genuine army-worm in the, 2009.

Hop growing in the, 235,279 .

Important observations on the grasshopper pest of the, 1571 .

Indies. Report on the cotton crop and it w: excmies in, 2343.

Locusts in the, 2014.

Wingcel pests of tlee, 2313 .

Western cricket, 1959, 2267. 
Western cricket, Bruner, I. Observations on the, 2267.

Histology of, 1959.

governors on the Rocky Mountain locust, 1557 .

grasshopper, 1998.

Missouri. Rarages of young locusts in, 1492.

striped cut-worm, 1059.

Westward progress of the imported cabbageworm, 1694, 1721.

What are army-worms? 1400.

becomes of bumble bees? 1032.

Wheat. Beetles supposed to be feeding on, 1746.

Bruchus. A new insect in, 19.

Cause of smut in, 1461.

cut-worm, 1059 .

Cut-worms destroyiug recently sown, 455 . Damage to, 1870.

fly. Companion, 2394.

head army-worm, 1570, 2418.

Hessian fly in seed, 494

insects, 1506.

WHEAT. INSECTS AFFECTING.

Aphis avenæ = Nectarophora granaria

A sopia farinalis, 980

Blissus leucopterus, 886, 888, 894, 895, 2363.

Brachytarsus rariegatus, $1461,1479$.

Bruchus sp., 19.

C.landra remotepunctata, 15.

Calocoris rapidus, 2363.

Cecidomyia destructor, $491,1506$.

Cecidomyid, 18

tritici $=$ Diplosis tritici

Chlorops sp., 2060.

Cicadula exitiosa, 1766.

Cut-worm, 1059.

Diedrocephala flaviceps. 1766, 1767, 2363.

Diplosis tritici, 109, 110, 142, 216, 280, 292, 372, $428,711,1512,2238,2267,2363$.

Dræocoris rapidus $=$ Calocoris rapidus

Euschistus fissilis, 2363.

Gort sna nitela, 1589, 1870.

Isosoma grande, 2288, 2291, 2363, 2394. hordei, 2394 .

nigrum $=\mathrm{I}$. hordei. tritici, $2060,2063,2123,2363,2394$

Jassus sexnotatis, 1766 . sp., 1766.

Lcucauia albilinca, 1507,1570 .

Longitar'sus sp., 636.

Lygus jratensis, 2363.

Meromyza a mericana, $727,1058,1506,1589,1818$, $1875,2394$.

Nectarophora granaria, 1806.

Noctuid, 455 .

Oscinus sp., 2394.

Prralis farinalis = Asopia farinalis.

Silvanus surinamensis, 1259.

Sitophilus remotepunctata $=$ Calandra re. motepunctata.

Tenebrio molitor, 980.

Wire-worm, 2418.

Wheat Isosoma, 2063, 2119

just before it lipeus, Merompza ameri. cana attacking, 1058.
Wheat. Leaf-hoppers injuring, 1766.

maggots, 727 .

widge, 109, 110, 142, 216, 280, 292, 428, 711,

$1512,2238,2291,2363$

A new euemy to, 1507 .

insect injurious to, 2288.

cats, and rye. Beetles working in, 1259.

plant. Klippart's (Reriew), 186.

rust and Hessian fly, 1605.

Sinut in, 1479 .

stalk-wor'm on Pacific coast, 2123.

stalks. Now depredator infestirg, 2060, 2063.

straw Isosoma, 2291, 2394.

Larger, 2291, 2394

Welster, F. M. Insects affecting, 2394.

fill, 2291,

wire-worm, 2418

2363,2394 .

Wor'm in joints of, 1848

worms, 980.

injuring, 1875 .

in reference to, 1589 .

White ant. Inquilines in galleries of, 1729.

blast, 2119.

clover. Webstcr, F. MI. Insects affecting, 2394.

grub, 68, 410, 1020, 1059, 223s, 2363, 2394.

fungus, 594, 1064, 1430, 1436, 1599, 1803 , 1823.

again, 640 .

information ranted, 1072.

parasite, 1363 .

grubs, $5+1$.

iu strawberry-beds, 1236

heart hickory Gelechia, 2363.

lined morning Sphinx, 630, 1198, 1301, 1643, 2291.

marked tussock-moth, 1059, 1363, 2238, 2378. again, 535 .

caterpillar, 1227.

eggs, 480, 600 .

oak. Leaf-miner on, 1879

Woolly gall on, 739 .

pine plaut-louse, 320 .

scale, 97

trees killed by borers, 1049

weevil, 781, 2363

worm, 465,956 .

Abbot $s, 1570$.

scale on acacias. Large, 1730 .

Neans a gainst 2374

waxy secretion on stems of bitter.sweet, 1913.

willow insects, 907. worm, 917,1211

worms in wells, 1015.

Why noxious insects increase upon us, 766 .

Wier, D. B. Native plums, 2388.

Wier's atpple- Wolm trap. Thomas, 1312.

trap. The coddling-moth, 1334.

Wild cherry. Caterpillar's nest on, 242.

cherry. Cocoon on, 259

grape-rine. Conical galls on leaves of, 1077.

suge. Galls growing on, 1347.

Will unimpreguated eggs hatch? 1029. 
Willow. Enemies of the black walnut and, 2333. gall. Pod.like, 1170.

galls, 46 .

of Cecidomyidæ on, 46, 197.

Gracilaria. Purple, 2363.

WILLOW. INSECTS AFFECTING.

Cecidom jia salicis-siliquæ, 1170.

Cecidomsida, 46, 197.

Cimbex americana, 1380, 2291, 2333. laportei $=$ C. americana.

Clostera americana $=$ Ichth 5 ura inclusa.

Colcopteron. 197.

Dipteron, 197.

Gracilaria, 2363.

Hymenopteron, 197.

Ichthyura inclusa, 856.

Nematus rentralis, 907, 917, 1211.

Saperda, 2267.

Tenthredinid $x, 197$.

Teras, 2363.

Vanessa antiopa, 907, 1234, 1609.

Willow insects. White, 907.

Teras, 2363.

worm. Large, 1380.

White, 917, 1121.

worms. Gregarious, 856 .

Winged pests of the West, 2313.

Phylloxera in California, 1895.

Wire-wurms, 224, 892, 932, 1030, 2238.

Means against, 103.

in potatoes, 816 .

Wits jump together. How great, 567.

W-marked cut-worm, 1059, 2291 .

Wonder. Back-rolling, 1363.

Wood-borers. Food habits of, 1902. Rearing, 1829.

gall on white-oak, 733 .

lice on grape-vine roots, 1900.

njmph. Beautiful, 1127, 1363.

Pearl, 1127, 1301, 1363.

Woolly elm-tree louse, 1059.

lice on the becch, 449.

slug-like worm on apple, 796.

Work in entomology, 202, 418.

Three worms and their, 1504.

Worker bees? Do toads eat, 544 .

Workers among hymenoptera, 311.

Works on North American microlepidoptera, 1975.

World. Insect, 1466, 1467.

Worm. Apple, 1666.

in apple, 177 .

Army, 11, 17, 120, 670, 876, 906, 1127, 1442,

$1482,1551,1570,2119,2239,2267,2269$.

on bark of walnut tree, 757 .

boring into cucumber, 808,813 .

$$
\text { peach, } 1182 .
$$

in wheat-stalk, 1870.

Canker, 86, 172, 1021, 1006, 1127, 1363, 2012.

in cor'n, 181.

Cottou, 1127, 1363, 1619, 1702, 1719, 2077, $2119,2130,2995$.

Currant, 877, 1204.

eating in green tomatoes, 734 .

Hundred legged, 219.

infesting meal sacks, 1896.
Worm. In joint of wheat, 1848.

question, 909.

and remedy. Strawberrs, 1586.

snake, 1662.

'Tobacco, 885, 2238.

Tomato, 152, 1059, 1558, 1661.

An unknown, 986.

Worms. Bee bread devoured by, 1293.

in cabbage, 1915.

Clover, 83. 675, 948, 1132.

in eotton rood, 1459.

Currant, 361, 882, 1696.

on Dutchman's pipe, 1321.

feeding on hawthorn, 1051.

in flonr and rye, 72 .

on horse-chestnut. Gregarious, 1192.

How to free wells of, 1015.

injuring wheat, 1875.

in joint wheat, 1848.

under mulch hay, 1161.

in osage orange seed, 597.

in potatoes. Wire, 846 .

in wells, 1015 .

Wire, 224, 892, 932, 1030, 2238.

and their work. Three, 1504.

Worthlessness of the sparrow as an insect killer, 2413.

Wyckoff's silk-industry in the United States (Review), 2268.

Wyoming, Montana, etc., in 1881. Bruner, L.

The Rocky Monutain locust in, 2267.

Xanthoptera ridingsii $n . s p ., 1411=$ Exyra riding sii.

semicrocea, 1385, 1390.

Xiphidium, 118

Xyleborus celatus, 2267.

obesus, 1583.

Packard, A. S. Derelopment of, 2267. pyri, 2, 149 .

Xyleutes robinia $=$ Cossus robinix.

Xylina cinerea $n . s p ., 1301=$ Lithophane antennata.

$\mathbf{X}$ locopa carolina $=\mathbf{X}$. virginica.

virginica, 372,1111 .

Xyloryctes sat5rus, $40,471$.

Xylotrechus colozus, 2267.

Tama-mai silkworm, 1311.

Year. Destructive insects of the, 2322.

Entomolorical notes of the, 2235.

-Insects of the, $2289,2331$.

Is this a grasshopper, 1565.

Yeast ferment in insects. Experiments with, 1930.

Yellow-bear. Common, 1301.

ferer-fly, 1950.

headed cut-worm, 1059.

locust, 2363.

tailed Tachina-fly, 1127, 1625.

swallow-tail, 361.

Yellows in peach trees. Supposed cause of, 515.

Yersin. Finction of the nerrous s 5stem of articulates, 1959.

Young grasshoppers, 2377.

locusts. Destruction of, 1577.

Ditching for, 1488.

Habits of, 1578. 


\section{INDEX.}

Young locusts in western Missouri. Ravages of, 1492.

pecan trees girdled, 489 .

tobacico-plants. Flea-beetle on, 1782.

trout. Death-web of, $1138,1160,1174$.

So-called web-worm of, 1283 .

Yucca, 1602, 1603.

angustifolia fertilized by Pronuba yuccasella, 1804.

borer, 1420, 1482, 1570.

Notes on the, 1465.

Fertilization of, 1329, 1336, 2171.

filamentosa. Prodoxus decipiens oriposit. ing in, 2049.

Further notes on the pollination of, 2000.

FuCCA. INsECTS AFFECTING.

Elaphidion tectum, 1602.

Megathymus yuccr, 1420, 1465, 1482, 1570, 1602.

Prodoxus decipiens, 2000, 2049.

Pronuba Juccasella, 1329, 1336, 1337, 1354, 1363, $160,2000,2171,2391$
YUCCA. INSECTS AFFeCTING-Continued.

Sycophorus yucca, 1602.

Yucca moth, 1363 .

Oviposition of the, 1354 .

Professor Riley and the, 2068.

True and bogus, 1804 .

Pollination of, 1603, 1804, 2000, 2371.

Pronuba and its connection with the pollination of, 2391.

Zaræa inflata, 2360.

Zarhipis, 2397.

Further notes on Phengodes and, 2411. Phengodes and, 2408.

Zebra cabbage-worm, 2232. caterpillar, 179, 1127.

Zeller. Death of Professor, 2179.

Zerene catenaria, 1140.

Zimmermann's flea-beetle, 2291.

Zoo-geographical map of North America. Pack. ard, A, S., 2267.

Zygæna minos, 2224. 
1 





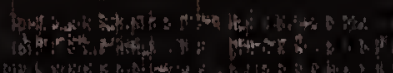
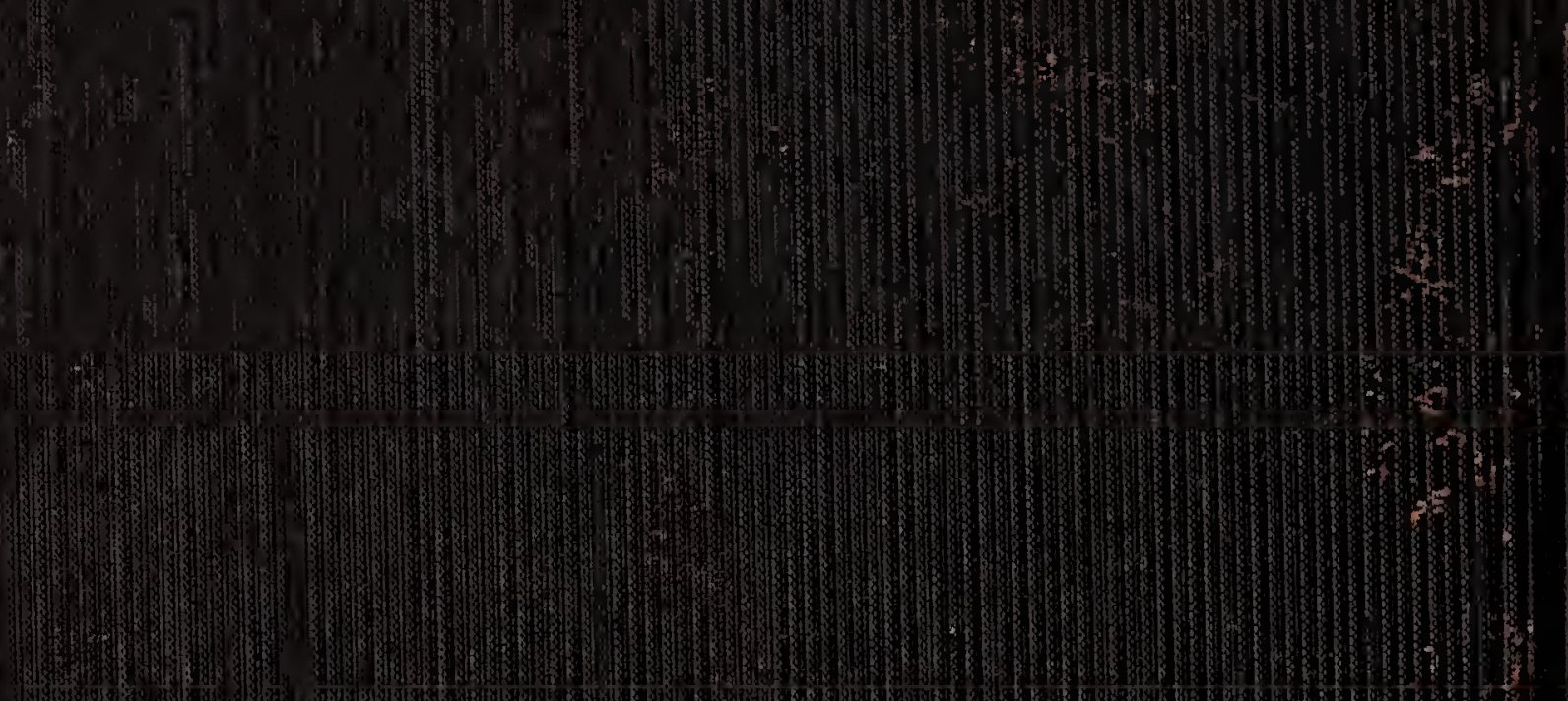

3. $6 x^{3}$

t.

145

1) 